Florida International University FIU Digital Commons

5-15-2017

\title{
Del etnovaivén al etnobúmeran: identidad cultural, estrategias de resistencia e impronta literaria del subalterno en el Perú
}

Frank Otero Luque

Florida International University, foter002@fiu.edu

DOI: $10.25148 /$ etd.FIDC001916

Follow this and additional works at: https://digitalcommons.fiu.edu/etd

Part of the Spanish and Portuguese Language and Literature Commons

\section{Recommended Citation}

Otero Luque, Frank, "Del etnovaivén al etnobúmeran: identidad cultural, estrategias de resistencia e impronta literaria del subalterno en el Perú" (2017). FIU Electronic Theses and Dissertations. 3478.

https://digitalcommons.fiu.edu/etd/3478 


\title{
FLORIDA INTERNATIONAL UNIVERSITY
}

Miami, Florida

\author{
DEL ETNOVAIVÉN AL ETNOBÚMERAN: \\ IDENTIDAD CULTURAL, ESTRATEGIAS DE RESISTENCIA \\ E IMPRONTA LITERARIA DEL SUBALTERNO EN EL PERÚ
}

A dissertation submitted in partial fulfillment of the

requirements for the degree of

DOCTOR OF PHILOSOPHY

\author{
in \\ SPANISH \\ by \\ Frank Otero Luque
}

2017 
To: Dean John F. Stack, Jr.

Green School of International and Public Affairs

This dissertation, written by Frank Otero Luque, and entitled Del etnovaivén al etnobúmeran: identidad cultural, estrategias de resistencia e impronta literaria del subalterno en el Perú, having been approved in respect to style and intellectual content, is referred to you for judgment.

We have read this dissertation and recommend that it be approved.

$\begin{array}{r}\hline \text { Andrea Fanta } \\ \hline \text { María Asunción Gómez } \\ \hline \text { Santiago Juan-Navarro, Major Professor }\end{array}$

Date of Defense: May 15, 2017

The dissertation of Frank Otero Luque is approved.

Dean John F. Stack, Jr. Green School of International and Public Affairs

Andrés G. Gil

Vice President for Research and Economic Development and Dean of the University Graduate School

Florida International University, 2017 


\section{DEDICATORIA}

A Domitila, en representación de todos los subalternos peruanos, aunque ella nunca ha sido subalterna en mi corazón 


\section{AGRADECIMIENTOS}

Les agradezco a mi esposa, a mis padres y a mi hermana por su aliento e incondicional apoyo, sin los cuales este proyecto habría sido imposible; a mi hijo por su ayuda material; a Poupée por haber revisado y corregido con mucho esmero casi todo lo que he escrito en los últimos tiempos; a mi sobrino Sebastián, piloto de aviones, por su buena disposición para traerme pesados cargamentos de libros; a todos mis profesoresen particular a las doctoras María Asunción Gómez, Andrea Fanta y Astrid Arrarás, quienes conforman mi Comité Graduado y, muy especialmente, al profesor principal, el Dr. Santiago Juan-Navarro, mi mentor-, porque sus conocimientos y sabiduría me acompañarán durante toda la vida. Mi agradecimiento a Florida International University por haberme otorgado el Dissertation Year Fellowship que me permitió completar este trabajo. 


\author{
ABSTRACT OF THE DISSERTATION \\ DEL ETNOVAIVÉN AL ETNOBÚMERAN: \\ IDENTIDAD CULTURAL, ESTRATEGIAS DE RESISTENCIA \\ E IMPRONTA LITERARIA DEL SUBALTERNO EN EL PERÚ \\ by
}

Frank Otero Luque

Florida International University, 2017

Miami, Florida

Professor Santiago Juan-Navarro Major Professor

In my dissertation, I explore social strategies that Peruvian subalterns have developed to survive against racism and discrimination. I have identified and coined one of these strategies as etnovaivén (ethno-sway), which I define as a pendulum-like approach that allows subalterns to swing/sway from blanqueamiento to cholificación, and vice versa. Blanqueamiento (whitening) refers to color gradient, i.e. the perception of individuals as being white in relation to their position in the class system, whereas cholificación depicts the reluctance of most mestizos to assimilate the cultural norms of the dominant group, while asserting their own ethnic identity. Conversely, etnobúmeran (ethno-boomerang) is a self-inflicted boycott to one's own ethnic groups. I claim that Peruvian subalterns shape their cultural identity between ethno-sway and ethnoboomerang.

My research has examined these social phenomena as reflected in the Inca Garcilaso de la Vega's Comentarios reales (1609), Clorinda Matto de Turner's Aves sin nido (1889), and Enrique López Albújar's Matalaché (1928). In addition, in La ciudad y 
los perros (1963) by Mario Vargas Llosa, Montacerdos (1981) by Cronwell Jara, La violencia del tiempo (1991) by Miguel Gutiérrez, and Hienas en la niebla (2010) by Juan Morillo, I have analyzed the historical connection between miscegenation, discrimination, inequality and violence, which progressively led to the Internal Conflict (1980-2000), the goriest and longest war in Peru's republican history that resulted in the assassination of approximately 70000 persons, most of them Quechua-speaking, ordinary civilians. Highlanders fleeing from terrorism during those two decades account for the depopulation of over $2 / 3$ of the Andean region.

This study is both relevant and pertinent because it intersects with contemporary debates about national identity formation, and because it provides a means to understand the aftermath of political violence, a phenomenon that periodically threatens the lives of Peruvians. My work contests the traditional thesis of racial and cultural miscegenation as the foundation of Peruvian national identity (the "melting pot" metaphor), which has proven to be ineffective. Instead, I propose a more inclusive identity concept that celebrates cultural diversity and accepts the coexistence of multiple ethnic and cultural groups within the confines of the nation. 


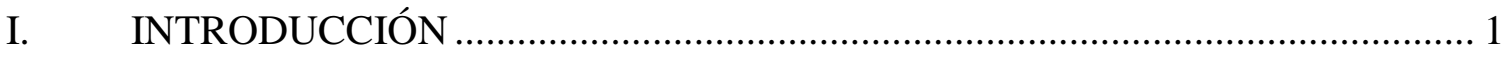

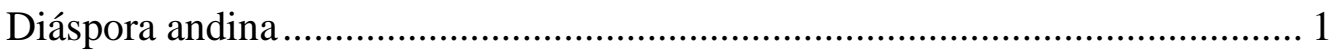

Alcance, relevancia y objetivos del estudio ………….................................... 2

Contenido y metodología ………………………………………………….... 7

II. LA NACIÓN: MARCO TEÓRICO Y ESTADO DEL DEBATE ....................... 11

Visión voluntarista .................................................................................... 12

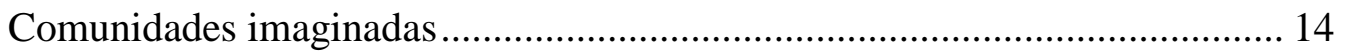

Visión modernista (construccionista) ……………………………………...... 17

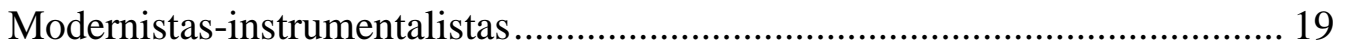

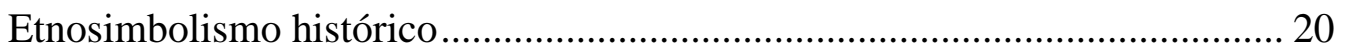

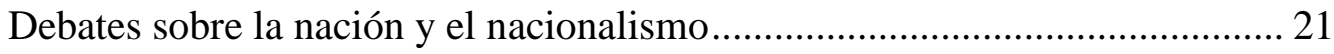

Nacionalidad, nacionalismo y otredad ......................................................... 22

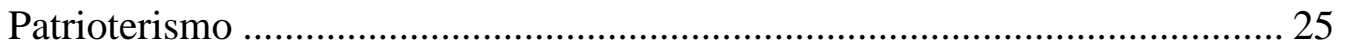

Surgimiento del Estado-nación .................................................................. 26

Auge de lenguas vernáculas y de la imprenta …………................................... 27

Debilitamiento de la Iglesia católica .............................................................. 29

Expulsiones de los jesuitas ........................................................................ 30

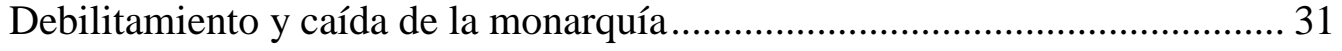

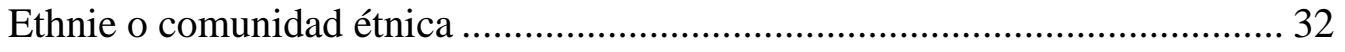

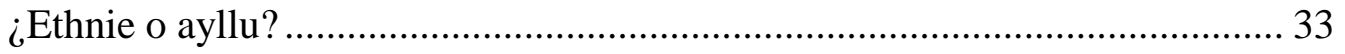

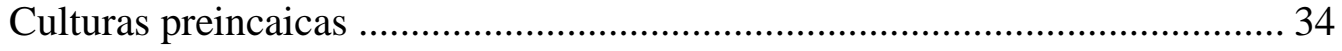

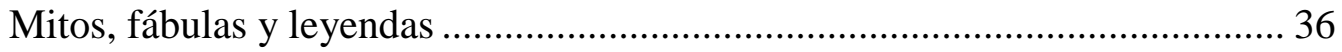

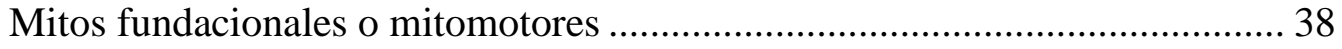

Escepticismo acerca de la identidad nacional peruana....................................... 44

III. SINGULARIDAD CULTURAL DEL SUBALTERNO PERUANO................... 48

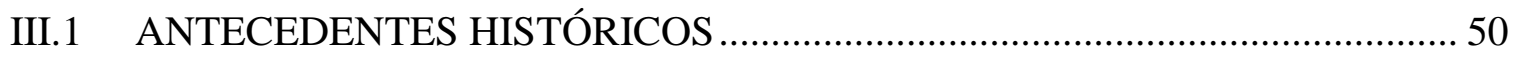

El Imperio inca ................................................................................... 50

Primeras encomiendas en el Perú …………………………………………... 53 


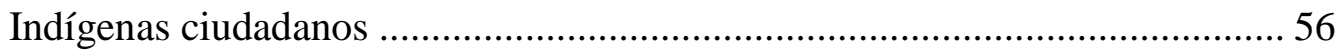

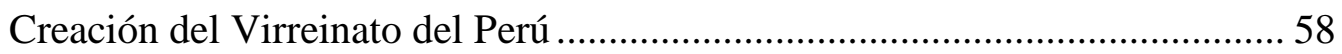

La gran rebelión de encomenderos de 1544 ................................................... 59

Causas de la Independencia del Perú .............................................................. 60

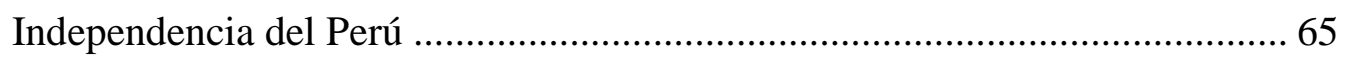

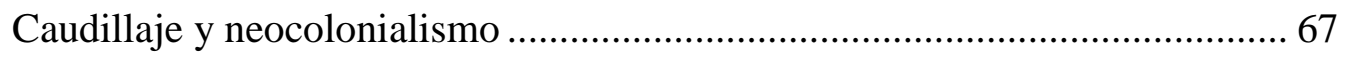

Convulsiones político-militares en el decimonónico peruano ........................... 72

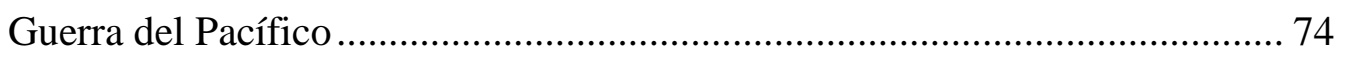

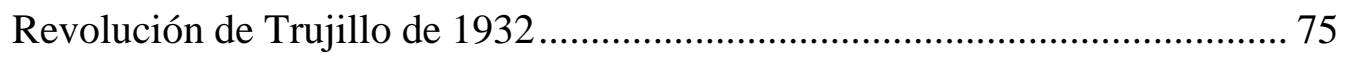

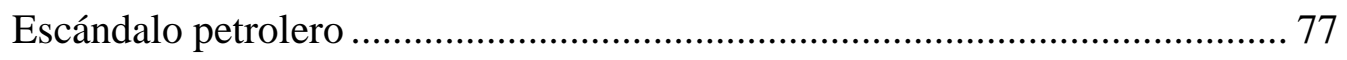

Gobierno Revolucionario de las Fuerzas Armadas ........................................ 79

Expropiación de yacimientos petrolíferos .................................................... 79

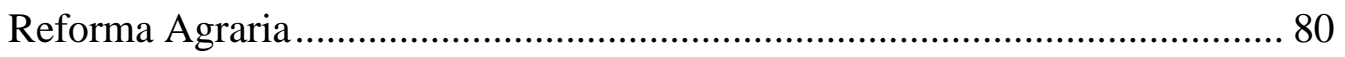

\section{III.2 DINÁMICA DEL ETNOVAIVÉN-ETNOBÚMERAN, ESTRATEGIAS DE} RESISTENCIA Y SINGULARIDAD CULTURAL.......................................... 83

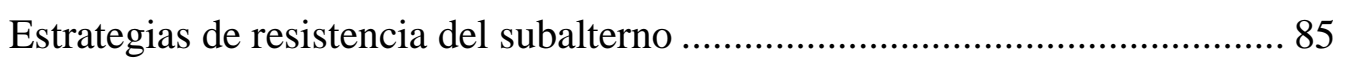

Etnovaivén: entre el blanqueamiento y la cholificación ..................................... 88

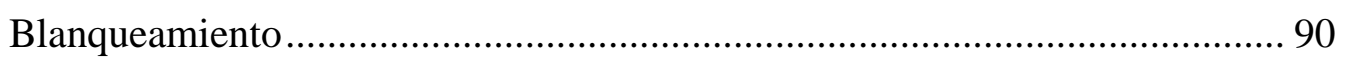

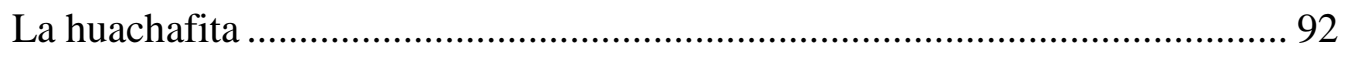

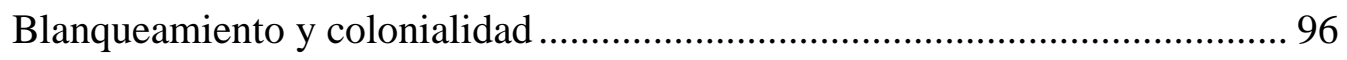

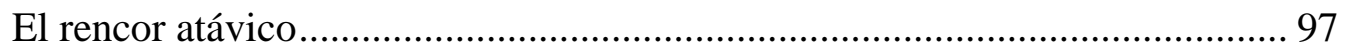

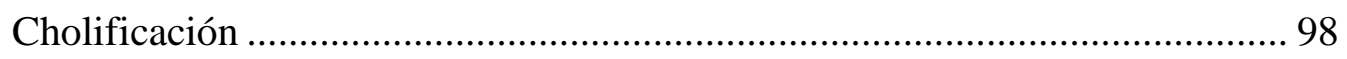

Homi K. Bhabha: estrategias de resistencia del colonizado............................. 100

Etnovaivén y Homi K. Bhabha................................................................... 102

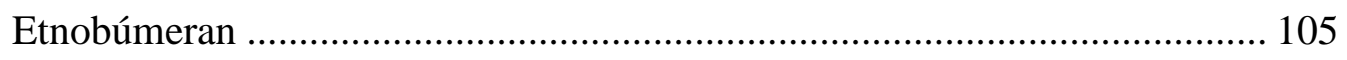

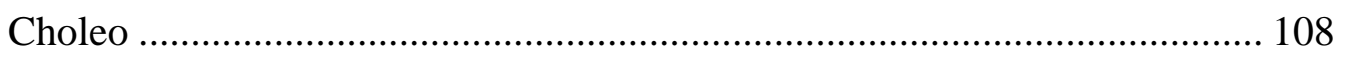

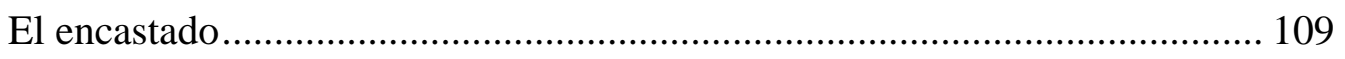

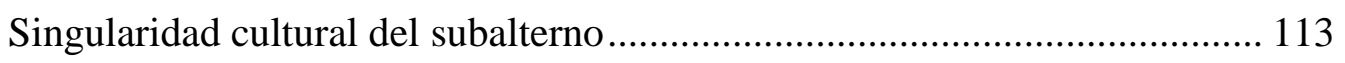

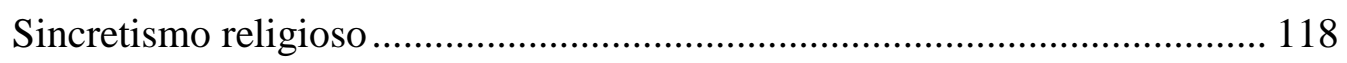

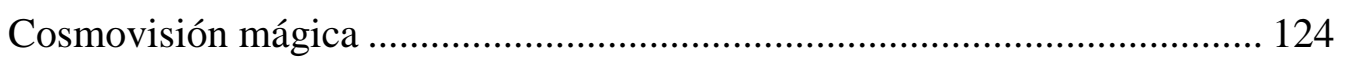

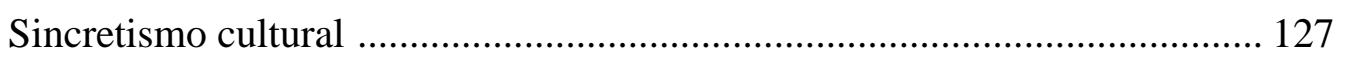

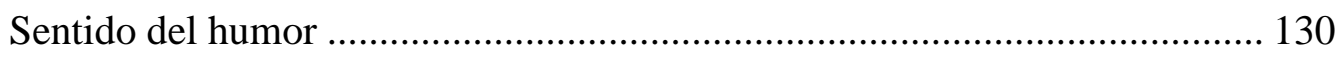

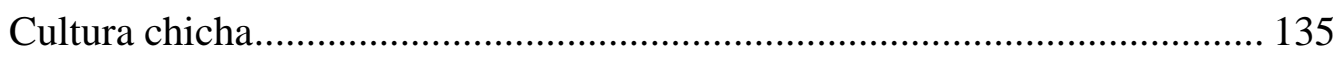




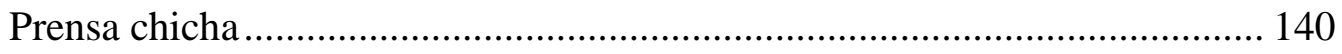

Mapa conceptual del modelo epistemológico etnovaivén-etnobúmeran ........ 142

IV. POSTULADOS DE (RE)CONSTRUCCIÓN DE NACIONAL DE MATTO

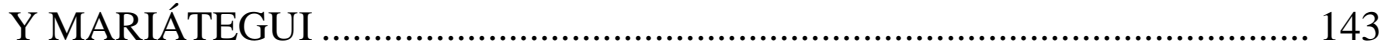

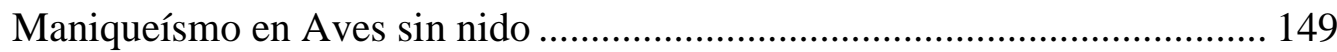

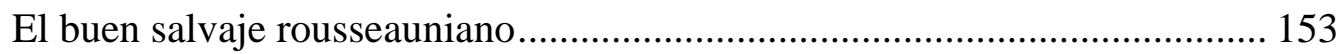

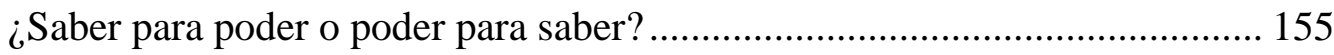

El humanismo y el sistema educativo ........................................................ 158

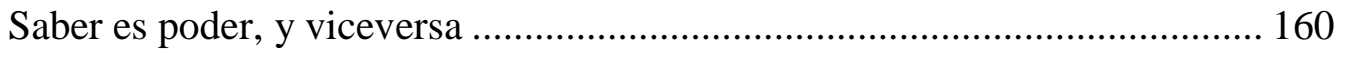

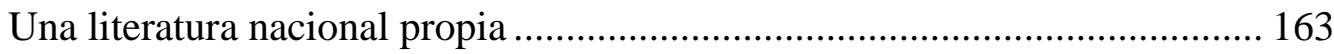

Lengua — ¿quechua o española? —y nación ................................................... 167

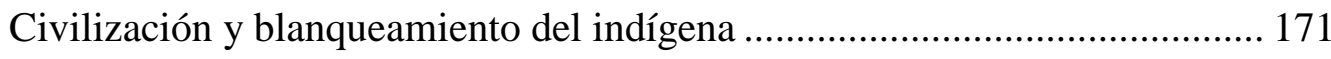

Ninguneo de Matto por parte de Mariátegui ................................................... 176

Falta de independencia de los poderes del Estado ......................................... 179

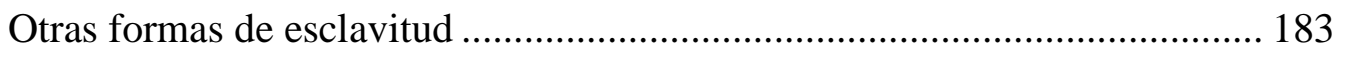

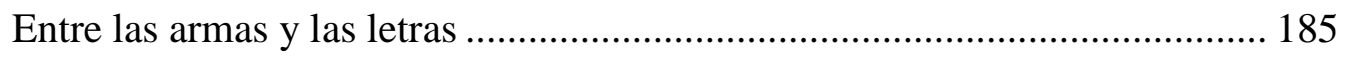

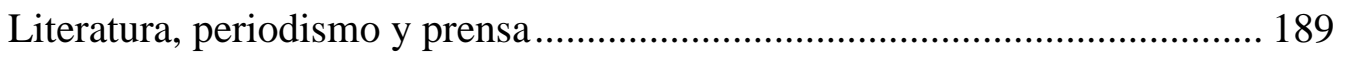

Fronteras abiertas, inmigración, comercio e industria ................................... 190

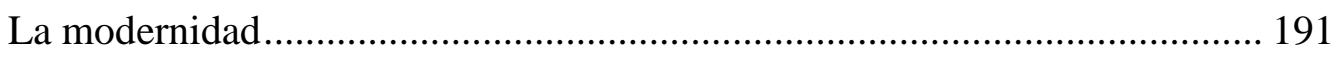

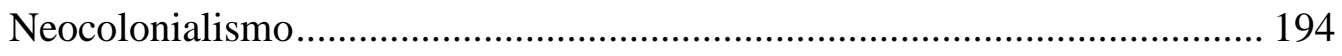

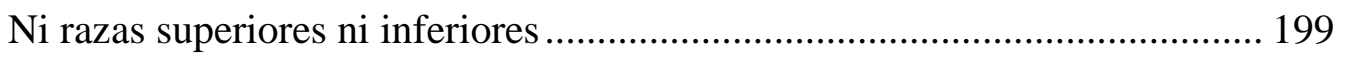

La tenencia de la tierra: el meollo de la inequidad .......................................... 204

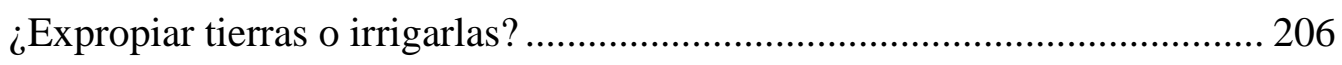

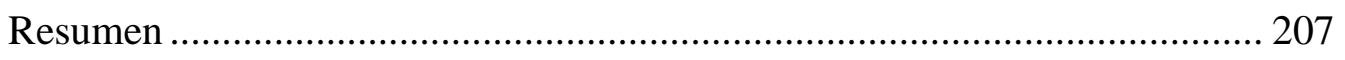

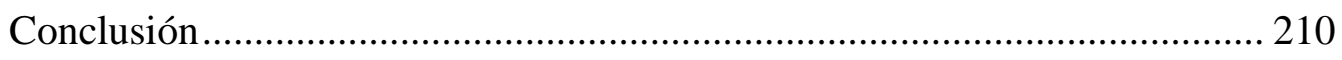

V. MESTIZAJE: ¿LA SOLUCIÓN INSOLUBLE? .......................................... 21414

Racismo y discriminación ........................................................................ 214

V.1 EL INCA GARCILASO DESDE EL ESCEPTICISMO: UNA IDENTIDAD MESTIZA CONFLICTIVA...................................................................... 21919

Los primeros transculturados ..................................................................... 219

La importancia de un nombre................................................................... 223 
Amancebamiento y bastardía ................................................................ 224

Viaje a España y gestiones infructuosas................................................... 227

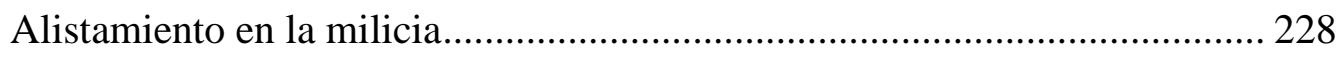

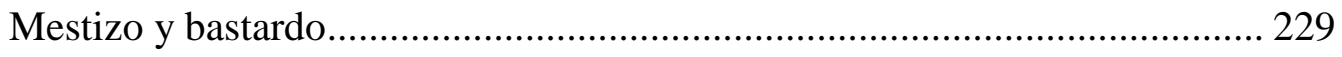

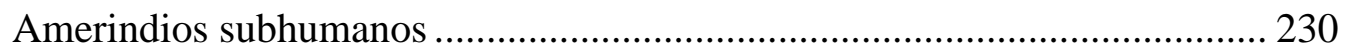

Florecimiento económico e intelectual................................................. 231

Genealogía, vástago biológico e hijos literarios....................................... 234

La personalidad de un modesto comentarista que protesta la historia oficial 235

Desacreditar lo preincaico para realzar lo incaico....................................... 242

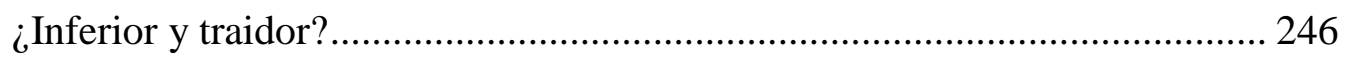

Complejo de superioridad ................................................................. 247

Incas contra preincas y españoles contra indígenas ................................... 249

Los incas como facilitadores de la cruzada evangelizadora ........................ 251

De dioses tangibles y ocupados ............................................................ 255

Estrategias del colonizado ................................................................ 258

Gruesas suturas de la hibridación cultural ................................................. 260

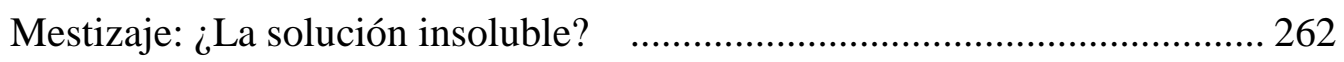

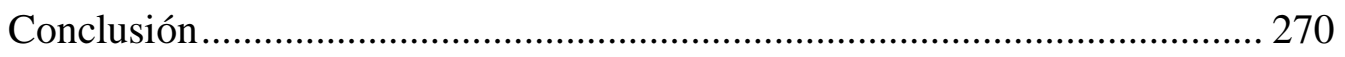

V.2 SIN GUITARRA NI CAJÓN EN EL PROYECTO NACIONAL:

MATALACHÉ (1928), UNA NOVELA ANACRÓNICAMENTE

ROMÁNTICA DE ENRIQUE LÓPEZ ALBÚJAR. 27373

VI. INJUSTICIA, RACISMO, DISCRIMINACIÓN Y VIOLENCIA...................... 312

VI.1 MONTACERDOS (1981) DE CRONWELL JARA:

SERES INMORTALES EN LA BARRIADA PERUANA ............................ 312

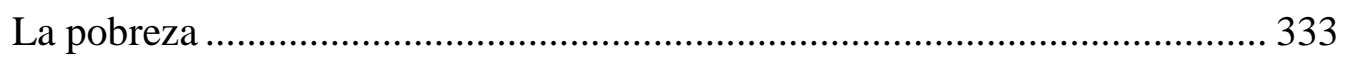

VI.2 LA CIUDAD Y LOS PELOS: LA REPRESENTACIÓN DEL INDÍGENA PERUANO EN LA CIUDAD Y LOS PERROS (1963) DE

MARIO VARGAS LLOSA ................................................................. 335

VII. CAUSAS DE LA VIOLENCIA: INEQUIDAD SOCIOPOLÍTICA Y

SOCIOECONÓMICA, RACISMO, ODIO Y RENCOR …............................ 362 


\section{VII.1 DESDE MARTÍN CORTÉS HASTA MARTÍN VILLAR: EL MESTIZAJE COMO ESTIGMA EN LA VIOLENCIA DELTIEMPO (1991) DE MIGUEL GUTIÉRREZ CORREA}

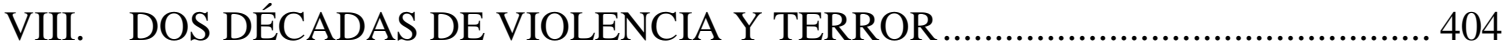

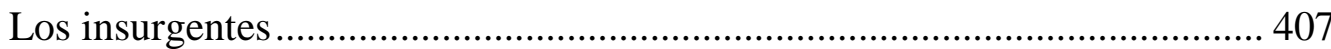

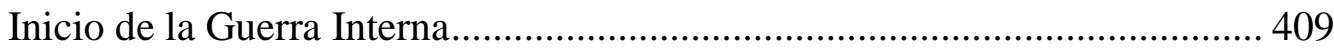

Fases de la Guerra Interna y captura de los líderes ......................................... 410

El Pensamiento Gonzalo ............................................................................ 411

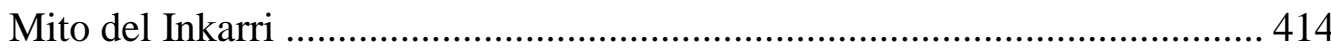

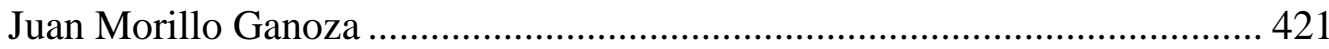

VIII.1 HIENAS EN LA NIEBLA (2010) DE JUAN MORILLO GANOZA: UNA REPRESENTACIÓN DE LA GUERRA INTERNA ............................ 42323

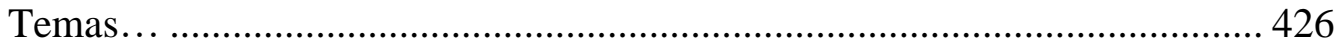

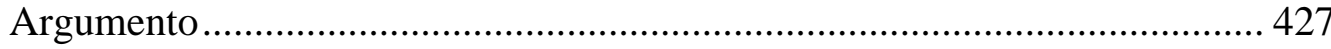

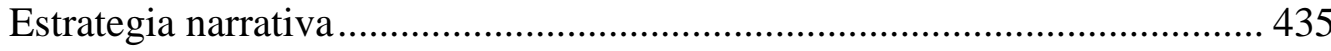

No equivalencia moral entre las víctimas........................................................ 439

Desazón existencial de los excombatientes de las fuerzas armadas................. 441

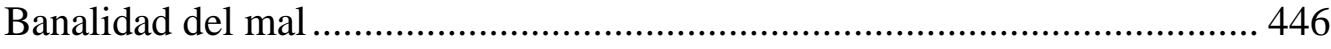

Abuso de poder.................................................................................... 449

Reclutamiento de cuadros senderistas en áreas rurales .................................. 450

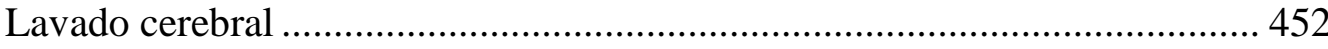

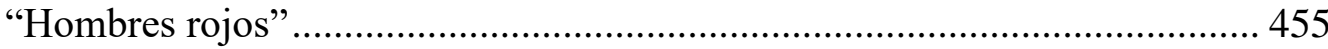

Reclutamiento de cuadros senderistas en áreas urbanas ................................. 456

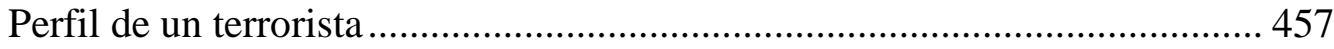

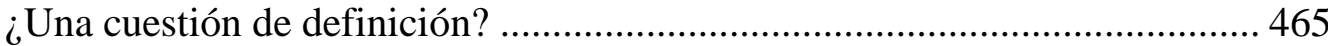

Desengaño de numerosos seguidores de SL................................................... 469

Formación de rondas campesinas y comités de autodefensa ........................... 470

Responsables de las víctimas fatales ............................................................ 472

Inconsecuencia de Abimael Guzmán con la doctrina que proclamaba ........... 474

Desvalorización de la vida humana e impunidad ............................................. 476 
La matanza de la Cantuta .................................................................... 479

Racismo y exclusión socioeconómica: el meollo del problema.................... 483

Situación actual ................................................................................ 485

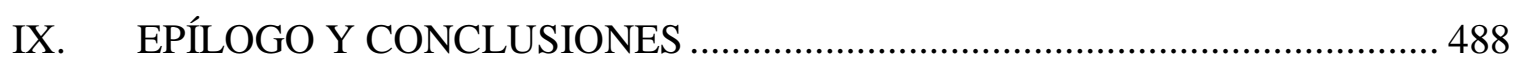

Clamor de justicia de los muertos a través de sus deudos........................... 491

Yuyanapaq (para recordar) y no repetir los errores.................................... 494

El arte como revisión del pasado y dignificación de las víctimas .................. 495

Corpus literario y cinematográfico ........................................................... 496

Ausencia de literatura chicha ..................................................................... 499

Asumir el pasado ................................................................................... 500

Una ventana abierta para otros estudios literarios .................................... 502

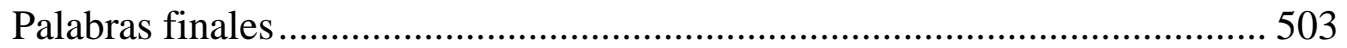

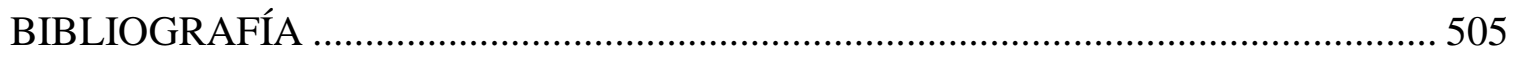

VITA 
1. Alcance de la investigación ................................................................................ 4

2. Las naciones: entidades naturales en oposición a entidades construidas................. 12

3. La nación y los nacionalismos: debate contemporáneo .............................................. 22

4. Pensadores escépticos a la existencia de una nación peruana................................... 45

5. Intersección del etnovaivén y las estrategias del colonizado que identifica Bhabha ………………….......................................................... 102

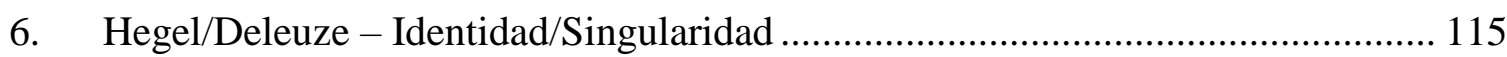

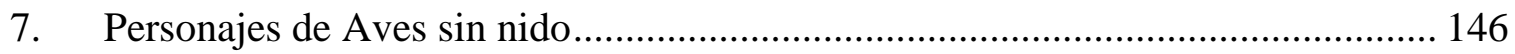

8. Ordenamiento de oposiciones binarias en Aves sin nido,

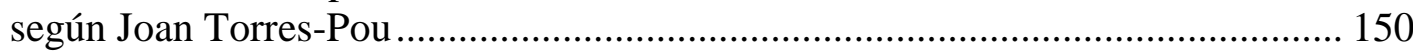

9. Comparación de los postulados de (re)construcción nacional de

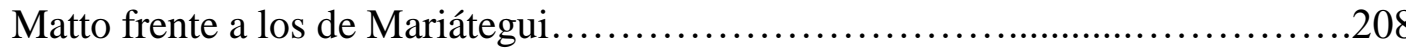

10. Descripción del carácter y del fenotipo de algunos personajes de La violencia del tiempo 


\section{ABREVIATURAS Y SIGLAS}

\begin{tabular}{|c|c|}
\hline AEMINPU & Asociación de la Misión Israelita del Nuevo Pacto Universal \\
\hline B & Blanqueamiento \\
\hline $\mathrm{C}$ & Conclusión \\
\hline $\mathrm{CCH}$ & Cultura chicha \\
\hline CEPAL & Comisión Económica para América Latina y el Caribe \\
\hline $\mathrm{CH}$ & Cholificación \\
\hline CVR & Comisión de la Verdad y Reconciliación \\
\hline EB & Etnobúmeran \\
\hline EPI & El Perú Ilustrado \\
\hline $\mathrm{EV}$ & Etnovaivén \\
\hline FREPAP & Frente Popular Agrícola del Perú \\
\hline HW & Hatun Willakuy: Versión abreviada del Informe Final de la CVR \\
\hline INEI & Instituto Nacional de Estadística e Informática \\
\hline JCM & José Carlos Mariátegui \\
\hline MRTA & Movimiento Revolucionario Túpac Amaru \\
\hline MVLL & Mario Vargas Llosa \\
\hline NN.UU. & Naciones Unidas \\
\hline OEA & Organización de Estados Americanos \\
\hline ONU & Organización de las Naciones Unidas \\
\hline PAP & Partido Aprista Peruano \\
\hline PCP & Partido Comunista Peruano \\
\hline PCP-SL & Partido Comunista Peruano - Sendero Luminoso \\
\hline
\end{tabular}




$\begin{array}{ll}\text { PG } & \text { Pensamiento Gonzalo } \\ \text { RAE } & \text { Real Academia Española } \\ \text { SG } & \text { Sincretismo cultural } \\ \text { SIN } & \text { Singularidad cultural } \\ \text { SL } & \text { Servicio de Inteligencia Nacional del Perú } \\ \text { SR } & \text { Sendero Luminoso } \\ \text { UNESCO } & \text { Organización de NN.UU. para la Educación, Ciencia y Cultura } \\ \text { UNICEF } & \text { Fondo de las Naciones Unidas para la Infancia } \\ \text { UNRISD } & \text { United Nations Research Institute for Social Development }\end{array}$




\section{INTRODUCCIÓN}

Is there a way to talk about making culture without making enemies?

Jean Jackson, 1989

\section{Diáspora andina}

Desde la década de 1940 se ha venido produciendo una inversión en los porcentajes de población rural y población urbana en el Perú. En 1940, apenas el 35\% de la población del país vivía en las ciudades, pero en el año 2007 esta cifra había escalado al 76\%: (INEI, Censos Nacionales de Población y Vivienda). Dicho a la inversa, si dos de cada tres peruanos (65\%) vivían en el campo en 1940, en el 2007 sólo uno de cada 4 (24\%) continuaba viviendo allí. La tendencia hacia el urbanismo es ascendente. ${ }^{1}$ Son dos los principales factores que explican el despoblamiento de los Andes durante el siglo XX: el primero, asociado a la ola migratoria que empezó en los años cuarenta, es la falta de oportunidades y de adecuadas condiciones de vida, en comparación con las que ofrece la costa (aunque tampoco son óptimas). Como consecuencia de la inmigración, Lima pasó de albergar el 8.6\% del total de habitantes del Perú en 1940, al 26\% en 1981 (de Soto, El otro Sendero 8). El segundo factor que ocasionó la diáspora andina fue la Guerra Interna librada entre 1980 y 2000, que constituyó “el episodio de violencia más intenso, más extenso y más prolongado de toda la historia de la República" ( $H W$ 433, C. $\left.\mathrm{N}^{\circ} 1\right)^{2}$ Atrapados entre dos fuegos — el del Partido Comunista del Perú-Sendero Luminoso (PCP-

\footnotetext{
${ }^{1}$ Un fenómeno similar ocurrió en Bolivia en la primera mitad del siglo XX: "La Paz pasó de una población de 40000 habitantes en 1900 a 350000 en 1950. Oruro, la tercera ciudad del país, pasó de 15.000 a 75.000 habitantes en el mismo lapso" (Ari Chachaki , "Construyendo la Ley de Indios" 226).

${ }^{2}$ Hatun Willaky $(H W)$ significa "gran relato" en quechua. Así se titula el Informe Final de la Comisión de la Verdad y Reconciliación (CVR).
} 
SL) y el de las fuerzas represivas del Estado-, los pobladores de los Andes centrales y orientales huyeron masivamente a la costa para salvar sus vidas.

\section{Alcance, relevancia y objetivos del estudio}

En el presente trabajo plasmo los resultados de la investigación que he realizado con el objetivo de demostrar las siguientes hipótesis: 1) en el Perú existe un inextricable vínculo histórico entre mestizaje, racismo, discriminación, inequidad y violencia; 2) el etnovaivén es una de las principales estrategias de resistencia que ha desarrollado el subalterno para defenderse contra la colonialidad; 3) el odio, el resentimiento y la sed de justicia que los peruanos de las clases desfavorecidas (subalternos) habían acumulado a lo largo de varios siglos no sólo propiciaron las circunstancias para que se iniciara la Guerra Interna, sino que, además, contribuyeron de un modo decisivo para que ésta se prolongara durante dos décadas; 4) la diáspora de los habitantes del campo a la ciudad, que ocasionó el despoblamiento de la región andina, es uno de los fenómenos sociales de mayor trascendencia del siglo XX; y 5) todo esto se refleja claramente en su correspondiente impronta literaria. ${ }^{3}$ Con ese propósito he analizado los Comentarios reales (1609) del Inca Garcilaso de la Vega, Aves sin nido (1889) de Clorinda Matto de Turner, Matalaché (1928) de Enrique López Albújar, La ciudad y los perros (1963) de Mario Vargas Llosa (MVLL), Montacerdos (1981) de Cronwell Jara Jiménez, La violencia del tiempo (1991) de Miguel Gutiérrez Correa, y Hienas en la niebla (2010) de Juan Morillo Ganoza, entre otros textos. Tradicionalmente, solían barajarse tres tesis en el discurso de la formación

\footnotetext{
3 "El vencido alimenta en silencio su odio secular; calcula fríamente el interés compuesto de cinco siglos de crueles agravios. ¿Bastará el millón de víctimas blancas? [...] Obseca [sic] el odio” (Valcárcel 24), se preguntaba en 1927 el autor de Tempestad en los Andes. Pero no fue hasta 1980 en que la colonialidad alcanzó un momento crítico y se tradujo en una guerra fratricida que duró 20 años.
} 
de la identidad nacional peruana: 1) la hispanista, que confiere a España el derecho de conquista por haber traído la "civilización" al Perú; 2) la indigenista, que proclama lo andino como el núcleo de la identidad peruana, y 3) la tesis de la hibridez, que considera que el mestizaje racial y cultural son condiciones sine qua non de la peruanidad. Mi trabajo refuta las tres tesis y, en lugar de la metáfora del "crisol de razas" o melting pot, muy popular en los años 1990, que ha probado ser ineficaz, propone un concepto de identidad mosaico, más incluyente, que celebra la diversidad y que acepta la coexistencia armónica de múltiples etnias y grupos culturales dentro de los confines de la nación. ${ }^{4}$

En la literatura peruana es imposible abordar los temas del mestizaje racial/cultural y del indigenismo sin pasar por ciertos referentes obligados, tales como los Comentarios reales y Aves sin nido. Además, analizar la novela de tesis de la autora cusqueña a contrapelo de los 7 ensayos de interpretación de la realidad peruana de José Carlos Mariátegui (JCM) sirve para comparar y contrastar la evolución de algunos postulados de reconstrucción nacional después de la Guerra del Pacífico (1879-1883), que dejó arruinado al Perú. De otro lado, la saga familiar de los Villar en La violencia del tiempo ofrece un recorrido histórico de mestizaje y violencia desde la independencia del Perú de España (1821-1824) hasta 1966 (Galdo, "Un conglomerado" 41). Por otra parte, la novela Matalaché está ambientada en los años previos a la Independencia y trata sobre el amor imposible entre un mulato esclavo y la hija blanca del amo blanco, quien acaba asesinando al osado pretendiente. Este hecho simboliza que ni los mulatos ni los negros tenían cabida en el proyecto nacional republicano que se avizoraba. Luego, Montacerdos

\footnotetext{
${ }^{4}$ La noción de diversidad e hibridez cultural está presente en la novela Todas las sangres (1964) de José María Arguedas y en Escribir en el aire: Ensayo sobre la heterogeneidad socio-cultural de las literaturas andinas (1994) de Antonio Cornejo Polar.
} 
y La ciudad y los perros permiten analizar el racismo y la discriminación en la urbe en contra de los migrantes andinos. ${ }^{5}$ Finalmente, el cotejo Hienas en la niebla con Hatun Willakuy (HW) (2003), el informe de la Comisión de la Verdad y Reconciliación (CVR) sobre la Guerra Interna, permite sacar valiosas conclusiones sobre las terribles consecuencias del racismo, de la postergación social, así como del odio y el resentimiento generados por la colonialidad (concepto de Quijano y Wallerstein).

Las obras primarias que he seleccionado cubren alrededor de 600 años de historia del Perú, desde la época preincaica hasta, aproximadamente, mediados de la década de 1990. El siguiente cuadro muestra estas obras y los períodos o hitos históricos en que están ambientadas: ${ }^{6}$

\begin{tabular}{|c|c|c|c|}
\hline \multicolumn{4}{|c|}{$\begin{array}{c}\text { Cuadro } \mathrm{N}^{\circ} 1 \\
\text { Alcance de la investigación }\end{array}$} \\
\hline \multicolumn{2}{|r|}{ PERÍODOS } & \multicolumn{2}{|c|}{ OBRAS PRIMARIAS } \\
\hline Antes de 1532 & Preincaico e incaico & \multirow{2}{*}{ Comentarios reales } & \\
\hline 1532 & Invasión & & \\
\hline $1532-1821$ & Resistencia a la imposición & \multirow{2}{*}{ Matalaché } & \multirow{6}{*}{$\begin{array}{l}\text { La violencia } \\
\text { del tiempo }\end{array}$} \\
\hline $1821-1824$ & Independencia & & \\
\hline $1789-1883$ & Guerra del Pacífico & Aves sin nido & \\
\hline \multirow{2}{*}{$1940-2000$} & \multirow{2}{*}{ Diáspora andina } & Montacerdos & \\
\hline & & La ciudad y los perros & \\
\hline $1980-2000$ & Guerra Interna & Hienas en la niebla & \\
\hline
\end{tabular}

\footnotetext{
${ }^{5}$ Patíbulo para un caballo, de Cronwell Jara, es la continuación de Montacerdos. En mi trabajo aludo constantemente a Patíbulo para una mejor comprensión de Montacerdos.

${ }^{6}$ Suscribo las respectivas propuestas de Carlos García Bedoya (Para una periodización 60-95) y de Gonzalo Portocarrero (La urgencia 328-9) de periodizar la historia desde la perspectiva americana para no secundar el discurso eurocéntrico. Por lo tanto, en el desarrollo de este trabajo algunas veces me referiré al Descubrimiento como Encuentro, a la Conquista como Invasión, y al Coloniaje como Resistencia a la imposición.
} 
En las referidas obras primarias analizo estrategias de resistencia que ha desarrollado el subalterno para sobrevivir a la colonialidad y también para subvertirla. Con este propósito me he servido de la teoría poscolonial, especialmente la de Homi K. Bhabha, y de la teoría literaria en general, así como de obras secundarias y ensayos críticos que me han permitido identificar algunos de los pilares sobre los que se apoyan ciertas singularidades o identidades que unen a algunos compatriotas y que, a la vez, desunen a otros. Como resultado de este análisis, he podido precisar que la singularidad cultural del subalterno peruano se manifiesta a través de la llamada "cultura chicha", la cual se forja en algún punto del trayecto pendular entre el etnovaivén y el etnobúmeran (otro concepto que he acuñado), y viceversa.

El presente estudio es tanto relevante como pertinente porque se intersecta con los debates contemporáneos sobre la formación de la identidad nacional. También es útil porque la Dinámica etnovaivén-etnobúmeran constituye un modelo epistemológico de teoría poscolonial ad hoc que explica la singularidad/identidad cultural del subalterno peruano (con la posibilidad de adaptar este modelo a otras sociedades similares). Por otro lado, este trabajo ayuda a comprender las secuelas de la violencia política, un fenómeno que periódicamente resurge y amenaza la vida de los peruanos. El número de muertos, la vesania y la violencia, la diáspora, el perjuicio económico y los consiguientes traumas ocasionados por la Guerra Interna han repercutido para siempre en la cotidianidad de todos los peruanos: "No hay nadie que no se vea afectado por la guerra $[\ldots]$ y como quiera que ella compromete a todos los sectores del país [...] es necesario estudiarla" (Fernández Salvatteci, Terrorismo 8). Finalmente, y esto es lo más importante, la crueldad de unos y el instinto de supervivencia de otros ha alterado la escala de valores 
de nuestros compatriotas en cuanto al respeto por la vida. Como consecuencia, las secuelas psicosociales del terror, del temor y de la angustia han devenido en una hiperbólica desconfianza hacia los connacionales. "No somos los mismos" han declarado con lucidez a la CVR algunas de las víctimas más seriamente afectadas (CVR (HW 354). Demás está decir que esta situación debe ser revertida para que sea posible construir una verdadera y sólida identidad nacional.

Invito al lector a que, durante la lectura de este trabajo, reflexione sobre las siguientes interrogantes e intente responderlas: ¿Cuáles son los lazos que unen a los peruanos en una nación? ¿Cómo hacer para integrar en una sola nación a un pueblo tan disímil como el peruano? ¿Puede construirse una identidad nacional sin justicia social? ¿Es la justicia social una utopía en el caso del Perú? ¿Es la identidad nacional una mera construcción cultural o, por el contrario, está basada en un sustrato étnico-cultural premoderno? ¿Es esto relevante? ¿Es imprescindible que un país tenga una identidad nacional para ser capaz de desarrollarse? ¿Cuáles son las ventajas y desventajas de fijar un patrón de identidad nacional? De hacerlo, ¿quiénes serían incluidos y quiénes no se ajustarían a dicho patrón? ¿Existen formas de integración nacional alternativas a la identidad nacional? ¿De qué manera están cumpliendo la literatura y el cine peruanos la responsabilidad de integrar a la nación? ¿Tienen la responsabilidad de hacerlo?

En junio de 1946, André Breton pronunció las siguientes palabras en una velada en homenaje a Antonio Artaud, quien acababa de salir del manicomio de Rodez: "Me parece motivo de burla toda forma de compromiso que no llegue a este objetivo triple e indivisible: transformar el mundo; cambiar la vida; rehacer, completamente, el entendimiento humano" (Gnecco, "De la arqueología" 26). Por mi parte, aspiro únicamente 
a que, en los textos analizados, el lector identifique las estrategias de resistencia que ha desarrollado el subalterno peruano y la manera en que, como resultado de alternar entre dos posturas opuestas — el etnovaivén y el etnobúmeran — se han forjado en él ciertas singularidades culturales que expresa mediante la cultura chicha.

\section{Contenido y metodología}

Si bien el enfoque principal de este trabajo es literario, la gran complejidad que reviste el tema de la identidad cultural exige, necesariamente, que la literatura se intersecte con otros campos del conocimiento; principalmente con la sociología, la antropología, la lingüística, la filosofía y la historia. He dividido este volumen en una introducción, ocho capítulos adicionales (II-VIII), y un epílogo con las conclusiones (IX). Todos los capítulos y subcapítulos pueden subsistir como ensayos independientes, pero su secuencia y yuxtaposición forman un todo armónico de unidad y continuidad que les confiere cierta sinergia semántica.

En el capítulo II, "La nación: marco teórico y estado del debate”, resumo la evolución del marco teórico sobre los conceptos de nación y nacionalidad, y expongo el estado actual del debate entre modernistas, primordialistas y aquellos que, como Anthony D. Smith, adoptan una postura ecléctica llamada etnosimbolismo histórico. ${ }^{7}$ El capítulo III, "Singularidad cultural del subalterno peruano", comprende dos subcapítulos. En el primer subcapítulo, “Antecedentes históricos", hago un recuento de algunos hitos trascendentales en la historia del Perú, tales como la instalación de las primeras encomiendas, la Guerra del Pacífico, la Revolución de Trujillo, etcétera. Esta

\footnotetext{
${ }^{7}$ He publicado una gran parte del contenido de este capítulo en "Literaturas y comunidades imaginadas de Mariátegui”. Argus.a 5.20 (2016): 1-25.
} 
información facilita la comprensión del contexto en el que están ambientadas las novelas que analizo. En el segundo subcapítulo expongo la dinámica etnovaivén-etnobúmeran, que es la parte medular de esta tesis. Allí explico que la singularidad del subalterno peruano, que se expresa mediante la cultura chicha, se fragua en algún punto intermedio entre el etnovaivén y etnobúmeran, las dos posturas antagónicas que, alternadamente, suele adoptar el subalterno. Asimismo, comento las principales estrategias de resistencia que ha desarrollado el subalterno peruano.

En el cuarto capítulo, "Postulados de (re)construcción nacional", cotejo algunos planteamientos que Clorinda Matto de Turner hace en su novela de tesis Aves sin nido (1889) a la luz de ideas afines que JCM expone en sus 7 ensayos de interpretación de la realidad peruana (1928). Contrasto, específicamente, la necesidad de instruir al pueblo que plantea Matto con la necesidad de agencia que reclama JCM para el indígena. Como fórmula conciliatoria, propongo rescatar la ancestral vocación cooperativista de los peruanos, que proviene del ayllu, para propiciar escenarios en donde sea posible la convivencia armónica del "saber" y del "poder".

El capítulo V, “Mestizaje: ¿La solución insoluble?”, está dividido en dos subcapítulos: "El Inca Garcilaso desde el escepticismo" 8 y "Sin guitarra ni cajón en el proyecto nacional: Matalachê". Mientras que el primer ensayo me da la oportunidad de problematizar la teoría que propone el mestizaje racial y cultural (de indígena con blanco) como la base de la identidad nacional, el segundo me permite mostrar que el mulato (negro con blanco) - y, por extensión, el negro "puro"-no estaba incluido en el

\footnotetext{
${ }^{8}$ Publicado en Inca Garcilaso de la Vega: 400 Aniversario. Comp. José Beltrán Peña. Lima, Gaviota Azul Editores, 2016.46-88.
} 
proyecto nacional cuando el Perú se hallaba ad portas de independizarse de España. Las obras primarias que analizo en este capítulo son Comentarios reales y Matalaché.

El capítulo VI, "Injusticia, racismo, discriminación y violencia", tiene un título autodescriptivo e incluye dos subcapítulos: “Montacerdos (1981) de Cronwell Jara: seres inmortales en la barriada peruana" y "La ciudad y los pelos: la representación del indígena peruano en La ciudad y los perros (1963) de Mario Vargas Llosa". ${ }^{10}$ Para analizar Montacerdos, comparo y contrasto esta novela con Patíbulo para un caballo (1989), del mismo autor, que es la continuación narrativa de las peripecias de una familia provinciana que se instala en una barriada limeña. Por otro lado, en el subcapítulo $L a$ ciudad y los pelos centro mi análisis en el personaje de Porfirio Cava, un indígena que reside en Lima y estudia en la Escuela Militar Leoncio Prado, en donde es humillado por sus compañeros. Aquí reviso los términos "indio", "serrano" y "cholo" desde el punto de vista sociológico, histórico y lingüístico, así como su correspondiente impronta literaria en la novela en cuestión, que inaugura el boom latinoamericano.

En el capítulo VII, "Causas de la violencia: inequidad sociopolítica y socioeconómica, racismo, odio y rencor", analizo La violencia del tiempo. Esta novela trata sobre la estirpe mestiza de los Villar desde la unión del patriarca español y de una india tallán hasta el último de la estirpe, quien se niega a tener descendencia para, de esa manera, ponerle punto final a su sangre mezclada. Este capítulo, que calza con mi ensayo "Desde Martín Cortés hasta Martín Villar: el mestizaje como estigma en La violencia del tiempo (1991) de Miguel Gutiérrez Correa", me permite explicar la relación que existe en

\footnotetext{
${ }^{9}$ Publicado en Palabra en Libertad 18.156 (2016) 15-34.

${ }^{10}$ Publicado en Argus-a 6.24 (2017): 1-27.
} 
el Perú entre mestizaje y violencia, un vínculo fatídico que, en mi opinión, desencadenó finalmente en la Guerra Interna. ${ }^{11}$ Como puede anticiparse, la novela de Gutiérrez es escéptica con respecto al mestizaje como fórmula conciliadora y, por lo tanto, es diametralmente opuesta al planteamiento armonioso del Inca Garcilaso de la Vega con respecto a la hibridez racial y cultural.

En el capítulo VIII, “Dos décadas de violencia y terror”, intento reflexionar sobre el tipo de ideología y de líderes con los que se identifica un grupo de peruanos, como es el caso de Diego de la Cruz, el protagonista de Hienas en la niebla (2010). Los conflictos ético-morales de este personaje dan pie a este análisis. Adicionalmente, comparo el contenido de la novela de Morillo con lo reportado por la CVR en su Informe Final (Hatun Willakuy, 2008), lo que ha permitido validar la ficción con la realidad. Para mi sorpresa, la segunda produce más espanto que la primera. ${ }^{12}$

Por último, en el Epílogo resumo los aspectos más importantes que he analizado, expongo las conclusiones a las que he llegado, hago énfasis en la importancia de preservar la memoria histórica a través del arte, e invito a otros intelectuales a que investiguen sobre algunos temas afines que exceden el alcance del presente trabajo; específicamente, a que indaguen por qué la literatura chicha es prácticamente inexistente, y si es posible agrupar a cinco autores (tres de los cuales forman parte de este ensayo) bajo una generación literaria que habría surgido en un momento clave en la génesis de la identidad cultural contemporánea de los peruanos.

\footnotetext{
${ }^{11} \mathrm{El}$ factor racial no formó parte del discurso del bando insurgente. Se trataba de una lucha de clases.

${ }^{12}$ Publicado en Argus-a 5.21 (2016): 1-20.
} 


\section{LA NACIÓN: MARCO TEÓRICO Y ESTADO DEL DEBATE}

Recordé que un antropólogo no puede pensar que sabe más que su informante, sino que aprende de éste; lo difícil para mí entonces era saber qué estaba aprendiendo

Elisenda Ardèvol ("El relato etnográfico")

Tradicionalmente, la nación era percibida como una entidad natural que había existido desde siempre, algo similar al concepto de familia (Smith, The Ethnic Origins 7). Esta percepción "primordialista" empezó a ser cuestionada en la década de los sesenta del siglo XX, cuando los estudios étnicos pusieron en duda que las naciones y los nacionalismos hubiesen surgido de manera espontánea en la antigüedad. Por el contrario, algunos audaces académicos planteaban que se trataba de construcciones culturales modernas. En The Idea of Nationalism: A Study in Its Origins and Background (1944) Hans Kohn hace una distinción entre pensadores voluntaristas, quienes conciben la nación como una entidad que resulta de la asociación libre y voluntaria de sus miembros, y pensadores orgánicos, para quienes la etnicidad es una parte esencial del ser humano (Smith, The Ethnic Origins 210) y la nación es un organismo que los signa desde que nacen hasta que mueren (Smith, Nationalism and Modernism 146). De lo anterior, puede inferirse que los pensadores modernistas, que tienen una visión voluntarista, son construccionistas. De otro lado, los pensadores con una visión orgánica se subdividen en primordialistas y en perennialistas. Los primeros sostienen que la nación y los nacionalismos son eternos (perennial) y naturales (Smith, The Ethnic Origins 12), en tanto que para los segundos los lazos étnicos y los sentimientos que dan origen a la nación y los nacionalismos son inmemoriales - por lo tanto, surgieron en el pasado premoderno (ibíd. 13) - y son universales. Anthony D. Smith califica a los modernistas 
de "heracliteanos" a los primordialistas y perennialistas de "parmenidianos" (ibíd. 210) y señala que "[t]he paradox of ethnicity is its mutability in persistence, and its persistence through change" (ibid. 33).

El siguiente cuadro resume las visiones en cuanto a la naturaleza de la nación:

\begin{tabular}{|l|l|}
\hline \multicolumn{2}{|c|}{ Las naciones: entidades naturales en oposición a entidades construidas } \\
\hline \multicolumn{1}{|c|}{ Visión orgánica ("parmenidiana") } & \multicolumn{1}{|c|}{ Visión voluntarista ("heracliteana”) } \\
\hline $\begin{array}{l}\text { La etnicidad es una parte esencial del ser } \\
\text { humano }\end{array}$ & La etnicidad es una construcción artificial \\
\hline La etnicidad es relativamente estática & $\begin{array}{l}\text { La etnicidad es muy cambiante } \\
\text { (dinámica) }\end{array}$ \\
\hline Las naciones son universales & [El concepto de nación es variable] \\
\hline $\begin{array}{l}\text { Las naciones son entidades naturales, } \\
\text { eternas o inmemoriales }\end{array}$ & $\begin{array}{l}\text { Las naciones son construcciones } \\
\text { culturales }\end{array}$ \\
\hline Las naciones surgieron en la antigüedad & $\begin{array}{l}\text { Las naciones surgieron entre mediados y } \\
\text { finales del siglo XVII }\end{array}$ \\
\hline \multicolumn{2}{|l|}{. } \\
\hline $\begin{array}{l}\text { Fuentes: Smith, Anthony D. The Nation in History. Hanover, NH: U.P. of New England, 2000. 2-3; } \\
\text { Smith, The Ethnic Origins of Nations, 1986. Oxford: Blackwell, 2005. 2010. }\end{array}$ \\
\hline
\end{tabular}

\section{Visión voluntarista}

En la conferencia titulada “¿Qué es una nación?”, que Ernest Renan (1823-1892) dio en la Sorbona el 11 de marzo de 1882 con motivo del sentimiento nacionalista que había nacido en Francia a raíz de la Revolución francesa (1789-1799), el filósofo e historiador galo postulaba que, si bien las fronteras de una patria, la raza, la lengua y la religión eran elementos que solían considerarse marcadores diferenciales entre las naciones, ninguno de ellos era condición sine qua non para definir a una nación. Para Renan era la herencia cultural compartida (un anclaje en el pasado) y el compromiso de mantenerla (un anclaje 
en el presente con visión de futuro) lo que realmente mantenía unidos a los integrantes de un pueblo:

Une nation est une âme, un principe spirituel. Deux choses qui, à vrai dire, n'en font qu'une, constituent cette âme, ce principe spirituel. L'une est dans le passé, l'autre dans le présent. L'une est la possession en commun d'un riche legs de souvenirs; l'autre est le consentement actuel, le désir de vivre ensemble, la volonté de continuer à faire valoir l'héritage qu'on a reçu indivis. ${ }^{13}$ (III)

En esa conferencia Renan añade que la nación es un plebiscito cotidiano: "L'existence d'une nation est $[\ldots]$ un plébiscite de tous les jours, comme l'existence de l'individu est une affirmation perpétuelle de vie" (III). ${ }^{14}$ Lo que más destaca en el pensamiento de Renan es el voluntarismo que asocia al proceso de construcción de la nación. Siguiendo a Renan, Adrian Hastings sostiene que, para que una nación se separe de otra, basta que una gran cantidad de personas, que no son parte de la élite gobernante, lo consideren de esa manera y que se comporten como tal (en Smith, The Nation in History 51-2). ${ }^{15}$ ¿Qué porcentaje o cantidad de personas? es la pregunta que surge de inmediato y se la hace el propio Smith, problematizando esta postura.

\footnotetext{
13 "Una nación es un alma, un principio espiritual. Dos cosas que no forman sino una, a decir verdad, constituyen esta alma, este principio espiritual. Una está en el pasado, la otra en el presente. Una es la posesión en común de un rico legado de recuerdos; la otra es el consentimiento actual, el deseo de vivir juntos, la voluntad de continuar haciendo valer la herencia que se ha recibido indivisa" (Renan, "¿Qué es una nación?”. Ed. digital: Franco Savarino, 2004).

14 "La existencia de una nación es (perdonadme esta metáfora) un plebiscito cotidiano, como la existencia del individuo es una afirmación perpetua de vida" (Renan, “¿Qué es una nación?”. Ed. digital: Franco Savarino, 2004).

${ }^{15}$ Hastings, Adrian. The construction of nationhood: Ethnicity, religion, and nationalism, 1997.
} 


\section{Comunidades imaginadas}

En Comunidades imaginadas: Reflexiones sobre el origen y la difusión del nacionalismo

(1983), Benedict Anderson postula que la nación es una comunidad imaginada. El politólogo irlandés había captado el aspecto volitivo que otros pensadores, como Ernest Renan (“¿Qué es una nación?, 1882) y Hugh Seton-Watson (Nations and States, 1977), ya habían advertido en los miembros que conforman las naciones. Por ejemplo, SetonWatson sostiene que una nación existe cuando, en una comunidad, un número significativo de miembros considera que forma parte de una nación, "o se comportan como si así ocurriera" (Nations and States 5; en Anderson 23).

Según Anderson, la nación es una comunidad imaginada, debido a que, entre otras cosas, “aun los miembros de la nación más pequeña no conocerán jamás a la mayoría de sus compatriotas, no los verán ni oirán siquiera hablar de ellos, pero en la mente de cada uno vive la imagen de su comunión” (ibíd. 23). ${ }^{16}$ Carlos Iván Degregori interpreta el concepto de Anderson de la siguiente manera: "A diferencia de las comunidades aldeanas, por ejemplo, no todos se conocen personalmente, pero se reconocen como miembros de un mismo Nosotros, de una misma comunidad", y esto se produce porque “en algún momento [esas comunidades] fueron imaginadas por alguien, generalmente por algún núcleo de intelectuales en el sentido amplio de la palabra", que teniendo en mente un proyecto nacional, "imagina el perfil de una nación todavía inexistente o en construcción” ("Perú: identidad” 214). Empero, piensa Degregori, “[h]abría que añadir

\footnotetext{
${ }^{16}$ Anderson afirma que, además, "[1]a nación se imagina limitada porque incluso la mayor de ellas [...] tiene fronteras finitas, aunque elásticas, más allá de las cuales se encuentran otras naciones" (24-5), y "[s]e imagina soberana porque el concepto nació en una época en que la Ilustración y la Revolución estaban destruyendo la legitimidad del reino dinástico jerárquico, divinamente ordenado" (25).
} 
que el perfil de esas 'comunidades imaginadas' puede variar con el transcurso del tiempo, e incluso pueden haber diferentes proyectos en competencia simultáneamente" (ibíd. 214).

Por lo menos un año antes de que Anderson publicara Comunidades imaginadas, Ángel Rama comprendía con gran lucidez la naturaleza artificiosa del concepto de nación: ${ }^{17}$ "La construcción de la ciudad futura [se refiere las naciones de las repúblicas nacientes en América Latina, en el siglo XIX] no fue menos obra del deseo y la imaginación [énfasis mío] ${ }^{18}$ [...] que la construcción de la ciudad pasada, salvo que ésta pudo ser engalanada con el discurso del realismo decimonónico" (La ciudad letrada 99). Es decir, las naciones-repúblicas son el producto de la voluntad de sus creadores y, como tales, son una fabricación. Rama dice enseguida: "Por lo cual es imprudente manejar como referencias históricas rigurosas, las que aparecen en la multitud de libros [...] Más adecuado es leerlos [sic] como la parsimoniosa edificación de modelos culturales que quieren establecer una nueva época” (ibíd. 99). Las naciones-repúblicas no son sólo modelos culturales basados en su pasado histórico, sino principalmente modelos que han sido construidos por el discurso: "Su fundamental mensaje no se encontrará en los datos evocativos, sino en la organización del discurso [...], en el tenaz esfuerzo de significación de que es capaz la literatura" (ibíd. 99). En la misma línea de pensamiento de Rama, Hayden White sostiene que es prácticamente imposible distinguir entre historiografía y literatura (Figural Realism: Studies in the Mimesis Effect, 1999). Más adelante prosigue Rama: “Un sueño en el futuro, un sueño en el pasado, y sólo palabras e

\footnotetext{
${ }^{17}$ La ciudad letrada (1984) fue publicada de manera póstuma, al año siguiente del fallecimiento de Rama.

${ }^{18}$ En esta cita, todas las palabras que aparecen destacadas en letra cursiva se deben al énfasis que deseo darles.
} 
imágenes para excitar el soñar. (ibid. 99-100). Lo soñado (la nación-república idealizada) en oposición a lo real y el discurso historiográfico/literario para representarlo.

Sin intención de restarle ningún mérito a los referidos autores y, en particular, a Anderson, es necesario señalar que, más de medio siglo antes de que se publicara Comunidades imaginadas, JCM ya intuía la nación como una construcción cultural (Otero Luque, "Literaturas y comunidades imaginadas de Mariátegui" 18). En sus 7 ensayos de interpretación de la realidad peruana (1928), al comentar sobre historiografía literaria y cuestionar la legitimidad de una literatura auténticamente nacional, el Amauta subraya la naturaleza abstracta de la idea de nación: ${ }^{19}$

En la historiografía literaria, el concepto de literatura nacional del mismo modo que no es intemporal, tampoco es demasiado concreto. No traduce una realidad mensurable e idéntica. Como toda sistematización, no aprehende sino aproximadamente la movilidad de los hechos (La nación misma es una abstracción, una alegoría, un mito, que no corresponde a una realidad constante y precisa, científicamente determinable) [énfasis mío]. (170)

No obstante, mientras que JCM apenas esboza el concepto de comunidades imaginadas, Anderson, por el contrario, sí lo desarrolla y lo explica en detalle en su obra capital, con la que revolucionó la noción que, hasta los años ochenta del siglo XX, se tenía acerca de la naturaleza y la edad de las naciones y los nacionalismos.

Resaltar el hecho de que JCM vislumbró precozmente la nación como una construcción cultural no tiene por finalidad insertarlo en el debate posmoderno, pues

\footnotetext{
${ }^{19}$ Amauta significa "sabio" o "maestro" en quechua. Amauta se llamaba la revista que JCM fundó en 1926. Por antonomasia, JCM se convirtió en el Amauta (en mayúscula) peruano.
} 
hacerlo sería anacrónico. Mi intención es mostrar que, de la misma manera en que "el nacionalismo debe entenderse alineándolo $[\ldots]$ con los grandes sistemas culturales que lo precedieron (Anderson, Comunidades imaginadas 30), ${ }^{20} \mathrm{JCM}$ concibió la nación de esa manera como resultado de la confluencia de factores y circunstancias en momentos y lugares específicos, de la misma manera en que la Revolución rusa de 1917, el fin de la Primera Guerra Mundial (1918) y la propagación de ideas marxistas en el Perú (con las que se intentaba explicar la situación socioeconómica del indígena) le sirvieron de combustible al surgimiento de un fervor indigenista (Veres, "El problema de la identidad nacional en la obra de José Carlos Mariátegui” 1). La noción que tenía JCM de que la nación es una comunidad imaginada debió esperar 55 años para que, en otra coyuntura propicia, que Anderson supo interpretar, pudiera difundirse, refinarse, convertirse en una nueva cosmovisión y, finalmente, cuajar en la intelligentsia.

\section{Visión modernista (construccionsita)}

Los modernistas sostienen que las naciones y los nacionalismos surgieron en la segunda mitad del siglo XVII (Smith, The Ethnic Origins 8) sobre una base económica que se creó en el siglo XVI con el expansionismo de algunos Estados, tales como Holanda, España, Inglaterra y Francia (ibíd. 9). Además, según Ernest Gellner, el Estado moderno era el único esquema capaz de desarrollar la homogeneidad cultural necesaria para que pudiera funcionar una sociedad industrial (Nations and Nationalism, 1983). Para Gellner, "[m]odern industry requires a mobile, literate, technologically equipped population and

\footnotetext{
${ }^{20}$ En su apogeo, la comunidad religiosa y el reino dinástico eran marcos de referencia "que se daban por sentados, como ocurre ahora con la nacionalidad" (Anderson, Comunidades imaginadas 30).
} 
the modern state is the only agency capable of providing such a work-force through its support for a mass, public, compulsory and standardized education system" (Smith, The Ethnic Origins 10). En otras palabras, a diferencia de lo que ocurría en las sociedades agrarias premodernas (pre-modern 'agro-literate' societies) — cuyas élites y masas productoras de alimentos "were always separated along cultural lines, and this type of society is unable to generate an ideology which could overcome this divide"-, las sociedades industriales requerían que los trabajadores compartieran la misma lengua y cultura para que pudieran comunicarse y desempeñarse con eficiencia. Por este motivo, se fomentó la homogeneidad mediante la cultura de masas o mainstream, lo que, a la vez, permitió el surgimiento de ideología, de nacionalismos.

Para otra escuela de modernistas, las naciones y los nacionalismos tienen un sustrato más político, considerando que, a pesar de sus diferencias internas, las comunidades étnicas demarcadas dentro de las fronteras de los referidos Estados se habrían prestado para que las élites, apelando a los símbolos étnicos que las identifican e individualizan, las comprometan bajo un solo estandarte en favor de la consecución de los objetivos de riqueza, poder y prestigio de dichas élites (Smith, The Ethnic Origins 9): ${ }^{21}$ Los incas emplearon un estrategia similar con los pueblos que fueron anexando al Imperio.

${ }^{21}$ Smith menciona a los siguientes académicos de la corriente modernista: Benedict Anderson, Paul Brass, John Breuilly, Anthony Giddens, Michael Hechter, Hermann Heller, Eric Hobsbawn, Miroslav Hroch, Elie Kedourie, Tom Nairm, Charles Tilly (Nationalism and Modernism 224). 


\section{Modernistas-instrumentalistas}

Los modernistas-instrumentalistas afirman que las naciones son el producto de un conjunto de actitudes y creencias que varían con el paso del tiempo, según las circunstancias. Para ellos, la representación del pasado colectivo-real, percibido o inventado - tendría como principal propósito satisfacer intereses y necesidades del presente (instrumentalismo). Smith no cree en el perennialismo de las naciones ni tampoco que éstas sean exclusivamente el producto de la modernidad. Él admite que los mitos, los recuerdos, los símbolos y los valores generalmente pueden ser adaptados a nuevas circunstancias, al dotarlos de nuevos significados y funciones (The Ethnic Origins $3)$.

Sin embargo, a Smith le resulta perturbadora su función netamente instrumentalista, porque le parece que tratar los hechos del pasado como un surtido de dulces que se eligen y se mezclan a voluntad socava la integridad de la empresa historiográfica (Chosen Peoples 168). Por lo tanto, es preferible pensar que la identidad cultural es moldeada por la memoria compartida, la cual, aunque sea también una construcción cultural— ¿qué hecho o fenómeno social no lo es en esencia?—, constituye el producto de un proceso muy prolongado a lo largo de mucho tiempo (la llamada "longue durée"). Así, pues, este tipo de memoria rebasaría ampliamente los límites de lo que comúnmente se entiende por un constructo utilitario.

Por mi parte, pongo en duda que la cosmovisión (Weltanschauung), la idiosincrasia (Volksgeist), el alma grupal (Volksseele) del ayni, el panteísmo o mente universal (Weltgeist) del ayllu, las tradiciones, los ideales, las creencias y los valores compartidos (Zeitgeist) con los que los peruanos nos identificamos actualmente y que nos 
proporcionan la sensación de pertenencia sean exclusivamente el producto de la manipulación del poder hegemónico para explotar a los grupos subalternos y mantener el statu quo.

\section{Etnosimbolismo histórico}

Smith refuta la propuesta primordialista de que la nación y los nacionalismos son naturales, así como la postura perennialista implícita de que los lazos étnicos son universales. Dice Smith que, si se acepta que las naciones y los nacionalismos son naturales, hay que aceptar también que son perennes, mas esta premisa pierde su lógica si se plantea a la inversa, porque es posible que las naciones y los nacionalismos hayan existido desde siempre sin ser, necesariamente, naturales (en el sentido en que lo serían, por ejemplo, la geografía o el idioma) (The Ethnic Origins 12).

Smith se adscribe a la corriente de pensamiento llamada etnosimbolismo histórico- que comparte, por ejemplo, con John Hutchinson (Dynamics of Cultural Nationalism, 1987) y con John A. Armstrong (Nations before Nationalism, 1982)—, la cual adopta una posición ecléctica entre voluntaristas y orgánicos: "[N]either a Parmenidean belief in the immutability and fixity of things, nor a Heraclitan commitment to eternal flux, can do justice to the variety and complexity of ethnic phenomena and to the recurrence and persistence of ethnic ties and sentiments" (Smith, The Ethnic Origins 211). Esta corriente considera que las comunidades étnicas precedieron a las nacionesconstrucciones culturales modernas - y son su fundamento (ibid. x), y que una particular configuración histórica de mitos, recuerdos, símbolos y valores diferencian a unas etnias de otras; es decir, definen su identidad: "[T]he core of ethnicity, as it has been transmitted 
in the historical record and as it shapes individual experience, resides in this quartet of 'myths, memories, values and symbols' and in the characteristic 'shape' or structure of such ethnie" (ibíd. 15). Ideológicamente, el etnosimbolismo histórico también se distancia de la visión organicista y se ubica próximo al constructivismo modernista, mas sin caer en el instrumentalismo que, prácticamente, ignora el pasado: "While we can no longer regard the nation as a given of social existence, a 'primordial' and natural unit of human association outside time, neither can we accept that it is a wholly modern phenomenon" (ibíd. 3).

\section{Debates sobre la nación y el nacionalismo}

De acuerdo con Smith, desde el punto de vista historiográfico los debates sobre la nación y el nacionalismo pueden resumirse en cuatro paradigmas: 1) primordialista, 2) perennialista, 3) modernista y 4) etnosimbolista. Estos paradigmas ofrecen diversas definiciones de los términos clave de nación y nacionalismo, e interpretan de manera muy distinta los temas en cuestión) que, para Smith, se circunscriben a tres: 1) la naturaleza y el origen de la nación y los nacionalismos, 2) cuándo surgieron, y 3) el rol que han jugado en la historia (The Nation in History 3)' De otro lado, Eric G.E. Zuelow incluye las definiciones entre los temas en debate y para él también es importante dilucidar si las naciones y los nacionalismos son o no endémicos, o si surgieron por "contagio" del Occidente al Oriente ("What is Nationalism"). Zuelow considera que, "[i]f nations are naturally occurring, then there is little reason to explain the birth of nations. On the other hand, if one sees nations as constructed, then it is important to be able to explain why and how nations developed" ("What is Nationalism?"). Por ejemplo, mientras que los 
primordialistas intentan explicar los sentimientos que hacen que algunas personas estén dispuestas a sacrificarse por su nación, los perennialistas quieren entender el papel que han jugado los vínculos étnicos en la historia de la humanidad en cuanto al desarrollo de sentimientos nacionalistas (Smith, Nationalism and Modernism 223-4).

El siguiente cuadro es mi interpretación gráfica de los debates que, de acuerdo con Smith, existen en relación con las naciones y los nacionalismos, así como de las posturas de las diferentes corrientes de pensamiento con respecto estos temas:

\begin{tabular}{|c|c|c|c|}
\hline \multicolumn{4}{|c|}{ La nación y los nacionalismos: debate contemporáneo } \\
\hline Temas: & \multicolumn{2}{|c|}{ Visión organicista } & Visión voluntarista \\
\hline \multirow{2}{*}{ Su naturaleza y origen } & Primordialista & Construccionista \\
\cline { 2 - 4 } & Perennialista & Etnosimbolista & Construccionista \\
\hline \multirow{2}{*}{$\mathrm{Su}$ antigüedad } & Perennialista & Etnosimbolista & $\begin{array}{c}\text { Construccionista } \\
\text { (vertiente modernista) }\end{array}$ \\
\hline Su papel en la historia & \multicolumn{3}{|c|}{ Cohesión } \\
\hline \multicolumn{4}{|c|}{ Instrumental } \\
\hline $\begin{array}{l}\text { Fuente: Smith, Anthony D. The Nation in History: Historiographical Debates about Ethnicity and } \\
\text { Nationalism. Hanover, NH: U.P. of New England, 2000. 2-3. }\end{array}$ \\
\hline
\end{tabular}

En mi opinión, habría que propiciar un debate separado para discutir temas afines al de la nación y los nacionalismos, pero vinculados a las grandes civilizaciones premodernas, una de las cuales fue la inca.

\section{Nacionalidad, nacionalismo y otredad}

Para Carlton J.H. Hayes, "la nacionalidad recibe su carácter, su signo distintivo, su individualidad, más frecuentemente de fuerzas culturales e históricas [énfasis mío] que de su estirpe biológica o de su geografía física" (El nacionalismo 3-4). El lenguaje y las tradiciones históricas - es decir, la "acumulación de experiencias, vividas o imaginadas, 
que difieren en contenido y motivaciones de un grupo lingüístico a otro" son los elementos constitutivos de la nación y son las bases culturales de la nacionalidad. Entre las tradiciones y los fundamentos históricos, Hayes identifica varios tipos de pasado: religioso, territorial, político, guerrero, industrial y económico, y el cultural (ibíd. 5-7). En el Imperio de los incas, los guardianes de la memoria colectiva-que abarca el pasado religioso, político, guerrero, industrial, económico y cultural-eran los quipucamayus (narradores), los amautas (maestros o filósofos) y los harauicus (poetas) (Inca Garcilaso, Comentarios reales VI.IX.231-2).

Por otra parte, Smith define el nacionalismo como "an ideological movement for the attainment and maintenance of autonomy, unity, and identity on behalf of a population deemed by some of its members to constitute an actual or potential 'nation'" (The Nation in History 10). Se infiere, entonces, que primero surge el nacionalismo y después la nación. ${ }^{22}$ Por analogía, una comunidad étnica sería al etnocentrismo lo que una nación sería al nacionalismo. Sin embargo, el uso generalizado del término nacionalismo no apunta a su dimensión englobante (la nación como la comunidad de comunidades, $^{23}$ y el nacionalismo como un etnocentrismo colectivo) sino a la exageración perniciosa del etnocentrismo.

El término nacionalismo no suele asociarse al sentimiento natural de amor a la nación, como podría suponerse, sino a un etnocentrismo exagerado e, incluso, al etnicismo; es decir, a la imposición de una etnia sobre otra(s) basada en una supuesta

\footnotetext{
${ }^{22}$ A diferencia de Smith, para Hayes los nacionalismos corren parejos con el surgimiento de las civilizaciones y, junto a ellas, pueden extinguirse o surgir otros nuevos.

23 " $[\mathrm{T}]$ he potential was there for nations to develop beyond single ethnies and incorporate and assimilate other ethnies or fragments thereof; or alternatively, to incorporate and accommodate diverse new ethnies in a polyethnic and multicultural nation" (Smith, The Nation in History 65).
} 
superioridad. "Llevada al extremo, esta tendencia a fortalecer la identidad propia en contraste con las diferentes [identidades] puede desembocar en la xenofobia o en las denominadas 'limpiezas étnicas' que hemos visto en tiempos recientes en diferentes partes del mundo" (Degregori, "Perú: identidad" 213). Por ejemplo, la política social de Hitler con respecto al pueblo judío fue, a todas luces, etnicista. En tiempos premodernos-dice Smith - el sentimiento de pertenencia de un individuo hacia su comunidad étnica era, esencialmente, etnocéntrico, con la consiguiente tendencia a excluir a los forasteros y a despreciar su cultura, comparándola desventajosamente con respecto a la propia, que se consideraba superior y, en ocasiones, hasta única (The Ethnic Origins 47).

El etnocentrismo que advierte Smith en las sociedades premodernas también se da en el mundo contemporáneo, debido a que la otredad se torna instrumental para que los miembros de una comunidad étnica se definan, por diferenciación y oposición, de los miembros de otras comunidades. "Nosotros, se define en contraste con los Otros, con los diferentes" (Degregori, "Perú: identidad” 213). Es así que, “[1]a invasión occidental, al reducir a todos los hombres andinos [que eran bastante distintos entre sí] a la condición común de indios o colonizados, [paradójicamente] hizo posible, sin proponérselo, que emergieran algunos factores de cohesión (Flores Galindo, "Europa y el país de los Incas", Obras completas 20). Pablo Macera explica que ese proceso se dio de la siguiente forma:

[L]os españoles hicieron de los indios una colectividad indivisa, una sola República $[\mathrm{L}]$ os indios aprendieron dolorosamente que por muchas que fueran sus diferencias internas [...] eran menores que la gran diferencia colonial que los separaba del grupo conquistador europeo [...] A partir de 
una pluralidad de afirmaciones individuales (lo no-inca) adquirieron por negación (lo no-español) una afirmación colectiva y homogénea (indios) [... La antigua dureza del Cuzco fue reinterpretada como justicia bondadosa frente al abuso europeo. ("El arte mural cusqueño” 111)

Como puede apreciarse, la otredad también puede servir para promover la cohesión interna de cada grupo: "[C]onforme se intensifican los contactos con esos otros diferentes, surge la necesidad o al menos la posibilidad de fortalecer ese Nosotros" (Degregori, “Perú: identidad” 213).

\section{Patrioterismo}

Cabe señalar que "nacionalismo" y "patriotismo" son dos conceptos asociados al tema de la identidad nacional que usualmente se utilizan indistintamente con el propósito de confundir y manipular a las masas. En el discurso "Elogio de la lectura y la ficción" que pronunció MVLL al recibir el Premio Nobel de Literatura 2010, el escritor peruano señala claramente la diferencia entre nacionalismo (que, en el mal sentido de la palabra, equivale a "patrioterismo") y patriotismo:

No hay que confundir el nacionalismo de orejeras y su rechazo del "otro", siempre semilla de violencia, con el patriotismo, sentimiento sano y generoso, de amor a la tierra donde uno vio la luz, donde vivieron sus ancestros y se forjaron los primeros sueños, paisaje familiar de geografías, seres queridos y ocurrencias que se convierten en hitos de la memoria y escudos contra la soledad. La patria no son las banderas ni los himnos, ni los discursos apodícticos sobre los héroes emblemáticos, sino un puñado 
de lugares y personas que pueblan nuestros recuerdos y los tiñen de melancolía, la sensación cálida de que, no importa donde estemos, existe un hogar al que podemos volver.

La manera en que MVLL concibe la patria y la nacionalidad coincide, en gran medida, con la percepción del poeta Rainer Maria Rilke (1875-1926), quien, en una carta que le escribe a la duquesa Aurelia Gallarati Scotti en 1923, le comenta lo siguiente: "We are born, so to speak, provisionally, it doesn't matter where. It is only gradually that we compose within ourselves our true place of origin so that we may be born there retrospectively and each day more definitely" (en Mason, Rilke, Europe, and the EnglishSpeaking World 11). La patria es, pues, el lugar en donde sentimos que se halla nuestro hogar, y ese sentimiento constituye — en el buen sentido de la palabra- el nacionalismo.

\section{Surgimiento del Estado-nación}

Según Anderson, fue posible imaginar la nación sólo cuando hubo un cambio de mentalidad originado en el declive progresivo de certezas interconectadas: 1) el latín no fue más la lengua que ofrecía un acceso privilegiado a la verdad, 2) se dejó de creer en el origen divino de las monarquías, y 3) el presente empezó a ser interpretado no, necesariamente, en función del pasado" (Comunidades imaginadas 61-2). ${ }^{24}$ El latín fue reemplazado por lenguas vernáculas, la Reforma y el capitalismo multiplicaron y difundieron ampliamente textos impresos en dichas lenguas, y las monarquías fueron

\footnotetext{
24 “La tercera era una concepción de la temporalidad donde la cosmología [énfasis mío] y la historia eran indistinguibles, mientras que el origen del mundo y el hombre eran idénticos en esencia" (Anderson 61). Tanto en la traducción al español como en el texto original en inglés figura la palabra "cosmología" en vez de "cosmogonía", que sería más apropiada para expresar la idea origen mítico, en oposición al origen meramente físico del universo.
} 
cuestionadas cuando la Iglesia católica perdió su papel hegemónico. El "sentido de transcendencia y pertenencia que previamente otorgaba el pensamiento religioso" ahora provenía la comunidad imaginada (Bastos, "Los indios, la nación y el nacionalismo" 3).

Por otro lado, mientas que en Europa el Estado-nación surge a finales del siglo XVIII como el resultado de la confluencia de varios factores ("procesos multidimensionales")—_tales como el declive de la monarquía, la consolidación de unidades territoriales con una clara demarcación de fronteras, el monopolio de los medios de violencia al interior de cada Estado, y la emergencia de la burguesía - ${ }^{25}$ que cambiaron las relaciones de poder en la sociedad, ${ }^{26}$ en Hispanoamérica el Estado-nación nace con la independencia de las colonias de España. Casi todos los países se independizaron durante el primer tercio del siglo XIX; el Perú lo hizo entre 1821 y 1824. Empero, anteriormente, ¿había conformado el Imperio de los incas una nación?

\section{Auge de las lenguas vernáculas y de la imprenta}

El capitalismo impreso "permitió un número rápidamente creciente de personas [que] pensaran acerca de sí mismos [sic], y se relacionaran con otros, en formas profundamente nuevas" (Anderson 62). La difusión de la palabra escrita en un idioma inteligible y familiar hizo que la gente se identificara con sus congéneres (ibíd. 62-3). Anderson está

\footnotetext{
${ }^{25} \mathrm{El}$ desarrollo de la burguesía y su papel desestabilizador del statu quo fue particularmente importante en Europa, debido a que "[n]unca antes había surgido un grupo social que fuese capaz de transformar estructuralmente todas las relaciones sociales" (Castro-Gómez, La poscolonialidad 13). En contraste, en la Hispanoamérica del siglo XVII y principios de XIX no existía una burguesía muy desarrollada (Anderson 78).

${ }^{26}$ Estas situaciones se dieron por la influencia de las ideas de la Ilustración que desembocaron, por ejemplo, en la Revolución Americana (1776) y en la Revolución Francesa (1789) (Guibernau, "Anthony D. Smith on Nations and National Identity" 139).
} 
de acuerdo con Marshall McLuhan (Gutenberg Galaxy 12) en que "el libro fue el primer producto industrial producido en masa, al estilo moderno" (Anderson 59). ${ }^{27}$

Es más que pertinente traer a colación que, para JCM, el auge de la producción literaria impresa en lengua nacional (en cualquiera) constituye la simiente legitimadora de la "literatura nacional":

Materia prima de toda literatura es el idioma. La literatura española, como la italiana y la francesa, comienzan con los primeros cantos y relatos escritos [énfasis mío] en esas lenguas [...] [L]a literatura nacional de dichos pueblos latinos nace, históricamente, con el idioma nacional, que es el primer elemento demarcador de los confines generales de una literatura.

\section{(7 ensayos 169)}

Para JCM, “[e]1 libro, la revista literaria y científica, no son sólo el índice de toda cultura, sino también su vehículo" ("El problema editorial”; Baeza 454). Nuevamente, en este asunto JCM se adelantó a Anderson.

Más allá de petroglifos, quellaqas y quipus, no hay evidencia de que los antiguos peruanos conocieran la escritura. ${ }^{28}$ En consecuencia, el lenguaje oral, además de servir de medio de comunicación, constituía el mecanismo por excelencia para preservar en un medio tangible la memoria colectiva que pasaba de boca en boca y de generación en generación (Pedro Sarmiento de Gamboa, Historia Índica, 1570-1572). ${ }^{29}$ Conscientes del

\footnotetext{
${ }^{27}$ McLuhan, Marshall. The Gutenberg Galaxy: The Making of Typographic Man. Toronto: University of Toronto Press, 1962.

${ }^{28}$ Quellaqa:: pictograma narrativo, en voz quechua.

${ }^{29}$ Mendizábal Losack considera que Guamán Poma de Ayala habría sido el último quellacamayoc (dibujante) de los incas (Pérez Cantó 14).
} 
poder de la palaba escrita, los cronistas de Indias que se ocuparon del Perú recogieron la tradición oral prehispánica en lengua quechua y la trasvasaron, con distorsiones, al idioma español. Sin embargo, en el Perú prehispánico la palabra escrita—entendida en el sentido tradicional, occidental—no había sido indispensable para poder imaginar una nación o potencializar los vínculos étnicos.

\section{Debilitamiento de la Iglesia católica}

Aproximadamente el año 800 d.C., con la coronación de Carlomagno la Iglesia católica empezó a tener una gran injerencia en los asuntos políticos y de administración pública en los reinados europeos. Este estado de cosas duró varios siglos hasta que Felipe IV (1268-1314), se rebeló contra las bulas promulgadas por Bonifacio VIII (1230-1303). Ante Clericis laicos, (clérigos laicos), de 1296, que prohibía que el clero fuera gravado con impuestos sin el consentimiento papal, Felipe el Hermoso reaccionó, anulando las exportaciones y el envío de dinero a Roma. Posteriormente, mandó quemar Ausculta fili (escucha hijo), de 1301, en la que el Sumo Pontífice lo reprendía por haber desacatado lo prescrito en Clericis laicos, con el agregado de que todo cristiano, incluso el propio rey, debía obediencia al papa. ${ }^{30}$ Por otro lado, Eduardo I de Inglaterra (1239-1307) también reaccionó contra Clericis laicos, retirándole su apoyo al clero; y Jaime II de Aragón (1267-1317) solicitó al papa que le aclarase la intención de la bula. Y Unam sanctam (una santa), de 1302, que reafirmaba la supremacía del poder espiritual sobre el

\footnotetext{
30 “Que nadie te persuada, queridísimo hijo, que no tienes superiores y que no estás sometido a la cabeza suprema de la Iglesia. Aunque indignos, Dios nos ha constituido por encima de reyes y reinos" (Bonifacio VIII, “Ausculta fili”).
} 
temporal, ${ }^{31}$ motivó el asalto del palacio papal de Anagni, el 7 se septiembre de 1303. Asimismo, en 1534 Enrique VIII de Inglaterra (1491-1547) rompió con la Iglesia católica y fundó la anglicana como reacción a la negativa del Papa Clemente VII de anular su matrimonio con Catalina de Aragón.

\section{Expulsiones de los jesuitas}

Pero hubo más: Diversos monarcas europeos se sintieron amenazados por la Compañía de Jesús, debido a su lealtad con el Papa, a su poder financiero y político, pero sobre todo debido a la formación intelectual de sus miembros. Por estas y otras razones, los jesuitas fueron expulsados de Portugal en 1759, de Francia en 1762, y de España en $1767 .^{32}$ Finalmente, cediendo a presiones internacionales, en 1773 el papa Clemente XIV suprimió la orden. Si bien ésta fue restablecida en 1814, nuevamente los jesuitas fueron expulsados de España en 1835, durante el reinado de María Cristina, así como en 1932, durante la Segunda República. Desde entonces, la Iglesia quedó subordinada al Estado.

En el Perú, los jesuitas estuvieron ausentes durante más de un siglo, desde que Carlos III los expulsó del Imperio español en 1767 hasta 1871, cuando, gracias a la gestión del obispo de Huánuco Teodoro del Valle, el presidente de la república, José Balta y Montero, autorizó su readmisión. Sin embargo, en 1886 el padre Ricardo Cappa publicó un libro en el que calificaba a los incas de bárbaros, ponderaba la invasión

\footnotetext{
31 “[E]xisten dos gobiernos, el espiritual y el temporal, y ambos pertenecen a la Iglesia. El primero está en manos del Papa y el segundo en las manos de los reyes; pero los reyes no pueden hacer uso de ese gobierno temporal más que por la Iglesia, por orden y con permiso del Papa. Si el poder temporal se tuerce, debe ser enderezado por el poder espiritual" (Bonifacio VIII, "Clericis laicos").

${ }^{32}$ Carlos III de España expulsó a los jesuitas del Imperio español en 1767, responsabilizándolos de haber instigado el Motín de Esquilache (1766).
} 
española y les restaba mérito a los héroes de la Independencia. Esta controversial publicación motivó, una vez más, la expulsión de la orden, aunque en esta ocasión la ausencia duró sólo dos años. "Fueron los masones de Lima los que precipitaron la primera crisis grave entre la Iglesia y el liberalismo después de la Guerra. ${ }^{33}$ En general, hasta la aparición del Partido Aprista en 1930 las logias masónicas constituyeron los focos más beligerantes del anticlericalismo en el Perú" (Klaiber, La Iglesia en el Perú 113).

\section{Debilitamiento y caída de la monarquía}

Hacia finales del siglo XVIII y principios del XIX, la Edad Moderna dio paso a la Edad Contemporánea con la Revolución liberal (política), la Revolución industrial (económica) y la Revolución burguesa (social). En oposición a las monarquías absolutistas, se formaron, entre otros, la Mancomunidad de Inglaterra (Commonwealth of England) (1649), los Estados Unidos de América (1776), la República (1792) y la Asamblea Nacional Constituyente francesas (1789), así como las Cortes de Cádiz (1812) en España, en donde el Antiguo Régimen había empezado a desplomarse cuatro años antes con el Motín de Aranjuez, las Abdicaciones de Bayona (en cascada, de Carlos IV en Felipe XVII, y de éste en Napoleón Bonaparte) y la invasión francesa. ${ }^{34}$

La acepción política del término nación asociada al concepto de Estado no habría surgido hasta la firma del Tratado de París de 1783, entre la Gran Bretaña y los Estados

\footnotetext{
${ }^{33}$ Se refiere a la Guerra del Pacífico (1789-1883), en la que el Perú fue vencido por Chile.

${ }^{34}$ En 1814, Fernando VII fue restituido en el trono y disolvió las Cortes de Cádiz. El absolutismo monárquico en Europa (dinastías Romanov, Habsburgo y Hohenzollern) no terminó de caer sino hasta la Primera Guerra Mundial y a consecuencia de ella. El Imperio turco otomano (dinastía Osmanlí) tampoco había caído antes de la Primera Guerra Mundial.
} 
Unidos, mediante el cual la potencia europea reconocía la independencia de sus colonias en Norteamérica. Unos años después, la Revolución francesa (1789-1799) y la caída del Ancien Régime desembocarían en el nacimiento de Francia como una nación política. Hasta antes de esos acontecimientos no existían naciones sino imperios, reinos, principados, ducados, marquesados, virreinatos, etcétera.

\section{Ethnie o comunidad étnica}

La nación cultural es la comunidad étnica con la cual un individuo se siente identificado por lazos culturales, lingüísticos, raciales, históricos, emocionales, etcétera, y cuyos miembros, en la mayoría de los casos, comparten un territorio (una patria). Alegando la ausencia en inglés de un término igualmente sintetizador, Anthony D. Smith se refiere a las comunidades étnicas con la palabra francesa ethnie, que él define como "named human populations with shared ancestry myths, histories and cultures, having an association with a specific territory and a sense of solidarity" (The Ethnic Origins 32). En contraste, Smith define la nación como "a named human population occupying a historic territory or homeland and sharing common myths and memories; a mass, public culture; a single economy; and common rights and duties for all members" (The Nation in History 3). Como puede apreciarse, la ethnie está emparentada con la nación cultural, en tanto que la definición de nación que proporciona Smith coincide con la de nación política y/o con la de Estado-nación. La principal diferencia entre ambos conceptos es que, "[w]hile ethnies share with nations the elements of common name, myth, and memory, their center of gravity is different: ethnies are defined largely by their ancestry myths and historical memories" (Smith, ibid. 65). 


\section{¿Ethnie o ayllu?}

Antes de la llegada de los españoles, la economía incaica estaba regida por el trabajo comunitario organizado en ayllus o comunidades familiares:

El Ayllu, como forma de organización generalizada en los Andes, estaba constituido por un grupo de familias circunscritas a un territorio, unidas por relaciones de parentesco, con un idioma común, religión propia y trabajo colectivo. Anteriormente correspondía a la comunidad familiar extensa que reconocía una ascendencia común, es decir, descender de un antepasado común y adorar al mismo tótem familiar, de allí que términos como comunidad, linaje, genealogía, casta, género, parentesco se asocian al ayllu. ("Los conceptos del ayllu y la marka"). ${ }^{35}$

Debido a la vocación totémica del habitante andino, el ayllu se extiende a abarcar, además de los humanos, a otros seres animados e inanimados, incluyendo las pacarinas o lugares míticos: "Dentro del ayllu, los miembros de la familia constituyen los parientes, pero también los cultivos, la chacra y todo lo que se cría; igualmente, el mundo físico es pariente: el agua, el manantial, la lluvia, el granizo, siendo entonces visto el ayllu como la agrupación de parientes humanos, parientes chacras, parientes sallqa (naturaleza física) y parientes espirituales" (ibíd.). En la concepción holística del ayllu son difusos o se diluyen los límites entre el medio ambiente y la comunidad.

Stefano Varese sostiene que: "[n]ingún otro elemento constitutivo de la individualidad e identidad colectiva de cada pueblo indígena ha jugado un papel tan axial

\footnotetext{
${ }^{35} \mathrm{El}$ aillu (ayllu, en voz quechua; hatta, en aimara) es "un grupo humano unido por vínculos de sangre, asentado en la tierra que la posee y trabaja en común y cuyos miembros se dividen, por igual, el fruto de su esfuerzo" (Fellman, Los imperios 37). La marca (marka) era la tribu, o sea "la federación de ayllus establecidos alrededor de una misma aldea" (Ugarte, Bosquejo 9).
} 
y fundamental como su identificación espiritual y emocional con el propio espacio territorial, el paisaje marcado por la historia de los antepasados reales y míticos, la tierra, las aguas, las plantas, los animales, los seres tangibles e intangibles que participan del complejo y misterioso pacto cósmico de la vida" ("Territorio, tierra y recursos" 47). De ahí el ancestral y estrecho vínculo del indígena-campesino con la tierra y su profundo sentimiento de apego a ésta. 'El 'totemismo', consustancial con el 'ayllu' y la tribu, más perdurables que el Imperio [inca], se refugiaba no sólo en la tradición sino en la sangre misma del indio" (Mariátegui, 7 ensayos 122-3). ${ }^{36}$ Resulta lógico, pues, que la tesis central de JCM, quien estaba plenamente consciente de la identidad ontológica del indígena con el ayllu y se hallaba embebido de la concepción marxista de estructura y superestructura, ${ }^{37}$ sea que el problema del indígena se origina en la tenencia de la tierra (ibíd. 29).

\section{Culturas preincas}

Antes de los incas, en el Perú habían florecido magníficas civilizaciones, algunas de las cuales eran mucho más que meras comunidades étnicas. ${ }^{38}$ Ése no fue el caso del llamado "hombre de Nanchoc" (Valle Alto, Cajamarca), el horticultor más antiguo de América,

\footnotetext{
${ }^{36}$ En el tiempo de los incas, el ayllu se convierte en una unidad administrativa, semejante al calpulli ("casa grande" en náhuatl) en México. JCM pone énfasis en aclarar que el ayllu "fue la célula del Imperio. Los inkas [sic] hicieron la unidad, inventaron el Imperio; pero no crearon la célula" ( 7 ensayos 61 ).

37 "El modo de producción de la vida material [estructura] condiciona el proceso de la vida social política y espiritual [superestructura] en general" (Marx, Prólogo a Contribución a la Crítica de la Economía Política).

38 "Los Andes son el escenario de una antigua civilización. Entre los 8,000 y los 6,000 años en las altas punas o los valles de la costa, sus habitantes iniciaron el lento proceso de domesticación de plantas que les abrió las puertas a la alta cultura" (Flores Galindo, "Europa y el país de los Incas", Obras completas 19).
} 
que data de unos 7000 a.C. (Kaulicke, Historia del Perú 51), pero es innegable el grado de desarrollo de otras culturas. Por ejemplo, las "momias negras" (c. 5000-3000 a.C.) de la cultura chinchorro - que se extendió desde Ilo (costa sur) hasta Antofagasta (actual costa norte de Chile) — preceden a las egipcias en 2000 años (Arriaza, "Chinchorro Bioarchaeology"); y la civilización caral (Supe, Barranca, Lima), que existió entre 3000 y 1800 a. C., creó la ciudad-Estado más antigua de América (Shady Solis 7-8). Estos ejemplos dan cuenta de que, en Sudamérica, específicamente en el territorio que luego sería denominado Tahuantinsuyo, surgieron importantes civilizaciones preincaicas, que, sin llegar a desarrollarse tanto como Tiahuanaco (1580 a. C. - 1187 d. C.) o Chavín (1200 a. C. - 200 a. C.), tuvieron un área de influencia bastante extensa. "Habría que esperar al primer milenio antes de la era cristiana para que desde un santuario de los Andes centrales, Chavín de Huántar, se produzca el primer momento de unificación panandina" (Flores Galindo, "Europa y el país de los Incas", Obras completas 19). Mas, sin duda, fue con el apogeo del Imperio de los incas (1438-1533) que las diversas etnias endémicas se convirtieron en nación y también en Estado.

Algunas de las culturas preincaicas ya se habían extinguido para el tiempo de los incas, pero otras devinieron en nuevas civilizaciones que fueron asimiladas por éstos. ${ }^{40}$ Culturas como sechín (1800 a.C. - 1200 a.C.), tiahuanaco (1580 a.C. - 1190 d.C.), chavín (1200 a.C. -200 a.C.), paracas (700 a.C. -200 d.C.), lima (100 d.C. -650 d.C.), moche

\footnotetext{
${ }^{39}$ El Tahuantinsuyo era el territorio del Imperio de los incas y estaba dividido en cuatro (tawa) suyos o regiones (Inca Garcilaso, Comentarios reales II XXI.66-67). El Antisuyo limitaba con la selva amazónica, el Contisuyo ocupaba el territorio de la actual Arequipa, el Chinchaysuyo se extendía hasta el sur de la actual Colombia, y el Collasuyo abarcaba el altiplano y llegaba hasta el norte de la actual Argentina. La capital era el Cusco.

${ }^{40}$ Por ejemplo, existen evidencias de la influencia de sechín en chavín, de tiahuanaco en wari, y de moche, wari y de cajamarca en sicán o lambayeque.
} 
(100 d.C. -700 d.C.), nasca (siglos 50 d.C. -600 d.C.), cajamarca (200 d.C. -800 d.C.), wari (600 d.C. -1200 d.C), lambayeque (700 d.C. -1375 d.C.), chachapoyas (800 d.C. 1470 d.C) y chimú (1200 d.C. - 1400 d.C.) tambien constituyeron Estados y fueron naciones independientes en alguna etapa de su desarrollo. Tiahuanaco y wari incluso llegaron a ser verdaderos imperios. Es importante señalar que, a pesar del aislamiento de Occidente en el que vivieron los antiguos peruanos (avant la lettre), "no produjeron un mundo homogenio y cohesionado" y "[a]la llegada de los españoles, con el derrumbe del estado incaico, reaparecen diversos grupos étnicos —como los huancas, chocorvos, lupacas, chancas - con lenguas y costumbres diferentes, muchas veces rivales entre sí, resultado de una antigua historia de enfrentamientos" (Flores Galindo, "Europa y el país de los Incas", Obras completas 19-20).

\section{Mitos, fábulas y leyendas}

Al igual que en todas las sociedades, la narrativa en el Perú tiene sus raíces en el mito, como contenido temático, y en la tradición oral de fábulas y leyendas, como vía de transmisión de conocimiento. Smith les confiere especial relevancia a los símbolos, a la memoria, a los valores y a los mitos que diferencian a unas naciones de otras (The Ethnic Origins ix). También sostiene que, para transformar a una multitud variopinta en una nación, se requiere de un marco simbólico que les dé, a la vez, movilidad y estabilidad a sus integrantes (ibíd. 200-1). Ya, en 1609, el Inca Garcilaso identificaba a la leyenda y a la fábula como simientes de la Historia (Comentarios reales I.XIX.36). Ciertamente, "lo histórico social no es ajeno al mundo mítico ni, menos aún, relega a éste a la categoría de ficción [...] Muy por el contrario, ambos son niveles de la total realidad, siendo lo 
histórico y lo concreto su nivel fenoménico y aparente, y lo esotérico y espiritual su nivel profundo, que da a aquél su sentido (Maduro 1972, 65)" (Camayd-Freixas, Realismo mágico 11). O, como lo plantea Carlos Iván Degregori, siguiendo a David E. Apter: "La historia se cuenta múltiples veces y se socializa. Las historias, colectivizadas, tienen consecuencia cuando, convertidas en mitos, pretenden ser historia, y como historia son reinterpretadas como teorías" (Qué difícil es ser Dios 250). ${ }^{41}$ En el proceso de fabricación de un discurso de corte mítico, "[a]lgún evento que, en circunstancias ordinarias, difícilmente hubiera producido comentario alguno, detiene súbitamente el tiempo y lo reinicia. Los significados se van cargando acumulativamente, el acontecimiento adquiere densidad simbólica" (ibíd. 250).

Stephen Slemson concibe que la alegoría—la figura literaria de la que suelen estar hechas las fábulas - es, más que una metáfora extendida, "a process of signification against a pre-existing master code or typological system" ("Post-Colonial Allegory" 162). Los colonizadores fueron muy conscientes del valor de la alegoría por su gran poder evocador: "Slemson implies that this mode of cognition has manipulative potential. In fact, allegorical thinking was used during the colonial period as a mode of representing imperial enterprises" (Juan-Navarro, "The Dialogic Imagination" 262). Tan es así que las crónicas de Indias fueron utilizadas como poderosas armas para infiltrar ideologías, perpetuar o subvertir el discurso hegemónico colonial, y legitimar o deslegitimar linajes y gobernantes, según los intereses de los respectivos autores.

\footnotetext{
${ }^{41}$ Las referencias bibliográficas que proporciona Degregori sobre David E. Apter son: 1) The Legitimization of Violence. Basingstoke: Macmillan - UNRISD, 1997. 2) "Democracy, Violence and Emancipatory Movements: Notes for a Theory of Inversionary Discourse". Ponencia presentada al Grupo de Trabajo sobre Violencia y movimientos sociales, UNRISD, Ginebra, 1992.
} 


\section{Mitos fundacionales o mitomotores}

En el "Proemio" de El pueblo maravilloso (1927) de Fernando Contreras se señala que, "[c]omo todas las sociedades primitivas, los pueblos hispanoamericanos tienen la intuición muy despierta de lo maravilloso, esto es, el don de encontrar vínculos más o menos figurados con lo desconocido, lo misterioso, lo infinito". Se trata de una manera de percibir y de entender el mundo y a nosotros mismos: "Myths organize the way we perceive facts and understand ourselves and the world" (Sproul, Primal Myths 1). Así, pues, "las supersticiones y su encarnación, el mito [...] constituyen verdades concretas" para mucha gente (Contreras) y "[w]hether we adhere to them consciously or not, they remain pervasively influential" (Sproul 1). "El mito, antes sinónimo de falsedad y superstición, se entiende ahora como un lenguaje útil y eficaz con el cual una cultura [...,] traduce las realidades fundamentales que la afectan, y ordena su mundo y su existencia en él" (Camayd-Freixas, Realismo mágico 61). En consecuencia, el pensamiento mágico es tan válido como la lógica de la cultura occidental. Bien mirada, "la realidad percibida es la realidad de los sentidos [..., ] una imagen parcial: veo esta columna, no los átomos que la constituyen; veo girar el sol, pero lo que gira es la tierra" (Campra, "Lo fantástico" 167). Los viejos mitos no son desbancados por evidencias científicas posteriores, por ejemplo, sino por nuevas percepciones y actitudes frente a los hechos; es decir, por nuevos mitos (Sproul 1-2).

Según Anthony D. Smith, “[m]yths of descent usually reveal several components and layers of legend. There are myths of spatial and temporal origins, of migration, of ancestry and filiation, of the golden age, of decline and exile and rebirth" (The Ethnic Origins 25). Por ejemplo, el Inca Garcilaso refiere que un anciano tío suyo por el lado 
materno-presumiblemente, el Inca Cusi Huallpa - le narró que la dinastía inca habría surgido con la aparición mesiánica y mítica de Manco Cápac y Mama Ocllo Huaco, a quienes una divinidad les habría encargado emprender la obra civilizadora:

Nuestro Padre el Sol, viendo los hombres tales [...] se apiadó, y hubo lástima dellos, y envió del cielo a la tierra un hijo y una hija de los suyos para que los doctrinasen en el conocimiento de Nuestro Padre el Sol, para que lo adorasen y tuviesen por su Dios, y para que les diesen preceptos y leyes en que viviesen como hombres en razón y urbanidad; para que habitasen en casas y pueblos poblados, supiesen labrar las tierras, cultivar las plantas y mieses, criar los ganados y gozar dellos y de los frutos de la tierra, como hombres racionales, y no como bestias. (Comentarios reales I.XV.29-30).

Enseguida el Dios Sol les dio pautas acerca de hacia dónde dirigirse y cómo proceder:

Con esta orden y mandato puso Nuestro Padre el Sol estos dos hijos suyos en la laguna Titicaca $[\ldots]^{42}$ y les dijo que fuesen por do quisiesen, doquiera que parasen a comer o a dormir, procurasen hincar en el suelo una barilla $[\mathrm{sic}]$ de oro $[\ldots]$ que les dio para señal y muestras que donde aquella barra se les hundiese [...] [A]llí quedaría el Sol Nuestro Padre que parasen y [sic] hiciesen su asiento y corte. A lo último les dijo: "Cuando hayáis reducido esas gentes a nuestro servicio, los mantendréis en razón y

\footnotetext{
42 El lago Titicaca, ubicado en la meseta del Collao a $3812 \mathrm{msnm}$, es el más alto del mundo. Tiene un área de $8562 \mathrm{~km}^{2}$ y una profundidad máxima de 280 metros. Las leyendas andinas más importantes hacen referencia a este lago y a un diluvio que le habría dado origen. De hecho, se han hallado ruinas sumergidas en sus aguas, vinculables a la cultura Tiahuanaco.
} 
justicia, con piedad, clemencia y mansedumbre, haciendo en todo oficio de padre piadoso para con sus hijos tiernos y amados [...] Y desde luego os constituyo y nombro por reyes y señores de todas las gentes que así doctrináredes [sic] con vuestras buenas razones, obras y gobierno". (Ibíd. I.XV.30)

Después de un largo andar, la varilla de oro se hundió en el cerro Huanacauri, en el Cusco - que luego se convertiría en la capital del Tawantinsuyo-, y, de esa manera, la dinastía incaica quedó legitimada. ${ }^{43}$ Es claro que, para el Inca Garcilaso, la civilización en el Perú empezó con los incas. ${ }^{44}$

El origen de los incas también es explicado por la Leyenda de los hermanos Ayar, que narra la emergencia espontánea de tres o cuatro parejas (dependiendo de la versión) de hermanos-esposos del cerro Tambotoco-ubicado en Pacaritambo, al noroeste del Cusco- , liderados por Manco Cápac y Mama Ocllo Huaco. ${ }^{45}$ Los varones respondían a los nombres de Manco Cápac, Ayar Auca, Ayar Cache y Ayar Ucho; y las damas a los nombres de Mama Ocllo, Mama Guaco, Mama Ipacura (también Mama Cura) y Mama Raua, respectivamente. Ellos serían los patriarcas y matriarcas de las estirpes elegidas por

\footnotetext{
${ }^{43}$ Hay, por lo menos, dos problemas a nivel ideológico. Primero, los enviados-Manco Cápac y Mama Ocllo - son hijos del Sol y de la Luna, de dioses de menos jerarquía que Pachacámac/Viracocha. Segundo, no es propio del mundo "civilizado" que inauguran los incas que Manco Cápac y Mama Ocllo sean, a la vez, hermanos y esposos (Comentarios reales I.XVI.32), máxime si el mismo Inca Garcilaso denuncia las relaciones incestuosas entre hombres y mujeres del Perú preincaico: "[S]e juntaban al coito como bestias, sin conocer mujer propia, sino como acertaban a toparse, y otras se casaban como se les antojaba, sin exceptuar hermanas, hijas ni madres" (ibíd. I.XIV.27).

${ }^{44}$ Este enfoque le permite al Inca Garcilaso proyectar en el "Otro" preincaico los atributos del salvaje y, al mismo tiempo, por oposición y contraste, realzar el linaje inca que ha heredado por el lado materno, seguramente con la intención de redimir ante los ojos de los europeos su estigmatizada condición de mestizo.

${ }^{45}$ Nótese que Manco Cápac y Mama Ocllo son los mismos protagonistas de la otra leyenda ya comentada.
} 
el Dios Viracocha para gobernar el Tahuantinsuyo. Juan de Betanzos es el primero en traducir la Leyenda de los hermanos Ayar del quechua al español y de registrarla por escrito (Suma y narración de los Incas III.9-12). Posteriormente, la refieren Pedro Sarmiento de Gamboa Historia Índica (1570-1572), el Inca Garcilaso en Comentarios reales (1609) (I.XVIII.33-5) y Felipe Guamán Poma de Ayala en Nueva crónica y buen gobierno $(1610-1615) .^{46}$

En Nueva crónica, con prodigiosa imaginación Guamán Poma consigna una descabellada genealogía del pueblo andino que se remonta a los tiempos del Diluvio universal, conocido como el uno yaco pachacuti (49). Asimismo, el cronista asevera que los incas habrían aparecido sobre la faz de la tierra recién durante la cuarta edad, de un total de cinco, asociando esta última edad con el advenimiento de Jesús, una fecha dislocada pero muy conveniente para los fines de la evangelización.

Ambas leyendas - la de Manco Cápac y Mama Ocllo, y la de los hermanos Ayar-constituyen lo que el historiador catalán Ramon d'Abadal i de Vinyals denomina "mitomotores" (mythomoteurs); es decir, ese tipo de metarrelato que le proporcionan al grupo étnico un origen, un propósito, un carácter y un destino particulares (“A propos du Legs Visigothique en Espagne”, 1958), ${ }^{47}$ además de establecer su derecho sobre la tierra que habita. En tal sentido, el mitomotor sintetiza elementos comunales, religiosos, políticos y dinásticos. Smith añade que "[t]he fused and elaborated myths provide an

\footnotetext{
${ }^{46}$ En 1908, Richard Pietschmann halla la Nueva crónica y buen gobierno en la Biblioteca Real de Copenhague. Al parecer, la obra—dedicada a Felipe III de España, quien reinó desde 1598 hasta 1621 —se extravió en su viaje a la Metrópoli.

${ }^{47}$ El término mythomoteur es retomado por John Armstrong (Nations before Nationalism, 1982) y por Anthony D. Smith (The Ethnic Origins of Nations, 1986).
} 
overall framework or meaning for the ethnic community. Without a mythomoteur a group cannot define itself or to others, and cannot inspire or guide collective action" (The Ethnic Origins 24-5).

Para Smith, la esencia de la identidad étnica reside en la particular configuración histórica de mitos, memorias, valores y símbolos (ibíd. 15). Aclara que no puede haber identidad sin memoria, aunque ésta sea selectiva, ni tampoco un propósito colectivo o destino sin el mito, y que tanto la identidad como el destino común son elementos necesarios para el concepto de nación (ibíd. 2). Las etnias crean mitos que preservan el recuerdo de un pasado generalmente glorioso. A la vez, las etnias del presente serán en el futuro los protagonistas de un pasado mítico ya perdido (ibíd. 44-5). Sin duda, los mitos fundacionales tienen una función social, religiosa y política, explican el origen divino o terrenal de la comunidad étnica, celebran un pasado glorioso del que se suelen enorgullecer sus miembros, rememoran los sufrimientos soportados en conjunto, ubican a la comunidad en el mundo (ibíd. 24), legitiman el sistema político, y le dan sentido a los esfuerzos desplegados en pro de un destino común. Por último, los mitos contribuyen a la formación de una identidad étnica, entendida como la percepción de unicidad e individualidad cultural que diferencia a un pueblo de otro, tanto a sus ojos como a los ojos de extraños (ibíd. 22).

En el caso del Perú, la Leyenda de Manco Cápac y Mama Ocllo, y la Leyenda de los hermanos Ayar son ejemplos de relatos alegóricos de la época prehispánica que asocian el origen de la civilización con el de las dinastías incaicas, con la evidente intención de legitimar ese linaje. Con algunas diferencias incidentales, todas las versiones de la Leyenda de los hermanos Ayar coinciden en la parte medular del relato. Sin 
embargo, lo que distingue sustantivamente a una crónica de las demás es el sesgo que le imprime cada etnógrafo, no necesariamente a las leyendas, en particular, sino en conjunto a la obra que las recoge. El discurso siempre es contestatario al del Otro, con la intención de ponderar el propio o, por lo menos, de igualarlo en jerarquía con el de aquél.

En general, los cronistas peninsulares-salvo honrosas excepciones, como Bartolomé de las Casas (Brevísima relación de la destrucción de las Indias, 1552), Bernal Díaz del Castillo (Historia verdadera de la conquista de la Nueva España, escrita en 1575 y publicada en 1632) y Pedro Cieza de León (El señorío de los incas, escrita entre 1540 y 1550, y publicada en 1880) — confirmarán la historiografía oficial, en tanto que los cronistas indígenas y mestizos bregarán para desmentirla o descalificarla. Por ejemplo, con respecto al carácter fantasioso de los relatos del Viejo Mundo, el Inca Garcilaso, revanchista, apostilla:

[D]e esta manera son todas las historias de aquella antigüedad; y no hay que espantarnos de que gente que no tuvo letras con que conservar la memoria de sus antiguallas trate de aquellos principios tan confusamente, pues los de la gentilidad del Mundo Viejo con tener letras y ser tan curiosos en ellas, inventaron fábulas tan dignas de risa, y más que estotras; pues una de ellas es la de Pirra y Deucalión, y otras que pudiéramos traer a cuenta. (Comentarios reales I.XVIII.33)

En realidad, ni los engaños ni las distorsiones son relevantes en las leyendas (Smith, The Ethnic Origins 2). Lo importante es que el legado de nuestros antepasados pervive hasta el presente y contribuye a moldear nuestra singularidad/identidad étnica. 


\section{Escepticismo acerca de la identidad nacional peruana}

En mi opinión, en el Perú no existe una única identidad nacional, sino una colección de singularidades/identidades culturales: "Nuestros clásicos del pensamiento nos lo advirtieron. No somos nación [...], somos una nacionalidad en formación [...] Este fue, es, uno de los pocos puntos [...] en que a pesar de diferencias, coincidían Haya [de la Torre], Mariátegui, Víctor Andrés Belaúnde y Basadre [...] ¿Solucionamos nosotros el problema que ellos anticiparon? La respuesta es ¡No!” (López Chau, “Destrucción y restauración” 170).

JCM consideraba que

[1]a unidad peruana está por hacer; y no se presenta como un problema de articulación y convivencia, dentro de los confines de un Estado único, de varios antiguos pequeños estados o ciudades libres. En el Perú el problema de la unidad es mucho más hondo, porque no hay aquí que resolver una pluralidad de tradiciones locales o regionales sino una dualidad de raza, de lengua y de sentimiento, nacida de la invasión y conquista del Perú autóctono por una raza extranjera que no ha conseguido fusionarse con la raza indígena ni eliminarla ni absorberla. (7 ensayos 150).

Belaúnde pensaba que "la peruanidad es una síntesis comenzada pero no concluida" ( $L a$ realidad nacional), debido a que "[1]a conciencia colectiva en el Perú ha sido débil [...] La cultura peruana no ha contribuido a crear esa conciencia colectiva, ni a orientar esas aspiraciones, ni a formar esos ideales" (Meditaciones Peruanas 142). Según Belaúnde, esta situación obedece, entre otras razones, a la diversidad de razas, a la falta de compenetración entre éstas, a las taras y efectos del virreinato, a la pobreza y "a la falta 
de intuición y sentimiento en la cultura peruana" (en Obando, Identidad peruana 30). Además de mencionar a Gabriel Escobar, a Jorge Bravo Bresani y a Rodrigo Montoya, Enrique Obando identifica a los siguientes pensadores y a sus respectivas obras en la que exponen su escepticismo acerca de la existencia "no solo de una nación peruana, sino de una identidad peruana" (30):

\begin{tabular}{|l|l|}
\hline \multicolumn{2}{|c|}{ Pensadores escépticos a la existencia de una nación peruana } \\
\hline \multicolumn{1}{|c|}{ Autor } & \multicolumn{1}{c|}{ Obra } \\
\hline Julio Cotler & $\begin{array}{l}\text { La mecánica de la dominación interna y del cambio social en el } \\
\text { Perú. Lima: Instituto de Estudios Peruanos, 1967. }\end{array}$ \\
\hline José Matos Mar & $\begin{array}{l}\text { "La urbanización y los cambios en la sociedad y cultura peruana". } \\
\text { Cuadernos de Antropología 4.9 (1966): 1-10. }\end{array}$ \\
\cline { 2 - 3 } & $\begin{array}{l}\text { Desborde popular y crisis de Estado: El nuevo rostro del Perú en } \\
\text { la década de 1980. Lima: Instituto de Estudios Peruanos, 1984. }\end{array}$ \\
\hline Augusto Salazar Bondy & $\begin{array}{l}\text { Entre Escila y Caribdis: Reflexiones sobre la vida peruana. Lima: } \\
\text { Casa de la cultura del Perú, 1969. }\end{array}$ \\
\hline \multicolumn{2}{|l|}{} \\
\hline $\begin{array}{l}\text { Fuente: Obando, Enrique. Identidad peruana: La percepción de los intelectuales. Lima: Instituto de } \\
\text { Estudios Políticos y Estratégicos (IDEPE), 2002. 30. }\end{array}$ \\
\hline
\end{tabular}

De acuerdo con Fernando Fuenzalida, "no existen las culturas del indio, el mestizo o criollo como realidades autónomas. Ni la identificación de personas o grupos como indios, mestizos o criollos se adscribe a condiciones estáticas como la etnía [sic] o la raza $[\ldots]$ Se trata de subculturas fluidas, en perpetuo estado de cambio. Su mutua relación es dinámica: los rasgos se desplazan en forma continua de la una a la otra. ("Identidad nacional”). Quizá sea utópico pensar que una sociedad multiétnica, multilingüística y multicultural pueda llegar a integrarse en una nación. ¿Lo son Canadá, Suiza, Bélgica, España o Malasia? Tal vez la nación sea un concepto demasiado ambicioso — quizás hasta vacío — en el caso del Perú, un país que tiene 76 etnias, que se 
expresan en 87 lenguas pertenecientes a 16 familias etnolingüísticas (Mapa Etnolingüístico del Perú, INDEPA). "Poco hay en común entre una persona de clase media limeña con un campesino de Huancavelica, uno de Puno, otro de Piura y un miembro de una comunidad tribal amazónica. Todos están en el territorio del Perú, pero no todos pertenecen a la misma nacionalidad" (Obando 30). Probablemente, sea mejor que nos concentremos en promover que las comunidades étnicas de la patria convivan armónicamente, celebrando sus similitudes y diferencias, aportando a la sociedad lo mejor de cada una de ellas. Mercedes Giesecke Sara-Lafosse resume esta actitud en la palabra "intraculturalidad", que define como

[r]elaciones entre subculturas al interior de un grupo cultural diverso. Es una dimensión de la interculturalidad [énfasis mío] desde el ejercicio práctico de la vida e interpretación de la propia cultura; diversidad propia en la misma cultura; y el libre desarrollo de ese complejo proceso de crecimiento desde una pluralidad de raíces en un suelo común dentro de una gran dinámica de autonomías que crecen en distintas direcciones. (“Cuestionando la globalización”159)

Expresado de manera un tanto más poética: "Nación es alma, espíritu, meta común, acuerdo en lo fundamental. Y llamar a trabajar por su unidad [...] [U]nidad no es unanimidad, implica diversidad. La Nación, en ese sentido, es, como decía Renan, un plebiscito cotidiano” (López Chau, “Destrucción y restauración” 171).

Giesecke subraya las siguientes características del concepto de “interculturalidad": 
Equidad, justicia y diálogo entre culturas que se reconocen entre sí en lo político, social y cultural [...] Es una praxis de vida que implica un modo comunicacional racional que se deja tocar, afectar e impresionar por el otro $[\ldots][T]$ iende a la construcción de una matriz polivalente que abierta al diálogo encara el conflicto que nace entre diversas tradiciones, busca reelaborar la herencia compartida y revitalizar el sentido de crear puentes o lazos entre las culturas. (“Cuestionando la globalización” 159-60)

Como puede advertirse, la pluriculturalidad es aplicable tanto a las relaciones entre las naciones en un mundo globalizado como dentro de ellas, pero por más que exista una política de pluralismo corporativo mediante la cual el gobierno avale y proteja oficialmente las diferencias étnicoculturales con el objetivo de promover una sociedad más igualitaria y que la riqueza sea distribuida de una manera más equitativa, finalmente es la toma de conciencia de cada individuo, su actitud y sus acciones—reflejando no sólo tolerancia sino una genuina apertura a la diversidad, que considera valiosa- las que hacen posible que acciones afirmativas dentro de una política de pluralismo corporativo puedan ser puestas en práctica con resultados exitosos. ${ }^{48}$

\footnotetext{
${ }^{48}$ Las acciones afirmativas consisten en medidas de discriminación positiva o afirmativa que intentan favorecer a las minorías.
} 


\section{SINGULARIDAD CULTURAL DEL SUBALTERNO PERUANO}

Con una superficie continental de 1285215 kilómetros cuadrados, el Perú ocupa el puesto 20 en extensión en el mundo. El territorio está claramente demarcado por tres regiones naturales que corren longitudinalmente de norte a sur: la costa, la sierra y la selva. La costa abarca el $10.6 \%$, la sierra el $31.7 \%$, y la selva el $57.9 \%$ del área total. Desde la época preincaica se asentaron pobladores de diversas razas y culturas en cada una de las tres regiones naturales. En consecuencia, el Perú era un país multirracial y multicultural desde mucho antes de que fuera invadido y conquistado por España en el siglo XVI.

Desde luego, fue durante la etapa de Resistencia a la imposición (coloniaje) (15331821) cuando se produjo el mestizaje entre indígenas autóctonos, españoles, y negros importados como esclavos. Según los datos del censo realizado en 1700, ese año la capital peruana tenía 34724 habitantes, de los cuales el 56.5\% eran españoles (Pérez Canto, "La población de Lima" 390). Posteriormente, la Era del Guano (1840-1870) atrajo inversionistas extranjeros blancos, principalmente ingleses y norteamericanos. ${ }^{49}$ Entre 1849 y 1875 también llegaron al Perú chinos culíes contratados bajo el régimen de enganche (debt bondage). ${ }^{50}$ Unos 87 mil chinos provenientes de Macao (Orrego Penagos, "La república oligárquica" 79) suplieron ampliamente la falta de mano de obra que había

\footnotetext{
${ }^{49}$ El guano es el excremento de aves marinas que se acumula sobre algunas islas de la costa, como en las Islas Chincha. En el siglo XIX era un fertilizante muy cotizado y su demanda produjo un gran auge económico.

${ }^{50}$ La presencia de chinos en el Perú data desde principios del siglo XVII (Vega Loyola 155).
} 
ocasionado la abolición de la esclavitud. ${ }^{51}$ Aproximadamente 26 mil negros esclavosque representaban el $1.3 \%$ de la población total (ibíd. 113)—se beneficiaron de la manumisión. ${ }^{52}$ Eduardo Salazar afirma que la inmigración china fue largamente la más numerosa en el siglo XIX (“Causas de la inmigración china”). En 1857 la población de extranjeros en Lima representaba el 50\% del total de habitantes (Orrego Penagos 188), pero ese porcentaje se había reducido a $18.6 \%$ hacia 1876 (ibíd. 189), a pesar de la ola migratoria de italianos, austroalemanes y japoneses que se produjo en ese período.

Con el descubrimiento de la vulcanización y de la cámara neumática vino la Fiebre del caucho (1882-1912). En 1851, Iquitos era una caleta de pescadores situada a orillas del río Amazonas. De los 200 habitantes que tenía en ese año pasó a tener 20000 en 1900 (Obando 95). ${ }^{53}$ En el siglo XX, a consecuencia de las dos guerras mundiales, el Perú acogió a europeos de diversas nacionalidades, especialmente croatas y judíos askenazis. Como resultado de los desplazamientos poblacionales antes mencionados, el Perú es un país multiétnico y plurilingüístico, en donde se habla español, quechua y otras lenguas vernáculas, además de los idiomas y dialectos en que se comunican los grupos de inmigrantes. Finalmente, en los últimos años el Perú está recibiendo inmigrantes de otros países de América Latina, de los Estados Unidos y de España.

\footnotetext{
51 "El destino no fue exclusivamente agrícola, en los primeros años se les destinó tanto a la agricultura como al trabajo en las islas guaneras y en la servidumbre urbana" (La Torre Silva, "La inmigración china en el Perú" 1).

${ }^{52}$ El presidente peruano Ramón Castilla abolió la esclavitud en 1854. Sin embargo, las quejas de los agricultores no se hicieron esperar debido a la imperiosa necesidad de mano de obra. Por este motivo, Castilla autorizó la inmigración de chinos. "[C]uando [al latifundista costeño] le faltaron los esclavos negros, les buscó un sucedáneo en los culis chinos" (JCM, 7 ensayos 46).

${ }^{53}$ La película Fitzcarraldo (1982) de Werner Herzog trata sobre el boom del caucho en el Perú.
} 


\title{
III.1 ANTECEDENTES HISTÓRICOS
}

\author{
Hasta que los leones no tengan sus propios historiadores, \\ el hombre seguirá ganando las historias de cacería
}

Autor desconocido

\section{El Imperio inca}

Hubo hasta dos dinastías incas: la Hurin Qusqu (Bajo Cusco), ${ }^{54}$ fundada por Manco Cápac, quien gobernó aproximadamente entre 1200 d.C. y 1230 d.C., y la Hanan Qusqu (Alto Cusco), que empezó con Inca Roca (c.1350 d.C. - 1380 d.C.). ${ }^{55}$ Sin embargo, no puede hablarse propiamente de un Imperio incaico sino hasta que Pachacútec sometió al pueblo chanca alrededor de 1438, hito que marcó el momento del inicio de la expansión del curacazgo del Cusco. Este Imperio duró apenas 94 años, hasta que Pizarro ejecutó al inca Atahualpa, en $1533 .{ }^{56}$ Para ese momento, el área de influencia de los incas, a fuerza

\footnotetext{
${ }^{54}$ Cusco: Toponímico que actualmente suele escribirse con "s" y no con "z", debido a que el fonema de la "s" es más parecido al de la pronunciación original de la palabra en quechua. En la actualidad, Cusco puede escribirse con "s", no con "z". Cusco es el nombre oficial tanto del departamento como de su capital. La nueva grafía fue adoptada con el propósito de guardar una mayor similitud con "Qosco", el nombre original en quechua. 〈http://www.wikilengua.org/index.php/Cuzco>

El Diccionario Prehispánico de Dudas admite ambas formas de escritura.

$\langle$ http://lema.rae.es/dpd/?key=Cusco $>$

55 "El Cuzco de los incas estaba dividido en una parte baja y una parte alta: Hurisunyo y Hanasuyo. No es muy fácil explicar este dualismo, y los cronistas que lo indican como un rasgo común a todo el Imperio, en su mayoría lo consideran una astucia de los incas para facilitar el control de los pueblos sojuzgados, oponiéndolos así por mitades" (Bourricaud 30).

El "mundo ideal" de las culturas andinas se caracteriza por "la manifestación doble en todas las realidades de la vida [...] La bipartición en el panorama cultural andino existió con anterioridad a la expansión inca. Constatamos que ese mundo desde los primeros mitos aparece dividido en pares o escindido entre fuerzas rivales y complementarias que a la vez interactuaban de manera conjunta, creando así el 'equilibrio' de las dos partes y con ello la armonía" (Accorsi 15).

De acuerdo con el Inca Garcilaso, los habitantes varones del Cusco, que estaban bajo la tutela de Manco Cápac, conformaban el Hanan Cozco, en tanto que las mujeres, que estaban bajo la tutela de Mama Ocllo, conformaban el Hurin Cozco (Comentarios reales I.XVI.31).

${ }^{56}$ Manco Inca Yupanqui, Sayri Túpac Inca, Titu Cusi Yupanqui, y Túpac Amaru I—los llamados incas de Vilcabamba o neoincas - sucedieron a Atahualpa, ofreciendo resistencia a los españoles entre 1537 y 1572. Sin embargo, el Tawantinsuyo ya se había desmembrado para entonces.
} 
de someter a un pueblo tras otro a lo largo de casi un siglo, abarcaba más de 2 millones de kilómetros cuadrados, comprendiendo porciones de los actuales territorios del Perú, Colombia, Ecuador, Bolivia, Chile y Argentina, en los que vivían alrededor de 15 millones de personas. "[C]uando llegaron los españoles, muchas etnias que ya habían entablado luchas encarnizadas contra los Incas para recuperar o conservar su libertad, vieron en los extraños visitantes la oportunidad para liberarse del yugo cusqueño" (Arrambide 13, en Rodríguez y Venturo, Ampay Perú 98). Algunos de los pueblos sometidos por los incas se volvieron contra ellos y se aliaron a los españoles durante la Conquista. Por ejemplo, los cañaris (Ecuador) y los chachapoyas (Amazonas). Adicionalmente,

[h]acia 1525, año de la muerte de Huayna Cápac, y mientras Cortés consumaba la conquista de Méjico, el Imperio Incaico se dirigía ya aceleradamente a su desintegración. La posterior guerra civil entre sus sucesores, Huascar y Atahualpa, no hizo sino polarizar antagonismos interétnicos ya latentes, que la llegada de los españoles no tuvo luego sino que capitalizar. (Fuenzalida, "Identidad cultural")

Cabe recordar que Atahualpa (1500-1533) era hijo de Huayna Cápac (1493-1525) y que asesinó a su hermano Huáscar (1491-1533) en la Guerra civil incaica para apoderarse del trono. Sin embargo, la derrota del Imperio inca frente al exiguo cuadro militar español no puede ser explicada únicamente por las divisiones internas. Tampoco los caballos y las armas de fuego de los conquistadores fueron la mayor razón de que un puñado de hombres lograra vencer a "un inmenso y multiétnico ejército de miles de indígenas" 
(ibíd.), no sólo en Cajamarca (1532) sino en el Cusco (1533), en el corazón mismo del Imperio. Según MVLL, la razón que mejor explica el fenómeno es que el Inca era un líder absolutista, que habría anulado la voluntad de sus súbditos:

The vertical and totalitarian structure of the Tawantinsuyu was without doubt more harmful to its survival than all the conquistadores' firearms and iron weapons. As soon as the Inca, that figure who was the vortex toward which all the wills converged searching for inspiration and vitality, the axis around which the entire society was organized and upon which depended the life and death of every person, from the richest to the poorest, was captured, no one knew how to act. And so they did the only thing they could do with heroism [...] They let themselves get killed. [...] Those Indians who let themselves be knifed or blown up into pieces that somber afternoon in Cajamarca Square lacked the ability to make their own decisions [...] [They] were incapable of taking individual initiative, of acting with a certain degree of independence according to the changing circumstances. ("Questions of Conquest" 4)

¿Cómo explicar, entonces, la actitud rebelde de algunos pueblos sometidos por el incanato? ¿Será que la “edad divina” y la “edad heróica” se hallaban traslapadas en la civilización inca, en tanto que los invasores ya habían alcanzado la "edad humana”, y eso hacía vulnerables a los primeros? ${ }^{57}$ Parece que sí: “Those 180 Spaniards who had placed the Indians in ambush and were now slaughtering them did possess this ability. It was this

\footnotetext{
${ }^{57}$ Me refiero a las tres edades en la evolución histórica que se suceden y repiten en la constante de corsi e ricorsi que identifica Giambattista Vico en Principi d'una scienza nuova intorno alla natura delle nazioni [Principios de ciencia nueva. En torno a la naturaleza común de las naciones] (1744).
} 
difference [el dominio de la voluntad individual], more than the numerical one or the weapons, that created an immense inequality between those civilizations" (MVLL, “Questions of Conquest" 4). El hecho de que no emergiera de inmediato un líder en reemplazo de Atahualpa da cuenta del vacío que suelen dejar los líderes absolutistas cuando caen o mueren.

\section{Primeras encomiendas en el Perú}

Después de que Francisco Pizarro tomó el Cusco (1534), los invasores se repartieron el botín de tierras e indígenas. Desde ese momento empezaron los conflictos entre

pizarristas y almagristas. ${ }^{58}$ Con el propósito de controlar los desmanes y de corregir la informalidad, ese mismo año la Corona emitió una real cédula denominada "Carta acordada sobre digresión de la tierra del Perú", cuyo tenor es como sigue:

[V]istas las dichas informaciones con acuerdo y parecer de nuestro consejo y por voluntad que tenemos de hacer merced a los conquistadores y pobladores de la dicha tierra especialmente a los que tienen o tuvieren intención y voluntad de permanecer en ella tenemos acordado que se les haga repartimiento perpetuo de los dichos indios tomando para nos y los reyes que después de nos vinieren las cabeceras y provincias y pueblos que vosotros hallareis por la dicha información ser cumplideras a nuestro servicio y a nuestro Estado y Corona real y del restante (AGI, L 565, lib. 1, cit. en Porras). (Salles y Nojeovich 48)

\footnotetext{
${ }^{58}$ Los hombres leales a Francisco Pizarro y los fieles a Diego de Almagro, respectivamente.
} 
El obispo Tomás de Berlanga fue comisionado para velar por el cumplimiento de esta real cédula. Y así, tempranamente, quedó instaurado el régimen de encomiendas en el Perú — una práctica generalizada por toda la América hispana-mediante el cual la Corona les concedía a los "beneméritos de Indias" el derecho a "cobrar para sí los tributos de los indios que se les encomendasen por su vida y la de un heredero, con rango de cuidar de los indios en lo espiritual y temporal y defender las provincias donde fueren encomendados" (Rodríguez Demorizi, Los Dominicos y las encomiendas de Indios 2526). De esa manera, la Corona compensaba a los conquistadores por los servicios prestados, promovía la creación de nuevos poblados (con un espíritu similar al donadío, a los repartimientos y las Cartas Pueblas en España durante la Reconquista), aculturaba y adoctrinaba a la población nativa, mantenía el orden y afianzaba su autoridad. Lamentablemente, su proyecto no incluía a los indígenas sino como medio de producción. Como dice Hildebrando Castro Pozo con agudeza:

Cuando se hace constar en un cuerpo de leyes que el Rey hace merced de encomiendas 'por gratificación de servicios' y se sabe o se ha ordenado que cada encomendero 'esté tasado en oro, o en mantas, o en cualquier otro aprovechamiento ${ }^{59}[\ldots]$, no cabe distinguir entre la acción generosa y cristiana del Estado en las Leyes de Indias, y la acción brutal del conquistador en la apartada Colonia. Ambos son una misma pieza. (Del ayllu al cooperativismo social 135 )

\footnotetext{
${ }^{59}$ Leyes de Indias: Ley XXXIII, título VIII, libro VI, página 260 (Castro Pozo, Del ayllu, nota $\mathrm{N}^{\circ} 110$, página 240).
} 
Difícil es, pues, distinguir la magnanimidad de la codicia cuando ésta se disfraza de aquélla, puesto que "oficialmente se ordenaba la explotación del vencido y se pedía humanidad y justicia a los ejecutores de la explotación; se pretendía que humanamente se cometiera iniquidades o equitativamente se consumaran injusticias" (González Prada "Nuestros indios", en Memorias 128).

En mayo de 1536 se inició el levantamiento de Manco Inca, el sucesor de Atahualpa designado nominalmente por los conquistadores. (En realidad, Manco Inca fue una figura simbólica que utilizaron con el propósito de pacificar a las masas). ${ }^{60}$ So pretexto de combatir al sublevado, algunos españoles se habían aprovechado de la situación para apropiarse indebidamente de tierras e indígenas. Para ponerles coto, el 20 de noviembre de ese año los reyes Carlos V y Juana I emitieron las "Ordenanzas de población del Perú", disponiendo, entre otros asuntos que, "ningún español de los que tuvieren títulos y cédulas y depósitos de encomiendas ocupen o se apropien a sí ningunos caciques, pueblos, ni naturales de los que en la tierra hubiere: salvo aquellos que, expresamente, tuvieren señalados en la tal cédula de depósito que les fueren dadas; ni se sirvan de ellos por cualquiera vía" (Archivo General de Indias, libro 563, folio 239 r., citado en Solano 183-85). En la práctica, “[n]i las medidas previsoras de Toledo, ni las que en diferentes oportunidades trataron de ponerse en práctica, impidieron que una gran parte de la propiedad indígena pasara legal o ilegalmente a manos de los españoles o criollos" (Ugarte 24; Mariátegui, 7 ensayos 50). Haya de la Torre explica la trascendencia de este hecho hasta nuestros días: “[E]1 latifundio representa la conquista, la invasión, los

\footnotetext{
${ }^{60}$ Manco Inca fue asesinado en 1545 por almagristas que se habían ganado su confianza, haciéndole creer que se habían plegado a sus filas, y después lo traicionaron.
} 
godos y los neogodos, la clase dominante, en una palabra el civilismo $;{ }^{61}$ y la Comunidad representa la nación, es la tradición social del Perú [énfasis mío], es la vértebra económica de una organización que perdió el poder político que le arrebató el latifundio" (Obras Completas 185).

\section{Indígenas "ciudadanos"}

Durante el período de estabilización colonial, ${ }^{62}$ la sociedad virreinal estuvo divida en dos Estados_llamados "repúblicas"_; es decir, en dos grupos de "ciudadanos" gobernados bajo estatutos jurídicos distintos: ${ }^{63}$ la "república de españoles", que abarcaba a peninsulares (españoles nacidos en la península ibérica) y criollos (hijos de españoles, nacidos en Indias), quienes conformaban un bloque bastante homogéneo en cuanto a raza, idioma y religión; y la "república de indios", una categoría que comprendía a miembros de muchas etnias que se expresaban en diversas lenguas, organizadas en grupos bajo la jerarquía de curacas, cuya función era armonizar la ley general con las particularidades de la idiosincrasia indígena. Debido a su condición de esclavos, los negros no formaban parte de la república. “[E]n el mundo indígena colonial se confundía raza, clases y

\footnotetext{
${ }^{61}$ Con la palabra "civilismo", con la que intenta sintetizar la idea de dominio hegemónico, probablemente Haya de la Torre se refiere al Partido Civil que formó el empresario Manuel Pardo y Lavalle en 1870, y cuyos miembros eran gente acaudalada e influyente: hacendados, consignatarios guaneros, grandes comerciantes, etcétera.

${ }^{62}$ García Bedoya llama "período de estabilización colonial” al comprendido entre 1580 y 1780 (71-7).

${ }^{63}$ Por ejemplo, el Tribunal del Santo Oficio de la Inquisición de Lima (1569-1820) no tenía jurisdicción sobre los indígenas, considerando su reciente iniciación en la fe cristiana; los indígenas no participaban de la vida política y se les imponía pesados tributos, principalmente en la forma de mano de obra, en pago del costo de su evangelización. Por otra parte, únicamente los peninsulares podían ocupar cargos públicos de importancia, lo que ocasionó resentimiento entre los criollos, quienes los llamaban despectivamente "gachupines" ("chapetones" eran los peninsulares recién llegados).
} 
‘status'; tal como lo ha demostrado Emilio Harth-Terré [Negros e indígenas, 1973], había indios caciques que tenían sus propios esclavos negros" (Klaiber 24). En realidad, la república de indios "fue una ficción porque, en realidad, no igualaba a los indios con los españoles o los criollos; antes bien, los subordinaba a los dos últimos" (Klaiber 24). ${ }^{64}$

En 1542, el emperador Carlos V promulgó las llamadas Nuevas Leyes, decretando que los indígenas no podrían ser obligados a hacer trabajos forzosos, debido a que se les reconocía como hombres libres, con derechos y obligaciones, en pie de igualdad con cualquier otro súbdito de la Corona; disponiendo la revocatoria de encomiendas confiadas a funcionarios públicos, a miembros del clero y a personas que no habían participado directamente en la Conquista, y prohibiendo que las encomiendas en manos de los primeros conquistadores fueran transferibles en herencia:

Ordenamos y mandamos, que de aquí adelante ningún virrey, gobernador, audiencia, descubridor ni otra persona alguna no pueda encomendar indios por nueva provisión, ni por renunciación venta ni otra cualquiera forma, modo, ni por vacación ni herencia, sino que muriendo la persona que tuviere los indios, sean puestos en nuestra real Corona; y las audiencias tengan cargo de informar luego particularmente de la persona que murió y de la calidad de ella y sus méritos y servicios de cómo trató los dichos

\footnotetext{
${ }^{64}$ El movimiento reivindicatorio indigenista Alcaldes Mayores Particulares (AMP) en Bolivia elaboró, alrededor de 1936, el proyecto descolonizador llamado Ley de Indios a partir de las Leyes de Indias, en el cual postulaba, curiosamente, la necesidad de que hubiese dos repúblicas separadas: la de indios y la de blancos, debido a "una cosmovisión religiosa y cultural que reflejaba las visiones de un nuevo tipo de movimiento étnico" con respecto a los derechos sobre la posesión de la tierra (Ari Chachaki 212-13, 219). Cabe mencionar que "[e]ntre 1920 y 1960 la AMP nutrió a dos generaciones de activistas" (Ari Chachaki 217). "El debilitamiento gradual de AMP ocurrió entre 1952 y 1971, luego de que el MNR (Movimiento Nacionalista Revolucionario) tomara el poder después de una insurrección popular" (ibíd. 220).

Aludo al caso boliviano porque el Perú y Bolivia comparten, en muchos aspectos, realidades sociales muy similares, debido a que el territorio boliviano constituyó el Alto Perú hasta 1835, cuando se creó esa nueva república, adoptando el nombre de Bolivia en honor a Simón Bolívar.
} 
indios que tenía, y si dejó mujer e hijos o qué otros herederos, [...] y nos mandamos proveer lo que sea nuestro servicio, y hacer la merced que nos pareciere a la mujer e hijos del difunto [...]. (cit. en García 2: 204) ${ }^{65}$

La promulgación de estas leyes prueban que, en la Controversia de Valladolid, Sepúlveda y de las Casas no habían quedado tablas; no había sido un empate: había ganado el segundo.

\section{Creación del Virreinato del Perú}

Mediante las Leyes Nuevas, Carlos V también dispuso la creación del Virreinato del Perú, designando a la Ciudad de los Reyes (Lima) como su capital, en reemplazo de las anteriores gobernaciones de Nueva Castilla y Nueva León. Dado que la sede de la Real Audiencia de Panamá fue trasladada a Lima, el Virreinato del Perú tuvo jurisdicción en los actuales territorios del Perú, Panamá, Colombia, Ecuador, Bolivia, Chile, Argentina, Paraguay y Uruguay, y la parte sur-occidental del Brasil. Duró alrededor de trescientos años, desde 1522 hasta 1824, cuando el Perú se independizó de España, aunque antes de esa fecha su extensión se había reducido con la creación de los virreinatos de Nueva Granada (1717) y Río de la Plata (1776), y con la expansión lusitana en el Brasil.

\footnotetext{
${ }^{65}$ En mayo de 1936, el líder indigenista boliviano Gregorio Titiriku manifestó en una asamblea lo siguiente: "[L]la tierra y el territorio nos han sido dados y bendecidos solamente por la Pachamama [madre tierra] y los Achachilas [vírgenes, espíritus de las montañas; los vivos se comunican con los achachilas por medio de los muertos], no por los españoles y sus leyes". En consecuencia, no eran necesarios los títulos coloniales de propiedad para defender las tierras y los derechos de las comunidades. "Por el contrario, [Titiriku] abogó por la legitimidad de lo que él y los otros tres activistas indígenas [...] llamaban la Ley de Indios, la cual era una reelaboración y reinterpretación de algunos segmentos de la legislación colonial del siglo XVII que se compiló como Leyes de Indias [...] Esta 'ley' elabora básicamente un discurso sobre los derechos y afirmaciones culturales indígenas, y aunque nunca fue reconocida por ningún gobierno de Bolivia, sus copias manuales o impresas circulaban de la mano de activistas y seguidores de un amplio movimiento, impulsando la defensa de sus derechos y de sus propios modos de vida" (Ari Chachaki 21112).
} 
Fernando Fuenzalida advierte con acierto que la entidad del virreinato habría sido "puramente nominal si esa creación jurídica, que otorgaba a los peruanos realidad política y administrativa $[\ldots]$, no hubiera venido acompañada de una paralela construcción del espacio social y geográfico del Tahuantinsuyo" ("Identidad cultural"). Es decir, sobre las bases del Tahuantinsuyo, entre los siglos XVI y XIX "la actividad jurídica y política de la Corona de Castilla construyó [...] un nuevo Imperio del Perú que, presentándose como prolongación histórica del primero" (ibíd.). En ese sentido, el Tahuantinsuyo fue el espacio geográfico (parcialmente), conceptual y, sobre todo, simbólico que sirvió de sustrato a ese nuevo Perú virreinal. ${ }^{66}$

\section{La gran rebelión de encomenderos de 1544}

En rebeldía a las nuevas disposiciones de la Corona en lo concerniente a la disposición de que las encomiendas no fueran heredables a perpetuidad, en 1544 la Real Audiencia de Lima destituyó a Blasco Núñez Vela, el primer virrey del Perú, y lo embarcó de vuelta rumbo a España. En su reemplazo, Gonzalo Pizarro fue nombrado gobernador. Sin embargo, el virrey destituido escapó en la travesía y organizó en Tumbes un ejército vengador. Ante la arremetida de las fuerzas gonzalistas para someterlo, Núñez Vela y sus hombres fueron obligados a retroceder progresivamente hasta el norte de Quito. Finalmente, el virrey murió decapitado en la batalla de Iñaquito, en 1546. Ese mismo año, Carlos V nombró a Pedro de la Gasca pacificador y presidente de la Real Audiencia de

\footnotetext{
${ }^{66}$ Felipe Guamán Poma de Ayala había advertido prematuramente la correspondencia que existía en las respectivas formas de organización y gobierno entre el Viejo Mundo y el Nuevo Mundo. De acuerdo con Rolena Adorno, "[h]e conceived political dominion as a world to be governed by the autochthonous princes of their respective realms under the titular (honorary) headship of the king of Spain" (The Nueva Corónica Y Buen Gobierno 10).
} 
Lima. La Gasca ofreció amnistiar a los rebeldes que se rindieran y arrepintieran de haberse sublevado contra el rey y, con la adhesión de los desertores del bando pizarrista—que eran bastante numerosos—más los refuerzos militares que le enviaron de Guatemala, Colombia y Chile, formó un ejército que, el 9 de abril de 1548, enfrentó al obstinado Gonzalo Pizarro en la batalla de Jaquijahuana (Cusco), capturándolo y ejecutándolo al día siguiente.

\section{Causas de la Independencia del Perú}

Carlos III reinó desde 1759 hasta 1788, cuando falleció. Desde su reinado en adelante, "Madrid impuso nuevos gravámenes, incrementó la eficiencia de su recaudación, hizo efectivos los monopolios comerciales metropolitanos, restringió el comercio intrahemisférico $[\ldots]$, centralizó las jerarquías administrativas y promovió una fuerte inmigración de peninsulares"; políticas y medidas que "frustraron, irritaron y alarmaron cada vez más a las clases criollas" (Anderson, Comunidades imaginadas 81). Dice Fernando Fuenzalida que, "con la separación de Río de la Plata y de Charcas en 1776, apenas diez años más tarde, el Imperio de Indias sufrió un nuevo golpe que, dos años después, con la Cédula de Libre Comercio [...] La profunda crisis económica que la Cédula produjo en el Perú no hizo sino ahondar resentimientos y protestas. ("Identidad cultural").

En el primer quinto del siglo XIX, en las postrimerías del período colonial, en el Perú había un puñado de encomenderos de tufillo cortesano a quienes, salvo por el aspecto tributario, y por el malestar que les causaba no poder comerciar libremente, poco les interesaba independizarse de España. A pesar de las drásticas medidas impuestas por 
la Corona, los encomenderos continuaban disponiendo a su antojo en sus respectivos feudos, en ocasiones con la complicidad de corregidores prepotentes y arbitrarios, cuya función era cobrar tributos y administrar justicia.

Por otro lado, el comportamiento déspota y parcializado de los corregidores habría sido una de las causas que motivaron a Túpac Amaru II (1738-1781) — quien no era criollo sino mestizo- a rebelarse en 1780 contra el yugo español. ${ }^{67} \mathrm{El}$ incremento en las tasas de alcabala (impuesto al comercio), así como la imposición de aduanas (cuotas y peajes al tránsito de arrieros), también habían afectado directamente la economía del curaca y comerciante, amén de que se sentía indignado por la explotación de los indígenas mediante el sistema de mitas mineras, hecho que denunció en varias ocasiones ante las autoridades sin lograr resultados positivos. Cabe mencionar que Túpac Amaru II leyó la segunda edición de los Comentarios reales, publicada en 1723, como lo evidencia una declaración de aduana que tuvo que hacer en un viaje de Lima al Cusco (Kuon Arce et al 40). Esta obra "[s]irvió de inspiración a quienes buscaban cambiar las condiciones sociales y políticas del siglo XVIII” (ibíd. 40). Fue tanto así que el rey ordenó que, con la mayor discreción, se retirasen todos los ejemplares disponibles; incluso pagándolos, de ser necesario (ibíd. 41).

Para JCM "[1]a revolución no era un movimiento de las poblaciones indígenas" (Mariátegui, "La unidad de la América indo-española"; Baeza 247). "Para Marx, América Latina era un conjunto de sociedades semi-feudales gobernadas por latifundistas que ejercían su poder despótico sobre unas masas carentes de organización. La revolución de

\footnotetext{
${ }^{67}$ José Gabriel Condorcanqui Noguera—quien se hacía llamar Túpac Amaru II—era Marqués de Oropesa y curaca de Surimana, Pampamarca y Tungasuca.
} 
la independencia habría sido obra de un puñado de separatistas criollos que obraron con el apoyo externo de la burguesía inglesa, sin contar para nada con el respaldo de las masas populares" (Castro-Gómez 16). A diferencia de Túpac Amaru II, el indígena de a pie no vislumbraba en la independencia el mejoramiento de su estatus social ni, mucho menos, económico. Por el contrario, liberados del freno de los funcionarios peninsulares, los criollos no tendrían impedimento para intensificar sus abusos en contra de ellos. ${ }^{68}$ Los temores de los indígenas eran fundados, pues, a lo largo del siglo XIX, cuando "no había más ni nobleza india, ni entrometidos jesuitas, ni intermediario peninsular alguno", se expandió la exhacienda colonial (Neira, Las independencias 85).

Benedict Anderson cree que, en el bando contrario, fue el temor que sentían los criollos y los peninsulares en América de que se produjera una rebelión de indígenas y de negros - un temor que se agudizó cuando Napoleón Bonaparte invadió España en 1808, debido a que se sentían desprotegidos—-lo que impulsó inicialmente el movimiento independentista (Comunidades imaginadas 78-79). "En el Perú estaban frescos todavía los recuerdos del gran levantamiento encabezado por Túpac Amaru” (ibíd. 78). ${ }^{69}$ Hugo Neira comparte la percepción de Anderson (34). Debido, precisamente, a la Gran rebelión (1780-1781) de Túpac Amaru II, Carlos III dispuso reemplazar los corregimientos con intendencias, con la finalidad de centralizar el poder $\mathrm{y}$, de esa manera, tener un mayor control sobre la población. Asimismo, fueron suprimidos el reconocimiento y los

68 “Conforme al concepto legal de la institución, el encomendero era un encargado del cobro de los tributos y de la educación y cristianización de sus tributarios. Pero en la realidad de las cosas, era un señor feudal, dueño de vidas y haciendas, pues disponía de los indios como si fueran árboles del bosque y muertos ellos o ausentes, se apoderaba por uno u otro medio de sus tierras" (Ugarte, Bosquejo 24; JCM, 7 ensayos 50).

${ }^{69}$ Haciéndose eco de Gerhard Mansur (Simón Bolívar, 1948), Anderson manifiesta que Túpac Amaru repudiaba más al gobierno de Lima que al rey de España (Comunidades imaginadas 79). 
privilegios que, hasta ese momento, gozaban los pocos descendientes de la nobleza incaica que estaban vigentes. Hugo Neira afirma que, luego de la insurrección de Túpac Amaru II, "la opción criolla es clara: 'Si gana el Visitador [José Antonio de Areche], malo, malo, malo. Si vence Túpac Amaru, peor, peor"' (Las independencias 35).

En el ámbito internacional, las ideas de la Ilustración calaron primero en pueblos no hispanohablantes. Prueba de ello son la Independencia de las Trece Colonias, de Inglaterra, (1775-1783), y la Independencia de Haití, de Francia (1791-1804). Hugo Neira piensa que la influencia de la Ilustración fue muy limitada en los que respecta a la independencia del Perú (34). Contrariamente a Neira, Jeffrey L. Klaiber sostiene que, "los colegios, las universidades y los seminarios de la Iglesia fueron centros de la Ilustración y en algunos casos se convirtieron en verdaderos focos de ideas reformistas, que prepararon el camino de la Independencia" (21). Fuenzalida informa que, "[d]esde 1551, la Universidad de San Marcos de Lima, una de las más antiguas del mundo cristiano, se encargó de la formación de una élite ilustrada en la teología, las humanidades clásicas y las ciencias, las escuelas de nobles de educar al cacicazgo al estilo de la aristocracia hispana, los seminarios y las escuelas parroquiales de reclutar un clero de origen local" ("Identidad cultural").

Según Neira, difícilmente el ánimo independentista de principios del siglo XIX habría surgido por imitación, "contagio" o presiones de otros pueblos hispanoamericanos, debido a que no había comunicación entre ellos. "Era un mundo en enclaves, encerrado cada país en sí mismo. Y si la guerra civil o revuelta criolla arranca de Buenos Aires o de Caracas, en México será guerra civil y en Perú, indiferencia" (Las independencias 34). Peor aún, cuando la confrontación se vuelve inevitable, "a diferencia de lo que sucedía en 
otros dominios, los criollos de las principales ciudades del virreinato peruano sufragaron las guerras que España mantenía en América y negaron su apoyo a los 1evantarnientos en las provincias. Estas demostraciones de fidelidad al Rey de España hizo necesaria la intervención de los ejércitos provenientes de otras jurisdicciones para derrotar el bando español, paradójicamente formado mayormente por 'peruanos'” (Cotler 34).

Asimismo, a diferencia del Perú, en los demás países hispanoamericanos había encomenderos menos preocupados de títulos nobiliarios y de formas cortesanas, y existía una burguesía más desarrollada que se hallaba descontenta debido al impedimento de poder comprar y vender libremente en el mercado internacional. Por el contrario, "para la élite criolla peruana, la prosperidad económica dependía no de la conquista de la plena libertad comercial, sino del retorno a las condiciones comerciales exclusivistas y monopólicas de la época colonial [...] [L]a vinculación con la metrópoli no fue un obstáculo sino una necesidad" (Bonilla, La Independencia en el Perú 107). Con todo, en opinión de Fernando Fuenzalida, la independencia del Perú fue el resultado del desarrollo de una conciencia identitaria criolla que empezó a formarse en el siglo XVI:

[L]a República de los Españoles se convierte en la República Criolla. Sometidos los conquistadores y sus descendientes a un régimen jurídico común que los distanciaba de los peninsulares y los acercaba unos a otros, en el Imperio del Perú desaparecieron en relativamente breve tiempo los particularismos étnicos que oponían en su patria de origen a los castellanos, andaluces, catalanes y a otros pueblos. Emergió tempranamente - mucho antes que en España misma - una conciencia de 
hispanidad común que se tradujo en la emergencia del criollo. ("Identidad cultural")

Hallo la tesis de Fuenzalida muy convincente, pero de ahí a que haya surgido un verdadero sentimiento patriótico hay un largo trecho: "[A]unque en ninguna parte de la América española se peca por demasiado patriotismo, no conozco otra en la cual este sentimiento sea más apagado [que en el Perú]", anotó Alexander Von Humboldt en Diario a principios del siglo XIX (en Cotler 33).

\section{Independencia del Perú}

El Perú logró su independencia entre 1821 y 1824, luego de casi tres siglos de dominación española. Desde entonces, los peruanos de aquella época empezaron a preguntarse, sin ponerse de acuerdo, cuál era su nueva identidad. Mediante un decreto supremo emitido el 27 de agosto de 1821, José de San Martín dispuso lo siguiente: "En adelante no se denominarán los aborígenes Indios ó Naturales; ellos son hijos y ciudadanos del Perú y con el nombre de 'Peruanos' deben ser conocidos". ${ }^{70}$ Sin embargo,

ni indígenas ni afroperuanos obtuvieron ese mínimo de ciudadanía que es el voto, pues el tributo indígena y la esclavitud continuaron hasta la década de 1850. Abolidos ambos, tampoco se cumplió 'la promesa de la vida peruana'. Los pueblos indígenas, que hasta la primera mitad del S.XX constituían la mayoría de la población, siguieron excluidos de la

\footnotetext{
${ }^{70}$ Este decreto fue publicado en la Gaceta del Gobierno de Lima Independiente, el 29 de agosto de 1821. Está firmado por San Martín y por Juan García del Río, un colombiano que había sido nombrado ministro de Relaciones Exteriores del Perú.
} 
ciudadanía, a merced de poderes locales en cuya cúspide se ubicaban por lo general los grandes terratenientes, que se expanden con fuerza entre fines del S.XIX y principios del S. XX. (Degregori, "Perú: identidad" 214).

A pesar de las buenas intenciones del libertador argentino, es evidente que la identidad nacional no se forja mediante la promulgación de dispositivos legales. En todo caso, sorteando el simplismo, el decreto de San Martín daba pie a hacerse algunas preguntas: ¿Eran peruanos sólo los habitantes nativos? De ser así, ¿cuáles? ¿Los serranos, los amazónicos, los costeños? ¿Todos? ¿Eran tan peruanos los criollos como los indígenas? ¿Y los mestizos? ¿Qué razas validaban la nacionalidad? ¿Era la raza un factor determinante de la nacionalidad? Sin duda, San Martín no pretendía crear una categoría excluyente sino, por el contrario, que los nativos fueran incluidos en la naciente y heterogénea República del Perú. Empero,

si bien [la Independencia] anuló las leyes de estratificación racial, no pudo ni siquiera mellar esa conciencia de discriminación. Al contrario, la continuación de los blancos nacidos en América en el poder político, la mantuvo con caracteres más pronunciados. El racismo, ingrediente consustancial de la explotación del indio, del negro y del mestizo, siguió irradiándose desde los centros de dominación blancos en la ciudad y en el campo. Las autoridades judiciales, policiales y eclesiásticas a su servicio se desplegaban contra los indios, negros y mestizos con más ensañamiento y rabia que los mismos gamonales. Y así continuamos viviendo. (Rendón Vásquez) 
Por todos estos hechos, Fernando Iwasaki concluye válidamente que "[l]a república falseó la igualdad real mediante la igualdad legal” (“El pensamiento político de Bartolomé Herrera” 137). Tanto fue así que, para efectos prácticos,

la "comunidad imaginada" se reducía en esos tiempos a varones, adultos, urbanos, criollos y mestizos hispanohablantes, educados (que sabían leer y escribir) y de buena posición económica. Esos eran los que tenían derecho al voto. Menos del $5 \%$ de los que actualmente lo tienen. No votaban las mujeres, ni los analfabetos, que eran la absoluta mayoría, sobre todo porque las lenguas andinas y amazónicas eran ágrafas. Existía además el "voto censitario". Es decir, sólo tenían derecho a voto los que tenían propiedades. El resto estaba excluido de la "foto de familia". (Degregori, "Perú: identidad" 214).

Fue necesario esperar hasta la Constitución 1979 para que los analfabetos fueran autorizados a votar.

\section{Caudillaje y neocolonialismo}

Durante la República, los antiguos encomenderos se convirtieron en gamonales latifundistas $\mathrm{y}$, en alianza con los caudillos de los gobiernos de turno, continuaron sometiendo y explotando al indígena. A lo largo del siglo XIX surgieron distintos grupos, liberales o conservadores, que entraron en competencia para capturar el poder y llenar el vacío. Pero más frecuentemente fue el caudillo, con o sin bandera ideológica, el que impuso orden y unidad en las distintas regiones" (Klaiber 24).: 
El caudillaje militar era el producto natural de un período revolucionario que no había podido crear una nueva clase dirigente. El poder, dentro de esta situación, tenía que ser ejercido por los militares de la revolución que, de un lado, gozaban del prestigio marcial de sus laureles de guerra y, de otro lado, estaban en grado de mantenerse en el gobierno por la fuerza de las armas. Por supuesto, el caudillo no podía sustraerse al influjo de los intereses de clase o de las fuerzas históricas en contraste. (JCM, 7 ensayos 54).

El caudillo (strongman) hispanoamericano es un personaje generalmente carismáticopor lo menos, al principio - que, sacando ventaja de la falta de consenso político, empuña las armas para usurpar el poder por la fuerza. Suele contar con el apoyo de los militares y lo respalda un segmento popular resentido al que logra encandilar con una inflamada retórica revisionista, indigenista o chola. Si el país tiene suerte- - y el caudillo de turno no se enquista en el poder por muchos años, hasta décadas, o es defenestrado por otro caudillo tanto o más indeseable_-, sintiéndose magnánimo convoca a comicios. El ciclo se repite cada vez que aparece otro caudillo que gobierna despóticamente como sus predecesores. En muchas ocasiones, estas dictaduras reciben apoyo económico de ricos no aristócratas a cambio de favores políticos que éstos reciben a través del corrupto aparato público. De esa manera, los caudillos colman sus arcas y las de sus esbirros de confianza, en detrimento de los intereses del pueblo. Primero el caudillo se cholifica para persuadir a las masa y, una vez que ha logrado su objetivo mercantilista, se blanquea. En Las independencias (2010), Hugo Neira le dedica el capítulo VI a la figura del caudillo. Una de sus conclusiones más interesantes es que "el Libertador no viene a cerrar el 
episodio abierto por el Conquistador [...] [E]n lo político, se prolonga con el caudillo y el mesianismo" (29).

Con la República ingresan el capital extranjero y el sistema capitalista al Perú. Los terratenientes, en alianza con los caudillos al frente del gobierno de turno, se convierten en intermediarios comerciales de los británicos y norteamericanos principalmente; es decir, se vuelven cómplices del neocolonialismo, esta vez de corte económico más que político. "La minería, el comercio, los transportes, se encuentran en manos del capital extranjero. Los latifundistas se han contentado con servir de intermediarios a éste, en la producción de algodón y azúcar” (JCM, 7 ensayos 25). Se consolidan, entonces, una oligarquía y una plutocracia. Aníbal Quijano observa que "[1]a nueva burguesía capitalista peruana no dejó de enriquecerse, pero sólo a condición de la pérdida de su hegemonía en el proceso capitalista" (Dominación y cultura xvii).

No obstante haber menguado el poder de los gamonales debido a la competencia, al interior de los latifundios ellos seguían siendo los “dueños” y señores de los factores de producción - incluyendo las vidas de los indígenas trabajadores - y la única ley que imperaba era la del amo, como si se tratase en la práctica de estados independientes, en donde "la ley se acata pero no se cumple". González Prada reflexiona lúcidamente: "Donde las haciendas de la costa suman cuatro a cinco mil fanegadas, donde las estancias de las sierra miden treinta y hasta cincuenta leguas, la nación tiene que dividirse en señores y siervos. ("Nuestros indios", Memorias 136).

JCM disgnostica con agudeza que, "contra el sentido de la emancipación republicana, se ha encargado al espíritu del feudo-antítesis y negación del espíritu del burgo- la creación de una economía capitalista" (7 ensayos 28). Ciertamente, la 
economía de tipo feudal no propiciaba la formación de ciudades. ${ }^{71}$ Con la Independencia, la situación cambió de forma mas no de fondo. "Los privilegios de la Colonia habían engendrado los privilegios de la República” (Mariátegui 7 ensayos 57).

Incluso en tiempos de González Prada, el pensador anarquista se pregunta: "Bajo la República ¿sufre menos el indio que bajo la dominación española?” Y se responde él mismo: "Si no existen corregimientos ni encomiendas, quedan los trabajos forzados y el reclutamiento [...] Le conservamos en la ignorancia y la servidumbre, le envilecemos en el cuartel, le embrutecemos con el alcohol, le lanzamos a destrozarse en las guerras civiles y de tiempo en tiempo organizamos cacerías y matanzas como las de Amantani, Ilave y Huanta". Ésta es la peor parte:

Apenas inaugurada la primera dictadura de Piérola [1880], los indios de Amantani, isla del Titicaca, lincharon a un gamonal que había cometido la imprudencia de obligarles a hacer ejercicios militares. La respuesta fue el envío de Puno de dos buques armados en guerra [sic], que bombardearon ferozmente la isla, de las 6 de la mañana a las 6 de la tarde. La matanza fue horrible, sin que hasta ahora se sepa el número de indios que ese día

71 En las sociedades latinoamericanas "no había tenido lugar la revolución burguesa, todavía predominaban las relaciones feudales de producción y el poder político era detentado por caudillos como Simón Bolívar, investidos con poderes dictatoriales que les permitían imponer su voluntad personal sobre las masas ignorantes. Las clases sociales propiamente modernas (la burguesía y el proletariado) todavía no se habían formado, lo cual explicaba por qué razón la pureza de sangre y los privilegios étnicos todavía constituían un criterio fundamental de honor y distinción. Pero cuando este orden pre-capitalista [el de la encomienda; Keith 445] desapareciera, cuando la burguesía se adueñara finalmente de los medios de producción, cuando las fuerzas productivas se desarrollaran plenamente, cuando todo lo sólido se hubiera disuelto en el aire, entonces el colonialismo sería cosa del pasado. Para Marx el colonialismo no era otra cosa que el pasado de la modernidad y desaparecería por completo con la crisis mundial que daría paso al comunismo" (Castro-Gómez 17-18).

La historia ha demostrado cuán equivocado estaba Marx sobre este asunto, puesto que "la colonialidad dista de ser un fenómeno colateral al desarrollo de la modernidad y el capitalismo” (ibíd. 20). 
perecieron, sin distinción de edad ni sexo. Sólo se ven esqueletos que aún blanquean metidos de medio cuerpo en las grietas de los peñascos, en actitud de refugiarse. ("Nuestros indios", Memorias 130)

Cabe recordar que, "durante el siglo XIX, el poder económico y político se generó a través de dos vías: el recurso de la deuda interna del Estado y el avance de las grandes propiedades terratenientes, en el contexto de casi total indefensión legal de las comunidades" (Nugent 19-20). En 1939, Armando Bazán observaba que: “[c]ien años de República, si bien han servido para desarrollar determinados aspectos secundarios de la economía, han dejado intactos los grandes problemas nacionales; el de nuestros cuatro millones de indios, por ejemplo, que continúan en situación de servidumbre y analfabetismo" (117-8).

Es importante destacar que, si "[b]ajo una aristocracia indígena, los nativos componían una nación de diez millones de hombres [... y] bajo una aristocracia extranjera los nativos se redujeron a una dispersa y anárquica masa de un millón de hombres" 43).

[w]e, the westernized Latin Americans, have preserved in the worst habits of our forebears, behaving towards the Indians during the nineteenth and twentieth centuries as the Spaniards behaved toward the Aztecs and the Incas, and sometimes even worse. We must remember that in countries like Chile and Argentina, it was during the republic (in the nineteenth century), not during the colony, that the native cultures were systematically exterminated. In the Amazon jungle, and in the mountains 
of Guatemala, the extermination continues. ${ }^{72}$ (MVLL, "Questions of Conquest" 6)

Por la magnitud en que fue diezmada la población nativa durante la República, la "leyenda negra española" en Hispanoamérica resultó, en comparación, un cuento para niños.

\section{Convulsiones político-militares en el decimonónico peruano}

Recién inaugurado como país independiente y poco tiempo después del gobierno de Simón Bolívar (1823-1827), el Perú libró la Guerra contra la Gran Colombia (18281829). ${ }^{73}$ Cinco años más tarde, liberales y conservadores se enfrascaron en una guerra civil (1834-1835). Mientras que los liberales abogaban por la división de los poderes del Estado, los conservadores creían en el autoritarismo de un jefe supremo. Felipe Salaverry del Solar (limeño), perteneciente al segundo grupo, se rebeló contra el presidente Luis José de Orbegoso y Moncada (natural de Usquil, departamento de La Libertad), quien, reconociéndose incapaz de controlar la insurrección, solicitó apoyo a Andrés de Santa Cruz y Calahumana, el presidente boliviano.

El ejército de Santa Cruz invadió el Perú y venció a Salaverry, quien fue fusilado. Inmediatamente después se formó la Confederación Peruano-Boliviana, bajo el protectorado de Santa Cruz, la que fue disuelta en 1839 por la intervención del Ejército (Unido) Restaurador de Perú y Chile. Entonces, Agustín Gamarra Messía (cusqueño)

\footnotetext{
${ }^{72}$ En Bolivia, asimismo, la expansión de las haciendas empezó a finales del siglo XIX (Ari Chachaki 211). "En 1874 se promulgó una reforma agraria en Bolivia que eliminaba oficialmente los ayllus, desconocía las representaciones indígenas y propiciaba la expropiación de tierras comunales en nombre de la civilización y la modernidad" (ibíd. 216).

${ }^{73}$ La Gran Colombia abarcaba los territorios actuales de Colombia, Venezuela, Panamá y Ecuador.
} 
asumió el gobierno del Perú, empeñándose en recuperar Bolivia, que había sido parte del Tahuantinsuyo. Sin lograr su objetivo, Gamarra fue derrotado por José Ballivián (boliviano) y muerto en la batalla de Ingavi, en 1841. La Guerra entre Perú y Bolivia finalizó al año siguiente mediante la firma del Tratado de Puno. Luego, el Perú tuvo un período de anarquía en el que se sucedieron varios gobiernos militares. Como puede apreciarse, "Los primeros años de la república son años de anarquía militar. La contradicción existente entre la estructura socioeconómica de tipo cuasi feudal y la organización política burguesa, junto a la debilidad de las clases dominantes, hacen que éstas sean incapaces de hacerse cargo directamente del poder, generando el caudillismo militarista" (García Bedoya, Para una periodización 81$){ }^{74}$

Después de tanta convulsión política, afortunadamente en 1845, el general Ramón Castilla y Marquesado (tarapaqueño) fue electo presidente y logró no sólo completar sino extender su mandato hasta 1851. Con el advenimiento de la Era del Guano (1840-1870), el Perú gozó de un inusitado auge económico y de relativa calma, aunque a un alto costo: "Hacia mediados del siglo [XIX], el aprovechamiento de los recursos guaneros posibilitará una estabilización del aparato estatal y dará lugar a una era de prosperidad falaz. Se recurre a grandes empréstitos externos para financiar el funcionamiento del estado, lo que generó una subordinación a Inglaterra" (García Bedoya 81). Ese período fue interrumpido por la invasión de las Islas Chincha por España (1864), un hecho que

\footnotetext{
74 "An 'organic crisis' is a crisis of the whole system, in which contradictions in the economic structure have repercussions through the superstructures. One of its signs is when the traditional forms of political representation (parties or party leaders) are no longer recognized as adequate by the economic class or class fraction which they had previously served to represent. It is therefore a crisis of hegemony, since it occurs when a formerly hegemonic class is challenged from below and is no longer able to hold together a cohesive bloc of social alliances" (Gramsci y Forgacs 427).
} 
desencadenó la Guerra hispano-sudamericana (1864-1866). En 1864, durante el gobierno del general Juan Antonio Pezet y Rodríguez de la Piedra (limeño) — derrocado por Mariano Ignacio Prado Ochoa (natural de Huánuco) al año siguiente—las Islas Chincha fueron tomadas por la Escuadra Española del Pacífico, que se hallaba frente a las costas peruanas en una supuesta expedición científica y diplomática. El motivo-o el pretextode la ocupación fue la muerte del trabajador vasco Juan Miguel Ormazábal, ocurrida en 1863 en la hacienda algodonera Talambo (Chepén, departamento de La Libertad), a consecuencia de un enfrentamiento entre peones vascos y los esbirros del terrateniente peruano Manuel Salcedo Peramás. A la sazón, reinaba en España Isabel II.

\section{Guerra del Pacífico}

Trece años después de la Guerra hispano-sudamericana, el Perú luchó en la Guerra del Pacífico (1879-1883) — también llamada Guerra del Guano y del Salitre-, en la que fue vencido por Chile y no sólo perdió los territorios de Tarapacá y Arica, sino que, además, el país quedó destruido, económicamente arruinado y, lo que es peor, los peruanos se sintieron humillados y desmoralizados: "La mano brutal de Chile despedazó nuestra carne i machacó nuestros huesos; pero los verdaderos vencedores, las armas del enemigo, fueron nuestra ignorancia i nuestro espíritu de servidumbre" (González Prada, "Discurso en el Politeama"). ${ }^{75}$

El detonante para que Chile le declarase la guerra a Bolivia fue un impuesto de 10 centavos por cada quintal de salitre exportado con el que el gobierno boliviano (presidido

\footnotetext{
${ }^{75}$ Se refiere al Teatro Politeama, que funcionó en Lima desde 1872 hasta 1911, el año en que se incendió.
} 
por Hilarión Daza Groselle), violando un acuerdo, gravó indebidamente a la Compañía de Salitres y Ferrocarriles de Antofagasta (CSFA), la empresa chileno-británica que explotaba yacimientos de salitre en territorio boliviano, mayormente habitado por chilenos. Con el propósito de impedir la expansión de Chile, de controlar el mercado del salitre que competía con el del guano, y de honrar un pacto secreto suscrito con Bolivia (el Tratado de Alianza Defensiva de 1873), el Perú, cuyo presidente era Mariano Ignacio Prado, respaldó a ese país, convirtiéndose automáticamente en enemigo de Chile.

En 1879, Nicolás [Fernández] de Piérola y Villena (arequipeño) aprovechó que Prado había viajado a Europa a comprar armamento, para darle un golpe de Estado. Bolivia abandonó la guerra al año siguiente, pero el Perú siguió en la contienda y los chilenos no se detuvieron hasta ocupar Lima, en 1881. La ocupación se extendió a otras partes del territorio nacional y se prolongó hasta 1883, cuando se firmó la paz mediante el Tratado de Ancón. ${ }^{76}$ Como resultado de esta guerra, Bolivia perdió Antofagasta -y, en consecuencia, su salida al mar-y el Perú perdió los territorios de Tarapacá y Arica. El Perú también perdió temporalmente el territorio de Tacna, que no le fue devuelto sino hasta 1929.

\section{Revolución de Trujillo de 1932}

El coronel Luis Miguel Sánchez Cerro, líder fundador del partido Unión Revolucionaria (UR), formado ex profeso para las elecciones presidenciales de 1931, resultó vencedor en aquellos comicios. El pueblo lo apoyó no porque contara con un programa de gobierno

\footnotetext{
${ }^{76}$ El Tratado de Ancón fue firmado por Miguel Iglesias Pino de Arce-cajamarquino-, autoproclamado Presidente Regenerador del Perú, y Patricio Lynch, por Chile. En ese momento, el presidente chileno era Domingo Santa María, y el boliviano era Narciso Campero Reyes.
} 
sólido y bien definido - en realidad, era lo contrario - sino porque probablemente se identificó como un candidato mestizo, demagogo, populista y, además, autoritario, de "mano dura"; una "feliz" combinación de características para quien aspire, en cualquier época, a gobernar el Perú. Dice Hugo Neira que los peruanos tenemos "la inclinación populista y autoritaria a elegir en las urnas a nuestros propios tiranos" (31). El coronel también recibió apoyo de la burguesía, temerosa de que ganara el APRA, de centroizquierda y miembro de la Internacional Socialista, que postulaba la nacionalización de industrias y tierras, y el repudio al imperialismo.

A pesar de haber triunfado con el $50.75 \%$ de los votos sobre el $35.38 \%$ obtenido por el APRA, Sánchez Cerro fue acusado de fraude electoral por su contrincante Haya de la Torre, por lo cual el nuevo mandatario lo hizo encarcelar y se ensañó contra los partidarios de éste. La intolerancia a la oposición, el desconocimiento de libertades políticas y las medidas inconstitucionales que adoptó Sánchez Cerro-como, por ejemplo, la facultad de detener a cualquier persona sin necesidad de contar con un mandato judicial (el comportamiento de un típico caudillo dictador)—desencadenó la Revolución de Trujillo de 1932 (del 7 al 18 de julio), realizada por estudiantes, obreros y campesinos apristas, quienes, como parte de sus acciones, tomaron por asalto el cuartel O’Donovan y secuestraron a los oficiales.

La revuelta cundió rápidamente fuera de la ciudad de Trujillo. Se plegaron varias zonas aledañas. Las fuerzas armadas reprimieron la revuelta no sólo recuperando el cuartel sino bombardeando a la población civil—para lo cual contó con el apoyo de la aerolínea Panagra y la tolerancia de la embajada de los Estados Unidos-y fusilando a los rendidos. Hubo más de cinco mil muertos, muchos de ellos apristas que debieron cavar 
sus propias fosas antes de ser fusilados sin previo juicio. Conscientes de su derrota, antes de huir los sublevados masacraron a los oficiales que habían secuestrado. (Giesecke, La insurrección de Trujillo, 2010).

En 1933, un aprista le disparó a Sánchez Cerro, hiriéndolo de muerte. "Muy pocos dudaron de la responsabilidad directa de la dirigencia del APRA en la consumación del crimen, y los apristas, los descentralistas, y algunos otros grupos, consideraron que la muerte del presidente era el correlato necesario a las masacres de los apristas de Trujillo, Chocope y otros pueblos" (Guerra, Historia General del Perú 28). Según las cifras oficiales, 43 apristas fueron fusilados. El año de 1932, recordado en el Perú como el "año de la barbarie", reafirmó el tradicional antagonismo y animadversión que, tradicionalmente, había existido entre el APRA y las fuerzas armadas e hizo que, de ahí en adelante, la ciudad de Trujillo_-la natal de Haya de la Torre_-fuera reconocida como el enclave electoral aprista por excelencia.

\section{Escándalo petrolero}

En 1889, el yacimiento petrolero La Brea y Pariñas-ubicado en Talara, Piura, en la costa norte del Perú—-fue dado en arrendamiento por 99 años a London Pacific Petroleum Co., considerando 10 pertenencias (unidad de medida utilizada en concesiones mineras). Sin embargo, en 1911, a raíz de una denuncia pública, se descubrió que la firma británica venía explotando 41614 pertenencias en vez de 10, razón por la cual adeudaba al físco S/. 1'248,420 anuales y no los S/. 300 que había estado pagando. Lejos de honrar su deuda, en 1914 la London Pacific Petroleum Co. vendió sus derechos de arrendamiento a la International Petroleum Company (IPC), subsidiaria de Standard Oil of New Jersey. En 
1919, el Congreso autorizó al Estado a someter el litigio a un arbitraje internacional, pero el presidente de la República del mandato siguiente, Augusto B. Leguía-que era pronorteamericano-, prefirió zanjar el asunto mediante un Convenio Transaccional que luego hizo refrendar por un tribunal arbitral (Acuerdo, Convenio y Laudo de París del 2 de marzo de 1922). Las muy desventajosas condiciones económicas para el Perú hacían de este acuerdo el summum del entreguismo estatal a la penetración angloestadounidense. Con el propósito de enderezar las cosas, durante el primer gobierno de Fernando Belaúnde Terry (1963-1968) se declaró nulo el laudo arbitral obtenido por Leguía. Es así que, el 13 de agosto de 1968, el Estado peruano y la IPC firmaron el Acta de Talara, en virtud de la cual los campos petroleros fueron transferidos a la Empresa Petrolera Fiscal (EPF) en pago a cuenta de la deuda. Sin embargo, fue inadmisible para la opinión pública que la IPC conservara la refinería de Talara, la distribución del combustible a nivel nacional y las Concesiones Lima. Los ánimos se exacerbaron aún más por la pérdida de la página número 11 del acta en cuestión. En Hienas en la niebla se narra que "una página del convenio con la empresa norteamericana en la que aparecían las grandes concesiones y beneficios que el Estado peruano le concedía, había desaparecido" (212-3). En la novela de Morillo Ganoza también refiere que la gente se había lanzado a las calles "para defender la dignidad nacional pisoteada por el gobierno al recibir de una compañía imperialista unos yacimientos agotados, a cambio de una compensación económica millonaria, el gobierno ha puesto de rodillas al país ante una empresa yanqui que ha saqueado por décadas nuestras riquezas" (211). 


\section{Gobierno Revolucionario de la Fuerza Armada}

El autodenominado Gobierno Revolucionario de la Fuerza Armada es la dictadura militar impuesta en el Perú entre 1968 y 1980. El 3 de octubre de 1968, el general Juan Velasco Alvarado (caudillo-dictador) le dio un golpe de Estado a Fernando Belaúnde Terry, el presidente de la República que había sido elegido democráticamente en los comicios de 1963 para el período 1964-1969. El verdadero motivo habría sido que los militares querían impedir, a toda costa, que el APRA llegara al poder, lo que era probable dado que Víctor Raúl Haya de la Torre, el líder de ese partido, gozaba en esos momentos de una gran popularidad. La razón: la masacre de oficiales a manos de los apristas en la Revolución de Trujillo de 1932.

Casi medio siglo más tarde, en 1978, durante la dictadura de Francisco Morales Bermúdez Cerruti, quien sucedió a Velasco en el poder y preparó el camino para devolverle la democracia al Perú, Haya de la Torre fue elegido presidente de la Asamblea Constituyente, a pesar de la animosidad existente entre apristas y militares. En su discurso inaugural, el líder aprista remarcó el carácter independiente de la referida convención. ${ }^{77}$

\section{Expropiación de yacimientos petrolíferos}

Fue el discurso populista de izquierda el que llevó al general Juan Velasco Alvarado (1910-1977) a nacionalizar la banca en 1968, a expropiar los yacimientos petrolíferos de la empresa norteamericana International Petroleum Company, a confiscar los yacimientos mineros de Cerro de Pasco Corporation y Marcona Mining, a estatizar la industria

\footnotetext{
${ }^{77}<$ http://www.congreso.gob.pe/museo/mensajes/Mensaje-1978-2.pdf >
} 
pesquera, a controlar las comunicaciones y a llevar a cabo una fallida Reforma Agraria (1969), entre otras medidas del mismo corte. Hienas en la niebla alude a estos hechos.

Todorov define el populismo como "una práctica basada en el uso de diversos medios para obtener poder y esos medios son esencialmente la manipulación demagógica, la simplificación, el maniqueísmo del bien y el mal... todas expresiones de un pensamiento simplista. Pero su contenido varía. Por ejemplo, el populismo de derecha suele calificar a los extranjeros y los inmigrantes como el enemigo [...] El populismo de izquierda tiene un sesgo de clase. Tomar del rico para dar al pobre [...] Ya en la antigua Grecia el modelo democrático era acusado de estar al servicio de los demagogos, llamados en aquel entonces sofistas" (entrevista con Boris Muñoz).

\section{Reforma Agraria}

Las bases ideológicas de la Reforma Agraria datan de 1918, cuando José Antonio Encinas publica Contribución a una legislación tutelar indígena, un libro en el que recomienda distribuir las tierras de la Iglesia y del Estado. En cuanto a los antecedentes históricos, la CVR refiere que, “entre 1958 y 1964 tuvo lugar en el Perú el movimiento campesino más importante por esos años en América Latina. Cientos de miles de campesinos y trabajadores agrícolas se organizaron y movilizaron a lo largo del país, ocupando cientos de miles de hectáreas en manos de grandes propietarios" ( $H W 345)$.

Después de haber pasado por la experiencia de ser empleado público y de haber comprobado que el gobierno revolucionario no era tal, Diego, el protagonista de Hienas en la niebla, reflexiona con suspicacia acerca de las supuestas verdaderas intenciones políticas y socioeconómicas de la Reforma Agraria (1969-1979) llevada a cabo por ese 
régimen: “¿No era la Reforma Agraria una maniobra que permitía, entre otras cosas cuidadosamente planificadas, a los hijos de los oligarcas, formados en universidades elitistas del país o de Europa, principalmente, rescatar a sus padres anquilosados en sus feudos, con mando y poder pero mimetizados en el subdesarrollo de sus siervos?” (108). No alcanzo a comprender el sentido de esta reflexión, considerando que, muy por el contrario, los hacendados resultaron seriamente afectados. Diego continúa elucubrando: “No obligaba la ley a los hacendados a invertir en la industria nacional, básicamente en la capital, el dinero obtenido en las expropiaciones de tierras?" (108). La realidad es que, a diciembre de 2014, se estima que la deuda del Estado peruano por bonos impagos ascendía a la suma aproximada de 15251 millones de nuevos soles o unos 5100 millones de dólares americanos a esa fecha. ${ }^{78}$

Lamentablemente, la Reforma Agraria fracasó debido a la ineficiencia administrativa de las cooperativas que fueron creadas, a la ineptitud del personal técnico que las asesoraba, así como a la obsolescencia tecnológica de las maquinarias a consecuencia de la falta de reinversión. A mediano plazo, la conjunción de estos nefastos factores hizo que la producción agropecuaria (sobre todo la agrícola) decayera a niveles impensables. En síntesis, la Reforma Agraria fue un desastre; sin embargo, al principio, cuando todavía no se vislumbraban bien los resultados, los campesinos, enardecidos por la retórica populista de que la tierra debe pertenecer a quien la trabaja (recordemos que, en la cosmovisión andina, el hombre y la tierra están íntimamente vinculados), apoyaron la Reforma con gran entusiasmo. No obstante, pronto los campesinos se desencantaron de

\footnotetext{
${ }^{78}$ Alianza por el Pago Justo de los Bonos Agrarios (APJ)

$<$ http://bonosagrarios.pe/preguntas-frecuentes-sobre-el-pago-de-bonos-agrarios/>
} 
la Reforma Agraria iniciada por los militares en 1969, no solo por la caída de la producción y la consecuente merma de sus ingresos sino debido al surgimiento de una nueva casta explotadora. En muchos casos y en varios aspectos, la figura tiránica del gamonal fue reemplazada por miembros de la cúpula dirigente (encastados) de las respectivas cooperativas agrícolas y agropecuarias, quienes gozaban de grandes privilegios y, en ocasiones, no llevaban las cuentas claras, apañados por enviados corruptos del gobierno (que nunca faltan) con quienes estaban en contubernio. 


\title{
III.2 DINÁMICA DEL ETNOVAIVÉN-ETNOBÚMERAN, ESTRATEGIAS DE RESISTENCIA Y SINGULARIDAD CULTURAL
}

\author{
El mundo era tan reciente, que muchas cosas carecían de nombre, \\ y para mencionarlas había que señalarlas con el dedo \\ Gabriel García Márquez (Cien años de soledad 9)
}

El subalterno peruano ha desarrollado estrategias de resistencia que le han permitido no sólo sobrevivir a la colonialidad sino también subvertirla. Utilizo la palabra subalterno en un sentido similar al que le dan Gramsci y Spivak, haciendo la salvedad de que, en el caso del Perú, la subalteridad suele coincidir con el indígena, el mestizo, el cholo, el negro y el mulato de bajos recursos económicos, ${ }^{79}$ y que ellos sí cuentan con un lugar de enunciación, ${ }^{80}$ especialmente porque gracias a la tecnología cualquiera que tenga un teléfono celular y/o acceso a las redes sociales es un reportero en potencia. ${ }^{81}$ De otro lado, la colonialidad - un concepto popularizado por Aníbal Quijano e Immanuel

\footnotetext{
79 "En la sociedad peruana existe una identificación entre raza y clase, por lo que clasificar a un individuo dentro de un grupo racial significa también clasificarlo socioeconómica y culturalmente" (Callirgos, "El racismo peruano" 16 ).

${ }^{80}$ Antonio Cornejo Polar es escéptico al planteamiento de Gayatri Spivak (1942-...) en "Can the Subaltern Speak?" (1985), en donde la pensadora india señala que los subalternos-los colonizados y, en general, los grupos oprimidos-no tienen un lugar de enunciación y que, al carecer de voz, requieren de intermediación. Al respecto, comenta Cornejo Polar: " $[\mathrm{N}]$ o voy a caer en el elegante sofisma de Spivak para quien el subalterno como tal no puede hablar; primero porque es obvio que sí habla y elocuentemente, con los suyos y en su mundo, y segundo porque lo que en realidad sucede es que los no-subalternos no tenemos oídos para escucharlo, salvo cuando trasladamos su palabra al espacio de nuestra consuetudinaria estrategia decodificadora $[\ldots][\mathrm{L}]$ a voz del subalterno nos invade en la vida cotidiana pero solamente la asumimos como parte de nuestras preocupaciones académicas cuando ha sido sometida por ciertos requerimientos [sic]: haber sido seleccionada y adecuada (y con frecuencia traducida) por colegas más o menos prestigiosos o haber quedado transpuesta y transformada (vía otro colega) en 'testimonio'" ("Las voces subalternas", Escribir en el aire 184).

${ }^{81}$ En el Perú, no es extraño ver a una campesina de pollera en plena Cordillera Central hablando por teléfono celular, o a un nativo selvático haciendo lo mismo en una canoa en el medio del río Amazonas. Por otro lado, hay cabinas de Internet hasta en los pueblos más pequeños y alejados. Además de aprovechar estas facilidades para comunicarse con parientes y amigos, el subalterno hace uso intensivo de las redes sociales para difundir sus protestas y reclamos motivados por abusos, injusticias y casos de corrupción.
} 
Wallerstein — ${ }^{82}$ se refiere a un patrón de poder que, en las excolonias latinoamericanas, jerarquizadas en función de las diferencias raciales, ha servido para mantener el statu quo y justificar la explotación del subalterno. ${ }^{83}$ En las sociedades racialmente estratificadas todas las relaciones interpersonales son afectadas por ese patrón de poder racista y discriminatorio. ${ }^{84}$ Aunque la mayoría de los países colonizados ha superado el coloniaje, la colonialidad lo ha transcendido y pervive hasta la actualidad. La colonialidad “[c]onsiste, en primer término, en una colonización del imaginario de los dominados [...] La represión recayó, ante todo, sobre los modos de conocer, de producir conocimiento, de producir perspectivas, imágenes y sistemas de imágenes, símbolos, modos de significación” (Quijano, “Colonialidad y modernidad-racionalidad” 438). ${ }^{85}$ Debido a que la colonialidad de poder supone una "violencia epistémica", en ese sentido es también una colonialidad de saber. $^{86}$

\footnotetext{
82 "Colonialidad y modernidad-racionalidad" (1991) de Quijano, y "La americanidad como concepto" (1992) de Quijano en coautoría con Wallerstein.

${ }^{83}$ En 1969, Margnus Mörner hizo notar que el color de la piel fue el factor preponderante de jerarquización social durante la Colonia (La mezcla de razas).

${ }^{84}$ Alejandro Lipschutz llama pigmentocracia a las sociedades racialmente estratificadas (El problema racial, 1963; en Bonilla-Silva, Racism without Racists 180-1). En estas sociedades, la clase gobernante suele estar asociada a un determinado grupo étnico.

85 “Aníbal Quijano, quien utilizó por primera vez la categoría [de colonialidad], afirmó que los colonizadores españoles entablaron con los colonizados amerindios una relación de poder fundada en la superioridad étnica y epistémica de los primeros sobre los segundos. No se trataba tan sólo de someter militarmente a los indígenas y destruirlos por la fuerza sino de transformar su alma, de lograr que cambiaran radicalmente sus formas tradicionales de conocer el mundo y de conocerse a sí mismos, adoptando como propio el universo cognitivo del colonizador" (Castro-Gómez 58).
}

${ }^{86}$ Durante el coloniaje, "[s]er 'blanco' no tenía que ver tanto con el color de la piel como con la escenificación personal de un imaginario cultural tejido por creencias religiosas, tipos de vestimenta, certificados de nobleza, modos de comportamiento y (esto es muy importante) formas de producir y transmitir conocimientos [énfasis mío]" (Castro-Gómez 60). 


\section{Estrategias de resistencia del subalterno}

Aunque no fue concebida como una estrategia de resistencia, la solidaridad mutua de los indígenas, que se plasma en la ancestral práctica del ayni, le ha permitido al subalterno sobrevivir a la adversidad en todos los tiempos (Castro Pozo, Nuestra comunidad indígena, 1924). Esta práctica consiste en la ayuda que los miembros de un ayllu se proporcionan unos a otros a través del trabajo voluntario realizado con espíritu festivo. El ayni se basa en la reciprocidad y sintetiza el espíritu al que alude el refrán popular "hoy por ti, mañana por mí". Reciprocidad e intercambio lo llamaría Karl Polanyi (The Great Transformation, 1944).

Además de su función instrumental, el ayni tiene una función simbólica, pues es la forma en que un subalterno demuestra adhesión y grado de compromiso con su comunidad. Por ejemplo, las faenas del campo que realiza de manera gratuita en apoyo a la comunidad, a un pariente o a un vecino son interpretadas como celebraciones rituales de intercambio. "Las siembras, las cosechas, las labores, no son trabajos solamente, son fiestas también" (Bourricaud, "Elogio al cholo" 30). José María Arguedas ofrece el siguiente testimonio acerca del espíritu ayni que prevalece entre los subalternos incluso cuando se trata de servir al amo:

[E]n las faenas que los patrones organizan a manera de fiestas, su rendimiento [el del indígena] es inmejorable. Las siembras y cosechas de maíz y trigo en los campos de los hacendados se hacen con rapidez extraordinaria, porque este tipo de trabajo no es pagado a jornal; se realiza a cambio de abundantes bebidas y comidas y se cumple ritualmente, con ceremonias de carácter religioso al empezar y concluir la faena; al compás 
de antiguas melodías que convierten la faena en una competencia [...] verdaderamente deportiva. Durante el tiempo que dura esta fiesta ningún trabajador piensa en el jornal ni en lo ajeno. (Cuentos mágico-realistas

Pero el ayni "no se limita al trabajo de la tierra. Cuando los habitantes del pueblo vienen a ayudar a los recién casados para poner el techo [de su nueva casa], también se trata de un 'ayni"” (Bourricaud 29). Asimismo, es ayni cuando los inmigrantes andinos invaden terrenos en la periferia de las ciudades costeñas para afincar sus respectivas viviendas $y$, con talante solidario, enseguida organizan una olla común y habilitan una guardería infantil (de Soto, El otro Sendero 22). ${ }^{87}$ Así como éstas, hay muchas otras formas de organización ciudadana autogestionadas, tales como los comedores populares, las polladas,${ }^{88}$ los comités educativos y deportivos, y hasta las cooperativas de vivienda son versiones contemporáneas del ancestral ayni, que es la mayor expresión de etnicidad del pueblo indígena peruano y que, como tal, le ha permitido sobrevivir a la adversidad y a la injusticia. $^{89}$

\footnotetext{
${ }^{87}$ En Patíbulo para un caballo (1989) de Cronwell Jara se mencionan reiteradas veces tanto la olla común como el Club de Madres Pobres.

${ }^{88}$ La pollada es un almuerzo benéfico que se organiza a favor de alguno de los miembros de la comunidad o de alguna causa comunal. Se llama pollada porque en esos almuerzos el platillo central es a base de pollo (macerado y frito).

${ }^{89}$ En Patíbulo, la manera de pensar del comandante Dantón Pflucker, quien personifica a la represión ejercida por el Estado en contra de los subalternos que invaden terrenos, refleja la actitud de muchos miembros de la clase dominante frente a quienes reclaman un pedazo de patria en donde afincarse: " $i[\mathrm{U}]$ na montaña de indios y negros, pero sobre todo de indios porque son la mayoría, fundarán una selva de barriadas en todo Lima! ¡Y eso sería el fin de la Capital! ¡Lima perdería su aspecto virreinal, aristocrático y europeo! Y se transformaría en una olla de grillos, un lugar de vagabundos y mendigos; sin mundo espiritual ni pan ni futuro inmediato. Pues, ¿qué harían aquí, dice él, si en Lima no hay centros de trabajo, industrias o fábricas para ellos?" (303). Cabe mencionar que el personaje de Pflucker es hijo de alemán con peruana y que, en la novela, es presentado como "hijo de las absurdas ideas de 'superioridad' de Hitler y que, con el secreto consentimiento del Ministro de Gobierno y Policía y de la Comandancia General"
} 
Por otro lado, ante las innumerables trabas legales, ${ }^{90}$ burocráticas y monetarias que se le presentan al subalterno para integrarse a la economía formal, éste opta por la informalidad, que no es sino "una réplica de las mayorías contra un sistema que los ha hecho tradicionalmente víctimas de una suerte de apartheid económico y legal" (MVLL, Prólogo, El otro Sendero xxv). ${ }^{91}$ En reacción a esos impedimentos, los subalternos "salieron a las calles a vender lo que podían [...] y amarraron sus viviendas en los cerros y arenales. Como no había trabajo, lo inventaron, aprendiendo sobre la marcha lo mucho que no sabían" (ibíd. xxv). Y cuando el subalterno se siente explotado-por ejemplo, por un patrón abusador-, su estrategia de resistencia consiste en "amarrar el macho", una expresión popular que quiere decir evitar el esfuerzo. "El Indio trabaja con desgano cuando lo hace a jornal [...] [E]ntonces el indio remolonea, engaña [énfasis mío]. (Arguedas, Cuentos mágico-realistas 121). En Crónica de músicos y diablos (1991) de Gregorio Martínez Navarro, el personaje "Don Metreque Candela, el tamborilero, era un (148), intenta utilizar a los pobladores de Montacerdos como conejillos de Indias para realizar un experimento de "resistencia humana en casos de sobrevivencia"(147).

${ }^{90}$ Telaraña legal es una expresión de MVLL y con ella se refiere al, aproximadamente, medio millón de dispositivos legales - $99 \%$ de los cuales han sido generados por el Poder ejecutivo y no por el Poder legislativo, como correspondería - que regulan la vida de los peruanos (Prólogo, El otro Sendero xxivxxv). Enseguida MVLL agrega: "Y son promulgados a tal ritmo que ya no sólo el ciudadano común, sino incluso el especialista o el afectado por la norma novísima, no están en condiciones de conocer, cotejar con el contexto jurídico vigente y acomodar al propio quehacer" (ibíd. xxv).

${ }^{91}$ El Instituto Libertad y Democracia (Lima, Perú), que dirige su fundador Hernando de Soto, realizó una investigación en la cual comprobó, por ejemplo, que "obtener autorización legal para abrir una mínima tienda o dispendio callejero alcanza contornos kafkianos: 43 días de trámites y un costo de 590.56 dólares (15 veces el sueldo mínimo vital)" (MVLL, Prólogo, El otro Sendero xix). Asimismo, "si un grupo de familias humildes solicita al Estado la adjudicación de un terrero eriazo para urbanizarlo y construir, deben tramitar asfixiantemente durante seis años y once meses por ministerios y municipalidades y desembolsar, por persona, una suma aproximada de 2,156 dólares (equivalente a 56 veces el sueldo mínimo vital a la fecha)" (ibíd. xix). Las respectivas historias de Montacerdos y Patíbulo se desarrollan en espacios urbanos de este tipo; es decir, en barriadas que se formaron, como la gran mayoría, como resultado de invasiones. 
experto en amarrar el macho, en embromar el tiempo, en prolongar hasta el infinito las faenas que no eran a destajo" (151).

Otra estrategia de resistencia del subalterno es la "mecida", o "el arte de darle largas a un asunto que, en ocasiones, jamás se resuelve" (MVLL, "El arte de mecer"). “'Mecer' - explica MVLL_es un peruanismo que quiere decir mantener largo tiempo a una persona en la indefinición y en el engaño, pero no de una manera cruda o burda, sino amable y hasta afectuosa, adormeciéndola, sumiéndola en una vaga confusión, dorándole la píldora, contándole el cuento, mareándola y aturdiéndola de tal manera que se crea que sí, aunque sea no, de manera que por cansancio termine por abandonar y desistir de lo que reclama o pretende conseguir" (ibíd.). Es necesario aclarar que la mecida es una estrategia de resistencia, similar a la de amarrar el macho, sólo cuando tienen por objetivo evitar el abuso. En otros casos, se trata de un ardid utilizado para timar y, por lo tanto, no tiene el propósito de oponer resistencia. ${ }^{92}$

\section{Etnovaivén: entre el blanqueamiento y la cholificación}

Aparte del ayni, la estrategia de resistencia más efectiva que ha desarrollado el subalterno peruano es la que denomino "etnovaivén". Dependiendo de la postura que le resulte más conveniente en determinadas circunstancias y en un momento dado, el subalterno opta ya por blanquearse o por cholificarse, en distintos grados y matices. Este comportamiento ambivalente desconcierta al enemigo y, por lo tanto, lo debilita. El Inca Garcilaso de la Vega habría sido el primer peruano (avant la lettre) en darse cuenta de las ventajas y del

\footnotetext{
${ }^{92}$ Por ejemplo, un contratista mece a su cliente si incumple al no proporcionarle el bien o el servicio que éste espera recibir a cambio del pago que ha hecho. Algunos funcionarios públicos corruptos también recurren a la mecida para que el solicitante de un servicio, cansado de que lo hagan volver tantas veces sin que se resuelva su pedido, les ofrezca una coima para agilizar el trámite.
} 
poder subversivo del etnovaivén (también avant la lettre). De una manera menos sutil, tras la derrota de Túpac Amaru en 1871, las autoridades "persiguieron a los jefes étnicos que se habían sumado a la rebelión, motivo por el que se transfiguraron en 'mestizos' y 'notables' de sus respectivas localidades [blanqueamiento], protegiendo y sometiendo a sus indios [ambivalencia], propiciando el languidecimiento de las identidades étnicas [etnobúmeran]" (Cotler 33). La alternancia entre estas dos posturas describe un desplazamiento pendular que ilustro mediante la siguiente imagen:

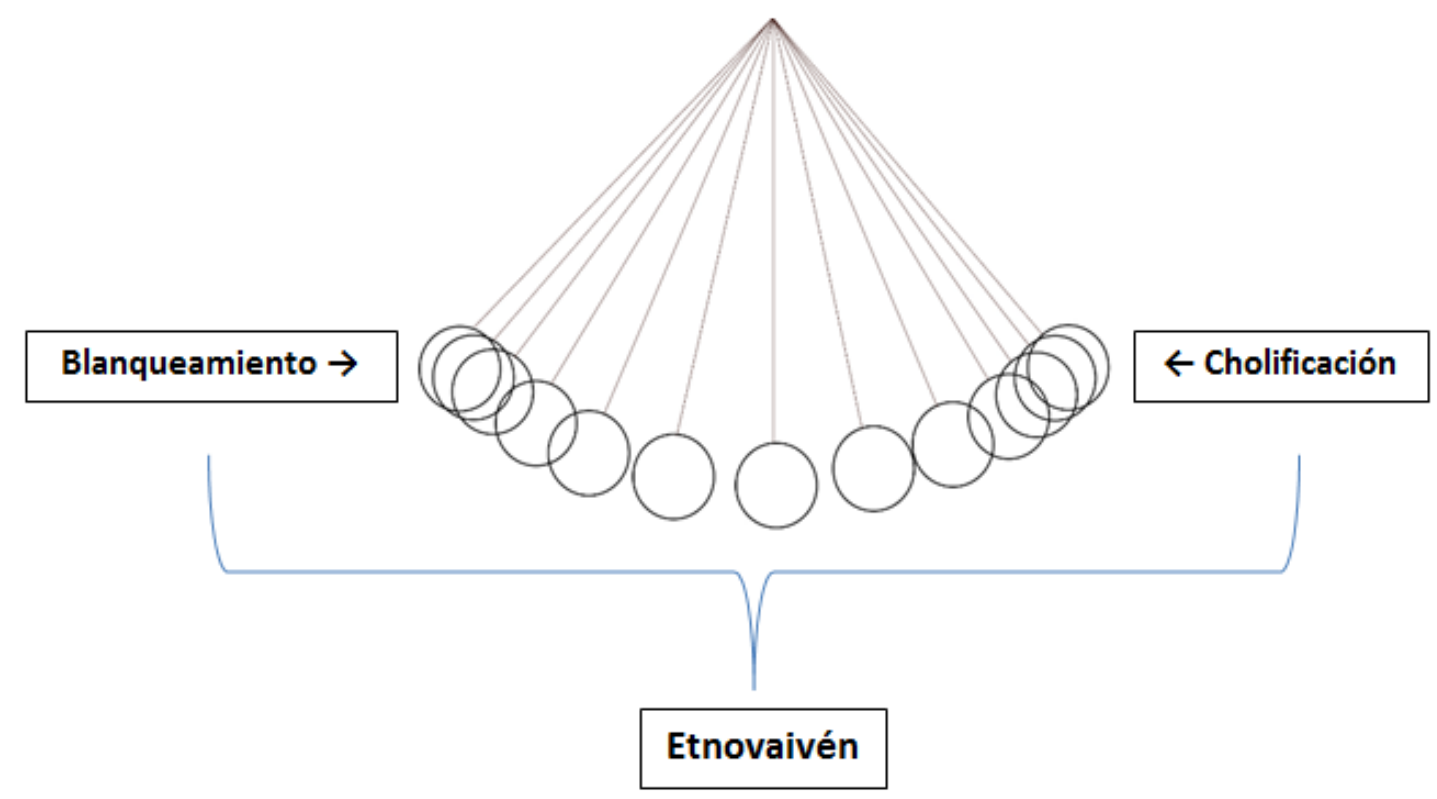

Guillermo Nugent advierte que "[1]o que llamamos sociedad no es más que un conjunto de escenarios, de contextos, de reglas, de juegos de lenguaje, que constantemente recorremos en un sentido o en otro [énfasis mío]" (El laberinto de la choledad 191). ${ }^{93}$

\footnotetext{
${ }^{93}$ Yo cambiaría la conjunción disyuntiva por una copulativa - “en uno y en otro sentido"- para sugerir la idea de un movimiento oscilante, recíproco y elusivo.
} 
Con el término etnovaivén intento destacar, precisamente, el movimiento pendular del subalterno al desplazarse de manera alternada entre las referidas dos posturas. ${ }^{94}$ En el desarrollo de este trabajo hago frecuentes referencias al blanqueamiento y a la cholificación por separado más que, puntualmente, al etnovaivén. Esto se debe a que resulta difícil hallar ejemplos que ilustren la dinámica misma del etnovaivén.

\section{Blanqueamiento}

El blanqueamiento se refiere al anhelo del subalterno de parecerse a los miembros del grupo hegemónico — conformado, tradicionalmente, por blancos y blanqueados-y en el esfuerzo que hace para asimilarse a la cultura occidental con la finalidad de ser aceptado por el grupo de prestigio y, de esa manera, poder ascender socialmente. ${ }^{95}$ Por ejemplo, el escritor Ricardo Palma - que “era hijo de un 'cholo' (tres cuartos de indígena) y una mulata cuarterona (mitad o un cuarto de negra)" (Portocarrero, La urgencia 87)—fue blanqueándose sucesivamente en varios retratos que le hicieron a lo largo de su vida, al

\footnotetext{
${ }^{94}$ En inglés, la palabra sway significa —además de vaivén, oscilación y fluctuación—ejercer influencia y control; una acepción que se aviene muy bien al concepto del etnovaivén. En consecuencia, etnovaivén puede traducirse al inglés como ethno-sway.

${ }^{95}$ Por ejemplo, en Hienas en la niebla (2010) de Juan Morillo Ganoza, el personaje de Lucila se aburguesa tan pronto adquiere holgura económica y le sugiere a Diego, su esposo, ostentar su nueva riqueza con la finalidad de blanquearse: "Dijo que el carro comprado el año anterior quedaría para el servicio de la casa, que ella lo manejaría. Para ti, dueño de la agencia de transportes, habría que comprar uno de mejor marca y mayor presencia, ¿por qué ser menos que los vecinos?... Le planteó, además, la necesidad de ampliar el personal de servicio doméstico. Nos hace falta, dijo, un mayordomo, un ama de llaves y un chofer para tu carro... una cosa que hay que hacer ya: uniformar a las empleadas y comprar un par de perros finos... Hay que contratar un decorador, dijo, porque todo esto hay que cambiar. Luego habló de los jardines y de las terrazas y de un error que había que reparar: abrir una cancha de tenis y construir la piscina en el espacio reservado por el diseño original. Tú y tus gustos, dijo, nos van a matar de vergüenza... Y ya que vas a tener un chofer personal con uniforme, dijo, lo mínimo sería que llevaras terno y corbata, todo diferente cada día. Y cuanto a la ropa, comprarla en boutiques y en tiendas elegantes o encargadas a modistas y sastres exclusivos... Y todavía falta, pero será un buen comienzo, verás cómo la gente importante empieza a respetarnos y a abrirnos las puertas [énfasis mío]" (321-2).
} 
punto de que "tras los rasgos blanqueados" es imposible "advertir la fenotipia [sic] del gran escritor" (ibíd. 87).

El blanqueamiento está relacionado con el concepto de degradé epidérmico (color gradient), que ubica la posición social de las personas de acuerdo con la percepción social de su color de piel. No se trata de un orden dicotómico de blancos y no blancos (indios, mestizos, negros y mulatos), sino de una escala de matices en la que los “blancos", los más acaudalados, están en la cúspide de la pirámide social y los no blancos (los subalternos) ocupan la base. Sin embargo, en una sociedad como la peruana, en donde existe movilidad social, el subalterno tiene la posibilidad de ascender en la escala de estratificación étnica mediante la educación, la occidentalización y la prosperidad económica. $^{96}$ A eso se le llama blanquearse.

El blanqueamiento está relacionado con el mimetismo (mimicry) y el camuflaje (camouflage), dos de las estrategias del colonizado que identifica Bhabha:

Como nos recuerda Lacan, el mimetismo es como el camuflaje, no una armonización de la represión de la diferencia sino una forma de parecido, que difiere de, o impide, la presencia, desplegándola en parte, metonímicamente. Su amenaza [... proviene de la prodigiosa y estratégica producción de "efectos de identidad" conflictivos, fantásticos, discriminatorios, en el ejercicio de un poder que es elusivo porque no

\footnotetext{
${ }^{96}$ Hay que distinguir el blanqueamiento racial (ratial whitening) del blanqueamiento social (social whitening). El blanqueamiento racial tiene que ver con la ideología eugenésica que, por ejemplo, estuvo en boga en Brasil a finales del siglo XIX y principios de siglo XX, y que proponía el mejoramiento progresivo de la raza negra a través del mestizaje con la raza blanca en sucesivas generaciones. De otro lado, el blanqueamiento social (social whitening) se refiere tanto al degradé epidérmico como a la estrategia empleada por los grupos subalternos para obtener movilidad social. Éste es el que me interesa tratar en el presente trabajo. Por comodidad, llamo blanqueamiento, a secas, al blanqueamiento social.
} 
oculta esencia alguna, ningún "sí mismo". Y esa forma de parecido es la cosa más terrible de contemplar. (En Bhabha, "El mimetismo y el hombre: la ambivalencia del discurso colonial", El lugar de la cultura 116)

Por ejemplo, en La ciudad y los perros (1963) de MVLL, el personaje de Cava intenta blanquearse mediante la mímica y el camuflaje cuando se echa gomina y hace lo imposible para que no se le paren los pelos hirsutos de la cabeza (258), que forman parte del fenotipo del hombre andino. Así como mimetismo implica "parecido y amenaza a la vez" (Bhabha, "El mimetismo" 86), el blanqueamiento constituye, al mismo tiempo, una estrategia de asimilación y de resistencia. Como ya he señalado, cuando al subalterno le conviene se blanquea y, cuando no, se cholifica.

\section{La huachafita}

Las palabras "huachafo" y "huachafería"-ordinario y de mal gusto pero popularaluden a cursilería (kitsch) ${ }^{97}$ y se refieren tanto a la afectación y exageración de ciertos modales que, con afán arribista, exhiben algunos subalternos considerados gente de medio pelo (tacky), así como a gustos y expresiones estéticas que les son típicas. Arturo Jauretche explica que en la Argentina "decir que un individuo o un grupo es de medio pelo implica señalar una posición equívoca en la sociedad; la situación forzada de quien

\footnotetext{
${ }^{97}$ En referencia al caso boliviano, Mauricio Sánchez Patzy se pregunta si las ornamentaciones cholas pueden ser calificadas de kitsch. Él mismo se responde que no exactamente, debido a que "el kitsch se refiere a la producción industrial y al consumo de obras baratas o de calidad menor de las obras artísticas legitimadas, en sociedades donde la autonomía del campo artístico es patente". Enseguida añade: "En Bolivia [como en el Perú], en cambio, no existe (casi) una cultura artística 'refinada' ampliamente extendida a la que enfrentar los consumos de obras artísticas baratas y de 'segunda' categoría [...] [L]o que está en juego no es tanto el buen o el mal gusto, sino el tipo de gente que es simbolizada por estos gustos y ante quien se enfrenta cada cual" ("Aproximaciones a la estética chola" 23-4).
} 
trata de aparentar un status superior al que en realidad posee" (Jauretche, El medio pelo en la sociedad argentina 9). La explicación de Jauretche también es aplicable al Perú.

La huachafita es, pues, el personaje femenino de medio pelo, ambicioso, arribista y de gustos huachafos que, rechazando su origen (etnobúmeran) y realidad, aspira a blanquearse. Generalmente, la huachafita se esfuerza, sin lograrlo, en aparentar que pertenece a una clase social superior y, a la vez, se distancia de la clase baja que le es propia (Guerra Martinière 74, en Watson 43). El dicho popular clasista y racista "Aunque se vista de seda...” da a entender que por más galas que una mujer de clase baja se ponga encima, no podrá evitar que se le note su baja extracción social.

En la comedia en verso Na Catita (1845), Manuel Ascencio Segura (1805-1871) incluye a personajes que representan a la gente de "medio pelo" en la sociedad limeña. Asimismo, JCM (1894-1930) le da a Ricardo Palma (1833-1919) el crédito de haber interpretado el medio pelo en sus Tradiciones peruanas (1872-1910) (7 ensayos 179), pero condena a la huachafita que aspira a blanquearse contrayendo matrimonio con un extranjero (blanco, por supuesto):

El yanqui desposa sin inconveniente de raza ni de religión a la señorita criolla, y ésta no siente escrúpulo de nacionalidad ni de cultura en preferir el matrimonio con un individuo de la raza invasora [eurofilia]. Tampoco tiene ese escrúpulo la muchacha de la clase media. La "huachafita" que puede atrapar [a] un yanqui empleado de Grace o de la Foundation lo hace con la satisfacción de quien siente elevarse su condición social [blanqueamiento]. ("Punto de vista anti-imperialista"; en Baeza, Tomo 2, 188) 
Cabe mencionar que Clorinda Matto de Turner (1852-1909) se casó con un inglés y le sacaba brillo a ese hecho, pero creo a nadie se le habría ocurrido tildarla de huachafita. Otro ejemplo de la vida real es la actriz María Micaela Villegas y Hurtado de Mendoza (1748-1819), más conocida como la Perricholi, quien a los 20 años entabló una relación sentimental con el virrey Manuel de Amat y Junyent, de 62. ${ }^{98}$ En los 14 años que duró esta relación, la pareja hacía apariciones en público "con no poca murmuración de la almidonada aristocracia limeña, que era por entonces un mucho estirada [sic] y mojigata" (Palma, "Genialidades de la Perricholi" 301). ${ }^{99}$ Quizás las murmuraciones obedecían más a la abismal diferencia social de los amantes-pues María Micaela era mestiza, de modesta extracción, y el virrey pertenecía a la nobleza catalana—que a la diferencia de edad o la irregularidad del estado marital. El caso es que ni todas las damas peruanas casadas con extranjeros son, necesariamente, huachafitas ni todas las huachafitas están, necesariamente, casadas con un extranjero.

José Guillermo Nugent considera que al Amauta se le pasó la mano al calificar de huachafitas a cierta clase de mujeres con parejas anglosajonas, máxime cuando él mismo se casó con una dama italiana (64). Sucede que en el Perú machista suele hablarse de "huachafitas" y no de "huachafitos". Por ejemplo, ¿quién calificaría de huachafito al personaje de Sebastián Pancorbo en Aves sin nido (1889), un hombre ignorante que ha

\footnotetext{
${ }^{98}$ En 1776, salió a la luz El Drama de los palanganas: veterano y bisoño, atribuido a la autoría de Francisco Ruiz-Cano y Sáenz-Galiano, marqués de Soto Florido, que en tono satírico trata sobre esos amores. Hay decenas de obras artísticas (teatro, cine, ópera y literatura) inspiradas en la Perricholi.

${ }^{99}$ Luis Alberto Sánchez (1900-1994) alude a María Micaela Villegas y Hurtado de Mendoza como "actricilla pizpireta" (Literatura peruana, 1989), y JCM emplea el término perricholismo literario para referirse despectivamente a la literatura colonial ( 7 ensayos 42$)$.
} 
ascendido en la escala social y se ha convertido en un "blanco honorario" gracias a su enlace matrimonial con doña Petronila Hinojosa, hija de un notable? ${ }^{100}$

El estereotipo de la huachafita se repite en otros países, aunque no se le conozca con ese apelativo: por ejemplo, en "Amor se escribe con G” (1987) — con G de gringode Rosa María Britton, María Caridad (que se hace llamar Kary) es una mulata panameña pobre que logra conquistar el amor de un soldado norteamericano de apellido White, a fuerza de frecuentar la Zona del Canal y de impostar una identidad blanqueada.

Quince Duncan denomina "eurofilia" a la identificación del sujeto con la cultura europea, a la que considera superior; y "etnofobia" al rechazo a las etnias no dominantes (Contra el silencio, 2001). Por ejemplo, en "Amor se escribe con G" Kary denota eurofilia mediante las siguientes palabras: "De los gringos estuve enamorada desde que tengo uso de razón" (118). Y manifiesta etnofobia con estas otras:

La mala suerte me acompaña desde el día en que nací [...] [J]amás hubiera escogido los padres que tengo si el destino me hubiera dado la oportunidad [etnofobia]. Los hubiera escogido ricos, blancos [eurofilia] y sobre todo muy lejos de este lugar. El gran problema de mi vida ha sido siempre mi familia [etnofobia]. Casi todos morenos [etnofobia]. Y todos, sin ninguna excepción, pobres y brutos que es lo peor [etnofobia y determinismo]. $(115-6)$

La etnofobia de Kary se manifiesta marcadamente en el rechazo a su fenotipo: "Jerry me invitó a la playa [...] En realidad, la idea no me entusiasmó para nada. El sol tiene la

\footnotetext{
${ }^{100}$ Blanco honorario era una de las categorías empleadas en el apartheid (Bonilla-Silva, Racism without Racists 180).
} 
costumbre de sacarle a uno la raza [etnofobia] y además, ni por nada me quería mojar en el mar mi cabello alisado, porque cualquiera se daría cuenta que me lo estiraba [blanqueamiento]. Insistió tanto, que no me quedó otro remedio y allá fui, con un vestido de baño Jantzen que me costó un montón de plata [huachafería, en el sentido de falsa ostentación]" (125). Como puede apreciarse, el blanqueamiento supone cierta dosis de etnofobia, debido a que implica autonegación.

\section{Blanqueamiento y colonialidad}

Jorge Rendón Vásquez puntualiza con agudeza que, “[d]urante los tres siglos que duró la dominación colonial en América, [la] estratificación racial de la sociedad modeló la conciencia de los habitantes [...] tan fuertemente como la imposición del feudalismo, de la lengua castellana, de la religión católica y de los usos y costumbres hispánicos”. Así de contundente y trascendental fue el impacto de la estratificación racial y de esa manera se construyó la raza en nuestros pueblos.

El afán de blanquearse obedece, principalmente, a una actitud eurofílica: "La cultura europea se convirtió en una seducción; daba acceso al poder. Después de todo, más allá de la represión el instrumento principal de todo poder es la seducción. La europeización cultural se convirtió en una aspiración. Era un modo de participar en el poder colonial" (Quijano, "Colonialidad y modernidad-racionalidad" 439). En ese sentido, "el imaginario de la blancura producido por el discurso de la pureza de sangre fue una aspiración internalizada [sic] por todos los sectores sociales de la sociedad

colonial y fungió como el eje alrededor del cual se construyó (conflictivamente) la subjetividad de los actores sociales" (Castro-Gómez 60). Pero, al mismo tiempo, de 
manera ambivalente, "[e]xiste un odio al blanco [podría hablarse de "eurofobia"]; es como si la dominación colonial hubiera creado una huella mnémica en la que los blancos surgen como seres agresivos y potencialmente peligrosos. Este odio, aunque no está teorizado y es en gran medida inconsciente, encuentra sin embargo canales por donde expresarse (Portocarrero, 1990: 60)" (en Callirgos. "El racismo peruano" 14). La Guerra Interna librada en el Perú (1980-2000) es una prueba de ello.

\section{El rencor atávico}

Gonzalo Portocarrero hace una distinción entre resentimiento y sed de justicia. ${ }^{101}$ Sostiene que "el resentimiento es voraz e insaciable, nada puede calmarlo; en cambio, la sed de justicia tiene límites y puede ser satisfecha". El resentimiento mora en "todos aquellos que viven en la amargura, que han hecho de la desilusión su morada, que culpabilizan, con razón o sin ella, a alguien de la decepción que los consume" (Profetas del odio 10).

Según Portocarrero, el resentido necesita que alguien pague por su sufrimiento. Por el contrario, la sed de justicia "puede ser saciada, pues busca el equilibrio, el fin del abuso y no su perpetuación. La búsqueda de justicia tiene objetivos definidos que son el castigo del perpetrador y alguna compensación por lo perdido" (ibíd. 10). El gran problema es que, quien no logra saciar su sed de justicia corre el peligro de convertirse en un resentido. Y, aunque "nada garantiza que los agravios sufridos encuentren una justicia

\footnotetext{
${ }^{101}$ De acuerdo con la RAE, "resentirse" significa "tener sentimiento, pesar o enojo por algo", en tanto que "rencor" es un "resentimiento arraigado y tenaz". En consecuencia, lo que Portocarrero llama resentimiento es rencor.
} 
cierta $[\ldots$,$] la sociedad debe esforzarse en ser justa pues de otra manera el resentimiento y$ la violencia no pueden ser contenidos" (ibíd. 10-11).

Yawar Fiesta (la fiesta de la sangre) es una manifestación popular de rencor y de sed de venganza, no de justicia. Como su nombre lo indica, esta fiesta consiste en un espectáculo sangriento, en el que un cóndor es atado de las patas al lomo de un constreñido toro que, espantado ante la amenaza de que le saque los ojos, corcovea intentando liberarse del dolor que le ocasionan las enormes garras del ave rapaz incrustadas en su cuerpo, y del intenso picoteo sobre el cogote y la cabeza. En este macabro ritual la simbología es obvia: el cóndor representa al mundo andino y el toro al mundo hispano del que se venga. Desafortunadamente, en otras ocasiones el odio no es canalizado a través de una fiesta ritual, y se traduce en violencia directa y manifiesta del hombre contra el hombre.

\section{Cholificación}

La "cholificación" es un término popularizado por Aníbal Quijano a partir de "La emergencia del grupo cholo en el Perú y sus implicaciones en la sociedad peruana" (Memorias del VII Congreso Latinoamericano de Sociología, Bogotá, 1965). ${ }^{102}$ Quijano hizo notar que el "grupo cholo", conformado por indígenas y mestizos

\footnotetext{
${ }^{102}$ Fernando Fuenzalida informa que los primeros en referirse al "estrato cholo" y a la "cholificación" fueron Gabriel Escobar ["La Cultura: sistema de valores", 1959], Richard Schaedel ["La organización social en el departamento de Puno", 1959], Jacob Fried ["The Indian and Mestizaje in Peru", 1961)], Aníbal Quijano [La emergencia del grupo cholo y sus implicaciones en la sociedad peruana, 1965], Francois Bourricaud [Cambios en Puno, 1967] y Julian Pitt-Rivers [ "Race, Color, and Class in Central America and the Andes", 1967] ("Poder, raza y etnia en el Perú contemporáneo" 77). En esta relación habría que incluir a Maxime Kuczynski (padre del actual presidente del Perú) y a Carlos Enrique Paz Soldán, quienes intuyeron tempranamente el surgimiento de una conciencia chola (Disección del Indigenismo Peruano: un examen sociológico y médico-social, 1948) (Obando 29).
} 
semioccidentalizados, "no [era] solamente un nuevo grupo social en emergencia [emergente]", sino fundamentalmente "portador de una cultura en formación, integrándose con elementos que proceden de nuestras dos culturas originales y con otros que son producto de la elaboración del propio grupo" (Dominación y cultura 73).

En el proceso de transculturación, el cholo "[h]a conservado mucho de la antigua cultura tradicional" (Bourricaud 33). ${ }^{103}$ No obstante, si por un lado el cholo retiene, defiende y se enorgullece de sus raíces indígenas, por el otro está llano a absorber la cultura occidental (Quijano 54; en Mayer, "Mestizo e indio" 124), siempre y cuando no exista conflicto entre ambas culturas. Cuando hay conflicto, el cholo reafirma su identidad étnica y celebra su marginalidad, evocando generalmente el pasado glorioso de los incas. César Vallejo y José María Arguedas son ejemplos de personajes de la vida real que se cholificaron.

Mediante su cholificación, el subalterno no sólo se adapta sino subvierte el medio social costeño (occidental) a través de la cultura chicha, la cual se expresa en un tercer espacio de hibridación, diferencia y ambivalencia (en terminología de Bhabha), en donde la fusión y el choque de culturas producen nuevas y singulares manifestaciones culturales y una entidad ontológica distinta. Según Bhabha, “[e]stos espacios 'entre-medio' [inbetween] proveen el terreno para elaborar estrategias de identidad [selfhood] (singular o comunitaria) que inician nuevos signos de identidad, y sitios innovadores de colaboración

\footnotetext{
${ }^{103}$ Fernando Ortiz prefiere el término transculturación al de aculturación por hallarlo más adecuado para expresar "las diferentes fases del proceso transitivo de una cultura a otra, porque éste no consiste solamente en adquirir una cultura, que es lo que en rigor indica la voz anglo-americana acculturation, sino que el proceso implica también necesariamente la pérdida o desarraigo de una cultura precedente, lo que pudiera decirse una parcial desculturación, y, además, significa la consiguiente creación de nuevos fenómenos culturales que pudieran denominarse neoculturación" (Contrapunteo cubano del tabaco y el azúcar, 1940, 86). Ángel Rama toma de Ortiz el concepto de transculturación y lo amplía para incluir el proceso mediante el cual la cultura dominada selecciona elementos de la cultura dominante (Transculturación narrativa en América Latina, 46).
} 
y cuestionamiento, en el acto de definir la idea misma de sociedad" ("Vidas en los bordes: el arte del presente", El lugar de la cultura 18).

Entre otras causas, la choledad sería el resultado de un proceso semiótico como el que Bolívar Echeverría denomina "codigofagia" (La modernidad de lo barroco 83), mediante el cual, si bien "el código identitario europeo devora al código americano [...,] el código americano obliga al europeo a transformarse en la medida en que, desde adentro, desde la reconstrucción del mismo en su uso cotidiano [lo que supone una desconstrucción previa], reivindica su propia singularidad" (Echeverría, Vuelta de siglo 214). En ese sentido, la choledad emergía, ante todo, como "una alternativa de descolonización del imaginario" y como "una propuesta de reconstitución de identidad para la amplia mayoría de la población peruana" (Quijano, "Colonialidad del poder, cultura y conocimiento" 146).

\section{Homi K. Bhabha: estrategias de resistencia del colonizado}

En El lugar de la cultura (1994), Homi K. Bhabha explica que el colonizado (quien, para nuestros fines, equivale al subalterno) se vale de varias estrategias de resistencia que, combinadas, tienen potencial subversivo. Estas estrategias son mimetismo, camuflaje, diferencia, ambivalencia e hibridación (este último es un concepto que Bhabha toma de Said). El colonizado se camufla (táctica bélica) imitando al colonizador para desconcertarlo (estrategia bélica) y se funde (se hibrida) con la cultura del colonizador 
para reelaborar el discurso de éste (neoaculturación) desde el punto de vista de los intereses del colonizado (ambivalencia) (Otero Luque, “El Inca Garcilaso” 69). ${ }^{104}$

Bhabha denomina mimetismo y camuflaje a aquellas estrategias que utiliza el colonizado cuando emula al colonizador (lo imita, mimetizándose con él, y se camufla) para apropiarse de sus códigos y valores [codigofagia]. El colonizado anhela ser como el colonizador [blanqueamiento] sin dejar de ser él mismo (ambivalencia y diferenciación) [cholificación] (ibíd. 69). En esa dialéctica, se crea un tercer espacio de hibridación y ambivalencia, de similitudes y diferencias, que coincide con el trayecto por donde se desplaza el etnovaivén. Ese trecho o camino (tercer espacio) le permite al colonizado (subalterno) poner en evidencia las fallas y defectos del colonizador (grupo dominante). De esa manera, el colonizado (subalterno) tiene la posibilidad de subvertir el discurso hegemónico y, por consiguiente, alterar las relaciones de poder a su favor (ibíd. 68-9).

Lo anterior no es una tarea fácil. Luis A. Ramos-García observa que, "[a]nte la dificultad de legitimar una cultura nacional capaz de multiplicar la diferencia o de sostener una diversidad fundada sobre la más amplia pluralidad y complejidad de posibles estilos de vida $[\ldots]$, el colectivo andino-marginal no sólo ha exigido una reinterpretación ecuménica del pasado nacional, sino que además se ha dado a la tarea de subvertir conscientemente los moldes culturales de la élite criolla, invadiendo sus espacios y resistiéndose tenazmente a sus viejos hábitos de superioridad moral y racial” (“Rock-and-roll en las barriadas peruanas" 123).

\footnotetext{
104 "El efecto del mimetismo es el camuflaje. [...] No es cuestión de armonizar con el fondo, sino de volverse moteado sobre un fondo moteado - exactamente como la técnica del camuflaje practicada en la guerra humana" (Lacan, "La línea y la luz", De la mirada; en Bhabha, "El mimetismo" 111).
} 


\section{Etnovaivén y Homi K. Bhabha}

El blanqueamiento, la cholificación y el etnovaivén son conceptos en los que resuenan fuertemente las estrategias del colonizado que explica Bhabha. Sin embargo, al "localizarlas" (en términos lingüísticos), obtenemos un modelo epistemológico que constituye una herramienta ad hoc para analizar la colonialidad en el Perú. El siguiente cuadro muestra de qué manera los conceptos de blanqueamiento, etnovaivén y cholificación se intersectan con las estrategias que identifica Bhabha:

\begin{tabular}{|l|c|c|c|}
\hline \multicolumn{3}{|c|}{$\begin{array}{c}\text { Cuadro N }{ }^{\circ} \\
\text { Intersección del etnovaivén y las estrategias del colonizado } \\
\text { que identifica Bhabha }\end{array}$} \\
\hline & Blanqueamiento & Etnovaivén & Cholificación \\
\hline $\begin{array}{l}\text { Estrategias del colonizado } \\
\text { (Homi K. Bhabha) } \downarrow\end{array}$ & $\checkmark$ & $\checkmark$ & \\
\hline Mímica / mimetismo & $\checkmark$ & $\checkmark$ & \\
\hline Camuflaje & & $\checkmark$ & $\checkmark$ \\
\hline Hibridación & & $\checkmark$ & $\checkmark$ \\
\hline Diferencia & & $\checkmark$ & \\
\hline Ambivalencia & & & \\
\hline
\end{tabular}

Vale traer a colación que la Historia general del Perú (1617) del Inca Garcilaso de la Vega contiene dos dedicatorias. La primera, a la Virgen María, denota que el Inca ha interiorizado la religión católica, uno de los principales valores del conquistador (mimetismo, hibridación, blanqueamiento). La segunda, que forma parte del Prólogo, reza así: "A los indios, mestizos y criollos de los reinos y provincias del grande y riquísimo imperio del Perú, el Inca Garcilaso de la Vega, su hermano, compatriota y 
paisano, salud y felicidad" (22). ${ }^{105}$ Con estas palabras, el Inca Garcilaso alinea en situación de igualdad al indio, al mestizo y al criollo, intentando romper el estereotipo de que son seres inferiores frente al español peninsular. ${ }^{106}$ El Inca les reasigna a estas categorías sociales (basadas en la raza) un significado distinto de aquél utilizado con el propósito de justificar un trato desigual (codigofagia). El Inca Garcilaso se sirve del idioma español, que es el código del colonizador (codigofagia y mímica), ${ }^{107}$ para expresar desde la postura de un escritor reconocido (camuflaje) un mensaje de hermandad entre grupos étnicos pertenecientes, por lo menos, a dos bandos antagónicos. ${ }^{108}$ Mediante esta

\footnotetext{
${ }^{105}$ Este texto da cabida a interpretar que la palabra mestizo, ubicada en la frase estratégicamente entre los vocablos indio y criollo, pretende hermanar a los de los extremos. Al respecto, Cornejo Polar manifiesta que "[s]ería tentador correlacionar estilísticamente las dos enumeraciones, asociando indio a hermano, mestizo a compatriota y criollo a paisano, pero en realidad la economía de la frase parece girar sobre el término mestizo, desde el cual se abraza al indio y al criollo (es decir, a todo el mundo americano) y se acumulan los significados afectivos de la segunda enumeración [...] [A]l reivindicar enfáticamente su carácter mestizo y al asociarse fraternalmente con indios y criollos, Garcilaso asume una representatividad múltiple y ubica su discurso en el espacio de lo vario [énfasis mío]. ("Garcilaso: la armonía desgarrada", Escribir en el aire 79).

106 “Los estereotipos juegan un papel muy importante en las relaciones entre mayorías y minorías o, más exactamente, entre dominantes y dominados. En su forma más extrema sirven para identificar fácilmente a un grupo minoritario cuando la mayoría busca una 'víctima propiciatoria', proceso por el cual la gente traspasa la responsabilidad de sus desgracias y frustraciones a otros grupos que suelen ser minorías $[\ldots]$ En lo que respecta al racismo y a la xenofobia, el estereotipo es - junto con el mecanismo del 'chivo expiatorio' (o cabeza de turco) - uno de los procedimientos cognitivos que subyace o fundamenta las concepciones, actitudes, creencias y conductas racistas. Dicho de otra forma, el estereotipo es uno de los mecanismos claves de la ideología racista" (Malgesini y Giménez, Guía de conceptos 150).
} 107 "Una de las maneras privilegiadas en que nuestro personaje asimiló la cultura renacentista [...] fue
mediante la apropiación del lenguaje, vale decir, del pulimento retórico de aquella era. El Inca realizó una
suerte de [...] "conquista historiográfica' del Viejo Mundo, basada en su dominación [sic] de la lengua y
estilo de los humanistas. En la mentalidad de la época, el propio arte de la escritura era visto como un
sistema ideográfico y el código de la lengua era asumido como base epistemológica para el conocimiento e
interpretación de la realidad (cf. Marichal 1976: 59; Pupo-Walker 1982a: 144-148) [*]" (Hampe Martínez,
"El renacentismo del Inca Garcilaso revisitado" 4).
[*] Marichal, Juan. "The New World From Within: The Inca Garcilaso." First Images of America: The
Impact of the New World on the Old. Berkeley: U of California P, 1976. 57-61; y Pupo-Walker, Enrique.
Historia, creación y profecía en los textos del Inca Garcilaso de la Vega. Madrid: Ediciones J. Porrúa
Turanzas, 1982.

108 “¿[Q]ué profesiones elegían los alumnos jóvenes de Puno que se negaban a servir en el campo? La carrera de abogado, militar, policía y comerciante. Cuando decimos que el indígena trata de identificarse con el modelo misti [hombre blanco o blanqueado], queremos decir simplemente que desea para sí mismo 
estrategia, el Inca plantea una situación ambigua (ambivalencia) que le permite, solapadamente (camuflaje), contravenir y subvertir el discurso oficial (Otero Luque, "El Inca Garcilaso" 69).

El colonizado aspira a ocupar el lugar del colonizador (blanqueamiento), pero sin dejar de ser él mismo (etnicidad y etnofilia), y "resuelve" esa ambivalencia hibridándose (Zhou, The Transcription of Identities 34-5). En todo caso, en el colonizado/sublaterno se produce una escisión esquizofrénica, debido al sentimiento de apego a la propia cultura (etnicidad) y, a la vez, a la necesidad de adquirir las nuevas formas culturales (neoaculturación). Según Bhabha:

El concepto de diferencia cultural se concentra en el problema de la ambivalencia de la autoridad cultural: el intento de dominar en nombre de una supremacía cultural que es producida en sí misma sólo en el momento de la diferenciación. Y la misma autoridad de la cultura como conocimiento de la verdad referencial está en juego en el concepto y en el momento de enunciación. El proceso enunciativo introduce una escisión en el presente performativo de la identificación cultural; una escisión entre la demanda culturalista tradicional de un modelo, una tradición, una comunidad, un sistema estable de referencia, y la necesaria negación de la certidumbre en la articulación de nuevas demandas, sentidos, y estrategias

\footnotetext{
o para sus hijos profesiones de misti. No vayamos a imaginar que trata de asimilarse [sic] todas las características de la cultura misti. Sobre todo no vayamos a creer que la cultura criolla pueda ser preferida por el indígena" (Bourricaud, "Elogio del Cholo" 26). "Sería una locura imaginar que la identificación con el modelo misti significa para el indio la asimilación de la cultura criolla" (ibíd. 27). Por otro lado, Spivak sostiene que el subalterno debe renunciar a su identidad y convertirse en un "intelectual del primer mundo" si desea ser resonante (“Can the Subaltern Speak?”, 1985).
} 
culturales en el presente político, como práctica de dominación, o resistencia. (El lugar de la cultura 55)

Como puede apreciarse, no sólo el colonizado sino también el colonizador padece de la referida escisión mental.

\section{Etnobúmeran}

El etnobúmeran es un boicot autoinfligido, que consiste en socavar la propia etnia. Mientras que la etnofobia es una mera actitud de "rechazo a las etnias no dominantes" en general (Duncan 13), el etnobúmeran es el rechazo hacia la propia raza y cultura, y conlleva la realización de acciones que, a la corta o a la larga, revierten en contra de la persona o del grupo que desprecia y discrimina a su gente. Por ejemplo, Martín Villar, el protagonista de La violencia del tiempo (1991) de Miguel Gutiérrez Correa, siente rechazo hacia su propia estirpe (etnofobia), a la que considera espuria (racismo), y se rebela ante su condición de mestizo racial y cultural por hallarla inviable (etnofobia), llegando al extremo de negarse a tener descendencia (etnobúmeran). Esto obedece a que el proceso de hibridación cultural no necesariamente conlleva a una fusión armónica. Por el contrario, el intento de allanar la diferencia cultural mediante la fusión probablemente producirá un ser híbrido cuyas partes darán cuenta de la "gruesa sutura" que las une (Camayd-Freixas, "Vacilación”, Etnografía imaginaria 20). ${ }^{109}$

\footnotetext{
${ }^{109}$ En Matalaché (1928) de Enrique López Albújar, el personaje de "José Manuel no era un buen negro; era un renegado, a quien el trato de los blancos había contaminado" (77).
} 
Otro ejemplo de etnobúmeran es cuando el personaje de Queca, en el cuento "Alienación" (1958) de Julio Ramón Riberyro, ${ }^{110}$ le dice a Roberto, el muchacho del barrio que está enamorado de ella: "Yo no juego con zambos". Queca hace realidad su sueño de casarse con un norteamericano (eurofilia) con la finalidad de blanquearse y de ascender socialmente. Mas, al cabo de un tiempo, al codiciado yanqui "le fue saliendo el irlandés que disimulaba su educación puritana" y empezó a maltratar y a despreciar a su esposa debido a su origen peruano, a quien terminó llamándola "chola de mierda". El personaje de Roberto, en el mismo cuento de Ribeyro, también resulta muy útil para ilustrar algunos de los conceptos barajados en este capítulo y para mostrar la vigencia de la colonialidad. Bob/Boby es un joven pobre, hijo de una lavandera, que

[a] pesar de ser zambo y de llamarse López, quería parecerse cada vez menos a un zaguero de Alianza Lima ${ }^{111}$ [etnofobia] y cada vez más a un rubio de Filadelfia [eurofilia] [...] Toda su tarea en los años que lo conocí consistió en deslopizarse [sic] y deszambarse lo más pronto posible [etnobúmeran] y en americanizarse [eurofilia, simulacro, hibridación y blanqueamiento] antes de que le cayera el huaico y lo convirtiera para siempre, digamos, en un portero de banco o en un chofer de colectivo [prejuicio determinista]. Tuvo que empezar por matar al peruano que había en él [desculturación voluntaria y etnobúmeran] y por coger algo de cada gringo que conoció [eurofilia, neoaculturación, simulacro,

\footnotetext{
${ }^{110}$ Este cuento forma parte de los reunidos en la compilación La palabra del mudo (Milla Batres, 1973).

${ }^{111}$ Una de las escuelas más importantes del club de fútbol Alianza Lima es El Guayabo, en Chincha, en donde la cantidad de población negra es bastante significativa.
} 
hibridación y blanqueamiento] [...] [S]e compuso una nueva persona, un ser hecho de retazos [en un Frankenstein, como dice Camayd-Freixas], que no era ni zambo ni gringo, el resultado de un cruce contra natura [prejuicio racial].

Por otro lado, Kary, en "Amor se escribe con G", ejemplifica el etnobúmeran cuando niega a sus sobrinos (realiza una acción) porque se avergüenza de ellos:

No veo a ninguno de mis sobrinos en un puesto importante [determinismo] [...] Cuando me los encuentro por ahí me da vergüenza que me saluden, con el tía, tía, delante de mis amigas de la oficina. Me di cuenta de la cara de extrañeza que puso Laura Requena, cuando le expliqué que eran los hijos de una empleada muy querida de mi madre y que por cariño me decían tía [...] Casi todos morenos. Y todos, sin ninguna excepción, pobres y brutos que es lo peor [etnofobia y determinismo]. (115-6)

Otra forma de etnobúmeran es el servilismo del subalterno frente al poder hegemónico blanco. Jorge Rendón Vásquez considera que este tipo de actitud y de comportamiento constituye una forma de racismo en sentido contrario:

La otra faz del racismo se ubica en la conducta sumisa de los mestizos e indios frente a los blancos y en su actitud discriminatoria de sus propios congéneres, como una manera normal de vivir en la sociedad. Manifestaciones de este racismo inverso o de sumisión, que va de abajo hacia arriba, es la tendencia general en numerosos indios y mestizos a considerar a los blancos como sujetos superiores a ellos, a creerles más 
que a quienes no lo son, a obedecerlos sin reflexión si los blancos tienen el poder de mandar y a preferirlos en las múltiples relaciones sociales.

Como puede advertirse, la mayor diferencia entre la etnofobia y el etnobúmeran es que la primera es una mera actitud en tanto que el segundo es un comportamiento.

\section{Choleo}

El choleo es la forma de etnobúmeran más común en el Perú. ${ }^{112}$ "El cholear al otro, como ejercicio de predominio del criterio étnico y de diferenciación social, económica y cultural, está arraigado en nuestra vida colectiva y aflora en algún momento crítico" (“Cholo Power" 85). En resumidas cuentas, mediante el choleo lo que se hace es proyectar las propias abyecciones en connacionales que, supuestamente, tienen más sangre indígena que la que uno mismo considera tener. Debido al carácter subjetivo y relacional del choleo, no existe un "cholo absoluto"; es decir, alguien a quien ya no se pueda seguir choleando (Nugent 66). Por esta sencilla razón, en un instante uno puede pasar de agresor a agraviado (ibíd. 65). ${ }^{113}$ Una anécdota de François Bourricaud al respecto:

El camión, completamente lleno, se detiene para que suba un viajero que a

la orilla de la carretera nos ha hecho señal para que nos detengamos. Pero

\footnotetext{
${ }^{112}$ No debe confundirse choleo con cholificación. Mientras que el primero es una forma de etnobúmeran, el segundo, por el contrario, es una estrategia de resistencia, que consiste en la renuencia del subalterno a asimilar la cultura occidental dominante, en la reafirmación su propia identidad étnica y de la celebración de su marginalidad.

${ }^{113}$ El significado del calificativo de cholo es relativo tanto a la intención del emisor como a la interpretación del receptor. En consecuencia, la palabra cholo se presta para un análisis semiótico bajo el concepto triádico del signo (objeto-representantem-interpretante) que propone Charles Sanders Peirce (Abrams, "Peirce, Kant, and Apel on Transcendental Semiotics" 645), debido a que la realización del representantem "cholo" está determinada por el interpretante dinámico de un objeto dinámico.
} 
el chófer se niega obstinadamente a cargar un bulto muy voluminoso, del cual el indio no se quiere separar y por cuyo cargamento el chófer pide una suma que aquél afirma que no puede pagar. El indio se humilla, finge que llora; el chófer se muestra inflexible y deja al viajero en tierra. "Así debe tratarse a estos indios", nos respondió bruscamente el chófer, al cual otras personas hubieran podido tratar igualmente de indio (Nota del 10 de marzo de 1953). ("Elogio al cholo" 29)

Irónicamente, en un país en donde el segmento amerindio constituye, en cifras redondeadas, por lo menos el 30\% de la población (UNICEF, 2007), y en una sociedad mayoritariamente mestiza en la que "el que no tiene de inga, tiene de mandinga", como dice Ricardo Palma, el hecho de insultar a un paisano utilizando el término "indio" o "cholo" funciona como etnobúmeran, debido a que, finalmente, ese Otro somos nosotros mismos.

\section{El encastado}

Con el término "encastado" algunos pensadores se refieren al subalterno (indígena, cholo, negro o mulato) que, empoderado por el patrón—generalmente blanco o blanqueadose vuelve un tirano de su propia gente y contribuye a que sus congéneres sean explotados aún más y más cruelmente. ${ }^{114}$ Durante el período de resistencia a la imposición (coloniaje), el curaca - el jefe político y administrativo del ayllu, al que los invasores

\footnotetext{
${ }^{114}$ Según el diccionario de la Real Academia Española (RAE), el verbo encastar tiene dos acepciones que aluden a la eugenesia: 1) Mejorar una raza o casta de animales, cruzándolos con otros de mejor calidad; y 2) Procrear, hacer casta.
} 
(conquistadores) llamaban cacique—, ${ }^{115}$ fungía de interlocutor entre el encomendero y los indígenas que éste tenía a su cargo. Mas la misión primordial del curaca/cacique era asegurar que los indígenas trabajaran y produjeran para el amo: "Both the administration and exploitation of the Indians were performed through the existing local political authorities, the caciques" (Keith, "Encomienda, Hacienda, and Corregimiento" 435). El curaca/cacique era una pieza clave en el mecanismo de explotación del indígena y el desempeño de esa vil función lo convirtió en un encastado.

En sus Memorias, don Pedro Álvarez de Toledo y Leiva-marqués de Mancera y virrey del Perú entre 1639 y 1648 -identificó a los tres principales enemigos de los indígenas de esa época: el corregidor, el sacerdote y el cacique:

Tienen por enemigos estos pobres indios la codicia de sus corregidores, de sus curas y de sus caciques, todos atentos a enriquecer de su sudor; era menester el celo y autoridad de un virrey para cada uno; en la fe de las distancias se trampea la obediencia, y ni hay fuerza ni perseverancia para proponer por segunda vez la quexa" (en González Prada "Nuestros indios", Memorias de América Latina 129). ${ }^{116}$

Sobre el personaje esterotípico del encastado, Manuel González Prada (1844-1918) comenta lo siguiente:

\footnotetext{
115 Cacique es una voz taína que los invasores importaron del Caribe. Vale aclarar que, aunque había jerarquías entre los curacas, los españoles empleaban la palabra cacique para denominar a cualquier autoridad política indígena, sin atención a su rango.

${ }^{116}$ Polo, José Toribio. Memorias de los virreyes del Perú: Marqués de Mancera y Conde de Salvatierra. Lima: Imprenta del Estado, 1889.
} 
[C]uando un individuo se eleva sobre el nivel de su clase social, suele convertirse en el peor enemigo de ella $[\ldots][\mathrm{N}]$ o hay quizá opresores tan duros del indígena como los mismos indígenas españolizados e investidos de alguna autoridad. El verdadero tirano de la masa, el que se vale de unos indios para esquilmar y oprimir a los otros es el "encastado". 117 ("Nuestros indios" 126).

Un poco más adelante, González Prada agrega: "Pocos grupos sociales han cometido tantas iniquidades ni aparecen con rasgos tan negros como los españoles y encastados [énfasis mío] en el Perú [...] Muy poco les ha importado el dolor y la muerte de sus semejantes, cuando ese dolor y esa muerte les ha rendido unos cuantos soles de ganancia" (ibíd. 127).

El personaje del encastado tiene tanta vigencia en 1904, el año en el que fue escrito el texto de González Prada, como en tiempos recientes. Por ejemplo, durante la Reforma Agraria iniciada por el gobierno de facto de Juan Velasco Alvarado en 1969, en muchos casos y en varios aspectos la figura tiránica del gamonal fue reemplazada por miembros de la cúpula dirigente de las cooperativas agrícolas y agropecuarias que se formaron, la que se constituyó en una nueva casta explotadora de encastados. De manera análoga, el capataz de antaño es, en ocasiones, equivalente al actual ejecutivo de la empresa privada, al funcionario público o el militar que sirve de eslabón entre la cúpula domimante y los subordinados, a quienes flagela amparado en la autoridad con la que ha sido revestido. Por ejemplo, en Matalaché, Chabaco — el mayordomo (intendente) de La

\footnotetext{
${ }^{117}$ Harold Eugene Davis define la palabra encastado como "those very Indians who are Hispanicized and invested with some authority". <http://evergreen.loyola.edu/tward/www/gp/english/Indians.htm>
} 
Tina-tiraniza a los esclavos bajo su mando; y el oficial Pitaluga, un personaje prejuicioso y racista de La ciudad y los perros, se expresa de manera peyorativa acerca de los andinos que se enrolan en el Ejército.

Por actitudes como éstas, Jorge Rendón Vásquez sostiene con acierto que "[u]n policía, un militar, un juez y un fiscal mestizos serán más benévolos o condescendientes con un blanco o un blancoide que con un indio o un mestizo de rasgos indígenas, sobre quienes descargarán todo el rigor de la ley y los harán víctimas de sus abusos más execrables, en tanto que hallarán siempre para aquéllos una causa eximente de responsabilidad". Asimismo, Rendón Vásquez señala las siguientes situaciones cotidianas en las que el subalterno encastado pasa de la actitud a la acción; es decir, del racismo a la discriminación:

[L]os blancos y blancoides gozarán para ellos de preeminencia en el ingreso al trabajo y a ciertas instituciones y en los ascensos; un guardián mestizo dejará pasar a un blanco o blancoide y hará valer la prohibición contra un indio o un mestizo; un vendedor, funcionario o empleado mestizo dejará de atender a un indio o un mestizo más prieto que él para ocuparse de un blanco o blancoide que llegó después. Para este racismo de sumisión no existen el orden de llegada, la igualdad de oportunidades, ni, finalmente, la igualdad ante la ley.

Con seguridad, son encastados los guardianes de discotecas que se reservan el "derecho de admisión", los jefes de personal de aquellas empresas que reclutan gente "de buena presencia”, así como los ejecutivos y capataces explotadores. Al igual que la huachafita, 
el encastado se blanquea, pero a diferencia de ella, él encarna el etnobúmeran en un grado mucho mayor.

\section{Singularidad cultural del subalterno}

El argumento vertebral de este trabajo es que la singularidad cultural del subalterno peruano se forja en su constante devenir entre el etnovaivén y el etnobúmeran. Planteo que, de manera similar a la dialéctica hegeliana (Fenomenología del espíritu, 1808), del conflicto entre el etnovaivén (tesis) y el etnobúmeran (antítesis) se produce una síntesis. Pero, a diferencia del paradigma de Hegel, esta síntesis no es concluyente porque, inmediatamente después de haberse (casi) alcanzado, se vuelven a poner de manifiesto las contradicciones irresolubles de los polos opuestos. En ese sentido, se trataría más bien de una dialéctica negativa, como la que concibe Adorno (Dialéctica negativa, 1966). Si bien la metáfora del péndulo es útil para sugerir la idea de un desplazamiento oscilatorio entre los dos extremos, es importante aclarar que la síntesis temporal no se cristaliza, necesariamente, en un punto medio ni siempre en el mismo lugar. Como quiera que fuere, debe repetirse la experiencia que catalizó la síntesis, replanteándola y refinándola constantemente para que cuaje la cultura. Aunque las siguientes palabras de Deleuze no se refieren a este proceso, describen con bastante aproximación algo similar a lo que hace el subalterno con respecto a la cultura (en este caso, la cultura chicha): "I make, remake and unmake my concepts along a moving horizon, from an always decentered centre, from an always displaced periphery which repeats and differentiates them" (Difference and Repetition xxi). 
Prefiero utilizar el término singularidad en vez de identidad para destacar el producto cultural (la cultura chicha) que identifica y define al subalterno, por encima del sentimiento de apego (la etnicidad, la identidad cultural) que pueda tener en relación con ese producto. ${ }^{118}$ En contraste con la identidad, que Hegel define en función de su diferencia (por oposición, analogía y parecido) y contrariedad (su negación), la singularidad para Deleuze surge de la diferencia per se y no como una característica secundaria, así como de la autorrepetición en una serie única, en contraste con patrones predecibles. Ambos conceptos—diferencia y repetición—-preceden al de identidad. ${ }^{119}$

El siguiente cuadro muestra las similitudes y diferencias entre las posturas de Hegel y Deleuze con respecto a la identidad/singularidad:

\footnotetext{
118 " [P]erhaps the majority of philosophers [have] subordinated difference to identity or to the Same, to the Similar, to the Opposed or to the Analogous: they had introduced difference into the identity of the concept, they had put difference into the concept itself, thereby reaching a conceptual difference, but not a concept of difference" (Deleuze, Difference and Repetition xv). Para Deleuze la ontología no puede definirse en función de negaciones, porque la negación no es sino una diferencia extrema: "For difference implies the negative, and allows itself to lead to contradiction, only to the extent that its subordination with the identical is maintained" (ibid. xix).

119 Judith Butler (1956-...) sostiene que el género, por ejemplo, es interiorizado mediante el acto performativo; es decir, mediante la mímica y la repetición: "[G]ender is in no way a stable entity of locus of agency from which various acts proceed; rather, it is an identity tenuously constituted in time-an identity instituted through a stylized repetition of acts" ("Performative Acts" 402). En consecuencia, "[i]f the ground of gender identity is the stylized repetition of acts through time and not seemingly seamless identity, then the possibilities of gender transformation [de diferencia a través del cambio] are to be found in the arbitrary relation between such acts, in the possibility of a different sort of repeating, in the breaking or subversive repetition of that style" (ibíd. 402).
} 


\begin{tabular}{|c|c|c|c|}
\hline \multicolumn{3}{|c|}{ Cuadro $\mathrm{N}^{\circ}$ 6 } \\
\hline \multicolumn{3}{|c|}{ Hegel/Deleuze - Identidad/Singularidad } \\
\hline (Fenomenología del espíritu, 1808) & (Diferencia y repetición, 1968) \\
\hline Contrariedad & Diferencia & & Repetición \\
\hline Su negación & $\begin{array}{c}\text { Por oposición, } \\
\text { analogía y parecido }\end{array}$ & En/por sí misma & Serie única \\
\hline IDENTIDAD & & SINGULARIDAD & \\
\hline
\end{tabular}

Para la filosofía tradicional la identidad radica en las propiedades y características esenciales. En contraste, la ontología diferencial (Derrida y Deleuze, entre otros) plantea que la identidad es el resultado de posiciones relacionales variables. Siguiendo la segunda lógica, tanto la singularidad (individualidad), en un extremo, como la multiplicidad, en el otro, deben ser entendidas en función de las diferencias. Debido a la dinámica cambiante de las relaciones, que se hallan en constante renovación en el eterno proceso de repetición, cada nueva "copia" única, posee una singularidad más que una identidad anquilosada. El cuento "Pierre Menard" de Jorge Luis Borges - en el que el protagonista reescribe el Quijote "sin incurrir en una tautología” (Narraciones 92)-ilustra la idea de que la repetición puede generar un producto que, aunque sea muy similar a otros, es totalmente distinto; ${ }^{120}$ es decir, singular.

Bhabha sostiene que la imagen, como referente de identidad, "hace presente algo que está ausente $[\ldots$, , temporalmente postergado: es la representación de un tiempo que está siempre en otra parte, una repetición” (ibíd. 72). Es así que, en la confrontación

\footnotetext{
${ }^{120}$ He analizado este cuento en: "Borges, uno de los tantos autores de 'Pierre Menard, autor del Quijote'." Argus-a 6.22 (2016): 1-17.
} 
constante de las fuerzas antagónicas del etnovaivén y el etnobúmeran, la singularidad del subalterno — escindida por naturaleza— ${ }^{121}$ se redefine y se hace más sui géneris en cada nueva repetición. Y la repetición, que es siempre parcial, refuerza la identidad. ${ }^{122}$ De manera similar a los ejercicios corporales y a los hábitos, la cultura se interioriza por repetición. $^{123}$

La cholificación se nutre del folclor, que es la seña identitaria de todo pueblo; es el patrimonio inmaterial que le ha sido transmitido - y que, al mismo tiempo, transmitede manera intergeneracional. De ahí que la etimología de la palabra folclor (folklore, en inglés proviene de folk $=$ pueblo y, lore $=$ saber, conocimiento, acervo. Constituyen el folclor la música, el baile, la vestimenta, la artesanía, la gastronomía, las costumbres, los mitos y leyendas, etcétera. Desde el romanticismo alemán-primero con Johann Gottfried Herder (1744-1863) y, luego, con Jacob Grimm (1785-1863) —, que buscaba identificar el Volksgeist-el espíritu del pueblo_-, ha habido un creciente interés en rescatar el folclor como la base fundamental de la identidad nacional (Hayes 88-9).

\footnotetext{
121 "Identification [...] is always the return of an image of identity that bears the mark of splitting in the Other place from which it comes" (Bhabha, The Location 45). "For identification, identity is never an a priori, nor a finished product; it is only ever the problematic process of access to an image of totality [...] For the image — as point of identification - marks the site of ambivalence. Its representation is always spatially split" (ibíd. 51).

122 "La imagen es a la vez una sustitución metafórica, una ilusión de presencia, y por lo mismo una metonimia, un signo de su ausencia y pérdida. (Bhabha, "Interrogar la identidad", El lugar de la cultura 73).

123 "The progress which is brought about by repetition and practice consists merely in unfolding what was previously wrapped up [...] The true effect of repetition is to decompose, and then to recompose, and thus appeal to the intelligence of the body. At each new attempt it separates movements which were interpenetrating; each time it calls the attention of the body to a new detail which had passed unperceived; it bid the body discriminate and classify; it teaches what is the essential; it points out, one after another, within the total movement, the lines that mark off its internal structure" (Bergson, Matter and Memory 137-8).
} 
No creo en los esencialismos; es decir, en propiedades que definen a los pueblos como entidades ontológicas inmutables; no obstante, pienso-como la mayoría de académicos contemporáneos-que en un muy largo plazo (la longue durée), mucho mayor al de apenas unos cuantos siglos, los pueblos van adquiriendo algunas características, dinámicas y moldeables, que luego los identifican y, a la vez, los diferencian de otros pueblos. Hay quienes afirman que, como estrategia de resistencia, el folclor es particularmente importante ante la amenaza de lo exógeno, de lo foráneo que en estos tiempos representa la globalización. Discrepo de esa manera de pensar. Debido a que el folclor es permeable a las influencias externas y permanentemente se enriquece con ellas, no es dable que se considere auténtico folclor únicamente a aquellas manifestaciones culturales ancestrales y autóctonas, puesto que las más recientes son tan legítimas como aquellas. Por ejemplo, la música chicha y los chichódromos (lugares en donde se baila este tipo de música), así como las tradicionales peñas de música criolla son, indudablemente, parte del folclor nacional. ${ }^{124}$

El siguiente diagrama ilustra la dinámica en la que el subalterno peruano forja su singularidad cultural, alternando entre el etnovaivén y el etnobúmeran. Esta singularidad se materializa en algún punto del trayecto en donde la masa pendular halla un intersticio, un tercer espacio propicio: ${ }^{125}$

\footnotetext{
${ }^{124}$ Por ejemplo, el Karamanduka era una famosísima peña limeña, de las hermanas Piedad y Rosa de la Jara, en donde solía reunirse la intelectualidad y la bohemia limeñas durante las décadas de 1960 y 1970.

125 "Es en la emergencia de los intersticios (el solapamiento y el desplazamiento de los dominios de la diferencia) donde se negocian las experiencias intersubjetivas y colectivas de nacionalidad [nationness], interés comunitario o valor cultural" (Bhabha, "Vida en los bordes: el arte del presente", El lugar de la cultura 18).
} 


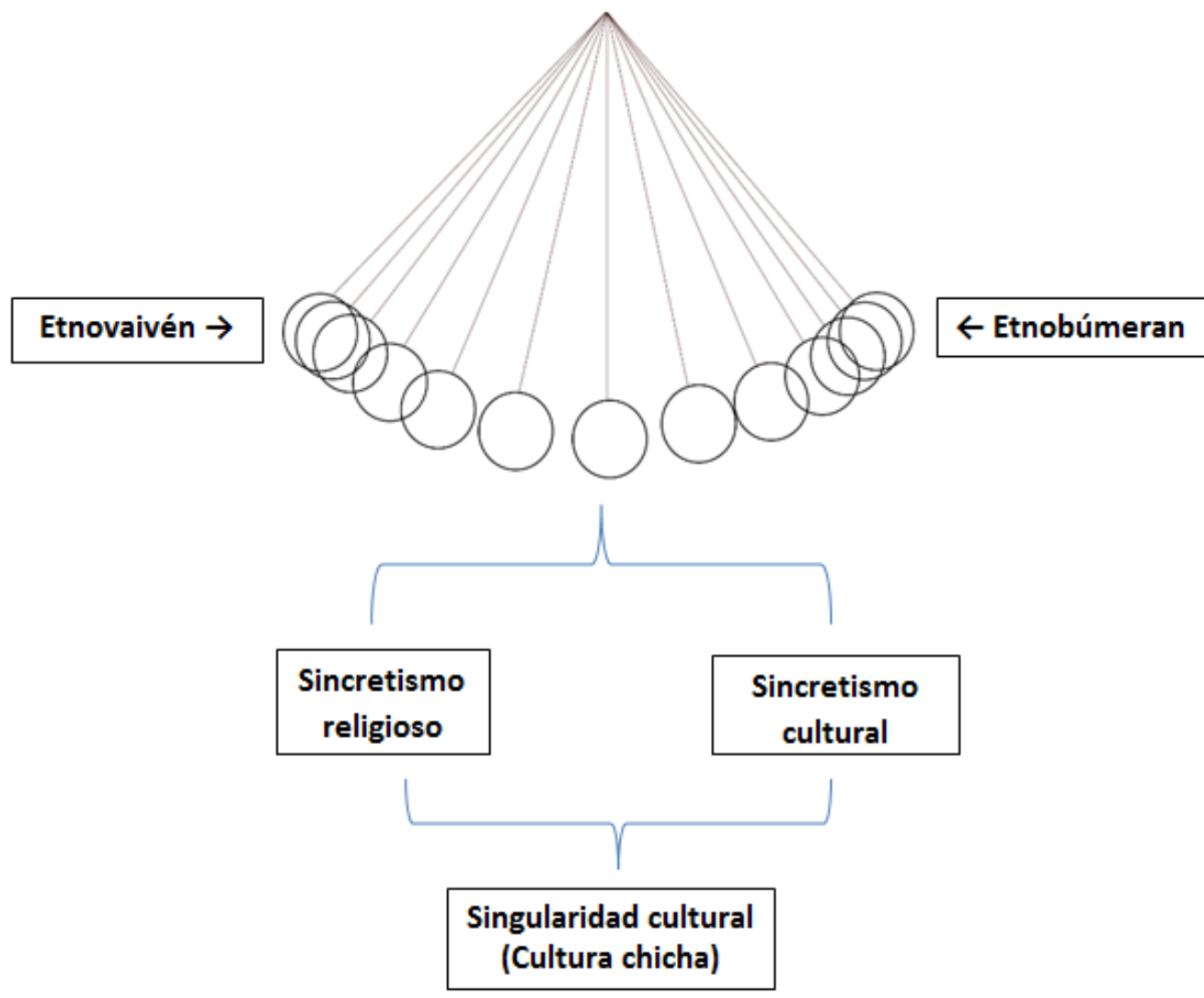

La llamada "cultura chicha" es la cristalización de la singularidad cultural del subalterno peruano contemporáneo.

\section{Sincretismo religioso}

El pretexto principal de la invasión española fue llevar la fe cristiana al Nuevo Mundo. Por tal motivo, la Iglesia católica jugó un papel crucial desde el incio de la Invasión, constituyéndose en "el principal mecanismo de socialización colonial" (Cotler 29). Tanto así que el sacerdote Hernando de Luque fue socio de Francisco Pizarro y Diego de Almagro en la expedición de conquista del Perú. Asimismo, en el encuentro entre Pizarro 
con Atahualpa el 16 de noviembre de 1532 estuvo presente el sacerdote dominico Vicente de Valverde. ${ }^{126}$ “

Como parte de la misión evangelizadora, en el siglo XVII hubo tres importantes campañas de extirpación de idolatrías: 1) la liderada por Francisco de Ávila (1609-1619), 2) la de Gonzalo de Ocampo (1625-1626), y 3) la del Arzobispo Pedro de Villagómez (1641-1671). En ese proceso, los curas - con el apoyo de los soldados - saqueaban y destruían los templos indígenas (por ejemplo, sobre las bases del Coricancha, un templo inca, fue construido el Convento de Santo Domingo), se robaban ídolos de oro y plata, violaban las huacas (lugares sagrados) y arrebataban malquis (mallquis), amén de despojar a los indígenas de sus tierras. ${ }^{127}$ En 1559, el virrey Andrés Hurtado de Mendoza, marqués de Cañete, ordenó retirar los malquis de sus respectivos adoratorios y algunos de ellos fueron enviados a Lima. ${ }^{128}$ De esa manera, las panacas se quedaron sin la

\footnotetext{
${ }^{126}$ Cuando el sacerdote Valverde le hizo el Requerimiento a Atahualpa, el inca se rehusó a aceptar la fe católica y la autoridad de la Corona española. Sin embargo, el 26 de julio del año siguiente accedió a ser bautizado a cambio de que, en la ejecución de la pena de muerte a la que había sido condenado, le conmutaran la hoguera por el garrote vil. En un juicio sumario, el inca había sido hallado culpable de idolatría, entre otros cargos (Juan de Betanzos, Suma y narración de los Incas, 1551). Aunque los indios estaban fuera de la jurisdicción de Tribunal del Santo Oficio, JCM considera que la de Atahualpa fue "la primera condena de la Inquisición en el Perú" (7 ensayos 124).

${ }^{127}$ Los malquis eran momias de antepasados que tenían una función tutelar. Los miembros del ayllu se turnaban un malqui en sus respectivos hogares para que los bendijera con su presencia. "[T]odas las decisiones importantes tenían que pasar por la consulta hecha a los Mallkis de cada comunidad, ya que tales seres hacían parte del mundo de los vivos, interviniendo, articulándolo y dinamizándolo" (Accorsi, "Los cuatro cantos del mundo" 14). "La injerencia de los muertos en el mundo de los vivos era especialmente significativa al interior de la esfera política: las momias de los Incas anteriores no sólo respaldaban al soberano reinante, sino que además tomaban decisiones y posiciones que comunicaban a través de sus panacas al nuevo Inca (Rostworowski, Historia del Tahuantinsuyu 35-41; en Accorsi 19-20).

${ }^{128}$ El historiador peruano Teodoro Hampe Martínez (1960-2016) había concebido el proyecto de ubicar los malquis que, en teoría, se hallaban enterrados en el Hospital San Andrés de Lima, el lugar donde se presume que fueron trasladados desde el Cusco. Este proyecto tenía previsto el uso de tecnología de punta, como, por ejemplo, un georradar (Ground-penetrating radar) para sondear el subsuelo y la realización de pruebas de ADN a los malquis que fueran hallados, con la finalidad de identificarlos con miembros vivientes de sus respectivas panacas (Muñoz-Nájar, "Buscando al Inca"). Se especulaba incluso que, de confirmarse el vínculo de consanguineidad, los parientes vivos de los malquis podrían tener derechos
} 
protección de sus ancestros. ${ }^{129} \mathrm{El}$ agravio en contra de los indígenas fue material, moral y, sobre todo, espiritual. A pesar de que los indígenas ya habían sido cristianizados para el año de 1660 (Kubler, "The Quechua in the Colonial World" 400), la violencia epistémica generó en el subalterno un sentimiento anticlericalista que se refleja en la literatura. Por ejemplo, en Aves sin nido, el cura Pascual Vargas—párroco de Kíllac—y el obispo Pedro de Miranda y Claro son caracterizados como personajes corruptos y opresores; y en Montacerdos, la Iglesia católica se muestra ajena e indolente ante la extrema necesidad de Griselda y su familia; incluso el sacerdote se niega a darles la comunión.

A pesar de que los curas-conquistadores intentaron extirpar lo que ellos consideraban idolatrías, destruyendo o robando el sustrato material de los cultos paganos, finalmente se dieron cuenta de que los indígenas continuaban adorando, por ejemplo, al illapa (rayo). De manera similar, las cumbres de numerosos cerros fueron coronadas con cruces cristianas, pero los indígenas volcaban su mirada hacia ellas para adorar al $a p u, o$ espíritu tutelar de la montaña, haciéndoles creer a los españoles que comulgaban con su fe. La cruz misma, sobre todo las que abundan en las encrucijadas de caminos, terminaron tachonadas de objetos simbólicos paganos (escaleras, gallitos, charreteras, etcétera) y reducidas a la categoría de percheros. No obstante, la cruz cristiana nunca habría perdido su significado original al no existir contradicción dogmática en la cosmovisión sincrétrica del hombre andino. "En el universo mental del indígena sí era

legales sobre las propiedades de sus antepasados. El doctor Hampe falleció recientemente e ignoro el estado actual del referido proyecto.

${ }^{129}$ Los miembros de un ayllu real conformaban una panaca. 
posible servir a dos señores" (de la Torre, Movimientos milenaristas 86). En la actualidad todavía son comunes las ofrendas a la Pachamama (madre tierra) y a los apus. La pervivencia del culto andino obedece tanto a la perseverancia del indígena en mantener sus tradiciones como a su capacidad de hacer una simbiosis de las religiones preinca, inca y católica.

El sincretismo religioso se dio, asimismo, entre los afroperuanos, quienes, hasta el siglo XIX, de manera similar a los santeros cubanos yoruba y a los practicantes del candomblé en el Brasil, emparentaban a los dioses cristianos con los del continente negro. Así, el Señor de los Milagros fue identificado con el Dios bantú Zambi. ${ }^{130}$ En veneración al Señor de los Milagros se realiza en la actualidad una de las procesiones cristianas más concurridas e importantes del mundo. El culto se originó en 1655, el año en que un terrible terremoto destruyó Lima, pero la imagen de un Cristo moreno que cuatro años antes un esclavo angoleño había pintado en un muro se mantuvo incólume. Sin embargo, lo más sobresaliente, según María Rostworowski (1915-2016), es que a la referida imagen se le habrían atribuido poderes del iracundo dios Pachacámac, generador y controlador de sismos. ${ }^{131}$ De acuerdo con la historiadora barranquina, los africanos bien podrían haber tomado la fe andina sencillamente por temor a los movimientos telúricos que son frecuentes en el Perú (“El Señor de los Milagros” 5). ${ }^{132}$

\footnotetext{
${ }^{130}$ Zambi es Olorúm — el dueño de los cielos o Dios Supremo — en el candoblé y en el culto yoruba.

${ }^{131}$ Rostworowski basa esta afirmación en el hecho de que el "milagro" ocurrió en Pachacamilla (pequeña Pachacámac), una zona limeña así llamada debido a que allí fue trasladado un nutrido número de indios nativos del Señorío de Pachacámac (Lurín), en donde está ubicado el gran templo erigido en honor a ese dios prehispánico.

${ }^{132}$ Al revés de lo que ocurrió en el Perú, en el Brasil, en donde el número de africanos era largamente mayor, prevalecieron las raíces y costumbres de éstos sobre las de la población nativa. Debido a ello, "los
} 
Jeffrey L. Klaiber hace notar que "la iglesia ha mirado con distintos grados de benevolencia estas manifestaciones populares. Las que parecían más 'paganas', sobre todo en el Altiplano, han sido condenadas; en cambio, las que parecían más aceptables han sido toleradas" (La Iglesia en el Perú 137) ${ }^{133}$ La percepción cambia con el paso del tiempo. Por ejemplo, “[e]n un primer momento la Iglesia censuró las solemnidades al Señor de los Milagros, luego las toleró y finalmente les dio su plena aprobación" (ibíd. 137). No obstante, "[e]l catolicismo, identificado con el orden tradicional, ha perdido terreno frente a nuevas confesiones como las protestantes, carismáticas y, más recientemente, expresiones vernaculares [sic] y sincréticas como la 'Asociación Evangélica de la Misión Israelita del Nuevo Pacto Universal'. 'Santitas' y 'beatitas' de origen popular y no reconocidas por la Iglesia, como la Melchorita o Sarita Colonia, están desplazando en la devoción local a Santa Rosa de Lima y [a] otros santos tradicionales" (de Soto 4).

Actualmente, podría hablarse de la cholificación del panteón cristiano. Por ejemplo, Sarita Colonia (Sara Colonia Zambrano, 1914-1940) es una santa apócrifa y chola, a quien un segmento postergado y marginal de la población chalaca (del Callao) empezó a rendirle culto en los años 1970, la década en que se intensificó la inmigración masiva de pobladores andinos a la costa. Esta santa surge, probablemente, de la necesidad de los indígenas y cholos de verse representados en la corte celestial. Los criollos ya

indígenas adoptaron los ritos africanos como el candombe [sic] y el Caboclo de Bahía como propios" (Rostworowski, "El Señor de los Milagros" 5).

${ }^{133}$ En Bolivia, por ejemplo, a mediados del siglo XX el movimiento de reivindicación del indígena Alcaldes Mayores Particulares (AMP) oficiaba "sus propias ceremonias de matrimonio, bautismo y ritos funerarios, en desafío a la autoridad de la Iglesia Católica, aunque incorporando ciertos aspectos del cristianismo de manera más sincrética" (Ari Chachaki 221). 
tenían a Santa Rosa de Lima y los negros y mulatos a San Martín de Porres, pero no había un santo andino ni mestizo.

Según JCM, los rasgos fundamentales de la religión incaica son el colectivismo teocrático y el materialismo (7 ensayos 120). De hecho, para José María Arguedas, “[e]1 concepto religioso de la propiedad y el trabajo, y por lo tanto de su colectivismo, corresponde a una concepción religiosa, primitiva, del mundo [...] Los elementos distintivos y profundos de la cultura india están ajustados sobre esta base" (Cuentos mágico-realistas 121). Debido a ello, Arguedas sostiene que la transculturación del andino es una consecuencia de la sustitución de sus creencias religiosas ancestrales:

Cuando tal concepción llega a ser sustituida realmente por la occidental; cuando por causa de la influencia constante y envolvente de factores muy poderosos, el indio se integra al sistema económico de nuestra cultura, entonces se inicia el cambio en el núcleo y por consecuencia en los elementos profundos de su cultura: cambia de vestido, de lengua y de costumbres; se convierte en un mestizo. (Ibíd. 121-2)

Es evidente que Arguedas no apostaba por una cultura híbrida. MVLL advierte que “Arguedas quería ver en el mundo indio [...] una cultura que ha preservado su entraña mágico-religiosa ancestral" (La utopía arcaica 283). ${ }^{134}$ Hasta cierto punto, Arguedas tenía razón: "En más de cuatro siglos de superposición, la cultura occidental ha

\footnotetext{
${ }^{134}$ La antigüedad es el valor más preciado en Todas las sangres de Arguedas. "Aquellos que tienen sentido de lo antiguo, que respetan la tradición y la costumbre, representan siempre lo mejor" (MVLL, La utopía arcaica 331). "La contrapartida de esta adhesión a lo antiguo como valor es el rechazo del progreso tecnológico. Arguedas intuía, de manera certera, que el desarrollo era incompatible con el ideal arcaico. No hay mundo campesino ni mágico, religioso, folclórico, que sobreviva a la modernización. No importa de qué signo sea el desarrollo industrial, capitalista o socialista. Y por eso, en la obra de Arguedas, hay un rechazo (visceral, irracional) de la idea misma de progreso. Esto es algo que él comprendía y que racionalmente le parecía inaceptable. Pero en su fuero íntimo no podía desprenderse de esa fe" (ibíd. 332).
} 
perturbado pero no ha destruido este fundamento" (Cuentos mágico-realistas 121). Por este motivo, el sincretismo religioso debe ser considerado una categoría aparte del sincretismo cultural. Todorov piensa que la Conquista de América fue exitosa para los españoles porque, entre otras cosas, ellos eran más eficientes que los indígenas en la comunicación de signos (La conquista de América, 1982). Lo afirmado por Todorov es discutible. En todo caso, el éxito de la resistencia indígena radica tanto en su empecinamiento en preservar el significado de algunos símbolos preincas e incas, como en la resemantizacion de otros signos autóctonos con la finalidad de adaptarlos, primero a la nueva religión y después a la nueva cultura.

\section{Cosmovisión mágica}

De manera similar al candomblé en el Brasil, a la santería en Cuba y al vudú en Haití, por dar tres ejemplos, en el Perú son populares la brujería y el curanderismo, siendo el chamanismo una de las expresiones del segundo. Si bien todas las prácticas mencionadas tienen un fuerte componente mágico, la gran diferencia de la magia peruana con respecto a las otras es que no se le considera una religión. No obstante, no hay que confundir la magia lega con las diversas, extendidas y ancestrales pero muy vigentes religiones andinas, aunque tengan muchos puntos de intersección con la magia secular. Lo importante es que, como quiera que se le llame y la categoría a la que pertenezca, la magia le permite al subalterno adelgazar y, en ocasiones, borrar del todo la línea que divide el pasado, el presente y el futuro, el mundo de los vivos y el de los muertos; en general, irrespetar las leyes físicas. Por ejemplo, en La violencia los Villar acceden a otra dimensión espacio-temporal a través de un estado alterado de conciencia inducido 
mediante la ingestión de un brebaje de sampedro, el cactus sagrado. Es en esa dimensión en donde arreglan cuentas con sus adversarios a través de la catarsis. El subalterno recurre a la magia y a elementos fantásticos como un recurso para zanjar la enorme distancia que existe entre la realidad de pesadilla y la nación idealizada que anhela. Por eso, en Patíbulo Yococo y el Gringo Pérez-basándose en un ejemplar del Códice sobre el vuelo de los pájaros de Leonardo da Vinci que Pompeyo-Gorilón-Flores le obsequia, fabrican una máquina voladora, "imposible" (debido a los precarios materiales de construcción) y logran elevarse por los cielos subidos en ella, liberándose así del mundo infernal de la barriada. ${ }^{135}$

En relación con la proclividad del peruano por el gusto de lo insólito, Portocarrero identifica que la "tradición"— el género literario que inventó Ricardo Palma, en el que "combina el cuento con la historia, la oralidad con la historiografía"-suele abordar con humor "un suceso curioso, o la trayectoria de un personaje, o la historia de una costumbre; en general, hechos extraordinarios que escapan a lo cotidiano" (La urgencia 93). Portocarrero piensa que a Palma le interesa lo extraordinario en la medida en que "resulta típico de una sensibilidad colectiva" (ibíd. 94). Analizar este fenómeno en la literatura constituiría una valiosa herramienta para comprender y explicar el entramado social del Perú y el tema de la identidad. Empero, ese análisis rebasa los límites del presente estudio.

\footnotetext{
135 “'[C]reí que jamás volvería a ver a mi hermano; empezaron a ascender y vagar por el cielo del barrio, y palomas y gallinazos se alocaron desconcertados por tan enorme pájaro; chillaban Yococo y el Celedunio, gritábamos los montacerdos tratando de seguir a la nave, de saltar, de atraparla con las uñas mientras corríamos de un lado a otro por la breve colina, hasta que la máquina se perdió de vista sumergiéndose en una montaña de algodón bajo la luz perpleja del sol" (Patíbulo 165).
} 
Desde luego, la magia es una estrategia de resistencia del subalterno, porque se entiende que el dominador no tiene poder ni competencia en ese campo, reservado para los iniciados. El chamán, el brujo o el hechicero vela por sus protegidos que, no por mera coincidencia, son también subalternos como él/ella. También deseo hacer notar que, en la narrativa peruana, la fantasía (entendida principalmente en el sentido de mágico) es un recurso que suele ser empleado para embellecer o mejorar la realidad. Asimismo, hay la tendencia a que, cuando el protagonista subalterno lleva las de perder, se recurra, además de a la parodia y al sentido del humor, a elementos mágico-fantásticos, incluyendo los milagros, con la finalidad de nivelar sus fuerzas con las del antagonista, que suele representar al poder hegemónico.

En otro orden de ideas, cabe mencionar que el elemento mágico-religioso, tan arraigado en la cosmovisión (Weltanschauung) del peruano, propicia el surgimiento de líderes mesiánicos:

Milenarismo y mesianismo gravitan en el Perú porque aquí la política no es solo una actividad profana. Como tantas otras cosas en este país, está también condicionada por el factor religioso. De allí la importancia de lo irracional. Las utopías pueden convocar pasiones capaces de arrastrar o conducir a las multitudes más allá de lo inmediato, hasta intentar tomar el cielo por asalto o arrebatar el fuego a los dioses. Pero esta mística se convierte fácilmente en fanatismo y en rechazo dogmático de quienes no la comparten. Subyace una vertiente autoritaria que a su vez genera los desbordes violentos. (Flores Galindo, "Sueños y pesadillas", Obras completas 375) 
No es sorprendente, pues, que de tiempo en tiempo aparezcan líderes mesiánicos en un país en donde el pensamiento mágico compite en pie de igualdad - a veces, e incluso con ventaja—con el científico. El mayor peligro que revisten los líderes mesiánicos para la sociedad es que se las arreglan para exacerbar pasiones en sus seguidores, al punto de que, luego de hipnotizarlos mediante un discurso pseudorevelador, ellos son capaces de "sobrellevar cualquier sacrificio" y de justificar "todas las atrocidades" bajo la tiranía del mesías (ibíd. 374). Este fue el caso de Abimael Guzmán y SL.

\section{Sincretismo cultural}

A lo largo de varias generaciones los inmigrantes andinos y sus descendientes se han forjado un espacio importante en la economía y han consolidado su posición social en la costa. Y aunque muchos andinos inmigrantes han mantenido usos y costumbres que son típicos de la sierra, me atrevería a afirmar que la mayoría de los que han logrado su asimilación estructural secundaria son los medianamente transculturados; es decir, los más occidentalizados, tanto geográfica como mentalmente, mediante la adquisición de capital cultural (educación, modales, modo de hablar, manera de vestir, etcétera). En otras palabras, el subalterno mejor acomodado sería aquél que, en la dinámica del etnovaivén, resulta más blanqueado que cholificado. ${ }^{136}$

\footnotetext{
${ }^{136}$ Desde luego, hubo quienes se resistían a la occidentalización. A José María Arguedas (1911-1969), por ejemplo, le producía zozobra y cólera "advertir a su alrededor, incluso en el ambiente de antropólogos y etnólogos estudiosos de la cultura andina, una suerte de resignación $-\mathrm{y}$, a veces, de entusiasmo - frente al proceso de aculturación del indio [...], es decir, el declinar de la cultura prehispánica -lengua, creencias, usos y costumbres - al ser absorbida la población campesina indígena por el Perú urbano e hispanohablante" (MVLL, La utopía arcaica 285). Aunque Arguedas sabía que este proceso era irreversible, lo "rechazaba con todas sus fuerzas como un crimen de lesa cultura y la culminación de la secular injusticia contra el indio perpetrada por el invasor europeo" (ibíd. 285).
} 
En relación con lo anterior, resulta paradójico que el chifa-la cocina fusión chino-peruana (oriental-criolla) que se popularizó en los años 1920 - sea uno de los ejemplos más exitosos de hibridación cultural en el Perú, debido a la gran aceptación que ha tenido esta comida de sabores agridulces entre todos los connacionales, independientemente de la clase social a la que pertenecen. ${ }^{137}$ Otro ejemplo de sincretismo cultural gastronómico en el Perú es la cocina novoandina, que surgió a mediados de los años 1980 y que cobró auge desde mediados de los años 1990 gracias al impulso que le ha dado el reconocido chef Gastón Acurio. Se trata de una cocina fusión que emplea ingredientes y modos de preparación autóctonos en la elaboración de platillos de las grandes cocinas internacionales. El "quinuoto"- un risotto en el que se sustituye el arroz por la quinua — es un ejemplo de este tipo de creatividad culinaria. A diferencia del chifa, la comida novoandina tiene un público nacional mucho más restringido, entre otras razones porque se sirve en restaurantes de cierto nivel— que no abundan como los chifas (restaurantes de comida peruano-china) y, en consecuencia, es bastante más costosa. ${ }^{138}$ Un tercer ejemplo de fusión gastronómica en el Perú es la cocina nikkei (peruanojaponesa), promovida internacionalmente desde finales de los años 1980 por el famoso

\footnotetext{
${ }^{137}$ Desde el siglo XIX, la ciudad de Lima cuenta con un importante barrio chino. Si bien existen registros que dan cuenta de la presencia de chinos en el Perú desde el siglo XVII, fue alrededor de la Era del Guano (1840-1870), específicamente entre 1849 y 1875, cuando llegaron al Perú decenas de miles de inmigrantes chinos contratados bajo el régimen de enganche (Lausent-Herrera "Tusans (tusheng) and the Changing Chinese Community in Peru" 116).

${ }^{138}$ Es importante mencionar que, debido a la gran demanda de algunos insumos oriundos, tal como la quinua, por parte de los restaurantes de lujo, muchos de esos productos se han encarecido a tal punto que ahora al subalterno le resulta difícil, si no imposible, adquirir esos productos que normalmente incluía en su dieta cotidiana. En este aspecto, el auge de la cocina peruana ha producido, sin proponérselo, un efecto de etnobúmeran.
} 
chef Nobu Matsuhisa. ${ }^{139}$ La gastronomía peruana, en general, se ha posicionado muy bien en las principales ciudades del mundo y, habiéndose convertido en una marca de identidad nacional, es un motivo de orgullo no solo para los andinos y mestizos sino para todos los peruanos. En consecuencia, no debe llamar la atención que haya más de 20 escuelas de gastronomía en Lima y que una de ellas sea el Instituto Le Cordon Bleu.

La moda étnica peruana también amerita un comentario especial, porque es un aspecto del sincretismo cultural que, a diferencia de la cultura popular, entusiasma e involucra cada día más a la clase alta, que adquiere prendas únicas en exclusivos talleres de alta costura y en pasarelas internacionales, así como ropa y accesorios étnicos hechos en serie que ofrecen elegantes boutiques y grandes almacenes. En su libro titulado El hilo conductor: Tradición y moda en el Perú (2013), Olga Zaferson hace una importante reflexión sobre la manera en que los peruanos han empezado a valorar la vestimenta étnica como marca de identidad:

Antes, ni siquiera se aspiraba a ver, como hoy en día, cadenas de tiendas famosas y ferias internacionales ofreciendo la artesanía y la ropa étnica como un trabajo muy especial, no sólo para el público extranjero, también y especialmente para los propios peruanos $[\ldots]$ Hace veinte años era imposible pensar en encontrar estos productos [hechos a mano] en grandes y hermosos almacenes [...] Hubiera sido casi un insulto y una ofensa para la burguesía consumista, que tenía su mirada puesta en el exterior. (197)

\footnotetext{
${ }^{139}$ De manera similar a lo que ocurre con la quinua y otros insumos oriundos, muchos restaurantes encarecen y acaparan el mercado de pescados y mariscos de primera calidad, al que cada vez menos subalternos tienen acceso.
} 
Los diseños de Zaferson se concentran, principalmente, en los siguientes tres aspectos: a) estilización de trajes nativos, b) aplicación de tejidos y bordados tradicionales a piezas contemporáneas, y c) recreación de iconografía (El hilo conductor 189). Todas éstas son expresiones de sincretismo cultural. Como resultado de la capacitación de diseñadores de moda étnica, del consiguiente aumento de la producción, y de la promoción, "ahora faltan pasarelas, concursos, exposiciones, para mostrar todo el caudal de diseñadores jóvenes y no tan jóvenes" (ibíd. 187).

\section{Sentido del humor}

La vena humorística en la literatura peruana tiene una larga tradición, desde Juan del Valle y Caviedes (1652-1697), un andaluz que llegó al Perú de niño. Este poeta y dramaturgo satírico — a quien Luis Alberto Sánchez considera el padre del criollismohizo de los médicos y curanderos — amén de militares, monjas y curas—el objeto de sus burlas (Diente del Parnaso). Otro andaluz, Esteban Terralla y Landa (1750-1805), que vivió primero en México y después pasó 10 años en el Perú (1787-1797), se hizo célebre por Lima por dentro y fuera (1797), en donde hace comparaciones entre Lima y la capital azteca, y se burla de las costumbres y de las mujeres limeñas.

Pero el sentido del humor que me interesa destacar es el de Ricardo Palma. Acerca del autor de las Tradiciones peruanas, Víctor Raúl Haya de la Torre comenta lo siguiente: “[N]inguna institución u hombre de la Colonia y aun de la República escapó a la mordedura tantas veces tan certera de la ironía, el sarcasmo y siempre el ridículo de la jocosa crítica de Palma. Bien sabido es que el clero católico tuvo en la literatura de Palma un enemigo y que sus Tradiciones son el horror de frailes y monjas" (en JCM, 7 ensayos 
178). El Amauta coincide con Haya de la Torre en que "[1]a sátira de las Tradiciones hinca con frecuencia sus agudos dientes roedores en los hombres de la República" (ibíd. 180).

Ciertamente, "[d]espreciado por la aristocracia criolla, que preservaba un modelo colonial, segregacionista y jerarquizante, Palma su burló de ella, erosionó su legitimidad histórica y terminó acercando al mundo popular" (Portocarrero, La urgencia 86). Lo insólito es-y éste es el punto-que "[1]a respuesta, aunque demorada, de esta aristocracia no fue otra que 'blanquear' a Palma [...] [E]l antiguo enemigo se convirtió, desde fines del siglo XIX, en el maestro admirado a quien la aristocracia criolla miraba agradecida, pues había abierto un cambio hacia el futuro. Un cambio que mermaba sus privilegios, pero en el que, a cambio, podía sentirse parte de la emergente nación peruana" (ibíd. 86-7). Tanta fue la acogida que tuvo Palma entre la clase alta que, cuando en 1912, el gobierno de Augusto B. Leguía lo fuerza a renunciar al cargo de director de la Biblioteca Nacional, que había mantenido desde 1883, y nombra a Manuel González Prada en su lugar, "la juventud aristocrática cierra filas en torno al 'patriarca' de las Tradiciones" (ibíd. 126-7). ${ }^{140}$ “[P]or una curiosa paradoja, Palma se vio rodeado, adulado y desvirtuado por una troupe de gente distinguida, intelectuales, católicos, niños bien y admiradores de apellidos sonoros" (Haya de la Torre; en JCM, 7 ensayos 178). Quizá por ese motivo, "al revés de la sátira reaccionaria de Felipe Pardo y Aliaga", Palma no ataca a

\footnotetext{
${ }^{140}$ Tal vez los aristócratas prefirieron a Palma - un self-made man-que a José Manuel de los Reyes, González Prada y Álvarez de Ulloa, que era un aristócrata, como ellos, pero renegado y anarquista. Por ejemplo, en 1904 González Prada había declarado públicamente que"[e]l animal de pellejo blanco, nazca donde naciere, vive aquejado por el mal del oro; al fin y al cabo cede al instinto de rapacidad" ("Nuestros indios", Memorias 130).
} 
la República misma" (JCM, 7 ensayos 180). ${ }^{141}$ "Palma comprende que, si se trata de crear una comunidad, los hechos no pueden narrarse tal como sucedieron, pues el resultado sería trágico e irresuelto en la medida en que la dominación étnica y la fragmentación del mestizaje seguían siendo los datos mayores de la realidad del país" (Portocarrero, $L a$ urgencia 97).

Dice Gonzalo Portocarrero que, en las Tradiciones peruanas — que, en su opinión, deberían llamarse "limeñas"-_[1]a historia de la comunidad tenía que ser fabulada remarcando las convergencias, y sin explorar demasiado las tensiones y la disgregación" (ibíd. 97). Para fines prácticos, era más conveniente reír que llorar, aunque el costo fuera alto: "De allí lo acertado pero también lo limitado de la solución 'tradicionalista'. La ironía aligera la realidad y resguarda al presente del poder paralizante de lo trágico, pero todo ello a costa de alejarnos de las posibilidades transformadoras que abre la verdad" (ibíd. 97). Valiéndose de una hábil y singular retórica, “[g]racias a la sonrisa que el autor arranca a sus lectores, la historia del Perú es despojada de su sustancia trágica” (ibíd. 98).

\footnotetext{
${ }^{141}$ Desde una postura aristocrática, Felipe Pardo y Aliaga (1806-1868) hallaba las costumbres criollas populares - como el baile de la zamacueca, por ejemplo - de muy mal gusto. Pensaba que eran contraproducentes para una sociedad que intentaba "civilizarse". Además de dramaturgo y poeta satírico, Pardo y Aliaga era también un escritor costumbrista. Fundó y dirigió el periódico El espejo de mi tierra, que utilizó bastante para burlarse y ridiculizar el "criollismo". Y era clasista y racista. Por ejemplo, le dedicó el siguiente epigrama sarcástico a su hijo Manuel (Manuel Justo Pardo y Lavalle, que en el futuro llegaría a gobernar el Perú) cuando cumplió la mayoría de edad: "Dichoso hijo mío, tú / que veintiún años cumpliste / dichoso que ya te hiciste / ciudadano del Perú / Este día suspirado / celebra de buena gana / y vuelve orondo mañana / a la hacienda y esponjado / viendo que ya eres igual / según lo mandan las leyes / al negro que unce tus bueyes / y al que te riega el maizal" ("A mi hijo en sus días", 1855). Asimismo, Pardo y Aliaga llamó "Alejandro Guanaco" a Andrés de Santa Cruz y Calahuama, el Protector de la Confederación Perú-Boliviana, cuyos rasgos andinos eran evidentes. "Guanaco" por el auquénido y "Alejandro", caricaturizando a Alejandro Magno. También le compuso un poema satírico titulado La jeta. Acerca de Pardo y Aliaga, JCM comenta que: "Toda la inspiración de su sátira—asaz mediocre por lo demás - procede de su mal humor de corregidor o de 'encomendero' a quien una revolución ha igualado, en la teoría si no en el hecho, con los mestizos y los indígenas. Todas las raíces de su burla están en su instinto de casta. El acento de Pardo y Aliaga no es el de un hombre que se siente peruano sino el de un hombre que se siente español en un país conquistado por España para los descendientes de sus capitanes y de sus bachilleres" (7 ensayos 173).
} 
Desde luego, "[e]sa sonrisa es un llamado al olvido del pasado", pero "[e]s también un culto al goce de vivir y una apuesta a futuro (ibíd. 98). La mejor prueba de que la fórmula de Palma conecta con el alma popular es que este autor escribiera sus Tradiciones durante más de medio siglo (1864-1910) y que aún hoy continúen divirtiéndonos. Tras comparar a Palma con José Antonio de Lavalle y Arias de Saavedra (1833-1893), JCM llega a la conclusión de que "[1]a obra pesada y académica de Lavalle y otros colonialistas ha muerto porque no puede ser popular. La obra de Palma vive, ante todo, porque puede y sabe serlo" (7 ensayos 177).

Hasta hace poco tiempo, en el Perú eran pocas las personas que—como Vallejo—se autodefinían cholas (Callirgos, "El racismo peruano" 20-1). Eran más los comediantes — tales como Tulio Loza, el "Cholo de acero inoxidable", La paisana Jacinta ((Jorge Benavides) y La chola Chabuca (Ernesto Pimentel)—quienes solían asumirse cholos e indios, aunque parodiándolos. En jerga peruana, maletear quiere decir hacer escarnio de alguien. Los referidos personajes se automaletean; es decir, se burlan de sí mismos y por eso resultan jocosos. La buena recepción de sus respectivos programas televisivos por parte de la audiencia explica que se mantuvieran en el aire durante muchos años. ${ }^{142}$

Tulio Loza ha desempeñado un papel muy importante en la cholificación del Perú, empezando con la creación del personaje "Nemesio Chupaca", un cholo audaz que, en la década de 1960 y desde Radio Central, rompió el estereotipo del andino sumiso. Un ejemplo de la vena jocosa de La paisana Jacinta es el nombre de su imaginario pueblo

\footnotetext{
${ }^{142}$ América Televisión transmitió la primera temporada de La chola Chabuca entre 1997 y 2000; y la de La paisana Jacinta fue transmitida por Frecuencia Latina desde el año 1999 hasta el 2002.
} 
natal: Chongomarca. En el Perú, chongo alude a burdel, a escándalo, a alboroto; chonguear, en jerga, es divertirse haciendo bromas. De otro lado, marka significa pueblo o aldea en idioma quechua. En consecuencia, La paisana Jacinta proviene de un pueblo en donde la gente se divierte, toma el pelo, se burla, chonguea. ${ }^{143}$ Por otra parte, La chola Chabuca es la chola cosmopolita, presumida y petoca, (pituca, con dicción quechua). Resulta hilarante no sólo por su español quechuanizado empleado con afectación, sino también por el anacronismo del personaje, en el sentido de oopart. También es necesario mencionar a Risas y salsa (dirigido por Aldo Vega y, luego, por Guillermo Guille), el programa más sintonizado de la televisión desde 1880 hasta 1996. Pero antes, entre 1967 y 1982, “el Zambo” Augusto Ferrando, había recorrido el Perú con sus revista cómicomusical La peña Ferrando, considerada la cuna de los llamados cómicos ambulantes.

En el Perú, como en muchos países del mundo, es muy común que en los programas televisivos se parodie a la clase política y a gente de la farándula. En algunos casos la caricaturización de estos personajes - que implica la exageración de sus rasgos físicos y morales - se convierte en una dura y mordaz crítica sobre ellos. En el mundo pedestre, tomarse el pelo mutuamente_vacilar a alguien y que a uno lo vacilen, en jerga peruana - es un deporte nacional. Lo significativo es cuando ese pasatiempo es puesto en práctica por reporteros y entrevistadores que, con toda desfachatez, ponen en aprietos especialmente a los políticos que acceden a ser interpelados.

\footnotetext{
${ }^{143}$ Carlos Iván Degregori hace notar que "[s]ería inconcebible, por ejemplo, un programa titulado "La catalana Jacinta" o "La vasca Jacinta" en España, o "La negra Jacinta" en los EEUU. Primero, porque a ningún libretista se le ocurriría algo así. Y si se le ocurre, ningún canal de TV lo aceptaría. Y si lo acepta, ningún auspiciador pondría anuncios. Y si lo haría [sic], miles de catalanes, vascos o negros según el caso, y no sólo ellos sino la mayoría de la población, protestaría" ("Perú: identidad” 217-8).
} 
Al subalterno le gusta contar y que le cuenten chistes. Nunca nadie sabe quién los inventa, pero invariablemente habrá uno nuevo para cada acontecimiento que haga noticia o que esté de moda. Las situaciones graves interpretadas desde la perspectiva del humor obligan a reflexionar sobre situaciones ridículas que, en ocasiones, parecen ser la norma. Ciertamente, el humor y la parodia son componentes importantes de la cholificación.

\section{Cultura chicha}

En la actualidad la cultura chicha se manifiesta en casi todos los ámbitos y aspectos de la vida diaria de los peruanos. Se habla, por ejemplo, de comportamiento y modo de hablar chicha, de moda chicha, de gustos chicha, de programas de televisión y cine chicha, de economía chicha, etcétera. Como he explicado, en la dinámica del etnovaivénetnobúmeran el péndulo se detiene en algún punto del trayecto y, en ese preciso lugar y momento (el tercer espacio intersticial al que se refiere Bhabha), se plasman expresiones culturales y espirituales nuevas y sincréticas, con características muy sui géneris: la llamada cultura chicha. Reflexionando sobre las ideas de Deleuze, podría especularse que la cultura chicha es la manifestación de un simulacro que, articulando las nociones de mimetismo, mascarada y camuflaje, niega tanto el original (la cultura hegemónica) como la copia (de la misma cultura hegemónica) (Deleuze 53). ${ }^{144}$ En tal sentido, la

\footnotetext{
144 "The simulacrum is not degraded copy, rather it contains a positive power which negates both original and copy, both model and reproduction. Of the at least two divergent series interiorized in the simulacrum, neither can be assigned as original or as copy" (Deleuze 53).

Cabe aclarar que el tipo de simulacro que conceptualiza Deleuze no reemplaza a la realidad, como sería el caso del concepto de Baudrillard, en el que el simulacro se torna híper real (Zohar, "Strategies of Camouflage" 173).
} 
ambivalencia sería una característica del arte popular chicha, porque "no tiende a copiar modelos anteriores pero tampoco los niega (Garvich, "El carácter chicha en la cultura peruana" 61). A partir de las ideas de Eugenio D’Ors (1923) y de Luciano Anceschi (1945), entre otros, Bolívar Echeverría plantea la existencia de un ethos barroco; es decir, de un modo de vivir barroco, algo que va mucho más allá de la mera estética: “[E]1 concepto de barroco ha salido de la historia del arte y la literatura en particular y se ha afirmado como una categoría de la historia de la cultura en general" ("El ethos barroco", La modernidad de lo barroco.32). Sin duda, la infinita capacidad sincrética de la cultura chicha sugiere barroquismo.

En los años 80 se volvió muy popular la música chicha, una de las primeras expresiones artísticas de esta cultura. Se trata de un género que, con el empleo de instrumentos musicales electrónicos, combina el huayno (música andina) y otros tipos de música autóctona peruana con tecnocumbia, ritmos tropicales y rock, entre otros. ${ }^{145}$ En esa época, bandas musicales como Los Shapis y Chacalón tuvieron un éxito masivo y vendieron miles de discos a gente que se identificaba con esa estética híbrida, empezando por los afiches que anunciaban los conciertos, muy compactos y copiosos en información,

Acerca de la manera que Baudrillard concibe el simulacro, MVLL comenta con sarcasmo lo siguiente: "[E]l desarrollo de la tecnología audiovisual y la revolución de las comunicaciones en nuestros días han abolido la facultad humana de discernir entre la verdad y la mentira, la historia y la ficción, y hecho de nosotros, los bípedos de carne y hueso extraviados en el laberinto mediático de nuestro tiempo, meros fantasmas automáticos, piezas de mecano privados de libertad y de conocimiento, y condenados a extinguirnos sin haber siquiera vivido" ("La hora de los charlatanes", El lenguaje de la pasión 166).

145 "[E]1 rock-chicha se refiere a un híbrido de rock-and-roll con música andina y/o cumbia serrana, costeña o selvática. Con frecuencia se identifica al rock-chicha como producto cultural de barriada" (Ramos-García 126). 
impresos con una tipografía característica y abigarradas tintas fosforescentes (kitsch). ${ }^{146}$ A principios de los años 90, Los Mojarras irrumpieron en el panorama musical peruano: "Era la primera vez que se escuchaba cantar con tanta fuerza y rabia contenida canciones contestatarias de 'rock-chicha' que describían la vida de grupos inexplorados por la temática del rock nacional: los migrantes, los informales, los achorados, la gente de barrio, el lumpen" (Ramos-García 126-7). ${ }^{147}$ La inmensa popularidad de Los mojarras puso en evidencia "la resquebrajadura parcial del modelo hegemónico criollo-español" (ibíd. 127) que hasta entonces, era un "Apartheid-a-la-peruana", y percibía "a sus miembros como [los] únicos herederos de la cultura y del poder legítimos, reaccionando con aversión a todo lo que significara 'cholo-serrano' o 'andino-chicha'.” (ibíd. 128).

Años más tarde, el grupo Juaneco y su Combo se hizo famoso por combinar ritmos de la selva con los otros mencionados. Consciente del poder de la música chicha para llegar a las masas, Fujimori y sus partidarios bailaron al ritmo del Baile del chino durante la campaña de las elecciones presidenciales del año 2000. Lo más importante es que la chicha trascendió al ámbito musical: “[N]acieron a su alrededor nuevas cadenas radiales, el nuevo sonido penetró en la televisión, alcanzó al cine" (Garvich 60). Por ejemplo, a lo largo de tres décadas (1966-1996) Panamericana Televisión (Canal 5) transmitió en vivo los días sábado el programa de entretenimiento Trampolín a la fama,

\footnotetext{
${ }^{146}$ Esta estética gráfica es también del gusto de muchos camioneros que pintan sus vehículos y los bautizan con nombres muy folclóricos: El rey de las curvas, Voy a volver, El Chasqui, Quítate que te tumbo (Bourricaud 29).

147 "El término achorado se aplica por lo general a individuos de dudosa conducta. Tiene una connotación de reacción violenta ante cualquier tipo de provocación real o imaginaria” (Ramos-García 126).
} 
conducido por Augusto Ferrando; ${ }^{148}$ en 1986 se estrenó la película Los Shapis en el mundo de los pobres, dirigida por Juan Carlos Torrico, y recientemente las comedias Asu mare (2013) y Asu mare 2 (2015), ambas dirigidas por Ricardo Maldonado.

Según Martín Tanaka, la adopción de una identidad chola, moderna, le permitió al indígena una mayor integración social y así logró conquistar la ciudad (Rodríguez y Venturo 18). "[L]os nuevos limeños fueron adecuando Lima a sus valores, costumbres y tradiciones. En todo este proceso coparon todas las instancias de la sociedad [...], transformando la Lima señorial y aristocrática, criolla y mazamorrera" (Quispe, "La cultura chicha" 6). El mismo fenómeno se dio en otras ciudades capitales de los departamentos de la costa. El sujeto chicha puso en práctica ingeniosas y pragmáticas formas empresariales, basadas en relaciones de parentesco (Garvich 62). Este fue el caso del huancavelicano Aquilino Gamarra, que emigró a Lima y, tras varias décadas de esforzado trabajo, se convirtió en el dueño de Topitop, una de las empresas textiles más importantes del Perú (Álvaro Vargas Llosa, Lessons from the Poor). Javier Garvich señala que, salido de las barriadas, el sujeto chicha empezó a ser percibido como "un triunfador, un auténtico self-made man [...] El cholo moderno que acumulaba capital, se elevaba socialmente y estaba cambiando el paisaje urbano y la composición social del país (62). ${ }^{149} \mathrm{Al}$ otro extremo de la economía, "[e]l sujeto chicha como consumidor masivo consolidó las estructuras comérciales de crédito y atrajo hacia sí costumbres de

\footnotetext{
${ }^{148}$ Cabe mencionar que, aunque tabloid talk shows como los de la presentadora de televisión Laura Bozzo forman parte de la cultura popular chicha, al mismo tiempo son un etnobúmeran porque muestran las peores facetas de la sociedad peruana.

${ }^{149}$ Luis Felipe Calderón Moncloa describe de la siguiente manera al "super cholo"; es decir, al cholo ideal que necesita el Perú para caminar hacia el desarrollo: "El 'super cholo' tiene buena autoestima, sabe poner límites. No aguanta más de la cuenta [...] No se deja maltratar ni maltrata. Genera liderazgo e innovación [a su] alrededor" ("Mal manejo emocional: clave del subdesarrollo").
} 
ocio y consumo impensables hace solo quince años" (ibíd. 62). Garvich da como ejemplo "la instalación de megacentros comerciales en los conos, idénticos a los de sectores hegemónicos de la ciudad" (ibíd. 62).

Arturo Quispe identifica tres "dimensiones" que se manifiestan en la cultura chicha: 1) la estética-cultural, 2) la informalidad, y 3) la laxitud en el cumplimiento de las normas (3). Ya desde finales del siglo XIX y principios del XX, en sus Tradiciones peruanas (1872-1910) Ricardo Palma describía a una comunidad que empezaba a identificarse por su proclividad "a la viveza, al ingenio, a la transgresión" (Portocarrero, La urgencia 129). Es más, “[e]n el mundo de Palma, los virreyes son los primeros en no cumplir las leyes" (ibíd. 128). Esa vocación a quebrantar la norma ha pervivió hasta la actualidad y el término "chicha" también sirve para aludir a lo que está mal hecho, que escapa a lo establecido, a lo inescrupuloso, a lo transgresor y hasta lo delictivo (Quispe 2).

Por ejemplo, la piratería de libros, de discos compactos, de software, de ropa de marca, así como el contrabando de artefactos eléctricos y electrónicos de última generación son una parte distintiva de la economía chicha. Chicha son también los ambientes en donde estos productos se distribuyen y consumen (Garvich 61), tales como los mercados como Polvos Azules y Polvos Rosados. Empero, si por una parte la piratería le ofrece al subalterno la posibilidad de adquirir, a un precio accesible, artículos (no tan finos ni confiables como los originales) que, de otro modo, no podría comprar; por otra parte la informalidad le causa graves pérdidas al sector formal de la economía que, en consecuencia, reinvierte menos y genera menos puestos de trabajo, produciendo un efecto de etnobúmeran. 


\section{Prensa chicha}

La llamada prensa chicha fue promovida por el Servicio de Inteligencia Nacional del Perú (SIN) durante el gobierno de Fujimori. Éste fue el impacto más negativo y transcendental de la cultura chicha en la esfera política. Los diarios y revistas sensacionalistas que se publicaban en esos años "se convirtieron en pasquines de la mentira, del engaño y del ocultamiento de la información de manera deliberada" (Quispe 1). ${ }^{150}$ Centradas en la crónica policial y en los chismes de farándula, diarios y revistas de esa estofa todavía circulan en el Perú, aunque ya desprovistos de la intención de confundir y de desviar la atención pública, o de difamar a enemigos políticos. ${ }^{151}$ El estilo de estas publicaciones es, decididamente, chicha y conecta con el gusto popular, especialmente por su diagramación y porque emplea una replana sui géneris en sus llamativos titulares y textos. Por ejemplo, "Cinco tibios y un frío" en el accidente tal quiere decir que el desafortunado suceso dejó un saldo de cinco heridos y un muerto. El equivalente radial del estilo chicha impreso sería la manera de hablar "estridente, atropellada, repetitiva" (Garvich 61).

\footnotetext{
${ }^{150}$ Quispe Lázaro considera que otro efecto negativo de la prensa chicha en la política fue que contribuyó a la reelección fraudulenta de Fujimori (Fujimori hizo promulgar la ley $\mathrm{N}^{\circ} 26657$ de Interpretación Auténtica de la Constitución para poder ser nuevamente candidato presidencial). Por otro lado, como lo evidencian los llamados vladivideos, muchos políticos "chaqueteros" y ejecutivos de los medios de comunicación se vendieron al gobierno fujimorista. Sin que ellos lo supieran, Montesinos, el jefe del SIN, los filmaba recibiendo el soborno. Estos videos empezaron a salir a la luz el 14 de septiembre de 2000 y ocasionaron un escándalo político mayúsculo. El filme Ojos que no ven (2003) de Francisco Lombardi trata sobre la corrupción que reinaba en el Perú en esos años.

${ }^{151}$ Existe otra vertiente de prensa chicha que trata temas que son de interés para su nicho de mercado, tales como medicina natural, trámites legales, búsqueda de trabajo en el extranjero, etcétera (Garvich 61).
} 
En resumen, la cultura chicha es la expresión contemporánea de la singularidad/identidad [Deleuze/Hegel] cultural del subalterno [Gramsci y Spivak] peruano. Se forja por la confluencia de factores religiosos y culturales en algún punto del trayecto pendular entre el etnovaivén y el etnobúmeran, y viceversa. El etnovaivén es la oscilación entre el blanqueamiento y la cholificación [Quijano], las dos posturas que suele adoptar el subalterno, según su conveniencia, en determinadas circunstancias. El blanqueamiento está emparentado con los conceptos de mimetismo y camuflaje [Bhabha], la cholificación con los de hibridación [Said y Bhabha] y diferencia [Bhabha], y el etnovaivén con el de ambivalencia [Bhabha] y los cuatro anteriores. Mientras que el etnovaivén es una muy efectiva estrategia de resistencia (principalmente por la naturaleza desconcertante de la ambivalencia) que ha desarrollado el subalterno peruano no sólo para sobrevivir a la colonialidad [Quijano y Wallerstein] sino también subvertirla, el etnobúmeran es un boicot autoinfligido en contra de la propia etnia subalterna. A diferencia de la etnofobia [Duncan], que es una actitud de rechazo por parte del subalterno a las etnias no dominantes (generalmente, la de sus pares subalternos), el etnobúmeran implica un comportamiento en contra de la propia raza y cultura, razón por la cual revierte en contra de la persona o del grupo subalterno que desprecia y discrimina a su gente.

La dinámica del etnovaivén-etnobúmeran, que condenso en el esquema de la siguiente página, constituye un modelo epistemológico que puede ser adaptado a otros países con realidades similares a la del Perú, tanto andinos como caribeños. En el último caso, el término cholificación tendría que ser reemplazado con el de negrificación. 


\section{MAPA CONCEPTUAL DEL MODELO EPISTEMOLÓGICO ETNOVAIVÉN-ETNOBÚMERAN}

Forjamiento de la singularidad cultural del subalterno peruano, estrategias de resistencia e impronta literaria

Cosmovisión indígena (ayni y ayllu), folclor autóctono, cultos prehispánicos $\rightarrow$ SC y SR

BLANQUEAMIENTO (B)

(huachafita, encastado)
CHOLIFICACIÓN (CH)

(El cholo celebra su marginalidad reafirmando su etnicidad sin rechazar la hibridez cultural)

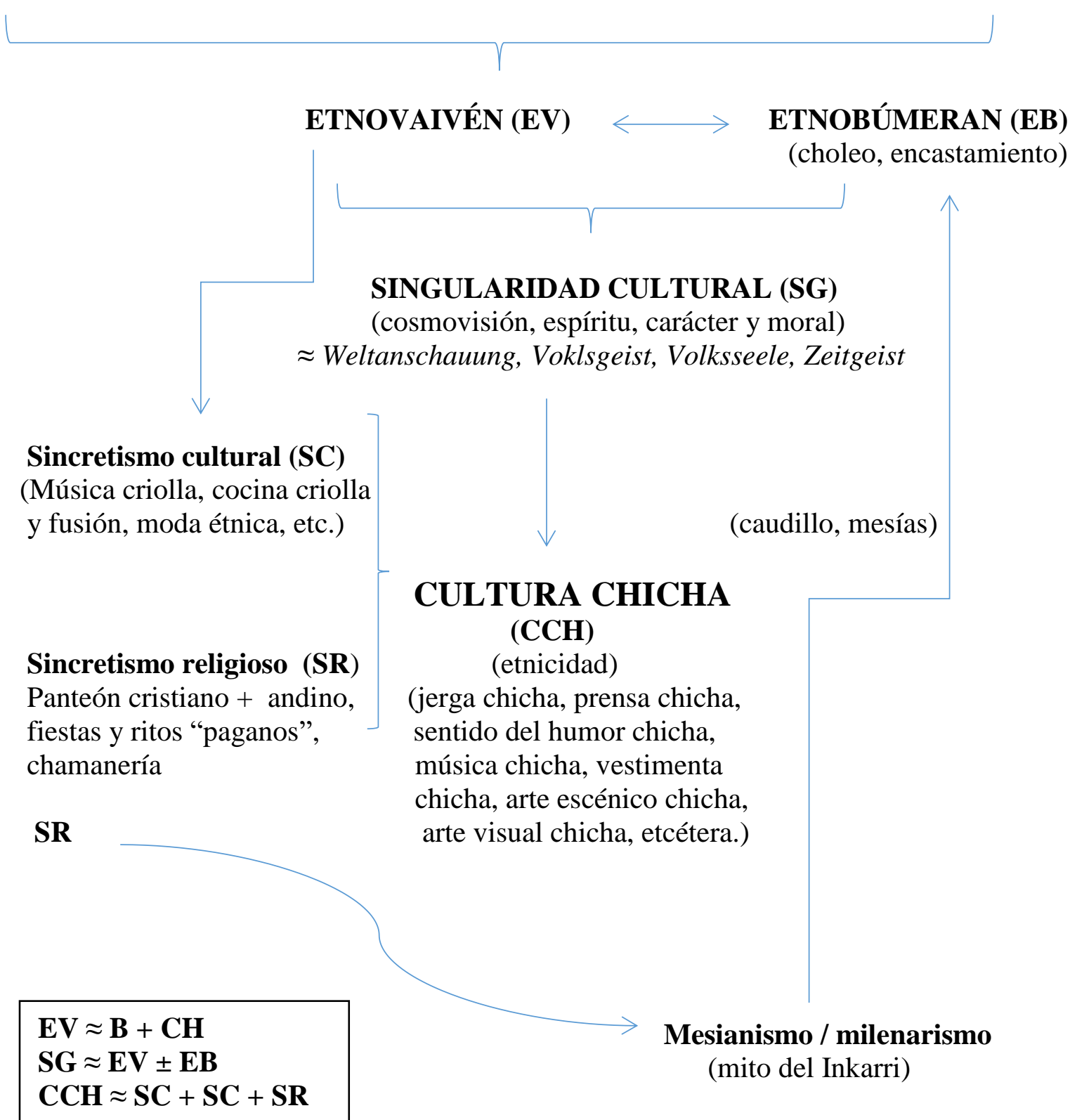




\section{POSTULADOS DE (RE)CONSTRUCCIÓN NACIONAL DE MATTO Y MARIÁTEGUI}

Este pasado nuestro aún no se convierte en auténtico pasado, sigue siendo un presente que no se decide a ser historia Leopoldo Zea (Dos etapas del pensamiento en Hispanoamérica, 1949)

Clorinda Matto de Turner (1852-1909) publicó Aves sin nido en 1889, cuando el Perú se hallaba en pleno proceso de reconstrucción tras la derrota sufrida en la Guerra del Pacífico (1879-1883). ${ }^{152}$ En esta novela—de corte realista-naturalista y de estética romántica por el melodrama —, ${ }^{153}$ la autora reitera la visión sanmartiniana en cuanto a la imperiosa necesidad de incorporar al indígena en el plan de (re)construcción nacional, y denuncia las taras sociopolíticas que habían impedido hacerlo desde que el Perú se convirtió en un país soberano (1821-1824); principalmente la explotación de los indígenas, la corrupción de las autoridades—sobre todo eclesiásticas-y la falta de justicia en los pueblos andinos. ${ }^{154}$ Influenciada por el pensamiento positivista, tan en

\footnotetext{
${ }^{152}$ Clorinda Matto era su nome de plume, al que posteriormente añadió Turner, el apellido de su esposo. Su nombre verdadero era Grimanesa Martina Mato Usandivaras.

153 "Luego de la guerra con Chile surge como secuencia emergente el realismo, para lograr desplazar al romanticismo y constituirse en dominante por muy pocos años. Este realismo superficial, sustentado en un positivismo morigerado, arrastra significativos rezagos románticos y aun costumbristas, como es visible en la obra de Clorinda Matto y Mercedes Cabello" (García Bedoya 83).

Tomás G. Escajadillo propone para Aves sin nido la designación de "indianismo-romántico-realistaidealista" (“Aves sin nido ¿Novela 'indigenista'?” 139).

154 “Cuando la crisis económica interrumpió la prosperidad creada por la explotación del guano y los empréstitos, y luego sobrevino la guerra con su abrumadora secuela, cayeron por tierra las ilusiones y las convenciones del romanticismo, y a un mismo tiempo se inició un implacable sondeo en los vicios engendrados por la política y la anhelosa búsqueda de nuevas energías. Denuncias y protestas caracterizaron el grito de la literatura, dándole a su estilo un tono palpitante" (Tauro 53).
} 
boga en su época, como fórmula de progreso Clorinda Matto de Turner proponía educar al pueblo, y se declaraba a favor de la inmigración y de una economía liberal. ${ }^{155}$

En el presente capítulo reviso algunos postulados socioeconómicos de Matto en Aves sin nido (1889) y en El Perú Ilustrado, a la luz de las ideas que JCM (1894-1930) tenía acerca de estos mismos temas, y que expuso, principalmente, en sus 7 ensayos de interpretación de la realidad peruana (1928). La comparación es particularmente interesante, debido a que el Amauta no incluyó a la escritora cusqueña-pionera del indigenismo, una corriente literaria tan importante para él— ${ }^{156}$ entre los autores sobre los que comenta en "El proceso de la literatura", el último y más extenso capítulo de su obra magna. Discrepando de Tomás G. Escajadillo, quien rechaza la clasificación de Aves sin nido como novela indigenista, porque considera que, en ella, la caracterización del indígena es muy pobre, y que la presencia de éste en la historia, más que protagónica, es

\footnotetext{
${ }^{155}$ Matto se aleja del pensamiento positivista cuando postula que la instrucción que se imparta debe estar vinculada a la fe en Dios: "Ataquemos las costumbres viciosas de un pueblo sin haber puesto antes los cimientos de la instrucción basada en la creencia de un Ser Superior, y veremos alzarse una muralla impenetrable de egoísta resistencia y contemplaremos convertidos en lobos rabiosos a los corderos apacibles de la víspera" (Aves sin nido 27).

Así como Matto concebía un positivismo católico, Emilia Pardo Bazán (1851-1921) planteaba unimprobable - naturalismo católico en La cuestión palpitante (1883-1884). Bazán se oponía al naturalismo determinista de Émile Zola - expuesto por este autor en La novela experimental (1880) y en Los novelistas naturalistas (1881) - , porque no le daba cabida al libre albedrio, que es la piedra angular del código moral cristiano.

156 “El 'indigenismo' de nuestra literatura actual no está desconectado de los demás elementos nuevos de esta hora. Por el contrario, se encuentra articulado con ellos. El problema indígena, tan presente en la política, la economía y la sociología no puede estar ausente de la literatura y el arte" (7 ensayos 238).

Por el contrario, Erik Camayd-Freixas sostiene, en América,"[a]demás de guardar aun ciertas formas sutiles de racismo, el indigenismo y el afroamericanismo adolecieron de la contradicción ideológica de buscar una idealidad nacional fundada en la raza, al mismo tiempo que pretendían eliminar las distinciones raciales en la sociedad y la cultura (Nicol 1961; cf. Bartra 1987). En el terreno del arte, estos movimientos carecieron de estética propia, fuera del superficial colorido nativista o de la protesta panfletaria del realismo socialista, carencia que redundó en menguado valor literario" (Realismo mágico 31).
} 
complementaria; ${ }^{157}$ opino que esta novela es pionera del indigenismo literario peruano

porque denuncia los abusos que se cometían en contra del indígena, porque aboga por su

causa, y le da voz en una historia en la que, aunque no sea el protagonista, el tema central

es la injustica de la que es víctima. ${ }^{158}$ Precisamente, debido a estos grandes méritos, es

sorprendente que JCM — para quien el indigenismo tenía una gran importancia "por estar

extirpando, poco a poco, desde sus raíces al "colonialismo"' (7 ensayos 253) — haya

omitido mencionar en sus 7 ensayos a la autora cusqueña. ${ }^{159}$

La historia de Aves sin nido está ambientada en Kíllac, un imaginario y pequeño

pueblo andino, por la misma época en que fue publicada la novela (1889). ${ }^{160} \mathrm{El}$

\begin{abstract}
157 "Pese a lo sincero de su denuncia, Clorinda Matto no pudo brindarnos ni siquiera "algunos escorzos del alma del indio", como dijera JCM a propósito de Cuentos andinos [de Enrique López Albújar, 1920], libro que, en mi concepto [...] inicia el indigenismo narrativo en el Perú" ("Aves sin nido ¿Novela 'indigenista'?" 148).

En contraste con el indígena caracterizado por Matto, según Escajadillo, "el indio logrado por López Albújar [...] sí tiene existencia autónoma [...y] no se limita a aparecer en función del explotador, sino que se instala en medio de la ficción narrativa” (“Aves sin nido ¿Novela 'indigenista'?” 146).

${ }^{158}$ El Centro Científico del Cuzco fue fundado en 1897. "[E]n 1900 la escritora cuzqueña Clorinda Grimanesa Martina Matto Usandivaras de Turner, autora de Aves sin Nido, novela escrita hacia 1890 y considerada una de las más grandes expresiones del indigenismo cuzqueño, se integra al Centro [...] Las denuncias que hiciera en su obra sobre los abusos que éstos sufrían, fueron leídas por los grupos ilustrados tanto de Lima como de provincias, lo que, a no dudar, fueron base para las posturas políticas indigenistas de principios del siglo XX" (Gutiérrez et al 35).
\end{abstract}

${ }^{159}$ En contraste con su indiferencia con respecto a Aves sin nido, JCM alaba, por ejemplo, los cuentos indigenistas "Los Tres Jircas", de Enrique López Albújar (Cuentos Andinos, 1920), y "Los hombres de piedra" (De la vida inkaria, 1925), de Luis E. Valcárcel (7 ensayos 243-45).

Por otra parte, JCM califica a González Prada como el "precursor de una nueva conciencia social" (7 ensayos 31, nota al calce $\mathrm{N}^{\circ} 2$ ), y justifica "la prescindencia deliberada de algunas obras [...] con incontestable derecho a ser citadas y tratadas en la crónica y en la crítica de nuestra literatura", porque "carecen de significación especial en el proceso mismo" (ibíd. 252).

${ }^{160}$ Kíllac significa, en voz quechua, "alumbrado con luz de Luna” (Gutiérrez de Quintanilla 15).

"No existe ninguna duda acerca de que Kíllac [...] es la versión literaria del pueblo de Tinta, donde Clorinda Matto radicó desde su matrimonio hasta abandonar el Cusco. Los quince años de observaciones a los que alude en el proemio corresponden gruesamente a su estadía en esa localidad, entre 1871, fecha de su matrimonio con José Turner, y 1886, cuando, con la transferencia de sus últimos negocios, se desvinculó definitivamente de ella, para irse a radicar a Arequipa" (Manrique 91).

Es significativo que Tinta sea también el pueblo en donde José Gabriel Condorcanqui-Túpac Amaru II(1738-1781) inició su rebelión. 
argumento gira en torno a cuatro grupos familiares-los Marín, los Pancorbo, los Yupanqui y los Champí-, además del cura Pascual, del obispo Pedro de Miranda y Claro (personaje ausente), de Hilarión Verdejo, de Estéfano Benites, de Pedro Escobedo y del coronel Bruno Paredes. He aquí un resumen:

\begin{tabular}{|c|c|c|c|}
\hline \multicolumn{4}{|c|}{$\begin{array}{c}\text { Cuadro } \mathrm{N}^{\circ} 7 \\
\text { Personajes de Aves sin nido }\end{array}$} \\
\hline Familia & Parejas & Ocupación & Hijos \\
\hline \multirow{2}{*}{ Marín } & Fernando & Empresario minero & \\
\hline & Lucía & Ama de casa & \\
\hline \multirow{2}{*}{ Pancorbo } & Sebastián & Gobernador y comerciante de lana & \multirow{2}{*}{ Manuel } \\
\hline & Petronila Hinojosa & Ama de casa & \\
\hline \multirow{2}{*}{ Yupanqui } & Juan & \multirow{2}{*}{ Campesinos } & \multirow{2}{*}{$\begin{array}{c}\text { Margarita y } \\
\text { Rosalía }\end{array}$} \\
\hline & Marcela & & \\
\hline \multirow{2}{*}{ Champí } & Isidro & Campanero y campesino & \multirow{2}{*}{$\begin{array}{l}\text { Miguel y } \\
\text { otros }\end{array}$} \\
\hline & Martina & Campesina & \\
\hline \multicolumn{2}{|c|}{ Individuos } & Ocupación & Hijos \\
\hline \multicolumn{2}{|c|}{ Pascual Vargas } & Párroco & \\
\hline \multicolumn{2}{|c|}{ Pedro de Miranda y Claro } & Obispo (anterior párroco de Kíllac) & $\begin{array}{l}\text { Manuel y } \\
\text { Margarita }\end{array}$ \\
\hline \multicolumn{2}{|c|}{ Hilarión Verdejo } & Juez de paz & \\
\hline \multicolumn{2}{|c|}{ Estéfano Benites } & Secretario del juez de paz & \\
\hline \multicolumn{2}{|c|}{ Pedro Escobedo } & Comerciante de lana & \\
\hline \multicolumn{2}{|c|}{ Bruno de Paredes } & Coronel y subprefecto & \\
\hline
\end{tabular}

La novela provee algunas referencias que indican la época en que se desarrolla la historia: “iQué horror! ¡Muchos sabrán lo que es despertar en la bulla del desorden, el tiroteo y la matanza, porque en el país se soportan y se presencian con frecuencia esos levantamientos y luchas civiles, que ya en nombre de Pezet, Prado o Piérola [énfasis mío] llevan el terror y el sobresalto, sea en el aura de una revolución, sea en los fortines de una resistencia! ¡Pero lo que pocos sabrán es el despertar del sueño de la felicidad entre el plomo homicida y la voz del degüello lanzados en los muros de su propio dormitorio!” (54), exclama don Fernando después del ataque a su residencia. En otro momento, Manuel le comenta a don Fernando que, en su tesis de bachiller, planteará la necesidad de que los sacerdotes contraigan matrimonio, a lo cual su interlocutor le responde: "Tocará usted un punto de vital importancia, punto que los progresos sociales tienen que dilucidar antes que el siglo decimonono cierre su último año [énfasis mío] con el pesado puntero que va marcando las centurias" (129).

Todas las citas de Aves sin nido incluidas en este trabajo han sido extraídas de la edición de Stockcero de 2004. 
La historia empieza cuando la campesina Marcela Yupanqui va a pedirle ayuda a doña Lucía—la esposa de don Fernando, un próspero empresario minero-, ${ }^{161}$ porque su marido recibirá la "visita del reparto", y no puede hacerle frente a las obligaciones económicas contraídas. Los Yupanqui-Juan y Marcela — se han gastado los cien pesos que "comerciantes potentados" les habían entregado el año anterior como pago adelantado de dos quintales de lana. ${ }^{162}$ Se compraron ropa, pensando que luego podrían reponer el dinero, pero no les fue posible hacerlo debido a que el cura Pascual les embargó la cosecha de papas para hacerse pago de los servicios fúnebres de la madre de Juan. Accediendo al pedido de ayuda de Marcela, doña Lucía-la esposa de un importante empresario minero - acude al referido cura para solicitarle que interceda por los deudores ante los acreedores laneros, pero la gestión de la dama es infructuosa. En ese estado de cosas, Sebastián Pancorbo, quien, además de ser el gobernador de Kíllac, comercia con lana de alpaca, manda a secuestrar a Rosalía, la hija menor de los

\footnotetext{
${ }^{161}$ Escajadillo considera absurdo que Matto haya elegido para don Fernando-uno los principales héroes, hombres buenos de la novela-la ocupación de empresario minero, que es "un trabajo típico de los 'explotadores' del indio" (“Aves sin nido ¿Novela 'indigenista'?" 140).

Por ejemplo, en el cuento "Los tres jircas" (Cuentos Andinos, 1920) de Alfredo López Albújar, refiriéndose al Marabamba, una de las montañas tutelares, el narrador se pregunta si "en sus entrañas duerme algún metal de esos que la codicia insaciable del hombre transformará mañana en moneda, riel, máquina o instrumento de vida o muerte" (8).

${ }^{162}$ El narrador de la novela explica en detalle la forma de usura implícita en el sistema denominado reparto: "En las provincias donde se cría la alpaca [...] existe la costumbre del reparto antelado que hacen los comerciantes potentados [...] Para los adelantos forzosos que hacen los laneros, fijan al quintal de lana un precio tan ínfimo, que el rendimiento que ha de producir el capital empleado excede del quinientos por ciento [...] Los indios propietarios de alpacas emigran de sus chozas en las épocas de reparto, para no recibir aquel dinero adelantado [...] [Pero el] cobrador, que es el mismo que hace el reparto, allana la choza [...] deja sobre el batán el dinero, y se marcha enseguida, para volver al año siguiente con la lista ejecutoria, que es el único juez y testigo para el desventurado deudor forzoso. Cumplido el año se presenta el cobrador con su séquito de diez o doce mestizos, a veces disfrazados de soldados; y, extrae, en romana especial con contrapesos de piedra, cincuenta libras de lana por veinticinco. Y si el indio esconde su única hacienda, si protesta y maldice, es sometido a torturas que la pluma se resiste a narrar" (Aves sin nido 7-8). La práctica semiesclavista del reparto [debt bondage] se conoce en otros países como servidumbre por deuda o peonaje.
} 
Yupanqui. Ante este delito, facilitado por el abuso de poder, doña Lucía persuade a don Fernando, su esposo, de que cancele la deuda de los Yupanqui. Don Fernando lo hace y, gracias a su generosidad, Pancorbo libera a la niña, pero a regañadientes, porque la intromisión de don Fernando- un forastero que recién se ha afincado en el puebloatenta contra los usos y costumbres de esa comunidad, que a los "notables" les interesa mantener para su propio beneficio: "L]a señora Lucía nos ha llamado para abogar por unos indios taimados, tramposos, que no quieren pagar lo que deben; y para esto ha empleado palabras que [...], entendidas por los indios, nos destruyen de hecho nuestras costumbres de reparto, mitas, pongos y demás" 22), le comenta el cura Pascual a Estéfano Benites ${ }^{163}$ En venganza, Estéfano Benites, Pedro Escobedo, el cura Pascual y Pancorbo se coluden para asesinar a los esposos Marín, pero no logran su propósito, porque ellos escapan del asalto perpetrado a su casa. ${ }^{164}$ Producto de esa conspiración, mueren, en cambio, Juan y Marcela Yupanqui, dejando huérfanas a Margarita y a Rosalía, "palomas sin nido" de catorce y tres años de edad, respectivamente. El matrimonio Marín decide adoptar a las niñas desamparadas. En otro hilo narrativo, Manuel—el hijo de Petronila Hinojosa y, supuestamente, de Sebastián Pancorbo, que ha llegado a Kíllac de Lima, donde estudia Derecho, para visitar a sus padres—entabla amistad con los Marín. Es así que Manuel conoce y se enamora de Margarita, pero los

\footnotetext{
163 “Se comprende entonces por qué los Marín chocan frontalmente con los 'notables': mientras aquéllos buscan la modernización del país dentro de los marcos de un capitalismo incipiente, éstos — ligados a los sectores más tradicionales - propician el inmovilismo social y el afianzamiento de una cultura básicamente feudal" (Cornejo Polar, "Prólogo").

${ }^{164}$ Los personajes Hilarión Verdejo (juez de paz) y Estéfano Benites (su secretario) son ejemplos de representantes corruptos del Poder judicial. Ellos inculpan falsamente al campanero Isidro Champí de haber organizado el ataque contra la casa de los Marín. La corrupción de los tribunales es posible debido a que, en la práctica, no hay separación en los Poderes del Estado.
} 
jóvenes resultan impedidos de comprometerse para casarse en el futuro, debido a que se descubre que son hermanos de padre, hijos de Pedro de Miranda y Claro, el anterior párroco del pueblo. Las respectivas madres-doña Petronila y Marcela—habían sido abusadas por el indecente sacerdote. ${ }^{165}$

\section{Maniqueísmo en Aves sin nido}

Probablemente, en su afán de producir un tipo de literatura comprometida, que por comparación y contraste denuncie las terribles condiciones en que viven sus connacionales menos favorecidos, en esta novela de tesis Matto caracteriza los lugares y personajes en Aves sin nido de manera bastante maniquea, de tal modo que los sujetos considerados buenos suelen estar vinculados a la capital peruana y haber recibido una educación adecuada; en tanto que los villanos, por el contrario, generalmente carecen de instrucción o han recibido una instrucción deficiente, y pertenecen al ambiente rural. Joan Torres-Pou identifica un ordenamiento de oposiciones binarias, que él agrupa bajo las categorías de Lima/Kíllac y Buenos/Malos (3):

\footnotetext{
165 “A la publicación de Aves sin nido en julio de 1889 le siguió una intensa controversia, pues el libro provoca un torrente de comentarios críticos en la prensa nacional, tanto de liberales como de conservadores. Varios críticos e intelectuales la alabaron por su oportuno coraje y posición progresista para con el indio, pero el consenso general del público lector fue que el libro era ofensivo por su 'espíritu anticatólico’ y sus intenciones difamatorias [...] Un año después la controversia todavía ardía y la Iglesia, valiéndose de un incidente ajeno a Aves sin nido, prohibió su lectura y excomulgó a la autora. El pretexto fue la publicación en El Perú Ilustrado, una revista dirigida por Clorinda, de 'La Magdala', del brasileño Henrique Coelho Netto, relato que las autoridades eclesiásticas consideraron herético, por narrar la historia del supuesto amor entre Cristo y María Magdalena. La iglesia en Lima, Arequipa y Cuzco movilizó sin dilación al público, que no tardó en manifestarse públicamente en contra de la autora" (Denegri 214-16).
} 


\begin{tabular}{|c|c|}
\hline \multicolumn{2}{|c|}{$\begin{array}{c}\text { Cuadro } \mathrm{N}^{\circ} 8 \\
\begin{array}{c}\text { Ordenamiento de oposiciones binarias en Aves sin nido, } \\
\text { según Joan Torres-Pou }\end{array}\end{array}$} \\
\hline LIMA & KÍLLAC \\
\hline \multicolumn{2}{|l|}{ Progreso } \\
\hline \multicolumn{2}{|l|}{ Liberalismo } \\
\hline BUENOS & MALOS \\
\hline Indígenas y clase media liberal-progresista & Conservadurismo feudal \\
\hline & $\begin{array}{l}\text { Poder civil y poder eclesiástico, } \\
\text { conservadores y retrógrados }\end{array}$ \\
\hline
\end{tabular}

Antonio Cornejo Polar anota que "[1]a familia de Fernando y Lucía Marín es presentada en el texto mediante el recurso de acumular virtudes y de enfrentarlas [...] con los vicios de los 'notables'. Emerge así una imagen ideal en grado extremo: jamás manchados por la más leve falta, los Marín son cultos, generosos, valientes, simpáticos, honestísimos" (“Prólogo", Aves sin nido). ${ }^{166}$ Es así que Lucía es un buen ejemplo de una persona buena e instruida: "[N]o era una mujer vulgar. Había recibido bastante buena educación, y la perspicacia de su inteligencia alcanzaba la luz de la verdad estableciendo comparaciones" (9). Asimismo, instruido es Manuel, quien sin haber "perdido un día en las labores escolares" (43) es ahora un estudiante de segundo año de Derecho, poseedor de "la sagacidad propia que deja la buena educación de un colegio sistemado [sic] y celoso" (59).

En el otro extremo, "lo que distingue a los notables de Kíllac es, pues, su pertinaz inmoralidad: todos ellos, incluyendo al cura, son ebrios, mujeriegos, ladrones" (ibíd.).

\footnotetext{
${ }^{166}$ Este prólogo recoge información del ensayo titulado "Aves sin nido: indios, notables y forasteros" que Cornejo Polar publicó en La novela peruana: siete estudios (Horizonte, 1977 y 1989).
} 
Del bando opuesto, "[1]os agentes de la opresión en Kíllac son un [sic] Sebastián Pancorbo, gobernador, el tata cura don Pascual y el subprefecto coronel Bruno de Paredes, ${ }^{167}$ como figuras principales; Estéfano Benites, tinterillo alborota-pueblos, Escobedo, secuaz de los expoliadores, y el señor juez de instancias don Hilarión Verdejo" (Gutiérrez de Quintanilla, "Juicio crítico" 15). Por ejemplo, el cura Pascual inspiraba "serias dudas de que, en el Seminario, hubiese cursado y aprendido Teología ni Latín; idioma que mal se hospedaba en su boca [...] Para un observador fisiológico [énfasis mío] el conjunto del cura Pascual podía definirse por un nido de sierpes lujuriosas, prontas a despertar al menor ruido causado por la voz de una mujer" (11). ${ }^{168}$ Acerca de don Pedro Miranda y Claro, la voz narrativa comunica al lector que fue “después obispo de la diócesis, de quien la gente deslenguada hace referencias no santas, comentando hechos realizados durante veinte años que don Pedro estuvo a la cabeza de la feligresía, época en que construyó 'Manzanares', destinada, después, a residencia veraniega de Su Señoría Ilustrísima” (1). ${ }^{169}$ Mediante la caracterización del gobernador Sebastián Pancorbo, epítome de la autoridad abusiva, Matto ilustra los nefastos efectos

\footnotetext{
${ }^{167}$ En la vida real—en 1868, durante el gobierno del presidente José Balta—, el padre de la autora, Ramón Mato y Torres, fue nombrado subprefecto de la provincia cusqueña de Calca. Asimismo, "Clorinda toma parte del argumento [de Aves sin nido] de la intervención que su abuelo, Manuel Torres y Matto, autoridad civil, había tenido ante la autoridad religiosa a consecuencia del asesinato cometido por un cura del lugar" (Carrillo 28, en Escajadillo, “Aves sin nido ¿Novela 'indigenista'?” 139).

${ }^{168}$ Nótese que la autora emplea el adjetivo "físiológico" para modificar al sustantivo "observador", y que ambas palabras evidencian su visión positivista.

${ }^{169} \mathrm{El}$ anticlericalismo que exuda Matto en esta novela mediante las caracterizaciones tan negativas que hace de los curas Pedro de Miranda y Claro, y Pascual Vargas no está reñido, en lo absoluto, con las creencias cristianas de la autora. Para ella, una cosa es Dios y otra son los hombres que dicen servirle de intermediarios: "Algunas mujeres creen que la suma de sus virtudes debe consistir en frecuentar el templo y consultar para todo al confesor. ¡Error! Lamentable error, que la ilustración de la madre cristiana está llamada á rectificar, mostrándole que, si bien es un deber ir á la casa de la oración á rendir el culto á Dios [...] ha de saber distinguir que existen consultas que solo debe hacerlas a su esposo ó a su padre" (Matto de Turner, "Luz entre sombras", Leyendas y recortes 82-3).
} 
sociales de la falta de instrucción, máxime cuando el sujeto en cuestión desempeña un alto cargo en la administración pública: "Don Sebastián recibió instrucción primaria tan elemental como lo permitieron los tres años que estuvo en una escuela de ciudad; y después, al regresar a su pueblo, fue llavero en Jueves Santo; se casó con doña Petronila Hinojosa, hija de notable, y en seguida le hicieron gobernador; es decir, que llegó al puesto más encumbrado que se conoce y al que se aspira en un pueblo [énfasis mío]" (12). Esta misma intención autoral se aprecia en la caracterización del subprefecto, el coronel Bruno Paredes:

$[\mathrm{H}]$ ombre conocidísimo en todos los partidos del Perú, así por gozar de influjos conquistados en torneos del estómago, o banquetes, como por sacar con frecuencia las manos del plato de la Justicia. Paredes era, además, antiguo camarada de don Sebastián, y hasta compañero de armas en una revuelta [...] Alto y grueso, de facciones vulgares [...] Nunca hizo ninguna clase de estudios militares, es verdad, pero las circunstancias le pusieron los galones el día menos pensado [...] Su instrucción pecaba de pobre y su habla se resentía de pulcritud [énfasis mío]". (85-6)

El gran inconveniente de estos planteamientos binarios es que reducen el espectro de análisis de la composición híbrida de los pueblos del Perú. Quizás con esta reflexión en mente, la autora presenta a Estéfano Benites - uno de los vecinos "notables" de Kíllac y cómplice del atentado que se comete en contra de los esposos Marín—como "un mozalbete vivo y de buena letra que, aprovechando de las horas de escuela algo más que los condiscípulos [énfasis mío]" (22). Es decir, Benites puede ser una persona mala y, a la 
vez, algo instruido y aplicado. ${ }^{170}$ También rompiendo la tendencia maniquea, la voz narrativa comenta que doña Petronila, la esposa de don Sebastián, "con educación esmerada, habría sido una notabilidad social", añadiendo a renglón seguido que la mujer suele ser "un diamante en bruto, y al hombre y a la educación les toca convertirlo en brillante" (30). A la inversa de Benites, que es malo pero instruido, doña Petronila es buena pero carece de instrucción. Mas, casi siempre, "la radical inmoralidad de los 'notables' se explica por su falta de educación" (Cornejo Polar, “Aves sin nido: indios 'notables' y forasteros" 12). Escajadillo observa que "todas las mujeres son buenas [con bastardilla en el texto original]; en Kíllac, sólo los hombres pueden ser "malos"” ("Aves sin nido ¿Novela 'indigenista'?’ 141). ${ }^{171}$

\section{El "buen salvaje" rousseauniano}

Los protagonistas andinos escapan al referido ordenamiento de oposiciones binarias porque no se espera que ellos hayan pasado por la escuela. Por el contrario, lo esperable de los indígenas es la ignorancia y la superchería, la segunda como engendro de la primera, tal como se aprecia en el siguiente diálogo entre Martina, la esposa de Isidro Champí - el pobre campanero acusado injustamente de un delito que no cometió (92, 109) — - y el hijo de ambos:

\footnotetext{
170 "En Aves sin nido [...] el juez de paz resulta opacado por la torva figura de su amanuense [Estéfano Benites], y desde entonces la tercera persona de la 'trinidad; es el 'tinterillo', sujeto cuyas ambiciones se sustentan en el conocimiento de algunas letras y son satisfechas mediante engaños rabulescos" (Tauro 57).

171 “[A]quí [refiriéndose a Kíllak] todos abusan y nadie corrige el mal ni estimula el bien; notándose la circunstancia rarísima de que no hay parecido entre la conducta de los hombres y la de las mujeres", comenta don Fernando. “iSí también las mujeres fuesen malas, esto ya sería un infierno, Jesús!”, le responde doña Lucía (Aves sin nido 135).
} 
—Miguel, ¿no te dije cuando rebalsó la olla y se cortó la leche que alguna desgracia iba a sucedernos?

—Mamá, también yo he visto pasar el cernícalo como cinco veces por los techos de la troje — repuso el indiecito.

— ¿De veras? — preguntó la india, cuyo rostro apareció velado por la palidez del terror. (97)

Erik Camayd-Freixas informa que, en las culturas primitivas, "[u]n presagio, digamos el vuelo de un pájaro, no es sólo el anuncio de un evento venidero sino también, al mismo tiempo, su causa (Lévy-Bruhl 1976)" (Realismo mágico 69). De ahí el genuino temor de Martina.

En la percepción de Cornejo Polar, "[1]a imagen que Aves sin nido ofrece de los indios $[\ldots]$ de alguna manera se asocia con el estereotipo del 'buen salvaje'. Los indios son alabados por la 'encantadora sencillez de sus costumbres', y aparecen siempre como seres inocentes, buenos y candorosos [...], pero esa misma bondad natural los hace singularmente vulnerables frente a la codicia de los potentados y de las autoridades de la región" (Prólogo a Aves sin nido). Luego agrega: "La bondad natural se lee, entonces, como condición similar a la de la niñez, e implica la obvia necesidad ética de 'proteger' a una raza que se debate en un mundo difícil como un niño indefenso. Obviamente, los forasteros intentarán asumir una condición paternal con respecto a los indios" (ibíd.). A este tipo de situaciones se refiere Gayatri Chakravorty Spivak (1942-...) en "Can the Subaltern Speak?" (1985), donde señala que los "subalternos"-los colonizados y, en general, los grupos oprimidos-no tienen un lugar de enunciación y, al carecer de voz, requieren de intermediación. 
Manuel González Prada refiere que, para Gustave Le Bon (Psychologie du Socialisme, 1898), la raza amerindia "ha pasado vertiginosamente de la niñez a la decrepitud, salvando en menos de un siglo la trayectoria recorrida por otros pueblos en tres, cuatro, cinco y hasta seis mil años" y que, "aunque [se hallan] situadas en las comarcas más ricas del Globo, son incapaces de aprovechar sus inmensos recursos". Le Bon opina, además, que “[e]l destino final de esta mitad de América es regresar a la barbarie primitiva, a menos que los Estados Unidos le presten el inmenso servicio de conquistarla [eugenesia y blanqueamiento]. ("Nuestros indios", Memorias 124-5). Dice González Prada que debemos admirar a Le Bon "por su vastísimo saber y su gran elevación moral, aunque representa la exageración de Spence, como Max Nordau la de Lombroso y Haeckel la de Darwin]”, y que, por lo tanto, "[m]rece llamarse el Bossuet de la Sociología, por no decir el Torquemada ni el Herodes" (Ibíd. 124). ${ }^{172}$

\section{¿Saber para poder o poder para saber?}

Matto insiste, reiteradamente, en que debe instruirse al pueblo: “[N]ecesitamos propagar en todos los tonos la urgencia de multiplicar la escuela y el taller, para que de allí salgan los verdaderos ciudadanos del Perú" (Editorial de El Perú Ilustrado del 3 de mayo de 1802; en Vargas Yábar, La empresas del pensamiento 68). Con una visión positivista propia de su época, un año antes de que Matto publicara Aves sin nido, Manuel González Prada (1844-1918) proponía básicamente lo mismo que la autora cusqueña: “[E]nseñadle [al indio] siquiera a leer i escribir, i veréis si en un cuarto de siglo se levanta o no a la

\footnotetext{
${ }^{172}$ Herbert Spencer (1820-1903), Max Nordau (1849-1923), Cesare Lombroso (1835-1909), Ernst Haeckel (1834-1919), Charles) Darwin (1908-1882), Jacques Bénigne Bossuet (1627-1704), Tomás de Torquemada (1420-1498), Herodes (73/74 a. C. - 4 a. C.).
} 
dignidad de hombre" ("Discurso en el Politeama"). Para JCM, sin embargo, no es suficiente que el indígena aprenda a leer y escribir: "El problema del analfabetismo del indio [...] desborda del restringido marco de un plan meramente pedagógico. Cada día se comprueba más que alfabetizar no es educar. La escuela elemental no redime moral y [sic] socialmente al indio. El primer paso real hacia su redención, tiene que ser el de abolir su servidumbre" (7 ensayos 118). ${ }^{173}$ El Amauta llegó, incluso, a afirmar que "el indio alfabeto [énfasis mío] se transforma en un explotador de su propia raza porque se pone al servicio del gamonalismo" (ibíd. 31). Las palabras de JCM acerca del "indio alfabeto" revelan que él establecía cierto vínculo entre saber y poder. Si bien es axiomático que quienes tienen el poder económico suelen también detentar el poder político, y que, además, cuentan con más posibilidades de procurarse una buena instrucción,

ni siquiera los especialistas $[\ldots]$ advirtieron las consecuencias que se deducían de esta concepción del poder y la política. Al separar tajantemente entre la cristalización económica por un lado —llamándola “estructura" - y la institucionalización política por el otro —llamándola "superestructura" - no se dieron cuenta de que al concebir al poder en

\footnotetext{
${ }^{173}$ En 1931, los hermanos Elizardo y Raúl Pérez Gutiérrez, y Avelino Siñani fundaron la Escuela Profesional de Indígenas de Warisata, ubicada en la comunidad indígena homónima ubicada a 110 kilómetros al norte de la ciudad de La Paz, en Bolivia. De la misma manera en que lo entendía JCM, para ellos "el problema del indio es económico-social, no se puede educar a estratos de servidumbre sin plantear una condición libertaria y las reivindicaciones consiguientes" (en Gutiérrez et al 69). La Escuela Profesional de Indígenas de Warisata funcionó hasta 1939, cuando fue cerrada por presiones de los gamonales, quienes temían que en las aulas los indígenas estuviesen fraguando un gran levantamiento: "Al final de 1931, 'el destino de Warisata ya estaba marcado (Pérez 1962: 324) y la escuela fue liquidada por represión y arremetida del latifundismo, siendo arrestado su director y varios de los maestros del núcleo como sus escuelas seccionales (op. cit.: 327-328)" (Alcón, Formación docente 66). Alcón toma la cita de: Pérez, Elizardo. Warisata. La Escuela-Ayllu. La Paz, Bolivia: Empresa Industrial Gráfica E. Burillo, 1962.
} 
términos relacionales se podían resolver gran parte de las aporías que había dejado sin respuesta el marxismo "ortodoxo". (Kohan, "El poder y la hegemonía")

Pero hubo que esperar hasta los años 1970 para que Michel Foucault popularizara la noción de que existe "una perpetua articulación del poder sobre el saber y del saber sobre el poder: (Foucault, "Entrevista sobre la prisión", Microfísica del poder 99). ${ }^{174}$

En un cuestionario que le hace Ángela Ramos, publicado en Mundial el 23 de julio de 1926, JCM reitera esta misma postura con respecto a la alfabetización del indio: "No soy de los que piensan que la solución del problema del indígena es una simple cuestión de alfabeto. Es, más bien, una cuestión de justicia" ("Una encuesta a José Carlos Mariátegui”; Baeza 485). Y en el prólogo a Tempestad en los Andes (1927) de Luis E. Valcárcel, el Amauta dice: "Lo que distingue al nuevo indio no es la instrucción sino el espíritu. (El alfabeto no redime al indio)" (9). Ya en el artículo "La enseñanza y la economía", publicado en la revista Mundial el 29 de mayo de 1925, JCM había advertido que "[e]l problema de la enseñanza no puede ser bien comprendido al no ser considerado como un problema económico y como un problema social” (439). ${ }^{175}$

Carlos Iván Degregori informa que, “[c]onforme avanza el siglo [XX], el ímpetu con que las poblaciones andinas se lanzan a la conquista de la educación resulta excepcional. Según las cifras de la CEPAL (1985) sobre cobertura educativa, entre los países de América Latina el Perú pasa del puesto décimo cuarto en 1960 al puesto cuarto en 1980" (Qué difícil 237). En la actualidad, "[1]a gente ha comenzado a invertir más en

\footnotetext{
174 “Entrevista sobre la prisión: el libro y su método" (1975).

${ }^{175}$ Muchas de estas exmansiones están ubicadas en la avenida Arequipa, de Lima.
} 
su preparación. Se ha incrementado notablemente la participación popular en la educación secundaria y superior, y han proliferado todo género de academias e institutos que brindan formación barata y práctica en las más diversas materias y que funcionan en lo que fueron antes las mansiones de la aristocracia" (de Soto 4). De acuerdo con los resultados de la Encuesta de Hogares, en el año 2012 el 93.8\% de la población peruana mayor de 15 años de edad sabía leer y escribir (INEI, "VI. Tasa de analfabetismo"). "El

poder tradicional, basado no sólo en los medios de producción sino, además, en el monopolio del conocimiento y su manipulación engañosa, se desmorona conforme los dominados rompen ambos monopolios" (Degregori, Qué difícil 238).

\section{El humanismo y el sistema educativo}

En una conversación de Michel Foucault (1926-1984) con unos estudiantes-publicada en el $\mathrm{N}^{\circ} 114$ de la revista Actuel en 1971-, el pensador francés les decía lo siguiente acerca del sistema educativo: "[E]s preciso no hacerse ilusiones sobre la modernización de la enseñanza, sobre su apertura al mundo actual: se trata de mantener el viejo sustrato tradicional del 'humanismo' además de favorecer el aprendizaje rápido y eficaz de un cierto número de técnicas modernas hasta ahora relegadas. El humanismo garantiza el mantenimiento de la organización social, la técnica permite el desarrollo de esta sociedad pero en su propia perspectiva" ("Más allá del bien y del Bien y del Mal”, Microfísica 34). Enseguida, Foucault define la particular manera en que él concibe el humanismo: "Entiendo por humanismo el conjunto de discursos mediante los cuales se le dice al hombre occidental: 'si bien tú no ejerces el poder, puedes sin embargo ser soberano. Aún más: cuanto más renuncies a ejercer el poder y cuanto más sometido estés a lo que se te 
impone, más serás soberano’ (ibíd. 34). ¿Cómo entender esta paradoja? Foucault lo explica con cierto sarcasmo:

El humanismo $[\ldots]$ ha inventado paso a paso estas soberanías sometidas que son: el alma (soberana sobre el cuerpo, sometida a Dios), la conciencia (soberana en el orden del juicio, sometida al orden de la verdad), el individuo (soberano titular de sus derechos, sometido a las leyes de la naturaleza o a las reglas de la sociedad), la libertad fundamental (interiormente soberana, exteriormente consentidora $\mathrm{y}$ 'adaptada a su destino'). En suma, el humanismo es todo aquello a través de lo cual se ha obstruido el deseo de poder en Occidente — prohibido querer el poder, excluida la posibilidad de tomarlo-. En el corazón del humanismo está la teoría del sujeto (en el doble sentido del término). Por esto el Occidente rechaza con tanto encarnizamiento todo lo que puede hacer saltar este cerrojo. (Ibíd. 34-5)

Lo que plante Foucault sobre el humanismo se corresponde lo que ya había obervado al respecto JCM en el caso del Perú:

[e]n el culto de las humanidades [las disciplinas humanistas] se confundían los liberales, la vieja aristocracia terrateniente y la joven burguesía urbana. Unos y otros se complacían en concebir las universidades y los colegios como una fábrica de gentes de letras y leyes. Los liberales no gustaban menos de la retórica que los conservadores. No había quién reclamase una orientación práctica dirigida a estimular el trabajo, a empujar a los jóvenes al comercio y [a] la industria. (Menos aún 
había quien reclamase una orientación democrática [énfasis mío], destinada a franquear el acceso a la cultura a todos los individuos). (7 ensayos 81$)$

Y, para que no quepa duda, JCM añade: "El privilegio de la educación persistía por la simple razón de que persistía el privilegio de la riqueza y de la casta” (ibíd. 81).

El sistema educativo - basado en el humanismo, a la manera en que lo entiende Foucault—condiciona y determina el saber. "El saber académico, tal como está distribuido en el sistema de enseñanza, implica evidentemente una conformidad política: en historia, se os pide saber un determinado número de cosas, y no otras $\multimap$ más bien un cierto número de cosas constituyen el saber en su contenido y en sus normas" ("Más allá", Microfísica 34).

\section{Saber es poder, $\mathbf{y}$ viceversa}

Para Foucault, saber es poder, y viceversa. Adicionalmente, el historiador francés advierte que "ejercer el poder crea objetos de saber, los hace emerger, acumula informaciones, las utiliza" ("Entrevista", Microfísica 99). De acuerdo con Foucault (1926-1984), el marco de verdad impuesto por un poder, no necesariamente político o gubernamental, durante toda una época determina la manera de comprender y concebir la realidad, que es socialmente construida. En consecuencia, el poder define la verdad y, a la vez, el conocimiento constituye un instrumento de poder (Otero Luque, "Literaturas y comunidades imaginadas de Mariátegui” 11). "Los fundadores de la democracia solían decir que el bien común no es lo que opinan las mayorías, sino la opinión del grupo ilustrado de la sociedad. Esta posición plantea preguntas difíciles" (Todorov, entrevista 
con Boris Muñoz). Como afirma Antonio de Nebrija en su introducción a su Gramática castellana (1492): "Siempre la lengua fue compañera del imperio" (En Todorov 36). Esto es tan cierto que "[1]a eficacia de una clase dominante se expresa en última instancia en su capacidad para introducir sus valores y concepciones entre los dominados. Cuando lo consigue puede abrigar la esperanza de una victoria prostrera: que el nuevo orden, con otros personajes, termina reproduciendo el viejo autoritarismo" (Flores Galindo, "Sueños y pesadillas", Obras completas 375).

Desde finales de la década de 1920, JCM tenía muy claro cuán inextricable es el vínculo entre saber y poder. Esto podemos apreciarlo cuando afirma que "[1]a escuela y el maestro están irremisiblemente condenados a desnaturalizarse bajo la presión del ambiente feudal, irreconciliable con la más elemental concepción progresista o evolucionista de las cosas [...] Los educacionistas, repito, son los que menos pueden pensar en independizarla de la realidad económico-social" (7 ensayos 34-35). En algunos aspectos, como la educacion, el ambiente feudal parece haber resucitado y haberse extendido a escala planetaria con la globalización: "Every relationship of 'hegemony' is necessarily an educational relationship and occurs not only within a nation, between the various forces of which the nation is composed, but in the international and world-wide field, between complexes of national and continental civilizations" (Gramsci y Forgacs, The Gramsci Reader 348).

En un famoso debate entre Michel Foucault (1926-1984) y Noam Chomsky (1928-...), llevado a cabo en Holanda, en 1971, el filósofo francés alertaba, acertadamente, que el poder político "también se ejerce a través de la mediación de ciertas instituciones que parecen no tener nada en común con el poder político, que 
se presentan como independientes a éste, cuando en realidad no lo son [...] [S]abemos que la universidad, y, de un modo general, todos los sistemas de enseñanza, que al parecer sólo diseminan conocimiento, se utilizan para mantener a cierta clase social en el poder y para excluir a otra de los instrumentos del poder" ("La naturaleza humana: justicia versus poder" 23). Y aquí Foucault no estaba refiriéndose solamente a un plan estratégico educativo que respondiera, por ejemplo, a la necesidad de mano de obra capacitada, sino aludía a algo similar a los mecanismos de infiltración ideológica, que Antonio Gramsci (1891-1937) denomina "hegemonía". ${ }^{176}$ En palabras simples: “[L]a hegemonía de un grupo social equivale a la cultura que ese grupo logró generalizar para otros segmentos sociales [...] [E]s algo más que la cultura porque además incluye necesariamente una distribución específica de poder, jerarquía y de influencia (Kohan, "El poder y la hegemonía”). ¿De qué hablaba si no de hegemonía cuando afirmaba lo siguiente?: "El pedagogo moderno sabe que la educación no es una mera cuestión de escuela y métodos didácticos. El medio social condiciona inexorablemente la labor del maestro" (7 ensayos 34-5).

\footnotetext{
${ }^{176}$ Una de las acepciones que Gramsci le da al término "hegemonía" es: "[T]he 'spontaneous' consent given by the great masses of the population to the general direction imposed on social life by the dominant social group" (306-7). La palabra "espontáneo" está sarcásticamente encerrada entre comillas porque, implica manipulación por parte del poder hegemónico para imponer su ideología, sus valores y creencias sobre la cultura de la población, con la intención de mantener el statu quo que garantiza precisamente el mantenimiento del sistema político, social y económico imperantes. Cabe aclarar que, en muchas ocasiones, tal imposición no se da de manera explícita sino sutil y soterrada, bajo el disfraz de la persuasión/disuasión. Como resultado de la hegemonía cultural, el pueblo incorpora inadvertidamente la manera de pensar y de sentir que la clase dominante le impone para lograr sus propios fines (instrumentalismo).
} 


\section{Una literatura nacional propia}

Ángel Rama sostiene que "[1]a constitución de literaturas nacionales que se cumple a fines del XIX es un triunfo de la ciudad letrada, la cual por primera vez en su larga historia, comienza a dominar su contorno. Absorbe múltiples aportes rurales, insertándolos en su proyecto y articulándolos con otros para componer un discurso autónomo que explica la formación de la nacionalidad y establece administrativamente sus valores" (La ciudad letrada 91). Es probable que, con una idea similar, Matto haya abogado - adicionalmente a la alfabetización—en favor de una literatura nacional propia: "Debemos concurrir a los certámenes del viejo mundo con elementos propios y no estar empeñados en la antigua labor de devolver con otra vestidura, elementos literarios que recibimos de Europa (EPI 147: 1482)" (Vargas Yábar, "Constructora" 224). ${ }^{177}$ Enseguida agrega: "La meta común deberá ser el "engrandecimiento de las letras patrias’ (ibíd. 224) (Cholificación). ${ }^{178}$ Pero, además, la literatura nacional que se produzca debe servir, según Matto, para denunciar la deplorable situación socioeconómica del indígena peruano, con la finalidad de que ésta sea corregida:

[A]l someter mi obra al fallo del lector, hágolo con la esperanza de que ese fallo sea la idea de mejorar la condición de los pueblos chicos del Perú; y

${ }^{177}$ El Perú Ilustrado 147 del 1 de marzo de 1890.

${ }^{178}$ Mercedes Cabello de Carbonera (1842-1909), coetánea de Matto, también señaló la necesidad de que los países hispanoamericanos cultivasen una literatura propia: "No es pues esa tendencia [naturalista] la que debe dominar a los novelistas sudamericanos [...] [S]i aquí en estas jóvenes sociedades, fuéramos a escribir una novela completamente al estilo zolaniano, lejos de escribir una obra calcada sobre la naturaleza, nos veríamos precisados a forjar una concepción imaginaria sin aplicación práctica en nuestras costumbres $[\ldots][\mathrm{N}] \mathrm{o}$ haríamos más que tornarnos en malos imitadores copiando lo que en países extraños al nuestro puede que sea de alguna utilidad, quedando aquí en esta joven sociedad completamente inútil esto cuando no fuera profundamente perjudicial" (Blanca Sol 4-5) (Etnovaivén). Es así que Cabello propuso-y se propuso-adaptar el naturalismo literario francés a la realidad regional (Otero Luque, "Mercedes Cabello y Blanca Sol" 52). 
aun cuando no fuese otra cosa que la simple conmiseración, la autora de estas páginas habrá conseguido su propósito, recordando que en el país existen hermanos que sufren, explotados en la noche de la ignorancia, martirizados en esas tinieblas que piden luz; señalando puntos de no escasa importancia para los progresos nacionales y haciendo, a la vez, literatura peruana. ${ }^{179}$ (Proemio, Aves sin nido viii)

Desde luego, la intención de Matto es mejorar el nivel de vida de los indígenas y su herramienta es la literatura, que aspira a ser nacional. A JCM, en contraste con Matto, le parece "absurdo y presuntuoso hablar [siquiera] de una cultura propia y genuinamente americana [... Lo único evidente es que una literatura vigorosa refleja ya la mentalidad y el humor hispano-americanos" ("La unidad de la América indo-española"” Baeza 250), a pesar de la importancia que le confiere a la—según él, todavía embrionaria—corriente indigenista.

Aunque "el indigenismo es una ideología de mestizos" (Bourricaud 26) y JCM estaba consciente de ello, ${ }^{180}$ “[e]l período nacional se anuncia con la poesía de Vallejo y con el Indigenismo, que recogen lo que Mariátegui considera [...] el eje de la forja de la

\footnotetext{
179 "[E]n 1900 la escritora cuzqueña Clorinda Grimanesa Martina Matto Usandivaras de Turner, autora de Aves sin nido, novela escrita hacia 1890 y considerada una de las más grandes expresiones del indigenismo cuzqueño, se integra al Centro [Centro Científico del Cuzco, fundado en 1897] [...] Las denuncias que hiciera en su obra sobre los abusos que éstos sufrían, fueron leídas por los grupos ilustrados tanto de Lima como de provincias, lo que, a no dudar, fueron base para las posturas políticas indigenistas de principios del siglo XX" (Kuon Arce et al 35).

${ }^{180}$ JCM considera que "[1]a literatura indigenista no puede darnos una versión rigurosamente verista del indio. Tiene que idealizarlo y estilizarlo. Tampoco puede darnos su propia ánima. Es todavía una literatura de mestizos. Por eso se llama indigenista y no indígena. Una literatura indígena, si debe venir, vendrá a su tiempo. Cuando los propios indios estén en grado de producirla" (7 ensayos 242).
} 
nación peruana: el aporte andino" (García Bedoya 37). ${ }^{181}$ Para JCM, la corriente indigenista no es una moda que surgió de repente, sino una nueva forma de sentir y de pensar que rebasa ampliamente el espectro meramente estético, literario, porque “representa el color y la tendencia más característica de una época por su afinidad y coherencia con la orientación espiritual de las nuevas generaciones, condicionada, a su vez, por imperiosas necesidades de nuestro desarrollo económico y social” (7 ensayos 242) (Cholificación):

La corriente 'indigenista' que caracteriza la literatura peruana, no debe su propagación presente ni su exageración posible a las causas eventuales o contingentes que determinan comúnmente una moda literaria [...] Basta observar su coincidencia visible y su consanguineidad íntima con una corriente ideológica que recluta cada día más adhesiones en la juventud, para comprender que el indigenismo literario traduce un estado de ánimo, un estado de conciencia del Perú nuevo. (Ibíd. 237-38)

JCM subraya que la literatura indigenista "tiene fundamentalmente el sentido de una reivindicación de lo autóctono" (ibíd. 241) (Cholificación), y emana de un sentimiento visceral, no de una mera elucubración abstracta: "Si el indio ocupa el primer plano en la literatura y el arte peruanos no será, seguramente, por su interés literario o plástico, sino porque las fuerzas nuevas y el impulso vital de la nación tienden a reivindicarlo. El fenómeno es más instintivo y biológico que intelectual y teorético" (ibíd. 241). El

\footnotetext{
${ }^{181}$ En opinión de Tomás G. Escajadillo, "Mariátegui tuvo la 'profunda intuición' de reconocer que la aparición de la comunidad en los Cuentos andinos (1920) [de Enrique López Albújar] representaba un hito en la narrativa peruana: es el indio de comunidades apartadas el que aparecía por primera vez en la literatura, y no es del todo casual que ello coincida con el inicio de lo que sería una larga y proficua corriente, el indigenismo, que rompe totalmente con los rezagos románticos, idealistas y 'humanitarios' que dominaban la narrativa temática indígena anterior" (Mariátegui y la literatura peruana” 31-2).
} 
Amauta destaca la importancia de la corriente indigenista en el panorama literario general, al considerarla no equiparable a la vieja corriente colonialista: "El colonialismo, reflejo del sentimiento de la casta feudal, se entretenía con la idealización nostálgica del pasado. El indigenismo en cambio tiene raíces vivas en el presente. Extrae su inspiración en la protesta de millones de hombres. El Virreinato era; el indio es” (ibíd. 243). ${ }^{182}$

Carlos García Bedoya confirma que, para el Amauta, "nuestra literatura lleva pues el sello de lo colonial, de la subordinación a la metrópoli española, de la que se torna no sólo la lengua, sino también el espíritu y el sentimiento" (36). A ese primer estadio "le sucede un segundo período al que tipifica como cosmopolita, en el que la literatura peruana se abre a múltiples influencias europeas, liberándose de la tutela excluyente de la española. El tercero es el período nacional, caracterizado por la expresión de la propia personalidad” (ibíd. 36). Sin embargo, "Mariátegui apunta que la literatura peruana surge como fruto de una imposición colonial, que la marca, al igual que a todos los aspectos de nuestra sociedad, con una desgarradura fundamental entre dos culturas que coexisten y se

\footnotetext{
182 "[José] Deustua y [José Luis] Rénique proponen que desde mediados del [siglo] XIX, existirían cuatro generaciones de indigenistas cuzqueños, siendo la primera la de los precursores como [Narciso] Aréstegui y Pio Benigno Mesa que editó la revista El Heraldo del Cuzco entre 1865 y 1877; el segundo grupo se ubicaría de finales del siglo XIX y a inicios del XX con Clorinda Matto de Turner, José Lucas Caparó Muñiz, Ángel Vega Enríquez, Antonio Lorena y Fortunato L. Herrera entre otros. La tercera generación estaría compuesta por los participantes en la primera reforma universitaria de 1909, Luis E. Valcárcel, José Uriel García, José Gabriel Cosío, Luis Felipe Aguilar, Félix Cosío, José Ángel Escalante, siendo posiblemente la más sobresaliente y la que alcanzó notoriedad nacional y la última, la de los jóvenes de los años 20 que participaban activamente en el ambiente cultural e intelectual de la ciudad, cuyos órganos representativos serían el Grupo Ande y las revistas Kosko y Kuntu" (Kuon Arce et al 40). El propio Luis E. Valcárcel reconoce tanto a Narciso Aréstegui Zuzunaga (c. 1820- 1869) como a Clorinda Matto de Turner como antecesores suyos: "Quienes entonces iniciamos estudios universitarios recibimos las influencias de personalidades excepcionales de las generaciones anteriores, que habían comenzado a abrir una brecha en el cerrado ambiente cuzqueño, en el que las ideas de la inferioridad del indígena eran expresadas con toda naturalidad. Narciso Aréstegui, autor del Padre Horán [1838], era estimado por los jóvenes como un predecesor de la preocupación por el indígena. En su famosa novela hizo público cómo el indio conservaba sus antiguas virtudes y que los responsables de su postración eran las autoridades, los clérigos y los hacendados. Como antecedente más inmediato a nosotros teníamos a Clorinda Matto de Turner, novelista que en Aves sin nido [1889] destacó las virtudes de la raza indígena y denunció los abusos de que era objeto" (Kuon Arce et al 42).
} 
entrelazan conflictivamente" (ibíd. 35-6). Marcel Velázquez parodia a JCM con respecto

a la periodización literaria que plantea:

Para utilizar las mismas categorías que Mariátegui: en el Perú, la literatura colonial creó espacios nacionales y cosmopolitas, la literatura cosmopolita creó nuevas formas de colonización y nacionalidades virtuales, la literatura nacional es una utopía anacrónica en un mundo de culturas desterritorializadas, memorias colonizadas, imaginaciones domesticadas, exacerbación de diferencias y comunidades virtuales (129).

Velásquez resalta el hecho de que, con una lógica ahistórica. JCM sitúa el surgimiento de la literatura indígena en la época republicana, y se pregunta: “¿[P]or qué condenar a la literatura indígena al futuro y negarle su pasado? (129). No en vano el ensayo de Velázquez se titula “Los 7 errores de Mariátegui” y el numeral 10, en donde se ocupa de este asunto, tiene por encabezado "Literatura nacional y dialéctica marxiana" [énfasis mío]. ${ }^{183}$

\section{Lengua — ¿quechua o española?-y nación}

Matto planteaba "establecer la cultura quechua [...] como base histórica para una nación que no se prestaba - como lo pretendía el discurso dominante - a los modelos europeos,

\footnotetext{
${ }^{183}$ Es sorprendente que JCM razone de esa manera en lo tocante a la literatura, debido a que él, como buen marxista, era muy consciente del papel que juega la Historia en los cambios culturales y del peso que ejerce sobre ellos. Por ejemplo, en la revista Mundial de septiembre de 1925, JCM hizo el siguiente comentario con respecto al primer libro de Luis E. Valcárcel: "Valcárcel va demasiado lejos [...] Ni la colonización occidental está tan agotada y putrefacta como Valcárcel supone. Ni una vez adquiridas su experiencia, su técnica y sus ideas, el Perú puede renunciar místicamente a tan válidos y preciosos instrumentos para volver, con áspera intransigencia, a sus antiguos mitos agrarios. La Conquista, mala y todo ha sido un hecho histórico. Contra los hechos históricos, poco o nada pueden las especulaciones abstractas de la inteligencia ni las concepciones puras del espíritu [...] En cuatro siglos se ha formado una realidad nueva. La han creado los aluviones de Occidente [...] Sería excesivamente romántico, decidirse hoy a ignorarla" (Prólogo a Tempestad en los Andes 8).
} 
precisamente debido a sus ricas y antiguas tradiciones nativas" (Denegri, El abanico y la cigarrera 205). La postura de Matto da cuenta de lo que Linda Ray Pratt señalará muchos años después en relación con el vínculo entre nación y lengua:

The prototype of the modern nation as imagined community was $[\ldots]$ mirrored in what people thought about language and the speech community. Many commentators have pointed out how modern views of language as a code and competence assume a unified and homoneneous social world in which language exists as a shared patrimony —as a device, precisely, for imagining community" (Rowe, A Future For American Studies 11).

“¿Por qué han ignorado su idioma, por qué no pueden cantar en la lengua de su madre patria? [cholificación] Esto significa simplemente una pérdida para la literatura americana" ("Estudios históricos: el qquechua [sic]", Leyendas y recortes 109), les reclamaba a sus colegas la escritora cusqueña. Contrariamente, según JCM "[1]a literatura nacional es en el Perú, como la nacionalidad misma, de irrenunciable filiación española. Es una literatura escrita, pensada y sentida en español, aunque en los tonos, y aun en la sintaxis y prosodia del idioma, la influencia indígena sea en algunos casos más o menos palmaria e intensa" ( 7 ensayos 170$)$.

El Amauta tenía la noción de que la lengua y la cultura se hallan imbricadas, de manera que la mutua influencia de una sobre la otra determina nuestra Weltanschauung o la manera en que percibimos y sentimos nuestra existencia. ${ }^{184}$ Por eso sostiene que la

\footnotetext{
${ }^{184}$ Weltanschauung ("observación del mundo", en alemán) es un concepto acuñado por el filósofo Wilhelm Dilthey (1833-1911) en Einleitung in die Geisteswissenschaften (Introducción a las Humanidades) de 1883.
} 
primera literatura nacional, escrita en castellano, estaba impregnada de la cosmovisión peninsular (blanqueamiento), dado que existe una correspondencia biunívoca—es decir, unívoca y, a la vez, recíproca-entre los elementos culturales y lingüísticos. Antonio Gransci tambien pensaba que el idioma condiciona, determina, moldea, manipula: "For Gramsci 'every language contains the elements of a conception of the world'. He sees the process by which a given conception of the world exerts an influence over others in terms of the influence of one form of a language upon another, as well as in relation to the educational process" (Gramsci y Forgacs 324). ${ }^{185}$

JCM considera que el quechua, por haber sido una lengua ágrafa—“[1]a civilización autóctona no llegó a la escritura y, por ende, no llegó propia y estrictamente a la literatura, o más bien, ésta se detuvo en la etapa de los aedas, de las leyendas y de las representaciones coreográfico-teatrales"-, en consecuencia :[1]a escritura y la gramática quechuas son en su origen obra española y los escritos quechuas pertenecen totalmente a literatos bilingües". Luego, concluye: "La lengua castellana, más o menos americanizada, es el lenguaje literario y el instrumento intelectual de esta nacionalidad cuyo trabajo de definición aún no ha concluido" (ibíd. 170). Carlos García Bedoya señala que el Amauta, "[m]ovido por el prejuicio (hoy ya superado) de reducir la literatura a lo escrito, conceptúa a la literatura peruana como aquélla escrita en español, dejando de lado la rica literatura oral andina (en verdad muy poco conocida en la época, lo que de algún modo

\footnotetext{
185 "It has been argued (by Franco Lo Piparo, Lingua intellettuali egemonia in Gramsci, Rome-Bari 1979), that Gramsci's conception of hegemony was influenced by the concepts of 'prestige' and 'radiation of innovations' in historical linguistics - the subject of his unfinished degree thesis. These terms designated the process by which the speakers of one form of a language exert an influence over others, changing the way the latter speak, either by simple everyday contact or through the mediation of the education system and other channels of cultural communication. Gramsci extends this process from language to other relations of political and cultural influence of an 'active', 'expansive' and consensual rather than a passive, mechanical or merely coercive kind" (Gramsci y Forgacs 324).
} 
explica su posición), aunque anuncia la posibilidad en ciernes de una literatura indígena (escrita)" (38).

En opinión de Marcel Velázquez Castro, JCM “considera a la literatura oral no como una manifestación autotélica sino como un período previo e inferior de la literatura escrita. $^{186}$ Los poemas orales, las leyendas y las representaciones dramáticas prehispánicas son consideradas formas embrionarias de literatura porque predomina una concepción positivista donde la cultura oral es considerada un antecedente de la cultura escrita y no se admite la posibilidad de la coexistencia e hibridación, que es justamente la característica central de las literaturas andinas" ("Los 7 errores de Mariátegui", Ajos \& Zafiros 119.). ${ }^{187}$

En el Perú actual se hablan más de 60 lenguas-agrupadas en 15 familias lingüísticas - entre las que destacan el español, que es el idioma oficial (y materno del 85.9\% de la población), el quechua (13.2\%) y el aimara (1.8\%) (Mapa Etnolingüístico del Perú 2010). La supremacía del español obedece a que las lenguas vernáculas fueron desplazadas durante la Invasión (conquista) y el Período de Resistencia (colonia). Evidentemente, este hecho trascendió a la literatura y explica la escasa producción literaria en la lengua vernácula" (Otero Luque, "Literaturas y comunidades imaginadas"

\footnotetext{
186 Augusto Tamayo Vargas (1980) '[i]dentifica [en JCM] una contradicción entre la equivalencia conceptual de escritura y literatura y el reconocimiento del dualismo quechua-español no resuelto' (6465)" (en Velázquez Castro).

187 "Esta concepción era ya anacrónica para su época; varios años antes, Adolfo Vienrich había recopilado textos orales andinos en Azucenas quechuas (1904) y demostrado la vitalidad de esa literatura. Edwin Elmore en su célebre libelo (1916) contra Ventura García Calderón, publicado en Colónida, sostenía que cuando su oponente "vaya hasta el más helado y agreste rincón andino y escuche de labios del aborigen una y mil leyendas, verá que hay diferencias entre la literatura peruana, honda, triste, fuerte y sobria, y la literatura colonial hecha por frailes, tahúres y andrójinos [sic]" (2:35). [Luis Alberto] Sánchez en 1928 había publicado su primera edición de La literatura peruana y había remarcado el carácter oral y anónimo de las literaturas prehispánicas" ("Los 7 errores de Mariátegui", Ajos \& Zafiros 120).
} 
17): “[E]1 Perú, tan fecundo en escritores prosadores y poetas cuenta con elementos de inspiración como pocas naciones en la tierra, y que á conocer su idioma escritores de la talla de Ricardo Palma y del galano autor de 'Catalina Túpac Roca' [Ricardo Rossel] cuántas minas de diamante habríanse explicado sacándoles á lucir en las páginas de la literatura patria para deslumbrar con ellas al mundo civilizado sin pedir galas prestadas al idioma del conquistador" (Matto, "Estudios históricos: el qquechua", Leyendas y recortes 108).

\section{"Civilización" y blanqueamiento del indígena}

Matto sostiene que la explotación del indígena por parte de los caciques, del cura y de sus respectivos cómplices es posible, entre otras causas, debido a la ignorancia del explotado:

[L]o que ocurre en Kíllac, como en todos los pequeños pueblos del interior del Perú, donde la carencia de escuelas [énfasis mío], la falta de buena fe en los párrocos y la depravación manifiesta de los pocos que comercian con la ignorancia [énfasis mío] y la consiguiente sumisión de las masas alejan, cada día más, a aquellos pueblos de la verdadera civilización [énfasis mío], que, cimentada, agregaría al país secciones importantes con elementos tendentes a su mayor engrandecimiento [blanqueamiento]. ${ }^{188}$ (Aves sin nido 27)

La identificación de las causas de la explotación del indígena por Matto es tan interesante como la solución que ella propone: la necesidad de transculturizarlo (blanqueamiento).

\footnotetext{
${ }^{188}$ La voz narrativa renuncia contantemente a la omnisciencia y se entromete tanto para comentar los hechos que narra como para exponer la ideología de la autora. García Bedoya anota acertadamente que el género predilecto de las escritoras realistas de finales del decimonónico peruano fue la novela, la cual estaba "generalmente orientada a la ilustración de alguna tesis de reforma moral" (83).
} 
Exagerando, podría decirse que, en este aspecto, la receta de Matto no está muy alejada del planteamiento de Thomas Babington Macaulay (1800-1859) contenido en su famosa "Minute Upon Indian Education" de 1835:

We must at present do our best to form a class who may be interpreters between us and the millions whom we govern, - a class of persons Indian in blood and colour, but English in tastes, in opinions, in morals and in intellect. To that class we may leave it to refine the vernacular dialects of the country, to enrich those dialects with terms of science borrowed from the Western nomenclature, and to render them by degrees fit vehicles for conveying knowledge to the great mass of the population. ("Minute by the Hon'ble T. B. Macaulay, dated the 2nd February 1835", numeral 34)

El jurista británico responsable de confeccionar el Código Penal indio consideraba que era preciso formar una casta de transculturados que sirviese de intermediaria entre colonizadores y colonizados (blanqueamiento). Por supuesto, Spivak califica las palabras de Macaulay de "infamantes líneas programáticas” (“¿Puede hablar el subalterno?” 14).

Retornando a Aves sin nido, Cornejo Polar comenta lo siguiente acerca de la visión eurocéntrica de Matto en esta novela:

Dentro del marco de la "conciencia posible" de entonces la educación no podía considerarse más que como un proceso que favorecía la realización de los ideales europeos [blanqueamiento]. Como recurso eficaz para la homogeneización del país, la educación no solo no preveía ni pluralismos ni contrastes sino que, al contrario, los condenaba abiertamente. En Aves sin nido se habla, en efecto, de 'la verdadera civilización' como de un 
sistema único y de la educación como vía para acceder a sus principios ordenadores. ("Aves sin nido", Escribir en el aire 110)

Recordemos que, en 1852, el pensador argentino Juan Bautista Alberdi (1810-1884)— cuya influencia debió de haber alcanzado a Matto—, postulaba que "[g]obernar es poblar, en el sentido [de] que poblar es educar, mejorar, civilizar, enriquecer y engrandecer espontánea y rápidamente [...] Mas para civilizar por medio de la población es preciso hacerlo con poblaciones civilizadas" (Bases 5). "Poblar es civilizar cuando se puebla con gente civilizada [énfasis mío], es decir, con pobladores de la Europa civilizada [énfasis mío]. Por eso he dicho en la Constitución que el gobierno debe fomentar la inmigración europea" (ibíd. 7). Aunque Alberdi era argentino, veía el mundo con ojos de europeo, con un tipo de mirada que — si bien, en la actualidad, es rechazada por la Academia y un gran segmento del pueblo llano tampoco tolera-todavía pervive hasta nuestros días en ciertas actitudes y modos de actuar de la clase política y del empresariado. Lo cierto es que

"Western civilization does not have a monopoly on rationality. Long considering itself proprietor of rationality, Western Europe judged all cultures in terms of technological performance and saw nothing but error, illusion, and backwardness in other cultures. We should know that every society has rationality — including archaic societies with their rationality in tool-making, hunting strategy, and knowledge of plants, animals and terrain — and all societies have myth, magic, and religion. In our Western societies we have myth, magic, and religion, including the myth of providential reason and the religion of progress. We start to become truly 
rational when we recognize the rationalization myths of our almighty reason and guaranteed progress. ${ }^{189}$ (Morin, Seven Complex Lessons 7)

El proceso de asimilación de la cultura dominante por la dominada, que describe Cornejo Polar, ha sido el patrón en todas las sociedades colonizadas. Sin embargo, lo que le preocupa a este crítico literario acerca del planteamiento en Aves sin nido es que "en la transformación radical de los Yupanqui en Marín [se refiere a Margarita y a Rosalía, que son adoptadas por el matrimonio de ese apellido] subyace un significado turbador: la salvación del indio depende de su conversión en otro, en criollo, con la consiguiente asimilación de valores y usos diferenciados" (ibíd. 110) (blanqueamiento).

Efectivamente, don Fernando planea mudarse a Lima con su esposa, llevarse a las niñas con él y su mujer, y en esa ciudad, que representa la civilización, colocarlas “en el colegio más a propósito para formar esposas y madres, sin la exagerada mojigatería de un rezo inmoderado, vacía de sentimientos" (Aves sin nido 100). La postura que, consciente o inconscientemente, adopta Matto al augurarle tal destino a las sobrevivientes de la familia Yupanqui-que, en el caso de Rosalía, representa al indígena peruano-, es interpretada por Cornejo Polar como la expresión práctica, tangible del pensamiento positivista propio del Volksgeist decimonónico: "[L]a historia de la adopción es un emblema de las convicciones de la época sobre el poder de la educación, como fuerza transformadora de la sociedad, pero a la vez de un concepto pedagógico que sólo

\footnotetext{
${ }^{189}$ Morin explica claramente la diferencia entre racionalidad y racionalización: "There is constructive rationality that develops coherent theories [...] This rationality must remain open to everything that disputes it; otherwise it closes itself into a doctrine and become rationalization [...] But rationality itself is subject to error and illusion when [...] it is perverted into rationalization [...] Rationalization is closed, rationality is open [...] A doctrine that obeys a mechanical, deterministic model to consider the world is not rational but rationalized [...] [I]f rationality does not maintain constant self-critical vigilance it can turn into rationalizing illusion. Which is to say that true rationality is not only theoretical, not only critical, but also self-critical" (7-8).
} 
entiende esta materia como una forma de occidentalización [blanqueamiento] del pupilo" (Prólogo a Aves sin nido). ${ }^{190}$

Si bien don Fernando y Lucía son peruanos, ellos son "extranjeros" en Kíllac y desempeñan el papel de salvadores del indígena oprimido. Según el historiador y sociólogo Nelson Manrique,

si por una parte es evidente que [...la novela] ofrece una visión positiva del indio: es agradecido, valiente, sus costumbres (de "encantadora sencillez") contrastan con las perversiones de los "notables", por otra, contradictoriamente, se establece la ineludible necesidad del "progreso nacional". Parece seguro que en la actitud de Clorinda Matto entran en conflicto dos esquemas interpretativos en el fondo inconciliables, la visión del indio como 'buen salvaje', como ser fundamentalmente bueno e inocente ('cuando hace algo malo es obligado por la opresión, desesperado por los abusos'), visión obviamente endeudada con la tradición romántica, y, en el otro extremo, una posición de tinte positivista que no puede menos que condenar el atraso y el primitivismo de un pueblo que, como el indio, está lejos del ideal de modernidad. ("Clorinda Matto y el nacimiento del indigenismo literario 90)

Con base en lo anterior, Manrique concluye: "Por consiguiente, el elogio a la inocencia indígena es, al mismo tiempo, una suerte de elegía y de proclama, algo así como una tierna despedida de un mundo históricamente insostenible y una apasionada arenga para

\footnotetext{
${ }^{190}$ Con referencia a la historia que se narra en El señor Presidente de Miguel Ángel Asturias (1946), Erik Camayd-Freixas comenta que, trágicamente, la redención social del indígena supone "un suicidio cultural: la adopción de valores modernos. El dilema se suscita precisamente porque el concepto de redención que se le ofrece es un concepto histórico occidental" (Realismo mágico 150).
} 
que se ingrese a un nuevo nivel de desarrollo. Naturalmente, el camino propuesto es la educación” (ibíd. 90). ${ }^{191}$

Por el contrario, para JCM "[1]a fé [sic] en el resurgimiento indígena no proviene de un proceso de 'occidentalización' material de la tierra keswa [quechua]. No es la civilización, no es el alfabeto del blanco [énfasis mío], lo que levanta el alma del indio [blanqueamiento]. Es el mito, es la idea de la revolución socialista. La esperanza indígena es absolutamente revolucionaria" (Prólogo a Tempestad en los Andes 10). ${ }^{192}$ Según el Amauta, la solución al problema del indio no estriba en "civilizarlo" mediante la educación [blanqueamiento], sino en liquidar el sistema feudal y en devolverle al indígena la tenencia de la tierra: "[e]l problema de la enseñanza no puede ser bien comprendido al no ser considerado como un problema económico y como un problema social” (“La enseñanza y la economía”; Baeza 439).

\section{Ninguneo de Matto por parte de Mariátegui}

Según el Amauta, "la mayor injusticia en que podría incurrir un crítico, sería cualquier apresurada condena de la literatura indigenista por su falta de autoctonismo integral o la

\footnotetext{
${ }^{191 ، S e ~ s u p o n i ́ a ~ q u e ~ l a ~ i n d u s t r i a l i z a c i o ́ n ~ g e n e r a r i ́ a ~ l a s ~ c o n d i c i o n e s ~ p a r a ~ d e j a r ~ a t r a ́ s ~ u n ~ t i p o ~ d e ~ c o n o c i m i e n t o ~}$ basado en los mitos y las supersticiones, reemplazándolos por el conocimiento científico-técnico de la modernidad. Se creía, además, que rasgos personales como la pasividad, la indisciplina o la indolencia, asociados, quizás, a defectos de la raza, dependían de una 'ausencia de modernidad' y podían ser superados en la medida en que el Estado resolviera problemas estructurales como el analfabetismo y la pobreza. En este sentido el paradigma moderno del desarrollo era, también, un paradigma colonial. Los conocimientos 'otros' [sic] tenían que ser disciplinados o excluidos" (Castro-Gómez 86).

${ }^{192}$ Aludiendo a Georges Sorel (1847-1922), el Amauta comenta: “[R]eaccionando contra el mediocre positivismo de que estaban contagiados los socialistas de su tiempo, descubrió el valor perenne del Mito en la formación de los grandes movimientos populares" (Prólogo a Tempestad en los Andes 14); "la experiencia histórica de los últimos lustros ha comprobado que los actuales mitos revolucionarios o sociales pueden ocupar la conciencia profunda de los hombres con la misma plenitud que los antiguos mitos religiosos" (7 ensayos 140). Extrapolando la fe al terreno de la política, aparentemente para JCM el socialismo podía llegar a ser como una nueva religión. "[E]l socialismo era el milenio. La Utopía" (Flores Galindo, La agonía de Mariátegui 54).
} 
presencia, más o menos acusada en sus obras, de elementos de artificio en la interpretación y en la expresión" (7 ensayos 242). Sin embargo, Ana Peluffo especula que "Mariátegui desconfiaba del sentimiento indigenista de Matto de Turner porque éste enfatizaba la educación sentimental del opresor más que la virilización del indígena" (Lágrimas andinas 23). De manera similar, Escajadillo opina que "Mariátegui, incapaz de hacer una apreciación positiva de Aves sin nido, novela que corresponde a una estrechísima óptica humanitaria que formula su 'denuncia' sobre la condición del indio sin atender ni remotamente al sustrato económico-político [...], optó por no mencionar en absoluto a doña Clorinda en su famoso ensayo. Omisión consciente; no un olvido" (Mariátegui y la literatura peruana 178). Escajadillo apoya la tesis de que JCM no ninguneó a Matto por olvido en las siguientes palabras del Amauta en "El problema primario del Perú":

Antes de que se apaguen los ecos de la conmemoración de la figura y obra de Clorinda Matto de Turner, antes de que se dispensen los delegados del cuarto congreso de la raza indígena, dirijamos la mirada al problema fundamental, al problema primario del Perú. Oigamos algo de lo que diría ciertamente Clorinda Matto de Turner si viviera todavía. Este es el mejor homenaje que podemos rendir los hombres nuevos, los hombres jóvenes del Perú, a la memoria de esta mujer singular que, en una época más cómplice y más fría que la nuestra, insurgió notablemente contra las 
injusticias y los crímenes de los expoliadores de la raza indígena. (Mariátegui y la literatura peruana 179$)^{193}$

No cabe duda de que JCM tenía muy presente a Matto. No obstante, en los 7 ensayos justifica "la prescindencia deliberada de algunas obras $[\ldots]$ con incontestable derecho a ser citadas y tratadas en la crónica y en la crítica de nuestra literatura", porque "carecen de significación especial en el proceso mismo" (7 ensayos 252$)$.

Peluffo percibe que el sentimentalismo y la feminización del indígena que pueden apreciarse en las páginas de Aves sin nido son aspectos contrarios a los valores que el Amauta admira en González Prada, por ejemplo, y que, debido a ello, objetó a Matto y su obra no la incluyó en el canon:

The association of sentimentality with femininity and the portrayal of Indians as feminized models of civility are undoubtedly what lead José Carlos Mariátegui to exclude Matto's novel from his canonic reflections about Peruvian letters [...] In Mariátegui's analysis of the Peruvian literary tradition, he endorses Prada's positivist view of the nation at the same time that he declares Prada's cosmopolitan approach to modernization as the first lucid instant in Peruvian literary history. When Mariátegui quotes in admiration a phrase from one of Prada's most anti-sentimental essays'War to sentiment! Divine cult to Reason!'-it becomes obvious for the reader that it is Matto's sentimental stance on national issues that Mariátegui finds objectionable in her works. (Peluffo, "Why can't an Indian?"15-6)

\footnotetext{
193 “El problema primario del Perú" fue publicado en la revista Mundial el 9 de diciembre de 1924.
} 
Es así como JCM se expresa de la siguiente manera acerca de Manuel González Prada: “[N]o interpretó este pueblo, no esclareció sus problemas, no legó un programa a la generación que debía venir después. Mas representa, de toda suerte, un instante —el primer instante lúcido-, de la conciencia del Perú” (7 ensayos 184). Más adelante, continúa:

La Ciencia, la Razón, el Progreso, fueron los mitos del siglo diecinueve. González Prada, que por la ruta del liberalismo y del enciclopedismo llegó a la utopía anarquista, adoptó fervorosamente estos mitos. Hasta en sus versos hallamos la expresión enfática de su racionalismo: “¡Guerra al menguado sentimiento! ¡Culto divino a la Razón!” (Ibíd. 188)

Curiosamente, "[h]ay consenso entre los críticos en relación a la honda influencia que tuvo González Prada sobre la producción literaria de Clorinda Matto" (Manrique, “Clorinda Matto" 83).

El Amauta hizo bien al optar por un "cortés silencio", concluye Escajadillo. Porque no habría podido elogiar a Matto por la manera en que la escritora cusqueña enfoca la literatura (Mariátegui y la literatura peruana 178). En cualquier caso, únicamente podremos especular, ya que nunca sabremos por qué JCM ninguneó a Matto.

\section{Falta de independencia de los poderes del Estado}

En el Proemio a Aves sin nido, Matto señala con dedo acusador a las autoridades civiles y eclesiásticas: “[L]a abyección a que someten esa raza [la indígena] [...] son, en general, los curas, gobernadores, caciques y alcaldes" (viii). Cornejo Polar manifiesta lo siguiente acerca de los villanos que aparecen en esta novela: 
El estrato de los "notables", formado por las autoridades civiles y religiosas, aparece consistentemente criticado a lo largo de toda la novela. Casi analfabetos, inmorales y abusivos, los jueces, gobernadores y curas (a los que González Prada había calificado en 1888 como la "trinidad embrutecedora del indio") no tienen otra meta que preservar sus injustas prebendas y los beneficios sociales y económicos que extraen sin límite de la explotación de los indios. (Prólogo, Aves sin nido)

En 1885 y bajo el seudónimo anagramático de José T. Itolararres, José T. Torres publicó la novela titulada La trinidad del indio o costumbres del interior (Lima: Imprenta Bolognesi), en la que señala un tipo similar de colusión: "Perdido entre las alturas de hosca serranía, [el] silencioso y olvidado pueblo [imaginario] de Cashcanca, vive sometido a las depredatorias gestiones del cura, el gobernador y el juez de paz [énfasis mío]" (en Tauro, Clorinda Matto 53). Dice Tauro que esta trinidad se extiende a todo el país, puesto que a los tres personajes mencionados se suman el subprefecto, el gamonal y el diputado con el objetivo de "mantener la opresión de las provincias nativas" (57-8). Cuando Tauro menciona al diputado se refiere al centralismo capitalino. Se dice que el narrador y poeta Abraham Valdelomar (1888-1919) aludía a este asunto con humor: "El Perú es Lima, Lima es el Jirón de la Unión, el Jirón de la Unión es el Palais Concert y el Palais Concert soy yo". ${ }^{194}$ Alexander Von Humboldt había sido bastante más crítico, como puede leerse en la siguiente entrada a su Diario de principios del siglo XIX: "En Lima mismo no he aprendido nada del Perú. Allí nunca se trata de algún objeto relativo a

\footnotetext{
${ }^{194}$ El Palais Concert era un célebre bar-café limeño, en donde solían reunirse intelectuales y artistas entre 1913, cuando fue inaugurado, y 1930 cuando cerró, aunque ya había empezado a decaer desde la década anterior.
} 
la felicidad pública del reino. Lima está más separada del Perú que Londres [...] Un egoísmo frío gobierna a todos, y lo que sufre uno mismo, no da cuidado a otro" (en Cotler 33).

JCM también subraya el problema de la indiferenciación en la actuación de los poderes del Estado: "Las leyes del Estado no son válidas en el latifundio, mientras no obtienen el consenso tácito o formal de los grandes propietarios. La autoridad de los funcionarios políticos o administrativos, se encuentra de hecho sometida a la autoridad del terrateniente en el territorio de su dominio" (ibíd. 68). Esto lo confirma González Prada: "Las autoridades que desde Lima imparten órdenes conminatorias de los departamentos, saben que no serán obedecidas; los prefectos que reciben las comunicaciones de la capital saben también que ningún mal les resulta de no cumplirlas” ("Nuestros indios", Memorias 129); "Hay regiones donde jueces de paz y gobernadores pertenecen a la servidumbre de la hacienda. ¿Qué gobernador, qué subprefecto ni qué prefecto osaría colocarse a [sic] frente de un hacendado?” (Ibíd. 131).

JCM comenta que, en 1921, al cumplirse exactamente un centenario desde la Proclamación de la Independencia, se reunió un congreso indígena, en el cual "[1]os delegados pronunciaban, en quechua, enérgicas acusaciones contra los 'gamonales', las autoridades, los curas [énfasis mío]” (“El problema de las razas en América Latina"; Baeza 191). Y, copiando parcialmente la nota al calce $\mathrm{N}^{\circ} 1$ del capítulo "El problema del indio" de sus 7 ensayos (30-1), el Amauta también expresa preocupación en el Prólogo a Tempestad en los Andes de Valcárcel:

El término "gamonalismo" no designa sólo una categoría social y económica: la de los latifundistas o grandes propietarios agrarios. Designa 
todo un fenómeno representado por los gamonales propiamente dichos. Comprende una larga jerarquía de funcionarios [énfasis mío], intermediarios, agentes, parásitos, etc. [...] El factor central del fenómeno es la hegemonía de la gran propiedad semifeudal en la política y en el mecanismo del Estado. (12)

Quizás Matto no supo exponer el problema tan articuladamente como JCM, tal vez no cabía hacerlo en una obra de ficción, aunque se tratase de una novela de tesis (lo del Amauta era un ensayo); sin embargo, con absoluta lucidez la escritora cusqueña identificó que no podía haber justicia social si los poderes del Estado estaban entremezclados. En mi opinión, el principal tema de Aves sin nido es la denuncia de que el poder legislativo, el poder ejecutivo, el poder judicial y el eclesiástico se hallan entremezclados al recaer, en la práctica, su administración en las mismas personas que se coluden y se confabulan para explotar al indígena.

En el Perú contemporáneo todavía hay tráfico de influencias y, hasta cierto punto, esto es inevitable, debido a que en muchos ámbitos de la sociedad prevalece lo que Pierre Bourdieu denomina capital social. ${ }^{195}$ No obstante, en ocasiones dicho tráfico de influencias se desborda desproporcionadamente cuando el poder ejecutivo tiene injerencia directa en las acciones de los otros poderes del Estado. La distribución de los Poderes del Estado es esencial para equilibrar las fuerzas, para la mutua fiscalización de

\footnotetext{
${ }^{195}$ El capital social es aquél basado en redes de relaciones sociales, generalmente conformadas por miembros influyentes de la misma clase social, que permiten obtener puestos de trabajo, beneficios económicos, políticos y demás, gracias a un acuerdo tácito de mutua reciprocidad y cooperación. En Esquema de una teoría de la práctica [Outline of a Theory of Practice] (1972), Pierre Bourdieu destaca la manera en que el capital social es un factor que agudiza el nivel de inequidad social.
} 
las instituciones y para garantizar la renovación de los funcionarios a quienes se les ha confiado la dirección y administración del país.

\section{Otras formas de esclavitud}

Cuando Matto alude a aquellos que "comercian con la ignorancia" (Aves sin nido 28), seguramente se refiere a quienes ejercen ciertas formas de esclavitud institucionalizada, tales como el reparto, la mita y el "pongonaje". Las dos últimas modalidades consistían en el servicio forzoso y no remunerado que debían prestar los indígenas en las respectivas casas de las autoridades civiles y eclesiásticas, en tanto que la mita era cumplida de manera rotativa por las mujeres y los pongos eran varones que servían a tiempo completo. ${ }^{196}$ Asimismo, existían los obrajes, o talleres textiles, que operaban con mano de obra prácticamente gratuita: "El indio laboraba durante todo el día o la semana para ganarse unos cuantos chaupicuna ${ }^{197}$ [...] De ellos se descontaban los tantos convenientes para el tributo debido al rey, al alcalde mayor, a los veedores, protector, juez que tenía a cargo la cobranza, para otros ministros y el hospital; en virtud de los cuales siempre quedaba debiendo" (Castro Pozo, Del ayllu 128).

JCM denuncia, particularmente, las taras coloniales del yanaconazgo y del enganche, que continuaban teniendo vigencia en el primer tercio del siglo $\mathrm{XX}$ :

Mediante el "enganche" y el yanaconazgo, los grandes propietarios resisten al establecimiento del régimen del salario libre $[\ldots] \mathrm{El}$ "enganche"

\footnotetext{
${ }^{196}$ También se llamaba mita al trabajo obligatorio y gratuito que debían realizar los indígenas varones durante algunos meses del año.

197 “Chaupi: la octava parte de un real sencillo. Con la partícula cuna se forma el plural. El salario que Toledo fijó a los indígenas fue superior, pero no se cumplió la ordenanza dictada por éste" (Castro Pozo, Del ayllu, nota $\mathrm{N}^{\circ} 111$, página 240 ).
} 
[...] desciende inequívocamente del tráfico semiesclavista de [chinos] culis; el "yanaconazgo" es una variedad del sistema de servidumbre a través del cual se ha prolongado la feudalidad hasta nuestra edad capitalista en los pueblos política y económicamente retardados. (7 ensayos 68)

El yanaconazgo (peonaje) y el enganche (debt bondage) se daban, principalmente en la costa peruana. El primero era un sistema mediante el cual el trabajador recibía una parcela de tierra que debía cultivar. En retribución, prestaba servicios no remunerados al "dueño" de la tierra y/o le entregaba un porcentaje variable de los productos que cosechaba en esa parcela. ${ }^{198}$ El segundo consistía en el trabajo mínimamente remunerado que debía realizar un bracero (trabajador no abonado o indentured servant) hasta satisfacer la deuda contraída con su empleador, quien generalmente le costeaba el viaje al Perú. ${ }^{199}$

Resulta alarmante que, en 1928, JCM denuncie la pervivencia de expresiones típicamente feudales: "El trabajo gratuito está prohibido por la ley y, sin embargo, el trabajo gratuito, y aun el trabajo forzado, sobreviven en el latifundio" (7 ensayos 30). El 28 de agosto de 1821, exactamente al mes de haber sido proclamada la Independencia del

\footnotetext{
${ }^{198}$ El sistema de haciendas se va configurando desde el comienzo del período [de estabilización de la época colonial (1580-1780)], en base al aprovechamiento de la mano de obra andina liberada por la destrucción del ordenamiento productivo ancestral [el ayllu]. Los denominados 'forasteros', indios que huyen de la mita, buscan la protección de las haciendas y se acogen a ella en condición de yanaconas" (García Bedoya 72).

${ }^{199}$ Mediante el sistema de enganche (debt bondage), "[e]l inmigrante firmaba un 'contrato' [indenture $]$ en donde se comprometía a realizar labores artesanales (agrícolas, domésticas, labores manuales en general) por un plazo de ocho años con un sueldo determinado, además de vestimenta y alojamiento a descontar de su sueldo durante ese tiempo, una vez concluidos los ocho años el contrato quedaba cumplido y el emigrante libre de sus obligaciones pactadas" (Salazar).
} 
Perú, San Martín dio un decreto aboliendo "toda forma de servidumbre, incluyendo mitas, pongos, yanaconazgos y encomiendas" (Gaceta del Gobierno de Lima Independiente). El siguiente comentario de JCM evidencia que el decreto dado por San Martín y todos los subsiguientes normando el mismo asunto resultaron ser letra muerta: [En] los primeros actos de la República, se contaron varias leyes y decretos favorables a los indios. Se ordenó el reparto de tierras, la abolición de los trabajos gratuitos, etc.; pero no representando la revolución en el Perú el advenimiento de una nueva clase dirigente, todas estas disposiciones quedaron sólo escritas, faltas de gobernantes capaces de actuarlas. La aristocracia latifundista de la Colonia, dueña del poder, conservó intactos sus derechos feudales sobre la tierra y, por consiguiente, sobre el indio. Todas las disposiciones aparentemente enderezadas a protegerla, no han podido nada contra la feudalidad subsistente hasta hoy" (Mariátegui, 7 ensayos 37).

Tan es así que, en el libro La realidad que encuentra el político nuevo (1957), Julio César Luque Luna indica que el sistema de yanaconazgo estaba aún vigente en el año de 1956 $(25-7)$.

\section{Entre las armas y las letras}

De acuerdo con JCM, además de índole económica, "[1]a solución del problema del indio tiene que ser una solución social" y "[s]us realizadores deben ser los propios indios" (7 ensayos 39). "[M]ientras la liquidación de los residuos de la feudalidad colonial se impone como una condición elemental de progreso, la reivindicación del indio, y por 
ende de su historia, nos viene insertada en el programa de una Revolución [énfasis mío]" (ibíd. 243). Matto, lejos de pensar en medios violentos, considera que las deficiencias educativas "hacen imposible imaginar siquiera el progreso de la [...] 'desheredada raza"” (Cornejo Polar, "Prólogo", Aves sin nido). La autora cusqueña conceptúa la novela costumbrista-naturalista $^{200}$ como el vehículo para denunciar los defectos y las deficiencias morales de la sociedad. Por consiguiente, concibe ese género literario como una poderosa herramienta para erradicarlos:

[L]a novela tiene que ser la fotografía que estereotipe los vicios y las virtudes de un pueblo, con la consiguiente moraleja correctiva para aquéllos y el homenaje de admiración para éstas. Es tal, por esto, la importancia de la novela de costumbres, que en sus hojas contiene muchas veces el secreto de la reforma de algunos tipos, cuando no su extinción [...] [M]e inspiro en la exactitud con que he tomado los cuadros del natural. ${ }^{201}$ (Aves sin nido, "Proemio" vii)

Aunque en la actualidad pueda resultarnos un tanto ingenuo que la novela (en este caso, naturalista-costumbrista) pudiese constituir la panacea para redimir a la sociedad, las

\footnotetext{
200 "Literary criticism on the novel [Aves sin nido] has not focused in the author's realism [...] [M]any authors have lambasted the work's often melodramatic prose" (Thomas, "Realism in Nineteenth-Century" 56-7).

${ }^{201}$ Por ejemplo, Mercedes Cabello de Carbonera — compatriota coetánea de Matto-hace una apología del valor epistemológico y profiláctico que tiene para ella el enfoque naturalista de la novela social (Otero Luque, "Mercedes Cabello de Carbonera" 47). En el prólogo a Blanca Sol (1888), Cabello sostiene que "el arte de novelar ha venido a ser como la ciencia del anatómico: el novelista estudia el espíritu del hombre y el espíritu de las sociedades, el uno puesto al frente del otro, con la misma exactitud que el médico [estudia] el cuerpo tendido en el anfiteatro" (2). Para Cabello, la novela social tiene la responsabilidad de "[e]studiar y manifestar las imperfecciones, los defectos y vicios que en sociedad son admitidos, sancionados y con frecuencia objeto de admiración y de estima" (ibíd. 2). Luego, añade: "[C]iertos vicios sociales $[\ldots]$ son susceptibles de refrenarse, de moralizarse y quizá también de extirparse, y a este fin dirige sus esfuerzos la novela social” (ibíd. 2).
} 
ideas de Matto deben ser aquilatadas en el contexto de finales del siglo XIX. No obstante, estas ideas son tan poderosas que Jean-Paul Sartre las retoma a mediados del siglo XX bajo el esquema del compromiso social del escritor. ${ }^{202}$ A pesar de su aparente candidez, Matto expuso su manera de pensar con franqueza y en pie de igualdad con sus colegas varones. Cabe recordar que ella apoyó a Andrés Avelino Cáceres-quien fue derrotado por Nicolás de Piérola en la guerra civil de 1894-1895-con la edición y el financiamiento del periódico Los Andes, el medio portavoz del ideario cacerista, en La equitativa, una imprenta de propiedad de ella y de su hermano Segundo David. Si el anticlericalismo de Matto le costó la excomunión por el apoyo que le brindó a Cáceres, los pierolistas saquearon su casa y su imprenta, y la obligaron a partir al exilio en 1895 . Entre las armas y las letras, Matto se decantó, decididamente, por las segundas.

JCM insiste en que el problema del indígena radica en que ha sido despojado de sus tierras:

El problema indígena no admite ya la mistificación a que perpetuamente lo ha sometido una turba de abogados y literatos, consciente o inconscientemente mancomunados con los intereses de la casta latifundista. La miseria moral y material de la raza indígena aparece demasiado netamente como una simple consecuencia del régimen económico y social que sobre ella pesa desde hace siglos. Este régimen

\footnotetext{
202 “[N]uestra intención es contribuir a que se produzcan ciertos cambios en la sociedad que nos rodea [...] $[\mathrm{N}]$ os colocamos al lado de quienes quieren cambiar a la vez la condición social del hombre y la concepción que el hombre tiene de sí mismo [...] Si podemos cumplir lo que prometemos, si hacemos compartir nuestras opiniones a algunos lectores, no sentiremos un orgullo exagerado; nos limitaremos a felicitarnos de haber vuelto a encontrar la tranquilidad de conciencia profesional y de que, al menos para nosotros, la literatura haya vuelto a ser lo que nunca debió dejar de ser: una función social" (Sartre, ¿Qué es la Literatura? 5-6).
} 
sucesor de la feudalidad colonial, es el "gamonalismo". Bajo su imperio, no se puede hablar seriamente de redención del indio. (Prólogo a Tempestad en los Andes 11-12; 7 ensayos 30).

Aunque el Amauta diagnostica que "[a] los indios les falta vinculación nacional. Sus protestas han sido siempre regionales. Esto ha contribuido, en gran parte, a su abatimiento [derrota y subyugación]. Un pueblo de cuatro millones de hombres, consciente de su número [..], mientras no sean sino una masa inorgánica, una muchedumbre dispersa, son incapaces de decidir su rumbo histórico" (ibíd. 39). Y, si bien habla sobre la necesidad de una revolución, no especifica los pasos que deben darse para llevarla a cabo. González Prada sugiere que al indígena le hace falta fortaleza de carácter, decisión y hasta valentía para enfrentarse al opresor:

La condición del indígena puede mejorar de dos maneras: o el corazón de los opresores se conduele al extremo de reconocer el derecho de los oprimidos, o el ánimo de los oprimidos adquiere la virilidad suficiente para escarmentar a los opresores [énfasis mío]. Si el indio aprovechara en rifles y cápsulas todo el dinero que desperdicia en alcohol y fiestas [énfasis mío], si en un rincón de su choza o en el agujero de una peña escondiera un arma, cambiaría de condición, haría respetar su propiedad y su vida [énfasis mío]. A la violencia respondería con la violencia, escarmentando al patrón que le arrebata las lanas, al soldado que le recluta en nombre del gobierno, al montonero que le roba ganado en bestias de carga. ("Nuestros indios" 137) 
En resumidas cuentas, "el indio se redimirá merced a su esfuerzo propio, no por la humanización de sus opresores" (ibíd. 138). Lamentablemente, no obstante los logros obtenidos por el subalterno mediante la cholificación, en los tiempos actuales todavía puede observarse la actitud sumisa de algunos mestizos e indígenas frente a los blancos (Rendón Vásquez).

\section{Literatura, periodismo y prensa}

Matto vincula el ejercicio literario al periodístico y ambos a la prensa como el medio sine qua non para alcanzar los objetivos docentes y económicos nacionales: “'Hagamos de las hojas impresas, perfumadas hojas otoñales, que volando como aristas al hogar y al taller, lleven, no sólo luz y aroma, sino el bienestar consiguiente al trabajo remunerado' (EPI 126: 722)" (Vargas Yábar, "Constructora" 224). ${ }^{203}$ Asimismo, la autora de Aves sin nido “"[s]ostiene que 'el secreto para inculcar las aficiones literarias en el pueblo, consiste en proporcionarle buena lectura en periódico barato' (EPI 149: 1554)” (ibíd. 224): ${ }^{204} \mathrm{El}$ siguiente esquema ilustra la organización de estas ideas:

Educación $\rightarrow\left\{\begin{array}{l}\text { Alfabetización } \\ \text { Literatura nacional propia } \rightarrow \text { Buena lectura en periódico barato }\end{array}\right.$

${ }^{203}$ El Perú Ilustrado 126, 5 de octubre de 1889.

${ }^{204}$ El Perú Ilustrado 149, 15 de marzo de 1890. 
Matto "pone énfasis en la profesionalización y los derechos del escritor. Matto articula bienestar, trabajo, capitalismo e industria con miras hacia el progreso" (Vargas Yábar, Las empresas del pensamiento 74), tal como se presenta en el siguiente esquema:

\section{Buena lectura en periódico barato \\ Letras \\ Periodismo $\rightarrow$ Prensa $\rightarrow$ Comercio}

Es sorprendente el nivel de especificidad de la estrategia de Matto, que ella misma llevó a la práctica en su vida personal. Para JCM, por su parte, “[e]1 libro, la revista literaria y científica, no son sólo el índice de toda cultura, sino también su vehículo. Y para que el libro se imprima, difunda y cotice no basta que haya autores. La producción literaria y artística y de un país depende, en parte, de una buena organización editorial" ("El problema editorial”; Baeza 454).

\section{Fronteras abiertas, inmigración, comercio e industria}

Matto se muestra a favor de las fronteras abiertas a la inmigración, al comercio y a la tecnología para fomentar la industria nacional:

La autora aspira "ver el Perú en el estado de la Gran República del Norte, donde la industria es todo" (EPI 128: 794)". ${ }^{205}$ Apoyará, a través de su obra periodística, la llegada al Perú de capitales extranjeros y la inmigración, que considera necesarias para el progreso de la nación, y

${ }^{205}$ El Perú Ilustrado 128, del 19 de octubre de 1889. 
hace referencia al 'inmigrante industrioso' (EPI 134: 1014). ${ }^{206}$ Valora como síntomas de salvación "el brazo del capitalista, y del industrial extranjero, que viene atraído por la paz y entusiasmado por las riquezas del Perú (EPI 154: 1730)". ${ }^{207}$ (Vargas Yábar, “Constructora” 227)

Esta manera de pensar continuó vigente hasta la segunda mitad del siglo XX: "Durante las décadas de 1960 y 1970 los Estados nacionales [...] definieron el desarrollo de los países del Tercer Mundo por referencia a los indicadores de industrialización [...] Salir del subdesarrollo equivalía a promover el despegue (take off) del sector industrial, lo cual redundaría en un aumento del ingreso per cápita de los índices de alfabetización y escolaridad, de la esperanza de vida, etc.” (Castro-Gómez 78). Mas, en la actualidad “[e]1 desarrollo económico ya no se mide por los niveles materiales de industrialización sino por la capacidad de una sociedad para generar o preservar capital humano [...; ] es decir, la promoción de los conocimientos, aptitudes y experiencias que convierten a un actor social en sujeto económicamente productivo" (Castro-Gómez 80).

\section{La modernidad}

El tema de la industrialización se relaciona con el de la educación, y Matto no avizoró lo que JCM confirmara en 1925: que la civilización (¿quiso decir el progreso?), “dominada por las consecuencias del industrialismo, reclama de la escuela más técnicos que ideólogos y más ingenieros que retores [sic]" ("La enseñanza y la economía"; Baeza 439). “[L]a enseñanza—concluye el Amauta—obedece a los intereses del orden social y

\footnotetext{
${ }^{206}$ El Perú Ilustrado 134 del 30 de noviembre de 1889.

${ }^{207}$ El Perú Ilustrado 154 del 19 de abril de 1890.
} 
económico" (ibíd. 448). Esta afirmación era tan válida en el tiempo del Amauta como en el de Matto, porque "si bien los civilistas argumentaban que había que incorporar al indio a la economía del Perú moderno mediante políticas que exigiesen la liberación de su fuerza de trabajo, la posibilidad de que estos contribuyesen al programa cultural nacional ni siquiera se planteaba" (Denegri 175). Desde que el Perú logró su independencia de España, casi todos los connacionales estaban de acuerdo en que era necesario capacitar a los indígenas, mas solo en función de incorporarlos al engranaje industrial, con la finalidad de desarrollarlo y hacerlo más rentable: "El juez, el subprefecto, el comisario, el maestro [énfasis mío], el recaudador, están enfeudados a la gran propiedad [el latifundio]. La ley no puede prevalecer contra los gamonales. El funcionario que se obstinase en imponerla, sería abandonado y sacrificado por el poder central, cerca del cual son siempre omnipotentes las influencias del gamonalismo, que actúan directamente o a través del parlamento, por una y otra vía con la misma eficacia (JCM, 7 ensayos 30). Recordemos el famoso debate de 1971 entre Foucault y Chomsky.

Es interesante la forma en que Matto desliza sus ideas acerca de las ventajas de la modernidad en la novela: cuando Lucía le pide al cura Pascual que condone la deuda de los Yupanqui, el sacerdote le responde: “¡Válgame Dios! ¿Quién vive sin rentas? Hoy, con el aumento de las contribuciones eclesiásticas y la civilización decantada que vendrá con los ferrocarriles, terminarán los emolumentos; y [...] fuera curas; ;moriremos de hambre...!" 13). Mediante estas palabras de preocupación con respecto al futuro, salidas de la boca de uno de los villanos, Matto sugiere que el progreso, simbolizado por el ferrocarril, es una de las claves para acabar con la corrupción y la injusticia. Ante este planteamiento, probablemente JCM habría respondido: "No se tiende [sic] un ferrocarril 
para satisfacer una necesidad del espíritu y la cultura" ("La unidad de la América indoespañola”; Baeza 249). Muy cierto: en el último cuarto del siglo XIX, el indígena era "percibido como necesario para el desarrollo económico peruano — de ahí el llamado para liberar a la mano de obra indígena a fin de que construyese los ferrocarriles y extrajese los recursos naturales de la sierra—, mas parecía que él no tenía papel alguno que desempeñar en el emergente nacionalismo cultural" (Denegri 100-1). "El Estado sólo se acuerda del indio para enrolarlo en el ejército", dice con sarcasmo Gutiérrez de la Quintanilla (9). Casi cuatro décadas en el futuro, JCM señalará la explotación del indígena convertido en proletario: "La industria ha penetrado muy escasamente en la Sierra. Está representada principalmente por las fábricas de tejidos del Cuzco [...] El personal de estas fábricas es indígena [...] El ambiente feudal de la agricultura se prolonga hasta estas fábricas" ("El problema de las razas en la América Latina"; Baeza 179).

Cuando los Marín deciden abandonar Kíllac y trasladarse a Lima con sus hijas adoptivas, toman un tren que, primero, los llevará hasta Puno. Lamentablemente, sufren un accidente debido a que un rebaño de vacas cruza, intempestivamente, la vía férrea (166). Es desconcertante que la pluma de Matto haya decidido accidentar al tren, que representa la modernidad. Por el contrario, Cornejo Polar interpreta el accidente ferroviario como una estrategia narrativa de la autora: "El que descarrile el tren que aleja de Kíllac a los protagonistas [...] sirve para enfatizar este aislamiento [el del pueblo]: a la distancia se le suma un signo de dificultad y peligro" (Prólogo a Aves sin nido).

En la novela, el inmigrante extranjero es representado por Mr. Smith, quien despliega todos los esfuerzos a su alcance para salvar a los pasajeros ante un inminente 
descarrilamiento. Afortunadamente, el accidente no fue tan grave y "con la energía que distingue a la raza [¿anglosajona?, blanqueamiento], se practicaron evoluciones de ruedas y chumaceras que, en constante trabajo de dos horas, sacaron el coche encallado, colocándolo sobre los rieles en disposición de continuar la marcha” (ibíd. 172).

\section{Neocolonialismo}

A diferencia de Matto, JCM analiza las repercusiones negativas de la apertura a la inversión foránea, en las que ella no reparó: "El capitalismo extranjero, en su perenne búsqueda de tierras, brazos y mercados, ha financiado y dirigido el trabajo de los propietarios, prestándoles dinero con la garantía de sus productos y de sus tierras. Ya muchas propiedades cargadas de hipotecas han empezado a pasar a la administración directa de las firmas exportadoras" (7 ensayos 26-27). Como resultado del referido proceso, los países indoamericanos son "productores de materias primas y de géneros alimenticios que envían a Europa y Estados Unidos, de donde reciben, en cambio, máquinas manufacturadas" (Mariátegui, "La unidad de la América indo-española"; Baeza 248). JCM incluso avizoró el peligro de penetración ideológica. Por ejemplo, frente a la propuesta de Valcárcel de apoyar la labor educativa de los Adventistas del Séptimo Día en los Andes, ${ }^{208}$ el Amauta se pronuncia adverso debido al "carácter de

\footnotetext{
${ }^{208}$ En Tempestad en los Andes, Valcárcel le dedica un capítulo a "La acción adventista", en el que incluye un artículo de Fabio de Camacho - "La obra educacional de los adventistas"- y otro de Dora Mayer- - "La instrucción en la República".
} 
avanzadas del imperialismo anglo-sajón que [...] pueden revestir estas misiones" (Prólogo a Tempestad en los Andes 9). ${ }^{209}$

En el discurso "Punto de vista anti-imperialista", que JCM presentó en la Primera Conferencia Comunista Latinoamericana, realizada en Buenos Aires en junio de 1929, el Amauta sostuvo la tesis ideológica de que "[1]a condición económica de estas repúblicas [indoamericanas] es, sin duda, semi-colonial, y, a medida que crezca su capitalismo y, en consecuencia, la penetración imperialista, tiene que acentuarse ese carácter en su economía” (Baeza 187). JCM pensaba que únicamente la revolución socialista podía hacerle frente a la neocolonización: “[C]onstatando que el régimen económico y político que combatimos se ha convertido en una fuerza de colonización del país por los capitalismos imperialistas extranjeros, proclamamos que éste es un instante de nuestra historia en que no es posible ser efectivamente nacionalista y revolucionario sin ser socialista" (Prólogo a Tempestad en los Andes 13). Por esa razón el Amauta afirma que "[e]1 socialismo aparece en nuestra historia no por una razón de azar, de imitación o de moda [...], sino como una fatalidad histórica" (ibíd. 13).

Por el contrario, en el colofón de la misma obra de Valcárcel, Luis Alberto Sánchez (1900-1994) se pronuncia a favor del cosmopolitismo: “Abrir las entrañas de nuestra tierra, sondearla con nuestras propias manos, no significa desdeñar lo ajeno.

\footnotetext{
${ }^{209}$ Para más información sobre las misiones adventistas en el Perú, consúltese: Armas Asín, Fernando. Liberales, protestantes y masones: Modernidad y tolerancia religiosa: Perú siglo XIX. Lima: Fondo Editorial de la Pontificia Universidad Católica del Perú y Centro de Estudios Regionales Andinos "Bartolomé de las Casas", 1998; específicamente, el capítulo 7: "El final de un camino: la tolerancia explícita que llega (1913-1915)" 185-204.

Viene al caso mencionar que, no los adventistas sino los evangélicos apoyaron a Alberto Fujimori en la elección presidencial de 1990, en la cual obtuvo la victoria. Esto evidencia que, tal como lo había intuido JCM, estas Iglesias lograron penetrar ideológicamente en la sociedad peruana.
} 
Aprovechemos cuantos elementos nos vengan [...] sin perder de vista la nacionalidad. Y de este modo, sea nuestra tarea, no la de adaptar la realidad peruana a cualquier país extraño, sino la de aprovechar lo exótico, en cuanto se acuerde, convenga e interese a nuestra urgente reforma nacional" (183).

Desde luego, el neocolonialismo también era previsible en la época de Matto. Por ejemplo, en 1888 el presidente Andrés Avelino Cáceres suscribió el Contrato Grace, mediante el cual el Perú le otorgó al Comité Inglés de Tenedores de Bonos de la Deuda Externa el monopolio para la explotación de los ferrocarriles durante 66 años: “A consecuencia de la guerra [con Chile], el país queda postrado, y su aparato productivo totalmente desarticulado. La reconstrucción se opera a costa de hipotecar el patrimonio nacional en el contrato Grace" (García Bedoya 82). Mediante el Contrato Grace-dice JCM—, el Perú reconoció implícitamente "su condición de economía colonial” y, a la vez, "ratificó el predomino británico en el Perú", dando "al mercado financiero de Londres las prendas y las garantías necesarias para nuevas inversiones en negocios peruanos" (7 ensayos 21). Precisamente, en el prólogo a Aves sin nido en la edición de 1906, Gutiérrez de la Quintanilla alertaba de los peligros de la inmigración vinculada al capitalismo: "Sea bien venida la inmigración; pero en vez de cederle patria, hogares y riquezas, obedezcamos cuando menos el instinto de propia conservación, no sea que el extranjero inmigrante, convertido en señor, condene al criollo á la misma decadencia y servidumbre que impusimos nosotros al indígena" (9).

Sin embargo, en la denuncia que hace Matto en Aves sin nido en contra de los rescatistas, ella sólo "ataca la base de la pirámide del circuito regional de acopio de lanas [...], pero no dice una palabra acerca del papel cumplido en el negocio por las casas 
comerciales del interior-como la suya-, del [papel] de las casas comerciales arequipeñas y británicas establecidas en Arequipa, ni menos del capitalismo inglés, el verdadero organizador del circuito y su mayor beneficiario" (Manrique, "Clorinda Matto" 97-98). En otras palabras, ella "[a]taca los síntomas, no la enfermedad [...], porque las atrocidades perpetradas por los laneros en contra de los indígenas [...] eran el resultado necesario de la existencia de esa estructura” (ibíd. 98). Sin duda, la omisión de Matto es elocuente. "El escritor tiene una situación en su época; cada palabra suya repercute. Y cada silencio también" (Sartre 3-4).

A Gutiérrez de la Quintanilla también le preocupaba que los inmigrantes agudizaran el nivel de desempleo local: "Nos sentimos solos y clamamos por la inmigración, como el único medio de adquirir los brazos que necesitan las industrias; cuando en casa viven dos millones de hombres ociosos é ignorantes, mendigos casi, que por lo menos tienen tanto derecho como nosotros á conservar y mejorar su existencia, la educación y el trabajo, á ser protegidos por la igualdad republicana” (9). Asimismo, Teresa González de Fanning (1836-1918) opinaba que "las políticas migratorias seguidas por el presidente Pardo [Manuel Pardo y Lavalle] no tenían mucho sentido, considerando que buena parte de la población femenina permanecía económicamente inactiva" (Denegri 166). ${ }^{210}$ Es claro que Matto no tenía tales recelos y que, para ella,

[1]a temática de la inmigración juega un papel importante dentro del proyecto nacional [...] Su interés por lo nacional—y por peruanizar-no descarta, sino que valora el aporte de lo extranjero para la construcción de

\footnotetext{
${ }^{210}$ González de Fanning expresó su desacuerdo en su ensayo "Trabajo para la mujer", publicado en $\mathrm{La}$ Alborada, semanario de las familias, el 30 de octubre de 1875. "Una versión de este artículo fue luego leído por su autora en la velada de Gorriti realizada en junio de 1876" (Denegri 167, pie de página $\mathrm{N}^{\circ} 12$ ).
} 
la nación $[\ldots]$ Matto se opone al localismo y sostiene que este "es al patriotismo, lo que el fanatismo es a la religión". Lo que considera intolerante e ignorante sobre lo que se gana "con la introducción de nuevas industrias y otras mejoras" (EPI 195: 1520). (Vargas Yábar, "Constructora" 228)

Si bien don Fernando y Lucía son peruanos, ellos también son "extranjeros" en Kíllac y, debido al papel que desempeñan como salvadores del indígena oprimido, "se desprende que los forasteros no sólo ocupan el punto más alto en la apreciación del narrador, con quien comparten además su actitud y perspectiva, su visión del mundo, sino que, además, ellos constituyen la condición indispensable para que Aves sin nido se realice como novela" (Cornejo Polar, "Prólogo").Por otra parte, “[e]ducados esmeradamente en la costa, pertenecientes a una burguesía liberal y modernizadora cuyos ideales podrían coincidir con los de la 'república práctica' del presidente Pardo [...,] los Marín perciben el destino del Perú en términos de una cierta industrialización, en el campo de la extracción de minerales, y de un floreciente comercio exterior, naturalmente vinculado a la venta de minerales" (ibíd.). ${ }^{211}$

\footnotetext{
${ }^{211}$ A pesar de las ideas liberales que, en materia económica, Matto filtra en la novela; en opinión de Francesca Denegri, "es un error dar por hecho y supuesto que Clorinda Matto y Joseph Turner formaron parte de la burguesía liberal civilista, que ondeaba las banderas de la modernización capitalista y la libertad para el trabajador indio" (206).

Nelson Manrique informa que José (Joseph) Turner era un "minero de poca fortuna, propietario de una casa en el pueblo de Tinta [...] y una tienda añeja [...], un molino harinero en Pampa y algunos terrenos en el mismo pueblo de Tinta [...] No se trataba, pues, de un terrateniente ni de un rentista. Turner se ganaba la vida sobre todo como comerciante, aun cuando alguna vez ejerciera otras actividades, como la de receptor de la oficina de correos" (85).

Asimismo, Manrique hace hincapié en que "[1]os Turner-Matto no eran, pues, hacendados, como equivocadamente se ha venido sosteniendo, sino acopiadores de lana. Clorinda Matto conocía al detalle el rescate de lana, porque su actividad mercantil principal de una década giró en torno a este negocio" (ibíd. 96-97).

Más aún, Manrique advierte que "[n]o puede asimilarse tampoco la condición de los Turner-Matto a la de una 'burguesía liberal, portadora de un proyecto de modernización capitalista, que necesitaría liberar a los
} 


\section{Ni razas superiores ni inferiores}

Vargas Yábar percibe que Matto, "en ocasiones pone en evidencia su aprecio por la raza blanca y, específicamente por la sajona" (eugenesia y blanqueamiento); por ejemplo cuando, en su artículo "El corsé", expresa: "Yo miraba las cosas sin verlas, porque el partido era ventajosísimo para mi amiga, pues sabía por experiencia propia la dicha infinita de casarse con un inglés de ojos de cielo y patillas doradas (EPI 159: 97-9)" (“Constructora" 239). ${ }^{212}$ Recordemos que Matto adquirió el apellido Turner al contraer nupcias con un comerciante inglés en 1871. En una carta que Matto le dirige a Andrés Avelino Cáceres en 1802, la autora de Aves sin nido le expresa abiertamente sus ideas acerca del "mejoramiento" de la raza: "[C]lamaremos por la inmigración extranjera que, con el cruzamiento de sangre, componga este país donde la mayor parte de los habitantes es de raquíticos y tuberculosos, moral y físicamente (EPI 156: 1802)" (Vargas Yábar "Constructora" 228) (eugenesia). Precisamente, en el prólogo a Aves sin nido, Gutiérrez de la Quintanilla acota lo siguiente acerca del planteamiento de Matto en cuanto a políticas de inmigración: "Sí, yo también aplaudo la inmigración, pues reconozco la urgente necesidad de que una sangre superior á la nuestra [énfasis mío] restablezca los honrados sentimientos, inculque de nuevo la noción del deber, funde la vida social y reconstituya el orden político, anude con poderosa ligadura los elementos de la

\footnotetext{
indígenas sometidos por el latifundio para disponer de ellos en tanto que fuerza de trabajo, y que la enfrentaría a los terratenientes y gamonales representantes de la feudalidad (no presentados en su obra pero implícitos como enemigos de este proyecto político), como lo ha postulado Cornejo Polar" Manrique explica que, [s]i en algo coincidían plenamente los intereses de los hacendados, los comerciantes laneros y el capital comercial británico - de cuyos engranajes formaban parte tanto quienes controlaban las casas comerciales de Arequipa cuanto los ingleses de menor fortuna avecindados en el interior, como José Turner- era la necesidad de perpetuar la sujeción servil del campesinado indígena, sobre el cual estaba organizado el orden social del que todos ellos usufructuaban" (97).

${ }^{212}$ El Perú Ilustrado 159 del 24 de mayo de 1890.
} 
nacionalidad, rotos por la anarquía, y dé rumbo a nuestra existencia” (9) (eugenesia). La manera de pensar de Gutiérrez de la Quintanilla no era aislada, pues reflejaba el Volksgeist finisecular decimonónico no solo peruano sino continental e, incluso, occidental. La inmigración no representaba únicamente la inyección de capitales y la importación de tecnología, sino el "mejoramiento" de una raza, supuestamente, según Matto, abyecta en el aspecto físico y hasta moral (Vargas Yábar "Constructora" 228). ${ }^{213}$ Siguiendo este mismo razonamiento, seguramente la posición de Matto era distinta con respecto a la inmigración de chinos, considerados inferiores en aquellos tiempos.

En 1904, refiriéndose a los inmigrantes asiáticos traídos al Perú bajo el régimen de enganche, González Prada comentaba que, "cuando en el Perú se habla de inmigración, no se trata de procurarse hombres libres que por cuenta propia labren el suelo y al cabo de algunos años se conviertan en pequeños propietarios: se quieren introducir parias que enajenen su libertad y por el mínimum de jornal proporcionen el máximum de trabajo" ("Nuestros indios", en Memorias 127). Con respecto a las ideas de Gustav Le Bon (1841-1941) sobre la evolución de las razas y la supuesta superioridad/inferioridad de algunas de ellas, González Prada decía que

Le Bon nos avisa que "de ningún modo toma el término de raza en el sentido antropológico, porque, desde hace mucho tiempo, las razas puras han desaparecido casi, salvo en los pueblos salvajes", para que tengamos un camino seguro por donde marchar [...] En los pueblos civilizados, no hay más que razas históricas, es decir, creadas del todo por los acontecimientos de la historia" ("Nuestros indios", Memorias 124).

${ }^{213}$ El Perú Ilustrado del 3 de mayo de 1890. 
Sin embargo, se contradice cuando, con respecto a los inversionistas extranjeros de raza blanca, exhibe racismo, aunque a la inversa; es decir, en detrimento de quienes detentaban el poder económico, vinculando el color de la piel a una avaricia intrínseca:

[P]or regla general, los dominables se acercan al indio para engañarle, oprimirle o corromperle. Y debemos rememorar que no sólo el encastado [énfasis mío] nacional procede con inhumanidad o mala fe: cuando los europeos se hacen rescatadores de lana, mineros o hacendados, se muestran buenos exactores y magníficos torsionarios [sic], rivalizan con los antiguos encomenderos y los actuales hacendados. El animal de pellejo blanco, nazca donde naciere, vive aquejado por el mal del oro; al fin y al cabo cede al instinto de rapacidad" ("Nuestros indios", Memorias 130).

Curiosamente, a González Prada se le consideraba blanco en el Perú y, si por un lado criticaba a su propia raza $-\mathrm{y}$, como aristócrata, también a su propia clase, por el otro se asumía mestizo: "[L]os mestizos de la Costa recordamos tener en nuestras [énfasis mío] venas sangre de los súbditos de Felipe II mezclada con sangre de los súbditos de HuaynaCápac" ("Discurso del Politeama").Los aciagos comentarios racistas de González Prada le restan objetividad y, por ende, credibilidad a sus brillantes ideas sobre otros temas diversos.

JCM se pronuncia en contra de la falacia del concepto de una raza superior (o inferior), que suele ser utilizada como pretexto y supuesta justificación del sometimiento de un pueblo a otro, conformado por una étnica distinta:

La suposición de que el problema indígena es un problema étnico, se nutre del más envejecido repertorio de ideas imperialistas. El concepto de las 
razas inferiores sirvió al Occidente blanco para su obra de expansión y conquista. Esperar la emancipación indígena de un activo cruzamiento de la raza aborigen con inmigrantes blancos [eugenesia] es una ingenuidad antisociológica, concebible sólo en la mente rudimentaria de un importador de carneros merinos. (7 ensayos 32-3)

Pareciera que JCM estuviese respondiéndole a Domingo Faustino Sarmiento (18111888), un apologista de la eugenesia quien, a mediados de la década de 1840, consideraba que una inyección de sangre anglosajona hubiese sido beneficiosa para 'mejorar la raza' hispanoamericana, tan deteriorada, en su opinión, debido al mestizaje, ${ }^{214}$ o a Juan Bautista Alberdi, quien, una década más tarde, sostenía que poblar es "instruir, educar, moralizar, mejorar la raza [énfasis mío]; es enriquecer, civilizar, fortalecer y afirmar la libertad del país" [eugenesia y blanqueamiento] (Bases y puntos de partida para la organización política de la República de Argentina 7).

Aunque hace la salvedad de que "[s]ólo a partir del movimiento nacionalista [...] la colonia china ha dado señales activas de interés cultural e impulsos progresistas" (7 ensayos 247), resulta sorprendente que JCM sea xenófobo con respecto a la influencia asiática en el Perú:

El chino [...] parece haber inoculado en su descendencia, el fatalismo, la apatía, las taras del Oriente decrépito. El juego, esto es un elemento de relajamiento e inmoralidad, singularmente nocivo en un pueblo propenso a

\footnotetext{
${ }^{214}$ Así lo asevera Sarmiento explícitamente en su ensayo Facundo o civilización y barbarie en las pampas argentinas, publicado (1845): "[D] de la fusión de estas tres familias [de blancos, indios y negros] ha resultado un todo homogéneo, que se distingue por su amor a la ociosidad e incapacidad industrial [...] Mucho debe haber contribuido a producir este resultado desgraciado la incorporación de indígenas que hizo la colonización".
} 
confiar más en el azar que en el esfuerzo, recibe su mayor impulso de la inmigración china [...]. El chino, en suma, no transfiere al mestizo ni su disciplina moral, ni su tradición y cultura filosófica, ni su habilidad de agricultor y artesano. Un idioma inasequible, la calidad del inmigrante y el desprecio hereditario que por él siente el criollo, se interponen entre su cultura y el medio.

Y es más xenófobo todavía con respecto a la inmigración africana: "El aporte del negro, venido como esclavo, casi como mercadería, aparece más nulo y negativo aún. El negro trajo su sensualidad, su superstición, su primitivismo. No estaba en condiciones de contribuir a la creación de una cultura, sino más bien estorbaba con el crudo y viviente influjo de su barbarie" (247). Por estos comentarios, Velázquez Castro concluye que el Amauta "no puede desprenderse de los compartimentos positivistas, que el ardoroso defensor del indígena desprecia a los negros y a los chinos" ("Los 7 errores 130.$).$

El concepto de "cultura" que tenía JCM se halla muy distante de la definición que proporciona la UNESCO. Esta organización define la cultura como el "conjunto de los rasgos distintivos espirituales y materiales, intelectuales y afectivos que caracterizan a una sociedad o a un grupo social y que abarca, además de las artes y las letras, los modos de vida, las maneras de vivir juntos, los sistemas de valores, las tradiciones y las creencias" ("Declaración universal de la UNESCO sobre la diversidad cultural”). Cabe señalar que el propio José Vasconcelos ofrece en La raza cósmica (1925) "una ambigua descripción de términos tan disímiles como 'raza', 'cultura' y 'civilización””, mostrando en su discurso de mestizaje "deudas con las ideologías positivistas de la mezcla racial que 
afirmaban en el siglo XIX el bienestar de la cultura a través del mejoramiento y pureza de la raza" (Grijalva, "Vasconcelos o la búsqueda de la Atlántida" 342).

\section{La tenencia de la tierra: el meollo de la inequidad}

Al igual que en la mitología de numerosas civilizaciones ancestrales, en los Andes se relaciona al Sol con la Luna en una suerte de matrimonio cósmico; el Inti (Sol) se casa con la Mama Quilla (Luna). Sin embargo, en este caso en particular el Inti también desposa a la Pachamama (Madre Tierra), a la que calienta y fecunda para que dé sus frutos y que, con éstos, alimente a sus hijos; es decir, a la población. En la práctica, la posesión simbólica de la tierra es también su posesión física (marka) y comunitaria (ayllu), en el sentido de tenencia, de propiedad y vínculo productivo. En consecuencia, "la Comunidad representa la nación, es la tradición social del Perú [énfasis mío], es la vértebra económica de una organización [el ayllu] que perdió el poder político que le arrebató el latifundio. (Haya de la Torre, Obras Completas 185). Por esta razón, a Cornejo Polar le resulta sorprendente que en Aves sin nido "no aparezcan los terratenientes (grandes personajes de la novela indigenista posterior) y que los comerciantes en lana sean una presencia poderosa pero elusiva" (Prólogo a Aves sin nido). En relación con este asunto, Nelson Manrique Gálvez defiende a Matto con los siguientes argumentos: "[S]i uno se remite a la realidad social de Tinta de fines del siglo XIX encontrará que el rescate, o contrato de lanas, era la columna vertebral del sistema de explotación de la población indígena cusqueña, y en general del sur andino" (93). Por lo tanto, "el papel de los hacendados, para el lugar y la época que ella describe en su novela éste no era relevante" (“Clorinda Matto" 94-5). 
Mientras que Matto localiza el problema del indígena "en las autoridades, y no en los propietarios de la tierra y el ganado", mostrando con ello que "interpreta el conflicto en los Andes en términos más éticos, educativos, administrativos y gubernamentales que como una situación de base y contenido económico-social" (Cornejo Polar, Prólogo a Aves sin nido), JCM atribuye las desgracias del indígena al hecho de habérsele despojado de su tierra. Lo mismo pensaba González Prada: "Una hacienda se forma por la acumulación de pequeños lotes arrebatados a sus legítimos dueños" ("Nuestros indios", Memorias 131) y lo ratifica Castro Pozo: "La forma legal de consolidación de la propiedad adquirida mediante aquellos despojos, exacciones y violencias fue la composición, de la que la Corona aprovechó para vender los ayllus sus propias tierras" (Del ayllu 135). ${ }^{215}$

Para el Amauta, el problema del indígena, que es un problema agrario en el caso del Perú, "se presenta, ante todo, como el problema de la liquidación de la feudalidad" (7 ensayos 40). González Prada, que era coetáneo de Matto, también pensaba que el problema del indígena radicaba en el aspecto económico, en oposición al educativo, como creía Matto: "Si por un fenómeno sobrehumano, los analfabetos nacionales amanecieran mañana, no sólo sabiendo leer y escribir, sino con diplomas universitarios,

\footnotetext{
215 "Resulta que las tierras no sólo fueron repartidas o confinado su reparto o apropiación violenta por quienes tenían facultad de hacerlo, sino que muchos repartimientos o concesión de estancias, haciendas, peonías o caballerías emanaban de personas que, como ciertos consejos, no tenían derecho de otorgarlos, o de otro modo aquéllos que se habían formado subrepticiamente, por medios vedados, sin respetar las tierra de propiedad de los ayllus o sus indios, las que en la Costa desaparecieron en casi su totalidad. Para subsanar estos hechos y convalecer [sic] el título con que se poseía, se dictaron una serie de disposiciones, que se nominaron composición, por las cuales [...] se legalizaron los despojos y, excepcionalmente, se permitió a los ayllus o curacas agraviados, caso de que sus heredades no hubieran sido tenidas por el despojante más de diez años, readquirirlas, comprándoselas a la Real Corona, con lo cual ésta se sustituyó en el lucro ominoso [...] De esa época arrancan los títulos de dominio de multitud de latifundios" (Castro Pozo, Del ayllu 135-6).
} 
el problema del indio no habría quedado resuelto [...] La cuestión del indio, más que pedagógica, es económica, es social” (“Nuestros indios”, en Memorias 136-7).

\section{¿Expropiar tierras o irrigarlas?}

En 1918, José Antonio Encinas publica Contribución a una legislación tutelar indígena, un libro en el que recomienda distribuir las tierras de la Iglesia y del Estado. En sus 7 ensayos JCM observa que Encinas no considera la posibilidad de expropiarles las tierras a los gamonales (31), a diferencia de lo que él proponía: “[el] fraccionamiento de los latifundios en favor de la pequeña propiedad" (ibíd. 41). Por otra parte, en 1956 el diputado por el departamento de Lima Julio César Luque Luna del partido Demócrata Cristiano estaba en desacuerdo con "la idea de expropiar una tierra cultivada" ( $L a$ realidad nacional 50). Según Luque Luna, "en el Perú lo que sobra es tierra para irrigar y seguramente faltarían peruanos para hacerlos propietarios; el problema peruano no radica en repartir entre más manos ese 3\% del área nacional dedicada a la agricultura, sino aumentar [...] el área bajo laboreo" (ibíd. 50).

La tesis ideológica de Luque Luna estaba centrada en el "uso sistematizado del agua que la naturaleza provee al Perú" (ibíd. 22), mediante obras de represamiento e irrigación, cuya ejecución él mismo propuso en el Proyecto de Ley $\mathrm{N}^{\circ} 14$, que presentó ante la Cámara de Diputados el 21 de agosto de 1956. Luque Luna sostenía que tales obras, "después de abastecidas las necesidades normales de la agricultura existente", traerían como beneficio "la incorporación de nuevas áreas vírgenes, con miras al incremento de la pequeña propiedad agrícola" (ibíd. 24-6). De esa manera, los yanaconas 
podrían convertirse en pequeños empresarios agrícolas y sería posible acabar definitivamente con la institución semifeudal del yanaconazgo (ibíd. 25-7). ${ }^{216}$

\section{Resumen}

Matto y JCM coinciden en que es imprescindible incorporar al indígena al plan nacional. Sin embargo, con una mentalidad distinta a la de Matto, que atribuye la situación de servidumbre del indígena al hecho de que sea analfabeto, JCM señala que el problema es, esencialmente, de índole socioeconómica y sociopolítica, y que la solución consiste en devolverle al indígena la tenencia de la tierra. Matto y JCM concuerdan en que la falta de independencia de los poderes de Estado propicia y agrava las deplorables condiciones de vida del indígena. Pero la gran diferencia entre ambos pensadores es que el Amauta plantea la necesidad de liquidar la feudalidad en el Perú como condición indispensable para que pueda ser efectiva cualquier medida que se adopte para reivindicar al indígena, mientras que Matto no se pronuncia con respecto al latifundio. En otro orden de ideas, si para Matto la influencia extranjera es deseable para el "mejoramiento de la raza" (eugenesia), JCM, sin oponerse a la inmigración, deja bien en claro que ninguna raza es superior ni inferior a otra. Asimismo, mientras que Matto se muestra proclive a la apertura a la inversión y cultura anglosajona (blanqueamiento), a JCM le preocupa que la penetración económica se traduzca en neocolonialismo. Por último, Matto aboga por una literatura nacional, de corte costumbrista-naturalista, que revalorice la producción cultural en idioma quechua (cholificación), en tanto que JCM es escéptico en cuanto a la existencia de una literatura esencialmente peruana, con excepción de la indigenista, que,

\footnotetext{
${ }^{216}$ Fernando Fuenzalida hace notar que el suelo de la costa — el que Luque Luna deseaba irrigar-es pobre en nutrientes minerales ("Identidad cultural").
} 
en su opinión, todavía se halla en estado embrionario (cholificación). Sin embargo, el

Amauta considera que el idioma español es, de hecho, el "instrumento intelectual" de la nacionalidad peruana.

El siguiente cuadro resume las semejanzas y diferencias en los temas que he comparado entre el pensamiento de Matto y el de JCM:

\begin{tabular}{|l|c|}
\hline \multicolumn{2}{|c|}{ Comparación de los postulados de (re)construcción nacional de } \\
Matto frente a los de Mariátegui
\end{tabular}




\begin{tabular}{|c|c|}
\hline \multicolumn{2}{|c|}{ Producción cultural en idioma quechua } \\
\hline $\begin{array}{l}\text { "[N]o es posible escribir historia peruana } \\
\text { que merezca el nombre de tal sin conocer el } \\
\text { idioma" (Matto, Leyendas y recortes } 107) \text {. }\end{array}$ & $\begin{array}{l}\text { "La lengua castellana }[\ldots] \text { es el lenguaje } \\
\text { literario y el instrumento intelectual de esta } \\
\text { nacionalidad" (7 ensayos 170). }\end{array}$ \\
\hline \multicolumn{2}{|c|}{ Economía abierta a la tecnología y a la inversión foráneas } \\
\hline $\begin{array}{l}\text { - "Matto se opone al localismo y sostiene } \\
\text { que este 'es al patriotismo, lo que el } \\
\text { fanatismo es a la religión'. Lo que } \\
\text { considera intolerante e ignorante sobre } \\
\text { lo que se gana 'con la introducción de } \\
\text { nuevas industrias y otras mejoras' (EPI } \\
\text { 195: 1520)" (Vargas Yábar, } \\
\text { "Constructora" 228). }\end{array}$ & $\begin{array}{l}\text { "La condición económica de estas repúblicas } \\
\text { [indoamericanas] es, sin duda, semi-colonial, } \\
\text { y, a medida que crezca su capitalismo y, en } \\
\text { consecuencia, la penetración imperialista, tiene } \\
\text { que acentuarse ese carácter en su economía" } \\
\text { (Mariátegui, "Punto de vista anti-imperialista", } \\
\text { 1929; Baeza 187). }\end{array}$ \\
\hline $\begin{array}{l}\text { - “La autora aspira 'ver el Perú en el } \\
\text { estado de la Gran República del Norte, } \\
\text { donde la industria es todo' (EPI 128: } \\
\text { 794). Valora como síntomas de } \\
\text { salvación 'el brazo del capitalista, y del } \\
\text { industrial extranjero, que viene atraído } \\
\text { por la paz y entusiasmado por las } \\
\text { riquezas del Perú (EPI 154: 1730)" } \\
\text { (Vargas Yábar, "Constructora" 227) }\end{array}$ & \\
\hline \multicolumn{2}{|c|}{ Fronteras abiertas a la inmigración para "mejorar" la raza (eugenesia) } \\
\hline $\begin{array}{l}\text { "“[C]lamaremos por la inmigración } \\
\text { extranjera que, con el cruzamiento de } \\
\text { sangre, componga este país donde la mayor } \\
\text { parte de los habitantes es de raquíticos y } \\
\text { tuberculosos, moral y físicamente' (EPI } \\
\text { 156: 1802)" (Matto, en Vargas Yábar } \\
\text { "Constructora" 228). }\end{array}$ & $\begin{array}{l}\text { "Esperar la emancipación indígena de un } \\
\text { activo cruzamiento de la raza aborigen con } \\
\text { inmigrantes blancos es una ingenuidad } \\
\text { antisociológica, concebible sólo en la mente } \\
\text { rudimentaria de un importador de carneros } \\
\text { merinos" (Mariátegui, } 7 \text { ensayos 32-33). }\end{array}$ \\
\hline \multicolumn{2}{|c|}{ La principal causa de la deplorable situación socioeconómica del indígena peruano } \\
\hline $\begin{array}{l}\text { "Interpreta el conflicto en los Andes en } \\
\text { términos más éticos, educativos, } \\
\text { administrativos y gubernamentales que } \\
\text { como una situación de base y contenido } \\
\text { económico-social" (Cornejo Polar, Prólogo } \\
\text { a Aves sin nido). }\end{array}$ & $\begin{array}{l}\text { "La cuestión indígena arranca de nuestra } \\
\text { economía. Tiene sus raíces en el régimen de } \\
\text { propiedad de la tierra. Cualquier intento de } \\
\text { resolverla con medidas de administración o } \\
\text { policía, con métodos de enseñanza o con obras } \\
\text { de vialidad, constituye un trabajo superficial o } \\
\text { adjetivo, mientras subsista la feudalidad de los } \\
\text { gamonales" (Mariátegui, } 7 \text { ensayos 29). }\end{array}$ \\
\hline
\end{tabular}




\section{Conclusión}

JCM diagnosticó que: “[n]o somos un pueblo que asimila las ideas y los hombres de otras naciones, impregnándolas de su sentimiento y su ambiente, y que de esa suerte enriquece, sin deformarlo [sic], su espíritu nacional" (7 ensayos 79). Sin embargo, la cocina novoandina es un buen ejemplo de fusión de la gastronomía autóctona con la universal. Empero, no obstante verificar con beneplácito que, en un mundo globalizado, los peruanos continuamos amando y practicando nuestras costumbres ancestrales, adaptándolas a las influencias del exterior, lamentablemente, en el interior del propio país todavía son válidos algunos aspectos de la falta de integración que JCM denunciaba en 1928:

Somos un pueblo en el que conviven, sin fusionarse aún, sin entenderse todavía, indígenas y conquistadores. La República se siente y hasta se confiesa solidaria con el Virreinato. Como el Virreinato, la República es el Perú de los colonizadores, más que de los regnícolas. El sentimiento y el interés de las cuatro quintas partes de la población no juegan casi ningún rol en la formación de la nacionalidad y de sus instituciones. (7 ensayos 79-80)

Aun valorando lo típico y tradicional, y preservando nuestra cultura, los peruanos todavía no hemos logrado integrarnos en una sola nación. Peor aún: el índice de pobreza alcanza al $40.4 \%$ de la población y coincide con el segmento que habla alguna de las lenguas nativas (INEI 117). ${ }^{217}$ JCM tenía razón al señalar que capacitar al indígena implica

\footnotetext{
${ }^{217}$ La pobreza "afecta más a la población que tiene como lengua aprendida en su niñez una lengua nativa: quechua, aymara o lenguas amazónicas. Así, en el año 2012, la pobreza alcanzó al 40,4\% (12,0\% pobre extremo y $28,4 \%$ pobre no extremo) de las personas que mencionaron tener como lengua materna una
} 
mucho más que, meramente, enseñarle a leer y a escribir, y que para reivindicarlo; es decir, para "abolir su servidumbre", es imprescindible empoderarlo mediante una reestructuración socioeconómica integral. Pero Matto también estaba en lo correcto cuando afirmaba que la capacitación del indígena-aunque no limitada a sólo alfabetizarlo y a enseñarle tecnología, sino también a formarlo en humanidades — era la condición indispensable para que los indígenas pudiesen impulsar los cambios necesarios y positivos en su Historia.

Luego de cotejar las ideas de Matto y de JCM, y de analizar la evolución del pensamiento intelectual en los 40 años que separan a Aves sin nido (1889) de los 7 ensayos de interpretación de la realidad peruana (1929), he llegado a la conclusión de que - como sostenían Víctor Raúl Haya de la Torre en 1927 y Hidebrando Castro Pozo en 1936 - el milenario ayllu (que supone el trabajo cooperativo del ayni), tan arraigado en el mundo andino, se presta para adaptarlo en el Perú a las exigencias actuales de las sociedades abiertas - con estándares meritocráticos, insertas en un mundo cada vez más globalizado-como modelo cooperativista de organización social y de producción económica. Para Haya de la Torre,

La lucha de cuatrocientos años de la Comunidad contra el Latifundio y la decadencia de éste, prueban históricamente que las bases de la Comunidad incásica, constituyen las bases de la restauración económica nacional. La reorganización de nuestra economía desquiciada, la gran cooperativa agrícola de producción, que debe ser el Perú no podrán establecerse sino

lengua nativa, siendo casi el doble de incidencia respecto a la población que tiene como lengua materna el castellano, $22,2 \%$ (4,6\% pobres extremos y 17,6\% pobres no extremos)" (INEI 117). 
sobre las bases de la maravillosa organización económica incásica, modernizada, dotada de todos los elementos de técnica contemporánea y resguardada por el Estado, no ya de los latifundistas sino de los productores. $^{218}$ (Obras Completas 187).

El ayllu es un tipo de comunidad en donde es posible que se hermanen el saber y el poder de manera recíproca y equitativa, poniéndose el uno al servicio del otro, con el propósito de capacitar y empoderar a los indígenas - no sólo de la sierra, sino también de la selva y de la costa—en el plano socioeconómico.

El modelo autogestionario del Distrito de Villa El Salvador, ubicado en el cono sur de Lima, es un excelente ejemplo de los logros que pueden alcanzarse mediante el trabajo comunitario. Antes de convertirse formalmente en un distrito en 1983, parte de los terrenos que ocupa en la actualidad fueron invadidos en 1970 por los damnificados de un devastador terremoto que ocurrió ese año. Por el éxito obtenido como comunidad urbana autogestionaria que no sólo venció la adversidad, sino que sacó provecho de ella, en 1987 recibió el Premio Príncipe de Asturias de la Concordia en mérito a "La práctica ejemplar para organizar un tipo de ciudad solidaria y económicamente productiva". Creo que, con un pie afincado en la tradición y con el otro orientado hacia el futuro, los indígenas-los subalternos, en general-por fin lograrán dar el salto cuántico y trascendental que, con miras a su reivindicación en el panorama nacional, tanto Matto como JCM anhelaban para ellos. "Es profesía [sic] apasionada que anuncia un Perú

\footnotetext{
${ }^{218}$ Haya de la Torre expuso estas ideas en 1927, en una carta-ensayo titulada "El problema del indio" que dirigió a Luis Valcárcel, el fundador y director del grupo indigenista Resurgimiento, cuya base era el Cusco. Este texto forma parte de Teoría y Táctica del Aprismo (Lima: Ed. Cahuido, 1931), y que, a la vez, ha sido incluido en Obras Completas de Víctor Raúl Haya de la Torre (Lima: Mejía Baca, 1977).
} 
nuevo. Y nada importa que para unos sean los hechos que crean la profesía [sic] y para otros sea la profesía [sic] la que crea los hechos" (Mariátegui, Prólogo a Tempestad en los Andes 15). 


\section{MESTIZAJE: ¿LA SOLUCIÓN INSOLUBLE?}

\section{Racismo y discriminación}

En España, los estatutos de limpieza de sangre habían fijado la noción de raza impura (Manrique, La piel y la pluma 13). Y al otro lado del océano, "la idea española de limpieza de sangre encontró una acogida tan favorable y una expansión tan general en territorio americano que se convirtió en criterio decisivo para la colocación de los individuos en el orden estamental de la sociedad colonial" (Konetzke, "Los mestizos" 125). ${ }^{219}$ Con la invasión al Tahuantinsuyo perpetrada por la etnia blanca, la nueva estratificación social se basó en la discriminación de las etnias nativas subalternas: “[R]ace and racial identity were established as instruments of basic social classification. (Quijano, "Coloniality of Power" 534). Esta práctica se afianzó durante la etapa virreinal (Manrique, La piel 13), afectando a los amerindios, a los mestizos y a los negros importados como esclavos, así como a sus descendientes negros y mulatos, y a otros grupos étnicos minoritarios, tales como los chinos y japoneses. "El discurso de pureza de sangre es, de acuerdo con la interpretación de [Walter] Mignolo, el primer imaginario geocultural del sistema-mundo que se incorporó en el habitus de la población inmigrante europea, legitimando la división étnica del trabajo y la transferencia de personas, capital

\footnotetext{
219 "La subjetividad de la modernidad primera está relacionada con el discurso de la limpieza de sangre, es decir, con el imaginario cultural de la blancura. La identidad fundada en la distinción étnica frente al otro caracterizó la primera geocultura del sistema-mundo moderno/colonial; esta distinción no sólo planteó la superioridad étnica de unos hombres sobre otros sino, también, la superioridad de unas formas de conocimiento sobre otras" (Castro-Gómez 57).
} 
y materias primas a nivel planetario" (Castro-Gómez 55). ${ }^{220}$ En 1791, el Mercurio

Peruano reportaba la siguiente información demográfica:

La población del Perú, en cuanto a las cosas originales, se compone de Españoles, Indios, y Negros. Las especies secundarias más conocidas, que proceden de la mixtión de estas tres, son el Mulato, hijo de Español y Negra; Cuarterón, de Mulata y Español; y Mestizo de Español e India. Las demás subdivisiones que se forman por la mezcla sucesiva, son tantas como las diversas combinaciones posibles de esas razas primitivas. ("Idea general del Perú")

Asimismo, ese medio informativo daba cuenta de la implicancia social de pertenecer a determinadas razas:

El trabajo de las Chacras [tierras de cultivo], y el servicio doméstico se ha hecho siempre por Negros. De cuatro años a esta parte muchos Blancos se ocupan en uno y otro. Anteriormente, fuese por preocupación o por soberbia, se reputaba en cierto modo infame aquel criado, que no era o Negro o Mulato. Algunos Políticos ilustrados opinan que sería más feliz el Reino, y especialmente esta Capital, si este perjuicio se desarraigase enteramente. (Ibíd.)

Como puede apreciarse, desde el momento de la Invasión el racismo y la discriminación han sido unos de los mayores problemas del Perú.

\footnotetext{
${ }^{220}$ El sistema-mundo es un modelo de análisis de las relaciones sociales, políticas y económicas a lo largo de la historia y a nivel global, en función del flujo y de la distribución de los recursos entre los países del centro (primer mundo) y los países periféricos (tercer mundo). Immanuel Wallerstein (1930-...) es uno de los pensadores que más ha contribuido al desarrollo de este modelo. De otro lado, habitus - un concepto sociológico popularizado por Pierre Bourdieu (1930-2002) - se refiere a que la clase social a la que pertenece un individuo influye decisivamente en su manera de sentir, pensar y actuar.
} 
Como resultado del intenso mestizaje y de la movilidad social propiciada gracias a las estrategias de resistencia del subordinado (el etnovaivén, sobre todo), "[l]as clases altas han descubierto que, de un tiempo a esta parte, en restaurantes, playas, aviones, directorios y hasta en Palacio de Gobierno, tienen que codearse con gente de origen popular (de Soto 4). Esto les produce, por decir lo menos, incomodidad (racismo). Mientras que el racismo es una actitud, la acción o inacción que se materializa como consecuencia de esa actitud es la discriminación que, en ocasiones, adopta la forma de autosegregación. "Por ello—-prosigue de Soto—, en muchos casos [las clases altas] han optado por reducirse en su cada vez más reducido mundo y consolarse con la añoranza de un tiempo que terminó. Existe gente que se atrinchera en exclusivos barrios residenciales, frecuenta clubes que parecen no haber sido tocados por el tiempo, transita en la medida de lo posible por avenidas arboladas y mantiene costumbres que la llevan a una segregación social y racial de facto" (ibíd. 4). ${ }^{221}$ La misma práctica de autosegregación"argolla" - es para algunos una forma de racismo encubierto en tanto que para otros se trata de ceguera racial. Cuando a los del segundo grupo se les pregunta por qué hay separación física entre las personas de distintas razas, responden que es natural que a la gente le gusta juntarse con gente afín o similar (Racism without Racists 28). Eduardo Bonilla-Silva denomina, precisamente, "naturalización" a este tipo de ceguera racial. ${ }^{222}$

\footnotetext{
${ }^{221}$ En el Perú ha habido segregacionismo-“argolla" y "argolleros"- desde época del virreinato: "La organización del espacio urbano colonial estuvo condicionado por la segmentación étnica: Así, en Lima el barrio de los españoles estaba claramente separado del barrio de los indios" (Flores Galindo, "República sin ciudadanos", Obras completas 236). Asimismo, en las parroquias había libros de registro de bautismos separados (ibíd. 236).

${ }^{222}$ El sociólogo Eduardo Bonilla-Silva identifica, además de la naturalización, otras tres formas de racismo encubierto y/o de ceguera racial: 1) el liberalismo abstracto, que racionaliza la inequidad socioeconómicoracial mediante la lógica de la meritocracia, argumentando que la sociedad ofrece iguales oportunidades a todos sus miembros (lo cual es falso) y, en consecuencia, se opone a las políticas de discriminación
} 
Pero la práctica de ceguera racial (color/race blindness) — también llamada de daltonismo racial—es, sobre todo, una herramienta política que consiste en no tomar en cuenta el factor raza/etnia en las decisiones que se adoptan en la sociedad. Por ejemplo, mucho tiempo antes de que en los Estados Unidos entrara en vigor la Ley de Derechos Civiles de 1964 y de que se hablara de políticas de ceguera racial, la raza era una categoría que había sido excluida en los censos poblacionales realizados en el Perú después de 1940. Desde entonces, la falta de información acerca de la composición racial y étnica del país ha venido siendo suplida con estudios de organizaciones internacionales. En apariencia, la ceguera racial aspira a lograr una sociedad más igualitaria mediante un trato equitativo a todas las razas y etnias; sin embargo, contribuye al mantenimiento del statu quo, lo que favorece al grupo hegemónico, amén de conferirle mucha flexibilidad para expresar ideas racistas sin que parezca racista (Marable, 1991). "Racismo sin racistas", es como Bonilla-Silva sintetiza los efectos de la ceguera racial. Ahora bien, "hecha la ley, hecha la trampa": Enith Pinedo Bravo alerta sobre distorsiones en la data sobre la composición poblacional, debido a que algunos grupos de pobladores se autocalifican de indígenas sin serlo, con la finalidad de obtener los beneficios destinados a éstos; por ejemplo, el derecho a la consulta previa a la aprobación de medidas legislativas o administrativas en relación con la explotación de recursos naturales (política de discriminación afirmativa) (“¿Quién es indígena en el Perú? 183).

Aunque, lamentablemente, la sociedad peruana es racista, se ha creado una conciencia acerca de la necesidad de ser, por lo menos, políticamente correcto. El tipo de

afirmativa; 2) el racismo cultural, que atribuye ciertos males sociales-por ejemplo, el poco éxito socioeconómico alcanzado por los miembros de algunas etnias/razas - a un determinismo cultural; y 3 ) la minimización, que localiza el meollo de los problemas socioeconómico-raciales fuera del ámbito racial. (Racism without Racists 28-30). 
racismo que prevalece hoy en día en el Perú es, mayormente, encubierto, asolapado, indirecto. Por ejemplo, no es raro hallar en el periódico avisos colocados por empresas solicitando personal "de buena presencia", lo que traducido significa de rasgos fenotípicos no andinos ni negroides. Hay empresas en que "sólo reciben para sus puestos de dirección, de oficina y de trato con el público a hombres y mujeres blancos y blancoides. Las leyes contra la discriminación laboral carecen de vigencia en esos ámbitos que gozan en la práctica de extraterritorialidad" (Rendón Vásquez). Tampoco es infrecuente que algunas discotecas se reserven el "derecho de admisión". 


\section{V.1 EL INCA GARCILASO DESDE EL ESCEPTICISMO: UNA IDENTIDAD MESTIZA CONFLICTIVA}

$Y$ aún más profundo es el significado de aquella historia de Narciso, que, por no poder aferrar la dulce imagen atormentadora que veía en la fuente, se sumergió en ella y se ahogó Herman Melville (Moby Dick, capítulo I)

Son muchos y grandes los méritos del Inca Garcilaso de la Vega (1539-1616). Fue el primer escritor hispanoamericano mestizo que-gracias a su vasta cultura, talento artístico, perseverancia y completo dominio del idioma español, así como del quechua y del italiano-logró forjarse un sitial sin parangón entre lo más selecto de la intelectualidad europea. Su obra, monumental sin duda, habla por sí sola: Traducción de los Diálogos de amor de León Hebreo (1590), La Florida del Inca (1605), Comentarios reales (1609), Historia general del Perú (1617) y Genealogía o Relación de descendencia del famoso Garci Pérez de Vargas (1929, póstuma). Sin embargo, todo esto ya ha sido extensamente analizado y comentado, así que prefiero revisitar la vida y obra del Inca Garcilaso desde una perspectiva distinta: la del escepticismo (que tampoco es novedosa). Mi intención no es menoscabar su genuina valía, sino contribuir a una mejor comprensión de este fascinante personaje histórico que se convirtió a sí mismo en uno literario.

\section{Los primeros transculturados}

Tras naufragar la expedición de Pedro de Valdivia en 1511, ocho años de convivencia forzada con los mayas fueron suficientes para que Gonzalo Guerrero y Gerónimo de Aguilar se transculturasen no sólo en cuanto a su apariencia física: el primero, hasta el 
punto de no querer volver con los hombres de Hernán Cortés cuando, en 1519, se le presentó la oportunidad de hacerlo; y el segundo, al extremo de haberse olvidado de hablar español con fluidez. ${ }^{223}$ Sin embargo, la mayor diferencia entre ambos náufragos es que, mientras Aguilar se contenta de ser rescatado y se apresta voluntarioso a retornar con los suyos, Guerrero, por el contrario, esgrime las siguientes razones para permanecer en Yucatán cuando Aguilar intenta disuadirlo: "Hermano Aguilar: yo soy casado y tengo tres hijos, y tiénenme por cacique y capitán cuando hay guerras; idos con Dios que yo tengo labrada la cara y horadadas las orejas. ¡Qué dirán de mí desde que me vean esos españoles ir de esta manera! Y ya veis estos mis hijitos cuán boniticos son” (Díaz del Castillo, Historia verdadera I. XXVII.117).

Los argumentos de Guerrero son tan insólitos como inexplicables para los conquistadores. Años más tarde, el poema “Andanzas a Jerónimo de Aguilar” de Francisco de Terrazas (1525-c.1604) reflejará la extrañeza de Aguilar ante la decisión de su compatriota de quedarse a vivir con los indígenas. ${ }^{224}$ Evidentemente, Guerrero tenía mejores perspectivas en Yucatán, en donde ostentaba el rango de cacique, que como soldado bajo las órdenes de Cortés. Por otro lado, Aguilar no era sino un sirviente o esclavo de una tribu maya y, en consecuencia, le mejoraba la suerte yéndose de vuelta

\footnotetext{
${ }^{223}$ Algo similar le sucedió al sevillano Juan Ortiz en la expedición a la Florida, a quien, luego de vivir once años (desde 1528 hasta 1539) entre los indios, sin tener contacto con sus compatriotas, se le olvidó hablar español: "[Y] viendo que Álvaro Nieto revolvía sobre él, dio grandes voces diciendo 'Xivilla, Xivilla', por decir Sevilla, Sevilla [...] [N]o acertando Juan Ortiz a hablar castellano, hizo con su mano la señal de la cruz para que el español viese que era cristiano. Porque con el poco o ningún uso que entre los indios había tenido de la lengua castellana, se le había olvidado hasta el pronunciar el nombre de la propia tierra" (Inca Garcilaso, La Florida del Inca II.I.VI.83-84).

${ }^{224}$ Lo siguiente es un fragmento del poema "Andanzas a Jerónimo de Aguilar" de Francisco de Terrazas: "Así se queda, y solo yo he venido [dice Aguilar] / porque él [refiriéndose a Guerrero] está ya en indio convertido / Los ánimos de todos los oyentes / dejó de un miedo helado casi llenos / los pelos erizados en las frentes / los corazones muertos en los senos / viendo que van a do se comen gentes / adonde de piedad son tan ajenos / do no valen palabras ni razones / regalos, ni promesas ni otros dones".
} 
con sus coterráneos. Por lo tanto, las respectivas elecciones de ambos personajes son enteramente comprensibles desde el punto de vista de la conveniencia. Aunque Aguilar, al igual que Guerrero, lucía como indígena y los hombres de Cortés no pudieron reconocerlo como español en un primer momento, ${ }^{225}$ podría argumentarse que la transculturación producida en él—a diferencia de la ocurrida en su compañero-había sido sólo cosmética y temporal, mas no ideológica como la de éste.

Hallándose nuevamente entre los que consideraba "suyos", Aguilar fungió de intérprete. Mientras que Doña Marina (c.1499 c.1529) — la amancebada de Cortés, apodada la Malinche — traducía del náhuatl al maya-yucateca, Aguilar lo hacía en cascada del maya al español, y viceversa; ${ }^{226}$ hasta que ella dominó la lengua castellana y Aguilar dejó de ser imprescindible. Muchos acusan a la Malinche de haber traicionado a su pueblo, especialmente por haber alertado a Cortés de que los cholulas planeaban emboscar a los españoles. ${ }^{227}$ Otros la consideran una víctima de las circunstancias, que logró sobrevivir - no obstante su condición de mujer, de indígena, de esclava, y al hecho

\footnotetext{
${ }^{225}$ De manera parecida, cuando Juan Ortiz se reencuentra con sus compatriotas, "no llevaba [puestos] sino unos pañetes por vestidura y un arco y flechas en las manos y un plumaje de media braza en alto sobre la cabeza por gala y ornamento" (Inca Garcilaso, La Florida del Inca II.I.VI.83).

"[D]ice [Joan Coles] que el gobernador le dio luego un vestido de terciopelo negro y que por estar hecho a andar desnudo, no lo pudo sufrir, que solamente traía una camisa y unos calzones de lienzo, gorra y zapatos, y que anduvo así más de veinte días, hasta que poco a poco se hizo a andar vestido" (ibídem 85).

226 “[D]oña Marina en todas las guerras de la Nueva España y Tlaxcala y México fué tan excelente mujer y buena lengua [intérprete] [...] [A] esta causa la traía siempre Cortés consigo" (Díaz del Castillo, Historia verdadera I.XXXVII.146).

"[D]oña Marina sabía la lengua de Guazacualco [náhuatl], que es la propia de México, y sabía la de Yucatán y Tabasco, que es toda una; entendíanse bien, y Aguilar lo declaraba en castellano a Cortés" (ibíd. XXXVII.147).

227 ،[U]na india vieja, mujer de un cacique [...] vino secretamente a doña Marina, nuestra lengua [...] le dijo y aconsejó que se fuese con ella [a] su casa si quería escapar con vida, porque ciertamente aquella noche y otro día nos habían de matar a todos [...] Y la doña Marina entra de presto donde estaba el capitán y le dice todo lo que pasó con la india, la cual luego la mandó traer él [...] Y la pusieron guardas por que no se fuese" (Díaz del Castillo, Historia verdadera LXXXIII, 286-87).

A consecuencia de la supuesta traición de la Malinche, en 1519 las huestes de Cortés masacraron alrededor de seis mil indígenas.
} 
de pertenecer a un pueblo vencido-, gracias a haberse convertido en amancebada de Cortés y de haber puesto al servicio del conquistador sus habilidades linguiísticas, culturales y diplomáticas (Barjau 20-1; Karttunen 313; Miller 23-4; Todorov 30; Valdeón 172-3).

A pesar de la gran importancia del papel de la Malinche en la conquista de México, para los fines del tema que me ocupa ella resalta más como la madre de Martín (1522-c. 1595), el hijo que tuvo con Cortés, por ser este vástago el primer mestizo identificable nacido en tierras americanas, aunque, en estricto rigor, los primeros hispanoamericanos habrían sido los hijos de Guerrero, personaje que - a pesar de que en su tiempo fue visto como un renegado y un apóstata-actualmente es considerado el padre del mestizaje en Hispanoamérica. En todo caso, tanto la Malinche, una india españolizada, y Guerrero, un español indianizado, son ejemplos icónicos de la transculturación que, desde el siglo XVI, se ha repetido ad infinitum en América. Como íconos culturales híbridos, la Malinche y Guerrero simbolizaban la posibilidad, en tanto que Aguilar significaba la negación (Otero Luque, "Intérpretes y transculturados" 37-8).

En su ensayo titulado El laberinto de la soledad (1950), Octavio Paz postula que "[1]a Chingada — encarnada supuestamente por la Malinche — es la Madre abierta, violada o burlada por la fuerza". Por lo tanto, el "hijo de la Chingada"-Martín Cortés y, por extensión, todos los mestizos hispanoamericanos_-serían "el engendro de la violación, del rapto o de la burla" (103). ${ }^{228}$ Anteriormente a Paz, en Perfil del hombre y de la

\footnotetext{
${ }^{228}$ Enseguida, Octavio Paz agrega: "Si se compara esta expresión con la española, 'hijo de puta', se advierte inmediatamente la diferencia. Para el español la deshonra consiste en ser hijo de una mujer que voluntariamente se entrega, una prostituta; para el mexicano en ser hijo de una violación" (103).

Contrariamente a la explicación de Octavio Paz con respecto a la procedencia del "hijo de la Chingada", Bernal Díaz del Castillo relata que, en 1523, cuando doña Marina se reencontró, luego de muchos años,
} 
cultura en México (1934) Samuel Ramos (1897-1959) sostenía-basado en las teorías de

Alfred Adler sobre los complejos-que "el mexicano ha desarrollado un sentimiento de inferioridad o inseguridad colectiva ante lo europeo (Oviedo, Historia del ensayo hispanoamericano 84). Según Ramos, “de una situación desventajosa nace el sentimiento de inferioridad que se agravó con la conquista, el mestizaje [énfasis mío], y hasta por la magnitud desproporcionada de la Naturaleza" (El perfil del hombre y la cultura en México 51).

\section{La importancia de un nombre}

El Inca Garcilaso de la Vega fue el hijo mestizo y bastardo que el capitán Sebastián Garcilaso de la Vega y Vargas, un conquistador español de noble abolengo, tuvo con Isabel Chimpu Ocllo, una palla inca. ${ }^{22}$ Fue bautizado como Gómez Suárez de Figueroa en honor a su ancestro, el Conde D. Gómez Suárez de Figuera (Riva-Agüero, Introducción, Comentarios reales ix) y usó ese nombre hasta que cumplió los 24 años de edad, en 1563, cuando decidió cambiárselo. De ahí en adelante empezó a firmar con el de

con su madre y con su medio hermano, les dijo que "Dios la había hecho mucha merced en quitarla de adorar ídolos y ahora ser cristiana, y tener un hijo de su amo y señor Cortés, y ser casada con un caballero como su marido Juan Jaramillo; que aunque la hiciera cacica de todas cuantas provincias había en la Nueva España, no lo sería, que en más tenía servir a su marido y a Cortés que cuanto en el mundo hay" (Historia verdadera XXXVII.147). En otras palabras, la Malinche se sentía feliz de ser, paradójicamente, bígama y cristiana a la vez, y se consideraba realizada por el hecho de haber concebido un hijo del Conquistador.

En ese sentido, la realidad de México no era muy distinta a la del Perú. El Inca Garcilaso relata que, "viendo los indios alguna india parida de español, toda la parentela se juntaba a respetar y servir al español como a su ídolo, porque había emparentado con ellos" (Historia general del Perú II.I.118).

La exclamación vulgar peruana “¡Puta madre!” (cuyo equivalente en inglés sería “Fuck!”, "Holy shit!”), tan arraigada en el vulgo, tendría sus orígenes en la madre ancestral que se entregó al extranjero invasor. La variante "de la puta madre" es empleada para dar a entender que algo o alguien es o está bueno(a) o excelente. Por ejemplo, "El día está de la puta madre" significa "Hoy está haciendo muy buen tiempo".

229 “[A] la Reina, mujer legítima del Rey, llama Coya [...] [A] todas las demás mujeres de la sangre real, llamaban Palla: quiere decir mujer de la sangre real" (Inca Garcilaso, Comentarios reales I.XVI.45). 
Garcilaso de la Vega, primero; y con el de Inca Garcilaso de la Vega, después. ${ }^{230}$ Aunque el Inca Garcilaso no explica qué lo indujo a cambiarse de nombre en varias ocasiones, es evidente que quería ser llamado como su padre (Mazzotti, "Garcilaso en el Inca Garcilaso" 186-77). Por otro lado, discrepando de Raúl Porras Barrenechea, Mazzotti descarta la posibilidad de que, debido a su vocación literaria, el Inca hubiese querido emular a Garcilaso de la Vega, el gran poeta del Siglo de Oro español, que era pariente suyo (ibíd. 187). En el último y definitivo cambio de nombre, nuestro personaje se antepone la palabra "Inca", probablemente porque anhelaba que la composición onomástica que lo identificaba aludiese tanto a su ilustre progenie extremeña como a su noble estirpe indígena. Max Hernández asegura que "la elección del nombre Garcilaso de la Vega que el Inca comparte con el conquistador y el poeta homónimos, apunta a una fantasía. La de restituir al padre, cuyos servicios no fueron reconocidos y cuya lealtad fue cuestionada, su gloria y valor" (Memoria del bien perdido 97).

\section{Amancebamiento y bastardía}

Durante la Conquista y los primeros años de la Colonia, la bastardía era algo relativamente común en el Perú, pues los "hijos naturales" abundaban en el Cusco de aquella época. ${ }^{231}$ Recuérdese que, a diferencia de la inmigración a la Nueva Inglaterra, a donde los colonos puritanos llegaron en familia, al Perú fueron hombres solos que se

\footnotetext{
230 "En esos siglos era costumbre general que el apellido paterno se reservara a los mayorazgos e hijos primeros, y que los restantes adoptaran los otros apellidos de la ascendencia, para mantener vivo el recuerdo de los más gloriosos enlaces" (Riva-Agüero, "Introducción" ix-x). El nombre Garcilaso proviene de la unión de Garcí con Lasso (ibíd. ix).

231 "La violencia, el desequilibrio numérico de los sexos entre los primeros inmigrantes — casi todos varones al principio- y las relaciones de fuerza se desbordaban hacia la violación, el concubinato y las relaciones de ocasión" (Hernández, Memoria del bien perdido 198).
} 
amancebaron con las indígenas. Riva-Agüero explica que "[1]os conquistadores encumbrados no solían casarse con mujeres de raza india, por augusta que fuera la cuna de ellas, a no ser con hijas o hermanas de los últimos soberanos" (Comentarios reales, Introducción x-xi). Pero Isabel Chimpu Ocllo, que pertenecía a "una rama menor y arruinada desde Atahualpa, mera sobrina de Huayna Cápac ${ }^{232}[\ldots]$ no fue sino manceba del orgulloso Garcilaso" (ibíd. x-xi). ${ }^{233}$ Es así que, en 1549 “el Capitán Garcilaso, ya mayor de cincuenta años, se resolvió a contraer proporcionado enlace con una dama castellana [doña Luisa Martel de los Ríos]” (ibíd. xvi-xvii). Cuando ocurrieron estos acontecimientos, el Inca Garcilaso, que entraba a la adolescencia, continuó viviendo con su padre - acompañado ahora de su esposa—, en tanto que su madre se casó con Juan del Pedroche, un español de a pie con quien tuvo dos hijas (Castro Arenas, "Las tres crisis del Inca Garcilaso” 272).

Tanto Riva-Agüero como Porras Barrenechea y Castro Arenas, entre otros, comentan el dolor que debió de haberle ocasionado al Inca Garcilaso el hecho de que su padre dejara a su madre. Es notorio el resentimiento con el que el Inca Garcilaso aborda el tema de las concubinas y de los hijos ilegítimos: "Algunos ha habido en el Perú que [...] han casado con indias, aunque pocos [...] Sus hijos dirán cuán acertado haya sido, pues desde los espitales [sic] en que viven, ven gozar a los hijos ajenos de lo que sus padres ganaron y sus madres y parientes ayudaron a ganar” (Historia general del Perú

${ }^{232}$ Huayna Cápac (1493-1525), hijo y sucesor de Túpac Yupanqui (1441-1493), era tío de Isabel Chimpu Ocllo, la madre del Inca Garcilaso.

La familia del Inca Garcilaso fue víctima de las crueldades cometidas por Atahualpa tras derrocar y asesinar a Huáscar, el legítimo inca (Comentarios reales IX.XXXII-XXXIX.435-37).

233 "En el tumultuoso desarreglo de la Conquista, reciente aún, [...] el concubinato era muy acepto y público, y casi siempre decoroso a los ojos de todos" (Riva-Agüero, Comentarios reales, Introducción xi). Sin embargo, posteriormente, "el gobierno instaba de continuo a los encomenderos que se casasen, para atender a la estabilidad y moralidad de la colonia, y al incremento de la población blanca" (ibíd. xvi- xvii). 
II.I.118). En la última parte de este fragmento, el Inca se refiere, probablemente, a los inconvenientes que se les presentarían a los hijos ilegítimos para reclamar herencias.

Richard Konetzke explica que, “[a] pesar de que la legislación permitía y en parte favorecía los matrimonios mixtos hispano-indios [...] el matrimonio legal de un hombre blanco con una india se consideraba socialmente degradante (123). Esto es contrario a lo que afirma Fernando Fuenzalida, según quien “[e]sta fusión no resultó impedida por el prejuicio racial que, para el español del siglo XVI, producto de más de tres mil años de mezclas raciales, era prácticamente inexistente" ("Identidad cultural”). Es más, el matrimonio entre conquistadores y miembros de la nobleza indígena fue alentado por las Leyes de India (ibíd.). Raúl Porras Barrenechea especula que el hecho de que el capitán Sebastián Garcilaso de la Vega Vargas se casara con la dama española doña Luisa Martel "por prescripción real a fin de conservar su encomienda, abandonando a su manceba india, a la que casó, según parece, con algún escudero llamado Pedrachi” probablemente fue "el primer dolor y resentimiento del joven Garcilaso, quien continuó viviendo al lado del padre y de la madrastra" ("El Inca Garcilaso de la Vega" 393). ${ }^{234}$ Javier Yarza Rovira indica que la posición social de los hijos ilegítimos en la sociedad dependía, en buena medida, del grado de aceptación paterna del que gozaban ("Génesis y evolución del mestizaje"). ${ }^{235}$ De hecho, el capitán Garcilaso de la Vega crio a su hijo y se preocupó de que recibiera una esmerada educación. Le asignó un ayo (Juan de Alcobaza), le hizo

\footnotetext{
${ }^{234}$ En 1558, cuando ocurrieron estos acontecimientos que habrían dejado desolado al Inca Garcilaso, él tenía alrededor de dieciocho años.

${ }^{235}$ Esto lo indica Enrique Javier Yarza Rovira en su trabajo titulado "Génesis y evolución del mestizaje en el Río de la Plata", en el cual puede apreciarse que algunos aspectos de la realidad argentina son también aplicables a la peruana.
} 
tomar clases de latín (con Juan de Cuéllar), y lo entrenó en equitación y en el manejo de armas. En 1557, el capitán redactó su testamento, en el que le dejó a su hijo una herencia de "cuatro mil pesos de oro y de plata ensayada" para que pudiera estudiar en España (Castro Arenas). El previsor padre murió dos años más tarde.

\section{Viaje a España y gestiones infructuosas}

En 1560, a los 21 años de edad, tras la muerte de su padre, el Inca Garcilaso viajó a la madre patria, mas no tanto con la intención de educarse sino, principalmente, para reclamar que le restituyeran a su madre las tierras que le habían expropiado, y para cobrar las mercedes reales que le correspondían a su padre por los servicios prestados en la Conquista (Riva-Agüero xxii). En España, el Inca Garcilaso agotó todos los recursos administrativos posibles sin lograr su cometido, debido a que su padre había sido acusado de traición por haber participado en la batalla de Huarina (1547) en el bando de las fuerzas rebeldes lideradas por Gonzalo Pizarro. ${ }^{236}$ En esa encrucijada de su vida, el Inca Garcilaso probablemente hubo de preguntarse si debía o no volver al Perú y optó, finalmente, por quedarse en Europa.

Fernando Rodríguez-Mansilla sostiene que la traición de Sebastián Garcilaso de la Vega marcó la vida de su hijo "como hierro caliente". A esta razón el crítico atribuye que una parte significativa de la obra del Inca Garcilaso se ocupe de reivindicar a su progenitor: "Seguramente con un afán de remediar este trauma, o al menos paliarlo, el

236 “[E]1 Licenciado Lope García de Castro [...], estando en su tribunal me dijo: ‘QQué merced queréis que os haga Su Majestad, habiendo hecho vuestro padre con Gonzalo Pizarro lo que hizo en la batalla de Huarina, y dándole aquella tan gran victoria?' Y aunque yo repliqué que había sido testimonio falso que le habían levantado, me dijo: 'Tiénenlo escrito los historiadores ¿y queréislo vos negar?"'(Inca Garcilaso, Historia general del Perú V.XXIII.480). 
Inca está obsesionado con la lealtad, con la ejemplar caballería, con el honor [...Las] reiteraciones en sus textos y su conducta no hacen más que contrarrestar la misma repetición de la escena traumática del padre traidor, que le obsesiona y no puede abandonar del todo" ("La sombra del padre" 179).

\section{Alistamiento en la milicia}

Tras sus infructuosas gestiones, el Inca Garcilaso decidió alistarse en el ejército en 1564, plegándose a las huestes de la misma corona que ha subyugado al pueblo inca y que, en esta ocasión, sometería a los moriscos en la Guerra de las Alpujarras. Esta aparente contradicción se explicaría por el anhelo del Inca Garcilaso de emular a su padre, y lo consiguió, pues a los treinta años de edad obtuvo el grado de capitán. ${ }^{237}$ Castro Arenas especula que lo hizo por necesidad económica, porque se le había acabado el dinero que le había dejado su padre. Para Max Hernández, el Inca Garcilaso se enroló en la milicia porque era un "cruzado de la fe" (118), tanto así que, en los Comentarios reales, declara que su motivación de escribirlos es, exclusivamente, su amor por la patria y su deseo de servir a la cristiandad (Proemio al lector 4). Asimismo, el Inca le dedica su Historia General del Perú a "la gloriosísima Virgen María, nuestra señora, hija, madre y esposa virginal de su criador, suprema princesa de las criaturas". En otra parte de esta dedicatoria, manifiesta que los "peruanos vencidos" resultaron "con favor del cielo vencedores del demonio, pecado e infierno, recibiendo un Dios, una fe y un bautismo" (20). De acuerdo con Camayd-Freixas, en la interpretación teológica de la historia que

\footnotetext{
${ }^{237}$ Martín Cortés, el hijo que tuvo Hernán Cortés con la Malinche peleó en la guerra de las Alpujarras en el bando cristiano y, al igual que el Inca Garcilaso, obtuvo el grado de capitán (Claro Valdés et al, Chilena o cueca tradicional 29).
} 
hace el Inca Garcilaso, el Tawantinsuyo "había alcanzado el pleno desarrollo de la razón, pero le faltaba el conocimiento de la fe" (Etnografía imaginada 31). De alguna manera, la devoción cristiana del Inca Garcilaso explicaría que se prestara a someter a los moriscos "herejes" en la Guerra de las Alpujarras (1568).

Aurora Fiengo-Varn opina que, si bien el Inca Garcilaso era biológicamente mestizo, ideológicamente se alineaba con la mentalidad del conquistador, representado por su padre ("Reconciling the divided self" 126). Lo cierto es que el Inca sentía una gran admiración por su progenitor, como lo evidencian "La Oración Fúnebre de un religioso a la muerte de Garcilaso, mi señor”, que Castro Arenas le atribuye a su autoría, así como el hecho de que el Inca Garcilaso obtuviera una bula papal para exhumar los restos de su padre, que yacían en el Cusco, e hiciera que los trasladaran a Sevilla para sepultarlos allí (Historia general del Perú XII.XII.719). Todo esto da cuenta del cariño y de la admiración que el hijo sentía por el padre y hace suponer que se alistó en el ejército, entre otros motivos, porque deseaba emularlo. ${ }^{238}$

\section{Mestizo y bastardo}

No obstante gozar de la aceptación paterna y de haber recibido una buena educación, el hecho de ser mestizo y bastardo son dos condiciones que debieron de haber marcado profundamente al Inca Garcilaso, especialmente por la época y los lugares en que le tocó vivir: primero en el virreinato del Perú (Gobernación de Nueva Castilla) desde 1539 hasta 1560; y luego en España (Corona de Castilla) desde 1560 hasta 1616. Como ya he

\footnotetext{
238 "Qué lengua podrá contar los trabajos que padeció, los peligros a que se puso, el hambre, sed, cansancio, frío y desnudez que padeció, las tierras nunca vistas que anduvo y las inmensas dificultades que venció" (Historia general del Perú VIII.XII.722)
} 
comentado, si al principio de la época colonial las uniones fuera del matrimonio entre conquistadores e indias contaban con el consentimiento tácito de la Iglesia católica, aquella laxitud inicial se fue rigidizando con el transcurso del tiempo (Yarza Rovira, entre otros). Alberto Flores Galindo considera a los mestizos bastardos "los verdaderos hijos de la conquista, producto de esa orgía colectiva que fueron las marchas y las huestes peruleras. Hijos naturales, personas ilegítimas. A su condición étnica sumaron una difícil [...]” (“Sueños y pesadillas”, Obras completas 373). Nada difícil resulta completar la oración con la serie de obstáculos y limitaciones que todos conocemos.

Berta Ares Quejia señala que, yéndose a España, el Inca Garcilaso se alejó del ambiente de marginación en que vivían los hijos ilegítimos en la colonia ("El Inca Garcilaso y sus 'parientes' mestizos” 15-16). Sin embargo, el Inca Garcilaso llegó a la Metrópoli en 1560, a inicios de la Contrarreforma (1560-1648). Felipe II acababa de ascender al trono (1556) y España, la potencia más importante del mundo en aquella época, se había erigido como la máxima defensora de la Iglesia católica que, para ese entonces, ya no veía con buenos ojos las uniones libres entre las parejas ni a los hijos tenidos fuera del matrimonio. El Inca Garcilaso llegó, asimismo, al país de los vencedores, donde él representaba al conquistado y donde su condición de mestizo probablemente lo hacía ser percibido—y percibirse—como un ser inferior por partida doble.

\section{Amerindios subhumanos}

El hecho de ser bastardo y mestizo debió de haberle causado al Inca Garcilaso una incomodidad mayor, por decir lo menos, en la Europa de mediados del siglo XVI. El Inca 
Garcilaso se hallaba en una España renacentista con cargados resabios medievales, en donde, si bien se afianzaba la noción de valorar al individuo, propia del Renacimiento, y se escribía en defensa de los derechos de los amerindios, ${ }^{239}$ en la práctica las normas promulgadas para protegerlos eran letra muerta en las colonias. ${ }^{240}$ Uno de los principales detractores de los indígenas fue el influyente filósofo y jurista Juan Ginés de Sepúlveda (1490-1573), quien justificaba la Conquista con el argumento de que los amerindios eran, respecto del hombre, tan inferiores como los niños y las mujeres (De la justa causa de la guerra contra los indios 306).

\section{Florecimiento económico e intelectual}

En 1570 falleció Alonso de Vargas, el tío que el Inca Garcilaso tenía en Montilla y que lo acogió con verdadero afecto, convirtiéndose en su benefactor. Es así que, en 1586, cuando murió doña Luisa Ponce, la viuda de don Alonso, el sobrino recibió una significativa herencia, gracias a la cual le fue posible dedicarse a sus intereses personales como historiador y literato en la ciudad de Córdoba, en donde residió hasta el fin de sus días. En 1586, siendo todavía militar, el Inca Garcilaso terminó la traducción al español

\footnotetext{
${ }^{239}$ Por ejemplo, la Brevísima relación de la destrucción de las Indias de Bartolomé de la Casas (1474 u 84-1566). La primera parte fue terminada en 1542 y la otra en 1547. Ambas fueron puestas en circulación en esos años y publicadas en 1552. Otro ejemplo es Historia Verdadera de la Conquista de la Nueva España de Bernal Díaz del Castillo (1492 o 98-1584). Esta obra fue terminada y puesta en circulación en 1568, pero no publicada hasta 1632.

En 1561, el Inca Garcilaso de la Vega conoció a Bartolomé de la Casas en Madrid (Riva-Agüero xxiii).

${ }^{240}$ Las Leyes de Burgos (1512 y 1513), las Leyes Nuevas (1542) y la Recopilación de Leyes de las Indias (1680), un compendio de preceptos jurídicos reivindicatorios de la dignidad del indígena.
} 
de los Dialoghi d'amore de León Hebreo. ${ }^{241}$ Riva Agüero afirma que "[l]a calidad de la obra lo catapulta de inmediato al centro de la atención de los círculos intelectuales de la época [...] [E]1 primer trabajo literario de este soldado, nacido en Indias, superó y eclipsó sin disputa, según la autorizada opinión de Menéndez Pelayo, las demás versiones castellanas" (xxvii). El Inca Garcilaso fue, pues, "el primer escritor mestizo que alcanzó los niveles más refinados de la cultura europea" (Pupo-Walker, "Sobre la configuración narrativa de los Comentarios reales" 135).

Sin duda, el Inca Garcilaso debió de romperles los esquemas a los intelectuales peninsulares, quienes lejos de toparse con un individuo descalzo, semidesnudo y hablando un dialecto ininteligible — como era de esperarse por el tipo de descripciones de amerindios que solían hacer los cronistas oficiales-, la intelligentsia de la época se encuentra con un individuo exótico, mestizo y refinado, ${ }^{242}$ que domina el castellano y otras lenguas, poseedor de una vasta cultura y, además, relativamente acaudalado. En ese sentido, el Inca Garcilaso "resumía, en términos humanos e históricos, la empresa española en América" (Pupo-Walker 124). No sería exagerado afirmar que, a través de su obra, el Inca Garcilaso se convirtió a sí mismo en un personaje literario.

\footnotetext{
241 "Hacia 1589, muertos ya sus tíos y favorecedores, D. Alonso de Vargas y el marqués viudo de Priego, Garcilaso se mudó de Montilla a Córdoba", en donde "vivió modesta y sosegadamente" (Riva-Agüero, Comentarios reales, Introducción xxix).

En esos tiempos el Inca Garcilaso gozaba de una economía relativamente holgada. Por ejemplo, “[p]oseía, fuera de otros censos pequeños, los juros sobre el Marquesado de Priego; y tenía como administrador y recaudador de sus rentas, y encargado de su capellanía en Montilla, al presbítero y licenciado Cristóbal Luque Bernaldino. Se mantenía con el decoro suntuario que creía deber a su clase" (ibíd. xxxii).

${ }^{242}$ El refinamiento del Inca Garcilaso provenía de la cuna: "El opulento Capitán Garcilaso [se refiere al padre] vivía con esplendidez extraordinaria. Por carta del Virrey Marqués de Cañete, sabemos que un tiempo comían de diario a sus manteles de ciento cincuenta a doscientos camaradas, fuera de algunos caballeros principales invitados especialmente a su mesa [...] En este medio de magnificencia y señoril boato se despertó el niño mestizo a la razón y al sentimiento" (Riva-Agüero xi).

"Siendo un clérigo solo y retirado, por su testamento y concilios vemos que lo servían seis criados [...]. Según sus inventarios lo prueban, usaba vajilla de plata sobredorada, y adornaban sus aposentos paños con dibujos de boscajes y lampazos, almohadas de seda carmesí, escritorios y bufetes de nogal" (ibíd. xxxii).
} 
En muy corto tiempo, los Comentarios reales fueron traducidos a varios idiomas. Fiengo-Varn cree que tuvieron tan buena acogida porque fueron considerados la prueba tangible de los esfuerzos de la Corona española destinados a "civilizar" y cristianizar a los pueblos andinos (126). En cuanto a la resonancia de los Comentarios, suele afirmarse que el utópico mundo incaico que el Inca Garcilaso describe en ella habría influido en la escritura de La Nueva Atlántida (1626) de Francis Bacon. Siguiendo a Mircea Eliade en The Two and the One (1965), Teodoro Hampe hace notar que "los Comentarios reales exponen el gobierno y la cultura de los incas bajo la forma neoplatónica del Estado perfecto, sugiriendo una identificación entre la época del Tahuantinsuyu y la anhelada ‘edad de oro' [...] [L]a utopía incaica garcilasiana trascendió en la Europa del siglo XVII hasta el punto de ser comentada por Francis Bacon, Bernard Fontenelle y otros pensadores notables" (“El renacentismo del Inca Garcilaso revisitado” 2-3). Asimismo, la historia de Pedro Serrano - un náufrago que vivió siete años en un isla solitaria ubicada entre La Habana y Cartagena de Indias-que el Inca refiere (Comentarios reales I.VIII.17-21) pudiera haber inspirado el Robinson Crusoe (1719) de Daniel Defoe. Lo que sí es más probable es que la lectura de los Comentarios le enardeciera la sangre a Túpac Amaru II (1738-1781) y lo impulsara a llevar a cabo su Gran rebelión anticolonial (1780-1782). Cabe recordar que, con el propósito de prevenir el surgimiento de otras sublevaciones, en 1783 la obra fuera prohibida en los virreinatos del Perú y de Río de la Plata. 


\section{Genealogía, vástago biológico e hijos literarios}

En 1588 nació Diego de Vargas, el hijo natural y mestizo que el Inca Garcilaso tuvo con Beatriz de Vega, su criada. ${ }^{243}$ Sin embargo, el padre no menciona este trascendental hecho ni en sus escritos ni en su testamento y, al no reconocer oficialmente a su vástago, lo condenó a la bastardía (Hernández 199-200). ¿Por qué haría el Inca tal cosa, habiéndola sufrido él en carne propia? En 1590, tomó los hábitos y, en 1597, figuraba en una escritura como clérigo; en consecuencia, había recibido las órdenes menores. En 1596, preocupado siempre por el tema de su estirpe, confeccionó la Genealogía o Relación de descendencia del famoso Garci Pérez de Vargas; es decir, la suya propia. En 1605, publicó en Lisboa La Florida del Inca y, en 1609, publicó, también en Lisboa, sus Comentarios reales. La Historia general del Perú; es decir, la segunda parte de los Comentarios reales, fue publicada póstumamente, en 1617, en Córdoba. En 1612, probablemente con la intención de perennizar su nombre, compró la capilla de Las ánimas, en la catedral-mezquita de Córdoba, un templo mestizo en donde fue enterrado en 1616, a la edad de 77 años. La inscripción en su lápida no hace sino evidenciar su afán de reconciliar ambos mundos, de resaltar su noble estirpe tanto por el lado paterno como por el materno; y de sacarle brillo a sus méritos literarios y militares: "El Inca Garcilaso de la Vega, varón insigne, digno de perpetua memoria. Ilustre en sangre. Perito en letras. Valiente en armas. Hijo de Garcilaso de la Vega. De las Casas de los duques de Feria e Infantado y de Elisabeth Palla, hermana de Huayna Cápac, último emperador de las

\footnotetext{
${ }^{243}$ Entre 1504 y 1544 nació Francisca de Moscoso y de la Vega, la hija que tuvo el Inca Garcilaso con su esposa, Francisca de Moscoso, quien también había sido mujer de Suero Vázquez de Mosquera y Moscoso. 〈https://www.geni.com/people/Francisca-de-Moscoso-y-de-la-Vega/6000000000477534453>
} 
Indias. Comentó La Florida. Tradujo a León Hebreo y compuso los Comentarios reales [...]". Parafraseando a Flores Galindo, el Inca Garcilaso convirtió el fracaso en creación.

\section{La personalidad de un modesto comentarista que protesta la historia oficial}

Algunos rasgos distintivos de la personalidad del Inca Garcilaso se ven nítidamente reflejados en toda su producción literaria, pero en particular en los Comentarios reales, su obra cumbre. Por ejemplo, se muestra pudoroso al solicitarles a sus lectores que mantengan una especie de castidad auditiva antes de que él pase a contarles que ciertos individuos preincaicos caminaban desnudos o semidesnudos a la intemperie: "El vestir por su indecencia era más para callar y encubrir que para lo decir y mostrar pintado, mas porque la historia me fuerza a que la saque entera y con verdad, suplicaré a los oídos honestos se cierren por no oírme en esta parte [énfasis mío], y me castiguen con este disfavor, que yo lo doy por bien empleado. [...] y no pasemos adelante que no es lícito" (Comentarios reales I.XIII.26).

Aun cuando la falsa modestia era una fórmula retórica empleada con mucha frecuencia en la época, es, además, una de las características saltantes en la personalidad del Inca Garcilaso. Por ejemplo, utiliza este recurso en los Comentarios reales para no enfrentarse directamente a aquellos a quienes, en realidad, intenta descalificar: "[N]o diremos cosa grande que no sea autorizándola con los mismos historiadores españoles que la tocaron en parte o en todo; que mi intención no es contradecirles, sino servirles de comento y glosa y de intérprete en muchos vocablos indios [énfasis mío]" (Proemio al lector 4). La reescritura de la Historia empieza para Garcilaso, como Dios en la Creación, con el acto mismo de nombrar. Enseguida añade: "Espero que se recibirá con la misma 
intención que yo le ofrezco, porque es la correspondencia que mi voluntad merece, aunque la obra no la merezca [énfasis mío]" (ibíd. 4). En otras palabras, el Inca Garcilaso manifiesta que no abordará temas distintos de los ya tratados por los cronistas peninsulares, aunque hace la salvedad de que algunos de esos temas han sido tratados de manera parcial. Asimismo, dice que su intención no es contradecirles sino comentar sus escritos y que desea contribuir a la correcta interpretación de las voces quechuas. Pero, acto seguido, solicita al lector que aprecie su obra desde la humilde perspectiva en que él la plantea, aunque la obra misma ni siquiera haga justicia a tal pretensión (nuevamente, su falsa modestia). Luego, agrega: “Aunque ha habido españoles curiosos [énfasis mío] que han escrito las repúblicas del Nuevo Mundo [..., ] no ha sido con la relación entera que de ellos se pudiera dar [...] de las cuales, como natural de la ciudad del Cuzco, que fue otra Roma en aquel Imperio, tengo más larga y clara noticia que la que hasta ahora los escritores han dado. Verdad es que tocan muchas cosas de las muy grandes que aquella república tuvo, pero escríbenlas tan cortamente que aun las muy notorias para mí (de la manera que las dicen) las entiendo mal" (Ibíd., Premio al lector 4). Cuando el Inca Garcilaso emplea el adjetivo de "curiosos" para calificar a los españoles que escribieron sobre el Nuevo Mundo, no se refiere a que hayan sido cuidadosos y diligentes en la ejecución de la tarea, pues está siendo irónico. Recordemos que la parodia es una de las estrategias del colonizado para socavar el discurso hegemónico (Hutcheon, A Theory of Parody, 1985).

A diferencia del Inca Garcilaso, cuya falsa modestia lo distingue, Felipe Guamán Poma de Ayala es abierto, directo y sincero; virtudes que se advierten desde el título mismo de su monumental obra: Nueva crónica y buen gobierno. Tanto el cronista 
mestizo como el indígena intentaban reconciliar el mundo inca con el español, pero utilizaron estrategias retóricas distintas. El legado de Guamán Poma ha sido ampliamente estudiado por Rolena Adorno, quien lo resume con las siguientes palabras:

[A] treatise on "good government" that would combine Inca social and economic organization with European technical achievements and religious culture modified to meet Andean needs [...] He called his book a "new" chronicle because he knowingly contradicted many established sources on matters of Inca and conquest political history in order to effectively put forward certain juridical arguments about the rights of native Andeans to hegemony over their own territories. ("Felipe Guamán Poma de Ayala")

La audacia de Guamán Poma de Ayala, en su atrevimiento de darle pautas a Felipe III para el desempeño de un buen gobierno en el Perú, ${ }^{244}$ es sólo comparable—sino mayor, debido al hecho de ser indígena - a la de Hernán Cortés, quien, en su cuarta cartarelación (1524), se permite aconsejarle al emperador Carlos V que la Casa de Contratación de Sevilla prohíba que zarpen hacia el Nuevo Mundo los navíos que no porten un cargamento de plantas europeas, destinadas a su reproducción en las tierras conquistadas. En Coronica, Pratt encuentra "autoethnography, transculturation, critique, collaboration, bilinguism, mediation, parody, denunciation, imaginary dialogue, vernacular expression” (37). Ciertamente, tanto el Inca Garcilaso-mestizo-como

\footnotetext{
${ }^{244} \mathrm{He}$ framed his outcry against injustice and his formal plans for viceregal reform on the basis of his concerns about the gradual extinction of the Andean race through miscegenation, abusive treatment by the colonists, disease [...] With respect to the future, Guaman Poma argued for broad colonial reforms consisting of the restoration of Andean leadership [...] He conceived political dominion as a world to be governed by the autochthonous princes of their respective realms under the titular (honorary) headship of the king of Spain. (Adorno, "Felipe Guamán Poma de Ayala").
} 
Guamán Poma de Ayala —indígena — principalmente se camuflan para reaccionar, desde un flanco menos riesgoso, en contra del bando oficial y subvertir su historiografía, que se regodeaba en enlodar la realidad prehispánica. "Después de todo—reflexiona CamaydFreixas-, la reescritura de la historia oficial siempre fue un aspecto fundamental de las crónicas mestizas del período colonial” (9).

Como puede apreciarse en el Proemio, el Inca Garcilaso también se vale de la ocasión para comparar a la capital del Tahuantinsuyo con la Roma imperial, en un intento de homologar el nivel de desarrollo cultural de los incas con el de los europeos. Sin embargo, el Inca reconoce que "Roma hizo ventaja al Cozco, no por haberlos criado mejores, sino por haber sido más venturosa en haber alcanzado letras y eternizado con ellas a sus hijos, que los tuvo no menos ilustres por las ciencias que excelentes por las armas; los cuales se honraron al trocado unos a otros [...] [L]a desdicha de nuestra patria, que, aunque tuvo hijos esclarecidos en armas y de gran juicio y entendimiento, y muy hábiles y capaces para las ciencias, porque no tuvieron letras no dejaron memoria de sus grandes hazañas y agudas sentencias, y así perecieron ellas y ellos juntamente con su república" (ibíd. XVII.XVIII.290). ${ }^{245}$

\footnotetext{
${ }^{245}$ Teodoro Hampe asevera que "[e]l mero hecho de describir los pueblos indígenas del Nuevo Mundo por medio del alfabeto y del libro, dando por sentado que los aborígenes no podían hacer lo mismo con la cultura colonizadora, sirvió para justificar coactivamente la magna empresa de ultramar" ("El renacentismo del Inca Garcilaso revisitado" 14). El Inca Garcilaso entendió perfectamente el poder de la palabra y eso debió de motivarlo a cultivarse como escritor.

En La ciudad letrada (1984), Ángel Rama (1926-1983) resalta el poder de la lengua escrita y de los letrados o intelectuales en la construcción de las naciones hispanoamericanas: "La escritura construyó las raíces, diseñó la identificación nacional, enmarcó la sociedad en un proyecto" (97). "[E]n las capitales virreinales hubo una ciudad letrada que componía el anillo del poder y el ejecutor de sus órdenes: Una pléyade de religiosos, administradores, educadores, profesionales, escritores y múltiples servidores intelectuales, todos esos que manejaban la pluma [...] Desde el último tercio del siglo XVI, ese equipo mostró dimensiones desmesuradas, que no se compadecían con el reducido número de los alfabetizados a los cuales podía llegar su palabra escrita" (ibíd. 25).
} 
El Inca Garcilaso pone mucho énfasis en la minusvalía que el desconocimiento del quechua les impone a los cronistas peninsulares: "En el discurso de la historia protestamos la verdad de ella [...] como extranjeros en aquella lengua, interpretaron fuera de la propiedad de ella (ibíd., Premio al lector 4). Camayd-Freixas señala que el Inca Garcilaso "iguala el saber lingüístico con el empírico, al que suple y sustituye", y que, ante el "texto oral de sus parientes Incas [..., ] que por ser el más antiguo constituye la última autoridad [...] Garcilaso sería a la vez redactor, traductor y exégeta" (Etnografía imaginaria 34). Margarita Zamora, por su parte, observa que el Inca Garcilaso basa su defensa del quechua siguiendo a Antonio de Nebrija, con cuya obra estaba familiarizado y quien, en Apología (1506), aboga por el estudio y la preservación del hebreo y del griego, argumentando que son las lenguas que recogen las ideas originales de la Iglesia y que, por lo tanto, las transmiten de manera más exacta (Language, Authority, and Indigenous History 25-6).

Lo sorprendente es que, en La Florida del Inca (1605), el Inca Garcilaso manifiesta haberse olvidado de hablar quechua: “[P]or no haber tenido en España con quien hablar mi lengua natural y materna, que es la general que se habla en todo el Perú [...], se me ha olvidado de tal manera que, con saberla hablar tan bien y mejor y con más elegancia que los mismos indios que no son incas [...] no acierto ahora a concertar seis o siete palabras en oración para dar a entender lo que quiero decir, y más, que muchos vocablos se me han ido de la memoria, que no sé cuáles son, para nombrar en indio tal o tal cosa. Aunque es verdad que, si oyese hablar a un inca, lo entendería todo lo que dijese, si oyese los vocablos olvidados, diría lo que significan; empero, de mí mismo, por mucho que lo procuro, no acierto a decir cuáles son. Esto he sacado por experiencia del 
uso o descuido de las lenguas, que las ajenas se aprenden con usarlas y las propias se olvidan no usándolas" (II.I.VI.84). En los Comentarios reales, el Inca reitera que adolece de este problema de memoria: “Cómo se llame el tigre en la lengua general del Perú, se me ha olvidado [...] Reprendiendo yo mi memoria por estos descuidos, me responde que por qué le riño de lo que yo mismo tengo la culpa; que advierta yo que ha cuarenta y dos años que no hablo ni leo en aquella lengua. Válgame este descargo para el que quisiere culparme de haber olvidado mi lenguaje" (VIII.XVIII.361).

Adicionalmente, el Inca Garcilaso reafirma su autoridad en el tema del incario, basándose en el mero hecho de haber nacido en el Cusco y de haber vivido durante dos décadas en esa ciudad: "Demás de habérmelo dicho los indios, alcancé y vi por mis ojos mucha parte de aquella idolatría, sus fiestas y supersticiones [...]. Yo nací ocho años después que los españoles ganaron mi tierra, y [...] me crié [sic] en ella hasta los veinte años, y así vi muchas cosas de las que hacían los indios en aquella su gentilidad, las cuales contaré diciendo que las vi" (Comentarios reales I.XIX.35). En consonancia con la noción renacentista de que lo visto y lo vivido vale más que lo aprendido de oídas, el Inca resalta la ventaja que tiene por haber sido depositario de historias preservadas por la tradición oral, y por haber recopilado testimonios de fuentes primigenias (un método historiográfico precoz para la época): “[P] ara entrar a dar cuenta del origen y principio de los Incas Reyes naturales que fueron del Perú, me pareció que la mejor traza y el camino más fácil y llano era contar lo que en mis niñeces oí muchas veces a mi madre y a sus hermanos y tíos y a otros sus mayores acerca de este origen y principio [énfasis mío], porque todo lo que por otras vías se dice de él viene a reducirse en lo mismo que nosotros diremos, y será mejor que se sepa por las propias palabras que los Incas lo cuentan que 
no por las de otros autores extraños [énfasis mío]" (ibíd. I.XV.28). En otro pasaje ratifica esta postura: "Sacada de la misma tradición que como a hijo natural [del Cusco] me cupo $y$ de lo que yo con propios ojos vi [énfasis mío]; diré los nombres antiguos que sus barrios tenían, que hasta el año de mil y quinientos y sesenta, que yo salí de ella, se conservaban en su antigüedad" (ibíd. VII.VIII.290)

Más adelante, el Inca Garcilaso vuelve a reiterar los cimientos de su autoridad en los hechos ya descritos, y subraya su labor de cotejo de otras fuentes fidedignas, que incluyen el desciframiento de los quipus por parte de los propios quipucamallocs de cada pueblo, ${ }^{246}$ una tarea que realiza por vía epistolar: "Sin la relación que mis parientes me dieron de las cosas dichas, y sin lo que yo vi, he habido otras muchas relaciones de las conquistas y hechos de aquellos Reyes. Porque luego que propuse escribir esta historia, escribí a los condiscípulos de escuela y gramática, encargándoles que cada uno me ayudase con la relación que pudiese haber de las particulares conquistas que los Incas hicieron de las provincias de sus madres; porque cada provincia tiene sus cuentas y nudos con sus historias, anales, y la tradición de ellas, y por esto retiene mejor lo que en ella pasó que lo que pasó en la ajena" (ibíd. I.XIX.35). Cabe mencionar que el sacerdote Diego de Alcobaza, hijo de Juan de Alcobaza, el ayo del Inca Garcilaso, fue uno de sus informantes (Historia general del Perú I.XXIII.76).

En este punto, es pertinente preguntarse ¿qué necesidad tenía el Inca Garcilaso de recurrir a fuentes secundarias cuando él mismo podría haber obtenido la información in

\footnotetext{
${ }^{246}$ El quipu ( $k h i p u$, en quechua) era un sistema de cuerdas de algodón dispuestas verticalmente y en paralelo, atadas generalmente a un palo, en las que se hacían nudos de varios tipos.

A los responsables de confeccionar, preservar e interpretar los quipus se les denominaba quipucamayocs (khipukamayuq, en quechua).

Los guardianes de la memoria eran los quipucamayus (narradores), los amautas (maestros o filósofos) y los harauicus (poetas) (Inca Garcilaso VI.VIII.231-2).
} 
situ? ¿Por qué nunca regresó al Perú? Cuando recibió la herencia de sus tíos, contaba con los medios económicos para costearse el viaje. ¿No extrañaba, acaso, a su madre? Cuando falleció Isabel Chimpu Ocllo en el Cusco, el Inca Garcilaso tenía 32 años y, aunque no se enteró de la muerte de su progenitora sino hasta tres años después, tampoco entonces volvió a su patria. (Castro Arenas reflexiona que, en comparación con las líneas que le dedica a su padre, el Inca apenas menciona a su madre). Continuando con las interrogantes: ¿se sentiría el Inca Garcilaso demasiado viejo para hacer un viaje transoceánico cuando empezó a escribir los Comentarios reales? Según Camayd-Freixas, el Inca no regresó a América porque no le fue posible conseguir cierto permiso que habría sido necesario (22-23).

En resumen, revestido de la autoridad que le confiere el hecho de haber sido testigo presencial de algunos eventos importantes durante sus primeros veinte años de vida transcurridos en el Cusco, de haber sido receptor de la tradición oral, de haber recopilado testimonios de fuentes primigenias, de haber cotejado otras fuentes fidedignas y de dominar el idioma quechua - a diferencia de los cronistas, a quienes atribuye un conocimiento limitado de esa lengua y, en consecuencia, interpretan mal no sólo las palabras sino también los acontecimientos-, el Inca Garcilaso protesta la veracidad de la historia oficial. "Protestación del autor sobre la Historia" es, precisamente, el título del capítulo XIX del libro primero de los Comentarios reales.

\section{Desacreditar lo preincaico para realzar lo incaico}

En los Comentarios reales, el Inca Garcilaso relata y comenta la historia del Perú hasta la llegada de los españoles. Tan interesante es lo que narra como la manera en que 
desacredita sistemáticamente al mundo preincaico y, al mismo tiempo, realza por oposición la obra civilizadora de los incas. Su coartada es descalificar a los preincas, asociándolos con los atributos del salvaje: “[E]n todo vivían y viven hoy como bestias y peores, porque no llegó a ellos la doctrina y enseñanza de los Reyes Incas” (I.X.22) En otras palabras, plantea una realidad inferior y primitiva anterior al imperio Inca.

El Inca Garcilaso distingue dos edades en la historia del Perú prehispánico: "Para que se entienda mejor la idolatría, vida y costumbres de los indios del Perú, será necesario dividamos aquellos siglos en dos edades: diremos cómo vivían antes de los Incas y luego diremos cómo gobernaron aquellos Reyes, para que no se confunda lo uno con lo otro ni se atribuyan las costumbres ni los dioses de los unos a los otros" (ibíd. I.IX.21). La estrategia discursiva del Inca es descalificar todo lo concerniente al mundo preincaico, tildándolo de salvaje y de bárbaro, para ponderar por contraste la obra civilizadora de los incas en los pueblos que ellos conquistaron: "[E]n todo vivían y viven hoy como bestias y peores, porque no llegó a ellos la doctrina y enseñanza de los Reyes Incas" (ibíd. I.X.22). Por ejemplo, afirma que los preincas desconocían el urbanismo y que algunos habrían sido incluso trogloditas: "Los más políticos tenían sus pueblos poblados sin plaza ni orden de calles, ni de casas, sino como un recogedero de bestias [...] Otros en chozas derramadas por los campos, valles y quebradas, cada uno como acertaba a tener la comodidad de su comida y morada. Otros vivían en cuevas debajo de tierra, en resquicios de peñas, en huecos de árboles, cada uno como acertaba a hallar hecha la casa, porque ellos no fueron para hacerla" (ibíd. I.XII.24). Es sorprendente que el Inca Garcilaso haya hecho semejantes generalizaciones del mundo preincaico, desconociendo civilizaciones con avanzada arquitectura - amén de otras artes y ciencias-, como lo son 
las culturas sechín, chavín, paracas, lima, moche o nasca, por citar unos ejemplos. Considerando que los incas reinaron en el Tahuantinsuyu desde circa 1200 d.C. hasta 1532 d.C.; es decir, muy posteriormente al apogeo de las civilizaciones antes mencionadas, larga data sobre ellas debieron de haber recolectado en el Cusco. De hecho, como hemos visto, en los Comentarios reales menciona el templo de Pachacámac, perteneciente a la cultura Lima (ibíd. II.II.50-53).

Metódicamente, el Inca Garcilaso subraya la obra civilizadora de los incas, contrastándola con la barbarie supuestamente existente en el mundo preinca. Para avalar su testimonio, el Inca refiere que un anciano tío suyo por el lado maternopresumiblemente, el Inca Cusi Huallpa-le contó lo siguiente: "Sabrás que en los siglos antiguos toda esta región de tierra que ves eran unos grandes montes y breñales, y las gentes en aquellos tiempos vivían como fieras y animales brutos, sin religión, ni policía, sin pueblo ni casa, sin cultivar ni sembrar la tierra, sin vestir ni cubrir sus carnes, porque no sabían labrar algodón ni lana para hacer de vestir. Vivían de dos en dos, y de tres en tres, como acertaban a juntarse en las cuevas y resquicios de peñas y cavernas de la tierra; comían como bestias yerbas del campo y raíces de árboles, y la fruta inculta que ellos daban de suyo, y carne humana. Cubrían sus carnes con hojas y cortezas de árboles, y pieles de animales; otros andaban en cueros. En suma, vivían como venados y salvajinas, y aun en las mujeres se habían como los brutos, porque no supieron tenerlas propias y conocidas" (ibíd. I.XV.29)

El Inca Garcilaso relata, asimismo, que los habitantes del mundo preincaico "se juntaban al coito como bestias, sin conocer mujer propia, sino como acertaban a toparse, y otras se casaban como se les antojaba, sin exceptuar hermanas, 
hijas ni madres" (ibíd. IXIV.27) y que eran antropófagos, filicidas, parricidas y matricidas: "[S]acrificaban hombres y mujeres de todas las edades [...] Y en algunas naciones fue tan inhumana esta crueldad, que excedió a la de las fieras, porque llegó a no contentarse con sacrificar los enemigos cautivos, sino sus propios hijos [...] [V]ivos les abrían por los pechos y sacaban el corazón con los pulmones [...] y comían al indio sacrificado con grandísimo gusto y sabor y no menos fiesta y regocijo, aunque fuese su propio hijo" (ibíd. I.XI.23). Peor aún: “[M]ataban a los hijos que habían engendrado, y los parientes que habían criado a trueque de comérselos, y lo mismo hacían con los padres, cuando ya no estaban para engendrar, que tampoco les valía el parentesco de afinidad. Hubo nación tan extraña en esta golosina de comer carne humana, que enterraban sus difuntos en sus estómagos" (ibíd. I.XII.25). ${ }^{247}$ Bien podemos imaginar al lector europeo de principios del siglo XVII, incrédulo ante estas líneas cargadas de una morbosidad tal que no hacían sino reafirmar la leyenda negra sobre el Nuevo Mundo tejida por cronistas como Ginés de Sepúlveda. En Orientalism (1978), el pensador palestino Edward Said (1935-2003) señala que el Oriente, más que un lugar concreto en el mapamundi, es una "geografía imaginativa" — o imaginaria — en la que mora un Otro supuestamente inferior (en ocasiones, atractivo por lo exótico) sobre el cual los "persistentes y sutiles prejuicios eurocéntricos" han proyectado, de manera falaz y

\footnotetext{
${ }^{247}$ Aunque no es posible afirmar que estas prácticas eran generales, hay otros testimonios de sodomía y canibalismo entre los antiguos peruanos. Por ejemplo, "[s]egún Guamán Poma, en el Antisuyo el difunto era comido por la comunidad y los huesos se depositaban en un árbol, olvidándolos para siempre. 'Aquí se olvidaba a sus muertos tras comerlos y enterrarlos; tampoco les lloraban (...)'; el autor expone además 'la inferioridad cultural de estos pueblos' manifestada en la sencillez de sus ritos fúnebres: 'Ni saben ninguna ceremonia como los indios de la sierra' (1979, p.209)" (Accorsi 21). De otro lado, Pedro Cieza de León "cautioned that the accounts of sodomy and cannibalism he presented regarding some groups-obviously considered the most grave among all Amerindian shortcomings - were not to be generalized to all [...] he acknowledged having created an account that, in spite of his own intentions, could be used by antiindigenist polemicists in debates on the rights of conquest" (Adorno, "The Depiction of Self and Other in Colonial Peru" 111).
} 
tendenciosa, sus propias abyecciones (Otero Luque, "Literaturas y comunidades imaginadas de Mariátegui” 12).

\section{¿Inferior y traidor?}

Frantz Fanon analiza el complejo de inferioridad que experimenta el sujeto negro como consecuencia del racismo y de la pérdida de su identidad (Piel negra, máscaras blancas, 1952); mas su análisis también es válido para los casos del indígena y del mestizo. Según el psicólogo austriaco Alfred Adler (1870-1937), los individuos que padecen un complejo de inferioridad necesitan descalificar y despreciar a otros para elevar su autoestima y sentirse mejor (Oberst et al, "La psicología individual de Alfred Adler" 36). A la luz de la teoría de Adler, no debería sorprendernos que el Inca Garcilaso descalifique al mundo preincaico para resaltar la valía de la civilización inca, de la que él es y se siente parte.

En "La Metaotredad en Comentarios reales", Francisco Manzo-Robledo, escéptico al postulado garcilasiano en cuanto a la acción benéfica de los incas sobre el mundo preincaico, interpela al Inca Garcilaso desde la perspectiva de la traición, comparándolo con Moctezuma y Doña Marina, en México, quienes facilitaron la Conquista. De otro lado, José Antonio Mazzotti opina que el desprecio del Inca Garcilaso por las culturas indígenas no cusqueñas y el encomio que hace a la labor de los conquistadores (Historia general del Perú I.II.35) lo descalifica como representante de la nacionalidad peruana (citado en Lima, “400 años de los Comentarios reales” 263). Peor aún, el Inca Garcilaso se abstiene de condenar el holocausto de la Conquista (FiengoVarn 119). En su defensa, me permito recordar que, siendo el Inca Garcilaso bastardo y 
mestizo, tuvo necesariamente que "camuflarse" (en terminología de Homi K. Bhabha) para poder sobrevivir en un ambiente adverso y en una peligrosa época inquisitorial.

\section{Complejo de superioridad}

Adler postula que algunos individuos desarrollan un sentimiento de minusvalía frente a los demás, generalmente debido a traumas infantiles motivados, entre otras causas, por la burla y el rechazo social. Inconscientemente, el individuo afligido intenta compensar ese sentimiento. Para algunos, es un estímulo que los impulsa a alcanzar ciertos objetivos. Por ejemplo, la baja estatura de Napoleón podría haber disparado en él su anhelo de conquistar el mundo. Pero a otras personas el mismo sentimiento les genera la necesidad de esconder las carencias o deficiencias de las que adolecen, o creen o temen adolecer y, con ese afán, resaltan exageradamente ciertas cualidades en las que sobresalen, obteniendo, de este modo, la percepción de considerarse superiores a los demás (IPolis). El complejo de superioridad emboza, pues, un complejo de inferioridad subyacente (Adler, Social Interest 226; Oberst et al, "La Psicología Individual de Alfred Adler" 3839; Ramos, Perfil del hombre y de la cultura en México 51).

Por el hecho de ser hijo de un conquistador español de origen noble y de una palla inca, el Inca Garcilaso sentiría que pertenecía a lo mejor de dos mundos-el Viejo y el Nuevo-y, sin embargo, a ninguno de ellos por entero. Su lado español representaba el poder dominante y el peldaño más alto en la escala social de la colonia. Mas él no era totalmente español y su sangre mezclada sería percibida por los peninsularesgachupines incluidos — como inferior. 
Por otra parte, los parientes del Inca Garcilaso por el lado materno eran los vencidos, los despojados, quienes lloraban y añoraban las glorias pasadas:

[R]esidiendo mi madre en el Cuzco, su patria, venían a visitarla casi cada semana los pocos parientes y parientas [...] en las cuales visitas siempre sus más ordinarias pláticas eran tratar del origen de sus Reyes, de la majestad de ellos, de la grandeza de su Imperio, de sus conquistas y hazañas, del gobierno que en paz y en guerra tenían, de las leyes que tan en provecho y a favor de sus vasallos ordenaban [...]. De las grandezas y prosperidades pasadas venían a las cosas presentes, lloraban sus Reyes muertos, enajenado su Imperio y acabada su república [...] y con la memoria del bien perdido siempre acababan su conversación en lágrimas y llanto, diciendo: "Trocósenos el reinar en vasallaje". (Comentarios reales 1. XV.28-29)

Cuando nació el Inca Garcilaso (1539) todavía no había transcurrido una década desde que Francisco Pizarro arribara al Perú (1532) y alterase el curso de la civilización inca. Incluso veinte años después, antes de que el Inca Garcilaso partiera a España, resulta fácil visualizarlo reunido con sus parientes por el lado materno, lamentándose del tan recientemente "bien perdido". Quizás, en el fondo, ellos también percibían al Inca Garcilaso-que, en ese entonces, todavía conservaba el nombre de Gómez Suárez de Figueroa — como el fruto de un ultraje más por parte de los invasores. 


\section{Incas contra preincas y españoles contra indígenas}

Como he mencionado, en la Europa de principios del siglo XVII los amerindios en general eran considerados bárbaros y paganos: "[S]iendo por naturaleza siervos los hombres bárbaros, incultos é inhumanos, se niegan á admitir la dominación de los que son más prudentes, poderosos y perfectos que ellos; dominación que les traería grandísimas utilidades, siendo además cosa justa, por derecho natural, que la materia obedezca á la forma, el cuerpo al alma, el apetito á la razón, los brutos al hombre, la mujer al marido, los hijos al padre, lo imperfecto á lo perfecto, lo peor á lo mejor, para bien universal de todas las cosas. Este es el orden natural que la ley divina y eterna manda observar siempre" (Sepúlveda, De la justa causa de la guerra contra los indios 350). Por la presunta inferioridad evolutiva de los amerindios preincaicos, pero, sobre todo, por el hecho de carecer de la "verdadera" fe, la Conquista habría estado plenamente justificada en la percepción del Inca Garcilaso: “[P]ara que se den gracias a Nuestro Señor Jesucristo y a la Virgen María su Madre, por cuyos méritos e intercesión se dignó la Eterna Majestad de sacar del abismo de la idolatría tantas y tan grandes naciones, y reducirlas al gremio de su Iglesia católica romana, Madre y Señora nuestra" (Comentarios reales, Proemio al lector 4).

Regido por esta lógica, el Inca Garcilaso loa a los conquistadores por haber traído la nueva religión al Nuevo Mundo, aunque en el proceso lo hayan saqueado: "[L]a predicación del Santo Evangelio [...] es lo más que se debe estimar [...] [Francisco Pizarro, Diego de Almagro y Hernando de Luque] "fueron los primeros cristianos que lo predicaron en aquel gran Imperio del Perú, y abrieron por aquella parte las puertas de la Iglesia Católica Romana, madre nuestra, para que hayan entrado y entren en su gremio 
tanta multitud de fieles $[\ldots]$ ¿Y quién podrá decir la grandeza de solo este hecho? ¡Oh nombre y genealogía de Pizarros, cuánto te deben todas las naciones del Mundo Viejo, por las grandes riquezas que del Mundo Nuevo les has dado! [énfasis mío]. Y cuánto más te deben aquellos dos imperios peruano y mejicano, por tus dos hijos Hernando Cortés y Francisco Pizarro, y los demás sus hermanos Hernando Pizarro y Juan Pizarro, y Gonzalo Pizarro, los cuales mediante sus grandes trabajos e increíbles hazañas les quitaron las infernales tinieblas en que morían, y les dieron la luz evangélica en que hoy viven! ;Oh descendencia de Pizarros, bendígante las gentes de siglo en siglo por padre y madre de tales hijos [...]! [énfasis mío]" (Historia general del Perú I.II.35).

En la apreciación del Inca Garcilaso, el aporte material del Nuevo Mundo al Viejo vale mucho menos que el aporte espiritual del Viejo Mundo al Nuevo. Una visión similar a la del Inca Garcilaso puede apreciarse en el poema titulado "A España" (incluido en el poemario Fe, patria y hogar) que, en 1886 y desde Bogotá, Lastenia Larriva de Llona (1848-1924) — una de las mujeres ilustradas del Perú decimonónico-le dedica al rey Alfonso XII con motivo de su reciente fallecimiento:

Madre de gloriosísimos anales, también mi parte en tu dolor reclamo.

Y, junto con tus lágrimas, derramo mis lágrimas amargas a raudales.

Fue mi patria en los tiempos coloniales.

De tu gran tronco, predilecto ramo. Y allá en su suelo que venero y amo, Palacios erigiste y catedrales. 
¡Lo están diciendo esas recientes ruinas

que hoy riegan mis hermanos con su lloro:

Si de sus ricas, fabulosas minas

Ella te dio un tiempo plata y oro,

Ciencias le diste y Artes peregrinas,

y de la Cruz el celestial Tesoro! [énfasis mío] (47)

\section{Los incas como facilitadores de la cruzada evangelizadora}

El Inca Garcilaso sostiene que los incas prepararon el camino para la evangelización: “[S]e ha notado cuánto más prontos y ágiles estaban para recibir el Evangelio los indios que los Reyes Incas sujetaron, gobernaron y enseñaron" (Comentarios reales I.XV.28). Según Teodoro Hampe, el pensamiento del Inca evidencia cierto "providencialismo de impronta agustiniana", por el cual "el Imperio de los incas es concebido —igual que la Roma de los Césares- como un estadio de preparación para la entrada triunfal del cristianismo en su territorio" (3). Pero el Inca Garcilaso va más allá del ámbito terrenal en sus disquisiciones, pues intenta extrapolar aspectos religiosos de los incas a la doctrina cristiana, y viceversa: "Demás de adorar al Sol por Dios visible [...,] los reyes Incas y sus Amautas, que eran los filósofos, rastrearon con lumbre natural al verdadero sumo Dios y señor nuestro, que creó el cielo y la Tierra [...] Tuvieron al Pachacámac en mayor veneración interior que al Sol [...] [N]o osaban tomar su nombre en la boca, y al Sol le nombran a cada paso" (Comentarios reales II.II.49). Un poco más adelante, continúa diciendo: "[L]os Indios rastrearon con este nombre y se lo dieron al verdadero Dios nuestro [...] Pero si a mí, que soy indio cristiano católico, por la infinita misericordia, me 
preguntasen ahora “¿cómo se llama Dios en tu lengua?”, diría "Pachacámac”, porque en aquel general lenguaje del Perú no hay otro nombre para nombrar a Dios sino éste" (ibíd. II.II.50-51). ${ }^{248}$ En resumen, "el Dios de los cristianos y el Pachacámac era todo uno" (ibíd. II.II.50). Empero, cuando "el Padre Fray Vicente de Valverde dijo al Rey Atahualpa que Cristo Nuestro Señor había creado el mundo", el Inca le respondió que "él no sabía nada de aquello, ni que nadie crease nada sino el Sol, a quien ellos tenían por Dios y a la Tierra por madre y a sus huacas; y que Pachacámac lo había creado todo" (ibíd. II.II.50). ${ }^{249}$

El Inca Garcilaso señala la ausencia de templos y sacrificios dedicados a este dios incorpóreo: "Demás del Sol, adoraron al Pachacámac [...] interiormente, por dios no conocido: tuviéronle en mayor veneración que al Sol; no le ofrecieron sacrificios ni le hicieron templos [énfasis mío], porque decían que no le conocían, porque no se había

\footnotetext{
${ }^{248}$ El Inca Garcilaso relata este incidente con base en su lectura de Historia del descubrimiento y conquista de la provincia del Perú, libro II, capítulo V (Amberes, 1555), del cronista peninsular Agustín de Zárate (1514-1585) (Comentarios reales II.II.49-50).

De acuerdo con Agustín Zárate, Felipillo, el indio tallán que fungió de "lengua" o faraute en aquella ocasión, habría hecho una mala interpretación con la intención de perjudicar a Atahualpa: "Y como las averiguaciones que sobre esto se hicieron era por lengua del mismo Felipillo, interpretaba lo que quería conforme a su intención; la causa que le movió nunca se pudo bien averiguar, mas [...] este indio tenía amores con una de las mujeres de Atabáliba y quiso con su muerte gozar de ella seguramente" (Historia del descubrimiento, Libro II, capítulo VII, citado en Garcilaso, Comentarios reales IV.IV.143 ).

Para más información sobre Agustín de Zárate, consúltese: Hampe Martínez, Teodoro. "Agustín de Zárate, contador y cronista indiano (Estudio biográfico)". Mélanges de la Casa de Velázquez 27.2 (1991): 129-54. Red.

<http://www.persee.fr/doc/casa_0076-230x_1991_num_27_2_2587>

Sin embargo, el Inca Garcilaso contradice la versión de Zárate: "Tal y tan aventajado fué el primer intérprete que tuvo el Perú, y, llegando a su interpretación, es de saber que la hizo mala y de contrario sentido, no porque lo quisiese hacer maliciosamente, sino porque no entendía lo que interpretaba y que lo decía como un papagayo, y por decir Dios Trino y Uno, dijo 'Dios tres y uno son cuatro', sumando los números por darse a entender. Consta esto por la tradición de los quipus" (Historia general del Perú I.XXIII.75, 78).
}

${ }^{249}$ El Inca Garcilaso reitera en veces ocasiones que los incas únicamente tenían dos dioses: "[N]no tuvieron más de dos dioses, que fueron el Pachacámac, no visto ni conocido, y el Sol, visible y notorio" (Comentarios reales V.XVII.197). 
dejado ver [énfasis mío]; empero que creían que lo había” (II.IV.53). Sin embargo, se contradice, puesto que antes había dado cuenta del "famoso templo que allí [en el valle llamado precisamente Pachacámac] edificaron a este Dios no conocido [no visto]” (ibíd. II.II.50). ${ }^{250}$ Es importante aclarar que Pachacámac y Wiracocha son el mismo dios (Historia general del Perú I.XXIII.78-79). ${ }^{251}$ Por lo tanto, hubo templos dedicados a Wiracocha/Pachacámac. Aunque existen distintas versiones acerca de la jerarquía que ocupaba este dios con respecto al Dios Sol, hay consenso de que, mientras el Dios Sol está, indiscutiblemente, más directamente vinculado a la mitología cusqueña y, específicamente, a la dinastía inca (de la Torre 56; Zamora 123; y Zuidema 167, entre otros), Wiracocha es el dios más destacado en el mundo andino (Rostworowski, Estructuras andinas del poder 30). María Rostworowski indica que, en las inmediaciones del Cusco, existían santuarios dedicados a este dios (ibíd. 30). De hecho, el propio Inca

\footnotetext{
${ }^{250}$ En 1653, el sacerdote y cronista Bernabé Cobo y Peralta (1582-1657) decía lo siguiente acerca del "famoso templo de Pachacama" [sic]: "Después del soberbio templo del Sol tenía el segundo lugar en grandeza, devoción, autoridad y riqueza el Pachacama; al cual, como á santuario universal, venían en peregrinación las gentes de todo el imperio de los Incas y ofrecían en él sus votos" (Historia del Nuevo Mundo, tomo IV XVII.47). Más adelante, Cobo dice: "No era este gran templo obra de los Reyes Incas, sino mucho más antiguo, como los indios cuentan y se echa de ver en la forma y calidad de su fábrica, que es muy diferente de las otras de los incas, que casi todas eran de piedra labrada, y si ésta lo fuera, pudiera competir con los más soberbios edificios del mundo" (ibíd. 52).

El gran templo de Pachacámac, perteneciente a la cultura Lima y ubicado a las afueras de esta ciudad, está conformado por edificaciones sucesivas que datan desde el siglo III d.C. hasta el tiempo de los incas. El material de construcción preponderante es el adobe.

${ }^{251}$ Pachacámac: pacha $=$ tierra; $k a m a q=$ creador; en quechua. Por lo tanto, Pachacámac significa "Creador de la Tierra".

Pachacámac "lo había creado todo [...] aquellos indios le tenían por hacedor de todas las cosas (Comentarios reales II.II.50).

Wiracocha: wira $=$ grasa o espuma; qocha $=$ gran cuerpo de agua, en quechua. Por lo tanto, Wiracocha puede interpretarse como "Espuma del mar" (Cieza de León, El señorío de los incas V).

Como referencia, Luis Eduardo Valcárcel Vizcarra (1891-1987) se graduó de Bachiller en Letras de la Universidad Nacional de San Antonio Abad del Cusco con la tesis "Kon, Pachacámac y Wiracocha" (1912).

Naylamp es otro dios vinculado al agua, que era adorado en la costa norte del Perú.

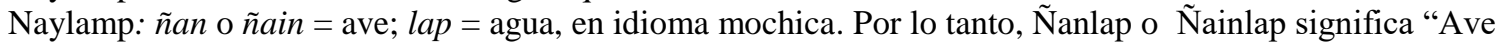
de agua".
} 
Garcilaso relata que el príncipe Viracocha (llamado originalmente Hatun Tópac) mandó construir un magnífico templo (que luego fue destruido por los españoles) en el pueblo de Cacha, ubicado a dieciséis leguas al sur del Cusco, en honor al fantasma de su tío-dios Viracocha Inca (Comentarios reales V.XXII.203-5), quien se le apareció en sueños (ibíd. V.XVII.194), y que se identificó como "hijo del Sol y hermano de los Incas" (ibíd. V.XXI.203).

Si bien Wiracocha/Pachacámac es un dios asociado a lo inmaterial y a lo abstracto - aspectos que el Inca Garcilaso desea destacar para hacerlo más parecido al Dios cristiano (blanqueamiento)—, curiosamente la imagen del fantasma que se le aparece a Hatun Tópac en sueños se corresponde con la de Jesús o con la de algún apóstol: "[T]enía barbas en la cara, a diferencia de los indios que generalmente son lampiños, y que traía el vestido hasta los pies, diferente del hábito del que los indios traen, que no les llega más de hasta la rodilla" (ibíd. V.XXI.201). "Era un hombre de buena estatura, con una barba larga de más de un palmo; los vestidos, largos y anchos, como túnica o sotana, llegaban hasta los pies" (ibíd. V.XXII.204). Pedro Cieza de León también presenta al Viracocha/Ticiviracocha/Tuapaca aparecido en Cacha a imagen y semejanza de Jesús (El señorío de los incas V). En suma, "el Dios de los cristianos y el Pachacámac era todo uno (Inca Garcilaso, Comentarios reales II.II.50).

Seguramente, con el mismo propósito de equiparar la deidad autóctona con la importada, el Inca Garcilaso informa acerca de la existencia, desde tiempos no determinados, de una cruz en la huaca inca de una casa real en el Cusco: "Tuvieron los Reyes Incas, en el Cuzco, una cruz de mármol fino, de color blanco y encarnado, que le llaman jaspe cristalino: no saben decir desde qué tiempo la tenían $[\ldots]$ La cruz era 
cuadrada, tan ancha como larga; tendría de largo tres cuartas de vara $[\ldots]$ y tres dedos de ancho y casi otro tanto de grueso; era enteriza, toda de una pieza, muy bien labrada [...] la piedra muy bruñida y lustrosa. Teníanla en una de sus casas reales, en un apartado de los que llaman huaca, que es lugar sagrado. No adoraban en ella, más de que tenían en veneración; debía ser por su hermosa figura o por algún otro respeto que no saben decir” (Comentarios reales II.III.51-52). Pero, ¿la forma de la cruz no representaría, quizás, los cuatro suyos del Tahuantinsuyo? Es extraño que el Inca Garcilaso no mencione la chakana, el símbolo andino en forma de cruz escalonada (12 puntas) y simétrica, con un círculo inscrito en el centro, que es empleado para ordenar visualmente el mundo.

\section{De dioses tangibles y ocupados}

Acerca de la interpretación de los cronistas sobre la teogonía del panteón andino, el Inca Garcilaso denuncia que "[1]os españoles aplican otros muchos dioses a los Incas, por no saber dividir los tiempos y las idolatrías de aquella primera edad y las de la segunda, y también por no saber la propiedad del lenguaje, para saber pedir y recibir la relación de los indios, de cuya ignorancia ha nacido dar a los Incas muchos dioses o todos los que ellos quitaron a los Indios que sujetaron a su imperio" (ibíd. II.IV.53-54). A partir de esta premisa, el Inca Garcilaso esboza dos interesantes conceptos que explicarían la voluntad politeísta del pueblo preincaico y la naturaleza material de su panteón de dioses: 1) el dios tangible y 2) el dios ocupado: "Y principiando de sus dioses, decimos que los tuvieron conforme a las demás simplicidades y torpezas que usaron, así en la muchedumbre de ellos como en la vileza y bajeza de las cosas que adoraban, porque era así que cada provincia, cada nación, cada pueblo, cada barrio, cada linaje y cada casa 
tenía dioses diferentes unos de otros, porque les parecía que el dios ajeno, ocupado con otro [énfasis mío], no podía ayudarles, sino el suyo propio [...] y porque no supieron, como los gentiles romanos, hacer dioses imaginados [énfasis mío], como la Esperanza, la Victoria, la Paz y otros semejantes, porque no levantaron los pensamientos a cosas invisibles, adoraban lo que veían [énfasis mío] [...,] sin consideración de las cosas que adoraban, si merecían ser adoradas, ni respeto de sí propios, para no adorar cosas inferiores a ellos; sólo atendían a diferenciarse éstos de aquellos y cada uno de todos" (ibíd. I.IX.21). Más adelante, añade: “Tuvieron asimismo los Incas, la resurrección universal, no para gloria ni pena, sino para la misma vida temporal, que no levantaron el entendimiento a más que esta vida presente" (ibíd. II.VII.60). Evidentemente, esta concepción está reñida con la promesa bíblica de la vida eterna. En este aspecto, Camayd-Freixas advierte que el Inca Garcilaso adopta "el hábito europeo de negarles a los indios la capacidad de pensamiento abstracto" (35).

De acuerdo con el Inca Garcilaso, los preincas adoraban tótems; es decir, objetos simbólicos e icónicos; o, avant la lettre, "huacas móviles”, en el caso específico del mundo andino (Arriaga 202, citado en de la Torre 59). ${ }^{252}$ Siguiendo a Mircea Eliade (Tratado de historia de las religiones 80-83), Arturo de la Torre señala que los "dioses mediadores", no tan poderosos en comparación con las deidades celestiales, cumplen la función de intermediarios entre el hombre y los grandes dioses uránicos, quienes suelen hacerse a un lado una vez concluida su creación y se desentienden de los asuntos

\footnotetext{
${ }^{252}$ Según Freud, un tótem generalmente es un animal. Las plantas y las fuerzas de la naturaleza son tótems menos comunes. El tótem constituye el espíritu tutelar y ancestral del clan y, aunque pueda infundir temor, es condescendiente con sus criaturas y les envía oráculos (Totem and Taboo 2).

Juan Polo de Ondegardo y Zárate confeccionó una larga y detallada lista de todas las cosas que adoraban los indígenas: Tratado y averiguación sobre los errores y supersticiones de los indios (1559).
} 
domésticos de sus criaturas. A diferencia de los dioses uranios-etéreos y ocupados, o distraídos-, los dioses mediadores son más concretos, cercanos y asequibles, y están más atentos a las necesidades terrenales (Movimientos milenaristas 57). Erik CamaydFreixas - siguiendo a Claude Lévi-Strauss y a Folco Quilici-afirma que expresarse en términos concretos es una de las características de las culturas primitivas. ${ }^{253}$ Enseguida explica: "Sus mitos explican los orígenes y las creencias religiosas, y establecen leyes, preceptos y costumbres, pero no directamente, sino mediante la representación de situaciones concretas y de las acciones ejemplares de personajes míticos" (Realismo mágico 71-2).

Según Freud, los clanes veneran tótems (dioses mediadores) para diferenciarse unos de otros y, de esa manera, adquieren un sentido de identidad colectiva. Cabe resaltar que Freud le da crédito al Inca Garcilaso por haberse percatado de que los antiguos peruanos tenían esa necesidad (Totem and Taboo 94-5). Pero no solamente los preincas adoraban tótems, debido a que los incas nobles—no los preincas atrasados e ignorantes a los que alude con desdén el cronista mestizo - veneraban a las momias de sus antepasados, llamadas malquis. El propio Inca Garcilaso da fe de haber visto malquis con sus propios ojos en la posada del corregidor Juan Polo de Ondegardo, justo antes de partir a España (Comentarios reales I.XXIX. 215-16). ${ }^{254}$

${ }^{253}$ Lévi-Strauss, Claude. The Savage Mind, Londres: Weidenfeld \& Nicholson, 1974. Quilici, Folco. Primitive Societies. Nueva York: Collins, 1972.

${ }^{254}$ En el Perú existe la costumbre de visitar a los parientes y amigos difuntos en el cementerio el 2 de noviembre de cada año, en que se celebra o conmemora el Día de todos los Santos y todos los Muertos. Sin embargo, a la usanza de los mexicanos, recientemente en el Perú ha revivido la costumbre de organizar un picnic macabro en honor a los difuntos amados. Esta manifestación tiene como antecedente la fiesta de la Pacarikuspa ("amaneciéndose). Es pertinente recordar que los incas enterraban a sus deudos con comida para que pudieran alimentarse en el viaje al más allá, pero al cabo de un tiempo los sacaban y les "dan de comer y beber, les ponen plumas en la cabeza, cantan y danzan con ellos y les ponen unas 


\section{Estrategias del colonizado}

El Inca Garcilaso de la Vega, además de dedicarle a la Virgen María Historia general del

Perú (la segunda parte de los Comentarios reales), publicada de manera póstuma en

1617, un hecho que implica la apropiación de la religión católica, uno de los principales

valores del conquistador, escribe otra dedicatoria en el Prólogo a esta misma obra: "A los

indios, mestizos y criollos de los reinos y provincias del grande y riquísimo imperio del

Perú, el Inca Garcilaso de la Vega, su hermano, compatriota y paisano, salud y felicidad"

(22). ${ }^{255}$ Con estas palabras, el Inca Garcilaso intenta romper con el estereotipo que

estigmatiza tanto al mestizo como al indio, ${ }^{256}$ reasignándoles un significado distinto que

no corresponde a la noción fija y prejuiciosa que les atribuye el colonizador con el

andas y andan con ellos de casa en casa y por las calles, plazas y después tornan a meterlos en sus pucullos dándoles su comida y su vajilla" (Guamán Poma de Ayala 179).

<http://chicha-gotika.blogspot.com/2011/11/la-fiesta-de-los-muertos.html>

${ }^{255}$ Este texto da cabida a interpretar que la palabra mestizo, ubicada en la frase estratégicamente entre los vocablos indio y criollo, pretende hermanar a los de los extremos. Al respecto, Cornejo Polar manifiesta que "[s]ería tentador correlacionar estilísticamente las dos enumeraciones, asociando indio a hermano, mestizo a compatriota y criollo a paisano, pero en realidad la economía de la frase parece girar sobre el término mestizo, desde el cual se abraza al indio y al criollo (es decir, a todo el mundo americano) y se acumulan los significados afectivos de la segunda enumeración [...] [A]l reivindicar enfáticamente su carácter mestizo y al asociarse fraternalmente con indios y criollos, Garcilaso asume una representatividad múltiple y ubica su discurso en el espacio de lo vario [énfasis mío]. ("Garcilaso: la armonía desgarrada", Escribir en el aire 79)

Miguel Gutiérrez Correa hace notar que, “[p]aradójicamente, mientras los destinatarios de los Comentarios reales son 'Los indios, mestizos y criollos' nacidos en el Perú, Guamán Poma escribe su Nueva Crónica y Buen Gobierno a un único lector: el Rey de España” (La generación 228).

${ }^{256}$ Los estereotipos pertenecen al ámbito de la creencia y son el componente cognitivo de una actitud particular" (Malgesini y Giménez 150). Tanto la discriminación como la xenofobia “están cognitivamente condicionadas por el estereotipo que nos hayamos formado de la persona o grupo objeto de dichas actitudes. Normalmente un estereotipo negativo está conformado por una serie de estigmas (atributos sociales negativos) que desacreditan al individuo que adscribimos a dicho grupo y que justifican esas actitudes [...] Los estereotipos juegan un papel muy importante en las relaciones entre mayorías y minorías o, más exactamente, entre dominantes y dominados. En su forma más extrema sirven para identificar fácilmente a un grupo minoritario cuando la mayoría busca una 'víctima propiciatoria', proceso por el cual la gente traspasa la responsabilidad de sus desgracias y frustraciones a otros grupos que suelen ser minorías [...] En lo que respecta al racismo y a la xenofobia, el estereotipo es - junto con el mecanismo del 'chivo expiatorio' (o cabeza de turco) - uno de los procedimientos cognitivos que subyace o fundamenta las concepciones, actitudes, creencias y conductas racistas. Dicho de otra forma, el estereotipo es uno de los mecanismos claves de la ideología racista” (ibíd. 15). 
propósito de justificar el trato desigual que les da a los integrantes de estos grupos. La reinterpretación de los significantes es una forma de resistencia que ejerce el colonizado. Como estrategia de resistencia, es muy importante el hecho de que el Inca Garcilaso utilice el idioma español, que es el código del colonizador (mímica, canibalización y blanqueamiento), ${ }^{257}$ para expresar, desde la postura de un escritor reconocido (camuflaje y etnovaivén), ${ }^{258}$ un mensaje de hermandad (filosofía neoplatónica, parte de los valores del colonizador; mímica y blanqueamiento) entre tres grupos étnicos pertenecientes, por lo menos, a dos bandos antagónicos. Mediante esta estrategia, el Inca plantea una situación ambigua que le permite, solapadamente, contravenir y subvertir el discurso oficial. $^{259}$

\footnotetext{
257 “Una de las maneras privilegiadas en que nuestro personaje asimiló la cultura renacentista [...] fue mediante la apropiación del lenguaje, vale decir, del pulimento retórico de aquella era. El Inca realizó una suerte de [...] 'conquista historiográfica' del Viejo Mundo, basada en su dominación [sic] de la lengua y estilo de los humanistas. En la mentalidad de la época, el propio arte de la escritura era visto como un sistema ideográfico y el código de la lengua era asumido como base epistemológica para el conocimiento e interpretación de la realidad (cf. Marichal 1976: 59; Pupo-Walker 1982a: 144-148) [*]" (Hampe Martínez 4).

[*] Marichal, Juan. "The New World From Within: The Inca Garcilaso." First Images of America: The Impact of the New World on the Old. Berkeley: U of California P, 1976. 57-61; y Pupo-Walker, Enrique. Historia, creación y profecía en los textos del Inca Garcilaso de la Vega. Madrid: Ediciones J. Porrúa Turanzas, 1982.

258 “[Q Q $]$ ué profesiones elegían los alumnos jóvenes de Puno que se negaban a servir en el campo? La carrera de abogado, militar, policía y comerciante. Cuando decimos que el indígena trata de identificarse con el modelo misti, queremos decir simplemente que desea para sí mismo o para sus hijos profesiones de misti. No vayamos a imaginar que trata de asimilarse [sic] todas las características de la cultura misti. Sobre todo no vayamos a creer que la cultura criolla pueda ser preferida por el indígena" (Bourricaud 26). "Sería una locura imaginar que la identificación con el modelo misti significa para el indio la asimilación de la cultura criolla (ibíd. 27). Cabe aclarar que el término "misti", empleado originalmente para referirse al hombre blanco (en especial, al hacendado), en la actualidad también denota al mestizo con poder. Gayatri Spivak (1942-...) sostiene que el subalterno debe renunciar a su identidad y convertirse en un “intelectual del primer mundo" si desea ser resonante (“Can the Subaltern Speak?”, 1985).

${ }^{259}$ Siguiendo a José Durand (*), Julio Ortega puntualiza que, el hecho de que el Inca Garcilaso abrace ideas neoplatónicas no responde exclusivamente al deseo de alinearse con la cultura hegemónica, debido a que el neoplatonismo trasciende cualquier discurso e, incluso, su propia crítica ("El Inca Garcilaso y el discurso de la cultura" 647).
} 
Cornejo Polar manifiesta que "al reivindicar enfáticamente su carácter mestizo y al asociarse fraternalmente con indios y criollos, Garcilaso asume una representatividad múltiple [híbrida] y ubica su discurso en el espacio de lo vario [ambiguo]" ("Garcilaso: la armonía desgarrada", Escribir en el aire 79). Ciertamente, el Inca Garcilaso intenta romper los estereotipos que estigmatizan al mestizo y al indígena, respectivamente, reasignándoles significados que no corresponden a las etiquetas fijas y prejuiciosas que les atribuye el colonizador con el propósito de "legitimar" el trato injusto que les da. ${ }^{260}$ Sin duda, la reinterpretación de los significantes es, pues, una de las formas de resistencia más efectivas que ha venido ejerciendo el subordinado desde el tiempo de la Invasión.

\section{Gruesas suturas de la hibridación cultural}

“A los hijos de español y de india, o de indio y española, nos llaman mestizos, por decir que somos mezclados de ambas naciones; fue impuesto por los primeros españoles en tener hijos en Indias, y por ser nombre impuesto por nuestros padres y por su significación me lo llamo yo a boca llena y me honro con él. Aunque en Indias si a uno de ellos le dicen 'sois un mestizo', lo toman por menosprecio" (Comentarios reales IX.XXXI.424-425), dice el Inca Garcilaso. Es desconcertante que se enorgullezca del apelativo de "mestizo", que, según él mismo admite, tiene una connotación peyorativa.

(*) Durand, José. “El Inca Garcilaso platónico”. Lima: Las moradas, 1949; y Miró Quesada, Aurelio. "Italia y el Inca Garcilaso". 451-76; o Miró Quesada, Aurelio. "Italia y el Inca Garcilaso". Mar del Sur 28 (1953): 1-24.

${ }^{260}$ Para Ferdinand de Saussure (1857-1913), la palabra está compuesta de un significante (la marca escrita o sonora) y de un significado (la imagen que el significante evoca en el receptor). En consecuencia, una misma palabra puede prestarse a interpretaciones múltiples (polisemia), algo así como una moneda con un sello fijo por un lado, y con uno variable por el otro, cuya interpretación depende de quien posea dicha moneda (o de quien la aprehenda, como sería en el caso de una palabra) (Otero Luque, "Borges, uno de los tantos autores de "Pierre Menard"' 3). 
En la lógica particular del Inca Garcilaso, el mero hecho de que el calificativo provenga de la voluntad de sus ancestros por el lado paterno, así sea despectivo, es motivo suficiente para enorgullecerse. Esta manera de razonar puede ser interpretada como un indicio de que el Inca Garcilaso está tratando de compensar la adversidad, reinterpretándola de una manera que, supuestamente, le resulte conveniente. ${ }^{261}$ "La escritura de los Comentarios reales pone en evidencia la falsedad de los conceptos orgánicos, biológicos y raciales aplicados a la cultura: conceptos como hibridación y mestizaje. El producto de la mezcla biológica es una nueva homogeneidad. En cambio, la mezcla cultural y la discursiva engendran un cuerpo de costuras expuestas y ontología de Frankenstein, un espacio de lo impensado que visto desde ambos polos es monstruoso, y que reconoce en sí mismo una humanidad problemática" (Camayd-Freixas 20). De otro lado, Antonio Cornejo Polar, escéptico a la realización de una mixtura racial no problemática, identifica que, en la obra garcilasiana se hace patente "su tenaz y hasta agónico esfuerzo por hacer valer la doble autoridad que le confiere su condición de mestizo y por asegurar que ésta es el signo mayor de una síntesis armónica, conciliante [sic] y englobadora [sic], trasmutando a tal efecto lo que es heterogéneo y hasta beligerante en homogeneidad tersa y sin fisuras" ("El discurso de la armonía imposible" 74).

\footnotetext{
${ }^{261}$ El Inca Garcilaso reinterpreta el significante de la palabra mestizo, suprimiendo la connotación peyorativa y reasignándole un valor que, para él, sería motivo de orgullo.

Adler denomina "comportamiento equivocado" ("misguided behavior") a ese tipo de lógica particular y errada, mediante la cual el individuo intenta compensar sus sentimientos de inferioridad e inadecuación (Social Interest 227).
} 


\section{Mestizaje: ¿La solución insoluble?}

En el discurso titulado "Elogio del Inca Garcilaso" que José de la Riva-Agüero (18851944) pronunció el 22 de abril de 1916 en la Universidad Mayor de San Marcos con motivo del tercer centenario del fallecimiento del cronista mestizo, el catedrático sanmarquino postulaba que, en la personalidad del Inca Garcilaso, "se fundieron amorosamente Incas y Conquistadores, que con soberbio ademán abrió las puertas de nuestra particular literatura y fue el precursor magnífico de nuestra verdadera nacionalidad [énfasis mío]" (Del Inca Garcilaso a Eguren 62). Con estas palabras, RivaAgüero suscribe el mestizaje racial y cultural como propuesta mediadora entre lo incario y la españolidad, y considera al Inca como el vivo ejemplo del tal planteamiento.

En opinión de Cornejo Polar, Riva-Agüero hace una "lectura plana", "avalada por una heurística positivista, que recoge con entusiasmo las afirmaciones de Garcilaso que mejor sirven a la indudable vocación armonizante y conciliadora del propio Inca, a la que suma otra lectura de igual índole, pero ésta de la biografía del personaje”. ("El discurso de la armonía imposible" 77). En otras palabras, Riva-Agüero suscribe la propuesta mediadora entre el incario y la españolidad del autor de los Comentarios reales-que surge de un tipo de pensamiento creativo, más que de un fundamento científico-, y la refrenda al considerar que el Inca es el vivo ejemplo del tal planteamiento. Cornejo Polar hace hincapié en que Riva-Agüero "no ve, o no quiere ver, las tensiones irresueltas, los conflictos dramáticos y las desgarraduras sin remedio que corroen, desde dentro, la tersura de ese discurso y la placidez de una existencia retirada" (ibíd. 77). Con cierta ironía, Cornejo Polar acusa a Riva-Agüero de haber cometido un "acto de prestidigitación retórica"-para emplear la expresión de Elmore-al equiparar a Tánatos con Eros, 
aunque comprende que lo haya hecho en aras de la construcción de la nación peruana: "Necesaria para imaginar la nación, la homogeneidad se afirma no sólo en la convergencia pacífica y constructiva de las 'razas' sino en su fusión amorosa. Casi insensiblemente, la palabra "conquista" pierde sus significados bélicos y se desplaza hacia un campo semántico tan imprevisible como — desde esa perspectiva— necesario: el del erotismo. Nacida del amor y no de la destrucción y la muerte, la patria resulta ser suma y unimismamiento de lo vario y distinto" (ibíd. 77). En todo caso, Cornejo Polar reconoce que Riva-Agüero "estableció un sólido estereotipo cuya trama $[\ldots]$ tiene dos grandes articulaciones: la que insiste en que la figura de Garcilaso es símbolo de un mestizaje armónico, y por ese camino símbolo de la peruanidad, y la que subraya la excepcionalidad de tal mestizaje por ser doblemente nobiliario. Hay que convenir que la primera de estas interpretaciones ha calado profundamente en la conciencia de vastos grupos sociales, incluso en sectores del pensamiento indigenista que, directa o indirectamente, apuestan a favor de un mestizaje integrador" ("Las figuraciones sociales del Inca", Escribir en el aire 88).

En el mismo hilo de pensamiento de Antonio Cornejo Polar, Peter Elmore colige acertadamente que, en la apología que hace Riva-Agüero del Inca Garcilaso,

del concubinato entre el capitán español Garcilaso de la Vega y la princesa quechua Isabel Chimpu Ocllo habría brotado, compleja pero sin complejos, una identidad que habría de ser propuesta extemporáneamente como espejo de la virtud cívica y modelo de la conciencia patriótica. El Inca Garcilaso de la Vega cobra, en esa versión, la calidad de ícono nacional. El deslizamiento del campo semántico de lo político al de lo 
erótico le permite a Riva Agüero, que ejecuta así un acto de prestidigitación retórica, reinventar el sentido de la invasión europea y de la destrucción de los Estados autóctonos andinos. Los bandos en contienda se transfiguran en una pareja auroral, idílica: la dicotomía formada por los vencedores y los vencidos cede, imaginariamente, su lugar a la pareja de los progenitores primordiales. La fecundidad de los cuerpos se proyecta y prolonga, además, en la abundancia de las letras, pues el vástago ejemplar habrá de convertirse en el primero de los autores canónicos del país futuro [35]. ("La sangre y la letra” 632).

Una prueba del efecto hipnótico que produce el discurso feliz del mestizaje es el poema “Blasón” de José Santos Chocano (1875-1934), incluido en el poemario Alma América (1908). He aquí un fragmento del referido poema:

Cuando me siento Inca, le rindo un vasallaje al Sol, que me da el cetro de su poder real; cuando me siento hispano y evoco el coloniaje, parecen mis estrofas trompetas de cristal.

Mi fantasía viene de un abolengo moro: los Andes son de plata, pero el León de Oro; y las dos castas fundo con épico fragor.

La sangre es española e incaico es el latido. ¡Y de no ser poeta, quizás yo hubiese sido un blanco aventurero o un indio emperador! 
A pesar del desbalance que plantea con la opción de ser "un blanco aventurero" o "un indio emperador", al igual que Riva-Agüero, Chocano se hace el ciego ante las tensiones socioeconómicas que perviven desde los horrores de la Conquista. El siguiente comentario de MVLL acerca del sentimiento del Inca Garcilaso podría ser aplicado perfectamente a la manera de sentir de Chocano: "[E]ste hombre tan orgulloso de su sangre india, que lo entroncaba con una civilización de historia pujante y altamente refinada, no se sentía menos gratificado de su sangre española, y de la cultura que heredó gracias a ella: la lengua y la religión de su padre, y la tradición que lo enraizaba en una de las más ricas vertientes de la cultura occidental” ("El Inca Garcilaso y la lengua de todos").

Debido al anhelo colectivo de imaginar una nación peruana racialmente homogénea y armónica (Cornejo Polar, "El discurso de la armonía imposible” 77), la propuesta de Riva-Agüero logró calar en un amplio segmento de la intelectualidad peruana (Cornejo Polar, "Las figuraciones sociales del Inca", Escribir en el aire 88). Es así que, Víctor Andrés Belaúnde Diez Canseco (1883-1966), por ejemplo, sostiene que la peruanidad es "una síntesis viviente de la cultura hispano-católica y de los elementos telúricos y biológicos que existían en este pedazo del nuevo mundo que habitamos" ("Peruanidad: elementos esenciales", Obras completas 411; ensayo publicado inicialmente en 1943 y ampliado en 1957); sin embargo, como puntualiza Rodrigo Montoya Rojas, Belaúnde no hace "referencia alguna a las lenguas y culturas indígenas" (Prólogo de la edición facsimilar a Tempestad en los Andes viii).

Con respecto al planteamiento reconciliador del Inca Garcilaso y al aprovechamiento que Riva-Agüero hace de ese discurso con el fin de preparar un terreno 
ideal para la construcción de la nacionalidad, Cornejo Polar concluye que, "no hay duda acerca de la estremecida tragicidad [sic] de la escritura de Garcilaso, que reproduce el crispamiento de todo acto de autoidentificación personal, social e histórica dentro del contexto de una situación colonial, ni sobre la gruesa manipulación que sufre en la recepción rivagüeriana, que sigue en buena parte vigente pese a la explicitez [sic] con que muestra las tretas de los discursos del poder" ("El discurso de la armonía imposible" 79). No obstante, según Cornejo Polar también cabe "la opción de leerlas [se refiere a las aludidas letras] dentro de un código mayor, más envolvente, que remite a la necesidad irrefutable de construir imaginaria y discursivamente un espacio sin conflictos, a la vez que, en el mismo acto, revela sus trizamientos insolubles en su propia constitución interna" (ibíd. 79). Pero, aun justificando la quimera, Cornejo Polar pone en tela de juicio que el mestizaje constituya el elemento amalgamador de la sociedad peruana en gran nación:

Cada vez creo menos en la ideología del mestizaje, entre otras muchas razones porque el concepto mismo de mestizo-mestizaje es absolutamente ambiguo y porque en el fondo sirva a cualquier fin [...] Hasta me atrevería a afirmar que el mismo Garcilaso vivió su mestizaje de muy diversas formas: a veces como legitimación doblemente nobiliaria y a veces como marginación social compartida colectivamente con los indios, los mestizos y los criollos despreciados por los españoles peninsulares; a veces como realización casi hímnica del armonismo [sic] neoplatónico y a veces como tragedia incurable. ("Cinco preguntas en torno a Garcilaso" 20) 
En todo caso, "la imagen de Garcilaso ha cambiado. Ya no se le ve como una figura armoniosa que ha superado el enfrentamiento de sus dos linajes; se le ve, más bien, como un ser angustiado, lleno de conflictos no resueltos: tiene un deseo de armonía, por supuesto, pero esa armonía es imposible" (Cornejo Polar, "Literatura peruana e identidad nacional" 299). Ya en 1927, Luis. E. Valcárcel exponía abiertamente sus recelos acerca del mestizaje, tanto racial como cultural: "La raza del Cid y don Pelayo mezcla su sangre a la sangre americana. A la violencia del asalto de los lúbricos invasores, sucede la tranquila posesión de la mujer india. Se han mezclado las culturas. Nace del vientre de América un nuevo ser híbrido: no hereda ni las virtudes ancestrales sino los vicios y las taras. El mestizaje de las culturas no produce sino deformidades" (Tempestad 111). (Me pregunto cómo se sintieron y reaccionaron los lectores mestizos de Valcárcel ante semejante afirmación). Lo cierto es que

hablar de Garcilaso como un representante adelantado de una quintaesencia peruana, nacional, o incluso de una identidad latinoamericana ya a estas alturas resulta aberrante. Es una manipulación ejercida desde Riva Agüero de manera interesada por las oligarquías gobernantes que pretenden convertir a este mestizo del XVI y XVII en una especie de modelo de la peruanidad, por supuesto destacando lo hispánico que hay en él y, en el caso de Riva Agüero, su importante línea nobiliaria peninsular (Mazzotti, en Lima, “400 años de los Comentarios reales” 262).

El optimismo tendencioso de Riva-Agüero alcanza, en tiempos relativamente recientes, incluso a MVLL, quien celebra con entusiasmo el espíritu amalgamador y universal del Inca Garcilaso: 
Lo notable y novedoso — revolucionario, habría que decir- en la actitud del Inca frente al tema de la patria, lo que ahora llamaríamos 'la identidad', es que es el primero en no ver la menor incompatibilidad entre un patriotismo inca y un patriotismo español, sentimientos que en él se entroncaban y fundían, como un todo indisoluble, en una alianza enriquecedora [...] El autor de los Comentarios reales está en las antípodas de la visión limitada, mezquina y excluyente de cualquier doctrina nacionalista. Su idea del Perú es la de una patria en la que cabe la diversidad [...], esa aptitud para abrirse a las demás culturas e incorporarlas a la propia, que tanto admiraba en sus ancestros incas. Por eso, al final, la imagen de su persona que su obra nos ha legado es la de un ciudadano sin bridas regionales, alguien que era muchas cosas a la vez sin traicionar ninguna de ellas: indio, mestizo, blanco, hispano-hablante y quechua-hablante (e italiano-hablante), cuzqueño y montillano o cordobés; indio y español, americano y europeo. Es decir, un hombre universal. ("El Inca Garcilaso y la lengua de todos")

No obstante, como bien señala Mazzotti, sería anacrónico considerar al Inca Garcilaso "multicultural" en el sentido posmoderno (Entrevista con Lima, "400 años de los Comentarios reales" 263).

Suscribo más el escepticismo de Cornejo Polar, quien pone en tela de juicio que el mestizaje constituya el elemento amalgamador por excelencia de la gran nación peruana: “[N]o creo que el mestizaje resuelva dilemas, ni dualidades, ni contracciones. De hecho, ahora todos somos mestizos y no hemos resuelto nada" ("Cinco preguntas en torno a 
Garcilaso" 20). Por otro lado, no concurro con Clorinda Matto de Turner (1852-1909), quien proponía "establecer la cultura quechua [...] como base histórica para una nación que no se prestaba - como lo pretendía el discurso dominante - a los modelos europeos, precisamente debido a sus ricas y antiguas tradiciones nativas" (Denegri 205). Tampoco pienso como Manuel González Prada cuando afirma que “[n]o forman el verdadero Perú las agrupaciones de criollos i estranjeros que habitan la faja de tierra situada entre el Pacífico i los Andes; la nación está formada por las muchedumbres de indios diseminadas en la banda oriental de la cordillera" ("Discurso en el Politeama" 11-12). ${ }^{262}$ Menos aún, repudio el mestizaje, como lo hizo Luis E. Valcárcel, quien, como habrá podido advertirse, confunde los conceptos de raza y cultura (Tempestad 111). ${ }^{263}$ Todo lo contrario: soy afín, por ejemplo, a las ideas de José Uriel García (1894-1965), para quien el híbrido cultural—no el mestizo racial—es el representante de la nueva sociedad peruana: "[L]a sangre limita y separa; el espíritu unifica, funde y ondula por el universo" (El nuevo indio 7), dice de manera casi poética.

Llevando el pensamiento de García un paso adelante, pienso que el genius loci del Perú de hoy debe ser la celebración de la diversidad racial y cultural. La amalgama, aunque bienvenida, no es imprescindible. En la actualidad, ya no cabe plantear la construcción de la nación sobre la base de esencialismos (corriente nativista), o

\footnotetext{
${ }^{262}$ Jeffrey L. Klaiber manifiesta que la protesta de González Prada en favor de la reivindicación indígena "no pasaba más allá del gesto literario romántico [...] El propio González Prada guardaba actitudes racistas hacia las clases populares" (111). Klaiber basa esta afirmación en su lectura de: González Prada, Adriana. Mi Manuel. Lima: Editorial Cultura Antártica, 1947. 135; y Podestá, Bruno. Pensamiento político de Manuel González Prada. Lima: Instituto Nacional de Cultura, 1975. 188-94.

263 "Luis E. Valcárcel se opuso a la educación y sindicalización del campesinado peruano como parte de los esfuerzos indigenistas por mantener 'pura' a la raza india (De la Cadena, 2000: 44-130)" (Ari Chachaki 221).
} 
cimentarla en un crisol de razas (la popular metáfora del "melting pot" de Israel Zangwill, 1909), sino más bien en el pluralismo cultural de diversas etnias que anhelan y que se comprometen a vivir en armonía. La raza no es una patente de legitimidad sobre los derechos a la patria, ni la marca de identidad de una nación y, aunque la cultura y la raza van aparejadas en el Perú, no son siempre inextricables. ${ }^{264}$ La tolerancia y el respeto mutuo son dos condiciones imprescindibles para garantizar el éxito de nuestra "comunidad imaginada" (Anderson).

\section{Conclusión}

He intentado mostrar la manera en que la vida y la obra del Inca Garcilaso evidencian la imperiosa necesidad que él tenía de recomponer el mosaico de su identidad fragmentada. Si, por un lado, ponderaba la síntesis racial y decía enorgullecerse de ser mestizo; por el otro, elaboró intrincadas interpretaciones histórico-religiosas para probar que la cultura inca, que él representaba a medias, valía tanto como la europea, que también era parcialmente suya; todo esto con el afán de reconciliar dos mundos antagónicos y enfrentados, con intereses irreconciliables para esa época. ${ }^{265}$ Los Comentarios reales, del Inca Garcilaso no son sino una extendida "Protestación del autor sobre la Historia"; es decir, de la historia oficial, la de los cronistas peninsulares. Los Comentarios reales son

\footnotetext{
${ }^{264}$ Haciéndose eco del pensamiento de Wilfredo Pareto (1848-1923) $(*)$, JCM señala que "[1]a raza es apenas uno de los elementos que determina la forma de una sociedad" (7 ensayos de interpretación de la realidad peruana 247).

(*) Pareto, Wilfredo. Trattato di sociologia generale. Tomo III. Firenze: G. Barbèra, 1916. 265.

${ }^{265}$ De acuerdo con Spivak, los "subalternos"- es decir, los colonizados y, en general, los grupos oprimidos - no tienen un lugar de enunciación y, al carecer de voz, requieren de intermediación ("Can the Subaltern Speak?" 1985). En ese sentido, el Inca Garcilaso se habría arrogado de papel de vocero de la cultura inca y de intermediario entre ésta y la cultura española.
} 
un colosal intento del Inca Garcilaso de reivindicar a sus ancestros incas y de paso o, quizás, principalmente, de reivindicarse a sí mismo con respecto a su condición de bastardo y a su calidad de mestizo. Pero, en esencia, se trata de una protestación del autor con respecto a su historia personal.

En resumen, una vez superado el andinismo, que reconocía a los andinos como los únicos "verdaderos” peruanos, empezó a cuajar en la intelligentsia la idea de que el mestizaje y el sincretismo cultural eran los cimientos de la identidad nacional. ${ }^{266}$ En ese contexto, el Inca Garcilaso se convirtió en la figura icónica de la anhelada coexistencia armónica de las razas y culturas del Perú. Sin embargo, la lectura de la monumental obra que el Inca Garcilaso nos legó ha ido variando con el paso del tiempo. ${ }^{267}$ Es así que, contemporáneamente, los textos del Inca son interpretados como el reflejo de su agónico anhelo de reconocimiento, y la plasmación literaria de una vida consagrada a la reafirmación personal. Por este motivo,

[p]erhaps what we repeatedly see in Garcilaso - much to our chagrin — is not that which proposes harmonious reconciliation, but that which-in spite of the gestures toward coherence-remains discontinuous, painful,

\footnotetext{
266 "Del prejuicio de la inferioridad de la raza indígena, empieza a pasarse al extremo opuesto: que la creación de una nueva cultura americana será esencialmente obra de las fuerzas raciales autóctonas. Suscribir esta tesis es caer en el más ingenuo y absurdo misticismo. Al racismo de los que desprecian al indio, porque creen en la superioridad absoluta y permanente de la raza blanca, sería insensato y peligroso oponer el racismo de los que superestiman al indio, como fe mesiánica en su misión como raza en el renacimiento americano" (JCM, "El problema de las razas en América Latina"; Baeza 173).

${ }^{267}$ Por ejemplo, los Comentarios reales que leemos hoy no son los mismos que escribió el Inca Garcilaso y que leyeron sus coetáneos. Los lectores actuales tenemos un "horizonte de expectativas" y un "horizonte de experiencias" (Hans-Robert Jauss) distinto y, al entrar en contacto con la obra en otra coyuntura histórica, emergen nuevos significados de la "fusión de horizontes" (Hans Georg Gadamer) que se produce en esa relación. El significado de un texto se materializa, pues, en el diálogo que se da entre el texto y el lector. En consecuencia, un mismo texto leído por un mismo lector en un momento distinto generará probablemente otra interpretación (Otero Luque, "Borges, uno de los tantos autores de 'Pierre Menard"”6).
} 
non-productive, and irremediably fragmented. In an age euphoric about its own multiculturalism and trans-nationalism, Garcilaso's experience five centuries ago is a sober reminder of the profound complexities that exist at the heart of inter-cultural communication. (Ortega, "Trauma and Narrative in Early Modernity" 421).

Sin embargo, es sin duda a partir del estudio del Inca Garcilaso-como personaje histórico, antropológico y literario - que los peruanos empezamos a indagar acerca de la naturaleza y las características de nuestra identidad, una tarea que no hemos concluido. En mi opinión, la llama que encendió el Inca Garcilaso y que continúa chisporroteando, inquietándonos a definir qué significa ser mestizo — a preguntarnos quiénes somos—, es donde reside principalmente el inmenso valor de su legado. 


\section{V.2 SIN GUITARRA NI CAJÓN EN EL PROYECTO NACIONAL: MATALACHÉ (1928), UNA NOVELA ANACRÓNICAMENTE ROMÁNTICA DE ENRIQUE LÓPEZ ALBÚJAR}

Pintor de santos de alcoba, pintor sin tierra en el pecho, que cuando pintas tus santos no te acuerdas de tu pueblo, que cuando pintas tus Vírgenes pintas angelitos bellos, pero nunca te acordaste de pintar un ángel negro Andrés Eloy Blanco ("Píntame angelitos negros")

De acuerdo con la periodización tradicional de la literatura peruana, que hace coincidir las etapas históricas del país (prehispánica, conquista y colonización, independencia y república) con movimientos intelectuales y sus correspondientes expresiones artísticas (renacimiento, barroco, neoclasicismo, etcétera), la novela Matalaché (1928) de Enrique López Albújar fue publicada en la época republicana, que ya era centenaria para ese momento, pero está ambientada en 1816, al final del virreinato. ${ }^{268}$ Es así que esta novela refleja las tensiones previas a la independencia y "cuestiona el rígido esquema de clases" (Veres, La narrativa del indio 140). Cuando López Albújar publicó Matalaché había transcurrido más de medio siglo desde que el romanticismo cediera el paso al realismo literario en el Perú. Ya había sido superado

\footnotetext{
${ }^{268}$ Abriendo la novela, se indica que 1816 es el año en que discurre (Matalaché 23): "Los acontecimientos nos remiten al año 1816, en el que se aprecia el deterioro progresivo del sistema colonial y los albores del proceso de la independencia. Son años de conflicto y de inseguridad. Del exterior, las noticias son alarmantes porque Buenos Aires ya se ha independizado, Chile se muestra rebelde al poder español y los piratas asoman por el puerto del Callao; mientras que, en el interior, se sabe de conspiraciones y 'talaveras', gente desalmada y revoltosa al margen de la ley" (Carazas Salcedo, "Una relectura de Matalachê" 246).
} 
incluso el modernismo y estaban en boga el indigenismo y las vanguardias. ${ }^{269}$ Precisamente, en contraposición al vanguardismo, el autor le colocó a Matalaché el subtítulo de "novela retaguardista" porque, sin renunciar al naturalismo, reúne muchas características de la novela romántica. ${ }^{270}$ Como veremos en el desarrollo del presente capítulo, esta novela da cuenta de que, por el año de 1816, ad portas de concluir el dominio español de casi trescientos años de duración (1530...1821-1824), los negros y mulatos estaban excluidos entre los actores que, según el consenso de la clase hegemónica, debían conformar la nación imaginada. Cuando Matalaché salió de la imprenta, "rebuscaba en el pasado la causalidad histórica de las tensiones que pervivían en el presente a pesar de haberse derrumbado el orden colonial" (ibíd. 140). Ahí es donde reside mi interés en revisar esta novela.

\footnotetext{
${ }^{269}$ En Para una periodización de la literatura peruana (2004) - la periodización más crítica que, en mi opinión, se ha hecho hasta el momento-, Carlos García Bedoya divide el proceso histórico del Perú en dos grandes etapas: 1) de autonomía andina (hasta 1530), y 2) de dependencia externa (desde 1530 hasta el presente). En la segunda etapa, García Bedoya identifica cinco períodos en los que vincula historia y literatura: 1) de imposición del dominio colonial (1530-1580), 2) de estabilización colonial (1580-1780), 3) de crisis del régimen colonial (1780-1825), 4) de la República oligárquica (1825-1920), y 5) de crisis del Estado oligárquico (1920-1975). Acerca de la producción literaria desde 1975 en adelante, García Bedoya manifiesta que "[e]l panorama social y literario de las dos o tres últimas décadas resulta aún demasiado confuso para el ojo de un observador de principios del tercer milenio" (90).

Erik Camayd-Freixas sostiene que "la vanguardia, con su rebelión contra la tradición académica europea, justificó la libertad estética del arte americano. Tanto más crucial era el contacto del indigenismo y del afroamericanismo con la vanguardia europea, puesto que ésta, en su admiración por las artes y culturas primitivas de África, Asia y Oceanía, había incorporado ya a su utilería importantes derivaciones plásticas de un primitivismo estético" (Realismo mágico 32).

270 "Estamos ante una novela que acoge elementos de la narrativa decimonónica, en especial el romanticismo y el realismo de orientación positivista. En este sentido no es exagerado plantear que Matalaché sea una novela que, además, esté emparentada con Sab (1841) de Gertrudis Gómez de Avellaneda, con La cabaña del tío Tom (1852) de Harriet Beecher Stowe (USA), e inclusive con Las consecuencias (1889) de Mercedes Cabello, para mencionar las más significativas" (Carazas Salcedo, "Una relectura de Matalaché"244).

"[E]s evidente la afiliación con la estética realista a la que respondían los regionalismos ortodoxos en América Latina, tal es el caso de Matalachê" (de Llano, "Problemáticas de la crítica literaria" 112).
} 
Cuarenta años antes de Matalaché (1928), en 1888 la escritora peruana Lastenia Larriva de Llona (1848-1924) ya había publicado en Guayaquil la novela Un drama singular, en cuyo argumento Carmela, la hija mestiza y espuria del amo criollo con una esclava negra, se enamora sin saberlo de su medio hermano, Carlos de Peñablanca. Esta historia es muy parecida a la de Cecilia Valdés $(1839,1879$ y 1882) de Cirilo Villaverde. En la novela del cubano, la mulata Cecilia también se enamora, sin saberlo, de su medio hermano, Leonardo de Gamboa. Volviendo a Un drama singular, no obstante ser la mulata Carmela un personaje central en la obra, no se le considera sino a Matalaché la novela fundacional del negrismo literario en el Perú, ${ }^{271}$ porque a pesar de que "no propone un nuevo orden [...sino] muy por el contrario, vuelve a sostener el orden establecido por la cultura hegemónica [...,] describe el sistema de trabajo de los negros esclavos $[\ldots$,$] denuncia los abusos [...y reivindica] los sentimientos, la habilidad$ artesanal y la vivencia especial de la música y la danza, característica saliente en la cultura africana" (de Llano, "Problemáticas de la crítica literaria" 112). ${ }^{272}$ Adicionalmente, Milagros Carazas Salcedo advierte que Matalaché es un personaje “capaz de cuestionar su identidad conflictiva" (245). De otro lado, para Luis Veres:

Matalaché presenta "al marginado, en este caso al negro, como protagonista de la historia y no únicamente como víctima $[\ldots][$ E]ra el negro, ese sujeto real que en Cuentos Andinos había sido el indio [...] el

\footnotetext{
${ }^{271}$ Con Cuentos andinos (1920) López Albújar también "puede reclamar el mérito de ser el iniciador del indigenismo literario en su país" (José Miguel Oviedo, Historia de la literatura hispanoamericana 3 451).

272 "En la literatura peruana del siglo XX, la figura del negro no pasaba de ser un personaje secundario dentro de un mundo representado en el que sólo aparecía perteneciendo al marco conceptual. Hay algunas excepciones, una de ellas es la narrativa de José María Arguedas, en la que el negro es un integrante más de la diversidad cultural plasmada en sus últimas novelas" (de Llano, "Problemáticas de la crítica literaria" 112).
} 
que se pretendía retratar de manera realista, sin caer en el telurismo y la lírica desbocada [...] El problema de razas que se presentaba en Cuentos Andinos con la figura del indio se transformaba en esta novela en el problema del negro con el blanco [...] La denuncia racial, por tanto, dotaba a la novelística peruana de un nuevo tipo que situaba en la historia al hombre marginado" (La narrativa del indio 140).

Con el propósito de mostrar que Matalaché se ajusta a las pautas del romanticismo - tanto o más que a las del naturalismo, estilo al que se le suele adscribir preferentemente-, compararé esta novela con $S a b$, una obra que pertenece, sin discusión, al período romántico y guarda varias similitudes con Matalaché. ${ }^{273}$ Recordemos que, en Latinoamérica, la vertiente social del romanticismo (1830-1860) fue más trascendental que su expresión de corte afectivo, intimista (1860-1880), aunque muchas de las novelas de amor que se escribieron en el siglo XIX pueden ser leídas (de hecho, lo son) como alegorías del proyecto nacional de los países recientemente independizados. (He ahí también mi interés en Matalaché). Todavía cargada de resabios neoclasicistas debido al poderoso influjo de la Ilustración (desde finales del siglo XVII hasta principios del siglo XIX), la estética romántica fue un poderoso instrumento de los pensadores latinoamericanos para transmitir su ideología acerca de la nación imaginada. Algunos ejemplos de las referidas novelas de amor-y, a la vez, fundacionales — son Cecilia Valdés (1839, 1879 y 1882) de Cirilo Villaverde (1812-1894), Sab (1841) de Gertrudis Gómez de Avellaneda (1814-1873), Amalia (1844) de José Mármol (1817-

\footnotetext{
${ }^{273}$ En "Alma blanca, cuerpo negro: la construcción de la ideología del mulato en la novela antiesclavista (Los casos de Sab y Matalaché)" (1994), Luis Millones-Figueroa ya había comparado Matalaché con Sab, aunque desde la perspectiva del cuestionamiento de la propuesta supuestamente antiesclavista.
} 
1871), María (1867) de Jorge Isaacs (1837-1895), Clemencia (1869) de Ignacio Manuel Altamirano (1834-1893), Aves sin nido (1889) de Clorinda Matto de Turner (1852-1909), y El conventillo (O cortiço) (1890) de Aluísio Azevedo (1857-1913).

El drama de ambas obras-Matalaché y Sab-es el amor imposible entre un mulato esclavo-José Manuel (Matalaché y Bernabé (Sab), respectivamente) y una criolla de raza blanca (María Luz y Carlota, respectivamente); los temas que tratan son el amor, la esclavitud, el racismo y la libertad; están ambientadas en una zona rural de la América colonial (Matalaché en La Tina, una fábrica de jabón y curtiembre, ubicada en las afueras de Piura; y $S a b$ en el ingenio azucarero de Bellavista, en Camagüey). Finalmente, los hechos ocurren más o menos en la misma época: Matalaché en 1816, y Sab aproximadamente en el año $1820 .{ }^{274}$ No obstante, lo que más me interesa rescatar y destacar de esta comparación es que ambas obras dan a entender que, debido al racismo imperante, el mulato había sido descartado en el proyecto de construcción de la nación imaginada.

En algún momento de principios del siglo XIX, en algunos países latinoamericanos se consideró que el mestizaje —si bien como eugenesia y entre el amerindio y el caucásico - podía ser la solución armónica al conflicto socioeconómico y sociopolítico. Por ejemplo, el precursor independentista colombiano Pedro Fermín de Vargas (1762-1813) proponía lo siguiente: "Para expandir nuestra agricultura habría

\footnotetext{
274 " $S a b$ traces the demise of the Cuban oligarchy, especially in the Central Region, due to foreign commercial interests. Sab himself explains the economic decline in some detail to Enrique Otway. In 1920 , the Bellavista plantation is running half its previous capacity" (Davis, Sab 7).

"Tiempos ha habido [...] que este ingenio daba a su dueño doce mil arrobas de azúcar cada año; porque entonces más de cien negros trabajaban en sus cañaverales; pero los tiempos han variado y el propietario actual de Bellavista no tiene en él sino cincuenta negros, ni excede su zafra de seis mil panes de azúcar" (Sab 106).
} 
necesidad de hispanizar a nuestros indios. Su ociosidad, estupidez e indiferencia hacia los esfuerzos humanos normales nos llevan a pensar que provienen de una raza degenerada [...] [S]ería muy conveniente que se extinguieran los indios, mezclándolos con los blancos". ${ }^{275}$ (En Anderson, Comunidades imaginadas 32). Esta manera racista de pensar se mantuvo vigente durante todo el siglo XIX. Por ejemplo, Javier Prado y Ugarteche (1871-1921) pronunció el siguiente discurso en la ceremonia de apertura del año escolar de 1894 en la Universidad Mayor de San Marcos:

Los negros considerados como mercancía comercial, e importados a la América como máquinas humanas de trabajo, debían regar la tierra con el sudor de su frente; pero sin fecundarla, sin dejar frutos provechosos [...] .[H]a desaparecido el esclavo en el Perú, sin dejar los campos cultivados [...] después de haberse vengado de la raza Blanca, mezclando su sangre con la de esta, y rebajando en ese contubernio el criterio moral e intelectual, de los que fueron al principio sus crueles amos, y más tarde sus padrinos, sus compañeros y sus hermanos". ("Estado social del Perú durante la dominación española” 125-6)

En la percepción de este historiador, filósofo y abogado, el esclavo africano y sus descendientes mulatos, lejos de aportar algo positivo a la sociedad, la habrían contaminado.

En una conversación que tienen Matalaché y ño Parcemón, “el esclavo más viejo de Tangarará y el más razonable y circunspecto de todos”, el anciano compara a los

\footnotetext{
${ }^{275}$ Benedict Anderson toma las palabras de Pedro Fermín de Vargas de: Lynch, John. The SpanishAmerican Revolutions, 1808-1826. Nueva York: Norton, 1973, 200. Impreso. (Comunidades imaginadas 32 , nota al calce $\mathrm{N}^{\circ} 6$ ).
} 
indios con los negros: $[\mathrm{S}] \mathrm{emos}$ unos desgraciaos, cien veces más desgraciaos que los mesmos indios de los obraje [...] Cierto que se les hase jipa como bestia a los pobresitos y se les cuerea hasta matalos, pero no se les vende. A nosotro, fijate, Jose Manue, a nosotro sí. ¡Caramba, semos pior que los indios!”. Sin embargo, reflexiona ño Parcemón, "a l'ora e cumbianga, los mesmo blanco, olvidao del coló, sin miero al tisne, bien que cucharean en nuestras ollita. Y sino, ai tas vos, que no eres más que un atravesao" (88). Es decir, ante los ojos del hombre blanco, el negro vale menos que un indígena, pero no tiene reparo en tener relaciones sexuales con una mujer de color, como lo evidencia la existencia de José Manuel.

Cuando Riva-Agüero afirma que, en la personalidad del Inca Garcilaso, "se fundieron amorosamente Incas y Conquistadores" y que él fue "el precursor magnífico de nuestra verdadera nacionalidad" ("Elogio del Inca Garcilaso", Del Inca Garcilaso a Eguren 62), ¿dónde encajan los amerindios de a pie, los que no provenían de una estirpe noble, incluyendo a los selváticos que no fueron conquistados por los incas? ¿Dónde el negro y el mulato? Casi una década más tarde, en 1925, José Vasconcelos (1882-1959) anticipaba celebratoriamente, aunque con graves errores conceptuales y contradicciones, el surgimiento en América de una "raza cósmica", producto de la fusión de todas las razas del mundo: "En Grecia se funda el desarrollo de la civilización occidental o europea, la civilización blanca, que al expandirse llegó hasta las playas olvidadas del continente americano para consumar una obra de recivilización [énfasis mío] y repoblación” (La raza cósmica 11). ${ }^{276}$ Juan Carlos Grijalva señala acertadamente que “el

\footnotetext{
276، El esplendor de la cultura es, para Vasconcelos, sinónimo de mezcla racial y cultural: el mestizaje es una metafísica histórica de progreso. Bien podría decirse que Vasconcelos piensa en el mestizaje americano como una suerte de 'Espíritu Absoluto', predestinado, hegeliano, que se iría desarrollando y
} 
discurso del mestizaje de Vasconcelos muestra sus deudas con las ideologías positivistas de la mezcla racial que afirmaban en el siglo XIX el bienestar de la cultura a través del mejoramiento y pureza de la raza" ("Vasconcelos o la búsqueda de la Atlántida" 342$).{ }^{277}$

Doris Sommer observa que, mientras "[m]iscegenation was the road to racial perdition in Europe [...], it was the way of redemption in Latin America, a way of annihilating difference and constructing a deeply, horizontal, fraternal dream of national identity" (Foundational Fictions 38-39). En realidad, la propuesta del mestizaje como solución socioeconómica no era ni tan horizontal ni tan fraternal, sino más bien de orden práctico, dado que en esa época se creía que una sociedad homogeneizada era más eficiente y productiva. Pero incluso desde esta perspectiva, no deja de ser sorprendente que, en 1928 - por coincidencia, el mismo año en que fue publicada Matalaché-, JCM hiciera comentarios xenófobos acerca de la contribución del africano a la cultura peruana (7 ensayos 247).

El protagonista de Matalaché es José Manuel, un fornido mulato que es utilizado como padrillo reproductor por su amo, don Juan Francisco de los Ríos y Zúñiga. Se ha ganado la fama de ser "un garañón capaz de apechugar a todas las criadas de la ciudad en una noche" (18), y lo apodan Matalaché a raíz del estribillo pícaro que, a modo de chanza, le suele cantar un esclavo congolés, aludiendo a la función de semental que

\footnotetext{
auto-reconociendo históricamente hasta llegar a la integración universal de todas las razas humanas en una raza final" (Grijalva 339).

277 "Hablar de la conquista y colonización de las poblaciones nativo-americanas es en último término, para Vasconcelos, pensar en procesos necesarios que posibilitan y completan la obra civilizadora de una síntesis racial superior. El discurso utópico del mestizaje afirmado por Vasconcelos borra las crueldades vividas en la historia del colonizado y trivializa el genocidio de la Conquista" (Grijalva 339-40).
} 
cumple el mulato: “Cógela, cógela, José Manué / mátala, mátala, mátala / ché” (48-9). ${ }^{278}$

Aunque el amo posteriormente abandona la práctica de controlar la reproducción de sus esclavos, ${ }^{279}$ sobreviven la reputación de padrillo de José Manuel y el mote con el que lo llaman. De esta manera, Matalaché se convierte en un personaje legendario viviente debido a su vigor sexual:

La curiosidad ardía en las pupilas. Entre las mujeres, particularmente, el interés en conocer al famoso Matalaché [...] rayaba en exaltación. Las esclavas, sobre todo, $[\ldots]$ eran las que con más impaciencia esperaban su salida: unas para conocerle; otras para ver una vez más al hombre que las hiciera madre en breves noches de felicidad [...] Y cada una de ellas se lo decía para sí, con cierto orgullo salvaje, con un íntimo reconocimiento de hembra poseída. (166)

\footnotetext{
${ }^{278}$ No tengo noticia de que la interjección "che" se use actualmente en el Perú. Sin embargo, considerando que en la Argentina, por ejemplo, el voseo y la interjección 'che' suelen utilizarse juntos ('Che, vos,...' 'Oye, tú,...'), quizás sea dable especular que ambas formas corrieron la misma suerte en cuanto a su uso y posterior desaparición en la región piurana.

Por ejemplo, cuando María Luz le pregunta a Rita si está "apalabrada" (comprometida) con Matalaché, la esclava le responde: "¡Che! [énfasis mío] ¡No me fatalise [sic], niña! Ni él piensa en mí ni yo en él” (54). La interjección "che" se emplea para llamar a personas o animales. Se usa en Valencia, Argentina, Bolivia, Paraguay y Uruguay "para llamar, detener o pedir atención a alguien, o para denotar asombro o sorpresa" (RAE).

En La violencia (1991) de Miguel Gutiérrez Correa, la voz que Martín Villar escucha bajo los efectos del brebaje del cactus sampedro emplea la interjección "che”: “¿Don Saldarriaga? Che, si antes parece el blanco Benalcázar el que viene cruzando el río" (532). Esta novela está ambientada en Piura, la misma región en donde se desarrolla la historia de Matalaché.

"Thanks to the testimony of various linguistic studies, and to the presence of the phenomenon in regional literature (particularly the novel 'Matalaché' by López Albújar), it is clear that 'voseo' usage survived in Piura until approximately 1950. It disappeared completely in the course of the second half of the 20th century" (Arrizabalaga, "Noticias de la desaparición del voseo" 257).

Por ejemplo, "Hay tantos señores allá abajo, que harían lo mismo por vos [énfasis mío], que te darían el oro y el moro solo con pedilo [sic]", le dice Casilda a María Luz (120).

${ }^{279}$ El control sexual y reproductivo de los esclavos había sido establecido en La Tina por don Diego Farfán de los Godos, el antiguo propietario. Cuando don Baltazar Rejón de Meneses le pide a don Juan Francisco de los Ríos y Zúñiga, el actual dueño, que Matalaché, esclavo del segundo, embarace a Rita, esclava del primero, don Juan Francisco le comenta que tiene ciertos reparos con respecto a esta práctica. Don Baltazar le responde: "Esclavos y animales son una misma cosa" (21).
} 
Matalaché es también un prodigio de la guitarra y del canto: "Las mujeres eran las divulgadoras de su fama donjuanesca, las que, a la vez que hacían alarde de temerle, salían a aguaitarle cuando pasaba; las que le mandaban pedir, con mucho misterio, una serenata [énfasis mío]; las que se ponían trémulas cuando las sacaba a bailar, pero que al fin terminaban sonriéndole, bebiendo con él una copa y rogándole que les cantara algunas de esas cosas tan bonitas que solo él sabía cantar [énfasis mío]" (73). El talento musical de Matalaché, aunado a su sensualidad, despierta pasiones en las mujeres, subyugándolas: "Su fuerza estaba en la fascinación de sus ojos negros y ofídicos; en su paciencia atávica, cultivada por sus antecesores en el sufrimiento del galpón o del ergástulo; en el tono de su voz [énfasis mío] [...] y en la reciedumbre de su cuerpo, gentil y musculoso, de dios bárbaro" (74).

En la época en que funcionaba el "empreñarero" (43), así llamada la habitación en donde Matalaché desempeñaba su tarea de macho reproductor. ${ }^{280}$ El "yogamiento forzado" (166) entre los esclavos, con el propósito de multiplicar selectivamente a los ‘semovientes' negros $(27,81$ y 93), era una práctica generalizada entre los hacendados del medio piurano. Pero Matalaché era selectivo con las mujeres que le imponían: "Todas, todas las que han entrao aquí, que no son pocas, me han aceptao luego luego. Más bien yo he despreciao algunas. Y me he acostao en esa tarima solo, dejándolas ai plantadas toda la noche. Matalaché [...] también tiene corazón y sentidos, y lo que no le gusta lo deja" (58), le explica, refiriéndose a sí mismo en tercera persona, José Manuel a

\footnotetext{
${ }^{280}$ En La violencia (1991) de Miguel Gutiérrez Correa, Martín Villar relata que se hizo amigo de un tal don Jiménez, un zapatero centenario "de grandes calancas y cuero negro, muy negro", quien le confió que había sido "engendrado en un sitio llamado el Empreñadero, donde los blancos poseedores de esclavos llevaban a las negras para que fueran fecundadas por los sementales que eran negros de fuerte complexión y sanos de salud, por fuera y por dentro, desde los dientes hasta el pellejo entero" (83).
} 
Rita, una esclava que le han encomendado preñar. $^{281}$ Sin embargo, en este caso es ella quien se rehúsa a perder la virginidad teniendo relaciones sexuales con él. Le dice que está "apalabrada" (comprometida) con un "chapetón pulpero" y que desea conservarse pura para él (54-7). ${ }^{282}$ Ante la negativa de la joven, el mulato le dice: "Eres tú [...] la primera mujer que rechaza a José Manuel, y por eso me has gustao y te respeto" (58-9). Con este pasaje, el autor destaca que Matalaché y Rita tienen sentimientos y valores (autoestima, compasión, honor, respeto), así como gustos y preferencias; es decir, que poseen un "yo".

A diferencia del respeto que José Manuel siente por Rita, él le guarda resentimiento a Casimira, su madre. La considera una traidora a su raza por haberse entregado supuestamente al amo, don José Manuel de Sojo, y por haberse rehusado a tener amoríos con ningún negro (etnobúmeran). José Manuel también le guarda rencor a su progenitora por haberle ocultado la identidad de su padre. ${ }^{283}$ Además, la culpa de haber traído al mundo a un mulato—él—que se avergüenza de serlo y que maldice su condición de esclavo: “¡Ah, la negra de su madre, que nunca quiso dejarse poseer por ningún negro como ella! Ésa fue la traidora de la raza. ¿Y todo para qué? Para salir con

\footnotetext{
${ }^{281}$ Además de su deseo de aplacar los celos de su esposa, don Baltazar quiere que Rita salga embarazada porque él y su esposa van a tener un hijo y, en opinión de la señora de Rejón, esta esclava "una vez parida sería una ama de cría envidiable" (Matalaché 20). María Asunción Gómez ha escrito un interesantísimo ensayo sobre las amas de leche o amas de cría: "El papel de la nodriza en la construcción del discurso de la maternidad: Los pazos de Ulloa de Emilia Pardo Bazán y La tía Tula de Miguel de Unamuno" (Decimonónica 13.2 (2016): 50-66).

${ }^{282}$ La esposa de don Baltazar, que está embarazada, le propone a su marido que Rita sea el ama de leche de su futuro bebé, para lo cual ni siquiera es necesario que la esclava se case antes de salir encinta: "En todas las casas de Piura las criadas paren, y no sé yo que esto sea, por supuesto, dentro del matrimonio. El matrimonio para la gente, para los de nuestra clase" (20).

283 "Sab tampoco conoce la identidad de su padre: “¡Mi padre!... Yo no le he conocido jamás [...] El nombre de mi padre fue un secreto que jamás [mi madre] quiso revelar" (109).
} 
ese mulatillo, que parecía avergonzado de su origen materno, lleno de humos señoriles y de susceptibilidades ridículas en un esclavo" (77-8). ${ }^{284}$ Los otros esclavos también leen en la fisonomía de José Manuel la traición de la madre:

Al compararse ellos con José Manuel descubrían en los rasgos fisonómicos de éste el sello inconfundible de la blanca intromisión del cruzamiento, al que, no obstante envidiárselo, consideraban como un agravio y una traición que no quisieron perdonarle nunca. La oculta soberbia de su raza les hacía ver en este mestizo, engendrado seguramente en una hora de vandalismo sexual, un tránsfuga, cuya falta se encargaba su rostro mismo de pregonar. (69)

Luego de mirarse José Manuel en el espejo y de reconocer que ha heredado por el lado materno especialmente el color de ojos y la forma de la boca, el narrador omnisciente reflexiona:

Además, que algo hubo de poner su madre en esa conjunción, esa madre, que, movida quizá por una inconsciente aspiración de grandeza [blanqueamiento], supo hacerse llevar hasta la misma alcoba señoril [...] Su boca era, pues, la de su madre, mejorada, desafricanizada; y su cabellera, y sus dientes, fuertes y blancos, y sus ojos brillantes, negros, crespos y fascinadores. (79)

\footnotetext{
${ }^{284}$ El caso de la madre de Sab es similar al de la madre de José Manuel: "Salía mi madre apenas de la infancia cuando fue vendida al señor don Félix de B..., padre de mi amo actual, y de otros cuatro hijos. Dos años gimió inconsolable la infeliz sin poder resignarse a la horrible mudanza de su suerte; pero un trastorno repentino se verificó en ella pasado este tiempo, y de nuevo cobró amor a la vida porque mi madre amó. Una pasión absoluta se encendió con toda su actividad en aquel corazón africano. A pesar de su color era mi madre hermosa, y sin duda tuvo correspondencia su pasión, pues salí al mundo por entonces" (109).
} 
José Manuel es demasiado blanco para ser negro y esto le causa el rechazo de los otros esclavos, quienes desconfían de él en grado sumo, ${ }^{285}$ lo envidian (blanqueamiento), ${ }^{286} \mathrm{y}$ por lo mismo lo odian:

Física y espiritualmente José Manuel era el negro menos negro de los esclavos de La Tina. Su tipo, su porte, cierto espíritu de orden e iniciativa y un marcado sentimiento de altivez diferenciábanle grandemente de la negrada, hasta el punto de despertar en ellos, especialmente en congos [congoleños] y carabalíes, antipatías y animosidad rayanas en el odio. En buena cuenta, José Manuel no era para sus compañeros de esclavitud un blanco ni un negro. ${ }^{287}(69)$

A diferencia del rencor que le guarda a su madre [etnobúmeran], José Manuel siente admiración por el Marqués don José Manuel de Sojo, quien, supone, es su padre:

285 "Todas estas desconfianzas y antipatías fueron acumulándose en torno de José Manuel hasta casi aislarle de los suyos" (Matalaché 78).

286 “"E]l perfil inconfundible de la raza sojuzgadora y, sobre todo, su porte señoril [...] era la envidia de sus iguales [blanqueamiento], la ironía de los demás y la causa de sus ocultos pesares" (Matalaché 79-80).

287 En la percepción de los otros esclavos, para ser blanco, a Matalaché "le faltaba el color definitivo y la libertad, el derecho de alternar como igual con esos hombres que disfrutaban de todas las comodidades de la vida, haciéndose servir por otros". Y para ser negro, "sobrábale su nariz, ligeramente roma, sus labios anabelfos, adelgazados por la ley misteriosa del mestizaje, que para ellos significaba la protesta más grave contra el distintivo de la raza, y aquellos cabellos suaves, delgados, y discretamente libres ya de las ásperas y rebeldes crespaturas [sic] de las ulótricas [sic] cabezas de sus mayores. Y a todas estas específicas diferencias venía a sumarse la del color de ámbar oscuro [...], sin el negror del azabache ni la exudación oleosa de la piel netamente africana. Y, más que todo esto, la diferencia moral e intelectual, que, mientras al uno le iba permitiendo salir paulatinamente, por obra del propio esfuerzo, del bajo fondo en que yacía, a los otros sumíalos en él cada día más. Y en medio de esta diferenciación, una acentuada conciencia de la dignidad personal, que unas veces despertaba en su alma ráfagas de indisimulable soberbia [blanqueamiento], y otras, le hacía resignarse ante la fatalidad de su destino; pero lleno de rebeldía y esperanza de manumisión. Todo lo que veía en torno suyo parecía estar allí para recordarle su origen y su suerte, sin que él pudiera sustraerse a su imperio, por más llevadera que se le hacia la vida en su condición de capataz, por más distinciones que le hacía su señor [José Manuel de Sojo], bondadoso y humano hasta hacerle abortar muchas veces sus planes de alzamiento y fuga" (69-70). 
A veces, [...José Manuel] se introducía cautelosamente en la alcoba señoril y allí, cruzado de brazos, junto al retrato vistoso de don José Manuel, abismábase en la contemplación de esa figura prócer, arrogante y marcial. Aquel rostro ovalado, de cabellera rubia y ondeada, emergido de un cuerpo cubierto de cruces y entorchados, como un símbolo de prosopopeya castellana, causábale una extraña sensación, mezcla de sumisión y respeto, de amor y orgullo [blanqueamiento]. (78)

Aunque la novela no lo dice explícitamente, del texto puede inferirse que José Manuel y don José Manuel se tenían mutuo cariño, porque, cuando la madre de José Manuel fallece, el amo de la hacienda adopta bajo su custodia y cuidado al mulatito de apenas nueve años de edad, y lo protege hasta que se convierte en un cultivado joven:

[A]hí estaban las distinciones, preferencias y miramientos que el señor Sojo tuvo para con él después de la muerte de la madre. Don José Manuel comenzó por separarle del contacto de los otros esclavos, ponerle un maestro que le enseñó a leer, escribir y contar, y cuando le creyó suficientemente preparado y capaz de manejar los asuntos de su escritorio, se los encomendó [...], poniéndolo así casi al nivel de sus empleados libres. Después se hizo acompañar por él en sus viajes [...], no solo por la necesidad de que alguien le atendiera en ellos sino por la confianza que le inspiraba el mozo. (72)

Las preferencias del amo por este esclavo eran evidentes y, cuando alguien alguna vez reclamó porque las consideró excesivas o fuera de orden-“"'Por ahí se dice, señor, que es usted quien le está dando alas a ese negro"—, "don José Manuel se irguió 
violentamente y con voz estentórea y airada le replicó: ‘[N]o es un negro como los demás. Y sepa usted, señor mío, para que no lo vuelva a repetir, que ese negro es tan blanco como yo y tan digno de respeto como usted" (74).

Cuenta el narrador que los años de estadía con don Manuel de Sojo "[f]ue la única época realmente feliz de José Manuel”. Y eso se debió también a que "[1] La infelicidad de su condición no podía apreciarla porque en el fondo tenía todas las apariencias de un estado de minoridad, gracias al cual todo se le daba a cambio de un poco de trabajo, agradable y ligero" (73). ${ }^{288}$ A José Manuel se le termina la relativa buena suerte cuando don José Manuel Sojo fallece y sus herederos peninsulares venden la hacienda de Tangarará, incluida la masa esclava, a don Francisco Javier de Paredes, Marqués de Salinas (81), quien lo pone a labrar el campo (80-3). Luego, José Manuel es vendido a don Diego Farfán de los Godos (93), propietario de La Tina, un negocio que, posteriormente, don Juan Francisco de los Ríos y Zúñiga adquiere en traspaso (135). ${ }^{289}$

Además de sentir admiración y gratitud, el vanidoso José Manuel le agradece a su desconocido padre blanco por el aporte genético caucásico, gracias al cual, de la mezcla resultante con la cepa africana, él ha resultado ser un mulato físicamente muy atractivo para las mujeres:

\footnotetext{
${ }^{288}$ Para Sab-que desempeña el puesto de mayoral del ingenio de Bellavista—, la vida también es relativamente placentera: "[J]amás he sufrido el trato duro que se da generalmente a los negros, ni he sido condenado a largos y fatigosos trabajos" (108-9), le comenta el mulato a Enrique Otway, el pretendiente de Carlota.

${ }^{289}$ En cambio a Sab, don Luis, presumiblemente su padre, lo dejó asegurado: "Tenía solamente tres años cuando murió mi protector don Luis, el más joven de los hijos del difunto don Félix de B..., pero dos horas antes de dejar este mundo aquel excelente joven, tuvo una larga y secreta conferencia con su hermano don Carlos, y según se conoció después, me dejó recomendado a su bondad. Así hallé en mi amo actual el corazón bueno y piadoso del amable protector que había perdido" (109).
} 
Y cuando al fin de la muda contemplación, satisfecho de la nobleza y prosapia de la figura prócer, sin descomponer su postura, volvía los ojos al espejo que colgaba más allá, poníase a examinar, de arriba abajo, la imagen de la suya, alta, musculosa, viril, como la de un dios bárbaro, y a compararla con la otra. Y de esta comparación iba sacando un mundo de gratas y consoladoras semejanzas. Sí, la talla era indudablemente igual; allí estaban en soberbio maridaje de gallardía, la pujanza y la virilidad. La nariz no podía ser más parecida: recta, firme, dominadora, sensual. Nada de ese horrible achatamiento de las de sus maternos progenitores, que vivieron exhibiéndolas eternamente como un signo de grosería y bestialidad $[\ldots]$ Verdad que la semejanza no había alcanzado hasta la boca, y menos a los ojos; pero esta misma disparidad era una afirmación de que entre la imagen reflejada por el espejo y la pintada en el cuadro había una afinidad, algo de común e indestructible [blanqueamiento]" (7879).

No obstante, a José Manuel lo tortura no saber quién es su padre: ““¡Ah! —pensaba después de estas contemplaciones-, si yo hubiera nacido blanco sería seguramente más hermoso que mi padre'. Y al pronunciar esta palabra, un dejo de amargura le subía del corazón a los labios, haciéndole modular esta interrogación: ¿¿Y si ese señor no fuera realmente mi padre?'” (79). José Manuel interpreta que el hermetismo de su madre en cuanto a revelar la identidad del hombre que la embarazó es una forma de protesta contra el racismo del hombre blanco: 
Pero no, el silencio de su madre estaba allí, imponiéndole a la vez silencio a todas las dudas que la maledicencia o el sarcasmo pudieran suscitar $[\ldots]$ Y José Manuel, después de este constante y doloroso devanar, se proponía este sorites: "Si mi madre guardó hasta la muerte su secreto es porque quien me engendró se lo impuso [...] Pero ¿por qué esta imposición? ¿Para ocultar su debilidad de hombre o su capricho de amo? No, seguramente fue por orgullo y quizá por vergüenza de haber opacado el brillo de su estirpe. Ante un orgullo semejante, que tuvo la crueldad de ahogar tranquilamente la voz de los afectos paternales, hizo bien mi madre en responderle con orgullo del silencio" [etnovaivén]. (80)

Considerando que "[s]er madre de un hijo de don José Manuel de Sojo, aun bajo la sombra del amancebamiento, significaba para muchas mujeres libres un honor, que ninguna habría querido silenciar" y que "[1]as mismas mulatas, jactanciosas y locuaces, no habrían sabido contenerse, a pesar de cualquier prohibición, ante la realidad de su aventura" (80), es interesante que la omisión y el silencio deliberados por los que opta Casimira, la madre de Matalaché, puedan constituir una forma de negación y de resistencia—si bien tardía - a la colonización blanca, que en este caso se había materializado en su propio cuerpo.

La madre de José Manuel fallece sin haberle revelado al hijo la identidad del padre, aunque ño Parcemón le proporciona a Matalaché algunas pistas acerca de su madre y el amo blanco:

Un señó, no sé qué señó, que tu mare no lo quiso isí, manque a mí me se pone quien juí, vido un día a la Casimira y se llení l'ojo. Como que la 
dijuntita jue canela y asuca. Y ¡sas!, arrunsó con ella pa su fogón y nosotros, ni pa olé. Y anque, segú el desí, le dió güena estimación, coma si juera un taleguito e onza, lo sierto e que la tuvo e taparito, como seda e contrabando. ¿Y sabes po qué, José Manué? Pue poque no jue blanca y, naturalosamente, le ofendía e lusila. (88)

José Manuel se preguntaba: ¿Correría quizá por sus venas la sangre de algún Sojo? ¿Quién podría decírselo? La única que lo sabía, su madre, se había llevado su secreto a la tumba” (71). Sin embargo, “¿[p]or qué le había puesto su madre José Manuel sino por el padre? Verdad que esta era una cosa corriente entre esclavos, tratándose del apellido. Pero ponerle el nombre del amo era casi una audacia" (72).

Entre los elementos característicos de la literatura romántica, en Matalaché hay cuadros de costumbres, como el siguiente, en el que la voz narrativa describe el ambiente festivo que habría sido típico en los años veinte del decimonónico piurano:

En las puertas y balcones de las casas solariegas los sedeños y floreados mantones y las colchas adamascadas vertían, en soberbia competencia, las cascadas de sus oros y sus flores sobre aquellas otras naturales $[\ldots]$ regadas por los fieles en una procesión madrugadora $[\ldots]$ a trechos mesas con $[\ldots]$ ventrudos vasos de chicha de maní y de jora $[\ldots]$ figurillas garapiñadas y canastos de bollos, alfeñiques, acuñas y mazapanes. (152-3) Asimismo, con motivo de un célebre contrapunteo de guitarra y canto entre Matalaché y Nicanor (otro esclavo talentoso apodado Mano de Plata), el narrador comenta: “[Matalaché] la emprendió con la música de la tierra, con los tonderos morropanos, de fugas excitantes $[\ldots]$ con toda esa música ajímordiente y revoloteadora, flor de galpón, 
deletérea, improvisada por la musa popular, como la resbalosa, el agua de nieve, la moza mala, la mariposa, el tondero, el pasillo y el danzón” (175) ${ }^{290}$ La descripción es tan vívida que provoca bailar.

Haciéndose eco de las ideas de Jacques Attali, ${ }^{291}$ Carol Beane sostiene que López Albújar, con el fin de demostrar la valía de Matalaché como ser humano, no pone énfasis en el hecho de que sepa leer y escribir-estrategia narrativa que, dice ella, estaba en boga, especialmente en Europa-, sino que prefiere presentar al esclavo como un payador; es decir, como contendor en el "duelo entre dos guitarristas, organizado alrededor de un contrapunteo improvisado de música y voces o bien sobre un tema dado o como repuesta a los retos que allí se lanzan” ("Un día solemne” 614). Dice Beane que “[1]a payada es el vehículo principal escogido por López Albújar para la declaración más completa y profunda de la identidad de su protagonista" (ibíd. 614). Muy discutiblemente, Beane manifiesta, asimismo, que la payada es una tradición muy africana: "Aunque popularmente asociada con la Argentina, la payada es un discurso musical de forma casi [énfasis mío] netamente africana” (ibíd. 614). Enseguida cita a Andrews, quien afirma que la payada es "una variación vocal de las tapadas, las competencias de tambores, y así un descendiente directo de la tradición africana (Andrews 170)" (ibíd. 614-15). ${ }^{292}$ De ser este dato correcto, también podría interpretarse

\footnotetext{
290 "Los bailes peruanos retratados en las pinturas de [Mauricio] Rugendas [1802-1858] y de [Pancho] Fierro [1809-1879], en especial la zamacueca y la moza mala, están identificados con el nuevo nacionalismo y la identidad nacional" (Watson, "Arte y literatura en el costumbrismo peruano decimonónico".59).

${ }^{291}$ Attali, Jacques. Noise, The Political Economy of Music [Bruits: Essai sur l'economie politique de la musique]. 1977. Trad. Brian Assum. University of Minnesota Press, 1985. 12.

292 Andrews, George Reid. The Afro-Argentines of Buenos Aires. Madison:University of Wisconsin Press, 1980.
} 
que la payada, en la medida en que reafirma sus orígenes africanos, era una forma de resistencia ejercida por los negros y mulatos piuranos.

Llama la atención, sin embargo, que López Albújar haya preferido caracterizar a Matalaché como un prodigio de la guitarra ${ }^{293}$ —introducida en América por los españoles-y no del cajón, que es el instrumento tradicional de los afroperuanos. ${ }^{294}$ Quizás la elección de las cuerdas por encima de la percusión haya tenido por finalidad resaltar la hibridez no solo racial sino también cultural del protagonista, dado que Matalaché "era todavía un negro por la piel, pero un blanco en todo lo demás. Y éste era su suplicio. Sus aspiraciones, sus ideas, sus gustos, se lo gritaban desde el fondo de su corazón" (70). JCM observa que "[e]1 mulato colonial aun en sus gustos, inconscientemente está por el hispanismo contra el autoctonismo. Se siente espontáneamente más próximo a España que del Incario” (7 ensayos 242). Matalaché es, pues, demasiado blanco para ser negro y demasiado negro para ser blanco [etnovaivén]. Luis Millones-Figueroa acierta en identificar que "[e]l mulato protagonista de las novelas [se refiere tanto a Matalaché como a $\mathrm{Sab}$ ] es, en principio, un sujeto de cuerpo negro (esclavo) y alma libre (blanca) [etnovaivén]” (“Alma blanca, cuerpo negro” 78). El alma blanca también se asocia, problemáticamente, con la nobleza de los sentimientos. Por ejemplo, Matalaché declara, refiriéndose a sí mismo y en tercera persona: "José Manuel piensa, siente y quiere como los caballeros, como los blancos" (192). La misma relación,

\footnotetext{
${ }^{293}$ Las mujeres se quedaban mirándole, boquiabiertas, fascinadas, estremecidas, compenetradas por los efluvios de seducción de este mulato, que sabía arrancarle a la vibrante caja [se refiere a la guitarra] cosas tan hondas y sentidas, que las hacia suspirar y humedecérseles los ojos" (Matalaché 72-3).

${ }^{294}$ Por ejemplo, Maida Watson hace notar que, en la escena final del sainete Lances de Amancaes (1862) de Manuel Ascencio Segura, cuando un personaje pide que toquen polka, le responden: “(¡Qué polka, ni qué mazurca! Cuando un limeño está en turca, no hay más polka que el cajón', refiriéndose por 'el cajón’ al tambor africano de la música peruana costeña" (“Arte y literatura" 59).
} 
pero a la inversa, del color blanco asociado a sentimientos nobles se hace patente cuando Matalaché, acerca del capataz, comenta: "Ese negro tiene el alma más negra que su cara [etnobúmeran]" (75).

Un factor crucial en la identidad de las comunidades étnicas es el modo de hablar de la gente que las conforman. A diferencia de Sab, que domina el idioma españolcomo lo evidencian todos sus parlamentos y, principalmente, la extensa carta que le escribe a Teresa (263-272), la prima de Carlota—, Matalaché, quien también ha recibido una instrucción privilegiada, presenta deficiencias al hablar, tales como la elisión de la "d" intervocálica al final de las palabras. Mientras que en la novela cubana el habla de todos los personajes es bastante uniforme (ni siquiera en la india Martina se observa una marcada distinción en el modo de expresarse), en la novela peruana, por el contrario, se recrean el dialecto, el sociolecto y el registro que corresponde a cada personaje según su extracción, educación, puesto en la sociedad e interlocutor. Adicionalmente, Matalaché incorpora abundantes peruanismos y voces netamente locales. Cabe recordar que los cuadros y artículos de costumbres - subgéneros del costumbrismo cuyos diálogos suelen reproducir el habla popular - surgen en Latinoamérica con el estallido romántico y que su estética es asimilada posteriormente por el realismo. Milagros Carazas Salcedo califica de "regionalismo" al subgénero literario de Matalaché y lo define como "una variante del realismo que intenta representar de forma verosímil los ambientes sociales y las zonas rurales de una región, incluyendo las costumbres, los usos y la manera de hablar tan características de los personajes populares" (243). 
Una característica de la literatura romántica es la voluntad de ensalzar la singularidad de la región nativa. ${ }^{295}$ De hecho, López Albújar le dedica en Matalaché todo un capítulo al sol piurano, atribuyéndole propiedades especiales, casi mágicas, que lo distinguen de la forma en que pudiera brillar en cualquier otra parte del orbe:

En Piura el sol tenía que [...] hacerla pensar en él y sentirlo dentro de sí. [...] Es una obsesión [...] Y para la mujer el sol piurano es todavía más sol que para el hombre [...] Es él quien primero le habla a su sexo; quien la prepara y la incita a conocer el misterio de la fecundidad; quien la espolvorea en la mente el polvo mágico de los ensueños y en la urna sexual, los primeros ardores de la feminidad; quien le despierta tempranamente la imaginación a las falaces sugestiones de la especie y quien, en fin, la arroja, implacable, a la tristeza de las vejeces prematuras.

De modo determinista, el soleado clima de aquel lugar, ubicado en la desértica costa norteña del Perú, condicionaría la conducta de María Luz, la predispondría a perder su virginidad y a quedar embarazada, y, en general, anticiparía su infausta suerte. "[L]os protagonistas principales se dejan arrastrar por un amor que intenta romper prejuicios raciales y el determinismo geográfico representado por el calor de Piura explica el porqué de la exaltación de las pasiones y el deseo carnal" (Carazas Salcedo, "Una relectura de

\footnotetext{
${ }^{295}$ Es $S a b$, el afán por resaltar la belleza nacional se traduce en un texto parecido al de un anuncio de promoción turística: Dice la voz narrativa: "[V]iaje por los campos de Cuba [...] Atraviese [...] sus montes gigantescos, sus inmensas sabanas, sus pintorescas praderías: suba en sus empinados cerros, cubiertos de rica e inmarchitable verdura: escuche en la soledad de sus bosques el ruido de sus arroyos y el canto de sus sinsontes. Entonces sentirá aquella vida poderosa, inmensa, que no conocieron jamás los que habitan bajo el nebuloso cielo del norte: entonces habrá gozado en algunas horas toda una existencia de emociones [...pero] no intente encontrarlas después en el cielo y en la tierra de otros países. No serán ya para él ni cielo ni tierra" (149)
} 
Matalaché” 244). Asimismo, Antonio Cornejo Polar advierte que, “[e]n la línea medular del relato hay un visible esfuerzo por encontrar y poner en claro la razón de la pasión [...] Piura es vista como un 'don de sol'. Todo lo que allí existe está condicionado por su irrestricto imperio" (La novela peruana 36). El determinismo sería, quizás, el rasgo más naturalista la novela.

Cautivada por la fama y por el porte de Juan Manuel, ${ }^{296}$ María Luz-la hija de don Juan Francisco, el amo de La Tina—, se le ofrece sexualmente al mulato, haciéndose pasar por la esclava Rita en la oscuridad de la noche. Pero la verdad es descubierta enseguida y Matalaché recibe gustoso a María Luz porque él también se siente profundamente enamorado de ella, aunque se había refrenado de hacérselo saber porque había creído que ese amor era imposible de alcanzar debido al injusto y estricto sistema de castas imperante. Después de que la pareja tiene relaciones sexuales, María Luz le confiesa a su amado: “[M]i corazón me ha empujado. Y casi no estoy arrepentida” (149). Matalaché le responde: “[P]puedo pagarlo con la vida, ¡qué feliz me siento! ¡No temo nada! Y es que después de este momento de felicidad [...] la muerte ya no me importa" (150). La infracción cometida por los amantes - el uno un esclavo y mulato; la otra una mujer blanca, perteneciente a la clase dominante—constituye una gravísima transgresión al orden patriarcal y hegemónico, porque subvierte escandalosamente las rígidas normas y los códigos sociales del siglo XIX peruano. La prevalencia del sentimiento sobre la razón que da rienda suelta a los instintos es, quizás, la pauta más romántica de esta novela.

\footnotetext{
296 “Tal vez si fue esa mañana que recorrí la fábrica con él y lo vi vestido con aquella piel de tigre. Me pareció tan hermoso y gentil, que creo que en ese instante lo elegí para siempre" (121), le comenta María Luz a la esclava Casilda, refiriéndose a Matalaché.
} 
La idealización del ser amado es otra de las fórmulas del romanticismo. ${ }^{297}$ Pero además del amor sublime que sienten José Manuel y María Luz, que los hace idolatrarse mutuamente, en Matalaché se narra de manera un tanto explícita, aunque sin llegar a la crudeza del naturalismo literario, la pasión que se manifiesta en la ardiente pareja:

[M]urmuró María Luz, acariciándole la cabeza al esclavo, la cual, reclinada sobre sus faldas, absorbía, ebria, la sensual emanación de aquella carne rubia y palpitante... ¡Ah, déjame!... ¡Basta!... — gemía ella, desmintiendo el mandato con el jadeo de su febril respiración y el deliquio de los párpados, caídos sobre sus ojos misericordiosamente-. ¡Ah, no!... ¡La puerta!... ¡La puerta!... ¡Cierra, José Manuel, la puerta!... (150-51)

La metáfora del estado del tiempo es otro recurso de la literatura romántica. ${ }^{298} \mathrm{Al}$ inicio del capítulo XIV de Matalaché, la voz narrativa sugiere una correspondencia irónica entre el estado del tiempo y los hechos recientemente acaecidos en el “empreñarero" entre José Manuel y María Luz: "Amaneció el día de Corpus resplandeciente, virginal [la cursiva es mía], abarrotado de cielo azul y alegría aldeana"

\footnotetext{
${ }^{297}$ En $S a b$, el mulato endiosa a Carlota y ella, por su parte, sublima a Enrique, su pretendiente que, en realidad, es un cazafortunas: "Ninguna duda, ningún asomo de desconfianza había emponzoñado un afecto tan puro [el de Carlota por Enrique], porque cuando amamos por primera vez hacemos un Dios del objeto que nos cautiva. La imaginación le prodiga ideales perfecciones, el corazón se entrega sin temor y no sospechamos ni remotamente que el ídolo que adoramos puede convertirse en el ser real y positivo que la experiencia y el desengaño nos presenta, con harta prontitud, desnudo del brillante ropaje de nuestras ilusiones" (118);

"Carlota amó a Enrique, o mejor diremos amó en Enrique el objeto ideal que la pintaba su imaginación" (ibíd. 122).

${ }^{298}$ En la novela cubana, el estado del tiempo presagia, por ejemplo, el accidente que sufre Enrique al desbocársele el caballo (136): "Hacía un calor sofocante que ninguna brisa temperaba; la atmósfera cargada de electricidad pesaba sobre los cuerpos como una capa de plomo: las nubes, tan bajas que se confundían con las sombras de los bosques, eran de un pardo oscuro con anchas bandas de color de fuego. Ninguna hoja se estremecía, ningún sonido interrumpía el silencio pavoroso de la naturaleza. Bandadas de auras poblaban el aire, oscureciendo la luz rojiza del sol poniente; y los perros baja y espeluznada la cola, abierta la boca, y la lengua seca y encendida, se pegaban contra la tierra; adivinando por instinto el sacudimiento espantoso que iba a sufrir la naturaleza" (130-31).
} 
(152). Pero enseguida el estado del tiempo cambia y el narrador añade: "Otoño, con la melancolía de un cincuentón que comienza a ver su rostro rubricado de arrugas, había querido hacer en este día un alarde de entusiasmo juvenil, para eclipsarse después entre las frías e irónicas sonrisas del invierno, que acechábale ya" (152). El metafórico tiempo invernal se materializa después, en el capítulo XVI, cuando María Luz comprueba que está embarazada del mulato esclavo, enferma de los nervios, se postra en cama, y desea quitarse la vida (179-84).

Con una lógica naturalista, la novela intenta explicar el talante rebelde y lascivo de María Luz por la manera en que fue criada desde niña: “[E]ntre olvidos y descuidos [de su padre y de sus tutores] creció como esas plantas que medran por ley de su propia vitalidad y no por obra de un cultivo paciente. Dejósela una relativa libertad, casi abandonada a sus propios instintos $[\ldots][\mathrm{N}]$ o tuvo en aquella época ningún afecto efusivo o sincero" (65). Por otro lado, en el caso de José Manuel, la novela alude a condicionamientos hereditarios que lo impelen a buscar su libertad: "La voz de la sangre de mi padre [José Manuel de Sojo] [...] me dice muchas cosas. Ella es la que me grita que me rebele cuando pienso en mi condición" (90). Asimismo, la voz narrativa resalta tanto la influencia del medio social como la predisposición genética: "No, José Manuel no era un buen negro; era un renegado, a quien el trato de los blancos había contaminado de doblez e insensibilidad. Por algo tenía sangre de blanco, sangre llena de crueldad y soberbia, hecha para sojuzgar y pervertir todo lo que cayera bajo su dominio" (77).

La rebeldía y el anhelo de libertad - tanto a nivel individual como de manera colectiva (las independencias nacionales) —son, asimismo, típicamente románticos. Tomás G. Escajadillo "propone que la novela plantea el entrecruzamiento de dos tramas: 
una que tiene que ver con la historia amorosa [...], y otra en la que se aprecia un alegato en favor de la libertad política de los hispanoamericanos y una denuncia del sistema de esclavitud" (Carazas Salcedo, "Una relectura de Matalaché" 245): ${ }^{299}$ Las referidas dos tramas son "la pasión de María Luz y el negro Matalaché con alegaciones explícitas contra los principios raciales", y "el doble alegato de la libertad política de los americanos del siglo XIX frente al asfixiante poder colonial de la metrópoli española y, además, la denuncia de la situación social del esclavo en dicha coyuntura histórica con el consecuente llamado a su liberación" (Escajadillo 182; en Veres, La narrativa del indio 140). María Luz cree que los prejuicios sociales, el racismo y la esclavitud carecen de fundamento: "Aquel deseo le hablaba de la igualdad de las almas ante el amor; de la caprichosa razón de los prejuicios sociales; de la mentira de la animalidad del esclavo; de la libertad de elegir y de amar; del derecho, en fin, de disponer cada uno de sí mismo y de trazarse su propio destino" (51). Este mismo anhelo de libertad, pero en una dimensión social, se trasluce en la siguiente conversación que sostienen Matalaché y ño Parcemón, en la cual el joven siembra la inquietud de emanciparse en el esclavo viejo:

[Ño Parcemón] jamás había oído hablar así a ninguno de los suyos, quienes, más o menos conformes con su suerte, sólo pensaban en holgar y evitar los castigos y tener por amos hombres providentes y benévolos, que

\footnotetext{
${ }^{299}$ Escajadillo, Tomás G. La narrativa de López Albújar. Lima: CONUP, 1972. 182- 3. El entrelazamiento de la causa amorosa con la causa política que el crítico Escajadillo advierte en Matalaché, también se manifiesta en Sab pero sólo en una ocasión puntual, cuando el protagonista conversa con Teresa a la vera de un río: "He pensado también en armar contra nuestros opresores, los brazos encadenados de sus víctimas; arrojar en medio de ellos el terrible grito de libertad y venganza; bañarme en sangre de blancos; hollar con mis pies sus cadáveres y sus leyes y perecer yo mismo entre sus ruinas, con tal de llevar a Carlota a mi sepulcro" (209).
} 
supieran gobernarles con el estómago satisfecho. ${ }^{300} \mathrm{Y}$ ahora salía este mocito con que la vida no era esto solamente sino algo más, mucho más: ser libres e igual [sic] a los blancos, poder fraternizar con ellos. (91)

Luis Millones-Figueroa indica que "integrar al mulato como sujeto social [supone] pasar de un propuesta antiesclavista a una propuesta antirracista" ("Alma blanca, cuerpo negro 84), y es esto lo que precisamente se plantea en Matalaché.

La percepción de ño Parcemón acerca de la resignada y pasiva actitud de los esclavos de La Tina frente a su desgraciada suerte coincide con la percepción que tiene Carlota, en $S a b$, acerca de la resignación y pasividad de los esclavos del ingenio de Bellavista: “¡Pobres infelices!—exclamó—. Se juzgan afortunados, porque no se les prodigan palos e injurias, y comen tranquilamente el pan de la esclavitud. Se juzgan afortunados y son esclavos sus hijos antes de salir del vientre de sus madres, y los ven vender luego como a bestias irracionales... ¡a sus hijos, carne y sangre suya!” (146). Cabe recordar que el caso del Perú es distinto al de Cuba en lo referente a la ruptura con España. Aunque el Grito de Yara se había producido en 1868 en el ingenio La Demajagua [sic] y desde entonces se barajaban ideas independentistas y antiesclavistas en Cuba, la independencia de ese país no se produjo hasta 1898. La del Perú, en cambio, había ocurrido entre 1821 y 1824, unos años después del momento en que está ambientada Matalaché. El contexto histórico ayuda a comprender mejor el siguiente comentario de retórica emancipadora que le hace José Manuel a ño Parcemón: "El día está por llegar [...] [E]sto no puede seguir así, ño Parcemón. No es posible que

\footnotetext{
${ }^{300}$ Cuando el narrador dice "holgar" (estar ocioso, no trabajar), se refiere a la estrategia de resistencia de "amarrar el macho".
} 
trabajemos como animales y que nunca tengamos nada para disfrutarlo a nuestro gusto [...] Cuando suene la hora, yo seré el primero que corra a verme la cara con los godos" (90). En el caso de $S a b$ (1841), todavía faltaban 27 años para que se produjera el Grito de Yara. Quizás la distancia temporal explique la relativa pasividad que Carlota advierte en los esclavos del ingenio de Bellavista. Como veremos más adelante, en la carta que Sab le envía a Teresa le comenta acerca de sus sueños juveniles de libertad política, que se le frustraban en el instante en que tomaba conciencia de que era mulato.

Aunque anacrónico, por cierto, debido a que Matalaché fue publicada más de un siglo después de la independencia del Perú, el autor alza su voz de protesta contra el yugo español y contra la esclavitud; es decir, enarbola los valores del romanticismo social decimonónico latinoamericano. Cornejo Polar sostiene que "[i]nteresaba en especial al creador de Matalaché condenar la jerarquía de las razas [...] De hecho, cuando la novela se escribe (1928), la esclavitud es cosa del pasado nacional, pero la discriminación racial mantiene, sin duda, todo su rigor" (La novela peruana 33). Sin embargo, López Albújar, embozado detrás de un narrador omnisciente, socava su propio discurso antirracista/antiesclavista cuando, por ejemplo, acerca de la belleza y perfección de un frontal que fabrica José Manuel para la capilla de La Tina, hace el siguiente comentario: “En su híbrido cerebro había prevalecido la célula más civilizada. El simbólico azul de su savia ibérica había comunicado mayor fuerza a su inspiración que el rojo de su sangre africana. Del esfuerzo de este consorcio el frontal había resultado un prodigio de gracia y delicadeza" (124). En otras palabras, lo loable del producto artístico se explica por la influencia prevaleciente y positiva de la raza blanca sobre la negra en la constitución ontológica de su creador. El desliz que comete López Albújar mediante una intervención 
aparentemente inocente de la voz narrativa revelaría la verdadera forma de pensar del autor. ${ }^{301}$ Dice Grau-Llevería que, debido a que la novela romántico-social decimonónica era percibida "como vehículo idóneo para educar al público lector”, en ella suele haber "un narrador con tendencia a filosofar, que guía la lectura, interrumpiendo la narración para exponer sus opiniones". De ese modo, "[e]l narrador se convierte en la voz ficcionalizada de la intencionalidad autorial" ("El romanticismo social” 34). Aunque en Matalaché la voz autoral no llega a entrometerse a ese extremo, los prejuicios raciales del autor también quedan al descubierto cuando la voz narrativa se hace eco de los remordimientos que siente María Luz por haberse entregado al esclavo. Recurriendo a triquiñuelas para engañar y sosegar su conciencia, en sus reflexiones la joven transmuta su pasión hacia el mulato interpretándola como un acto sacrificial, en el que ella se ha inmolado:

Verdad que su falta era grande, inaudita. ¿Pero era realmente una falta? ¿Era un pecado haber cedido a los impulsos del corazón, a la ley del amor [...] que une e iguala a todas las criaturas...? Porque, después de todo, ¿qué había hecho ella sino darse en un acto de amor, como Jesús en la divina hora; restañar con sus besos las heridas de un alma, hechas por ella misma, y alumbrar con un poco de su luz la noche interminable de un esclavo? (155)

\footnotetext{
${ }^{301}$ Cabe mencionar que López Albújar tenía sangre española, indígena y africana. MVLL describe los Cuentos andinos de López Albújar como "un impresionante catálogo de depravaciones sexuales y furores homicidas del indio" y que su autor, que era funcionario del Poder Judicial en distintos lugares del Perú, "sólo parece haber visto en el banquillo de los acusados" ("José María Arguedas"). Por el contrario, JCM considera que "Los Cuentos Andinos aprehenden, en sus secos y duros dibujos, emociones sustantivas de la vida de la sierra y nos presentan algunos escorzos del alma del indio" (7 ensayos 243-4).
} 
Cornejo Polar piensa que María Luz "tergiversa su afecto [...,] descubre que lo que la lleva a entregarse no fue un simple anhelo de goce sino un inconsciente sentimiento de piedad y sacrificio" (La novela peruana 42). Si María Luz considerase a José Manuel igual a ella, no habría cabida para sentimientos misericordiosos.

De modo similar a María Luz, Carlota expresa su conciencia de clase cuando, especulando con Enrique acerca de que Sab y Teresa habrían sido amantes, exclama: “¡Amarle! ¡Amarle!... ¡Oh! No es posible... ¡Amarle!... ¡A él! ¡A un esclavo! [...] [Y]o no he juzgado su corazón por su semblante: sé que su corazón es noble, bueno, capaz de los más grandes sentimientos; pero el amor, Enrique, el amor es para los corazones tiernos, apasionados... como el tuyo, como el mío...". Enseguida, Carlota se retracta: "Él era mulato $[\ldots]$ y nació esclavo: pero tenía también un noble corazón $[\ldots]$ y su alma era tan noble, tan elevada como la tuya, como todas las almas nobles y elevadas" (251). José Servera advierte que, en $S a b$, "[1]a fuerza motriz de la obra es poseer un alma sensible, ideal romántico, ya que las pasiones enaltecen al ser humano" (49). En todo caso, ni el aprecio que siente Carlota por Sab ni la pasión que devora a María Luz por Matalachéambos mulatos de "alma blanca"-impiden que ellas continúen siendo, en esencia, clasistas y racistas: "Entre Sab y Matalaché y sus blancas amadas sólo funciona la amistad a pesar de la supuesta reivindicación de los mulatos como individuos plenos" (Millones-Figueroa 82), aun cuando el final de $S a b$ sugiera que los sentimientos y pensamientos de Carlota son transformados en verdadero amor. Lo sugiere el hecho de que Carlota (se supone que es ella) visite la tumba de Sab cada noche.

En Matalaché, el clasismo y el racismo que operan a nivel individual adquieren una mayor relevancia y trascendencia cuando se extrapolan al ámbito social. La siguiente 
conversación entre algunos invitados de don Juan Francisco a la celebración de la fiesta de Corpus Christi ilustra bastante bien la confrontación de ideas entre quienes defienden a la Corona española y el continuismo, y aquellos de pensamiento liberal, prorrepublicano. En ambas posturas políticas, el elemento racial es gravitante,

- [...] Fernando VII será todo lo falso que usted quiera, pero, al fin y al cabo, es el rey de España y, como tal rey, el señor y amo de estas tierras. ¿Qué es lo que pretenden ustedes con ese cáncer que se llama la república? ¿Poner al frente de la colonia al primer mulato que se atreva a alzar la cabeza?...

$-[\ldots][\mathrm{N}]$ o se trata de cambiar de amo sino de sistema, de darnos un gobierno que garantice la libertad y el trabajo de todos los criollos y mestizos, indios y libertos; que nos reparta una justicia más equitativa y no se la dé al que mejor pague.

— Sobre todo, de la libertad de comerciar con quien querramos [...] Basta de trabas e imposiciones. (161)

Queda claro que la principal motivación de los liberales para impulsar la independencia del Perú no es la igualdad de derechos entre criollos, indios, negros y mestizos, sino zafarse del yugo del monopolio comercial que el gobierno peninsular impone a las colonias, impidiéndoles exportar e importar. Por otro lado, en este diálogo entre conservadores y liberales se menciona específicamente a los libertos-es decir, a los negros y mulatos que han dejado de ser esclavos-, de lo cual se desprende que el proyecto nacional habría de fundarse sobre la base de un escenario posabolicionista que, implícitamente, cuestionaría no sólo la esclavitud sino también el racismo. 
Marcel Velásquez Castro observa que "[e]l discurso criollo [del siglo XIX] carga con la terrible paradoja de fundar imaginariamente la homogeneidad en una sociedad heterogénea, de anclar significados nacionales desde una identidad precaria" (Las máscaras de la representación 27). ¿Cómo construir, pues, una identidad nacional conciliando un conjunto variopinto de individuos de diversa extracción y cultura, de intereses distintos y hasta contrapuestos? Esta misma problemática se trasluce en $S a b$, específicamente en la carta que el protagonista le envía a Teresa:

Cuando en mis primeros años de juventud Carlota leía en voz alta delante de mí [...,] [y]o encontraba muy bello el destino de aquellos hombres que combatían y morían por su patria $[\ldots][\mathrm{M}] \mathrm{e}$ agitaba con un ardor salvaje a los grandes nombres de la patria y libertad: mi corazón se dilataba, hinchábase mi nariz, mi mano buscaba maquinal y convulsivamente una espada $[\ldots]$ mi alma se lanzaba a aquellos hermosos destinos hasta que un súbito y desolante recuerdo venía a decirme al oído: 'Eres mulato y esclavo'. Entonces un sombrío furor comprimía mi pecho y la sangre de mi corazón corría como veneno por mis venas hinchadas. (266-7)

De la lectura de estas líneas puede inferirse que Sab no se considera parte del movimiento emancipador (?) y que, si éste llegara a triunfar, tampoco vislumbraría una esperanza de cambio social que no estuviera reñido con el color de la piel y con la subordinación forzada de unos hombres a otros. Contrariamente a la opinión de Susan Kirkpatrick en cuanto a que "Sab concreta la amenaza histórica que experimentaron los cubanos durante el siglo que siguió a la revolución de Haití” (Las Románticas 148), después de comparar Sab con Bug-Jargal (1826) de Victor Hugo, Doris Sommer concluye: "No doubt 
Avellaneda preferred not to follow Hugo's lead in making his black hero a leader of the slave rebellion in Haiti; she rather chose to imagine the possibility of a peaceful and legitimate marriage of signs inside the existing order of things" (Foundational Fictions 137). Esto explica que, aunque a Sab se le haya pasado alguna vez por la mente sublevarse contra sus opresores y que incluso, en un arrebato de ira, hasta haya deseado bañarse con la sangre de sus adversarios, pisotear sus cadáveres y sus leyes-como le comenta a Teresa-, este mulato no tiene una vocación independentista porque, en definitiva, su rebeldía es contra aquello que le impide la realización de su amor con Carlota:

¡Cuántas veces las novelas que leía Carlota referían el insensato amor que un vasallo concebía por su soberana, o un hombre oscuro por una ilustre y orgullosa señora!... Entonces escuchaba yo con una violenta palpitación, y mis ojos devoraban el libro: pero ¡ay! aquel vasallo o aquel plebeyo eran libres [...] La gloria les abría las puertas de la fortuna, y el valor y la ambición venían en auxilio del amor. ¿Pero qué podía el esclavo a quien el destino no abría ninguna senda, a quien el mundo no concedía ningún derecho? Su color era el sello de una fatalidad eterna, una sentencia de muerte moral. (267)

De hecho, las muertes de Matalaché y de Sab simbolizan la inviabilidad de la integración social del mulato en el proyecto nacional. Para Mathew Bush, en el caso de Matalaché "[t]he author's attempts to define national culture rooted in the modern state's conflictive foundation are more in line with Peruvian intellectualism of the 19th century than that of 
the 20th century" (“A History of Violence" 7). De ahí el "retaguardismo" que el propio López Albújar le atribuye a su novela.

Matalaché y Sab se perciben a sí mismos como marcados por la fatalidad del destino: "Todo lo que veía en torno suyo parecía estar allí para recordarle su origen y su suerte, sin que él pudiera sustraerse a su imperio [...] [L]a privación del derecho de elegir una compañera de amor y poder formar con ella una sociedad como la de los blancos [...] eran para José Manuel un oprobio y un suplicio" (70), informa la voz narrativa; en tanto que "[u]na maldición terrible pesa sobre mi existencia y está impresa en mi frente. Ninguna mujer puede amarme, ninguna querrá unir su suerte a la del pobre mulato, seguir sus pasos y consolar sus dolores" (220), le dice Sab a Teresa, autocompadeciéndose. La exaltación del "yo" romántico de ambos mulatos es hiperbólica. Otra de las coincidencias en las dos novelas comparadas es que los respectivos protagonistas acaban sus respectivas vidas con un final trágico que los convierte en genuinos héroes románticos: a Matalaché lo asesina don Juan Francisco, el padre de María Luz, hirviéndolo en la tina en que se fabrica el jabón (194-5); y a Sab literalmente se le revienta el corazón de tanto amor $(227,236$ y 246).

Aunque parezca increíble, la manera en que Matalaché es torturado y asesinado probablemente rebase los márgenes de la ficción, debido a que, tanto en la época en que está ambientada la novela (alrededor de 1816) como 80 años más tarde:

un patrón ejerce sobre sus peones la autoridad de un barón normando. No sólo influye en el nombramiento de gobernadores, alcaldes y jueces de paz, sino que hace matrimonios, designa herederos, reparte las herencias, y para que los hijos satisfagan las deudas del padre, les somete a una 
servidumbre que suele durar por toda la vida. Impone castigos tremendos como la corma, la flagelación, el cepo de campaña y la muerte ("Nuestros indios", Memorias 131).

Esto lo denuncia Manuel González Prada en 1904. En contraste con el asesinato de Matalaché, el final de $S a b$ es muy propio de la ficción romántica, porque "su muerte es la culminación de lo que simboliza" (Servera 73). Sab es el epítome del sacrificio por amor: "El cielo puso a Carlota sobre la tierra para que yo gozase en su plenitud la ventura suprema de amar con entusiasmo; no importa que haya amado solo: ¡mi llama ha sido pura, inmensa, inextinguible!” (222).

Aunque no se describa en detalle la horrible forma en que muere Matalaché, sino sólo se mencione el método empleado en el asesinato, este aspecto de la novela es, a todas luces, naturalista: "Y sobre el crepitar de la enorme tina de jabón se oyó de repente un alarido taladrante, que hendió el torvo silencio del viejo caserón y puso en el alma de los esclavos una loca sensación de pavor" (195). Son, asimismo, naturalistas el supuesto determinismo genético, social y ambiental; y algunos escuetos párrafos que describen la tortuosa dinámica laboral y doméstica en La Tina:

Eran éstas [las tinas] cuatro enormes vasijas de cobre, sentadas sobre sendos cubos de mampostería, especie de tarascas insaciables en las épocas de cocción, por cuyo vientre habían pasado en su vida semisecular bosques enteros de algarrobo. En cada una de aquellas vasijas podía cocerse una tonelada de jabón. Aparecían en fila, panzudas, ennegrecidas y laqueadas por el fuego; circuidas por una plataforma de adobes y tablas, destinada a facilitar el acarreo y extracción de las materias saporíferas, 
para lo cual se hacía uso de unos grandes cucharones de zapote. Era esta una operación bastante penosa, que salcochaba el vientre de los que la ejecutaban, atosigándoles y derritiéndoles en sudor. (45)

Milagros Carazas Salcedo advierte que la descripción de las tinas, del proceso de saponificación y de las penurias de los esclavos que lo llevan a cabo "se demora en detalles $[\ldots]$ Las tinas resultan ser elementos significativos en la obra, porque José Manuel es lanzado a una de ellas cuando se descubren sus amoríos con María Luz, en un intento desesperado [de don Juan Francisco] de limpiar la honra de la muchacha y el oprobio familiar" (248): "Don Juan, ¿va usted a hacer jabón conmigo? Si es así, que le sirva para lavarse la mancha que le va a caer y para que la niña María Luz lave a ese hijo que le dejo, que seguramente será más generoso y noble que usted, como que tiene sangre de Sojo", son las últimas palabras que, insolente, porque ya no tiene nada que perder, pronuncia Matalaché.

Independientemente de que el futuro bebé pudiera ser nieto de don José Manuel de Sojo (lo que ni siquiera Matalaché sabe, sino sólo sospecha), y al margen de que el crío por venir tenga o no sangre noble (lo que es irrelevante), lo cierto es que, si llegara a nacer, tendría la piel más clara que la de su padre, probablemente recibiría una buena educación y ascendería en la escala social. En consecuencia, la novela plantearía un mensaje esperanzador para los mulatos. Sin embargo, es improbable que el embarazo de María Luz prospere porque ella quiere morir, suicidarse (184-5). Y, si don Juan Francisco es capaz de hervir a un ser humano en una tina de jabón, hacer que su hija aborte equivaldría a realizar un mero trámite. 
Retomando la estética de la novela, desde luego también es naturalistatremendista la escena en la que Nicanor, derrotado por Matalaché en la contienda de guitarra y canto, se amputa la mano con un machete:

[A]firmó sobre ella [sobre una mesa] su diestra, desenvainó con la otra el machete, y con feroz resolución se la amputó de un tajo, a la vez que, cogiéndola y tirándola a los pies de su vencedor [...] Una exclamación de horror brotó de todas las bocas, horror que se acrecentó cuando el pobre vencido, mostrando el rojo muñón al jurado, disparó contra él un copioso chorro de sangre. (177-8)

El regodeo morboso por parte de la voz narrativa en esta cruda y sanguinolenta escena es, sin duda, una característica típica de la literatura naturalista, incluso esperpéntica. Sin embargo, en Matalaché no se profundiza en la miserable vida que llevan los esclavos, no se percibe en el autor la voluntad de explicar las causas del racismo ni de la esclavitudrecordemos que "la esclavitud encuentra un apoyo ideológico en el racismo" (Millones Figueroa, "Alma blanca, cuerpo negro" 77) —, ni tampoco se habla de otras taras sociales; es decir, no se apunta completamente a un norte naturalista.

A pesar de "la dificultad de ubicar la obra de López Albújar en el proceso de la literatura nacional" (Cornejo Polar, La novela peruana 36), tomando en consideración las características temáticas y formales de Matalaché es dable concluir que, a pesar de su anacronismo, esta novela se adscribe a las convenciones literarias del romanticismo quizás tanto o más que a las del naturalismo. ${ }^{302}$ Resumiendo, el argumento de Matalaché

\footnotetext{
${ }^{302}$ Debido a la evolución poco ortodoxa de la literatura en el Perú, Raúl Porras Barrenechea "examina la República, distinguiendo en ella una fase costumbrista, un Romanticismo al que considera tardío e insincero y en el que descuella Palma, un momento caracterizado por el predominio de Modernismo y
} 
se centra en el amor imposible entre José Manuel—“Matalaché”-, un mulato esclavo, y María Luz, la hija de su amo. Ellos se rebelan y transgreden, amándose, los límites que les impone la sociedad, infracción que el mulato paga con su propia vida. La muerte por amor convierte automáticamente a Matalaché en un héroe romántico. A estos aspectos típicamente románticos de la novela se suman otros que no lo son menos, tales como la idealización del ser amado, la correspondencia entre el clima y el estado del tiempo con los acontecimientos, el regionalismo, la incorporación de cuadros de costumbres que ensalzan el folclor y la singularidad de la región piurana, la reproducción del modo de hablar de los personajes y, principalmente, el anhelo de libertad tanto a nivel individual como en el ámbito colectivo.

Matalaché finaliza con las siguientes palabras: "Quince días después, los parroquianos que iban por jabón a La Tina se encontraban con las puertas cerradas, y sobre éstas un lacónico letrero, que decía: 'Se traspasa. En San Francisco darán razón'” (195). De la misma manera en que don Diego Farfán de los Godos le había traspasado La Tina, con "semovientes” negros incluidos, a don Juan Francisco de los Ríos y Zúñiga, ahora éste haría lo propio con otro empresario que se mostrara interesado en continuar con el negocio. El tiempo se vuelve cíclico y la recurrencia de prácticas esclavistas (aunque cada vez mejor disimuladas) explicaría el rótulo de "novela retaguardista" que López Albújar decidió colocarle a esta pieza literaria ambientada en 1816 que publicó en 1928. Al morir Matalaché, simbólicamente el mulato (y, por ende, el negro) es descartado como actor en el proyecto de nación. Si bien su existencia es reconocida e incluso ocupa

Positivismo, en el que sobresalen Prada y Chocano, y que abarca hasta López Albújar (García-Bedoya, Para una periodización de la literatura peruana 46). 
un papel protagónico en la novela, no le es permitido continuar mezclando su sangre con

la del blanco. Por lo tanto, sin solución de continuidad su descendencia—su vida misma - queda trunca. 


\section{INJUSTICIA, RACISMO, DISCRIMINACIÓN Y VIOLENCIA}

\section{VI.1 MONTACERDOS (1981) DE CRONWELL JARA: SERES INMORTALES EN LA BARRIADA PERUANA}

La esperanza es el sueño del hombre despierto

Aristóteles

Los hombres son libres, y la vida humana comienza al otro lado de la desesperación

Sartre (Las moscas)

Montacerdos (1981) es una novela breve de Cronwell Jara Jiménez (1949-...). Constituye el texto germinal de Patíbulo para un caballo (1989), una novela mayor, considerada una pieza fundacional de la narrativa sobre la barriada peruana (Vich, "Entre el mito y la historia" 139). ${ }^{303}$ Luis E. Cárcamo-Huechante vincula acertadamente a Montacerdos con la tradición literaria de Enrique Congrains Martin (1932-2009) en Lima, la hora cero (1954), y de Julio Ramón Ribeyro Zúñiga (1929-1994) en "Los gallinazos sin plumas" (1955), obras que tratan sobre la vida miserable de los habitantes de las barriadas en la ciudad de Lima (“Cuerpos excedentes” 169). ${ }^{304}$

El protagonista de Montacerdos es Yococo, un niño travieso y feliz a pesar de su extrema pobreza y de su precario estado de salud, debido a una sempiterna llaga purulenta causada inicialmente por una picadura de araña. La herida "le quedó infectada, le lloró hasta crecer y crecer como tarántula de pus, chupándole el seso, para

\footnotetext{
${ }^{303}$ Cronwell Jara se refiere a Montacerdos como novela breve y, en ocasiones, también como cuento. Luis Cárcamo-Huechante sopesa el término "nouvelle" para clasificar esta pieza literaria ("Cuerpos excedentes" 165).

${ }^{304}$ Enrique Congrains también es el autor de No una, sino muchas muertes (1957), una novela neorrealista (hiperrealista) ambientada en los sórdidos extramuros de Lima. Francisco Lombardi hizo la película Maruja en el infierno (1983) basada en la referida obra. Coincidentemente, Maruja es también el nombre de la narradora de Montacerdos.
} 
chisguetearle, fino, un hilito de sangre de cuando en cuando. $\mathrm{Y}$ el mal oler [sic]. Insoportable" (18). ${ }^{305}$ Griselda es la madre de Yococo y de Maruja, una niña un poco mayor que su hermano. El padre de Yococo (la novela no indica si también lo es de Maruja) está muerto, pero ejerce su influencia desde el más allá: "[L]a araña era el difunto brujo de tu padre, Yococo. Si no araña, se hacía zancudo. Si no zancudo, se hacía alacrán. En todos ellos podía vivir el dijunto brujo de tu padre" (18), le dice la madre al niño, que ha heredado poderes sobrenaturales del padre, puesto que el pequeño es insensible al dolor físico y, debido a esa particularidad, es llamado por sus amiguitos "el inmortal": "Lo creían un muerto. Un muerto vivo. Un muerto vivo pudriéndose. Un inmortal. Y que se burlaba de los seres vivos" (10).

Maruja es la narradora de Montacerdos. Relata la época en que ella y su familia se instalan en una barriada, tras migrar de algún lugar desconocido y cruzar la pampa de Amancaes. Andrea Fanta Castro denomina "cuerpos residuales" a "los remanentes humanos de la generalizada violencia social, política y económica inherente a las sociedades de consumo" (Residuos de la violencia xiv). ${ }^{306}$ Sin duda, Griselda y sus dos hijos, quienes pueden llevar a cuestas la totalidad de sus posesiones materiales, son

\footnotetext{
${ }^{305}$ El personaje de Yococo está inspirado en un ser de carne y hueso: “Sabes que Yococo existió? Y la realidad, tú sabes, suele ser más sórdida y grosera que cualquier fantasía literaria [...] Yococo fue real. Y es verdad, verlo era un asco y a la vez conmovía. Pero tenía virtudes. Vivió entre los años 1958 y 1965 [... Murió] en un accidente: lo aplastaron unos caballos de la policía. Cuando me enteré, sentí una profunda nostalgia y recordé sus mataperradas y su carácter alegre y juguetón. Su madre falleció después, creo que a consecuencia de un aborto [...] [L]a herida infectada también fue real. Mi padre, que era jefe de enfermeros del Hospital Militar, se la curó. La primera vez, a solicitud de mi viejo, yo lo llevé a mi casa, con engaños, pero después él mismo llegaba de buena gana y salía contento con su venda en la cabeza. Finalmente, sanó después de varias sesiones", me comenta el autor en una entrevista que le hice el 10 de febrero de 2005 (“Cronwell Jara: 'Las palabras brotan como una cascada y me inundan”" 53-54).

${ }^{306}$ El trabajo de Andrea Fanta analiza una parte de la narrativa colombiana (literatura, cine, artes plásticas) producida entre 1990 y 2010, que tiene como tema central el narcotráfico, en el que la figura del sicario es protagónica. En Montacerdos, ni Griselda ni sus hijos pertenecen al mundo lumpen del que trata el libro de Fanta, pero sí se ajustan a la definición de "cuerpos residuales" que proporciona la autora.
} 
ejemplos de esos cuerpos residuales. Y, probablemente, porque "tanto la memoria como el pasado del cuerpo residual se encuentran perdidos" (ibíd. 21), Maruja comenta: "No sé de dónde habíamos venido ni adónde habíamos llegado" (ibíd. 7). ${ }^{307}$

Podría pensarse que la novela se titula Montacerdos porque Yococo se convierte en el diestro jinete de un marrano, el Celedunio. ${ }^{308}$ No obstante, en la introducción de la obra se indica que la barriada limeña en donde se desarrollan los hechos se llama Montacerdos (7). ${ }^{309}$ Cabe mencionar que la barriada que sirve de escenario a Patíbulo se llama igual. ${ }^{310}$ En cuanto a las coordenadas temporales, Montacerdos podría estar ambientada alrededor de 1981, el año en que fue publicada la nouvelle, que coincide con las tensiones sociales, políticas y económicas que se vivían en el Perú al inicio de la Guerra Interna (Cárcamo-Huechante 170). De otro lado, Vich señala que, en 1989, el año en que Patíbulo salió de la imprenta, el referido conflicto armado había alcanzado un pico tan alto de violencia que propició una segunda gran ola migratoria de los Andes a la

\footnotetext{
${ }^{307}$ El texto de Jara no revela la procedencia de Griselda y su familia. Sin embargo, nos da algunas pistas. Por ejemplo, Griselda llama "guanacu" (guanaco) a Yococo (8); el niño toca un "huainito" con su clarinete (¿quena?) (20); y, a veces, Maruja elabora oraciones con una sintaxis alterada, en la que el objeto es enunciado antes que el sujeto, que es propia del idioma quechua: "El canto del pájaro churretita imitaba..." (28). Estos detalles hacen suponer que ellos son de la sierra. Más aún, Griselda llama a Maruja "Mi corazón de quindi" (37). Siendo "quindi" la palabra quechua para picaflor, que se usa en el sur del Ecuador, es posible suponer que ellos son de la sierra norte, quizá de la provincia piurana de Ayabaca, que limita con el vecino país. Dicho sea de paso, Cronwell Jara es piurano.

${ }^{308}$ El Celedunio es un cerdo que ha sido desechado por su dueña porque está enfermo, y ha sido adoptado por el niño, quien le da ese nombre.

${ }^{309}$ Vale comentar que, en la actualidad, la mayoría de narradores peruanos muestran desinterés por las villas miseria, que eran los espacios predilectos en la narrativa de los escritores neorrealistas. Fue Enrique Congrains Martin (1931-2009) quien, con su libro de cuentos Lima, hora cero (1954), inició la estética literaria del realismo urbano en el Perú, a la que luego se adscribieron Oswaldo Reynoso y muchos otros escritores. A la generación de Congrains, conocida como Generación del 50, también pertenecen MVLL (1936-...), Carlos Eduardo Zavaleta (1928-2011) y Julio Ramón Ribeyro Zúñiga (1929-1994).

${ }^{310}$ Daniel Castillo-Durante señala la equivalencia de la barriada peruana a la favela brasileña y a la villamiseria argentina, y pone de relieve el propósito manipulador del discurso en la denominación de "pueblo joven" (Los vertederos de la postmodernidad 32-33).
} 
costa, sumándose a la que ya se había iniciado desde finales de los años cuarenta (139). No obstante, ella sitúa la historia de Patíbulo en 1948 (140). En mi opinión, los hechos que se narran en Montacerdos también podrían haber ocurrido a mediados del siglo XX, en la época en que la pampa de Amancaes, que había gozado de protección estatal hasta 1864 (Watson 57), fue invadida masivamente. Además, las barriadas del Rímac, en general, surgen en la década de 1950 (Pacheco Ibarra, "La fiesta de San Juan de Amancaes"). ${ }^{311}$

Cuando Griselda y sus hijos se aproximan por primera vez a Montacerdos, los perros salen a su encuentro y les ladran (8). Esta escena prefigura el rechazo a los advenedizos por parte de los habitantes de la barriada, quienes "[n]o podían creer que vivíamos [viviéramos] apretados a una pared, como arañas" (11). Los arácnidos, otros insectos y roedores son un leitmotiv en la historia de Yococo. Al día siguiente de que la familia se instala en Montacerdos (9), "Yococo fue el centro del espectáculo en la mañana que nos aguaitó ahí mismo". A los niños de la barriada que, curiosos, lo rodearon, "Yococo les mostró una caja y aparecieron seis alacranes vivos y cuatro cucarachas muertas [...] Metió la mano a un bolsillo y sacó dos pericotes, uno muerto y el otro medio muriéndose. Luego fue a casa y sacó su botella preferida con cientos de arañas y moscas vivas peleándose dentro" (10).

A Griselda y sus hijos la gente los considera una "[r]ara familia de muertos. Muertos vivos. Pudriéndonos" (11), especialmente a Yococo, a quien los niños de la

\footnotetext{
${ }^{311}$ A partir de 1955, Chimbote, un puerto localizado en la costa del departamento de Ancash, empieza a convertirse de un pueblo de pescadores en una ciudad barriada: "La barriada por excelencia es Chimbote, que es casi sólo una barriada: el casco urbano es pequeñísimo, es una ciudad que ha surgido en el arenal, de la nada y en muy poco tiempo. Es la ciudad de migración por excelencia" (Flores Galindo "Los últimos años de Arguedas" 45). La novela El zorro de arriba y el zorro de abajo de José María Arguedas, publicada póstumamente el 1971, está ambientada en el Chimbote de los años 1960.
} 
barriada "le tocaban despacito por [sic] ver si era de verdad, si era humano; condolidos, mofándose de él, riéndose con pena, mirándole los harapos y la llaga pestilente que reventaba en su cabeza $[\ldots]$ ¿cómo era que Yococo podía vivir teniendo tanta llaga, mitad pus, mitad costra, tan grande como sandía rajada y casi abierta, deshaciéndose en la cabeza. Pero Yococo se divertía más riéndose de todos aquellos que lo miraban embobados y les arrancaba los panes que traían en la mano" (8-9).

Evidentemente, Yococo y su familia pasan hambre y deben saciarlo como sea: "Silbando la noche, mamá Griselda encendió la hoguera y desapareció el mundo alrededor de la candela. Yococo había cruzado la alambrada que da a la chacra y había robado unos choclos ya dientones y olorosos. Antes, había cazado dos cuyes tal como mamá se lo había enseñado. ${ }^{312}$ Ahora ya sé que a esos cuyes los llaman con otro nombre horrible $[\ldots]$ Los chibolos se reían porque yo los llamaba cuyes $[\ldots]$ [S]e tapaban la nariz y la boca, con asco" (12). "Esa noche comimos cuyes y choclos fritos y yo ya no iba a vomitar. Vomitaba sólo cuando mamá me forzaba a comer cucarachas" (14).

El adjetivo "indigentes" resulta insuficiente para calificar a Griselda y a sus hijos por la paupérrima vida que llevan. La dramática situación de esta familia es extrapolada al ámbito social en Patíbulo: "Estamos sobre la miasma. Olemos a mierda. Comiendo carne de rata; tuzas, raíces de caña, palos, chala seca; lo que mastican los chivos y los puercos; durmiendo sobre colchones de moscas, con gente desesperada que no teniendo nada que comer, empieza a cortarse los dedos, las orejas, para cocinarlos y dar qué comer a los hijos, y es macabro, truculento, espantoso, ipero es cierto!” (281), le dice la

\footnotetext{
312 "Recuerda: tú te sientas sobre una piedra y esperas con un palo en alto hasta que asomen los pelos de la trompa, en su cueva. Contienes la respiración, quedito, ¿oyes? Y cuando aparece el animal, te recoges en tu garrote y ¡zas!, ¡zas!, ¡chirr!, tú le zampas sin pena, ¡chirr!, así se queje. Porque es una necesidad hacerlo, porque si no morimos, porque alacranes y cucarachas son feos para comer" (Montacerdos 13).
} 
Santísima al cura Villalobos, que trata de persuadirlos de que depongan su actitud de resistirse a las autoridades policiales que pretenden desalojarlos.

En Montacerdos, el dueño de la casa contra la cual se apoya la choza que ha parapetado Griselda le pide al presidente de la junta directiva de Montacerdos que los eche de la barriada, esgrimiendo como argumento sus reprobables hábitos alimenticios: “[S]on sucios como ratas. Se las comen. Están convirtiendo en madriguera y chiquero de cerdos mi propia casa. Nos van a pasar la peste bubónica" (19). Atendiendo a estas razones, más que suficientes para el presidente de la barriada, éste les da a Griselda y a sus hijos una semana de plazo para que se marchen.

Daniel Castillo-Durante emplea el concepto de "basurización” para referirse a los mecanismos estratégicos que utilizan los países hegemónicos (Centro) - incluyendo el discurso, también hegemónico-para descongestionar sus residuos en otros países que utilizan como basurero (Periferia) ("Los oscuros senderos" 21). ${ }^{313}$ Vich extrae la esencia del concepto "basurización" de Castillo-Durante (143) y lo utiliza para analizar las relaciones de poder entre los personajes de Patíbulo, quienes se hallan agrupados en torno a dos bandos antagónicos: las autoridades, las llamadas "fuerzas del orden" —en realidad, de represión—, de un lado; y los habitantes de Montacerdos, del lado contrario. Por ejemplo, en Patíbulo Dantón Pflucker, el comandante de los fusileros, le increpa al padre Villalobos cuando se le enfrenta en defensa del Puma: "Yo no entiendo cómo es que pueden existir espíritus que apoyen a estos puercos [los inmigrantes de la sierra] que

\footnotetext{
313 "Parte significativa de la narrativa de fin de siglo centra su mirada sobre los individuos marginales que pueden ser actores o espectadores de las condiciones de violencia, impunidad, corrupción, y que usualmente quedan fuera de aquella historia que suele escribirse con mayúsculas [...] Todos estos son cuerpos abandonados por el Estado, la sociedad y la economía. En este sentido, estas son narrativas que hacen pasar al centro lo que generalmente ha permanecido en los márgenes" (Fanta, Residuos de la violencia $\mathrm{xvi}$ ).
} 
sólo llegan a Lima a atosigarla de inmundicia, a envenenarla con su podrida habla pestilente a coca y a llenar las calles de indigencia y sarna; a mendigar y saturar las escuelas, y a ocasionar deplorable aspecto con sus ropajes de vagos y piojos. ¿No se imagina la Iglesia las enfermedades que nos acarrean y las probables epidemias a las que nos someten? ¿Ni el desorden económico que ocasionan al país?" (294). En este fragmento puede apreciarse de qué manera los prejuicios y falsedades acomodaticias se convierten en paradigmas discursivos que los centros hegemónicos ponen en circulación, y que constituyen en sí mismos una forma de basurización.

Retomando el hilo narrativo de Montacerdos, vence el plazo que les ha dado el presidente de la barriada y los inquilinos precarios no se han mudado, así que les incendian la choza. ${ }^{314}$ En esta situación de desamparo, Griselda y sus dos pequeños no son más que "cuerpos residuales" (aplicando la terminología de Fanta). Entre los escombros, que son mínimos en cantidad de material cuantificable, Yococo ubica lo que fuera su más preciado tesoro: "unos ratones y alacranes achicharrados y el revoltijo de vidrios de su botella de moscas con arañas carbonizadas" (22). Pero la vida continúa: al día siguiente, "[a]manecimos detrás de un quiosco de madera. Levantamos nuestra casa en un cerrar de ojos. A oscuras, cuando nadie nos veía y no podían molestarnos. Pero ahí hacía mucho frío y los ojos de las ratas me daban miedo. Cientos y cientos de ratas habían llegado a vivir debajo del quiosco mucho antes que nosotros. Las pulgas nos

\footnotetext{
314 "Era la hoguera tan alta y brava que parecía surgir desde el fondo de la tierra, saltaba como puma, rugía la candela y parecía quemar las nubes, puentes y los torreones del cielo. Increíble era ver cómo tan pocos palos hacían tanta llamarada [...] Afligidos, los vecinos procuraban ahogar el fuego que amenazaba incendiar el barrio [...] A fuerza de pala arrojaban tierra, gritaban: ¡Coño! ¡Tierra! ¡Coño! ¡Agua! Y escupían, tosían. Y preguntaban: iCoño! ¿Gasolina? Sí. ¡Buena gasolina! ¡Y bien que huele!” (Montacerdos 21-2).
} 
picaban, el frío mordía y no dejaban dormir. Y zumba y zumba dándonos su negra serenata toda la noche los zancudos" (23).

Al poco tiempo la salud de Yococo empeora: "Griselda "con su saliva le limpiaba las legañas, acariciándolo. Luego, conteniendo el asco y la respiración se acercaba a esa charola de pus y pelos. Le limpiaba herida por herida con orines tibios de ocho días, del mismo Yococo, hervidos antes con hojas de yantén y yerbabuena. Pero la cosa iba cada vez peor porque Yococo se quedaba mudo y sonso a veces. Sonámbulo en cualquier lugar [...] Que daba ya apariencia de difunto. Y yo veía que se iba muriendo de pie, sin quejarse, chupado de pellejos, que se le hinchaba la cara, la cabeza, y que ahora se le notaba como nunca el esqueleto [...] Que parecía más difunto. Que se muere. Que se muere mi gorrioncito" (24-25). Desesperadas, Griselda y Maruja escarban en los basurales para conseguir algo vendible que pueda generarles algo de dinero para poder comprar la medicina que necesita Yococo: “Íbamos entonces mamá Griselda y yo por los basurales confundiéndonos pronto en un bosque de revoltijos pestilentes, en un mar de ratas envenenadas y gatos agusanados por todo lugar. Y nos poníamos a escarbar compitiendo y peleando con perros vagabundos, gallinazos destartalados y las muchas garras de mendigos hambrientos, en donde gusano, gallinazo, perro y gente, valíamos la misma nada" (25).

En este pasaje se sienten fuertes resonancias de "Los gallinazos sin plumas" (1955) (La palabra del mudo, 1973), el cuento de Ribeyro en el que dos niños, que son hermanos, rebuscan los basurales. ${ }^{315}$ Pero, ¿qué autor no bebe de la tradición literaria?

\footnotetext{
${ }^{315}$ Una de las tres historias que conforman el filme Caídos del cielo (1990 de Francisco Lombardi es una adaptación cinematográfica del cuento "Los gallinazos sin plumas" de Ribeyro.
} 
(T.S. Eliot, Lo clásico y el talento individual). ${ }^{316}$ La gran diferencia con "Los gallinazos sin plumas" es que en este cuento los niños se desplazan de su casa hasta un basural, en donde escarban la basura para alimentar a un cerdo, en tanto que, en Montacerdos, Maruja y su madre se hallan allí mismo, en el basural del basural: "Buscábamos fierros y vidrios que juntábamos en cajones y latas para venderlos al señor del triciclo que nos compraba esas cosas. Pero, ¡nos pagaba tan poco!, que no alcanzaba gran cosa para comprar medicamentos para Yococo" (26). Según Jean Baudrillard, la cantidad de basura que desecha una urbe guarda relación con el nivel de deterioro en la cualidad ¿calidad moral y ética? — de la estructura social que la genera ("La violencia política y la violencia transpolítica" 325).

Sintiéndose impotente de curar a su hijo enfermo, "[m]amá Griselda entonces volvía a llorar viendo a su hijo más chupado por las fiebres y más hinchado por las llagas, cabizbajo, muriéndose en pie: que no se muera mi niño. Dioooss, sálvalooo. Y luego lloraba a gritos, aullando [...] [D]e cólera se ponía a comer tierra [...] Y lloraba así, arañándose la cara y jalándose con rabia los pelos” (26). En ese estado de degradación de la dignidad humana, Griselda y sus hijos se convierten en parte del basural. ¿Y Dios? ¿Dónde está Dios? ¿Cómo reaccionan ante este desgarrador drama quienes se llaman a sí mismos sus intermediarios? Griselda y sus hijos ni siquiera pueden refugiarse en la religión. Haciendo la salvedad de que su madre nunca había pedido limosna, la narradora relata que un domingo fueron a la iglesia para rogarle a Dios por la salud de su hermanito

\footnotetext{
${ }^{316}$ En "La tradición y el talento individual" (1919), T.S. Eliot (1888-1965) postula que todo autor está inmerso en una tradición literaria. Lo original de una obra nueva no sería sino el resultado de remozar la producción literaria ya existente, y su modesta contribución equivaldrá a insertar una pequeñísima pieza en un gigantesco mosaico dinámico (i.e. la producción literaria de todos los tiempos) que dicha pieza modificará (65-67). (Otero Luque, "Borges, uno de los tantos autores de 'Pierre Menard, autor del Quijote"” 8).
} 
y que, al momento de la comunión, el cura "los miró desconcertado, no supo qué hacer, y luego hizo como si Yococo y mamá fuesen invisibles. No los vio. [...] Y jamás les dio la hostia" (26-27). Baudrillard sostiene que la indiferencia y el odio son mecanismos mediante los cuales la sociedad se exorciza a sí misma cuando ha perdido sus valores y cuando sus miembros se convierten en el desperdicio de su propio desperdicio (326).

Después de que les incendian la covacha a Griselda y a sus hijos, en el club de madres de la barriada deliberan acerca de la posibilidad de que ellos vivan en el local de la institución. Finalmente deciden que no, porque la mayoría cree que Griselda está loca (23). Mas, cierto día Yococo se cae a una acequia desde lo alto de un árbol de pacae, en el que solía encaramarse para tocar la trompeta o el clarinete, y el agua sucia le contamina y agrava las heridas. En vista de la situación, en un acto de humanidad doña Juana, la presidenta del club de madres, ${ }^{317}$ invita a los desvalidos a que vivan en su casa y les asigna un rincón, cerca del palomar (28). Sin embargo, si bien a Griselda y su familia se les solucionan los problemas de vivienda y de alimentación, se les complica la vida en otro aspecto: Eustaquio, el esposo de Juana, aprovechando las ausencias de su mujer debido al trabajo que desempeña en el referido club de madres, fuerza a Griselda a mantener relaciones sexuales con él: “[D]on Eustaquio tumbó a mamá en la cama, la desarmó como a una ranita, la hizo crujir los huesos. Echados volvieron a pelear de nuevo, arañándose, mordiéndose, trenzándose como arañas. Cuando vi cómo enfurecido él le abría las piernas a mamá y le bajaba un trapo, yo me fui al techo [...] Vi antes cómo hecho un toro enfurecido don Eustaquio se hundía sobre ella, aplastándola, y cómo

${ }^{317}$ En Patíbulo, se indica que Juana apellida Almontes y que es la presidenta del Club de Madres Pobres (42). 
hacían esa cosita, temblando, como uno sobre otro lo hacen los cuyes. Parecía tan rico. Imaginé estar en el lugar de mamá” [énfasis mío] (32)

El comentario que hace Maruja al final de esta parte sugiere cierto determinismo. Me explico: la niña, que siente envidia de su madre, estaría condenada a correr una suerte similar. Cuando Maruja es testigo del forcejeo entre Eustaquio y Griselda, la agredida justifica al agresor: "Eustaquio, ese día no trabajaba. Vi cómo mamá se defendía a puñetes. Don Eustaquio le forzaba la falda, la levantaba en vilo y la llevaba hacia la cama. Creí que iban a matarla y esta vez lloré fuerte. Pero mamá misma me dijo que me callara, que don Eustaquio era bueno y para prueba le besó la mejilla [énfasis mío]. Los dos dijeron que me fuera a ver las palomas, que les diera maicito" (32). Griselda ya había empezado a prostituirse desde antes de mudarse a casa de doña Juana: "Mamá Griselda a veces escuchaba un silbido que pronto se nos hizo familiar entre las sobras de la noche, y salía sigilosa, sola (23). También cabe mencionar que el padre de Yococo dudaba de la paternidad del niño: “Creía que tú no eras su hijo. ¡Borracho desconfiau!” (18), le comenta la madre al vástago. Además, en la historia hay otro pasaje de violencia sexual, pero perpetrada no contra Griselda sino contra Maruja. La propia narradora cuenta: “Pablo, sin que viera Yococo, me levantó en peso y me metió dentro de la casa. Como le digas a tu mamá, te mato. Te bajo el calzón y te meto un cuchillo; luego, todo el palo de escoba en el poto; luego, te clavo seis ajíes ahí delante, con pepa y todo, como al Celedunio, ${ }^{318}$ lo oí decirme" (31). No se indica si la niña llega a ser penetrada por su agresor. Por todo esto, da la impresión de que Maruja estaría condenada a volver sobre

\footnotetext{
${ }^{318}$ Una de las mataperradas de Lolo, "el negrito de doña Juana", y de Pablo, el primo de éste (29-30), consistía en introducirle a Celedunio un ají por el ano para que, torturado por el ardor, el marrano corriera más rápido (33).
} 
los pasos de su madre; ${ }^{319}$ sin embargo, estos indicios son desvirtuados en Patíbulo, porque Maruja retorna a la barriada como una joven universitaria que se ha superado intelectual y socialmente, y que, sobre todo, transmite un mensaje esperanzador.

Como era previsible, Griselda queda embarazada de Eustaquio y, tan pronto Juana se entera, empieza a indagar sobre la identidad del responsable: "Diabla. ¡Quién ha sido, quién! Para denunciarlo a la policía [...]" (34). Luego, le llegan a Juana las murmuraciones de los vecinos y le increpa a Griselda: “¿Qué es eso de que el Eustaquio ha pisado y hace poner huevo a dos gallinas?" (34). Desde ese momento la benefactora cambia radialmente de actitud ante sus — hasta entonces — protegidos: “[E]mpezó a renegar de mamá, ya no curaba a Yococo, al Celedunio lo arrojaba a escobazos, ya no se preocupaba de darnos de comer. Yococo y yo empezamos a extrañar los cuyes fritos" (34). Ante la hostilidad de Juana, Griselda decide que ella y sus hijos deben regresar al campo, pero no llegan a hacerlo porque Yococo, mientras jugaba cabalgando el marrano en medio de una persecución policial, es atropellado por la guardia montada: "Y Yococo, metido entre los perros, subido sobre el Celedunio, ladrando como perro [...] Pasaban los caballos y Yococo: guau, guau, sobre el Celedunio. Los caballos los patearon y pisotearon" (36). Para Cárcamo-Huechante, esta escena evoca a los conquistadores, a los hombres a caballo que sometieron al mundo andino (171-72).

Mientras Yococo agonizaba luego de ser arrollado y revolcado por los caballos, Lolo y Pablo aseguraban "[q]e sus huesos soldarían pronto. Que esa costilla que le

\footnotetext{
${ }^{319}$ Influida por del naturalismo literario de Émile Zola (1840-1902), que presume un fatalismo implícito en los condicionamientos sociales (La novela experimental, 1880), la estética tremendista -inaugurada por Camilo José Cela (1916-2002) con su novela La familia de Pascual Duarte (1942) — se caracteriza por presentar un realismo crudo y brutal, con tramas sórdidas y personajes marginales cuyo destino está determinado por la herencia genética, las taras sociales y el entorno social y material, que los sumerge generalmente en un estado de angustia existencial permanente.
} 
saltaba del pecho no era nada. Que lo que vomitaba sólo era sangre de muerto. Un muerto vivo porque Yococo estaba muerto y no podía morir" (35). Finalmente, "Yococo murió esa misma noche [...] Mamá Griselda murió a los dos días, vomitando por arriba, abortando por abajo" (37). Andrea Fanta subraya que la visibilidad de los cuerpos residuales "es posible [, precisamente,] por lo que resta, por el propio cuerpo que usualmente se debate entre lo vivo y lo muerto" (13).

Voy a permitirme una digresión. El 19 de febrero de 2010, el artista Gonzalo Gamero inauguró en Puchi Art Studio, de Miami, la muestra fotográfica titulada "Deep Inside Lima”, que incluyó equis vistas de la Lima profunda; es decir, del sector más decadente de la ciudad. Las fotos que conformaban la muestra contrastaban dramáticamente, por omisión con lo antagónico, con la esplendorosa arquitectura virreinal, con los opíparos restaurantes y con los magníficos clubes privados que constituyen la excepción—no la regla—en la capital peruana, alguna vez llamada Ciudad jardín o Ciudad de los reyes. De esa manera, estas vistas de la Lima profunda interpelaban e invalidaban el mito de la "Arcadia colonial". Una de las fotos más conmovedoras es la que Gamero captó en el cementerio de un "pueblo joven"; 320 y en particular la de la tumba de un niño, demarcada en la tierra con trozos de sardinel traídos de sabe Dios dónde, y presidida por dos cruces (?) y un florero con flores frescas (Otero Luque, "La Lima profunda" 26). Esa tumba bien podría haber sido la de Yococo.

\footnotetext{
320 "Pueblo joven" es un eufemismo acuñado en la época del gobierno militar de Juan Velasco Alvarado (1968-1975) para designar a las barriadas. Gonzalo Portocarrero hace un interesante análisis de la palabra "barriada". La halla inadmisible, por peyorativa, al igual que la denominación de "barrio marginal". De otro lado, dice que el término "asentamiento humano" nos remite a la arqueología y le sugiere "precariedad y primitivismo" (La urgencia 336).
} 
A través de su ojo de fotógrafo, agudo y sensible, Gamero asimismo compartió con el espectador el rostro surcado y los roídos zapatos de una vendedora de flores, así como escenas de orates, mendigos y de gente que, como Griselda-la madre de Yococo-que espera, ignoramos qué. ¿O sí lo sabemos...? En un desesperado intento de cambiar la cruda realidad—que era, sin duda, la propuesta del artista—, se hallaban yuxtapuestas réplicas de las mismas vistas que, con la ayuda de alguna herramienta cibernética, habían sido no solo distorsionadas sino también coloreadas con alegres y brillantes tonos (ibíd. 27). En Montacerdos Yococo también "colorea" su sórdido mundo mediante la música que sabe arrancarle a su clarinete — ¿quena? — para emular el trino de las aves: "Yococo trinaba su clarinete como pájaro. Imitaba a los periquitos australianos [...] Imitaba a los loros que llegaban al pacae [...] Imitaba a los ruiseñores [...] A los pájaros chigüisa [...] A los colibríes [...] Imitaba el chiu chiu del halcón [...] Imitaba que bien el croc croc de la gallina clueca. Y el canto bravo del gallo” (ibíd. 28).

La foto emblemática de la muestra de Gamero es impresionante. Ilustra un sector sobrepoblado y caótico de Lima, aunque bien podría corresponder a un mercado pobre de Calcuta. Dejando atrás el caos de apiñados comercios ambulantes, polvorientos parasoles y apurados transeúntes, amén de construcciones precarias que reptan cuesta arriba por un cerro, un raudo mototaxi irrumpe violentamente en el primer plano, amenazando con salirse del encuadre y arrollar al espectador. Estas elocuentes fotografías constituyen una denuncia social elevada al grado de arte, porque de un porrazo obligan al espectador a tomar conciencia de que la barriada limeña es, aunque se pretenda negarlo u ocultarlo, parte de la urbe. Las elocuentes fotografías de Gamero reclaman que se tome acción inmediata para mejorar la realidad. Al final del recorrido por la galería, se hallaba la foto 
de un hombre durmiendo plácidamente en una carretilla, aparentemente ajeno al ruido y a los problemas del mundo. Afortunado él, porque dudo que Griselda-como tampoco los espectadores que asistieron a la galería, después de haber visto las perturbadoras imágenes de Gonzalo Gamero-sean capaces de conciliar el sueño con facilidad" (ibíd. 27). Fin de la digresión.

Vich advierte que, en Patíbulo, el personaje Pompeyo-Gorilón-Flores subvierte el ataque basurizador mediante un mecanismo de resignificación en un plano fantasioso, mágico (145). Es así que Gorilón sobrevive a un balazo en la cabeza que le descargan los fusileros y regresa a la barriada para ufanarse ante sus vecinos y amigos de su increíble - y heroica - resistencia:

-Pero, ¡cómo te han dejado, Gori $[. .$.$] ¿Y por qué esa venda?$

-Por la bala — dijo Gorilón.

$[\ldots]$

-Nadie vive con una bala en la cabeza — dijo Pablo el Malo, incrédulo.

—No sería yo el primero que siga viviendo [...] Tengo hambre. Un hambre de siglos.

$[\ldots]$

Se agachó y se quitó la venda. Nos mostró la frente.

-Miren. Está adentro. Y no me molesta. ¿La ven?

[...]

—Eso es — dijo algo orgulloso de su fortaleza, anudándose la venda- Ese forado fue hecho por la bala. Ahí duerme.

$[\ldots]$

-Pero un día a esa bala la cagaré por el culo. ¡Y me la pondré de collar! (12122)

Con una actitud similar ante la adversidad, cuando a Yococo los niños del barrio "[1]e preguntaban: ¿te duele? [...,] él decía que no y se reía señalando con su dedo de muerto a quien le hubo preguntado [...] y volvía a arrebatar una naranja, un limón” (10). Damary Ordóñes, interpretando el concepto sartreano del ser-para-el-otro (El ser y la nada, 1943), 
puntualiza que "el observado puede escoger sólo dos actitudes: afirmarse como sujeto, apropiarse de la propia libertad y cosificar a quien lo observa, ${ }^{321}$ o bien, captar a quien lo observa como a aquel que lo convierte en una cosa, en el otro, pero a costa de perder la propia libertad y convertirse en un mero objeto" (“Acercamiento existencialista" 159). Yococo, insensible al dolor, se vale de su precario estado de salud —que en gran medida es consecuencia de un sistema socioeconómico no equitativo, que le niega los cuidados médicos que requiere - para burlarse de quienes que, con su "mirada" (Sartre), intentan "basurizarlo". Y se ríe cuando los chiquillos de la barriada lo derriban del pacae en donde se ha encaramado para tocar su clarinete y evadirse del mundo pedestre. Manuel Baquerizo advierte con agudeza que "Cronwell Jara se burla de todo el mundo: principalmente, de los poderosos y opresores [...] En los cuentos abundan [...] los milagros, los hechos insólitos y las situaciones inverosímiles; lo real coexiste con lo irreal, lo fáctico con lo ilusorio, lo posible con lo imposible [...] Sin embargo, nada de esto hace perder a los relatos contacto con la vida" ("Cronwell Jara Jiménez y sus cuentos" 30-31).

El caso es que "Yococo trinaba su clarinete como pájaro [...] El canto del pájaro churretita imitaba cuando los hombrecitos a jebazo [hondazo] limpio le arrearon piedras,

\footnotetext{
${ }^{321}$ Una manera de apropiarse de la propia libertad y de cosificar al que observa sería la siguiente: "Inesperadamente se azuló el día al oírse una algarabía de oro y verse una suerte de farsa y feliz catástrofe; de carnaval y apocalipsis; una fiesta de demonios en el paraíso. El estruendo de la banda de músicos de los Zorros, unos cholos bonachones y muy alegres, relumbró con el esplendor de un sol, con alegría incontenible y pródiga; a golpe de platillos y tamboriles en armonía con flautines, sexofones [sic], trombas y clarinetes, se derramó en huainos y pasacalles, obrando la feliz sensación de que se venía en voraces oleajes la inundación de un río de flores perfumando los aires y calles: ícono para demostrar que todo el mundo en Montacerdos estaba alegre porque habían vuelto los fusileros y no les teníamos miedo! [énfasis mío]. El espectáculo, la violencia bélica del ritmo de la danza, el furor diablo y festivo de los músicos, enfervorizó las sangres y el espíritu de fuego de algún dios guerrero surgido de todas las tribus, comunidades, naciones y razas, latió invicto y retador en los pulsos y sienes; se tornó carcajada, mofa, salto y giro de baile" (Patíbulo 85-86).
} 
una oleada de piedras. Y Yococo reía, seguía tocando [énfasis mío] hasta que cayó a las aguas de excremento y fango de la acequia, desplumándose en el aire como un pájaro [...] Mamá lo fue a ver y, a palos, se lo llevó a casa. Lo calateó y lo dejó ahí como a una lagartija, sentado sobre una piedra. Y riendo, colmillos de piraña, ojos de rata, volvió al clarinete [énfasis mío]. (27-28). Tras sufrir este accidente, las heridas se le infectan a Yococo y su estado de salud se agrava. Sin embargo, logra recuperarse gracias a los esmerados cuidados de Griselda y de Juana (27-29). Esta última, dejando de lado los celos y el despecho por el marido infiel y la protegida traidora, se apiada del desvalido niño.

Mientras que en Montacerdos se narra la historia de una familia que padece penurias porque no consigue, entre otras necesidades elementales, unos cuantos metros de la patria para establecer su vivienda, en Patíbulo se cuenta el drama de toda una comunidad que lucha contra un gobierno que intenta cercarla, aislarla de la gran Lima y, de ser posible, hasta desaparecerla (Vich 142). A propósito del locus de exclusión, Andrea Fanta sostiene que "[1]a ciudad es de facto el lugar por donde fluyen y circulan los cuerpos residuales. Los cuerpos residuales tienen como característica la pobreza, en la medida en que son cuerpos excluidos de la economía y de la historia" (13).

Es significativo que, para llegar a Montacerdos, Griselda y su familia atraviesen la pampa de Amancaes (8) debido a que, desde el primer tercio de decimonónico peruano, tras haberse logrado la independencia de España, a la fiesta de San Juan de Amancaes que se celebraba en ese lugar en el mes de junio asistía gente de todas las clases sociales, y se convirtió en uno los símbolos icónicos de la nación idealizada que los peruanos 
empezamos a imaginar. ${ }^{322}$ Esta fiesta se hizo tradicional y llegó a ser tan importante que fue ampliamente documentada por diversos artistas. ${ }^{323}$ Lamentablemente, la concurrencia empezó a decaer desde fines del siglo XIX (Pacheco Ibarra, "La fiesta de San Juan de Amancaes"). En clave metafórica, puede leerse que el penoso tránsito de Griselda y sus hijos — quienes, en la nouvelle de Jara, representan a la clase social pauperizada del Perú - por la pampa de Amancaes — un lugar que otrora fuera idílico, un locus amoenus en donde "todas las sangres" (Arguedas) podían confluir armónicamente, aunque sólo fuera por un día de celebración carnavalesca (en el sentido bajtiniano en La cultura popular)_, es el paso sin remedio hacia un destino de "infierno de desmonte y chozas" (Montacerdos 7), pues el mensaje esperanzador deberá aguardar hasta la publicación de Patíbulo. Pero incluso en esta novela se aprecia claramente que la pampa de Amancaes ya no se asocia con un espacio de diversión y confraternidad, sino con un lugar de tránsito, de discriminación racial y de basurización: “¡Hei! — nos gritaron; era una treintena de chacareros de la hacienda $[\ldots]$ — ¡Hei, ustedes, esa indiada! [...] El dueño de esta hacienda dice que no quiere que le pisen jamás esta tierra; ordena que se larguen, que

\footnotetext{
322 "Tanto Manuel Ascencio Segura como Pancho Fierro ayudan a crear esta nueva 'nación imaginada' [...] Es una nación cuyos símbolos icónicos serán retratados por el arte de Fierro y el teatro de Segura; la tapada, el paseo al Puente y el paseo a Amancaes el 24 de junio [énfasis mío], dibujan el mundo idealizado que queda del pasado e ignoran la realidad social del presente" (Watson "Arte y literatura en el costumbrismo peruano decimonónico" 42). Lances de Amancaes, de Manuel Ascencio Segura, identifica "la bebida como parte de la fiesta y la exaltación de lo nacional peruano" (ibíd. 59).

${ }^{323}$ La fiesta de Amancaes es documentada, por ejemplo, por el acuarelista Pancho Fierro (1809-1879) (Borrachera de Amancaes, La carga de los amancaes, etcétera), por el pintor alemán Johann Moritz Mauricio- Rugendas (1802-1858) (Fiesta de San Juan en Amancaes, circa 1843), por el dramaturgo Manuel Ascencio Segura (1805-1871) (Lances de Amancaes, 1862), y por el escritor costumbrista además de dramaturgo - Felipe Pardo y Aliaga (1806-1868) ("El paseo de Amancaes", 1840), entre otros (Watson, "Arte y literatura en el costumbrismo peruano decimonónico" 57).

Incluso a mediados del siglo XX, la cantautora Chabuca Granda menciona la pampa de Amancaes en la letra de su conocido vals peruano "José Antonio" (1957).
} 
nunca se malacostumbren por aquí. Que para eso tienen ese otro camino por la pampa de Amancaes [énfasis mío]” (65).

Como señalé, Maruja es la narradora de Montacerdos. Nuria Vilanova resalta el hecho de cuán persuasivo resulta el punto de vista de una niña, que simboliza la inocencia, al relatar semejante drama (“La ficción de los márgenes” 203-4). Al igual que Cárcamo-Huechante (“Cuerpos excedentes” 170), Vilanova vincula la estética literaria de Jara a la del esperpento de Valle-Inclán, ${ }^{324}$ que, aplicada a la "submarginalidad" (Vilanova), al submundo paupérrimo de Montacerdos y al estilo narrativo del autor, producirá una nueva estética que ella denomina "estética de la miseria" ("La ficción de los márgenes” 204). Como se recordará, mediante el esperpento, Ramón del Valle-Inclán (1866-1936) intentaba exagerar los rasgos grotescos de la realidad para mostrar, con gran dramatismo, sus aspectos más desgarradores. La "estética de la miseria" de Montacerdos

\footnotetext{
${ }^{324}$ Cárcamo-Huechante advierte en Montacerdos, además de la estética esperpéntica, la tremendista (“Cuerpos excedentes" 170).

En Patíbulo, Pompeyo — Gorilón- Flores es el personaje que mejor ejemplifica las referidas estéticas: "El altísimo ojos mosquientos no era un hombre común; aunque semejante a todos los mortales, ostentaba en su rostro un lejano aire que lo emparentaba con muchos seres vivos del reino animal; poseía una mirada algo porcina, unas orejas duras y demasiado grandes, con cerdas, en un cráneo algo caballuno y grueso, que por momentos no parecía cráneo de caballo sino de león o de algún saurio" (18).

"Nací tamaño de un alacrán. Capaz de esconderme en un zapato. Pero que empezó a ensancharse feo desde que recibió un garrotazo en la nuca por la mano de su padrastro, el Pólvoras Flores. Le agarró la enfermedad del crecimiento y se le dio por comer de todo. Nos dijo que [...] su madre era la Pájaro Flores. Que odiaba a su padrastro y algún día lo iba a matar, arrancándole los testículos [...] Su rostro así nervioso [...] mantenía ese raro aire de saurio y cerdo. De redivivo engendro antediluviano" (Patíbulo24).

En la entrevista que le hice a Cronwell Jara en febrero de 2005, a la pregunta "¿Por qué sería un placer leer algo tan sórdido", refiriéndome a Montacerdos, me responde: "Por la calidad de la escritura [...] En contraste a ese mundo sórdido, el cuento está escrito con un sostenido tono poético y mantiene un ritmo adecuado a ese tono. En consecuencia, gusta por la eufonía. Por eso, este cuento fue considerado por el diario El Mercurio como una de las mejores obras publicadas en Chile en el año 2004 ("Cronwell Jara: "Las palabras brotan como una cascada y me inundan" 53). Asimismo, el autor resalta los valores humanos que transmite el cuento: "[E]n medio de su extrema pobreza, la madre loca nunca descuida a sus hijos; siempre se preocupa de su alimentación, llegando incluso, en determinado momento, a cazar ratas para procurarles algo de comer. En estos extremos difíciles, ella demuestra ternura y lucha por la integridad de su familia, en oposición a la hostilidad y la violencia del entorno [...] la insensibilidad de la junta directiva del barrio, la prepotencia del marido de doña Juana, quien prácticamente viola a Griselda, provocándole luego un aborto, la muerte y la subsiguiente desintegración de la familia" (ibíd. 53).
} 
adquiere dimensiones hiperbólicas en Patíbulo debido a que el drama ya no se circunscribe a una familia nuclear sino a toda una aldea barrial $\mathrm{y}$, sumados los hechos violentos que allí se producen, se emparienta entonces con la "Estética del hambre" del Cinema Novo. ${ }^{325}$ Cabe mencionar que, en 1987, Cronwell Jara viajó a Brasil para especializarse en guiones de telenovelas bajo la guía del maestro Aguinaldo Silva (Otero Luque, "Cronwell Jara: reseña biográfica" 60). ${ }^{326}$ Considerando que el Cinema Novo cultivado, además de Rocha, por Nelson Pereira dos Santos, Ruy Guerra y Carlos Diegues, entre otros - tuvo auge en las décadas de los años sesenta y setenta del siglo $\mathrm{XX}$, es dable suponer que, aunque éste se concentre más en la pobreza rural, alguna influencia debió de tener en la obra de Jara.

Contrariamente al punto de vista unívoco en Montacerdos, que corresponde al de Maruja, la narradora, en Patíbulo es polifónico, coral. ${ }^{327}$ En Patíbulo Maruja regresa a la barriada para entrevistar a sus pobladores y reunir el material que necesita para documentar su tesis de grado. "A las ciencias sociales les interesa este acelerado proceso de migración desde los Andes y la selva hacia Lima, en esos años de posguerra y fundaciones de barriadas" (375), le comenta a Juana Almontes. Aunque la narradora

\footnotetext{
325 Javier Garvich resalta el hecho de que "aún dentro de quienes escriben historias ambientadas en pueblos jóvenes, el carácter chicha brilla por su ausencia. Por mencionar algunos nombres: uno piensa en el célebre cuento Los gallinazos sin plumas de Julio Ramón Ribeyro, la estupenda narrativa de Cronwell Jara (Montacerdos, para mencionar un título mítico) y las historias que crea Daniel Alarcón desde los Estados Unidos [...] y advierte que, más que un eco de la cultura chicha, lo que hay allí es la descripción de la pobreza y sus secuelas, la denuncia de la injusticia y la degradación a que son sometidos buena parte de peruanos. En suma, una literatura de la miseria, no solo física, sino moral, existencial” (64).
}

\footnotetext{
${ }^{326}$ Aguinaldo Silva (1944-...), afamado escritor y director brasileño, es conocido especialmente por ser el creador de las telenovelas Señora del destino [Senhora do Destino] (2004), Dos caras [Duas caras] (2007), e Imperio [Império] (2014). La primera cuenta la historia de María, una provinciana, abandonada por su marido que, a fines de los años sesenta, llega a la urbe con sus hijos, buscando una mejor vida.

${ }^{327}$ En Patíbulo, además de polifonía, hay "heteroglosia", puesto que Jara hace hablar a sus personajes que tienen y expresan ideologías propias-, recreando literariamente los respectivos dialectos, sociolectos $\mathrm{y}$ registros (el decorum).
} 
principal es Maruja - la joven universitaria_, su voz se mezcla con la de Maruja niña, así como con la voz de los múltiples habitantes de la barriada a quienes ella entrevista, y con la de otros personajes foráneos.

En Patíbulo, Yococo, Griselda, doña Juana y hasta el Celedunio son "resucitados" por el autor, lo que, metafóricamente, puede ser interpretado como que estos personajes son capaces de vencer a la muerte (No en vano los amigos de Yococo lo creían inmortal). Contra todo pronóstico racional y a pesar de tantísima adversidad, los pobladores de Montacerdos-gracias a su tenacidad, a su empecinamiento, a su terquedad, sencillamente al conatus aristotélico - terminan imponiéndose a los fusileros, el brazo armado del poder hegemónico: "Vimos entonces que súbitamente la caballería volvía las espaldas al barrio de Montacerdos y se largaba [...] Se retiraban en columna de a uno, serenos al inicio, luego ligeros, como del infierno hacia un lugar impredecible, de pestes seguras, hambrunas, epidemias, en otro mundo [...] Lo veíamos y no lo creíamos, pero se iban" (Patíbulo 371). Un poco después, anuncia el comunicado radial: "Anhelando pues un país digno y libre, cesa desde hoy toda violencia contra las clases sociales desfavorecidas; todo cerco y toda prisión contra aquellos, ejemplares peruanos [énfasis mío], que lucharon por la defensa de los intereses de los verdaderos humildes; ¡viva la Renovación Nacional!" (Patíbulo 373). Sin ninguna intención peyorativa, es posible establecer una analogía entre los habitantes de la barriada peruana y los insectos que atesora Yococo. Como se recordará, en La crónica Hellstrom (1971), el filme de ciencia ficción (mockumentary dramático) dirigido por Ed Spiegel y Walon Green, se plantea que los insectos, no los humanos, son los que finalmente sobrevivirán y reinarán sobre el planeta Tierra, debido a su capacidad de adaptación (la supervivencia del más apto, de 
Darwin) y a la velocidad con que se reproducen. En tal sentido, los montacerdos serían, pues, inmortales.

\section{La pobreza}

MVLL sostiene que "[l]a libertad económica es la contrapartida de la libertad política y sólo cuando ellas se funden en una unidad, como el anverso y el reverso de una moneda, son operativas y genuinas" (Prólogo, El otro Sendero xxvii). Es evidente que la pobreza, más que una causa, es la principal consecuencia de un sistema en el que la riqueza no se distribuye de una manera equitativa. Sin embargo, cuando el nivel de pobreza llega a ser extremo, como en muchos sectores del Perú, ésta se convierte en sí misma en una causa que impide la acción para mejorar, que inhibe la voluntad, que suma a sus víctimas en un marasmo material, mental y espiritual. En la pobreza quedan subsumidas casi todas las demás taras sociales.

Griselda y su familia son un ejemplo de aquellos que, si bien flaquean, nunca se dan por vencidos. Lamentablemente, algunos-como el pequeño Yococo-mueren resistiendo. El subalterno sufre la pobreza especialmente cuando enferma y no tiene los recursos para curarse. Hay gente que ni siquiera tiene acceso al ineficiente sistema público de salud. Ante la imposibilidad de hacerse tratar con profesionales y medicinas convencionales, el subalterno suele recurrir a remedios caseros, así como a curanderos y santeros, que no siempre resultan efectivos.

A Guillermo Nugent le sorprende que "[n]i Mariátegui en los Siete ensayos de

interpretación de la realidad peruana, ni Haya de la Torre en El antimperialismo y el APRA, por mencionar dos textos clásicos de polémica social [...], vieron la necesidad de 
mencionar la pobreza como un aspecto destacable de la sociedad peruana de entonces" (28). Siguiendo a Mirko Lauer, Nugent vincula la pobreza como categoría social al “crecimiento de las ciudades debido a la migración interna" y se plasma en la formación de barriadas (ibíd. 28). ${ }^{328}$ Esto obedece a que, ante la pobreza, el subalterno opone la improvisación, la creatividad y la informalidad o, sencillamente, impone su presencia. Lo último sucede, a veces, de manera masiva, cuando un grupo de gente invade un terreno, ya sea de manera paulatina o violenta e intempestiva (de Soto 19). "Para ser exitosas, estas ocupaciones requieren [...] una masa crítica mínima que proporcione a los pobladores cierta capacidad de presión y negociación para disuadir al propietario de intentar recuperar el terreno" (ibíd. 20). A Griselda y a los niños les va mal como invasores porque eran solamente ellos tres: "Mamá cargando su ruma de palos y cartones. Yococo jadeando apenas, debajo de su ruma de carrizos y costales. Eso era todo. Traíamos nuestra casa en hombros" (Jara Jiménez, Montacerdos 7); "Mamá arrojó al suelo la ruma de palos y cartones y alzó nuestro laberinto de colgajos” (ibíd. 9). Nugent puntualiza que "la barriada muestra el carácter fundacional de la pobreza en el espacio urbano.", que se trata de "la renovación del espacio urbano a través de la pobreza" (29).

\footnotetext{
${ }^{328}$ Lauer, Mirko. El sitio de la literatura: Escritores y política en el Perú del siglo XX. Lima: Mosca Azul, 1989. 10, 73-6.
} 


\title{
VI.2 LA CIUDAD Y LOS PELOS: LA REPRESENTACIÓN DEL INDÍGENA PERUANO EN LA CIUDAD Y LOS PERROS (1963) DE MARIO VARGAS LLOSA
}

\author{
El ignorante afirma, el sabio duda y reflexiona \\ Aristóteles \\ La palabra es mitad de quien la pronuncia, mitad de quien la escucha \\ Michel de Montaigne
}

¿De qué manera Mario Vargas Llosa (MVLL) representa al aborigen peruano en La ciudad y los perros ${ }^{329}$ ¿Afecta tal representación la imagen del indígena? ¿Cuáles son las estrategias narrativas del autor para tratar el componente racial? Aunque mi objetivo no es hacer un análisis sociolingüístico-racial (raciolinguistic analysis); es decir, uno que intente explicar de qué manera el idioma moldea la raza y viceversa (Alim, Rickford et al, Raciolinguistics), para responder estas preguntas revisaré los términos "indio", "serrano" y "cholo" desde una perspectiva sociológica e histórica vis-à-vis su correspondiente impronta literaria en la novela en cuestión. Asimismo, intentaré mostrar en qué momento y de qué manera se cholificó el Perú. ${ }^{330}$

\footnotetext{
${ }^{329}$ Es pertinente comentar que la publicación La ciudad y los perros (Seix Barral, 1963) marcó un antes y un después en la narrativa del mundo occidental, porque dio a conocer internacionalmente las obras del propio MVLL, de Julio Cortázar, Carlos Fuentes y Gabriel García Márquez. Otros talentosos escritores latinoamericanos que fueron ampliamente reconocidos posteriormente se quedaron un tanto a la zaga de la ola mediática que catapultó a la fama mundial a los cuatro del boom. Tal es el caso de los peruanos Alfredo Bryce Echenique (Un mundo para Julius, Seix Barral 1970) y Julio Ramón Ribeyro (La palabra del mudo, Milla Batres 1973), por citar dos ejemplos. (1933-...) también precede en edad a Los cinco, pero a diferencia de Reynoso y de Bryce Echenique, sí está temática y estéticamente emparentado con los miembros de ese grupo.

${ }^{330}$ La pregunta "¿en qué momento se cholificó el Perú? es un juego de palabras que alude a la célebre interrogante con la que Santiago Zavala-Zavalita-, uno de los protagonistas de Conversación en La Catedral (1969), de MVLL, abre esta novela: “EEn qué momento se había jodido el Perú?” (15). No obstante, en el caso que me ocupa la cholificación del Perú es motivo de celebración y no de congoja.
} 
En los Comentarios Reales (1609), el Inca Garcilaso de la Vega define al "cholo" como hijo de mulatos: "Al hijo de negro y de india, o de indio y de negra, dicen mulato o mulata. A los hijos de éstos llaman cholo; es vocablo de la isla de Barlovento; quiere decir perro, no de los castizos sino de los muy bellacos gozcones; y los españoles usan por él por infamia y vituperio" (9.xxxi.424). ${ }^{331}$ Sin embargo, los términos "mulato" y "cholo" tienen otro significado en el Perú contemporáneo: mulato es el vástago de una persona de raza blanca con otra de raza negra, y se denomina cholo tanto al serrano transculturado como al mestizo (indio con blanco) que tiene un fuerte componente andino.

Sin emplear el término "pigmentocracia", en 1927 Luis Alberto Sánchez reflexionaba acerca de la dificultad de distinguir entre un indio y un criollo: "Desde el punto de vista cultural y étnico, existen 'indios' absolutamente mestizos y 'criollos' completamente 'indígenas'. De donde he venido a sospechar que lo característico del indio no es el nacimiento ni la cultura, sino el ambiente y la situación económica" (Colofón a Tempestad en los Andes 180). En el año 2006 MVLL comentaba que, en Latinoamérica, quienes se hallan hacia arriba de la pirámide socioeconómica; es decir, los que tienen dinero y poder, se blanquean, en tanto que las personas ubicadas en la base de la pirámide, o cerca de ella, se cholean o indianizan ("Raza, botas y nacionalismo").

Cabe destacar que, cuando todavía no se hablaba de antropología biológica ni se pensaba realizar el Proyecto Genoma Humano (1990-2003), los preclaros antropólogos

\footnotetext{
${ }^{331}$ En aimara, se dice "chulu anuqara" para designar un can cruzado o chusco: "Perro engendrado de padre que es de diferente casta, como bastardo" (Bertonio, Vocabulario de la Lengua Aymara 363).

"La palabra cholo, que implica hibridez, viene de la palabra aimara ch'ulu. Lo cholo se refiere a un estilo híbrido de vestimenta - distinto tanto de la ropa de los blancos como de la de los indios- y a un modo híbrido de hablar en el que se mezclan los idiomas nativos con el castellano" (Ari Chachaki 226).
} 
Franz Boas (1911) y Robert Redfield (1958) ya concebían la raza como una invención social (Redfield, "Race as a Social Phenomenon" 67). ${ }^{332}$ Los rasgos fenotípicos visibles de los seres humanos - el color de la piel, de los ojos y del cabello, la forma y el tamaño del cuerpo y de la cabeza, entre otros-habían dejado de ser relevantes para la biología. $^{333}$ No obstante, la apariencia racial continuó-todavía continúa-siendo un fuerte marcador de diferenciación social (Pitt-Rivers, "Race, Color, and Class in Central America and the Andes", 1967), ${ }^{334}$ lo cual no debe sorprendernos, debido a que si bien “la palabra 'raza' no está ligada de inmediato con un significado biológico estable [...,] esto no significa que se trate de una palabra incierta e indeterminada. Ella designa, en último análisis, un corte histórico-político sin duda amplio" (Foucault, Genealogía 69).

\footnotetext{
332 Ari Chachaki asume totalmente esta verdad: "Considero que la raza es una construcción social” (227). "Entiendo la noción de raza como un discurso que categoriza a la gente por su apariencia exterior y construye relaciones jerárquicas sobre esta base, en tanto que la etnicidad se relaciona más con discursos que ponen el acento en la diferencia cultural (Weistmantel y Eisenman, 1998: 121-142)" (ibíd. 225).

Peter Barry alerta sobre el peligro que implica renunciar completamente a los esencialismos - de género y de raza, por ejemplo-y asumir la identidad únicamente como algo variable y fluido por ser el resultado de una construcción cultural (Beginning Theory 140). Si, apegándonos a los significados posestructuralistas de Saussure, desarrollamos un concepto de identidad antiesencialista, según el cual, por ejemplo, ser negro (o blanco, o cholo o chino, gay o lesbiana) ya no es más una categoría fija sino dinámica, la identidad no es otra cosa sino "una serie de máscaras, roles y potencialidades, un tipo de amalgama en donde todo es provisional, contingente e improvisado" (traducción mía), entonces perderían fuerza los argumentos en que suelen basarse las políticas que abogan a favor de grupos desfavorecidos (ibíd. 140-1).

333 "La unidad de la especie humana es un hecho irrebatible. El origen común ha sido demostrado con creces por los antropólogos [...], sobre todo a partir de los trabajos de los Leakey [Louis Mary y Richard] [...] Todo parece indicar que el ser humano se originó en Kenya [sic] [...] El último anuncio establece en más de seis millones de años la presencia humana en dicha región" (Duncan 24).

${ }^{334}$ El planteamiento de que la raza es una invención social más que un hecho biológico (Redfield, "Race as a Social Phenomenon", 1958) no ha tenido en la sociedad el impacto revolucionario esperable. Por el contrario, la idea de concebir la nación y los nacionalismos como construcciones culturales (Anderson, Comunidades imaginadas, 1983) sí ha cuajado en la intelligentsia. Cabe mencionar que esta noción ya estaba presente, si bien en forma embrionaria, tan tempranamente como en Ernest Renan ("¿Qué es una nación?”, 1882) y en JCM (7 ensayos de interpretación de la realidad peruana, 1928). Amerita que se lleve a cabo un meticuloso estudio para explicar la diferencia en el grado de aceptación de la raza y de la nación, respectivamente, como construcciones culturales.
} 
Ciertamente, hoy en día es difícil precisar quién es indio y, por extensión, quién es cholo. La percepción de las diferencias raciales es subjetiva, móvil y varía (Neira, $L a$ piel 17). En el Perú actual, el degradé del color de la piel (color gradient) no es una escala uniforme con intervalos regulares que significan lo mismo para todos. ${ }^{335}$ Juan Carlos Callirgos advierte que las élites perciben al cholo como al indio que, debido a su "acriollamiento", ha dejado de ser servil, se ha desbordado de los supuestos límites sociales que le corresponden, y se ha vuelto irrespetuoso, agresivo, arribista y amenazante ("El racismo peruano" 20). ${ }^{336}$ "[E]1 término 'cholo' no estaba incluido, previsto, en el sistema clasificatorio inicial de blancos, indígenas y mistis" (Nugent 64). En 1962, François Bourricaud decía lo siguiente: “[E]l cholo no tiene buena reputación. Según un dicho corriente, reúne en sí mismo los vicios de las dos culturas [india y blanca], sin poseer las virtudes de ninguna de ellas" (27). Bourricaud cita a Luis A. Valcárcel: "Los indios de la ciudad y los mestizos de indios (con predominancia mestiza) son los yanacunas de los incas, desertores de su comunidad, desarraigados de su tierra, fuera de la protección, del apoyo del grupo, de la gran familia" (Valcárcel, Historia de la antigua cultura del Perú). ${ }^{337}$ Sin embargo, Bourricaud lo cita para expresar su desacuerdo: “[E]l cholo es un viajero, pero conserva sus antiguos lazos, y hasta cuando

\footnotetext{
${ }^{335}$ Nugent hace la siguiente brillante observación: "Es cosa curiosa: si alguien de piel blanca se oscurece la piel en el verano, es una regia, pero si alguien de piel oscura quiere empalidecer [blanquearse], es una alienada, huachafa, brichera, etc. (213).

Un brichero(a) es la persona que anda a la caza de turistas extranjeros, mayormente anglosajones, para relacionarse sexualmente con ellos y, de esa manera, obtener beneficios materiales.

336 "El indio urbano no era un mero trasplante espacial, una simple intrusión, como de hecho se lo intentó representar. Con el tiempo, esa presencia fuera de lugar dio origen a una identidad que al principio nadie reconoció como tal: cholo" (Nugent 63).

337 “El yanacuna o el 'cholo' es el indio desarraigado, extrañado del medio rural, de la aldea y la etnía [sic] y expuesto a la homogenización de la urbe" (Fuenzalida, "Identidad cultural").
} 
abandona su pueblo de origen, es raro que se desarraigue completamente" (28); "[e]1 cholo no es, ni mucho menos, el individuo anónimo estigmatizado por Valcárcel: está ligado a un 'grupo primario' bastante flexible, pero que le sujeta a un sistema de recompensas y castigos, relativamente estable y eficaz" (ibíd. 29). Pero Valcárcel dice más: "Hoy como entonces, un espíritu de yanaconaje está presto en todo momento a ayudar al invasor, con Pizarro y Almagro, contra las gentes de su propia raza" (Valcárcel, Historia de la antigua cultura del Perú). ${ }^{338}$

Con el paso del tiempo, el término "cholo" ha adquirido una gran amplitud semántica (Mayer 151). Incluso tiene derivados, entre los cuales destacan: cholada, cholear, cholerío, cholero, acholar(se), acholado y acholamiento (Córdova, El habla del Ecuador 370; en Fletcher, "Más allá del cholo"). En el Perú, ninguna otra palabra tiene tantas acepciones (Nugent 63). Y al combinarla con modificadores-como en el caso de "cholo lindo" o "cholo de mierda"-, su significado puede oscilar desde una expresión de profundo cariño hasta otra de máximo desprecio. A César Vallejo, por ejemplo, sus amigos lo apodaban afectuosamente "El cholo", y él, que era mestizo, lo tomaba a bien, como lo prueba el poema que le dedica al compositor y pianista Alfonso de Silva Santisteban: "Alfonso: estás mirándome, lo veo [...] [T]u inolvidable cholo te oye andar

\footnotetext{
${ }^{338}$ En Bolivia, "los mestizos (descendientes de blancos e indios) se identificaron y tomaron partido por las élites blancas, movidos por el deseo de hacerse parte del poder. En el caso boliviano, los mestizos perpetuaron las desigualdades surgidas en el período colonial, y sometieron a los pueblos indígenas a nuevas formas de colonialidad" (Ari Chachaki 223).

Después de la Reforma Agraria de 1953 en Bolivia, "los mestizos controlaban las instituciones locales y bloqueaban cualquier intento de la gente indígena por asumir posiciones de poder" (Ari Chachaki 220).

Diane Nelson "sostiene que el esquema discursivo del mestizaje ha domesticado a los Mayas en Guatemala, convirtiéndolos en 'los peores destructores de su propia cultura' [A Finger in The Wound 349], cuando se vuelven mestizos y se alejan de su identidad de origen” (Ari Chachaki 225).
} 
en París" (Poemas humanos). En consecuencia, podría decirse que el cholo es más el producto de una mezcla social que propiamente racial (Kubler).

El inconveniente de ser llamados cholos, indios o serranos no radica en el significante sino en el significado. Suzanne Oboler admite que, viviendo en sociedad, es casi imposible no categorizar a grupos sociales; el problema radica en estigmatizar a sus miembros con rótulos negativos ("El mundo es racista y ajeno" 16), debido a que "el estereotipo impide la circulación y la articulación del significante de 'raza' como otra cosa que su fijeza como racismo", afirma Bhabha (El lugar 101). Un ejemplo de esto es la siguiente entrada correspondiente a la palabra "cholo" en el Diccionario de peruanismos (1884) de Pedro Paz Soldán (más conocido por el seudónimo de Juan de Arona): "Una de las muchas castas que infestan el Perú; es el resultado del cruzamiento entre el blanco y el indio. El cholo es tan peculiar a la costa, como el indio a la sierra; y aunque uno y otro suelen encontrarse en una y otra, no están allí más que de paso, suspirando por alzar el vuelo; el indio por volverse a sus punas y a su llama, y el cholo por bajar a la costa" (en Méndez, "De indio a serrano" 86-87). ${ }^{339}$ De otro lado, la definición que proporciona el Diccionario de la Lengua Española (RAE) para el peruanismo "cholear" es, sencillamente, "tratar a alguien despectivamente". Sin embargo, como sostienen Edward Sapir y Benjamin Lee Whorf, el lenguaje no sirve exclusivamente para describir realidades, sino también para crearlas. Más aún, los

\footnotetext{
${ }^{339}$ Además de discriminar a los indígenas y mestizos, Pedro Paz Soldán también discriminaba a las mujeres. La historiadora Margarita Giesecke Sara Lafosse refiere que, en opinión de Paz Soldán, escribir era "cosa de hombres" ("Escribir no es sólo cosa de hombres" 42). Este intelectual decimonónico llegó incluso a insultar a la reconocida escritora Mercedes Cabello de Carbonera, llamándola "Mierdeces Caballo de Cabrón-era" (Guardia, "La escritura femenina" 18).
} 
discursos (textos, al fin de cuentas) están preñados de ideología. ${ }^{340}$ "Después de [Edward]

Said y [Michel] Foucault el texto ya no se ve como mediación sino como lugar de construcción de realidad" (Gnecco, "Discursos sobre el otro" 102). El que representa no escapa a la representación (ibíd. 101). ${ }^{341}$

Entrando en materia—el análisis de la novela que me ocupa—, algunos críticos sostienen que el Colegio Militar Leoncio Prado-el escenario en donde se desarrolla la mayor parte de la trama de La ciudad-funge como un microcosmos de la sociedad peruana (Montes, "El imaginario perruno" 75). Si interceptamos este microcosmos espacial ubicado en la ciudad de Lima con las coordenadas temporales en que está ambientada la historia - los años cincuenta del siglo $\mathrm{XX}$ - , podremos apreciar lo que Mijaíl Bajtín denomina un "cronotopo"; es decir, la plasmación artística del espacio y del tiempo - éste vinculado inextricablemente a aquél, como su cuarta dimensión—en la forma y contenido literarios (Teoría y estética de la novela 237). En tal sentido, la caracterización que MVLL hace de Porfirio Cava — un joven indígena trasplantado a la

\footnotetext{
${ }^{340}$ Es la ideología la que posibilita que el poder de un grupo dominante no reside tanto en su fuerza coercitiva sino en su habilidad para promover y mantener un sistema de creencias y sentimientos entre los subalternos que le permiten legitimar la inequidad (Marger 28-9). "La primera característica de la colonialidad de poder, la más general de todas, es la dominación por medios no exclusivamente coercitivos. No se trató sólo de reprimir físicamente a los dominados sino de conseguir que naturalizaran el imaginario cultural europeo como forma única de relacionamiento [sic] con la naturaleza, con el mundo social y con la propia subjetividad" (Castro-Gómez 59).

${ }^{341}$ En un plano mucho más amplio pero aplicable a este hecho en particular, cabe señalar que "[s]in la construcción de un imaginario de 'oriente' y 'occidente', no como lugares geográficos sino como formas de vida y pensamiento capaces de generar subjetividades concretas, cualquier explicación (económica o sociológica) del colonialismo resultaría incompleta. Para Said tales formas de vida y pensamiento no se encuentran, solamente, en el habitus de los actores sociales sino que están ancladas en estructuras objetivas: leyes de Estado, códigos comerciales, planes de estudio en las escuelas, proyectos de investigación científica, reglamentos burocráticos, formas institucionalizadas de consumo cultural. Said piensa que el orientalismo no es sólo un asunto de 'conciencia' (falsa o verdadera) sino la vivencia de una materialidad objetiva" (Castro-Gómez 22). Por esta razón es que "[e]l dominio europeo sobre el mundo requirió una legitimación 'científica', en la cual empezaron a jugar un papel fundamental las nacientes ciencias humanas: filología, arqueología, historia, etnología, antropología, paleontología. Al ocuparse del pasado de las civilizaciones orientales estas disciplinas 'construyeron', en realidad, el presente colonial europeo" (ibíd. 24).
} 
urbe y cadete del referido colegio militar, quien representa a un amplio segmento de la sociedad peruana—nos permite mirar la "fotografía", incluso la "película" literaria, de un fenómeno social en un momento dado en la historia, debido a que, mediante el cronotopo, el tiempo "se condensa [...], se comprime, se convierte en visible desde el punto de vista artístico; y el espacio, a su vez, se intensifica, penetra en el movimiento del tiempo, del argumento, de la historia” (Bajtín 238). Esto, quizás, se hace más palpable en el cine.

Como es sabido, MVLL fue alumno del Colegio Militar Leoncio Prado en los años 1950 y 1951. En esa época el Perú era gobernado por el general Manuel Arturo Odría Amoretti, un presidente de facto. Al inicio del "ochenio odriísta" (1948-1956) MVLL tenía doce años de edad y, cuando Manuel Prado y Ugarteche sucedió al dictador, MVLL tenía veinte. Tanto la pasantía por el colegio militar como la corrupción, el abuso y la represión que caracterizaron al mandato de Odría debieron de marcar profundamente a MVLL. ${ }^{342}$

No resulta difícil hacer una conexión entre la historia que se cuenta en La ciudad y el militarismo abusivo y el temor a ser castigado que reinaban durante el ochenio. José Miguel Oviedo indica que "[1]os únicos valores que la novela deja intangibles son la

\footnotetext{
${ }^{342}$ De manera similar a Conversación en La Catedral (1969) de MVLL, el tema del caudillismo (chieftainship) es recogido por la literatura hispanoamericana en Facundo o civilización y barbarie en las pampas argentinas (1845) de José Faustino Sarmiento; en la novela El señor Presidente (1946) de Miguel Ángel Astudias, inspirado en Manuel Estrada Cabrera, un tirano y asesino que mantuvo subyugado al pueblo guatemalteco desde 1898 hasta 1920; de alguna manera en La muerte de Artemio Cruz (1962) de Carlos Fuentes; en El recurso del método (1974) de Alejo Carpentier, que describe con ironía—en sentido opuesto al ordenamiento cartesiano de razón y verdad en el Discurso del método (1637) - la realidad dictatorial en algún país latinomaericano de los años 1920; en Yo el Supremo (1974) de Augusto Roa Bastos, inspirado en José Gaspar Rodríguez de Francia, dictador supremo y vitalicio del Paraguay desde 1814 hasta 1840; en El otoño del patriarca (1975) de Gabriel García Márquez, que cuenta la historia de un ficticio dictador caribeño; y en La fiesta del chivo (2000) de MVLL, que cuenta las maldades del dictador y asesino dominicano Rafael Leónidas Trujillo (1891-1961).
} 
supremacía y la imposición" (110). ${ }^{343} \mathrm{Si}$ bien el significado de un escrito surge en el momento en que es leído, ${ }^{344}$ en ocasiones la biografía del autor permea el texto, tal como sucede en el caso de esta novela.

Los dos grandes ejes argumentales de La ciudad son, por un lado, el robo del examen de Química y la expulsión de Cava del colegio por haber cometido ese delito; y, por el otro, el asesinato del Esclavo y la impunidad del crimen. A lo largo de la narración, los condiscípulos de Cava-que son mayoritariamente mestizos y pertenecen a otras clases sociales_ ${ }^{345}$ se dirigen y se refieren constantemente a este personaje como "el serrano Cava". El trato humillante que recibe Cava puede apreciarse desde el principio de la historia, cuando regresa a su cuadra después de copiar las preguntas del examen de Química y le cuenta al Jaguar que ha roto accidentalmente un vidrio. En ese instante, "[1]as manos del Jaguar vinieron hacia él como dos bólidos blancos y se incrustaron en las solapas de su sacón [...] 'Serrano-murmuró el Jaguar, despacio-Tenías que ser serrano"" (La ciudad 20). Aunque tambalea, sin bajar la mirada Cava intenta retirar de su pecho las manos del Jaguar. Pero “' ¡Suelta!... ¡Serrano!', le ordena el cabecilla, despectivamente, casi escupiéndole la cara, y el subordinado obedece, dejando caer sus propias manos" (ibíd. 20).

\footnotetext{
${ }^{343}$ En el Prólogo a Conversación en La Catedral (1969), la tercera novela de MVLL, el autor revela que "[e]se clima de cinismo, apatía, resignación y podredumbre moral del Perú del ochenio, fue la materia prima de esta novela" (7). En esta obra también puede apreciarse el cronotopo bajtiniano.

${ }^{344}$ Me refiero a la llamada teoría de la recepción (Hans Robert Jauss y Wolfgang Iser, entre otros), así como a las ideas de Roland Barthes en "La muerte del autor" (1968) y de Michel Foucault en "¿Qué es un autor?" (1969).

${ }^{345}$ En la escala social y ordenados de arriba abajo, Alberto Fernández Temple (el Poeta), Ricardo Arana (el Esclavo) y el Jaguar pertenecen a estratos distintos (Declaraciones de MVLL a Mario Benedetti, en Oviedo. "Mario Vargas Llosa" 120).
} 
La manera en que el Jaguar emplea la palabra "serrano" para abordar o referirse a Cava no tiene sólo una función denotativa—es decir, expresar sencillamente y en tono neutral que Cava es oriundo de la sierra—, sino también connotativa: la de insultarlo, decirle que es un inepto. Cecilia Méndez explica que, "[c]uando uno busca un insulto en el Perú, uno de los más fuertes es 'serrano', que es en realidad un eufemismo para 'indio' [...] La asociación de 'indio' con sierra, y de sierra con condición rural y pobreza, está tan profundamente arraigada en el Perú que se toma como natural. No se cuestiona su origen" ("De indio a serrano" 73). Es así que, tanto en la costa como en la selva del Perú el término "serrano" también es empleado como insulto entre la gente local (Ardito Vega. Reflexiones Peruanas 57).

Cabe señalar que los apelativos de "serrano" y de "indio" se han vuelto intercambiables con el de "cholo", especialmente cuando son empleados en sentido peyorativo. El ánimo desdeñoso de estos términos se aplica, por extensión, a otros grupos raciales y étnicos. Esto puede apreciarse claramente en La ciudad cuando Alberto le advierte a Paulino - un comerciante homosexual que atiende un expendio de sodas y golosinas dentro del colegio—, quien, en rigor, no es ni cholo ni serrano ni indio—que no lo trate de tú: "No me gusta que me tutees, cholo de porquería" (139), así como cuando el Boa le increpa a Paulino por haberle mordido el pene durante una felación: "Me mordiste, cholo maldito, serrano, voy a matarte" (144).

En la percepción del Jaguar, la impericia de Cava—que, en esa ocasión, había ocasionado la rotura del vidrio - sería propia de toda la raza amerindia hacia la cual siente desprecio. Cabe traer a colación que, en una carta que Ricardo Palma le escribió a Nicolás de Piérola, el intelectual le manifiesta al político que, en su opinión, las batallas 
de San Juan y Chorrillos, ambas libradas contra los chilenos el 13 de enero de 1881 en el contexto de la Guerra del Pacífico (1789-1844), se perdieron por culpa de los indígenas:

En mi concepto la causa principal del gran desastre del 13 está en que la mayoría del Perú la forma una raza abyecta y degradada [falacia de causa cuestionable, racismo abierto] que usted quiso dignificar y ennoblecer. El indio no tiene sentimiento de la patria; es enemigo nato del blanco y del hombre de la costa y, señor por señor, tanto le da el ser chileno como turco [prejuicios]. Así me explico que batallones enteros hubieran arrojado sus armas en San Juan sin quemar una cápsula [sesgo retrospectivo, falacia de causa cuestionable]. Educar al indio, inspirarle patriotismo, será obra no de las instituciones sino de los tiempos [discriminación, nepotismo étnico]. Por otra parte, los antecedentes históricos nos dicen con sobrada elocuencia que es orgánicamente cobarde [argumento ad antiquitatem y falacia secundum quid] (Palma, 1979, p. 20). (Cartas a Piérola: sobre la ocupación chilena de Lima, en Portocarrero, La urgencia 121-2)

Lo más sorprendente de esta carta es que el remitente - cuyo padre tenía tres cuartos de indígena y cuya madre era mulata (ibíd. 87) — se distancia de sus raíces por el lado paterno. ${ }^{346}$ Pero es peor aún que, en pleno siglo XX, en el Perú hubiese intelectuales que pensaban que el indígena no tenía salvación. Tal sería el caso de Alejandro Deustua Escorza, un filósofo y escritor que ocupó altos cargos académicos y de servicio público.

\footnotetext{
346 Según Carlos Joaquín Córdova, en 1892 Ricardo Palma propuso la incorporación del americanismo "acholarse" a la lengua española, con la acepción de "timidez característica de nuestros indios cuando se ven forzados a hablar con la autoridad o con personas de superior categoría" (en Fletcher). Nataly Fletcher advierte que la definición que proporciona Palma supone tanto la cortedad como la inferioridad de los indígenas (ibíd.). Por lo tanto, no debe sorprendernos que Palma, quien tenía una percepción tan devaluada de los indígenas, renegase de sus raíces andinas.
} 
Según Nelson Manrique, Deustua escribió en su libro La cultura nacional (1937) lo siguiente:

El Perú debe su desgracia a esa raza indígena [etnocentrismo], que ha llegado, en su disolución psíquica, a obtener la rigidez biológica de los seres que han cerrado definitivamente su ciclo de evolución [determinismo genético] y que no han podido transmitir al mestizaje las virtudes propias de razas en el período de su progreso [falacia de la pureza racial] [...] Está bien que se utilice las habilidades mecánicas del indio [racismo abierto y explotación]; mucho mejor que se [le] ampare y defienda contra sus explotadores de todas las especies [paternalismo] y que se introduzca en sus costumbres los hábitos de higiene que carece [racismo cultural]. ${ }^{347}$ Pero no debe irse más allá, sacrificando recursos que serán estériles en esa obra superior y que serían más provechosos en la satisfacción urgente de otras necesidades sociales [discriminación, nepotismo étnico]. El indio no es ni puede ser sino una máquina [racismo abierto]. ${ }^{348}$ (Citado en La piel y la pluma 19)

Carlos Iván Degregori ya había hecho notar la manera de pensar de Deustua (“Ocaso y replanteamiento" 234) y, además, comentaba el antropólogo que “[n]o es de extrañar, entonces, que hacia 1900 un diputado por Puno presentara un proyecto de ley para el exterminio de la raza aborigen" ("Perú: identidad” 214).

\footnotetext{
${ }^{347}$ En la jerarquización de la sociedad, "se optó por dar un particular significado a la suciedad [...La impureza,] la suciedad humana, la suciedad primordial [...] fue el verdadero elemento de reconocimiento cotidiano, ante la dificultad sensorial de distinguir nítidamente un fenotipo de otro" (Nugent 47).

${ }^{348}$ Deustua, Alejandro. La cultura nacional. Lima: Empresa Editora de El Callao, 1937.
} 
Incluso el propio José Vasconcelos (1882-1959), famoso por su planteamiento grandilocuente del surgimiento de una raza cósmica, no está libre de la influencia positivista decimonónica (Grijalva 343), ${ }^{349}$ que pone de manifiesto cuando, al sopesar la calidad resultante de la mixtura de determinadas razas con otras, hace la siguiente salvedad: "Resulta entonces fácil de afirmar que es fecunda la mezcla de los linajes similares y que es dudosa la mezcla de tipos muy distantes según ocurrió en el trato de españoles y de indígenas americanos [énfasis mío] [...] Sucede que el mestizaje de factores muy disímiles tarda mucho tiempo en plasmar" (La raza cósmica 11). Contradictoriamente, en América, el continente destinado a realizar su utopía, la fusión racial hispano-amerindia no es la óptima, según su percepción. ${ }^{350}$

Si personas instruidas - como Palma, Vasconcelos y Deustua_pensaban de esa manera tan retrógrada, ¿qué podía esperarse del ciudadano común? Por lo tanto, no debe llamarnos la atención que, en uno de los diálogos de la novela, el oficial Pitaluga afirme lo siguiente en relación con los andinos que se enrolan en el Ejército: "Los soldados que llegan al cuartel son sucios, piojosos [énfasis mío] y ladrones. Pero a punta de palos se civilizan. Un año de cuartel y del indio sólo les quedan las cerdas” (204). Mas nótese que,

\footnotetext{
349 "En la América Española ya no repetirá la naturaleza uno de sus ensayos parciales, ya no será la raza de un solo color, de rasgos particulares, la que en esta vez salga de la olvidada Atlántida; no será la futura, ni una quinta ni una sexta raza, destinada a prevalecer sobre sus antecesoras [poligenesia]; lo que de allí va a salir es la raza definitiva, la raza síntesis o raza integral" (Vasconcelos, La raza cósmica 30).

350 "Vasconcelos, que subestima un poco las culturas autóctonas de América, piensa que, sin un libro magno, sin un código sumo, estaban condenadas a desaparecer por su propia inferioridad. Estas culturas, sin duda, intelectualmente, no habían salido aún del todo de la edad de la magia" (JCM, 7 ensayos 124). "[E]n México, los indigenistas glorificaban el mestizaje o mezcla racial entre blancos e indios, como parte del imaginario nacional, pero también rechazaban las lenguas nativas y excluían a las minorías. Los escritos de José Vasconcelos son un ejemplo de este discurso (Rénique, 2003: 215) [en Appelbaum, Race and Nation 215]" (Ari Chachaki 221).

Appelbaum, Nancy P, Anne S. Macpherson, y Karin A. Rosemblatt. Race and Nation in Modern Latin America. Chapel Hill: University of North Carolina Press, 2003.
} 
a diferencia de Deustua (personaje real), para Pitaluga (personaje literario) el indio puede salvarse si se le somete a una férrea disciplina.

Al igual que el Jaguar, también el Boa percibe torpeza y falta de inteligencia en Cava: "Cuando se reunía el Círculo y había que sortear a uno [...] y salía el serrano, yo decía mejor elegimos a otro, éste se hará chapar y nos caerán encima” (260-61). ${ }^{351}$ Los hechos parecieran confirmarle al Boa sus reparos en cuanto a la aptitud del sorteado: “[H]ay que ser bruto para romper un vidrio. Los serranos son un poco brutos [...] Es una suerte no haber nacido serrano" (191), piensa. Para construir su identidad y definirse, el Jaguar y el Boa necesitan diferenciarse de los serranos, que son el Otro. ${ }^{352}$

El Boa es el personaje de la novela que más animadversión expresa hacia los andinos, que son los enemigos comunes de su grupo social, al extremo de sentir más simpatía hacia su perra que hacia aquéllos: "[L]a Malpapeada no era la que traía las pulgas; yo creo que el colegio le contagió las pulgas a la perra, las pulgas de los serranos" (229). Su desprecio hacia los andinos se habría originado en una vendetta de la que fue víctima su hermano camionero, a quien, tras engaños y ardides, acuchillaron unos serranos, dejándolo gravemente herido: "Esperaron que yo estuviera bien borracho, con pisco que ellos mismos me convidaron, para echárseme encima” (258). En los recuerdos

\footnotetext{
${ }^{351}$ Para protegerse y también para vengarse, cuatro cadetes de tercer año-el Boa, Rulos, Cava y el Jaguar, liderados por el último - forman una asociación clandestina llamada el Círculo. Debido a la conducta prepotente y violenta de sus integrantes, el Círculo se vuelve una amenaza para los demás estudiantes.

${ }^{352}$ Esta dinámica de la construcción de la identidad no sólo ocurre a nivel personal, individual, sino también en el ámbito social y a escala planetaria. Es así que "[1]a identidad del sujeto burgués en el siglo XVII se construyó, a contraluz, mediante las imágenes que cronistas y viajeros habían difundido por toda Europa de los 'salvajes' que vivían en América, África y Asia” (Castro-Gómez 67).

"La identidad del Yo europeo se produce en este movimiento dialéctico ["dialéctica del colonialismo"]. Una vez que el sujeto colonial es construido como Otro absoluto, entonces puede ser subsumido (anulado e integrado) dentro de una unidad más elevada. Sólo mediante la oposición al colonizado se vuelve realmente él mismo, el sujeto metropolitano" (Hardt y Negri, Imperio 152, en Castro-Gómez 99).
} 
del Boa, la voz de su hermano le dice: "[S]i quieres saber si un tipo es serrano, míralo a los ojos, verás que no aguanta y tuerce la vista" (256). Sin embargo, Cava-que es serrano-le sostiene la mirada al Jaguar cuando éste le increpa por haber roto el vidrio (20).

La discrepancia entre lo afirmado por el narrador omnisciente, que no es confiable, y lo afirmado por el Boa no es sino el contraste de distintas percepciones de la realidad, y un ejemplo del multiperspectivismo que ofrece La ciudad con la intención de transmitir un tipo de realismo que no privilegia un enfoque en particular (muy distinto del de la visión unívoca que ofrecía el narrador omnisciente decimonónico). ${ }^{353}$ En el análisis que hace Bajtín de las novelas de Dostoievski, el crítico denomina "polifonía" al multiperspectivismo y al diálogo entre varias voces que son característicos en la narrativa de este novelista: "En sus obras no se desenvuelve la pluralidad de caracteres y de destinos dentro de un único mundo objetivo a la luz de la unitaria conciencia del autor, sino que se combina precisamente la pluralidad de las conciencias autónomas con sus mundos correspondientes $[\ldots]$ La conciencia del héroe aparece como otra, como una conciencia ajena" (Problemas de la poética de Dostoievski 15).

El multiperspectivismo se aprecia, por ejemplo, cuando en uno de sus monólogos interiores el Boa presenta a Cava como un abusivo-“[D]espués del Jaguar, Cava era el peor; le quitaba [al Esclavo] los cigarrillos, el dinero, una vez había orinado sobre él mientras dormía" (155) —, en tanto que en otra parte de la novela se resalta la lealtad y el espíritu de sacrificio de este personaje. Cuando el Jaguar se sulfura debido a la rotura del

\footnotetext{
${ }^{353}$ En Hienas, el narrador hace referencia a algunas complejidades formales de La ciudad: "[D]e buenas a primeras, cuando empezabas a encontrarle el gusto, de repente te despistaba un cambio total [...] hasta que descubriste las claves y, ya ducho en el arte de armar las piezas de ese complicado rompecabezas, te metiste en cuerpo y alma en el libro" (228).
} 
vidrio, para tranquilizarlo Cava le asegura que, si llegaran a descubrirlo, sólo él sufriría las consecuencias: "Si nos chapan, pago solo y ya está" (20). Aunque podría argüirse que, de acuerdo con el código de honor castrense, la reacción de Cava sería la esperable de cualquier cadete, o que se trata de dos aspectos distintos de la conducta de este personaje, en todo caso Cava muestra un rasgo positivo que contradice la percepción negativa que el Boa tiene de él.

En la mente del Boa resuenan constantemente las palabras de su hermano en contra de los andinos: "Los serranos... mala gente, lo peor que hay. Traidores y cobardes, torcidos hasta el alma" (44). Y recuerda sus consejos: "Cuídate siempre de los serranos, que son lo más traicionero que hay en el mundo. Nunca se te paran de frente, siempre hacen cosas a la mala, por detrás" (258). Las aseveraciones de su hermano inducen al Boa a pensar: "Será por eso que los serranos siempre me han caído atravesados" (258). Este es un típico ejemplo de estereotipo étnico; es decir, de una creencia infundada, exagerada y simplista, usualmente adquirida por influencia de terceros-efecto Bandwagon-, y que el creyente se resiste a desestimar aunque existan evidencias desvirtuándola (John Harding, 1968; Thomas Pettigrew, 1980) (Marger, Race and Ethnic Relations 52). Aunque el Boa juzga negativamente a Cava también basado en el comportamiento que éste exhibe, como por ejemplo el hecho de que maltrate a su mascota - "Varias veces lo pesqué tirándole piedras, pateándola al descuido cuando yo no lo veía. Los serranos son bien hipócritas y en eso Cava era bien serrano" (256) —, las ideas que tiene en contra de los andinos están fundadas principalmente en el incidente relacionado con su hermano y en generalizaciones que particulariza en Cava: "Cava decía que iba a ser militar [...] Los serranos son tercos, cuando se les mete algo en la cabeza 
ahí se les queda. Casi todos los militares son serranos. No creo que a un costeño se le ocurra ser militar. Cava tiene cara de serrano y de militar" (191).

Sin temor a caer en el sesgo cognitivo que implican los estereotipos y las generalizaciones, es posible confirmar lo que indica el Boa en cuanto a que el Ejército peruano solía estar integrado por muchas personas de origen andino, a diferencia de la Fuerza Aérea, que incorporaba más mestizos, y que la Fuerza Naval, en la que, proporcionalmente, había más oficiales de raza blanca. Debido a la inequidad económica, la concentración de la etnia andina también resalta en algunos ambientes civiles destinados al bienestar social, como es el caso de la Asistencia Pública de Lima, en donde internan al hermano del Boa después de haber sido acuchillado. En ese lugar, el Boa reflexiona: "[C]ómo me chocó cuando entré aquí la cantidad de serranos. Son más que los costeños. Parece que se hubiera bajado toda la puna, ayacuchanos, puneños, ancashinos, cusqueños, huancaínos, carajo y son serranos completitos, como el pobre Cava" (258). ${ }^{354}$

La estrategia narrativa de MVLL consistiría en poner de relieve cuán gaseosos, insustanciales e infundados son los discursos del Boa y de otros personajes, por el hecho de estar basados en exageraciones, prejuicios y generalizaciones. Esto se hace palpable cuando el Boa-no la voz narrativa-, recordando una pelea que tuvo con Cava, caricaturiza el aspecto, la obstinación y la falta de agilidad de su condiscípulo andino:

\footnotetext{
${ }^{354}$ En el prólogo a la segunda edición de Tempestad en los Andes, (1972), Luis E. Valcárcel escribió lo siguiente: "No se había producido la 'TEMPESTAD EN LOS ANDES' que yo vaticinaba [en 1927] [...Sin embargo,] un incontenible aluvión humano cayó sobre Lima y otras ciudades. Más de un millón de personas 'tomaron' la Capital, como un ejército invasor, sin armas. La 'tempestad' ahora anda por dentro" (xxxiv).
} 
Cava es bajo, pero eso sí, muy maceteado. No tiene cuerpo, es todo cuadrado, ya me había fijado. Y cuando le daba, parecía que no le hacía nada, aguantaba lo más fresco. Pero es muy bruto, muy serrano, se me prendía del pescuezo y la cintura y no había modo de zafarse, le molía la espalda y la cabeza para que se alejara, pero al ratito volvía como un toro, qué resistencia. Y daba pena ver lo poco ágil que era. Eso también lo sabía, los serranos no saben usar los pies [...] Los serranos pelean sólo con las dos manos. Ni siquiera saben usar la cabeza como los criollos, y eso que la tienen dura. (261-62)

Es verdad que los andinos, en general, son bajos de estatura. También se suele explicar que, debido al enrarecimiento del oxígeno en las alturas de la cordillera de los Andes, algunos andinos desarrollan una caja torácica más amplia que la de los costeños y selváticos, adquiriendo una capacidad que los hace resistentes al esfuerzo físico y les confiere una complexión maciza que luce poco elástica. Asimismo, es cierto que a los andinos se les considera perseverantes. Es el tono caricaturesco y despectivo de la descripción que hace el Boa de Cava y de los andinos lo que mina la validez de su discurso. La caricatura llega a ser hiperbólica cuando el Boa caracteriza a Cava como epítome del andino peruano por la abundancia de cabello enhiesto e indócil que le crece en la cabeza debido a su fenotipo:

¡Qué pelos! No me explico cómo un hombre puede tener esos pelos tan tiesos. Me consta que se avergonzaba. Quería aplastárselos y se compraba no sé qué brillantina y se bañaba en eso la cabeza para que no se le pararan los pelos y le debía doler el brazo de tanto pasarse el peine y echarse 
porquerías. Ya parecía que se estaban asentando, cuando, juácate, se levantaba un pelo, y después otro, y después cincuenta pelos, y mil, sobre todo de las patillas, ahí es donde los pelos se les para como agujas a los serranos y también atrás, encima del cogote. (258)

Los pelos que se multiplican en el cráneo de Cava también le invaden la parte superior de la cara: “[C]asi no se le ve la frente, le crecen sobre las cejas [...] Una vez lo encontraron afeitándose la frente" (259), comenta el Boa. Por la exagerada efervescencia capilar descrita en este pasaje, en el título de la novela podría sustituirse la palabra "perros" por "pelos"”: La ciudad y los pelos. La escasa inteligencia que el Jaguar y el Boa perciben en Cava pareciera estar vinculada a la particularidad de que este personaje no tenga, como reza el refrán popular, "dos dedos de frente”. Esta representación del andino se haría eco de la fisiognomía, una seudociencia positivista emparentada con la frenología que estuvo en boga en el siglo XIX y que postula la correlación entre ciertos rasgos físicos del ser humano con determinadas habilidades, discapacidades y tendencias.

A propósito de pelos, en El pez en el agua (1993) MVLL relata un episodio en el que fue atacado por una turba en un pueblo de Piura (un departamento ubicado en la costa norte del Perú) durante su campaña política en las elecciones presidenciales del año 1990, en las que él fue candidato: "Armada de palos y piedras y todo tipo de armas contundentes, me salió al encuentro una horda enfurecida de hombres y mujeres [...] $[\mathrm{P}]$ arecían venidos del fondo de los tiempos, una prehistoria en la que el ser humano y el animal se confundían [...] Semidesnudos, con unos pelos y uñas larguísimas, por los que no había pasado jamás una tijera" (520). Por la manera en que son narrados los hechos, Mary Weismantel y Stephen F. Eisenman interpretan que MVLL le temía menos a los 
palos y las piedras que a los pelos y las uñas de los atacantes ("Race in the Andes" 131). Wilfredo Ardito Vega explica que la palabra serrano "no tiene en el Perú una connotación geográfica sino cultural: alude a un ser primitivo, sucio [énfasis mío], ignorante" (Reflexiones Peruanas 56).

¿Afectan la imagen del indígena los comentarios racistas en La ciudad y los perros? El propio MVLL aclara que, en general, su estrategia narrativa es exponer con crudeza los males sociales (el racismo es uno de los más graves) con el propósito de que el lector los rechace: “[J]ustamente esas sociedades que ellas [las novelas] reflejan, que ellas muestran, son sociedades roídas por la descomposición, son sociedades enfermas, y las novelas son también, al mostrar ese mal, esas deficiencias, esos daños, esas lacras, como tentativas de exorcismos de esos mismos daños, de esas lacras y deficiencias" ("La novela” 355). No obstante el mentís, María de las Mercedes Ortiz Rodríguez sostiene que MVLL representa desfavorablemente al indio en La casa verde (1966), en El hablador (1987) y en Lituma en los Andes (1993), debido a que asocia la sierra y la selva con la barbarie y el salvajismo, respectivamente, mientras que el mundo costeño es para él sinónimo de civilización. Ortiz Rodríguez opina que MVLL reactiva en estas obras “desde tópicos coloniales como el canibalismo y la extirpación de idolatrías hasta el evolucionismo lineal del siglo XIX, para caracterizar una vez más a los indígenas como salvajes, caníbales, atrasados y paganos, los cuales constituyen un obstáculo para el desarrollo del Perú en un mundo neoliberal y global" ("La fisura irremediable" 111). ${ }^{355}$

\footnotetext{
${ }^{355}$ Por ejemplo, en Bolivia, como expresión de la violencia simbólica, “[1]as ordenanzas municipales [...], institucionalizando la vestimenta indígena como emblema de raza y etnicidad, prohibieron a los indios el ingreso a ciertos espacios urbanos. En los años veinte, los varones fueron obligados a abandonar sus ponchos y pantalones de bayeta y a adoptar los ternos occidentales cuando estaban de paso por la ciudad. A su vez, a las mujeres se les permitió seguir usando una vestimenta que combinaba elementos indígenas
} 
Como bien señala Carlos Iván Degregori, "hasta hace algunas décadas se creía que un país desarrollado era sinónimo de país occidental y cristiano; que para desarrollarse los pueblos tenían que olvidar sus tradiciones y volverse modernos. Tradición y modernidad se entendían como dos polos excluyentes; y el desarrollo" ("Perú: identidad" 212). En tal sentido, MVLL considera inevitable la aculturación del indígena (su asimilación de - y por — la cultura dominante) para que sociedades con una etnia autóctona significativa, como la peruana, puedan integrarse plenamente:

Sólo se puede hablar de sociedades integradas en aquellos países en los que la población nativa es escasa o inexistente. En las demás, un discreto, a veces inconsciente, pero muy efectivo apartheid prevalece. En ellos, la integración es sumamente lenta y el precio que el nativo debe pagar por ella es altísimo: renunciar a su cultura —a su lengua, a sus creencias, a sus tradiciones y usos-y adoptar la de sus viejos amos. Tal vez no hay otra manera realista de integrar nuestras sociedades que pidiendo a los indios pagar ese alto precio; tal vez, el ideal, es decir, la preservación de las culturas primitivas de América, es una utopía incompatible con otra meta

\footnotetext{
y occidentales, pero debieron usar telas industriales en lugar de los textiles tradicionales hechos a mano. Las cholas urbanas de las principales ciudades de Bolivia han llegado a elaborar formas refinadas de esta vestimenta. En La Paz, el término ch'ukutas fue acuñado para reflejar estos cambios" (Ari Chachaki 226). "En las áreas rurales, el "estilo moderno de vestir" fue impuesto obligatoriamente después de 1952, cuando dirigentes mestizos controlaban los sindicatos campesinos y los dictados revolucionarios prohibían a la gente indígena el uso de cabello largo o de textiles tradicionales" (ibíd. 227). "Hasta mediados de la década del sesenta, la gente que optaba por mantener sus estilos propios de vestimenta seguía enfrentando restricciones cuando ingresaba a espacios urbanos tales como salas de cine o restaurantes" (ibíd. 227).

Ángel Rama sostiene que "[1]a constitución de la literatura, como un discurso sobre la formación, composición y definición de la nación, habría de permitir la incorporación de múltiples materiales ajenos al circuito anterior de las bellas letras que emanaban de las élites cultas [...] La constitución de literaturas nacionales [...] [a]bsorbe múltiples aportes rurales" (La ciudad letrada 91). Sin embargo, "[n]o sólo había que diseñar una nueva rejilla clasificatoria, usando el concepto de literatura, para incorporar esos materiales populares; era también necesario que estuvieran muriendo en cuanto a formas vivas de la cultura rural" (ibíd. 90).
} 
más urgente: el establecimiento de sociedades modernas, en las que las diferencias sociales y económicas se reduzcan a proporciones razonables, humanas, en las que todos puedan alcanzar, al menos, una vida libre y decente. (“El nacimiento del Perú” 811).

Por el contrario Degregori sostiene que el camino a la modernidad y al desarrollo "no es necesariamente único, lineal, ni conduce necesariamente a la uniformización”, y que tampoco "hay oposición tajante y excluyente entre tradición y modernidad. Más bien las tradiciones, o al menos algunas, pueden ser útiles para el desarrollo, pueden constituir un activo y no un pasivo en los esfuerzos por incorporarse ventajosamente en el mundo global" ("Perú: identidad" 212).

En el caso de La ciudad, la representación del indígena y, en particular, de su moral, da pie a que los lectores se pregunten si MVLL es segregacionista e incluso racista, de lo que suelen acusarlo algunos de sus detractores. Por ejemplo, en estilo indirecto libre, se insinúa que Cava o sus paisanos de la sierra han tenido experiencias sexuales con auquénidos (42). Asimismo, en la novela es Cava quien insta a sus compañeros cadetes a practicar la zoofilia con una gallina (42). El bestialismo del personaje andino queda confirmado cuando, a los remilgos de último minuto que, contradictoriamente, tiene para penetrar al ave_-"Oye, ¿y si me infecto?" (03)—, sus cómplices le responden: "Qué te pasa [...] qué tienes serranito, de cuándo acá te echas atrás” (43), sugiriendo que la zoofilia es en él una práctica acostumbrada.

También es bastante elocuente la descripción que hace el narrador omnisciente de Paulino: “[E]1 injerto: ojos rasgados de japonés, ancha jeta de negro, pómulos y mentón cobrizos de indio, pelos lacios" (133), de "figura ágil, simiesca" (139), de "grandes labios 
tumefactos $[\ldots$ con] una dentadura desigual, incompleta" (139). La repulsiva imagen de Paulino corre pareja con su extrema corrupción moral, no debido a su homosexualidad, sino porque se prostituye con los cadetes y, de esa manera, fomenta la degradación de éstos. Por la forma en que Paulino ha sido caracterizado, podría interpretarse que su naturaleza corrupta está determinada por su turbiedad racial. ${ }^{356}$ Del mismo modo, podría argüirse que MVLL, al haberle atribuido al personaje de Cava inclinaciones zoófilas, contribuyó a perennizar la leyenda negra que estigmatiza a los pobladores rurales de los Andes peruanos como practicantes de bestialismo. No obstante, es necesario distinguir claramente entre el autor, el narrador y las demás voces no autorales. Además, debemos tener en cuenta que se trata de una novela, de una obra de ficción, y no de un ensayo. En todo caso, los escrúpulos que exhibe Cava para penetrar a la gallina son incongruentes con el hilo argumental, y el hecho que el Boa también sienta atracción sexual hacia un animal—su mascota, la perra Malpapeada (43) —indica que no sólo los serranos pueden tener inclinaciones zoófilas. Por último, Cava, a diferencia de sus compañeros, no participa en la escena homosexual entre Paulino y los otros cadetes, que no son de la sierra. Estos hechos tendrían más bien el propósito de minar la referida leyenda negra.

Por otro lado, considerando el papel protagónico de Cava en la trama de la novela, llama la atención que MVLL no le haya dado una voz propia (sus parlamentos son mínimos) y que el lector deba conocer el aspecto físico, la catadura moral, las actitudes, las acciones y reacciones de este personaje a través de otros personajes, así como por

\footnotetext{
${ }^{356}$ La noción de raza impura fue traída a América por los españoles con la invasión. Vale una digresión: Con este término, Carlos García Bedoya (Para una periodización 63, 66-70) y Gonzalo Portocarrero ( $\mathrm{La}$ urgencia 329) denominan, desde la perspectiva amerindia, al Descubrimiento. De otro lado, los primeros registros escritos de la palabra "injerto" datan de principios del siglo XX (Lausent-Herrera 118).
} 
retazos de información que proporciona el narrador omnisciente, quien casi nunca "lee" la mente de Cava. Habría sido interesante saber-por la propia boca de Cava y no mediante una especie de ventriloquía_ — 357 cómo se percibe a sí mismo. El siguiente pasaje es uno de los pocos, si no el único, que le ofrece al lector un acercamiento a la psiquis de Cava: El narrador omnisciente cuenta que, en el trayecto hacia la oficina en donde estaban guardados los exámenes, Cava se cruza con una vicuña—la mascota de la escuela $-\mathrm{y}$ recuerda que, dos años y medio antes, cuando recién había ingresado al colegio militar, le sorprendió hallar en la costa, tan fuera de contexto, a "ese animal exclusivo de la sierra" (18). Cava rememora que, cuando los cadetes le lanzaban piedras a la vicuña, utilizándola de blanco en apuestas de tiro (134), el inexpresivo animalito se hacía calmadamente a un lado para evitar que le cayera una pedrada. De manera explícita, Cava asocia la reacción de la vicuña a ciertas actitudes pasivas que suelen atribuírseles a los indígenas: “'Se parece a los indios’, pensó Cava” (18).

Es el Boa quien informa al lector que Cava es un andino aspirante, que deseaba ser soldado, y que su expulsión del colegio echó por tierra sus ilusiones: “Cava decía que quería ser militar, no infante, sino de artillería [...]. y ya le jodieron todo, el colegio, la vocación, eso es lo que más le debe arder" (191). Aunque la práctica de las torturas públicas desapareció entre finales del siglo XVIII y principios del XIX (Foucault, Vigilar

\footnotetext{
${ }^{357}$ Es tentador elucubrar que MVLL silenció la voz de Cava con el propósito de resaltar la condición subalterna de este personaje, quien, al carecer de un lugar de enunciación, requiere de la intermediación de otros personajes - el Jaguar y el Boa-y del narrador para que el lector tome conocimiento de su manera de pensar, de su personalidad, de sus acciones, etcétera. Los Cuadernos de la cárcel de Antonio Gramsci ya habían visto la luz para el momento en que fue publicada La ciudad y los perros (1962) y el concepto de subalternidad ya se había difundido. Sin embargo, "Can the Subaltern Speak?", el famoso ensayo de Gayatri Spivak en el que la pensadora india afina el concepto de subalternidad — y que sería más aplicable al caso que nos ocupa—no salió de la imprenta sino hasta 1985.
} 
y castigar, 1975), el episodio de la degradación militar de Cava es, a todas luces, un ritual de escarnio público:

Y en eso lo trajeron al serrano Cava [...] estaba amarillo [...] El serrano estaba inmóvil pero se seguía poniendo más pálido, su cara, que era tan oscura, se había blanqueado [empalidecido], desde lejos se notaba que le temblaba la barbilla. Pero aguantó. No retrocedió ni lloró cuando Piraña le arrancó la insignia de la cristina y las solapas y después el emblema del bolsillo y lo dejó todo harapos, el uniforme roto [...] El serrano casi no levantaba los pies [...] El pobre no podía seguir el paso, se tropezaba y, a ratos, bajaba la cabeza, seguro para ver cómo le había quedado el uniforme de jodido. (242-43)

Este tipo de ceremonia-reservada para sancionar faltas o delitos que deshonran a las instituciones castrenses - probablemente estaba contemplada en el Código de Justicia Militar peruano que se hallaba en vigor en los años cincuenta del siglo XX. Por tal motivo, este pasaje no debería ser interpretado como un acto orquestado por el autor para humillar al andino. Por el contrario, sirve para sensibilizar tanto al lector como al Boa, que es el personaje que más ojeriza le tiene a Cava hasta ese momento y que, de ahí en adelante, cambia, para bien, drásticamente de actitud: "Ya debes estar en la calle, serrano, esperando el ómnibus, mirando la Prevención por última vez, no te olvides de nosotros, y aunque te olvides, aquí quedan tus amigos del Círculo para ocuparse de la revancha" (243), piensa. Obsérvese que el término "serrano" ya no es empleado peyorativamente; en este contexto es hasta cariñoso. Un poco más adelante, el Boa admite sus prejuicios y 
reconoce la virtud en Cava: "Pobre serrano, no era mala gente, después nos llevamos bien. Al principio me caía mal, sólo por ser serrano" (260).

Para Rosa Boldori, Lima es la protagonista principal de la novela; una ciudad aplastante que, por determinismo ambiental, expele a "cuerpos extraños" e "inadaptados", como Ricardo Arana (el Esclavo) y Porfirio-serrano-Cava (11) ("La ciudad y los perros, novela del determinismo ambiental" 93). Siguiendo esa misma lógica, Oviedo piensa que la expulsión de Cava del colegio sería el resultado esperable de un sistema cuyos mecanismos están diseñados para exudar al elemento que no puede o no quiere procesar, que excreta lo que no le es posible digerir (Mario Vargas Llosa: la invención de una realidad 93). ${ }^{358}$ Estoy en desacuerdo con lo planteado tanto por Boldori como por Oviedo, porque desde los años cuarenta del siglo XX Lima ha sido receptora de una gran masa migratoria provinciana, al punto de que la capital alberga en la actualidad a un tercio de la población del país. ${ }^{359}$ Concurro más con la idea contraria: que el andino, mediante su "cholificación", no sólo se adapta sino subvierte el medio social costeño.

Cuando los personajes de la novela se dirigen a Cava como el "serrano Cava", no hacen sino tratarlo como, probablemente, se trataba a las personas de procedencia indígena en la época en que está ambientada la historia y en lugares como el Colegio Militar Leoncio Prado, en donde la violencia física y verbal solían ser sinónimos de

\footnotetext{
${ }^{358}$ Coincidentemente, en Hienas se compara a la ciudad capital con una hembra a quien el hombre provinciano debe subyugar para poder sobrevivir a su animosidad y adversidad: "Lima era una hembra que ponía a prueba la hombría de los provincianos que pretendían conquistarla. Luego de sopesar su temple, bien podía devorarte para luego dejarte triturado por ahí, como bagazo, convertido en nada 'hecho mierda'...-, o bien, rendida, abrirse de piernas para que la gozaras a tu antojo con dominio de macho" (84-5).

${ }^{359}$ La ola migratoria de la sierra a la costa que empezó en la década de 1940 ha transformado drásticamente al Perú contemporáneo (Nugent 31).
} 
valentía y en donde el indio servía de chivo expiatorio. ${ }^{360}$ Pero la situación ha cambiado y, desde luego, ese tipo de trato resultaría chocante en la actualidad. Salvo que sea en el contexto de una discusión o pelea, no creo que hoy en día sea bien visto que los compañeros de escuela antepongan la palabra "serrano" al apellido de un condiscípulo de origen andino para dirigirse de manera despectiva directamente a él.

Oboler admite con sinceridad que "nadie escapa de tener percepciones positivas y negativas del otro $[\ldots]$ a través de lo racial o étnico, del género, del idioma o acento, de la religión, de la clase social, la generación y [...] sobre todo, de la articulación de varias o todas de estas características" (10). MVLL no sería la excepción. Sin embargo, insisto en que el autor y el narrador son entidades ontológicas distintas. Además, aun cuando los parlamentos y pensamientos de algunos de los protagonistas de La ciudad son indiscutiblemente racistas, sus respectivos discursos se socavan a sí mismos debido a su evidente falta de objetividad por estar basados en meros prejuicios. Sin duda, MVLL optó por escribir una novela polifónica que no privilegia ningún punto de vista en particular y que, mediante contrapesos argumentales, insta al lector-la voz ausente en el texto-a reflexionar acerca del tema del racismo, obligándolo a sacar sus propias conclusiones. Debido al conflicto resultante entre los diversos discursos- - tanto de los personajes como de los varios tipos de narradores-, me complace elucubrar que la obra en cuestión también podría haberse titulado La ciudad y los peros (con "r").

\footnotetext{
${ }^{360}$ El papel que cumple el chivo expiatorio-la persona o el grupo social al que se singulariza para responsabilizarlo inmerecidamente de algo — es explicado por la Teoría de la frustración-agresióndesplazamiento.
} 


\title{
VII. CAUSAS DE LA VIOLENCIA: INEQUIDAD SOCIOPOLÍTICA Y SOCIOECONÓMICA, RACISMO, ODIO Y RENCOR
}

\author{
Nadie puede ser sensato con el estómago vacío
}

George Eliot

\section{El Grupo Narración}

Tanto Miguel Gutiérrez Correa como Juan Morillo Ganoza-dos de los autores que abordo en el presente trabajo-pertenecieron al Grupo Narración que, entre 1966 y 1976, congregó a importantes escritores peruanos de la talla de Oswaldo Reynoso, Antonio Gálvez Ronceros, Gregorio Martínez, Augusto Higa, Hildebrando Pérez Huarancca y Roberto Reyes Tarazona (Ágreda, “Jaque perpetuo”). Si bien Reynoso era el escritor más reconocido, Gutiérrez-de orientación maoísta-era el ideólogo, aun cuando no todos los miembros compartían esa filiación política (Manrique, "Historia, literatura y violencia"109). El caso es que, a mediados de los años 70 del siglo XX, Oswaldo Reynoso, Miguel Gutiérrez y Juan Morillo Ganoza viajaron a la China y trabajaron allí como docentes y periodistas; sin embargo, “en el fondo, [estaban] guiados por el afán de apreciar personalmente el histórico proceso de construcción del socialismo en la era post Mao" (Reyes Tarazona, Hienas 10). ${ }^{361}$

El Grupo Narración tenía una "tendencia política radical” (Manrique, "Historia, literatura y violencia" 108) y "un explícito carácter político literario" (ibíd. 109). Su

\footnotetext{
${ }^{361}$ Miguel Gutiérrez Correa, que vivió en Pequín desde 1966 (el año en que murió Mao Zedong) hasta 1979. Precisamente desde ese año hasta la actualidad, Juan Morillo Ganoza ha residido en la capital china. También Oswaldo Reynoso, entre otros intelectuales peruanos de la misma época, vivió doce años en el país de Mao. Es interesante observar que, a diferencia de estos autores que, movidos por el anhelo de ser testigos de excepción, buscaron colocarse en el epicentro de los cambios sociopolíticos en el ámbito mundial, en la actualidad muchos escritores peruanos aparentemente buscan estar más cerca de los grandes centros editoriales y de distribución para el mundo hispanohablante. Por ejemplo, MVLL y Fernando Iwasaki viven en España.
} 
órgano de prensa era la revista homónima, de la que publicaron apenas tres espaciados números, en los años 1966, 1971 y 1974, respectivamente. En el primer número de la revista

queda clara la mirada sobre la realidad del grupo: "Como hombres y narradores, seres sociales, luchamos por la transformación integral y completa de nuestra Patria. Queremos la instalación de un sistema socialista de trabajadores, porque comprendemos que es la única manera de hacer de nuestro país un lugar donde todos puedan vivir como hombres. Comprendemos, como narradores revolucionarios, comprometidos con su pueblo, que nuestra tarea es formar, a través de la acción y de la obra creadora, en la conciencia de las clases explotadas, la necesidad urgente de la Revolución. Por eso nuestra misión es aprender del pueblo, para poder escribir, sin equivocarnos, sobre la realidad nacional". (Citado en Enríquez, "El marxista rabioso")

Además de los tres números de la revista, el Grupo Narración publicó Los ilegítimos, un compendio de cuentos en los que Hildebrando Pérez Huarancca denuncia las injusticias sociales que sufren algunos personajes de la sierra peruana.

Reynoso atribuye la disolución de Narración al hecho de que sus integrantes se dispersaron. No obstante, Nelson Manrique postula que, para ese momento, el grupo había ya cumplido su ciclo histórico. Caído Velasco Alvarado y en medio de un periodo de acelerada acentuación del carácter represivo del régimen de Morales Bermúdez [...] se hacía necesario asumir opciones que debían procesarse en el nivel individual [...] [S]us integrantes 
orgánicos tuvieron que optar o por profundizar su compromiso literario o por anteponer a este un compromiso político que pasaba por la militancia. ("Historia, literatura y violencia" 110)

El último fue el caso de Hildebrando Pérez Huarancca, quien luego se convertiría en un líder de SL.

"Podrán haber mostrado equívocos, pero, aun así, no hay duda de que esa vigilancia y permanente cuestionamiento que ha ejercido sobre el funcionamiento de las instituciones y las acciones del gobierno es imprescindible en una democracia para que ésta no se corrompa y se vaya empobreciendo en la rutina”, sostiene David Abanto en su prólogo al libro El Grupo Narración en la literatura peruana (2006) de Néstor Tenorio (citado en Torre 37). ${ }^{362}$ A partir de este prólogo, María Elena Torre colige que "el Grupo es visto como uno de los últimos proyectos del siglo XX de la estirpe a la que perteneció el Amauta José Carlos Mariátegui” (377). Unas líneas más adelante, Torre agrega: "Este prólogo [...] titulado sugestivamente 'Grupo Narración: la redención a través del compromiso', refleja, aunque atenuada, una valoración de la figura del escritor comprometido y del intelectual revolucionario de amplia acción en el campo literario latinoamericano de los años sesenta y setenta que parece hoy desarticulada" (ibíd. 337). ${ }^{363}$

\footnotetext{
${ }^{362}$ Tenorio Requejo, Néstor. El grupo Narración en la literatura peruana. Lima: Arteidea Editores, 2007.

363 "No sé hasta qué punto un escritor puede ser revolucionario. Por lo pronto, está trabajando con el idioma, que es una tradición" (Borges).
} 


\section{VII.1 DESDE MARTÍN CORTÉS HASTA MARTÍN VILLAR: EL MESTIZAJE COMO ESTIGMA EN LA VIOLENCIA DEL TIEMPO (1991) DE MIGUEL GUTIÉRREZ CORREA}

\section{La violencia es la comadrona de toda vieja que lleva en sus entrañas otra nueva \\ Marx (El capital I 639)}

En La violencia del tiempo, Martín Villar Flórez, el protagonista de la novela, accede al pasado bajo los efectos alucinógenos del extracto del cactus sampedro, y se remonta hasta el tiempo de la pareja fundadora de su linaje: "Me figuraba [...] a la india Sacramento Chira, todavía púber, siendo ungida por las indias viejas con yerbas de amor y flores del diablo, aquellas flores bermejas incitadoras de las pasiones sin reposo para ir a apaciguar la intemperancia y la ira del soldado godo [énfasis mío] Miguel Villar, aquel rubio y lujurioso anticristo que como un viento maligno había aparecido por la región y se había entregado a una estrafalaria guerra contra los pacíficos habitantes de todos esos contornos" (40). ${ }^{364}$ Es decir, la joven Sacramento había decidido sacrificarse, ofreciéndose al militar español para que dejara en paz a su tribu:

Sacramento Chira era casi una niña cuando se propuso salvar a las indias núbiles como ella del terror que había despertado en la comarca la aparición de aquel viento maligno, que despechado por la derrota o la deserción o la miseria de su destino, con pistolón y sable en manos, asaltaba y vejaba a los caminantes y estupraba a las mujeres, más que por sensualidad, por odio, por venganza, por desesperación. De modo que ella era casi una niña cuando decidió inmolarse [énfasis mío], pero no salió

\footnotetext{
${ }^{364}$ Todas mis referencias a La violencia del tiempo corresponden a la edición de Santillana.
} 
desamparada: antes de partir, las indias viejas la bañaron y ungieron con yerbas de amor y bálsamo de flores rojas de la pasión. (104)

De manera similar al ensayo de Paz, La violencia presenta el origen del mestizaje en Hispanoamérica como el producto de una violación, aunque la entrega voluntaria de Sacramento habría sido una violación "consentida", si es posible el oxímoron. Esta interpretación se basa en el hecho de que las unturas de las matriarcas tallanes no le garantizaron a la Ifigenia incaica una cópula sublime, de satisfactoria y placentera entrega mutua. Por el contrario, desde la primera unión carnal los encuentros fueron muy violentos y humillantes para ella, debido al sadismo, a la ira y al ensañamiento del soldado español:

Sacramento Chira, dice la voz [que Martín escucha bajo la influencia alucinógena del brebaje extraído del sampedro], fue ultrajada por Miguel Villar con crueldad no muy diversa a la que padecieron sus antepasados, que son también los tuyos [...] Está amarrada allí [al vichayo, un árbol que crece en el desierto] medio desnuda, y [Miguel] la flagela y la amenaza con matarla con la espada, mientras la hinca y la hace sangrar y la llama "india" y desfoga con ella no la derrota, sino los años que estuvo prisionero y el haber sido sacado de su cárcel no para alcanzar la libertad sino para ser enviado, junto con otros canallas, a combatir [...] a la indiada de esas comarcas que pretendía desobedecer y alzarse contra la ley [...] Y allí la dejaba amarrada todo el día y la noche, y después, como si eso le encendiera la sangre, la desataba para gozarla con furia y desprecio. (333) 
En esa guerra cuerpo a cuerpo, tan desigual en fuerzas, el irascible macho aplaca su rabia contra el mundo violando a la hembra, sometiéndola sexual y psicológicamente, en la creencia ingenua de que, al hacerlo, venga al menos una cuota de toda la inquina que, en su percepción, se ha acumulado contra él. "El 'Macho' es el Gran Chingón”, sostiene Octavio Paz. 'El 'macho' hace 'chingaderas', es decir, actos imprevistos y que producen la confusión, el horror, la destrucción. Abre el mundo; al abrirlo lo desgarra [...] A su manera es justo, restablece el equilibrio, pone las cosas en su sitio, esto es, las reduce a polvo, miseria, nada" (105). ${ }^{365}$

Según Horst Nitschack, la traumática escena originaria— "la posesión de la joven india Sacramento Chira por parte del desertor español Miguel Villar"-constituye tanto "el acto fundador de la familia a comienzos del siglo XIX" como el anuncio de la violencia que habrá de "repetirse adoptando modos diferentes en las siguientes generaciones" ("Miguel Gutiérrez - La violencia de la historia" 136). Para Gutiérrez Correa, la deshonra del indígena radicará en su feminización voluntaria. Simbólicamente, el indio accederá a ser sodomizado por el conquistador-colonizador blanco, a cambio de aclarar el color de la piel de sus descendientes:

\footnotetext{
365 "Una palabra resume la agresividad, impasibilidad, invulnerabilidad, uso desmedido de la violencia, y demás atributos del 'macho': poder. La fuerza, pero desligada de toda noción de orden: el poder arbitrario, la voluntad sin freno y sin cauce [...] El desgarramiento provoca una gran risa siniestra [...] El humorismo del 'macho' es un acto de venganza” (Paz 105).

Acerca de la relación existente entre la inadaptación posbélica masculina y la violencia sexual, Leo Braudy comenta lo siguiente: "Immediately after the war, for example, realistic film stories of returning veterans stressed the problem of reentry into a world (primarily of women) [...] [S]oldiers without guns in real life read about dicks with guns in detective novels, intent or seeking revenge on an uncaring or hostile world for the murdered friends, their lost values, and their own wounds [...] [S] exual and personal disappointment often turned against women to make up for impotence in the world. In The Naked and the Dead [1949], for instance, [Norman] Mailer writes of the ferocious lovemaking between General Cummings and his wife [...]: '[...] [I]t is completely naked, apparent to her, that he is alone, that he fights out battles with himself upon her body, and sometimes withers in her' (416)" (From Chivalry to Terrorism 499).
} 
Lo que importaba era el porte, la sangre, la buena casta. Así lo consideró Sacramento Chira cuando revestida de sus mejores galas y untada con flores del amor loco, marchó a su encuentro para usurparle su semilla. Pues a eso se redujo ella: a ser un surco abierto, un surco indio anhelante y feraz, porque los indios (y este era un saber adquirido desde la más remota infancia, quizá en el mismo pezón materno) fuesen varones o mujeres, eran hembras por naturaleza, como hembras condenadas por Dios para ser violadas por el macho [énfasis mío] y por el macho convertidas en siervas, en esclavas, en concubinas y en zorras de los señores de cuero blanco. Y así, como un viento providencial, como un don del Altísimo, había aparecido Miguel Francisco Villar. (655)

Los vástagos mestizos - producto de los favores sexuales prodigados por la madre al padre de éstos, en canje por el blanqueamiento de la raza-adquirirán una conciencia escindida, porque, aun en su condición de ilegítimos, agradecerán el aporte del semental blanco, pero la humillación de la madre los deshonrará y atormentará para siempre: “[H]e llegado a conocer a numerosos bastardos que [...] rendían loas a [sic] Dios de los cielos por haber propiciado la incursión nocturna del padre blanco en el cuartito de la oscura mamá (hubiese sido o no la sirvienta de la casa), dignificándolos por el lado del pellejo y del apellido que podían usufructuar con orgullo, con podrido orgullo [blanqueamiento]" (391). Pero, además, así como Miguel Francisco Villar había aparecido de la nada, también se había marchado de repente, abandonando a su familia, en cuyos miembros se instaló desde aquel momento una malsana y masoquista nostalgia por el mal perdido: 
Él [Miguel Villar] llegó, engendró, procreó, llenó con su presencia y sus palabras el hogar, señoreó en él, y un día desapareció. Despareció y desde entonces reinó la nostalgia, y Sacramento Chira consagró su vida a mantener su memoria (sus palabras, sus manías, mi padre decía que también su oscuro instinto de rebeldía), negándose (la Sacramento) a contraer un nuevo compromiso, pese a que aún era joven, con la ilusa esperanza de su retorno [...] Y mi bisabuelo [Cruz Villar] cayó en la misma trampa [sentir morriña por la ausencia del reprobable semental fugado], y [...] cuando se amarraba el trapo rojo a la cabeza se entregaba a convocar las pocas imágenes que de él guardaba, ¡Por eso no había amado a su madre! El recuerdo de Miguel Villar había usurpado todo el amor o el poco amor que tuviera en su corazón. (655)

Octavio Paz observa que "el atributo esencial del 'macho', la fuerza, se manifiesta casi siempre como capacidad de herir, rajar, aniquilar, humillar" (105). Por esta razón, Paz colige que "[n]ada más natural, por tanto, que su indiferencia frente a la prole que engendra. No es el fundador de un pueblo; no es el patriarca que ejerce la patria potestas, no es rey, juez, jefe de clan. Es el poder aislado en su misma potencia, sin relación ni compromiso con el mundo exterior. Es la incomunicación pura, la soledad que se devora a sí misma y devora lo que toca" (ibíd. 105-6). Con la explicación de Paz, quizás pueda entenderse mejor el sentido del siguiente comentario que hace el protagonista de la novela de Gutiérrez Correa: "[M]i bisabuelo vivió obsesionado con la imagen paterna, y en cambio olvidó [...] a la madre [...] Y así fuimos criados recibiendo en herencia, por lo menos de mi padre, la nostalgia por el soldado español Miguel Francisco Villar. Y hasta 
allí llegaba la memoria familiar, nuestra memoria, mi memoria, y más allá era no la oscuridad, sino la nada, como decir, el no ser" (290).

William J. Cheng sostiene que un hijo mestizo que no ha sido reconocido por su padre, quien, además, se halla ausente, "hereda una psiquis lacerada que se manifiesta y se expresa sintomáticamente a través del rencor, el odio y de una aguda conciencia de la bastardía; de ahí la marca de la ilegitimidad” ("La función de la memoria en La violencia del tiempo" 5). En opinión de Nitschack, "[e]1 hijo mestizo [Cruz Villar Chira] perdió la instancia paterna con la cual podría identificarse y que le indicaría su lugar en la cultura y en la sociedad. Se desprende de este modelo que las expectativas de un mundo mestizo que funcionará como intermediario entre los blancos y los indios [...] son completamente gratuitas: la condición mestiza esta signada por este agravio, lo que le causa un odio profundo" (139). En ese sentido, María Elena Torre opina que "[1]a novela se puede leer como una indagación de la identidad en relación con la violencia fundadora: una saga familiar sobre el telón de fondo de la historia de una comunidad que almacena en la memoria acontecimientos violentos como heridas reales o simbólicas [...], sostenida por la voz de un narrador que sobre el final hace su balance: 'He logrado fabular la historia de una herida que a todos nos alcanza y la historia de la vindicación primitiva y bárbara y el rencor inextinguible, junto al itinerario de vidas que arrastran consigo los furores de la Historia’ (La videncia III 307)" ("Entre la fundación y el derrumbe” 379). ${ }^{366}$ Por eso es que, cuando en su viaje al origen Martín se entrevista con Simón Guerra para indagar sobre sus antepasados (la búsqueda), éste le dice: "Sí, eres de la sangre de los Villar [...]

\footnotetext{
${ }^{366}$ La página 307 del tercer tomo de la novela editada por Milla Batres en 1991 corresponde a la página 1034 de la reedición de Santillana de 2010.
} 
Te estoy viendo y me parece estar delante del desdichado Inocencio [Villar Dioses, su tío abuelo]. ¿Es que nunca terminará este rencor? [énfasis mío]” (197).

Como resultado del trueque sexual y genético entre el soldado godo Miguel Francisco Villar y la india tallán Sacramento Chira, nacen Cruz-el primogénito varón y primer mestizo de la estirpe—, así como varias hijas mujeres. Con las hermanas Trinidad y Lucero Dioses, con quienes convive bajo el mismo techo, Cruz procrea una numerosa prole. $^{367}$ Pero es con Trinidad Dioses con quien engendra a Santos, el hijo que más nos interesa en este análisis. Santos se une a Isabela Victoriano y, producto de esa unión, nace Cruz Villar Victoriano, quien, a su vez, toma por mujer a Altemira Flórez. Cruz Villar Victoriano y Altemira Flórez son los padres de Martín Villar Flórez, el protagonista de la novela, quien trascenderá en la vida no teniendo descendencia, sino escribiendo un libro sobre la historia familiar: "De modo que yo, Martín Villar, hijo de su único hijo [Martín es el unigénito de Cruz Villar Victoriano, y éste es el unigénito de Santos Villar Dioses], engendrado sin amor en las noches eternas en la matriz de Isabela Victoriano Nima [...] y aún antes de que Cruz Villar, el padre que no conocí, dejara su amarga semilla en el vientre de Altemira Flórez, estaba condenado a ser el último heredero de la sangre, el rencor, la voluptuosidad furiosa y el enojo de Santos Villar” (338). Tras indagar sobre las raíces de su familia, Martín terminará escribiendo una novela que se engendra a sí misma. ${ }^{368}$ Según Peter Elmore, "para prolongar la memoria más allá de los límites de su

\footnotetext{
${ }^{367}$ Los hijos que tuvo Cruz Villar Chira con Trinidad Dioses fueron: Miguel, Catalino, Santos, Luis, Román, Primorosa e Inocencio. Y los hijos que tuvo con Lucero Dioses fueron: Jacinto, Isidoro, Tomás, Silvestre y Práxedes (La violencia 259).

${ }^{368}$ Se trata de una self-begetting novel; es decir, una novela que se engendra a sí misma. Este concepto fue acuñado por Steven Kellman en 1976.
} 
vida, el protagonista elige la representación textual sobre (y en contra de) la reproducción biológica [...] El legado de Martín Villar será un texto que La violencia del tiempo alberga y, en buena medida, completa" ("La sangre y la letra" 643-35). El leitmotiv de la novela es, pues, "el intento de Martín Villar de desentrañar el misterio de un estigma que pesa como una maldición sobre la historia de la familia" (Manrique, La piel 105). La novela abarca cinco generaciones de la familia Villar, afincada en el imaginario pueblo de Congará, ubicado en Piura, en la costa norte del Perú, desde inicios del siglo XIX hasta el año de 1966. He aquí el árbol genealógico desde el primero hasta el último de la estirpe:
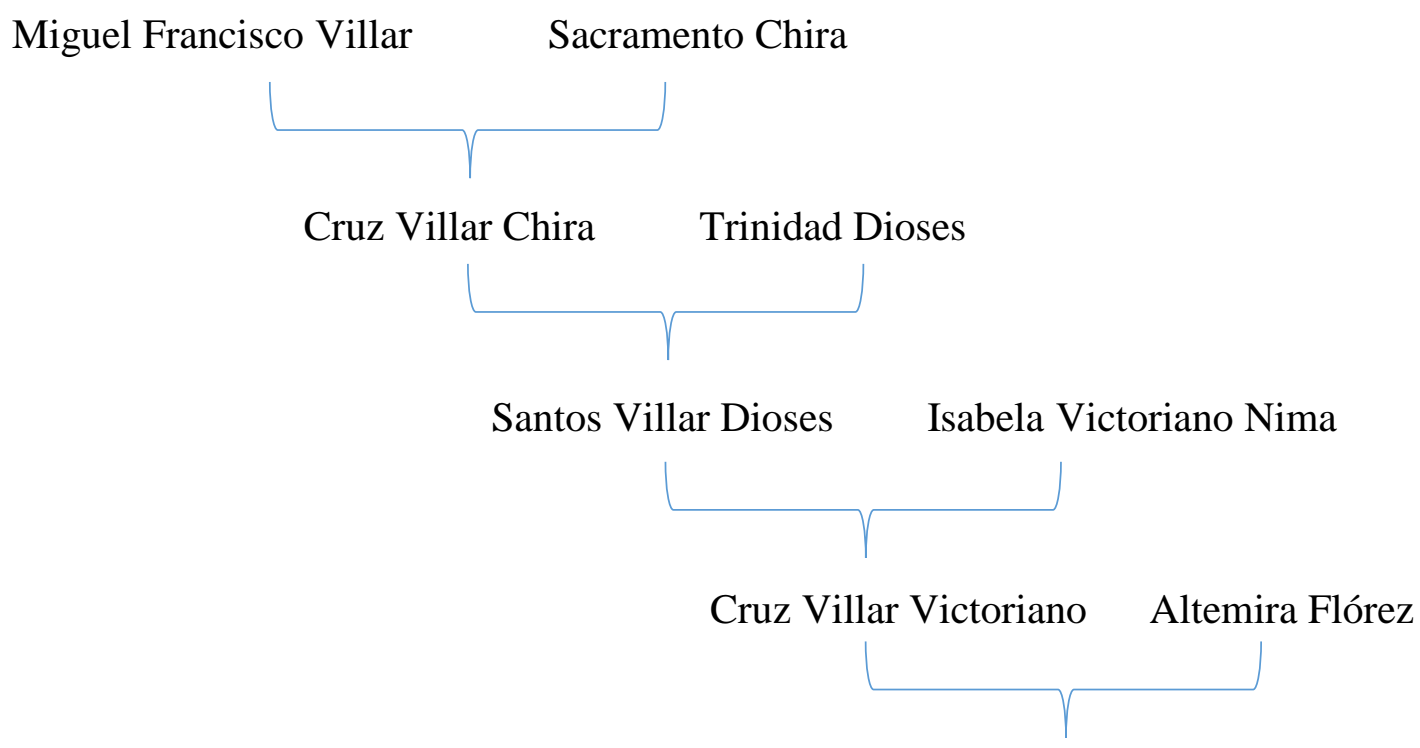

Martín Villar Flórez

Este árbol genealógico está simplificado, ya que no considera a segundas mujeres (ni a Lucero Dioses en el caso de Cruz Villar Chira, ni a la ciega Gertrudis en el caso de 
Santos Villar Dioses), ${ }^{369}$ ni tampoco a los hermanos ni a las hermanas de los protagonistas varones. Juan Carlos Galdo establece que la genealogía peruana de los Villar empieza en 1821 - el año en que se inicia la independencia del Perú de España, lo cual puede deducirse medianamente del texto de la novela (La violencia 333)—, y termina en 1966 ("Un conglomerado de voces" 41). Ignoro en qué se basó Galdo para precisar este último año. ${ }^{370}$

Debido a que Cruz Villar Victoriano fallece antes del nacimiento de Martín, el niño es criado por su abuelo Santos Villar Dioses, quien tenía "un rostro hermoso, varonil, recio y salvaje. La melena crecida (no tenía barba ni bigote) le daba la apariencia de una fiera contenida y segura del poder de sus zarpas y colmillos. Los ojos eran pequeños, pero no la mirada, ilimitada y taladrante y capaz de leer en lo más escondido y secreto del corazón de un cristiano” (58-59). “Sabía usted que en este pueblo no hubo hombre, blanco o indio, capaz de guapearle la mirada?" (231), le comenta a Martín don Timaná, el más reciente inquilino de la antigua casa familiar. Si Santos era hombre indómito de carácter fuerte, parecido a su abuelo—el soldado godo fundador, Miguel Francisco Villar-, el hijo de éste, Cruz Villar Chira le guardaba más similitud aún, puesto que solía victimizar a sus mujeres e hijos, repitiendo el mismo patrón de tiranía, violencia y sadismo que su progenitor, el patriarca de la estirpe, había seguido contra su madre, Sacramento Chira: "Nunca las hermanas [Trinidad y Lucero] Dioses temieron

\footnotetext{
${ }^{369}$ A la perversa ciega Gertrudis "apodaban La Verraca por su manía de convertirse en chancha, una chancha furiosa y lasciva y hambrienta de porquería" (20).

${ }^{370}$ Sin duda, Cien años de soledad (1967) fue una influencia decisiva en la escritura de La violencia (1991), tanto así que Martín Villar menciona esta novela (905). En 1991, también sale a la luz en el Perú Crónica de músicos y diablos (1991) de Gregorio Martínez Navarro. En esta novela se narra la saga de los Guzmán y, de manera similar a la saga de los Villar en La violencia, nos recuerda la de los Buendía en la obra cumbre de García Márquez.
} 
más la furia de su marido que cuando las requería para la posesión, pues cuando aquello terminaba debían soportar las atrocidades verbales de quien se había erigido en tirano y señor de sus vidas. Y la misma furia (sádica, destructiva, irracional) empezó a descargarse contra los hijos que le iban naciendo, calculando la intensidad de la misma según viera en ellos el triunfo de una u otra sangre" (657).

Sin duda, el gran tema de La violencia es el mestizaje; sin embargo, en este caso, tiene la particularidad de ser entendido y sentido como una mácula hereditaria, dolorosa e indeleble:

La historia de los Villar se presenta como una cadena de agravios: los agravios primeros de Sacramento Chira y de su hijo Cruz [Villar Chira] por Miguel Villar [el patriarca] dan motivo a reacciones de odio y rencor, y conducen así a una violencia siempre renovada. Interpretado de esta manera, lo problemático del mestizaje no reside en la dimensión puramente étnica del mismo, sino en el agravio que sufrieron la madre india y el hijo mestizo por el abandono del padre blanco. (Nitschack 139)

Una constante en La violencia es que los personajes principales-además de ser descritos por su carácter y sus excentricidades_-, invariablemente también son detallados por su fenotipo, y cuando en éste prevalece el componente indígena, se considera que han sufrido un retroceso, una involución. Por ejemplo: 


\begin{tabular}{|l|l|}
\hline \multicolumn{2}{|c|}{ Descripción del carácter y del fenotipo de algunos personajes de } \\
La violencia del tiempo
\end{tabular}

Además del trauma fundacional ocasionado por la violencia del padre, la humillación de la madre y el abandono del hogar por el patriarca, la saga de los Villar gira en torno a otros dos ejes argumentales. El primero es la venta de Primorosa Villar Dioses al terrateniente y gamonal Odar Benalcázar por parte de Cruz Villar Chira, a cambio de un lote de terreno, de un espléndido mulo y de unos cuantos gallos de pelea $(73,103-4,110)$. El padre de la joven vende a su hija al terrateniente, motivado tanto por 
la codicia como por su anhelo de ascenso social, "para intentar colocarse, de este modo, en las cercanías de los señores blancos [blanqueamiento]" (Nitschack 136). Este hecho ominoso será un motivo de vergüenza para los descendientes de Cruz Villar Chira y, especialmente, para Santos Villar Dioses, hermano de Primorosa, quien les prohibirá a sus familiares hablar del asunto (02).

Una subhistoria clave para comprender el argumento de la novela es la de la relación incestuosa entre los hermanos Inocencio y Primorosa. ${ }^{371}$ Aunque no tienen descendencia, la sangre de los Villar se espesa en la estrecha relación que ellos mantienen hasta que los separa la venta de la joven a Odar Benalcázar. ${ }^{372}$ Inocencio enloquece y se interna en un bosque de algarrobos. Cuando Primorosa es vendida a Odar Benalcázar por Cruz Villar Chira, ${ }^{373}$ Inocencio [m]urió un poco cuando la vio abandonar el hogar subida sobre la yegua mora del patrón" (235) y la siguió, impotente, en su "recorrido por la larga Calle Real. Camino real de la deshonra, de la infamia, de la vergüenza. Pobre tía, así se refería a ese trance. Y en lo que duró el trote (un trote remolón, impuesto adrede por ella) se mantuvo rígida, la mirada al frente y con un sobrio desdén en sus labios, mientras que la porquería que jubilosamente le arrojaban desde ambas aceras castigaba su rostro"

371 "Y los dos niños que desnudos e inocentes se bañan y acarician son Inocencio y Primorosa" (313). "Jugaban como los animalitos del Señor. Ella era la colamba, la pacasa, y él, el colambo macho, el pacaso macho, y se amaban y tenían crías" (65).

${ }^{372}$ En la novela hay varios casos de "incesto", en mayor o en menor grado, además del que se da entre Inocencio y Primorosa. Por ejemplo, Gertrudis se acuesta con Silvestre, su cuñado, durante el novenario del finado marido: "La ciega Gertrudis, vieja y todo, copula con mi tío Silvestre en la misma cama donde agonizó y murió mi abuelo apenas nueve días antes” (335), y seduce al pequeño Martín: “¿Profané yo también el lecho de agonía donde expiró el poderoso Santos Villas? Más adelante, tal vez, habré de referirme con alguna prolijidad a estas largas noches que compartí con la ciega Gertrudis" (70). Asimismo, Martín adulto tiene relaciones sexuales con Zoila Chira y con la madre de ésta.

373 “"[A]marrado al vichayo, Inocencio seguía escuchando la voz arcana del sampedro que su padre le diera a beber la noche anterior. Muchísimos años después, mi tía Primorosa, en sus enardecidas y alucinadas pláticas $[\ldots]$ aseguraba seguir escuchando a su dulce Inocencio anunciándole su deshonra" (109). 
(100). ${ }^{374}$ Inocencio murió “otro poco cuando, sin decirle adiós, huyó Primorosa, ${ }^{375}$ y otro poco aun cuando el manaturaloso del blanco Benalcázar mandó a quemar el bosque" (235), porque sabía que, tras volverse loco, allí moraba él, Inocencio, el verdadero amor de Primorosa. ${ }^{376}$ "En las noches veías arder el bosque y durante el día, desde el Alto del Gavilán, te la pasabas mirando el camino por donde huyó tu hermana" (ibíd. 180). ${ }^{377} \mathrm{Al}$ cabo de un tiempo, Inocencio muere devorado por las alimañas del bosque, luego de haber sido herido por jóvenes irresponsables que hacían escarnio de su condición y sufrimiento. ${ }^{378}$ Primorosa también enloquece y "[s]olo el recuerdo de su hermano Inocencio confería sosiego a sus palabras, abriendo su memoria al paraíso de la infancia.

\footnotetext{
374 “[S]antos Villar] seguía allí parado en la puerta cuando volvió corriendo su hermano Inocencio. Conteniendo las lágrimas, el muchacho le rogó que fuera a proteger a la hermana de la furia homicida de las mujeres. Mi abuelo (supongo) lo observaría con la castradora mirada que era la virtud de sus ojos, lo haría a un lado con un manotazo y entraría a la casa" (101-2).

375 El vínculo de Primorosa con el circo ya estaba prefigurado desde su infancia: "Por las noches, en tanto los hermanos mayores dormían con sueño agitado, ellos, en el petate que compartían y abrazándose para protegerse de los terrores de la noche, imaginaban la ingenua y rústica velada ('el espectáculo' lo llamaban ellos, imitando el lenguaje circense) que estaban preparando en secreto para exhibirlo ante la madre y los hermanos cualquier tarde que por una u otra razón se ausentasen el padre temible y Santos, el hermano enigmático cuya mirada era mejor no resistir" (119-20).
}

376 "En el jardín del Edén, dos culebritas del Señor se aman. No son culebritas, sino pacasos. Yo soy el pacaso macho y tú la pacasa, le dice Inocencio a su hermanita, y desnudos se bañan en el jagüey de aguas cristalinas, y Dios sonríe benigno y no los expulsa del Paraíso, que ahora empieza a arder y enrojece el cielo nocturno de Congará” (335).

377 "Eres demasiado pichón_-le dice el chamám a Martín_para que sepas nada del inmenso algarrobal que muchos años atrás nos daba fresco y protegía nuestro pueblo [...] consumido y reducido a cenizas" (179).

378 “Espera, ahora. Date un respiro, agárrate el alma, fortalece tu corazón, que te mostraré la muerte de Inocencio que tanto te angustiaba y deseabas saber-le dice a Martín el chamán que guía su viaje en el tiempo, inducido por la ingestión del brebaje sagrado-[...] Ahí lo tienes de nuevo, niño y demente, y sin ninguna ilusión que le despierte codicia para seguir viviendo [...] [H]a perdido hasta el instinto que empuja al animal a defender su vida. Era diversión de los mozos de esos años internarse en el monte de cacería y buscar al Moñón Inocencio para martirizarlo con bromas y pendejadas. Pero, hoy, las burlas han pasado a los golpes y el pobre Inocencio ni siquiera atina a defenderse [...] con garrote y niculas lo apalean [...] el pobre atormentado sangra hasta por vicio, ni se queja ya, casi ni respira [...] La carne del humano es el festín para las fieras y aves de presa" (314-15). 
Paraíso secreto y prohibido [...] que en sus últimos años evocaba en toda su cruda belleza. Inocencio, dulce hermanito, llévame al bosque" (171-2).

Transcurrido algún tiempo, Primorosa le es infiel a Benalcázar en su propia cama, se roba las joyas de su hija lisiada, y lo abandona para marcharse con un artista circense. ${ }^{379}$ Cuando el marido se entera, despechado manda incendiar el bosque y también "se venga" de la situación flagelando y humillando a Cruz Villar (226, 686-8). Éste es el segundo eje argumental de la novela. Una y otra vez los personajes se referirán a estos hechos, casi míticos por el protagonismo de "héroes" y "monstruos" en los prodigiosos acontecimientos narrados, así como por su fusión etiológica. Cada personaje aportará un punto de vista diferente, proporcionando información que confirma o desvirtúa la leyenda familiar, remozándola y actualizándola en el proceso. A la afrenta pública de Cruz Villar le sigue una confesión, también pública, de Cruz Villar:

Confesó que, apenas empezó a hacerse hombre, la nostalgia que desde que guardaba memoria sintió por su progenitor se trocó en deseo y ansia y urgencia de comunicación y de presencia. Convocar su espíritu, recuperar su voz y aprisionar su imagen se convirtieron en pasión y en principio y razón de vida $[\ldots]$ De modo que de aquí y de allá [...] fue recogiendo

\footnotetext{
379 Primorosa "quería herir y humillar lo más íntimo y sagrado de Odar Benalcázar, su orgullo y complacencia y satisfacción viril, huyendo con un joven más joven y más fuerte y más animal, quitándole así para siempre el respeto, el sosiego, y proyectando un manto de dudas sobre los éxtasis carnales que él había creído arrancarle" (497-98).

Faraona Cherres, una anciana del pueblo de Congará, le cuenta a Martín que, "cuando el niño Odar llegó, la muy zorra ya se había embarcado con esos hijos del viento que son la gente del circo [...] [L]a muy chuchumeca, no contenta con putear con los del circo, cargó con las joyas que el bueno de don Odar le regaló $[. .$.$] Pero allí no paraba su ambición [. .$.$] ¡Tuvo que cargar también con las joyas de la pobre ñaña$ Paulina [la hija lisiada de Benalcázar!" (195).
} 
instrucciones sobre el cactus de cuyas virtudes los antepasados de

Sacramento Chira habían hecho una ciencia hermética. ${ }^{380}$ (658)

Cuando Martín confirma que, en efecto, su bisabuelo había sido azotado "[a] manos de

Benalcázar y sus lacayos", tal como se lo habían contado, confiesa lo siguiente: "No solo

me sentí agraviado, mancillado, ultrajado, sino degradado en mi condición de individuo

de la especie humana" (307-8). ${ }^{381}$ Para Peter Elmore,

[e]l castigo que ante el pueblo de Congará padece Cruz Villar [...] es una

minuciosa ceremonia de degradación: su propósito es marcar

espectacularmente la inferioridad étnica y social de quien, hasta entonces,

había sido un hombre orgulloso y despótico [...] La sanción tiene, por eso,

un carácter perversamente edificante y ejemplar: sirve para poner en su

sitio a un sujeto de las capas populares que, de acuerdo a las jerarquías de

\begin{abstract}
380 "Y con ello [consultar al cactus sagrado] Cruz Villar estatuyó un hábito, una herencia, más bien una fatalidad, que ninguno de los Villar de las generaciones siguientes pudo eludir, pero que Santos, el hijo preferido, asumió con oscuro y salvaje orgullo, haciendo de la soledad un bastión inexpugnable y un valor $\mathrm{y}$ un poder, en tanto que para Inocencio fue el vasto territorio de la demencia, donde cada día recuperaba a Primorosa" (La violencia 658).

"La atmósfera de mito y de magia, al provocar miedo, actúa como una realidad indudable. Al aterrorizarme, me integra en las tradiciones, en la historia de mi comarca o de mi tribu, pero al mismo tiempo me asegura, me señala un status, un acta de registro civil. El plano del secreto, en los países subdesarrollados, es un plano colectivo que depende exclusivamente de la magia. Al circunscribirme dentro de esa red inextricable donde los actos se repiten con una permanencia cristalina, lo que se afirma es la perennidad de un mundo mío, de un mundo nuestro [...] Las fuerzas sobrenaturales, mágicas, son fuerzas sorprendentemente yoicas. Las fuerzas del colono quedan infinitamente empequeñecidas, resultan ajenas. Ya no hay que luchar realmente contra ellas puesto que lo que cuenta es la temible adversidad de las estructuras míticas. Todo se resuelve como se ve, en un permanente enfrentamiento en el plano fantasmagórico" (Fanon, Los condenados XX).

381 “El 'resentimiento', cuya importancia descubrió Federico Nietzsche y ha desarrollado magistralmente Max Scheler, es una autointoxicación psíquica. Su origen no es espontáneo y libre; es una reacción. Tiene un propósito de venganza, pero acompañado de cierta conciencia de impotencia o inferioridad dentro de una aparente igualdad de nivel con el contrario. No es algo fugaz, que se satisface con facilidad; tiende a convertirse en algo permanente, continuamente 'ofensivo', sustraído a la voluntad del ofendido. No proviene, a veces, de fracasos determinados o concretos, sino de un malestar interior difuso" (Basadre, "Ubicación sociológica de González Prada". Perú: problema y posibilidad 103).
\end{abstract}


la semifeudalidad rural, se ha permitido un comportamiento impropio de su origen. ${ }^{382}$ ("Vallejo, Arguedas y Gutiérrez" 30)

Este tipo de "escarnio para escarmiento", el método que utiliza el dominador con el propósito de que el dominado "se ubique" frente a él y que asuma el rol que "le corresponde", es explicado por Frantz Fanon con las siguientes breves palabras: "En el contexto colonial, el colono no se detiene en su labor de crítica violenta del colonizado, sino cuando este último ha reconocido en voz alta e inteligible la supremacía de los valores blancos (Los condenados de la tierra 38). ${ }^{383}$ Dice Foucault que el "discurso de la lucha de razas", que hasta el siglo XVII solía darse entre pares de razas, se convirtió con el tiempo en "el discurso del poder" hasta convertirse en el discurso" no entre dos razas, sino entre una raza puesta como verdadera y única (la que detenta el poder y es titular de la norma) y las demás, que constituyen un peligro "para el patrimonio biológico"

\footnotetext{
382 "Escondiendo las garras y revistiéndose de la mítica campechanería de los blancos de la región, Odar Benalcázar interpeló a mi bisabuelo en la pelea de gallos durante la feria de la Bajada de los Reyes Magos. En tono jocoso y levantando la voz para que lo escuchara todo el mundo, dijo que lo vieran bien, que allí frente a ellos tenían al gran don Cruz Villar, el hombre más orgulloso y mísero de Congará. Orgulloso, explicó, porque tiene a mal quitarse el sombrero mientras habla con la gente decente, y mísero, paisanos, porque en la burrada de veces que he pasado delante de su casa, fatigado de tanto cabalgar bajo el sol inclemente, nunca ha tenido la piedad de ofrecerme aunque sea una chicula de agua para mitigar la sed. Don Cruz Villar (mi primer abuelo) [...] sin aludir al asunto de su orgullo, le dijo que si nunca lo convidó ni le ofreció hospitalidad fue por temor a sufrir un jodido desaire, pero que si el patrón no tenía a menos compartir la mesa de los pobres, desde ya lo invitaba a su humilde morada para el día que su hija cumpliese quince años" (La violencia 106).

La actitud de Cruz Villar cae dentro del concepto de hibris (desmesura) de los griegos, aplicable cuando un mortal transgredía el espacio reservado para los dioses y era castigado debido a ello.

383 "El colonizado está siempre alerta, descifrando difícilmente los múltiples signos del mundo colonial; nunca sabe si ha pasado o no del límite. Frente al mundo determinado por el colonialista, el colonizado siempre se presume culpable. La culpabilidad del colonizado no es una culpabilidad asumida, es más bien una especie de maldición, una espada de Damocles. Pero, en lo más profundo de sí mismo, el colonizado no reconoce ninguna instancia. Está dominado, pero no domesticado. Está inferiorizado, pero no convencido de su inferioridad" (Fanon, Los condenados de la tierra XX). Recordemos que Frantz Fanon era psiquiatra.

Aunque la historia de los Villar se desarrolla durante la etapa republicana, el Perú continuó por muchos años sumido en una semifeudalidad propia de los tiempos de la Colonia. Por este motivo viene al caso comentar las reflexiones de Fanon en relación con la historia de los Villar en La violencia.
} 
(Genealogía del racismo 56). "En ese momento aparecerán todos los discursos biológicoracistas sobre la degeneración [,] y todas las instituciones que, dentro del cuerpo social, harán funcionar el discurso de la lucha de razas como principio de segregación, de eliminación y de normalización de la sociedad" (ibíd. 55-6). En la novela de Gutiérrez Correa, la afrenta sufrida por Cruz Villar Chira se extiende a toda su familia y descendencia: “[E]ste agravio y vejamen inferido públicamente a mi primer abuelo—dice Martín - [...] es como el blasón, el escudo de armas humillado de los de mi sangre" (289). De manera similar al efebo Narciso, Martín ve un rostro reflejado en la fuente, mas no es el suyo sino el de Cruz, y en el afán de atrapar la imagen del bisabuelo para identificarse con él, ${ }^{384}$ termina ahogado en las aguas del rencor.

Después de haber abandonado sus estudios universitarios en la Universidad Católica, en donde era becario, Martín retorna al lugar donde nació y halla un "pueblo fantasmal" (289) que evoca a Comala de Juan Rulfo en Pedro Páramo (Elmore, "La sangre y la letra" 639): "Desde hace muchísimos años el viento y la arena vienen sepultando a Congará, pero la memoria persiste" (184). Elmore interpreta la similitud con las obras de Rulfo no como meros "guiños intertextuales" o ejercicios estilísticos de Gutiérrez Correa, sino como la intención del autor peruano de aludir "a una coincidencia de fondo: el viaje hacia el progenitor [...], las vicisitudes y el fracaso final del viaje hacia un origen donde se halle la fuente del sentido. Ese reencuentro, ese momento de fusión plena con la propia esencia, está destinado a frustrarse, pues el instante epifánico de la presencia queda siempre como deseo insatisfecho, como el inalcanzable horizonte de la

\footnotetext{
${ }^{384}$ Inconscientemente, Martín anhelaría reunificarse, no con su madre (complejo de castración) sino con Miguel Francisco Villar a través de su bisabuelo. En otras palabras, y aunque parezca contradictorio, desearía blanquearse.
} 
nostalgia" ("La sangre y la letra” 639). La solución que halla Martín Villar Flórez para romper con el determinismo de odio y rencor-originado en su familia principalmente a consecuencia del supuesto "pecado original" que cometieron Miguel Francisco Villar y Sacramento Chira al engendrar hijos mestizos-consiste, precisamente, en negarse a tener descendencia. Por esta razón, Martín obliga a Zoila Chira—su pareja sentimental— a provocarse abortos (176). Dado que Zoila pertenece al linaje tallán, el mismo de la matriarca Sacramento, el hecho de negarle a la joven el derecho a la maternidad cierra simbólicamente un círculo en la historia de los Villar y le pone punto final a la estirpe espuria. En opinión de Antonio Cornejo Polar, con su rechazo a procrear hijos "el narrador hace la más cruda denuncia del mestizaje entendido [...] como [una] maldición. La historia que cuenta es la del linaje del narrador [...] sobre el que pesa algo así como un pecado original: la violación de la madre primordial por el conquistador. Esa violación marca a fuego y para siempre el destino de ese linaje [...] Entonces, la única manera de borrar la ignominia no consiste en asimilar y superar el trauma originario sino en liquidar el linaje mestizo y maldito" ("Literatura peruana e identidad nacional" 299).

El aborto es un tema recurrente en La violencia. Uno de los pasajes más dramáticos es aquel en el que se relata que Primorosa Villar, tía abuela de Martín, habiendo sido embarazada por su comprador, Odar Benalcázar, interrumpe el proceso de gestación e incinera al feto (131-2). Asimismo, Altemira Flórez, la madre de Martín, tuvo dos abortos (20). De modo similar, en los cuadernos que Cruz Villar Victoriano le legara a su hijo Martín se narran los abortos que se procuraron muchas mujeres peruanas que fueron violadas por soldados chilenos durante la Guerra del Pacífico (1879-1883) (73) y que - de la misma manera en que había procedido el soldado godo Miguel Francisco 
Villar con sus hijos—, abandonan a sus respectivos retoños. Por otro lado, Deyanira—la amiga de Martín por quien él siente un amor platónico—-le comenta que "[1]as mujeres no deben parir. Antes de quedar preñada, me haría extirpar los ovarios" (176). Más adelante, Deyanira ratifica su postura frente a la maternidad: "Desde niña consideré como un ultraje la preñez de la mujer" (284); "[1]a maternidad es el peor agravio que se le ha infligido a la mujer como ser humano" (216).

Tampoco es gratuito que el libro abra con las preguntas “¿Quién castró al gran padrillo? [...] ¿Quién tumbó al borrego padre, orgullo de nuestra pobreza, para que papá aplicara el tajo que le cercenó sus enormes y pestíferas verijas? [...] ¿Qué ya no recuerdan el aullido del animalaje de los corrales vecinos como si acompañaran con su lamento la herida padecida por el más valiente de los machos y cabrones del pueblo? (13). ${ }^{385}$ A lo largo de la novela se menciona reiteradas veces el episodio de la emasculación del semental. La respuesta a la pregunta inicial es que Cruz Villar Chira castró al animal con la ayuda de su hijo Santos Villar Dioses $(13,321)$, del que se sentía orgulloso por lo despiadado que era. "Y allí estaba, reiterativa, la imagen del mozo Santos luchando con el gran padrillo, y los ojos extasiados del bisabuelo Cruz pensando que este era el hijo que merecía la primogenitura" (58). El gran padrillo puede transparentar tanto a Miguel Francisco Villar como a Odar Benalcázar: “[R]ecuerdo que en sus rememoraciones intrincadas mi pobre tía [Primorosa] —comenta Martín—aludía a cierto flagelamiento [sic] que en la desnudez de su cuerpo soportó sin una queja de manos del gran semental [énfasis mío], al sentirse ultrajado este por la frigidez que hubo

\footnotetext{
385 "So far as masculinity is concerned [...] for many centuries it was less the large of the penis than the testicles that determined the man [...] The testicles stood for (an in their Latin etymology witnessed) courage, even if the courage was the prime possession of one social class" (Braudy 180).
} 
mostrado ella a su furiosa acometida" (111). Este gamonal era el progenitor de una larga prole bastarda (con excepción de la ñaña Paulina), a la que le reconoció su paternidad sólo tardía y parcialmente. Otro indicio del símil que encubre la figura del gran padrillo lo ofrece el momento en que Cruz Villar Chira está siendo flagelado por orden de Odar Benalcázar y confunde al agresor con su propio padre. De la sarta de improperios que le lanza al victimario durante la flagelación, el terrateniente capta el yerro en que incurre el torturado y objeta: “¿Qué habla, so viejo cojudo? ¿Yo, Miguel Villar? ¡Váyase a la puta que lo parió!"' (687). La castración del gran padrillo simboliza, en mi opinión, la imperiosa necesidad que plantea la novela de acabar con la prosapia poluta. Según Cornejo Polar, "la única salida posible [que tiene Martín] de acabar con su 'linaje maldito' es obligando a abortar a la muchacha india que él embaraza" ("Literatura peruana e identidad nacional" 299). Erik Camayd-Freixas aclara que "el símbolo es principalmente estático, y la alegoría, dinámica. Sin embargo, la necesidad de darle al significado alegórico una forma concreta hace del símbolo un componente importante de la alegoría" (Realismo mágico 233-4). En este caso, la castración y el aborto son los símbolos, y el hecho de negarse a tener descendencia, más que una tesis per se, es la alegoría de la necesidad de ponerle punto final a una raza supuestamente abyecta.

Por esta razón, Cornejo Polar colige que La violencia "es una insólita novela antimestiza [...] [A]l menos, es un texto que admite esa lectura" (ibíd. 299). María Elena Torre refiere que, a la interpretación de este crítico, Gutiérrez Correa replicó en $D a$ Gama 78 que su novela no era "una recusación del mestizaje, sino más bien una problematización de 'la condición mestiza' por ser el producto de la conquista y colonización” ("Entre la fundación y el derrumbe” 386). El autor define su novela como 
una “"zona de contradicciones, conflictos, rencores y furores' en la que además del componente de la raza y la sangre, intervienen factores históricos, sociales, económicos, morales y sicológicos que constituyen las particularidades del mestizaje en el Perú y [que] se erige en una suerte de destino para los individuos y las colectividades" (ibíd. 386). En todo caso y no obstante el mentís del autor, La violencia da cabida a entender: 1) el aborto, 2) la esterilidad voluntaria, y 3) la castración como metáforas del anhelo colectivo de la familia Villar-y, en especial, de Martín—de truncar su estirpe mestiza.

Otro tema reiterativo en la novela es el desamor de los hijos hacia la madre, empezando por Cruz Villar Chira:

Sacramento Chira no había sido su madre: había sido su sierva, la simple matriz india en que Miguel Villar depositó su preciosa semilla, su preciosa sangre, la puta que lo parió. Y él, único hijo varón, y agraciado con el pellejo y los ojos de su progenitor, habría sentido desprecio por las hermanas que heredaron [...] la sangre inferior de Sacramento Chira. No, no amó a su madre. Tampoco la odió. La sintió ajena, distinta a él. (65556)

Así como lo había hecho su padre, "Santos en sus mocedades repudió la memoria de Sacramento Chira" (289). De otro lado, Zoila Chira-la amante de Martín, quien también había compartido el lecho con la madre de ésta-siente rechazo hacia su progenitora (192). Y a la inversa, en la novela se presenta el desamor de una madre hacia su hijo. Éste es el caso de Isabela Victoriano, quien echa del hogar a Cruz Villar Victoriano-el vástago producto de la violación perpetrada contra ella por Santos Villar Dioses (335-36, 
908) - y se lo entrega al "cuidado" de Clemente Palacios. ${ }^{386}$ Es dable suponer que el desamor o el repudio hacia la madre que sienten algunos de los personajes de la novela obedece a que ellos consideran contaminante la porción de sangre indígena que corre por sus venas como producto del mestizaje, y que da origen a una supuesta estirpe corrupta. Esto se evidencia, por ejemplo, cuando Martín relata que la misión que su abuelo Santos consideraba tener en el mundo era la de "sacar adelante a su familia y, para ello, era necesario huir [...] de sí mismo, abjurando de la sangre a la que (oscura, agrestemente) atribuía toda la desventura y la dicha de la vida" (653). El propio Martín confiesa: “[H]ubo un tiempo en que yo también abjuré de mi sangre y repudié mi cuerpo y pretendí huir y saltar y dejar atrás (olvidándola, aniquilándola) aquella sangre que para mí representaba no sólo la pobreza, la ignorancia y la superstición, sino también la fealdad, la derrota, el rencor y el odio, el lado oscuro y abyecto de la vida" (654). Tanto es así que, tras leer "Memorias del Cusco", un cuento ambientado a principios de la Colonia, escrito por Martín, su amigo J.L. advierte que el autor percibe la raza aborigen como abyecta y que abriga resentimiento hacia ella:

Me refiero, claro, a los sobrevivientes y a los traidores, porque la mayoría murió combatiendo entre 1532 y 1544 . Despreciados y vejados por los españoles, odiados por los indios que sufrieron su despotismo, hazmerreír de mestizos y negros, sobre todo de los zambos, tan cachacientos los putas, sin dioses o con dioses destronados carentes de todo poder. ¡Qué orfandad! Y lo que es peor: sin tierras ni siervos que las trabajasen. Se

\footnotetext{
${ }^{386}$ Clemente Palacios es un hombre que había pactado con Satanás (37, 683-84). Posteriormente, el doctor González rescata a Cruz Villar Victoriano del influjo de Clemente Palacios y lo convierte en su asistente (La violencia 1007).
} 
hallan reducidos a la mendicidad. Y los que no se suicidan o se dejan morir por orgullo, tienen que extender la mano para recibir limosnas y alimentarse con la sopa boba que reparten los frailes que ahora habitan en lo que apenas unos años atrás habían sido sus palacios. Esto es lo que tú mismo cuentas (o lo que cuenta el narrador colectivo) y el asunto resulta trágico. Sí, humanamente trágico. Y aquí es donde la cagas, compadre, y todo por tu maldito rencor [énfasis mío]. (266-67)

Creo que esta cita ilustra el sentimiento de orfandad y de despojo que-adicionado al complejo del mestizaje — alimenta el odio y el rencor en los protagonistas de la novela de Gutiérrez Correa, quienes representarían a un gran segmento de la población del Perú. Reyes Tarazona hace notar que, "del oprobio personal [...] se salta al agravio nacional [...] [E]n la historia nacional, la conquista española, con su secuela de explotación, iniquidad e injusticia, es el punto inicial para la degradada condición de los habitantes del país. Según Martin Villar: 'éramos, pues, un pueblo de bastardos, frutos de la violencia, la derrota y el engaño"” (“Aproximación a La violencia del tiempo" 161).

El mismo salto que da el personaje de ficción Martín Villar desde el ámbito individual al social, lo da el Inca Garcilaso en la vida real, pero a una escala mayor y en sentido inverso: "Español en los Andes e indio en Iberia, arrastró en su nombre la paradoja de una búsqueda que no termina porque se originó en una superposición no deseada. Y que el Inca resolvió haciendo historia de su drama familiar, y moral de la tragedia de su pueblo [énfasis mío]" (Millones Santa Gadea, "Cinco preguntas" 24). Néstor García Canclini probablemente estaría en desacuerdo con Millones Santa Gadea 
sobre este asunto. Refiriéndose a la globalización — un tema que, aparentemente, sería anacrónico con respecto al Inca Garcilaso-, el antropólogo argentino señala lo siguiente:

Uno de los puntos clave en que se juega el carácter —opresivo o liberador - de la globalización es si nos permite imaginarnos con varias identidades, flexibles, modulares, a veces superpuestas [énfasis mío], y que a su vez cree condiciones para que podamos imaginar legítimas y combinables, no sólo competitivas o amenazantes, las identidades, o, mejor, las culturas de los otros" (García Canclini, La globalización imaginada 123).

Esto es exactamente lo que hizo el Inca Garcilaso al construir su identidad: utilizó la estrategia del etnovaivén, alternando entre el blanqueamiento y la cholificación. ¿Será que la aldea empezó a hacerse global desde 1492, cuando se encontraron el Viejo y el Nuevo mundo? ${ }^{387}$ De hecho, el legado de la cultura autóctona aunado a la posibilidad de acceder a la denominada "alta cultura"-asociada, en esos tiempos, a la producción artística de la antigüedad clásica y del renacimiento, la cual era percibida como universal-le permitió al Inca Garcilaso fabricarse una identidad cultural sincrética.

Por el contrario, la novela de Gutiérrez Correa trasmite la noción de que el mestizaje es algo aberrante, pero no solamente entre seres humanos sino también entre los animales. Cierto día, Santos Villar, "siendo todavía un churre [...,] se apareció con un polluelo de gavilán que más tarde logró cruzar con una gallina de pelea" (101).

\footnotetext{
387 “'[P]dríamos decir que la globalización se remonta a tiempos muy antiguos, desde que Colón llega a América y Magallanes da la vuelta al mundo, o desde la expansión imperialista del capitalismo, especialmente a partir del S.XIX. Pero en estas últimas décadas se producen un conjunto de transformaciones que dan origen al fenómeno que hoy se conoce como globalización" (Degregori "Perú: identidad" 213).
} 
“[F]orzando a la naturaleza, [Santos] obtuvo un animal réprobo, carnívoro, asesino y estéril que habría de convertirse en instrumento de desagravio, compensación y venganza cuando ocupó Congará un numeroso destacamento del ejército chileno" (101). En clave alegórica, cabe interpretar que el ser híbrido y yermo que resulta del cruce "imposible" de ave de presa con ave de corral, es monstruoso debido a su origen antinatural. Rememorando los días de la infancia, Catalino - el hermano mayor al que Santos le "robó" la progenitura (101) — les pregunta a sus otros hermanos: “¿Es decente unir lo que Dios creó separado?" (13). Sin embargo, el engendro creado por Santos conlleva en su esencia ontológica la violencia necesaria para vindicar el honor perdido en la Guerra del Pacífico, al vencer en un duelo al gallo de pelea opuesto por el chileno invasor. La personificación simbólica del gavilán-gallina en la familia Villar es el bandolero Isidoro, hijo de Cruz, quien le dispara a Benalcázar en la pierna, dejándolo inválido, en venganza del agravio que les hizo a su padre y a su media hermana, y ajusticia a los jóvenes que apalearon a su medio hermano Inocencio en el bosque (314-5). ${ }^{388}$

Al parecer, Santos había logrado darle vida a su "horrendo huésped" (Frankenstein) de gavilán-gallina, utilizando los poderes malignos que había adquirido mediante una alianza con Satanás (788). Asimismo, Santos "usó los poderes que recibió para maldecir a Congará y al linaje entero de los Benalcázar" (238), vengando, de esa manera, el agravio que Benalcázar le hiciera a Cruz, su padre, al degollar a sus animales en su presencia e incendiarle su chacra (73), pero sobre todo al flagelarlo en público (178). Mas al cabo de cierto tiempo, Santos se arrepiente del trato hecho con Lucifer y

\footnotetext{
${ }^{388}$ En muchos casos, cuando el subalterno se da cuenta de que el sistema de justicia no funciona para él, opta por tomar la justicia en sus manos, por impartirla él mismo.
} 
decide regenerarse, aunque transitar por la senda del bien le cueste, por haber roto el acuerdo, el contagio de una enfermedad venérea (238). Tras romper lazos con el demonio, Santos se convierte en un afamado y querido curandero, particularmente servicial para con los indígenas, actitud que sugiere una forma de reconciliación con sus raíces maternas (288).

La rehabilitación moral de Santos nunca estuvo reñida con la fuerza de su personalidad y carácter, que resultaba agobiante y castrante para los miembros de su familia, quienes respiraron aliviados después de que él murió (291). Cuando ocurre el deceso, Martín se siente liberado del yugo opresor y confiesa: ““¡Al fin!, se había dicho cuando le comunicaron la muerte de Santos Villar. ¡Al fin! ¡Al fin!, se dijo el niño experimentando por primera vez un desconocido sentimiento de liberación [...] Con ingenuidad y candor creyó que con la muerte de Santos Villar expiraban no solo el despotismo que había ejercido sobre él y los suyos, sino también el entero mundo, sombrío, rudimentario y cruel, del linaje paterno" (77). "Con ingenuidad", dice el narrador, porque, si bien Martín se siente liberado, al mismo tiempo el fallecimiento de su abuelo dispara en él la avidez de conocer la historia familiar; anhelo que se convertirá en su razón de vida: "Y ahora que por fin terminó de morirse el abuelo Santos habría más y más porqués y la vida sería indagar tantos enigmas y vergüenzas y padecimientos hasta descubrir la herida inicial, el hueso y la caída, el traspié del alma y sus desolladuras iridiscentes, triunfales y rencorosas" (16). Sin embargo, las indagaciones que hará Martín en el futuro no se convertirán en el "sustento de una socialización satisfactoria e integradora", sino, por el contrario, caerán en "un territorio al cual envuelve una atmósfera de alienación y malestar" (Elmore, "La sangre y la letra" 635). "Pobre Martín 
Villar, poco habría de durarle esta ilusión, pues no transcurrió mucho tiempo para que tuviera la evidencia de que, en realidad, Santos Villar no había muerto sino accedido a un nuevo orden de existencia desde el cual seguiría ejerciendo su dominio y perturbando sus sueños, e imponiéndole el juramento de permanecer fiel a su sangre" (77).

William J. Cheng señala que "la visión polémica del mestizaje que propone $L a$ violencia del tiempo [...] socava la alegoría romántica [de la] mezcla armónica de la sangre europea con la indígena" (16). Sucede que, desde el inicio de la Colonia, "[l]as sutiles codificaciones ligadas al grado de pigmentación de la piel en las que el poder español se esforzó por encerrar a las poblaciones mestizas [...,] [1]a vigencia de las normas, su expresión en la vida cotidiana y su reflejo en las conductas, fue produciendo sus efectos psicológicos: penetró en el mundo interno de los individuos, definió sus esquemas valorativos y se afirmó en sus estructuras inconscientes" (Hernández 198). Víctor Vich explica que, a lo largo de los años y con un trasfondo político (la pretensión de "ocultar conflictos y problemas sociales de honda raíz histórica"), el discurso apologético del mestizaje "ha modelado la conciencia nacional" ("El secreto poder del discurso" 188).

Michel Foucault sostiene que "ejercer el poder crea objetos de saber, los hace emerger, acumula informaciones, las utiliza" ("Entrevista sobre la prisión”, Microfísica del poder 99). Es así que, con respecto al mestizaje se ha producido "un tipo de discurso"-un "saber"-; vale decir, "un conjunto de prácticas relacionadas con la reproducción del poder [...] que celebra una supuesta 'unidad' nacional y que ha funcionado siempre mediante una compleja operación que le sustrae a la historia su carácter histórico (digamos, conflictivo) a partir de un elogio de los incas que nunca ha 
sido simultáneo con una celebración de la heterogeneidad étnica cultural del presente (Méndez, "Incas sí, indios no", en Vich, "El secreto poder del discurso" 188). ${ }^{389}$ O, como lo dice Carlos Iván Degregori: “Tal como fue soñada por los criollos, la 'comunidad imaginada' llamada Perú incorporó desde muy temprano en su historia las glorias del Imperio Inca, pero negó tener algo que ver con los indios contemporáneos" ("Perú: identidad" 214). En opinión de Rodrigo Montoya Rojas, Valcárcel supo zanjar la brecha existente en la percepción de la propia raza aborigen en horizontes temporales distintos: "Luis E. Valcárcel fue vocero de una mirada del país desde el Cusco en la que el pasado inca y el presente indígena se dieron la mano en el mismo grito político frente a la visión limeña casi esquizofrénica que separaba al indio histórico constructor de una gran sociedad inca del indígena del presente" (Prólogo de la edición facsimilar de Tempestad en los Andes viii).

En La violencia hay varios guiños intertextuales a la figura del Inca Garcilaso, aunque, a veces, las alusiones son directas. Por ejemplo, con afán deconstructivo y ánimo paródico, J.L. le comenta a Martín precisamente sobre las fuentes historiográficas del Inca, uno de los temas que el protagonista de la novela aborda en su cuento "Memorias del Cusco":

Garcilaso (y, aquí entre nos, te confieso que no me resulta simpático el Inca, aunque solo sea porque mereció el elogio del Marqués de Aulestia [José de la Riva-Agüero]), el aristócrata Garcilaso envía una carta a sus

\footnotetext{
389 "Nationalist sentiments expressed through the anti-confederationist [se refiere a la Confederación Peruano-Boliviana, 1836-1839] press, satiric poetry and pamphlets, glorified the Inca past while spurning the Indian present. During this period, a nationalist, essentially racist, rhetoric whose roots can be traced to the late eighteenth century, took shape. This rhetoric would provide the foundations of an ideology which has prevailed in Peruvian history. This rhetoric reached its peak in the twentieth century, while evolving into discourse instrumental to the exercise of power" (Méndez, "Incas sí, indios no" 197).
} 
aristocráticos parientes cusqueños solicitándoles información para escribir sus Comentarios Reales, libro que, si no fuera por su excelente prosa, yo habría ordenado quemar, como destruían los incas toda memoria que les resultaba perniciosa. Así no habría hecho cojudo al Perú presentándonos a unos incas magnánimos y justicieros, cuando la verdad es que fueron unos explotadores y déspotas de marca mayor, además de fornicarios insaciables que no respetaban ni a sus propias hermanas [...] De modo que los parientes reciben la carta y la panaca [familia real] en pleno le responde a aquel sobrino Yupanqui que ya no vive en el ombligo del mundo sino en su parte más remota y posterior. Y la carta de respuesta es el cuento "Memorias del Cusco". Esto es un acierto y un acierto todavía mayor constituye que la epístola, para decirlo en forma elegante, esté escrita por un yo colectivo, por un nosotros que vive en un mundo despedazado. (266-7)

Hay puntos de contacto entre los tipos de fuentes de consulta que utiliza el Inca Garcilaso para documentar su obra, y las que emplea el personaje de ficción Martín Villar:

[P]or las pasiones desencadenadas entre los hermanos Villar durante los funerales de Santos Villar, por los monólogos extraviados de mi tía Primorosa, por las murmuraciones insidiosas de la ciega Gertrudis, por lo ilimitado (reiterativo) del relato de Altemira Flórez y por las alusiones crípticas, figuradas, simbólicas, de los cuadernos que me legara mi padre, pude reconstruir (¿imaginar?), ¿inventar?) desde sus orígenes el 
acontecimiento que fue uno de los baldones que cayó sobre los descendientes [de...] Miguel Villar. (102-3)

En el año 1958, cuando Martín es un estudiante becado en la Pontificia Universidad Católica (133), sustenta la monografía "Los Benalcázar León y Seminario" que ha escrito para su curso de Preseminario de Historia del Perú-cuyo titular es el doctor Ventura Candamo de la Romaña y Sancho-Dávila_ ${ }^{390}$ con una bibliografía de lo más heterodoxa, que incluye textos espurios y testimonios orales hasta de orates. ${ }^{391}$ Con

\footnotetext{
${ }^{390}$ Con una gran dosis de sarcasmo, Martín nos presenta a su profesor con las siguientes palabras: "El doctor Ventura Candamo de la Romaña era uno de los hombres más ricos del Perú y principal benefactor de la Pontificia Universidad Católica del Perú. En la universidad ocupaba un cargo en Facultad de PreLetras y, como director del Instituto Riva-Agüero (era al mismo tiempo, sobrino nieto, tío y primo, en distintos grados de parentesco, tanto por vía varonil como femenina, por los laberínticos senderos genealógicos, del marqués don José), el doctor Candamo, decíamos, se había impuesto la misión de mantener vivo el espíritu del gran historiador, bisnieto del primer presidente del Perú y descendiente directo del conquistador Diego de Agüero y, por línea femenina y colateral, de los dos conquistadores Nicolás de Ribera, el Viejo y el Mozo. El doctor Candamo de la Romaña y Sancho-Dávila pertenecía a varias academias de Historia y Geografía del Perú, de Hispanoamérica y de España, a instituciones patrióticas de carácter honorífico, como la Sociedad de Próceres de la Independencia y a instituciones benéficas y filantrópicas ligadas a la Iglesia. En la actualidad ejercía la presidencia de la estricta Comisión de Admisión al Club Nacional" (La violencia 139).

El símil del personaje ficticio Ventura Candamo de la Romaña con el personaje histórico José de la RivaAgüero es evidente.

Si bien podemos encontrar muchos ejemplos en la Biblia de personas que vocean los nombres de sus ancestros, Leo Braudy explica la importancia de genealogía en la Edad Media: "In the diffuse political world of the Middle Ages, when central authority, whether the king or country, was weak or nonexistent, loyalty to a local lord was complemented with loyalty to family. Questions of genealogy-who actually was your father, and what was his family - became paramount, especially for those seeking to expand their own power or status, for those in the warrior and noble classes believed that true honor was their sole possession" (From chivalry to terrorism 64).

"In the world of an aristocracy that defines masculinity in terms of its own physical valor [..., ] genealogical vaunting is essential to the warrior's identity [...] Most important, it insures that one's immediate opponent is worthy and that true honor will result from the combat" (ibíd. 63).
}

391 “[L]a heterodoxia (y esto era lo que le producía la taimada, viciosa alegría al universitario Villar) eran los puntos IV y V de las fuentes, dedicados a los documentos y testimonios orales. Porque, por ejemplo, junto a las actas y ponencias del Primer Congreso de Genealogía y Heráldica de 1929, celebrado en Madrid (y al que asistió don José de la Riva-Agüero con el título de Marqués de Montealegre de Aulestia), o frente al Libro de Cabildos de la ciudad de San Miguel de Piura, correspondiente a los años de 1737 a 1748, incluía los Diarios manuscritos del doctor Augusto González o los cuadernos de Cruz Villar, padre del pichón de historiador. Y en cuanto a los testimonios orales, la heterodoxia adquiría la dimensión de un verdadero escándalo hermenéutico, pues incorporaba la comunicación que le concedió la acreditada (y piurana) historiadora, doctora Ella Dunbar Temple, gran conocedora de los linajes patricios de la región de 
un espíritu revanchista e infantil, Martín se empecina en demostrar en su estudio los dudosos orígenes de una alcurnia que era considerada en Piura de incuestionable noble cepa, cuando se trataba, en realidad, de sangre judía y, por lo mismo, impura, según los anacrónicos y prejuiciosos cánones coloniales. ${ }^{392}$ A diferencia del Inca Garcilaso, cuyos Comentarios reales — que incluyen su "Protestación del autor sobre la Historia"-fueron bienvenidos por la intelligentsia de la época, Martín Villar no corre la misma suerte ante su profesor, el doctor Ventura Candamo de la Romaña y Sancho-Dávila, quien evalúa la monografía que le presenta el pupilo de manera ambivalente, pero siempre condenándolo por su "[m]anejo nada ortodoxo de las fuentes de la ciencia historiográfica". 393

Piura, junto a los monólogos delirantes, llenos de ruido y furia de Primorosa Villar, más la rescatada voz, por la memoria y la invención, de los fantasmales habitantes de Congará" (La violencia 138).

392 “"A "A finales del siglo XVII y al alborear el siglo XVIII llegaba a Piura don Faldrique, convertido ya en un servidor de los reyes de España, en calidad de corregidor [...] Y entre el aceptable número de sirvientes [...] venía un Benalcázar, Juan o Pedro, en calidad de caballerizo [...] aunque la descendencia apócrifa fraguara un aristócrata árbol genealógico que empezó con la fusión de los apellidos del quimérico Benalcázar con el de los León asentados desde más de cien años atrás en la región piurana y convertidos en clase propietaria de haciendas [...] No puedo, eso sí, ni afirmar ni desmentir la ascendencia hebrea del primer Benalcázar y de los León" [... Sin embargo,] [p]ronto el corregidor descubrió las habilidades fenicias, o si tú quieres, judías, del caballerizo Benalcázar. De modo que lo promovió a recaudador de impuestos y tributos" (La violencia 208-9).

393 "Trabajo meritorio, señor Martín Villar. Manejo nada ortodoxo de las fuentes de la ciencia historiográfica. Audacia y apresuramiento en los juicios. En historia, señor Villar, hay que saber controlar la sensualidad de la imaginación. Estilo churrigueresco. Conozco el noble y limpio linaje de la casa Ontaneda y Gándara y por eso me parece inaceptable la tesis central de la monografía. Epígrafe irrelevante. Confusión de espíritu e irreverencia frente a la tradición, fundamento de la patria. Estos defectos rebajan la indudable calidad del trabajo" (La violencia 146).

"También seré breve — prosiguió el doctor Candamo- en relación con los aspectos nada ortodoxos [...] de las fuentes historiográficas empleadas por usted con indudable audacia; en contra de ciertas corrientes que empiezan a manifestarse [en realidad, desde los tiempos del Inca Garcilaso], las fuentes orales no son relevantes para la ciencia histórica; si, desde luego, para la etnología que investiga a las agrupaciones humanas ágrafas. Pero aun si yo fuera partidario de las corrientes a las que acabo de aludir, no aceptaría la manera en que usted hace uso de los testimonios orales [...] [D]udo [...] que a Ella Dumbar [una prestigiosa historiadora a la que ha entrevistado Martín] le agrade que su valioso y a todas luces erudito testimonio ocupe la misma jerarquía, no solo de los fantasmales pobladores del fantasmal [...] pueblo de Congará, sino de los delirios de un demente, con las alucinaciones de un pobre de espíritu o con las confidencias de un bandolero (fusilado por sus múltiples crímenes, latrocinios y otras barbaries) [se refiere a Isidoro Villar], recogidas por el escritor Sansón Carrasco, típico escritor que encubre su mediocridad con la ferocidad del iconoclasta, espíritu extraviado por la prédica del mal entendida de don Manuel González 
En La violencia, el resentimiento es el sentimiento característico que todos los miembros de la familia Villar tienen hacia los dominadores de origen caucásico, porque, empleando las palabras afiladas de Valcárcel, ellos "[s]on los Hombres Blancos, los felones que mataron a sus reyes y a sus dioses. Los Hombres Blancos que violaron a las abuelas y a las madres, de cuyos vientres venerados salió el Engendro, el Mestizo, vasallo del Opresor y verdugo del Vencido" (Tempestad 90-91).

Hemos visto la crueldad de Francisco Miguel Villar para con Sacramento Chira y los coterráneos de ésta, así como la vesania de Cruz Villar Chira y Santos Villar Dioses: “Tu bisabuelo Cruz Villar [Chira], y todavía más su hijo Santos, heredaron esa sangre brutal y desalmada. Ahí tienes a tu abuelo viejo [Cruz] con el trapo rojo atado a la cabeza después de haber castigado a sus dos mujeres, a sus hijos y a los animales. Cuando se sentía más desdichado castraba a los animales" (333). Juan Carlos Galdo interpreta que el trapo rojo con el que Cruz Villar

se cubre la cabeza en momentos de ira es el emblema de este dolor sin sosiego posible — motivado por el mestizaje, la bastardía y el abandono del padre blanco — que bajo la máscara de la furia encubre el profundo duelo que lo embarga y que lo lleva a tiranizar a sus dos mujeres indígenas [...] y a su numerosa prole. Pero también, no hay que olvidarlo, en el primer mestizo de esta estirpe, entre los extremos de la crueldad y el desamparo, fermenta un temperamento orgulloso, rebelde, insuflado de una furia

Prada, anticlerical, antihispanista (me sigo refiriendo a Carrasco) y apologista de aquella aberración que él denomina, de manera infeliz, 'hibridismo racial'” (ibíd. 154-5). 
vindicativa que habrá de transmitir a sus herederos. ("Un conglomerado de voces" 42)

Fanon lo habría explicado así: "El hombre colonizado se libera en y por la violencia" (Los condenados de la tierra 77).

Sin duda, Martín Villar alberga mucho resentimiento y tiene una gran sed de justicia. En La violencia los Benalcázar eran los amos y señores de Congará, incluyendo las vidas y destinos de los habitantes del pueblo, en donde hasta la joven más bella jamás antes vista—Primorosa Villar—podía ser comprada y, peor aún, vendida. Pero, si bien los Benalcázar eran los amos de Congará, probablemente no eran los legítimos dueños de la tierra, puesto que, además de los despojos realizados a los indios durante la Conquista y la Colonia, en la etapa republicana "los blancos de toda esa inmensa región [...,] en la confusión de la guerra y la ocupación chilena habían usurpado, al amparo del poder vigente, las tierras comunales de la parte alta del valle de Piura" (346).

Cuando J.L. critica el cuento "Memorias del Cusco" escrito por Martín, el autor le comenta a su amigo lo siguiente acerca de Felipillo ${ }^{394}$ y lo que significa para éste la pérdida de la tierra:

[S]urgido de un caos infernal, ha nacido un nuevo hombre cuya sustancia es el odio absoluto [...] Un oscuro azar lo sustrajo del destino signado para los indios de abajo, los hatun runa: ya no vivirá con el temor de ser deportado en calidad de mitimae ${ }^{395}$ ni tendrá que cultivar las tierras del

\footnotetext{
${ }^{394}$ Felipillo es el indígena tallán que fungió de "lengua" al servicio de los conquistadores cuando capturaron a Atahualpa en 1532.

${ }^{395}$ Los mitimaes (desterrados) eran los súbditos del imperio inca obligados a mudarse de comunidad. Esta práctica tenía fines políticos. Había dos modalidades: o infiltrar al mitimae leal en un pueblo recién
} 
pequeño reyezuelo ni del gran déspota ni de ningún dios, ni se verá obligado a cargar las literas de los señores, ni será reducido a la condición de yana [yanacona], de perro sirviente, la última escala en la humillación de raza de los hombres de abajo. A cambio de ello [...] [h]a perdido la tierra y lo que, al principio, consideró una elevación de su destino, no ha sido otra cosa que una vertiginosa caída hacia la nada y el vacío. (Ibíd. 276-7)

Para Felipillo— que, en este caso, representa simbólicamente a todos los indígenas — su vida terrenal carece de sentido si no posee un pedazo de tierra. Y no obstante odiar a Atahualpa, reconoce que el Tahuantinsuyo, aunque sea una tiranía, le permite al hombre común mantener la propiedad de una parcela de terreno. Cuando Felipillo, según el cuento, traiciona a Atahualpa al traducir inapropiadamente el diálogo que tiene con el sacerdote dominico Vicente de Valverde - una malinterpretación maliciosa que al inca le cuesta la vida—, el "lengua" traidor-y ahora también nihilista—se convierte automáticamente en un descastado; en la percepción de Martín Villar, en "el primer indio desarraigado, forastero en su propia tierra, a la vez apóstata y apátrida y fundador de la gran soledad y rencor [énfasis mío] que grava la conciencia del hombre peruano" (27879). Al adoptar la fe católica, "si [Felipillo] ha abjurado de los dioses, no ha abjurado de la sangre de su nación, que siente fluir ardiente y agraviada y conminatoria” (277). ${ }^{396}$

conquistado para que lo supervisara y les hiciera cumplir la mita (trabajo forzado); o, por el contrario, trasladar a un mitimae potencialmente peligroso a un pueblo leal para mantenerlo vigilado y desalentar en él ideas de insurrección.

${ }^{396}$ El Inca Garcilaso no considera a Felipillo un traidor sino, sencillamente, un ignorante del idioma: "La torpeza de aquel intérprete, que fué así al pie de la letra, y no fué culpa suya sino ignorancia de todos; que aún en mis tiempos, con ser veintinueve años más adelante de los que vamos hablando, y con haber 
Martín Villar canaliza su inconformidad, rebeldía y resentimiento escribiendo la monografía Los Benalcázar León y Seminario-mediante la cual intenta descalificar el supuesto rancio abolengo de estirpe piurana-y, transgrediendo los planos narrativos, también escribiendo, supuestamente, la self-begetting novel titulada La violencia del tiempo, a la que los lectores de carne y hueso tenemos acceso. ${ }^{397}$

Llegado este punto, es dable concluir que el hecho de ser mestizo representa un estigma para Martín Villar (tanto como lo habría sido para el Inca Garcilaso). Sin embargo, la percepción de menoscabo que tiene Martín Villar y, probablemente, también el Inca Garcilaso acerca de su composición racial no podría ser extrapolada a los mestizos del Perú de hoy, en el que la población mestiza suma más del $40 \%$ del total de la población, sino es ya la mitad y, además, tiene agencia. El Perú es ahora mestizo, indígena, blanco, negro y asiático. En todo caso, la raza es solo uno de los principales

tratado los indios a los españoles, y estar más acostumbrados en la lengua castellana, tenían la misma torpeza y dificultad que Felipillo, que nunca hablaba con los españoles en lengua española sino en la suya" (Historia general del Perú I.XXIII.75).

La nota al pie $\mathrm{N}^{\circ} 13$ de la edición de Historia general del Perú que utilizo en el este trabajo aclara que "[n]o fue Felipe o Felipillo el intérprete que acompañó a Valverde durante el encuentro con el Inca en la plaza de Cajamarca, sino un muchacho tallán llamado Martinillo, tal como lo afirman testigos del suceso: los cronistas Pedro Pizarro y Miguel Estete" (74).

${ }^{397}$ El personaje de ficción Martín Villar emula al Inca Garcilaso al apropiarse del código del colonizador (en tiempos republicanos) y emplearlo para subvertir el discurso hegemónico avalado por la historiografía oficial.

Algo similar ocurre en el cuento “Alienación” (1958) de Julio Ramón Ribeyro, donde Roberto (Bob) López, el protagonista, logra dominar el inglés luego de ver innumerables películas en ese idioma con el único afán de aprenderlo, de memorizar palabras del diccionario y de completar un curso en el Instituto Peruano-Norteamericano con notas sobresalientes. Su compañero de aventuras (o de infortunios) José María Cabanillas, hijo de un sastre de Surquillo a quien conoce precisamente en ese centro de estudios, también llega a hablar bien la lengua inglesa.

Asimismo, en el cuento "Amor se escribe con G" de Rosa María Britton, María Caridad (Kary), la protagonista, también llega a adquirir un manejo aceptable del idioma inglés: "Durante toda la escuela secundaria me dediqué a estudiar inglés con ahínco. No me perdía película americana haciendo un esfuerzo por no leer los subtítulos en español y compraba revistas que leía párrafo a párrafo, diccionario en mano. Mis esfuerzos dieron fruto" (119). "Conseguí trabajo enseguida: Rubia, bien vestida, un inglés pasable [...]" (120). 
lazos que, generalmente, unen a las comunidades étnicas, y no es determinante en la construcción de la nacionalidad. ${ }^{398}$ Carlton J. H. Hayes aclara que, si bien la palabra nacionalidad "deriva del latín natio, que significa ascendencia racial común, [...] pocas o ninguna de las nacionalidades modernas pueden constituir una 'raza' distintiva" (2-3). ${ }^{399}$ En consecuencia, todas las razas serían mestizas, aunque en algunos casos esto no sea tan evidente como suele serlo, por ejemplo, el resultado de la mezcla de blanco con amerindio.

En el siguiente fragmento de la novela de Gutiérrez Correa, el bramido del padrillo castrado puede interpretarse, metafóricamente, como que los grandes y graves desequilibrios en la sociedad peruana — originados de la usurpación, de la injusticia y del atropello - se prolongan hasta nuestros días desde que el Perú se independizó de España: "El mozo [Santos Villar Dioses] ha logrado vencer al animal y el padre [Cruz Villar Chira] con el enorme cuchillo de matanza aplica el tajo de la humillación. Sigue el prolongado bramido [énfasis mío]" (321). El prolongado bramido sería, pues, el rencor,

\footnotetext{
${ }^{398}$ De acuerdo con Edward Shils y los "primordialistas" (término acuñado por Anthony D. Smith), los lazos que unen a las comunidades étnicas son: raza, idioma, religión, territorio y etnicidad.

En contraposición, Smith y quienes se adscriben a su llamado "etnosimbolismo histórico" identifican seis características que se hallan presentes en la mayoría de las comunidades étnicas: un nombre colectivo, un mito de origen común, una historia compartida, una cultura distintiva, la asociación con un territorio específico, y el sentido de solidaridad (Smith, The Ethnic Origins of Nations 22-31).

399 "Los franceses forman una nacionalidad resultante de tipos tan diversos como el mediterráneo, el nórdico y el alpino. Entre los alemanes podemos ver rubios de cráneo alargado y morenos de cabeza redonda. El italiano es una curiosa mezcla de etrusco, fenicio, celta primitivo, sarraceno, godo y escandinavo. En Estados Unidos, el negro no pertenece ya a ninguna nacionalidad africana, sino que, junto con hombres de piel blanca y roja, forma la nacionalidad norteamericana. Todas las nacionalidades de que yo tengo noticia son o han sido una mezcla biológica y racial" (Hayes 3).
} 
mejor dicho el resentimiento que abrigan las clases desfavorecidas desde hace casi cinco siglos. 400

En un artículo titulado "Perú: los nuevos dueños de la tierra" (2010), Iván Oré Chávez identifica a un puñado de personas - muchas de ellas socias del Club Nacional, fundado en 1855-como los "neo terratenientes" de la costa norte peruana. Aparentemente, Oré Chávez intenta demostrar que en el Perú la oligarquía, la plutocracia y los terratenientes conforman una misma clase social que detenta el poder económico. ${ }^{401}$ Aunque este triunvirato ya no tiene hoy la misma vigencia que ayer, de alguna manera su complicidad en el pasado en perjuicio de los intereses del subalterno explica la violenta reacción de Cruz Villar, que su bisnieto Martín vislumbra bajo los efectos del brebaje del cactus sagrado. Él lo ve "afilando el cuchillo de matanza y luego [oye] el rugido del gran padrillo, tu corazón, mi corazón heridos, pisoteados, flageladas nuestras carnes” (489). La ambigüedad del lenguaje obedece a su origen onírico. La castración del gran padrillo, un hecho irracional y contraproducente, tiene un valor simbólico en el conflicto familiar, debido a que sugiere una escatología dramática e irreversible en el relato etnográfico de los Villar.

Según se desprende de la novela, la "culpa" de Cruz Villar Chira y sus descendientes - salvo Martín, que tomó una decisión drástica-radicaría en haber continuado un linaje mestizo, condenado a ser víctima del racismo, que es uno de los principales aspectos del mecanismo empleado por la clase dominante para mantener el

\footnotetext{
${ }^{400}$ Me refiero al tipo de resentimiento que definen Jorge Basadre ("Ubicación sociológica" 103) y Gonzalo Portocarrero (Profetas 10), como ha sido explicado en otras partes de este trabajo.

${ }^{401}$ Cabe aclarar que no todos los socios del Club Nacional son gente adinerada, así esté considerado uno de los clubes más elegantes del mundo.
} 
statu quo: "[P]or mi culpa permanecerás siempre amarrado al vichayo y yo nunca terminaré de recorrer la calle de la infamia" (ibíd. 489). De acuerdo con la Teoría del conflicto, para que se configure una situación de violencia y de estratificación étnicas el poder hegemónico debe negarle o frenarle significativamente al subalterno el acceso a recursos escasos o limitados (en la Teoría de juegos, esto se conoce como juego de suma cero o conflicto puro) y debe desarrollar una ideología que legitime su conducta:

The stability of systems that rely primarily on coercion is always precarious. For government and other supportive institutions of the dominant group to establish and sustain a ruling system that is popularly supported over many generations requires that power be legitimized in less repressive and less direct ways. In protecting their privileges, dominant groups try to engender loyally and respect in subordinates, not fear (Jackman, 1994). People must come to see the inequalities in power and wealth as just and even socially bifacial. Only then do systems of social inequality attain stability. When this is accomplished, ruling groups need no longer resort to force as the principal means of assuring their power and privilege. Such long-range stability and legitimacy require the development of an effective ideology and its communication through socialization. (Marger 28).

Uno de los discursos preferidos del grupo hegemónico para legitimar y proteger sus privilegios es, precisamente, la supuesta inferioridad racial del subalterno. Sin embargo, en períodos de extrema inequidad socioeconómica, la ideología es cuestionada y, debido a la presión social, el sistema entra en crisis y se desarticula, desembocando 
inexorablemente en violencia: "Estamos en medio de una Guerra entre dos bandos: el Gobierno, que defiende el sistema, sus características y el statu-quo, y los guerrilleros de Sendero Luminoso, que insurgen contra todo ello, por considerarlo negativo, optando por un cambio total, es decir, estamos en una guerra eminentemente política" (Fernández Salvattteci 7).

Lamentablemente, hay momentos de la historia, como en el caso de la Guerra Interna, en que la violencia se torna más revanchista y vengativa que reivindicadora: "Estamos en una Guerra entre la ciudad y el campo, entre el indio y el 'blanco' [...], entre pobres y ricos, entre vivos y muertos que acusan" (ibíd. 7). Por lo mismo, alcanza niveles demenciales como, por ejemplo, el chamán o la voz del cactus sagrado le pregunta a Martín lo siguiente, haciéndolo reflexionar acerca de la diabólica fuerza motriz que impelió a los muchachos a masacrar a Inocencio en el bosque: “Sabes lo que es el frenesí? Una fuerza oscura, asesina que, quien más, quien menos, todos los humanos llevan refundida en la entraña" (314). El frenesí que se describe es el tipo de sentimiento que alimenta y lubrica la violencia cuando ésta se desborda desproporcionadamente. 


\section{DOS DÉCADAS DE VIOLENCIA Y TERROR}

Cuando el Estado desaparece, aparece la tribu

Manuel Azaña

La Guerra Interna abarcó una vasta parte del territorio nacional, ${ }^{402}$ ocasionó incalculables pérdidas materiales y, lo que es peor, dejó un saldo de alrededor de 69280 muertos ( $H W 433$, Conclusiones $\mathrm{N}^{\circ} 2$ y $\left.\mathrm{N}^{\circ} 3\right)$. Los "actores armados" fueron, por un lado, el Partido Comunista del Perú - Sendero Luminoso (PCP-SL) y el Movimiento Revolucionario Túpac Amaru (MRTA); y, por el otro, las fuerzas represivas del Estado. Pero fue la población civil indefensa y menos favorecida, especialmente campesina y quechuahablante, la que resultó más perjudicada. De acuerdo con el Informe Final de la Comisión de la Verdad y Reconciliación (CVR), "existió una notoria relación entre situación de pobreza y exclusión social, y probabilidad de ser víctima de la violencia" (HW 433, C. $\left.\mathrm{N}^{\circ} 4\right)$; “[d]e la totalidad de víctimas reportadas, el 79\% vivía en zonas rurales y el 56\% se ocupaba en actividades agropecuarias” (ibíd. 434, C. N5); y “el 75\% de las víctimas fatales [...] tenían el quechua u otras lenguas nativas como idioma materno" (ibíd. 434, C. N6).

Aunque la Guerra Interna no fue un conflicto étnico, la CVR "tiene fundamento para aseverar que estas dos décadas de destrucción y muerte no habrían sido posibles sin el profundo desprecio a la población más desposeída del país, evidenciado por miembros del Partido Comunista del Perú Sendero Luminoso (PCP-SL) y agentes del Estado por igual, ese desprecio que se encuentra entretejido en cada momento de la vida cotidiana de

${ }^{402}$ Con una superficie continental de $1285215 \mathrm{~km}^{2}$, el Perú ocupa el puesto $\mathrm{N}^{\circ} 20$ en extensión en el mundo. 
los peruanos" ( $H W$, Prefacio de Salomón Lerner Febres a la primera edición 10). Carlos Iván Degregori manifiesta que

no existe una sola línea en los documentos oficiales de Sendero Luminoso que hable sobre las diferencias étnicas, lingüísticas o culturales en general, que constituyen un problema y una posibilidad en nuestro país. Considero que esa ceguera ante la diversidad cultural fue una de las causas de la derrota de Sendero Luminoso, que terminó reprimiendo las costumbres "atrasadas" de los campesinos quechuas, aymaras o de los asháninkas y otros pueblos amazónicos a los que supuestamente quería representar. ("Perú: identidad" 213)

Para Guillermo Nugent "[f]ue una gran frustración antropológica [...] que Sendero Luminoso, en medio de una violencia sin límites, no planteara algún tipo de apelación racial durante su docenio sangriento (1980-1992)" (208).

Durante las dos décadas que duró este conflicto bélico, el terrorismo practicado por ambos bandos-los insurgentes y el Estado — en la sierra y en la selva, forzó a los habitantes a huir hacia la costa. ${ }^{403}$ Cualquiera de los agentes armados obligaba a los miembros de las comunidades indígenas a proporcionarles comida o alojamiento, y esa colaboración forzada podía significar ser condenado a muerte por el bando contrario $(H W$ 358). Un aspecto positivo de la diáspora de la población rural es que, desde 1940 en adelante, en apenas cuatro generaciones de aproximadamente veinte años cada una, los descendientes de los serranos afincados en la costa han cambiado la composición de la

${ }^{403}$ El territorio peruano está claramente demarcado por tres regiones naturales que corren longitudinalmente de norte a sur: la costa, la sierra y la selva. La costa abarca el $10.6 \%$, la sierra el $31.7 \%$, y la selva el $57.9 \%$ del área total. En la costa se hallan los centros urbanos más desarrollados. 
sociedad y, mediante un lento pero irreversible proceso de inclusión, están contribuyendo a reivindicar el papel protagónico del ancestro andino en el quehacer nacional. La importancia de este fenómeno migratorio es equiparable, quizás, a la de otros hitos históricos—como la Conquista y la Colonia — que, aunque fueron más dramáticos y violentos, igualmente replantearon las bases de la identidad nacional:

Quienquiera observe la evolución del Perú en los últimos 40 años reconocerá en la urbanización, la economía informal, la cultura chola y la organización popular cuatro de los más poderosos, profundos y complejos cambios de la fisonomía de nuestra sociedad. Estos cambios alteraron dramáticamente el modo de reproducción y de autogeneración de la sociedad peruana de forma de hacerla irreconocible para cualquier observador del Perú de los 50. Estos cuatro cambios son inexplicables sin la migración, lo que es otra manera de decir que sin esta el Perú actual no podría reconocer su rostro en el espejo de los 90. Por cierto, no estoy afirmando que la migración sea su única y exclusiva causa. Lo que digo es que sin ella, ni esos cambios ni ese rostro del Perú serían los que conocemos. (Franco, “Exploraciones en 'otra modernidad' 29)

Lamentablemente, en el Perú ha habido—y continúa habiendo — una extrema inequidad socioeconómica que, históricamente, ha corrido pareja con el color de la piel, y que, a pesar de que este vínculo negativo ya no es tan fuerte ni evidente como antes debido al intenso mestizaje, todavía continúa aumentando y profundizando las diferencias entre los peruanos. 


\section{Los insurgentes}

A finales de los años sesenta, Abimael Guzmán Reynoso-profesor de Filosofía de la Universidad Nacional de San Cristóbal de Huamanga (Ayacucho) — formó el Partido Comunista del Perú - Sendero Luminoso (PCP-SL), el cual "surgió del encuentro, que tuvo lugar en las décadas de 1960 y 1970 en Ayacucho, entre una élite intelectual provinciana mestiza y una juventud universitaria también provinciana, andina y mestiza" (Qué difícil 235). La génesis de esta agrupación política nos remite al Partido Comunista Peruano (PCP), fundado por JCM en $1928 .{ }^{404}$ En el ámbito internacional, en 1964, durante la Guerra Fría, el Partido Comunista Chino rompió con el Partido Comunista de la Unión Soviética (la llamada "ruptura sino-soviética"), debido a discrepancias ideológicas, especialmente porque Mao Zedong no compartía la política de "coexistencia pacífica" con Estados Unidos que había adoptado el gobierno de Nikita Kruschev. Emulando la postura china, ese mismo año el grupo peruano PCP-Bandera Roja (pro China) se separó del PCP, de ahí en adelante denominado PCP-Unidad (prosoviético). SL (promaoísta) es, a la vez, una facción que se escindió de PCP-Bandera Roja en 1970 (Portocarrero, Razones de sangre 48; Degregori, "La maduración de un cosmócrata", Qué difícil 251-2) y que la doctrina de esta organización es una heterodoxa amalgama de marxismo-maoísmo-leninismo-Pensamiento Gonzalo ( $H W$ 158-62).

Por otro lado, el Movimiento Revolucionario Túpac Amaru (MRTA) nació del APRA Rebelde (“Comité Aprista de Defensa de los Principios Doctrinarios y de la Democracia Interna", 1958), conformada por Luis Felipe de la Puente Uceda y un grupo

\footnotetext{
${ }^{404}$ El Partido Comunista Peruano (PCP) inicialmente se llamaba Partido Socialista del Perú. Cambió de nombre por exigencias de la III Internacional Comunista.
} 
de disidentes que fueron expulsados del Partido Aprista Peruano (PAP) por expresar su desacuerdo con la alianza pactada entre el PAP (de posición centroizquierdista) y el gobierno conservador y plutocrático de Manuel Prado y Ugarteche (1956-62). ${ }^{405}$ En 1962, el APRA Rebelde se convierte en el Movimiento de Izquierda Revolucionaria (MIR), de la Puente es entrenado en Cuba como guerrillero y, tras algunas incursiones armadas del movimiento, en 1964 de la Puente muere en un enfrentamiento con el ejército. En 1967, el MIR se divide en MIR El Militante (MIR-EM), MIR Voz Rebelde (MIR-VR) y MIR IV Etapa (MIR-IV). Los dos últimos grupos se unen a la Unidad Democrática Popular (UDP), una coalición de partidos de izquierda con la que participan en la asamblea constituyente de 1979. Posteriormente, la UDP se integra la Izquierda Unida (IU), legalmente reconocida y apta para realizar actividad política pública. Por el contrario, la facción MIR-EM se asocia con el Partido Socialista Revolucionario Marxista Leninista (PSR-ML) y, de manera conjunta, en 1982 fundan el Movimiento Revolucionario Túpac Amaru (MRTA).

El 17 de diciembre de 1996, 14 miembros del MRTA tomaron la residencia del señor Morihisa Aoki, embajador japonés en Lima, secuestrando a cerca de 800 personas - muchos de ellos diplomáticos, importantes oficiales del gobierno, militares de alto rango y empresarios—que habían sido invitados para celebrar el $63^{\circ}$ aniversario del nacimiento del emperador Akihito. Casi todos fueron liberados esa misma noche, pero mantuvieron a 71 rehenes durante 125 días, hasta que las Fuerzas Armadas lograron liberarlos mediante la llamada Operación Chavín de Huántar. La principal demanda de

\footnotetext{
${ }^{405}$ Con aspiraciones de aplicación continental, en 1924 Víctor Raúl Haya de la Torre fundó en México la Alianza Popular Revolucionaria Americana (APRA. El Partido Aprista Peruano (PAP) es la expresión contemporánea y peruana del APRA.
} 
los secuestradores era que pusieran en libertad a 465 emerretistas que se hallaban en prisión, incluyendo a la esposa de Cerpa Cartolini. ${ }^{406}$

\section{Inicio de la Guerra Interna}

A pesar de las condiciones favorables para el diálogo y la vía pacífica que existían en el Perú de los años 1980, un sector de la población consideró que la lucha armada era el único medio viable para remecer las bases de un sistema socioeconómico-político anquilosado e injusto, heredado de la época colonial. Es así que, cuando el general Francisco Morales Bermúdez convocó a elecciones tras doce años de gobierno militar (1968-1980), SL se abstuvo de participar en el proceso electoral del 18 de mayo de 1980 y, en la víspera de los comicios, incendió las cédulas y las ánforas en Chuschi, un pueblo de Ayacucho. Ese fue el primer acto terrorista realizado por SL (Barrow 1), a pesar de que la coyuntura histórica no les resultaba favorable para justificar la guerra que se habían propuesto desencadenar: "La reforma agraria emprendida por el gobierno militar (1968-1980) había terminado de borrar el escenario 'semifeudal' de señores terratenientes y campesinos siervos, indispensable para una revolución del tipo que Guzmán tenía en mente. Por otro lado, Mao Zedong acababa de fallecer en 1976" (Degregori, "La maduración de un cosmócrata", Qué difícil 254). Pero las cosas se le complicarían aún más a Guzmán con el advenimiento de "la perestroika y el derrumbe de los 'socialismos reales', la crisis de las ideologías pesadas y de los partidos doctrinarios” (ibíd. 254). Debido a la referida coyuntura histórica, el líder de SL tuvo que "pasar de la disquisición escolástica al discurso profético" (ibíd. 254).

\footnotetext{
${ }^{406}$ Se denomina “emerretistas" a los miembros del MRTA.
} 


\section{Fases de la Guerra Interna y captura de los líderes}

En 1984, al cuarto año de haberse iniciado la Guerra Interna, el gobierno le confía la lucha antisubversiva a las Fuerzas Armadas. En ese año, a la CVR le es reportado el mayor número de víctimas fatales y de "desaparecidos". Carlos Iván Degregori manifiesta que, entre 1983 y 1984, las Fuerzas Armadas "son ciegas o, mejor dicho, daltónicas. Donde ven piel oscura disparan sin discriminar” (“Jóvenes campesinos ante la violencia política”, Qué difícil 195). Hay un segundo pico en 1989. Los altos niveles de violencia se prolongan hasta 1992, cuando es capturado Abimael Guzmán ( $H W$ 24). Debido a que la cohesión interna de SL estaba centrada en gran medida en el culto a Guzmán (ibíd. 435, C. №17), el encarcelamiento del líder-sentenciado a cadena perpetua en el año 2006 - significó un duro y desestabilizador golpe para la organización subversiva. Óscar Ramírez Durand - Camarada Feliciano — se erige, entonces, en líder de la facción Proseguir del PCP-SL, pero es capturado en 1999. En 2012 también cae José Eleuterio Flores Hala_Camarada Artemio_-, otro de los sucesores de Guzmán. En 2013, el Grupo Especial de inteligencia Lobo embosca y mata a Alejandro Borda CasafrancaCamarada Alipio, el segundo al mando de SL-, así como al Camarada Alfonsopersona de confianza del anterior-, y a Marco Antonio Quispe Palomino-Camarada Gabriel—, el cuarto hombre en la jerarquía de la organización senderista. ${ }^{407}$ En cuanto al otro grupo insurgente, Víctor Polay Campos, el líder del MRTA, fue capturado en 1992 y

\footnotetext{
${ }^{407}$ Hienas alude a la captura de los líderes de SL con las siguientes palabras: "[D]e pronto, sucedió algo que ensombreció tu visión del futuro: la noticia de la muerte de todos los grandes líderes que habían dado inicio a la revolución en el Perú [...] El ejercito los cercó en unas montañas del sur del país y aplicando su política de tierra arrasada, no solo los ejecutó de uno en uno a todos los que encontró sino que masacró a las poblaciones del contorno mientras desataba una brutal represión contra las personas y las organizaciones de izquierda" (106-7). Más adelante: "La guerra ha terminado. Los altos dirigentes de la insurrección están presos o muertos, pero no cesa la persecución y la muerte" (239).
} 
se halla encarcelado desde entonces. Fue sucedido en el liderazgo de la organización por Néstor Cerpa Cartolini-Camarada Evaristo-, quien murió el 22 de abril de 1997 durante la Operación Chavín de Huántar.

\section{El "Pensamiento Gonzalo"}

Si el hombre está hecho de la madera de sus sueños, es indudable que nos encontramos frente al producto de una desmesurada pesadilla Carlos Iván Degregori (Qué difícil es ser Dios 266)

Carlos Iván Degregori identifica cuatro discursos de Abimael Guzmán, pronunciados entre 1979 y 1980 ante sus seguidores, todos anteriores al inicio de la guerra, que el crítico considera como los cruciales del líder de SL. El primero se titula "Por la nueva bandera" (junio de 1979), el segundo es "Sobre tres capítulos de nuestra historia" (3 de diciembre de 1979), el tercero se llama "A derrumbar los muros" (marzo de 1980), y el último es "Somos los iniciadores" (19 de abril de 1980). Degregori percibe un significativo cambio de tono entre otros textos previos producidos por Guzmán y los cuatro referidos: "Hasta entonces sus escritos, plagados de citas del panteón marxista, era áridos y obtusos. Pero súbitamente, su discurso se transforma", pues los recientes “carecen de una estructura 'racional', están llenos de viñetas, metáforas, llamamientos reiterativos apasionados" ("La maduración de un cosmócrata", Qué difícil 255). Entre otras cosas, en el primer discurso Guzmán dice: "[U]no no vale nada, la masa es todo. Si algo hemos de ser, ser como parte de la masa" (ibíd. 257). En el segundo discurso, Guzmán funge como una especie de médium o ventrílocuo: "Hay momentos en que los hombres recurrimos a hablar en símbolos, metáforas, en formas no tan directamente 
intelectuales, sino que preferimos que nuestro conjunto de seres comunistas hablen por nosotros directa y ampliamente" (Guerra popular 145). Al respecto, Degregori comenta que Guzmán, “[c]omo si fuera un oráculo, el conjunto de comunistas van a hablar por su boca, pero curiosamente, no se expresan en lenguaje científico sino simbólico" (Qué difícil 258). En el tercer discurso, aludiendo a la necesidad de sacrificar la vida por la causa revolucionaria y a la garantía de un destino glorioso en la muerte, Guzmán arenga: "Mañana la materia nos recogerá en su bélica paz, allí es donde podremos descansar definitivamente" (ibíd. 263). Por último, en el cuarto discurso, que Degregori cataloga como el más importante, de espaldas a la realidad Guzmán anuncia que la hora de la lucha armada ha llegado:

El pueblo se encabrita, se arma y alzándose en rebelión pone dogales al cuello del imperialismo y los reaccionarios, los coge de la garganta, los atenaza; y, necesariamente, los estrangula [...] Las carnes reaccionarias las desflecará, las convertirá en hilachas y esas negras piltrafas las hundirá en el fango, lo que queda lo incendiará... y sus cenizas las esparcirá a los vientos de la tierra para que no quede el siniestro recuerdo de lo que nunca ha de volver porque no puede ni debe volver [...] Ellos en su vieja y sangrienta violencia, en su paz de bayonetas, en su guerra maldita que liquida en las cárceles [...] Esa siniestra violencia encuentra hoy la horma de su zapato. (Guerra popular 165)

Lo cierto es que SL había llegado tarde a la Historia. Como recuenta Degregori, la Gran Revolución Cultural Proletaria de Mao Zedong había llegado a su fin, en el Perú ya se había llevado a cabo la Reforma Agraria, se había retornado al camino democrático y, 
además, "[e]ran los años de mayor auge de movilizaciones sociales del presente siglo: movimientos sindicales, de campesinos, barriales, magisteriales, regionales" y la izquierda marxista había obtenido el 28\% de los votos en la Asamblea Constituyente de 1978 (Qué difícil 264-5).

Hasta antes de mayo de 1988, los senderistas no hablaban de Pensamiento Gonzalo, sino de Puka Inti; Sol Rojo, en quechua (Granados, "El PCP Sendero Luminoso" 73). Y ¿qué significa? El contenido del Pensamiento Gonzalo es un enigma para los no iniciados. "Al parecer, los lineamientos básicos del PG solamente son enseñados a los militantes y cuadros del PC-SL, casi siempre en forma oral. Nada tiene que decir el PG a los extraños. Es una manera de hacer sentir el desprecio a los enemigos" (ibíd. 75). Pero incluso a la mayoría de adeptos a SL les resulta difícil definir qué es Pensamiento Gonzalo; ellos sencillamente "reafirman su lealtad al PG, pregonando que están luchando por él y que morirán por su revolución. No hablan de un triunfo en vida, sino de la muerte necesaria para que viva y triunfe el PG" (ibíd. 75). El pensamiento Gonzalo puede ser interpretado como el culto a la personalidad de Abimael Guzmán y el sometimiento incondicional por parte de sus seguidores, quienes lo consideraban 'la encarnación del pensamiento más elevado en la historia de la humanidad"” (HW 435, C. N¹7).

En líneas generales, “[E]1 PCP-SL sustentó su proyecto en una ideología de carácter fundamentalista, centrada en una rígida preconcepción del devenir histórico, encerrada en una visión únicamente estratégica de la acción política y, por tanto, reñida con todo valor humanitario. El PCP-SL desdeñaba el valor de la vida y negaba los derechos humanos" ( $H W 435$, C. № $\left.^{\circ} 6\right)$. Gonzalo Portocarrero sostiene que, sin Guzmán 
no habría habido Sendero Luminoso" (Oído en el silencio 371). Manuel Jesús Granados sostiene lo mismo acerca del culto a Guzmán: "[L]a revolución del PCP-SL es un hombre. La cabeza es el Pensamiento Gonzalo, el cuerpo es el Partido Comunista, y los brazos y piernas son el Ejército Guerrillero Popular. Pero el PCP y el EGP nada son sin el PG” (73).

En la retórica de SL_el Pensamiento Gonzalo_-, el propio Guzmán se erige en la "cuarta espada"; es decir, capaz de interpretar el marxismo-leninismo tan bien como Marx, Lenin y Mao (Granados 74; Hidalgo Morey 108). "La carta de sujeción al líder, que firmaba cada miembro que se incorporaba a Sendero era, simplemente, un detalle más de ese culto. Y es en nombre de ese mesianismo de Abimael que la idea de la 'cuota' (de sangre, de sacrificio) que se exigía a cada militante de Sendero, fuera un compromiso muy serio, con calidad de religioso, para muchos de los que morían dando vivas a su líder y a la lucha armada" (Hidalgo Morey 108). En síntesis, "el lazo exegético que cohesionaba la comunidad-de-discurso se desarrolló a lo largo de tres líneas entrelazadas: culto a la muerte, abolición del ego y exaltación del líder" (Degregori, "Maduración de un cosmócrata", Qué difícil 267). Un mesianismo demencial y macabro había sucedido al caudillismo militar del siglo XIX y al militarismo institucional de los primeros 4/5 del siglo $\mathrm{XX}$.

\section{Mito del Inkarri}

JCM sostiene que "[1]a religión del quechua era un código moral antes que una concepción metafísica [...] El Estado y la Iglesia se identificaban absolutamente; la religión y la política reconocían los mismos principios y la misma autoridad. Lo religioso 
se resolvía en lo social” (7 ensayos 120). En ese sentido, "[1]a iglesia tenía el carácter de una institución social y política. La iglesia era el Estado mismo" (ibíd. 121). Por lo tanto, "[1]as tribus del Imperio más que en la divinidad de una religión o un dogma, creían simplemente en la divinidad de los Inkas" (ibíd. 122). Este hecho sugiere que la evolución histórica de la cultura inca se habría hallado a medio camino entre la "edad divina" y la "edad heroica", de acuerdo con la clasificación de Giambattista Vico en Principios de ciencia nueva (1744).

Debido a la invasión española, en el mundo del amerindio había ocurrido un "cataclismo cósmico" (Ossio, Ideología mesiánica 157). Es necesario resaltar que, en la cosmovisión andina, el tiempo es cíclico. En la cosmovisión andina, se pasa de un estado de orden a otro de caos de manera recurrente, cada vez que se agota el mundo (la Pacha), vale decir la humanidad (de la Torre 40,47-8), y los dioses ya no escuchan las plegarias (mañay). ${ }^{408}$ Esto es similar a la cosmogonía y renovación circular-salvo que, con destrucción previa - que los antiguos egipcios y griegos representaban mediante la imagen del uróboro, o reptil mítico que se muerde la cola. Se trata del eterno retorno del que hablaban los estoicos y, en el caso del Tahuantinsuyo, el fuego de los arcabuces de los invasores y las muertes que ocasionaron equivale a la conflagración universal—el Pachacuti - que ocurría al final de cada aión, o año cósmico. En consecuencia, "[1]a única interpretación válida de lo que estaba sucediendo era la ruptura del mañay [del pacto con los dioses] y el consiguiente fin del tiempo. La Pacha [el mundo] había muerto y el Universo quedaba sumergido en un nuevo Pachacutec" (ibíd. 67).

\footnotetext{
${ }^{408}$ Otra acepción de la palabra mañay es "pacto con los dioses".
} 
El Pachacutec es, pues, la renovación del cielo (de la Torre 52-3) mediante una especie de hecatombe cósmica (ibíd. 214) ${ }^{409}$. Por eso, aunque el inca no era amado por todos, ante el despojo y los terribles abusos perpetrados por los invasores en contra de los indígenas, "hubo de ser el salvador mesiánico que no podía morir (Arguedas, Roel). De nada vale que los españoles corten y escondan su cabeza. Poco a poco, dormido bajo la tierra, le irá creciendo mágicamente su cuerpo. Cuando esté completo, resucitará triunfante y los indios volverán a ser felices" (Macera 111). Ésta es la versión más generalizada y popular del mito del Inkarri, que ha sido plasmada en una leyenda, según la cual, la cabeza de un inca que ha sido decapitado y que sigue con vida se recompondrá con su respectivo cuerpo y, cuando el milagro suceda, regresará para vengar las atrocidades cometidas por los conquistadores españoles y, de esa manera, restituirá el orden (Fox-Lockert). ${ }^{410}$

Un hecho histórico que guarda cierta relación con el mito del Inkarri es el siguiente: hacia 1655 apareció un grupo de hombres y mujeres liderados por Juan Chocne—los taquiongos —en el Corregimiento de Parinacochas (Ayacucho) anunciando que las huacas (divinidades) destruidas por los conquistadores habían resucitado y que se aprestaban a eliminar al Dios cristiano, a los españoles y a los indígenas infieles mediante el contagio de enfermedades (de la Torre 84-5). Así surgió el movimiento anticristiano denominado el Taki Onqoy (locura bailada), que se expresaba mediante danzas extáticas

${ }^{409}$ Pacha $=$ Tierra, mundo; $k u t i=$ al revés, vuelco, turno.

${ }^{410}$ Probablemente, se refiere a Túpac Amaru I, el cuarto y último inca rebelde de Vilcabamba, que fue decapitado en 1572. Una leyenda popular cuenta que la cabeza de este inca fue ensartada en una picota para disuadir a otros de rebelarse, pero en lugar de pudrirse con el paso de tiempo, ésta se embellecía (Ossio, Ideología mesiánica 228). No se trataría, pues, del inca Atahualpa, porque él recibió la pena del garrote vil y, por consiguiente, murió estrangulado, no decapitado. 
(ibíd. 92-3). Este movimiento fue rápidamente reprimido. Juan Chocne no reúne las características propias de un líder mesiánico; sin embargo, ha dejado huellas psicológicas y sociológicas hasta la actualidad, por ejemplo, a través del mito del pishtaco, vinculado al del Taky Onqoy. ${ }^{411}$ Dado que las culturas revisan sus mitos constantemente (Sproul, Primal Myths 3), la idea del retorno del inca ha sustentado "rebeliones como las que tuvieron lugar en la sierra de Lima hacia 1666, en la selva central hacia 1742 con Juan Santos Atahualpa en el sur andino con la 'gran rebelión' de Túpac Amaru. Es evidente la permanencia de la utopía andina para comprender los movimientos sociales" (Flores Galindo, "Sueños y pesadillas", Obras completas 369).

A diferencia de Chocne, Ezequiel Ataucusi-fundador de la Asociación de la Misión Israelita del Nuevo Pacto Universal (AEMINPU) y máximo dirigente desde 1968 hasta que falleció en el año 2000—, sí fue un líder mesiánico (de la Torre 261-87) que se autoproclamó como un avatar del Espíritu Santo. El correlato político de esta organización religiosa es el Frente Popular Agrícola del Perú (FREPAP). Mientras que este partido político obtuvo menos del $2 \%$ del voto popular en los comicios legislativos de 2001 y 2006, la AEMINPU se ha difundido en varios países del continente americano. 412 "El líder del FREPAP fue acusado de asesinato, de violar a adolescentes de su misión,

\footnotetext{
411 "El pishtaco, ser sobrenatural semejante al vampiro occidental, extraía de sus víctimas el sebo-fuerza vital en la Sierra. El monstruo, asociado al hombre blanco, aprovechaba los parajes solitarios para asesinar a los campesinos que hubiesen confiado en los españoles" (de la Torre 89). Estos mismos pishtacos de mediados del siglo XVII, "usarían la grasa, durante el s. XIX, para hacer funcionar las maquinarias de la Revolución Industrial europea. Actualmente, en las últimas versiones recogidas, los pishtacos se han convertido en médicos gringos sacaojos que, en la Lima metropolitana, se cobran la deuda externa, robando los órganos para trasplantes" (ibíd. 89-90). La canción "Qué lindos sus ojitos" (Porotazos super bailables, 1993) del grupo peruano de rock Nosequien y Los Nosecuantos sugiere que ocurre lo último, aunque en este caso el infanticida sería un holandés.

${ }^{412}$ Arturo E. de la Torre informa que el FREPAP obtuvo 62995 votos (1\%) en las elecciones generales 1990, 46102 (1\%) votos en las de 1995, y 216953 votos (2.18\%) en las de 2000 (198).
} 
incluso de tener como esclavos a los israelitas que vivían en la selva. Incluso, su sucesor Ezequiel Jonás, el último de sus nueve hijos, fue baleado por desconocidos en 1995" (Loli, “Ezequiel Ataucusi”).

El antropólogo Juan Ossio compara las figuras mesiánicas de Abimael Guzmán y Ezequiel Ataucusi, y halla las siguientes semejanzas y diferencias:

[L]los israelitas forman parte de un estrato social muy semejante al de la gente que se adhería a Sendero Luminoso. Era gente que buscaba adherirse a verdades que le permitieran superar su sentimiento de crisis. Cuando se vive una crisis lo que la gente busca es esperanza. Y la alternativa estaba entre un movimiento que les ofrecía la posibilidad de ser ellos los dueños de la riqueza quitándosela a los propietarios, a los ricos, criticando al Estado burgués al que responsabilizaba del estado de pobreza y frustración en que se encontraban; o encontrar el orden a través de un profeta que les ofrecía llegar a la Tierra Prometida siempre y cuando aceptaran las reglas de su religión. Si no hubiese existido esta vertiente pacífica, digamos que los senderistas hubiesen campeonado. Sendero tenía esta cosa metafísica de un líder que se había convertido en el verdadero intérprete del socialismo. En el otro caso, Ezequiel Ataucusi era el intérprete de la Biblia, el que les podía dar las luces necesarias para comprender el Antiguo y el Nuevo Testamento. Entre una y otra, muchos prefirieron la ruta pacífica. (Entrevista con David Hidalgo, "Ezequiel Ataucusi: el profeta que contuvo a Sendero Luminoso") 
Esta larga cita se justifica porque Ossio, además de contrastar a estos dos personajes históricos, plantea que la influencia de un líder mesiánico puede ser positiva, como en su opinión lo habría sido Ataucusi por el mero hecho de haberle ganado adeptos a SL. Si bien la posición del referido antropólogo me hace pensar en Jesucristo, el Mesías, cuya huella en la humanidad ha sido, sin duda, benéfica, pienso que esta figura vinculada a la acción política, como en el caso de Abimael Guzmán-y el propio Ataucusi-es muy peligrosa porque se centra en el culto a la personalidad de sus líderes, a quienes, usualmente, el poder los trastorna.

Simone Accorsi advierte que, si para los primeros cristianos el mesianismo o milenarismo era el período de mil años tras el cual Cristo reencarnaría y volvería para reinar en este mundo, hoy en día esa creencia ha dado pie a la manifestación de fenómenos sociales que rebasan los límites de la tradición judeocristiana. Accorsi reporta que, en un congreso celebrado en la Universidad de Chicago en 1960, se barajaron varias explicaciones acerca de la vigencia del fenómeno del milenarismo en la actualidad. Una de ellas es que "surge como un síntoma de la opresión socioeconómica y de la desarticulación sociocultural" (12). Otra "lo plantea como una expresión de las tendencias al enfrentamiento que existe entre los que ocupan puestos de liderazgo religioso e intelectual y sus supuestos rivales" (12). Considero que, por lo menos en el caso del mito del Inkarri, existe un motivo mucho más básico y profundo que explica su vigencia: "El mito adquiere su plena verificación y su máxima actualidad, cuando se lo reconstituye en una alegoría de la historia" (Camayd-Freixas, Realismo mágico 151).

Sin embargo, cuando leemos los mitos como alegorías; es decir, cuando buscamos “entenderlos mediante paralelos con ciertos ejemplos históricos, a veces muy recientes 
[....,] [p]erdido el contexto sagrado y reverencial que inspiraba una recepción más directa y visceral", solemos "conformamos reemplazando el original con una interpretación domesticada" (ibíd. 232). Esto representa un gran peligro cuando hábiles manipuladores, como Abimael Guzmán, no sólo se confirman, sino que se apropian del mito y lo distorsionan, transformándolo en un discurso de cruzada. "Según [David] Apter, el discurso necesario para la violencia política comienza con acontecimientos que sirven de materia prima a partir de la cual se elabora una interpretación razonada. Tal interpretación es un proceso, emplea ciertos ingredientes, paradigmas o ejemplos: doctrinas, mitos [énfasis mío] y teorías; magia o fantasía [énfasis mío] y lógica; metáfora y metonimia; narrativa y texto" (Degregori, Qué difícil 250). Todos estos elementos estaban presentes en el discurso de SL. Prosigue Degregori: "Es a través de esta alquimia lingüística que, por ejemplo, manifestaciones espontáneas, motines o demostraciones, se vuelven movimientos autosostenidos. Sin discurso dichos eventos, no importa cuán profunda y antigua sea la rabia de alguna gente o cuán graves sus reclamos, pueden explosionar como fuegos artificiales, brillar por un momento y luego apagarse" (Ibíd. 250). La Historia está plagada de ejemplos de insurrecciones fugaces y fallidas. "Es cuando los acontecimientos son incorporados en discursos interpretativos y se encarnan en lo que Apter llama 'comunidades discursivas'-puntualiza Degregori-, que la violencia política puede no sólo retroalimentarse, sino volverse autovalidante y autosostenible" (ibíd. 250). ${ }^{413}$ Esto explica que la Guerra Interna se mantuviera durante

\footnotetext{
413 "Las características que [John Malcolm] Swales propone como requisito para que una comunidad discursiva pueda considerarse tal, son las seis siguientes: 1) Una comunidad discursiva está orientada al logro de unos objetivos públicos ampliamente consensuados. 2) Tiene determinados mecanismos de comunicación entre sus miembros. 3) Utiliza esos mecanismos de participación prioritariamente para proporcionar información y retroalimentación. 4) Utiliza, de hecho es poseedora de uno o más géneros
} 
dos largas y sangrientas décadas, incluso el hecho de que "en los últimos años del gobierno de Fujimori el conflicto armado interno fue[ra] manipulado con la finalidad de hacer que el régimen permaneciera en el poder" (CVR 452, C. 104).

\section{Juan Morillo Ganoza}

Juan Morillo Ganoza es un escritor, profesor y periodista peruano. Nació en Taurija, provincia de Pataz, departamento de La Libertad, en el año 1939. En su juventud formó parte del Grupo Trilce (llamado así en honor al poemario vanguardista de César Vallejo), integrado por Eduardo González Viaña, Jorge Díaz Herrera y Santiago Aguilar, entre otros (Reyes Tarazona 9-10). El Grupo Trilce fue la continuación de la Bohemia de Trujillo y del subsiguiente Grupo Norte (1915-1930), en el que militaron el propio Vallejo y Ciro Alegría, entre otros intelectuales y artistas. Como ya lo he mencionado, Morillo Ganoza también formó parte del Grupo Narración, liderado por Miguel Gutiérrez Correa.

Morillo Ganoza cursó estudios superiores en la Universidad de Trujillo. Ejerció la docencia en varias universidades peruanas y fue jefe de edición del Diario La Crónica, en Lima. Desde 1978 reside en la República Popular China. En el contexto de la conmemoración del $50^{\circ}$ aniversario de su fundación, le fue otorgado el Premio de la Amistad. En ese país, Morillo Ganoza trabajó como profesor de lengua española y literatura hispanoamericana en el Instituto de Lenguas Extranjeras de Pekín (actual

para el logro comunicativo de sus fines. 5) Junto a los géneros que le son propios, dispone de una terminología específica. 6) Está compuesta por un determinado número de miembros que poseen los conocimientos relevantes y la experiencia discursiva necesaria" (Gil Martínez). La referencia bibliográfica que Gil Martínez proporciona sobre John Malcolm Swales es: Genre Analysis. English in academic and research settings. Cambridge: Cambridge University Press, 1990. 
Universidad de Estudios Extranjeros), así como corrector de estilo y editor de la programación en español de Radio Internacional de China. Además de Hienas en la niebla (Lima: Universidad Ricardo Palma, 2010) —la novela que analizo-, Morillo Ganoza ha publicado las siguientes obras: el libro de cuentos Arrieros (1964), el cuento "Pedro y Pilanco", incluido en Visión del Perú (1970) y en la antología Narrativa peruana 1950-1970 (Madrid: Alianza Editorial, 1973) de Abelardo Oquendo. Bajo el sello de la Editorial San Marcos, publicó las novelas: Las trampas del diablo (1999), El río que te ha de llevar (2000), Matar el venado (2002), Fábula del animal que no tiene paradero (2003), Aroma de gloria (2005) y Memoria de un Naufragio (2009). Su obra más reciente es La casa vieja (Lima: Editorial Summa, 2014). César Ángeles L. señala que "uno de los grandes temas de la cantera generacional de la que proviene Morillo [es] el compromiso del escritor, al abrigo de las tesis y la praxis de Jean Paul Sartre" ("Dos novelas sobre la guerra"). 


\title{
VIII.1 HIENAS EN LA NIEBLA (2010) DE JUAN MORILLO GANOZA: UNA REPRESENTACIÓN DE LA GUERRA INTERNA
}

\author{
No hay violencia política sin discurso. La gente necesita convencerse o ser convencida \\ para ejercerla \\ Carlos Iván Degregori (Qué difícil es ser Dios 249)
}

Hay que tener cuidado al elegir a los enemigos porque uno termina pareciéndose a ellos

Jorge Luis Borges

El reconocido crítico literario Ricardo González Vigil considera que Hienas en la niebla de Juan Morillo Ganoza es la mejor novela publicada en el Perú en el año 2010. ${ }^{414}$ Trata sobre la guerra interna que se libró en el Perú entre los años 1980 y 2000, aproximadamente; la más grave de todas las guerras en la historia republicana debido a su intensidad, extensión y duración $\left(H W 433, \mathrm{C} . \mathrm{N}^{\circ} 1\right) \cdot{ }^{415}$ Este conflicto bélico involucró directa o indirectamente a todos los peruanos, abarcó una vasta parte del territorio nacional, ocasionó incalculables pérdidas materiales (ibíd., C. $\left.\mathrm{N}^{\circ} 3\right)^{416}$ y, lo que es peor, dejó un saldo de alrededor de 69280 muertos (ibíd., C. N²) ${ }^{417}$. Los "actores armados" eran el Partido Comunista del Perú - Sendero Luminoso (PCP-SL) y el Movimiento Revolucionario Túpac Amaru (MRTA), por un lado; y, por el otro, las fuerzas represivas

\footnotetext{
${ }^{414}$ Diario El Comercio (Lima) del 1 de enero de 2011.

415 “[El conflicto armado interno que vivió el Perú entre 1980 y 2000 constituyó el episodio de violencia más intenso, más extenso y más prolongado de toda la historia de la República” ( $H W 433, \mathrm{C}$. № 1 ).

416 "El conflicto abarcó una proporción mayor del territorio nacional que cualquier otro conflicto, provocó enormes pérdidas económicas expresadas en destrucción de infraestructura y deterioro de la capacidad productiva de la población y llegó a involucrar al conjunto de la sociedad" (HW Hatun 433, C. ํ3).

417 “[L]a cifra más probable de víctimas fatales de la violencia es de 69,280 personas. Estas cifras superan el número de pérdidas humanas sufridas por el Perú en todas las guerras externas y guerras civiles ocurridas en sus 182 años de vida independiente" ( $H W 433$, C. №2).
} 
del Estado. Sin embargo, fue la población civil indefensa y menos favorecida, especialmente rural y quechuahablante, la que resultó más perjudicada (ibíd. 434):

De cada cuatro víctimas, tres fueron campesinos o campesinas cuya lengua materna era el quechua. Se trata [...] de un sector de la población históricamente ignorado por el Estado y por la sociedad urbana [...] La CVR no ha encontrado bases para afirmar [...] que éste fue un conflicto étnico. Pero sí tiene fundamento para aseverar que estas dos décadas de destrucción y muerte no habrían sido posibles sin el profundo desprecio a la población más desposeída del país, evidenciado por miembros del Partido Comunista del Perú Sendero Luminoso (PCP-SL) y agentes del Estado por igual, ese desprecio que se encuentra entretejido en cada momento de la vida cotidiana de los peruanos. (Ibíd., Prefacio de Salomón Lerner Febres a la primera edición 10).

En las comunidades indígenas "[1]a circunstancia de encontrarse "entre dos fuegos", sin posibilidad de acogerse a la protección de algunos de los actores armados en particular [ni a las fuerzas de seguridad del Estado ni a las organizaciones subversivas], agravó la zozobra de la vida cotidiana [...] Para salvar la propia vida, los pobladores se veían obligados a colaborar, habitualmente con comida o con alojamiento, con el PCP-SL y con las fuerzas de orden. En muchos casos, estas colaboraciones forzadas fueron castigadas con la muerte por la otra parte” (ibíd. 358). Manuel Jesús Granados explica que, además de ser los campesinos víctimas por el hecho de hallarse constantemente en una posición conflictiva, algunos de ellos eran asesinados por SL debido a que "los conceptos de poder y riqueza son mínimos en las zonas rurales, pero existen. Un campesino poseedor de 
cinco carneros, terrenos y una pequeña tienda ya es visto como rico y ocupa muchas veces cargos gubernamentales o comunales. Es recreada, a niveles mínimos, la gran ilusión de la "decencia", sinónimo de riqueza y blanqueamiento" (51). Un poco más adelante añade: “[E]l campesino poseedor de bienes materiales empieza a adoptar las poses características de la gente decente: niveles de prepotencia, ostentación de su magra riqueza y trato despectivo a los comuneros más pobres” (51-2). Bajo un esquema de lucha de clases, ése era el razonamiento. Adicionalmente, aniquilando a las autoridades locales, SL aprovechaba el vacío de liderazgo que dejaban para ocupar sus respectivos lugares.

El Informe Final de la CVR confirma la densa atmósfera que se respiraba en el Perú durante la época de la Guerra Interna: "Cualquiera podía ser víctima en las zonas afectadas por la violencia, o eso era, al menos, lo que hacía creer la conducta de los actores armados. Ese temor, prolongado en el tiempo, se transformó en angustia, esto es, en la percepción de un riesgo impreciso, pero siempre inminente, que perturbaba la vida cotidiana" ( $H W$ 355). Las secuelas psicosociales del temor y la angustia han devenido en la hiperbólica desconfianza que los peruanos sienten actualmente hacia sus connacionales. Sin duda, la Guerra Interna es un hecho histórico que ha repercutido para siempre en la vida social, cultural, política y económica de todos los peruanos, replanteando las bases de la identidad nacional. "No somos los mismos" han declarado algunas de las víctimas a la CVR (ibíd. 354). 


\section{Temas}

Diego de la Cruz, el protagonista de la novela, se debate entre consagrarse a la causa revolucionaria y cumplir con las responsabilidades que tiene frente a su familia. Éste es el eje en torno al cual se vertebran otros temas que atañen al ámbito individual del personaje, tales como la frustración que le produce haberse involucrado sólo parcialmente con la revolución, claudicando de alguna manera a sus ideales, y el hecho de sentirse por momentos un traidor debido a ello. Otros temas que aborda la novela son la decepción que siente Diego porque algunos aspectos de la revolución han devenido en terrorismo; la aversión que le producen los métodos violentos de los revolucionarios (aunque piensa que no hay otro camino); su avidez por la lectura de libros iluminadores (muchos de ellos de pensamiento marxista); y el hábito de registrar por escrito los principales acontecimientos de su vida, simbolizando con ello la imperiosa necesidad de preservar la memoria.

En Hienas en la niebla (2010), la opción por la lucha armada es planteada de la siguiente manera:

Con todos sus ideales y con toda su nobleza, a la revolución le era ineludible moverse en estos terrenos [de violencia] y a eso había que atenerse si a uno le picaba el gusanillo de cambiar, con la lucha armada, la patética situación del país. Y, al parecer, no había otro camino porque, según las lecciones de nuestra historia, ningún gobierno, ni militar ni civil, ni dictatorial ni democrático, tenía las agallas suficientes como para enfrentarse al poder económico y obligarlo, a fuerza de leyes, a una distribución racional de la riqueza producida por la fuerza del trabajo. La 
tendencia es, más bien, a proteger con la fuerza y con las leyes, los intereses del verdadero poder, el económico. (43)

Según Roberto Reyes Tarazona, quien presenta la obra," [1]a novela de Morillo es [...] un intento de establecer los lazos históricos y las contradicciones con quienes aspiraron en las décadas anteriores a considerar la necesidad de un cambio radical de la sociedad mediante la lucha armada" (13).

En la novela se distinguen claramente tres líneas narrativas: la biografía de Diego durante su adolescencia; su vida familiar de adulto, tratada como un aspecto biográfico aparte; y su actividad conspiradora enmarcada en un contexto histórico. Con esta estructura, "Morillo logra hacer converger de manera solvente los dos principales niveles ambicionados por los escritores que intentan abarcar la existencia humana en su forma más amplia: la historia social y las historias individuales” (Reyes Tarazona 15).

\section{Argumento}

Aunque "la memoria de Diego transcurre por diversas épocas y espacios [...] de la historia peruana, e hilvana su recuerdo con otros personajes que cubren un amplio espectro: desde los años 40-50" (Ángeles, “Dos novelas sobre la guerra”), el tiempo narrativo de la mayor parte de la trama corresponde a principios de los años noventa. En ese momento, Diego tiene unos cuarenta años de edad, está casado con Lucila y es padre de cuatro hijos: el mayor y el menor, varones; y dos niñas intermedias. El protagonista se ha convertido también en un exitoso empresario, pero su aburguesamiento no le impide colaborar ocasionalmente con los insurrectos: "De cuando en cuando, entregabas recados 
a desconocidos que te esperaban en la carretera o en alguna calle de la ciudad [...] Lo negabas, pero, en [el] fondo, ellos te servían para lavarte la conciencia" (109).

Con sueños de convertirse en un revolucionario, a los dieciocho años de edad Diego emigra a Lima desde su pueblo - ubicado en la costa norte del Perú (no se menciona el nombre)—en la tolva de un camión. "Allí [en la capital] podías unirte a las brigadas clandestinas de propaganda de la revolución. ¿Podrías luego ir al monte y volver con las barbas largas y el pelo crecido como los guerrilleros de Fidel Castro? [...] [E]ran los tiempos en que se hablaba mucho de Rusia, de China, de Cuba, de guerrilleros" (845). Para ese momento, ya ha terminado la secundaria a pesar de la oposición del tío pescador que se hizo cargo de él cuando quedó huérfano de ambos padres unos años antes. Sus hermanos mayores, que radicaban en la capital, han "desaparecido". Desde Lima, se marcharon, supuestamente, al extranjero con una beca de estudios, pero el relato sugiere que ése fue el pretexto para pasar a la clandestinidad tras haberse involucrado con alguna organización subversiva. Diego es un ávido lector y sus románticos anhelos revolucionarios surgen, precisamente, de la lectura de los mismos libros que sus hermanos mayores leían a escondidas. ${ }^{418}$ Asimismo, Gaspar, su mejor amigo, solía prestarle volúmenes de la biblioteca de su padre, entre cuyos títulos destacan Sachka Yegulev (1911) de Leonidas Andreiev y La madre de Máximo Gorki (1907), siendo el último "determinante para orientar... tus simpatías por la revolución" (102-3). Adicionalmente, un par de veces Diego asiste a reuniones clandestinas de "un círculo de estudios cuyo objetivo era acercarse a la realidad del país", invitado por el sanitario de la

${ }^{418}$ El Manifiesto del partido comunista (1848) de Karl Marx y Friedrich Engels, Nuestra comunidad indígena (1924) de Hildebrando Castro Pozo, La guerra revolucionaria (1955) de Mao Zedong, Fuego sobre los Andes (1942) de Carleton Beals y Francisco Jara, y Así se templó el acero (1956) de Nikolai A. Ostrovskii, entre otros (85-6). 
escuela, quien, al poco tiempo, es acusado de agitador y metido a la cárcel (103). El azar hace que, no bien Diego se baja del camión que lo ha llevado a la capital, conozca a Elías Guevara (cuyo apellido sería un trasunto del Che), un dirigente estudiantil que le proporciona hospedaje y le consigue una credencial para que se alimente en el comedor universitario. En ese entorno Diego se involucra progresivamente con el activismo político de los estudiantes. $^{419}$

Desempeñándose en varios oficios menores, desde armador de escobas hasta lavador de botellas vacías, cumpliendo largas jornadas laborales a cambio de un salario ínfimo, Diego comprende a cabalidad qué significa ser proletario. Además, no tarda en darse cuenta de que la alienante rutina podría anquilosarlo en una misma ocupación y alejarlo cada vez más de sus sueños revolucionarios: "[M]ozo de restaurante para siempre, mecánico para siempre, conserje para siempre-, entonces habrías de decir adiós, también para siempre, a las aspiraciones" (194). Más adelante, Elías, que a la sazón es el jefe de una oficina estatal, le ofrece un trabajo de chofer: "[A]traído por Elías, te subiste al carro de la revolución — atestado, en ese entonces, de muchos revolucionarios que, luego de haber estado en el monte con armas en la mano o presos por subversivos, habían sido amnistiados por el gobierno revolucionario de los militares” (107). Pero, al poco tiempo, Elías y sus subordinados son despedidos por discrepancias ideológicas con los jefes superiores de aquella oficina. El incidente les da la oportunidad de confirmar

\footnotetext{
419 “¿Habría sido posible, sin Elías, que vieras de cerca lo que era la prédica y la práctica de las ideas de izquierda, de la solidaridad y del compromiso político? [...] En esos tiempos entrañables alcanzaste también a entender lo importante que era tener una ubicación en el mundo, es decir, contar con una perspectiva para ver y apreciar las cosas. Tú optaste — en realidad no fue un acto de elección, pues la vida te había orientado desde siempre en esa dirección-por la única perspectiva justa, la de los desposeídos" (Hienas 181-82).
} 
que la autodenominada Revolución Peruana no era tal: "[D]espués de la experiencia de trabajar para el Estado, comprendiste que el gobierno militar seguía agitando las banderas de la revolución para frenar la verdadera" (108).

Diego consigue, entonces, un puesto de chofer interprovincial y conoce a Carolina — apodada la Buena Moza—, la administradora de un restaurante ubicado al pie de la carretera Panamericana Norte, quien, coincidentemente, no sólo había participado en la vida política de la Ciudad Universitaria, sino que también conocía a Elías, con quien había engendrado un hijo, aunque el padre no lo sabía. Sin admitirlo al principio, Diego se enamora perdidamente de la Buena Moza, pero su amor no es correspondido. Pasa el tiempo, la Buena Moza y Elías se reencuentran, él se entera de la paternidad del niño, ellos vuelven a ser pareja, y deciden vivir y luchar juntos por la "verdadera revolución". En uno de sus viajes de retorno a Lima, Diego halla una maleta repleta de dinero que había sido arrojada al desierto, cerca del camino. Con ese capital inicia su propia agencia de transportes y, con el tiempo, se convierte en un próspero empresario. Sin embargo, se siente mal consigo mismo debido a su falta de compromiso con el pueblo y a su escaso coraje para levantarse en armas en contra de un sistema que considera injusto. En su afán de no claudicar de sus ideales, Diego se involucra a través de Elías con el movimiento subversivo, en calidad de colaborador: "Facilitar un dato, llevar algo delicado en uno de tus camiones, incluso, camuflarlo por unos días en algún lugar de la ciudad sin que se te ocurriera preguntar nada, eran los imprevisibles encargos que te dejaban los contactos" (32).

Por aquellos tiempos, "los militares tenían la certeza de que todo estudiante es un subversivo" (128-9), y la policía arresta al hijo mayor de Diego y a algunos de sus 
amigos, acusándolo falsamente de poner bombas. Era cierto que estos muchachos tenían una actitud contestataria en contra del gobierno, ${ }^{420}$ pero eso no los convertía en terroristas $y$, aunque lo hubiesen sido, tampoco justificaba el trato inhumano que recibieron de parte de la policía antisubversiva: "[Y]o fui arrestado y torturado terriblemente, y el más loco y hablanchín de todos encontrado muerto en una playa" (420). ${ }^{421}$ A raíz del arresto y de la tortura de su hijo, y del asesinato del amigo de éste, Diego adquiere plena conciencia de que su colaboración con los insurrectos pone en peligro a su familia y decide ponerle fin a ese vínculo: “[D]e ahí en adelante, no quedaba[n] libre de riesgos, ni él, ni los muchos jóvenes que estudiaban en la universidad, ni tú. Tenías que cortar con los contactos porque si caías, volvería a caer entonces tu hijo y entonces no tendrían salvación. No eras militante y tu familia estaba por encima de todo" (111). En la dependencia central de la lucha contra el terrorismo, Diego clama la inocencia de su hijo, pero le piden "pruebas de la equivocación" que, en el supuesto negado, habría cometido la policía (131). Además de la angustia, de la sensación de impotencia, y de soportar vejámenes y humillaciones, obtener la libertad de su hijo le cuesta a Diego la suma de 6300 dólares americanos en sobornos a las autoridades, encarnadas en los personajes del comandante Blanco y del oficial de alto rango, no uniformado, que funge de intermediario en las negociaciones.

\footnotetext{
420 "Detestábamos el orden y aunque muchos de nosotros carecíamos de una posición ideológica mirábamos con simpatía la prédica política contra el sistema y el poder [...] [C]iertas noches leíamos en el bar, en la calle, en un ómnibus, un poema, una declaración de principios, una proclama literaria, inconscientes de los riesgos que no tardaron en hacerse efectivos" (Hienas 420).

421 “[L]a lucha contra la subversión reforzó en miembros de la policía prácticas autoritarias y represivas preexistentes. La tortura en interrogatorios y las detenciones indebidas, que habían sido frecuentes en el trato con la delincuencia común, adquirieron un carácter masivo durante la acción contrasubversiva $[\ldots]$ [L]as violaciones más graves de los derechos humanos por parte de agentes de la policía fueron: ejecuciones extrajudiciales, desaparición forzada de personas, torturas, tratos crueles, inhumanos o degradantes" ( $H W 441$, C. N $\left.{ }^{\circ} 46\right)$.
} 
Una vez que el muchacho queda libre, Diego lo envía a estudiar a París con el propósito de alejarlo del peligro.

Es la década de los noventa y han transcurrido casi veinte años desde que Elías y la Buena Moza se marcharon al campo y pasaron a la clandestinidad. Desde hace mucho tiempo Diego ha perdido toda comunicación con ellos. Con la quimérica ilusión de encontrarlos, dos o tres veces al año viaja a la sierra en un camión con el pretexto de comprar productos agrícolas para negociarlos en Lima. En uno de esos viajes, Diego y su ayudante son emboscados por subversivos, quienes los obligan a participar en el asalto a un puesto policial. Este evento, por demás sanguinario, echa por tierra las convicciones revolucionarias de Diego, porque se siente asqueado de la violencia extrema empleada por los terroristas. Por su desconfianza en las autoridades policiales, Diego decide no presentar la denuncia respectiva, contrariamente a lo que le sugería su ayudante: “¿Denunciar lo que nos ha pasado? ¿Cómo se te ocurre? Ni que estuviéramos locos, ¿Y cómo les vamos a demostrar que no somos cómplices? ¿No sabes que por una simple sospecha te pegan un tiro o te sepultan en la cárcel?" (25). Al final de la novela, se revela que el ayudante era un policía encubierto.

A los pocos días de la emboscada y del asalto al puesto policial, Diego es arrestado y llevado a un calabozo, en donde lo torturan y lo mantienen incomunicado. La realidad del calabozo es constantemente interrumpida por pensamientos y recuerdos que se le vienen a Diego a la cabeza. Por ejemplo, piensa en el conflicto que representa para él haber claudicado a sus ideales revolucionarios, pues se involucró con la causa sólo a medias-principalmente llevando y trayendo ocasionalmente "encargos" de los "contactos"-, por el temor de exponer a su familia a riesgos demasiado altos, que podían 
significar la muerte misma; y también porque él era responsable de satisfacer las necesidades de su aburguesada esposa e hijos, lo cual no le permitía renunciar a la estabilidad económica que le proporcionaba la empresa de transportes que poseía. En los últimos tiempos Diego se pasaba largas horas "vacilando entre dejarlo todo y buscar un contacto para pasar a la clandestinidad $[\ldots]$ o entregarte de lleno a tus negocios y a tu familia y renunciar para siempre al martirio del compromiso político, sin que te importe que alguien te diga que te has convertido en un traidor, en un renegado, porque, salvo tú mismo, ¿quién podría tomarte cuentas de nada si nunca asumiste ninguna obligación de militante? (31).

Cuando Diego le pregunta a uno de sus torturadores por qué lo tienen secuestrado, en vez de responderle éste le arroja un periódico a la cara:

Cuando empiezas a darte cuenta de las cosas una ola de terror te paraliza [...] [E]mpiezas a leer: Cae en Lima siniestro bastión del terrorismo [...] Conocida agencia de transporte era tapadera de un nido de subversivos que planeaban reiniciar acciones en todo el país [...] Gerente, hoy en la clandestinidad, dirigió personalmente, hace poco, toma de puesto policial en [1a] Sierra Central [...] Joven agente del servicio de inteligencia infiltrado en la agencia descubrió siniestro plan que buscaba ensangrentar de nuevo el país [...] Rastros de caja fuerte encontrada abierta hacen pensar que [el] gerente alcanzó a llevarse [una] cuantiosa cantidad de dinero en efectivo [...] Esposa cómplice logra huir. Se presume que también ha pasado a la clandestinidad [...] Hijo mayor con residencia en Europa, enlace internacional de la subversión. (406-7) 
Cando Diego se entera de que su esposa también ha sido "desaparecida" y presiente la inminencia de su propia muerte a manos de las fuerzas antisubversivas, se arrepiente de haber renunciado a sueños revolucionarios: "Y si estos te van a matar, ¿no hubiera sido mejor meterse a la candela, como decía Elías, para darle sentido y dignidad a tu muerte? ¿Qué sentido tenía morir así, inculpado de hechos que más valiera que los hubieras cometido?" (244). Sin embargo, en la última página de la novela se relata el momento en que Diego descubre que su esposa está embarazada del primogénito; es decir, del narrador de la historia:

[L]a escena final de la novela no puede ser más luminosa, ya que, mediante esta suerte de diálogo virtual, el hijo narra a su padre su recuerdo más antiguo, cuando éste adivina que su mujer está embarazada, esperándolo a él, al primogénito. Cuando su mujer le pregunta cómo supo que estaba embarazada si a nadie se lo había dicho todavía, Diego le da una respuesta que cierra la historia, y revela la conciencia feliz, aunque en duelo, que prevalece en esta excelente novela surcada por cierta nostalgia durante los azarosos tiempos de la guerra. Diego le responde con una simple oración (o simple canción) 'La noticia está en tu cara, en el aire, en mi intuición, cómo no lo voy a saber si llevas en tu barriga una presencia que empieza a ocupar todos los espacios de mi vida' (449)". (Ángeles, "Dos novelas sobre la guerra").

Con este final, es dable interpretar que el hijo mayor de Diego y Lucila, quien sobrevive a la Guerra Interna y supervive a sus progenitores, simboliza el futuro y la esperanza del Perú. "Hienas en la niebla se cierra con este canto a la vida por encima de la muerte del 
protagonista, por encima de penas y maltratos, por encima del duelo del hijo. O habrá que decir que ese canto por la vida brota de todo lo anterior" (ibíd.).

\section{Estrategia narrativa}

La novela empieza con un "Prólogo" en el que se presenta el drama in medias res, cuando Diego de la Cruz, tras haber sido secuestrado y torturado por la policía, está a punto de ser asesinado:

Es entonces cuando te sobresalta la noción de que te encuentras, precisamente, en el centro de una danza macabra que anuncia y celebra tu muerte... [S]e te aclara en la conciencia la idea de cómo son las fieras... dueñas de una fuerza descomunal y de una pericia que les permite saltar sobre sus presas con las fauces cerrándose y clavándose, con férrea precisión, en los puntos vitales de la garganta- $\mathrm{y}$ te tocas el cuello... [S]i no hay escapatoria y has de morir, anhelas morir así, de una sola dentellada, en lugar de que esas fauces que adivinas cerca te arranquen a mordiscos la carne cuando aún sientas en tu sangre el hervor de la vida. $(20-1)^{422}$

\footnotetext{
${ }^{422}$ Reyes Tarazona observa que "[s]on numerosas las ocasiones en que, en relación a [sic] los captores del protagonista, se los asocia a fieras, mediante alusiones a fauces amenazantes, amagos de zarpazos, instinto asesino, presagiando una muerte violenta" (11).

En su discurso titulado "Somos los iniciadores" (1990), Abimael Guzmán menciona la palabra "hiena": "Sueños de sangre de hiena [énfasis mío] tienen la reacción; agitados sueños estremecen sus noches sombrías; su corazón maquina siniestras hecatombes; se artillan hasta los dientes pero no podrán prevalecer, su destino está pesado y medido. Ha llegado la hora de ajustarle cuentas" ("Somos los iniciadores", Guerra popular 164).
} 
En el siguiente capítulo_- "Uno"—-se narra que un grupo de insurgentes embosca a Diego y a su ayudante de camión en un paraje de la sierra peruana, involucrándolos luego en el asalto de un puesto policial:

Las explosiones y el ruido de la balacera trizan tus oídos, retumban en tu pecho, te parten en pedazos, te hacen volar por los aires, vivo, y esas carreras y esos gritos y ese humo, qué pasa, qué está pasando. Un escalofrío recorre tu cuerpo cuando por un resquicio de tu mente revuelta se abre paso una luz que te hace tomar conciencia de que adentro, en el interior del puesto, acaban de morir, con toda seguridad, la mayoría de guardias del destacamento. (23)

Cuando termina este violento y sangriento episodio, que es el que pone en movimiento los acontecimientos que han de desembocar en la muerte del protagonista a manos de las autoridades policiales, Diego se pregunta: “¿Así es la revolución? ¿Es temple conseguido a fuerza de fe y convicción o simple ferocidad engendrada por altos niveles de fanatismo? ¿Cómo si no se puede ser capaz de desatar una violencia tan ciega y demencial?” (25).

En la percepción de Diego hay un divorcio entre los ideales revolucionarios que lo inspiran—o que solían inspirarlo—y los métodos violentos que rechaza. Si bien ésta pareciera ser la tesis del autor, más adelante podemos darnos cuenta de que no necesariamente lo es. Por ejemplo, el personaje de Elías Guevara—el apreciado amigo de Diego y líder subversivo - manifiesta que "la guerra revolucionaria es, como toda guerra, cruenta y feroz, lo cualitativamente diferente es la motivación, los objetivos, la moral con la que la llevas a cabo" (151). La coexistencia de voces contradictorias en la novela 
probablemente obedece a la intención del autor de lograr un texto polifónico, en el sentido bajtiniano.

Diego lleva aproximadamente un año de haber muerto cuando es relatada su historia. Al final de la novela el lector descubre que el narrador es el hijo mayor de Diego, cuyo nombre nunca es mencionado. Es también en ese momento cuando cobra sentido que 410, de un total de 449 páginas de extensión que tiene el libro, estén escritas en segunda persona $\mathrm{y}$, en ocasiones, en estilo indirecto libre. Indiscutiblemente, la narración en segunda persona tiene la finalidad de que el lector se identifique con Diego, el protagonista del drama: "Narrar todo en segunda persona le permite [al hijo de Diego] sentirlo vivo [a su padre] [...] Pienso que dicho recurso, además, envuelve mejor al lector, como interpelándolo desde la narración misma" (Ángeles, "Dos novelas sobre la guerra").

La historia de Diego a la que los lectores tenemos acceso es la recreación literaria hecha por su hijo mayor a partir de las cartas y de los cuadernos autobiográficos que su padre le había enviado a París. Si bien, para escribir las memorias de su progenitor el muchacho debe recurrir a sus propios recuerdos, porque se le han extraviado los cuadernos, así como a las referidas cartas, el hecho de que los principales acontecimientos de la vida de Diego hayan sido escritos y reescritos refuerza la credibilidad de la historia. Adicionalmente, que el hijo mismo haya sido una víctima del terrorismo de Estado, supuestamente le permite imaginarse con fidelidad la sofocante angustia y el terrible miedo que debió de haber sentido su padre cuando se hallaba detenido e incomunicado en uno de los calabozos de la policía, antes de que lo asesinaran. 
Cabe destacar que, aunque la novela está escrita en segunda persona y el narrador no es el protagonista, hábilmente se mantiene el punto de vista de Diego. Es a través de sus ojos que los lectores percibimos el mundo narrado. Este personaje es presentado como un ser idealista, cuya colaboración con un movimiento subversivo violento y sanguinario no está reñida con sus rasgos de nobleza. Por ejemplo, Diego posee un gran sentido de familia, es un amigo fiel y confiable, y es un patrón que no explota a sus trabajadores sino, por el contrario, les paga un sueldo digno y les proporciona una buena cobertura de beneficios sociales. Pero en donde más se destaca la nobleza de Diego es, quizás, en la buena disposición y tierna actitud que manifiesta hacia Cholito, su hijo menor, quien padece de una discapacidad mental severa: "Era simplemente un dolor clavado en tu vida y siéndolo, lo querías a morir" (151). Las nobles cualidades que posee el protagonista probablemente hacen que el lector promedio llegue a identificarse con él.

Aunque en la Guerra Interna los bandos armados subversivos eran Sendero Luminoso y el MRTA, no se les menciona con identidad propia en Hienas. De hecho, el relato está focalizado en el terrorismo de Estado, cuyos actores son equiparados a las fieras carroñeras a que alude el título de la novela y que terminan asesinando al protagonista. Por otro lado, la "niebla"-el segundo sustantivo que completa el nombre de la obra—, representa "la confusión social, de turbidez ideológica, de opresión ambiental en que viven inmersos los peruanos en los años de la guerra interna" (Reyes Tarazona 11). La Comisión de la Verdad y Reconciliación (CVR) da cuenta de la densa atmósfera que se respiraba en el Perú durante esa época: "Cualquiera podía ser víctima en las zonas afectadas por la violencia, o eso era, al menos, lo que hacía creer la conducta de los actores armados. Ese temor, prolongado en el tiempo, se transformó en angustia, esto 
es, en la percepción de un riesgo impreciso, pero siempre inminente, que perturbaba la vida cotidiana" (HW 355).

\section{No equivalencia moral entre las víctimas}

Si bien en Hienas "hay un intento de recreación exhaustiva de una época, de un espacio social, con sus personajes, ambientes e incidencias propias del momento y del ámbito en que se desenvuelven" (Reyes Tarazona 12), de ninguna manera Diego de la Cruz representa al ciudadano común. Mientras que el protagonista colaboraba con los insurrectos en favor de la causa revolucionaria en la que creía, el grueso de la población peruana-no obstante verse, en ocasiones, obligada por las circunstancias a apoyar momentáneamente al contendor más fuerte — se abstuvo de tomar partido por alguno de los bandos armados enfrentados. ${ }^{423}$

Debido a que "la concepción ideológica del PCP-SL implicaba la destrucción del ‘viejo estado' desde sus cimientos” ( $H W$ 437, C. $\mathrm{N}^{\circ} 27$ ), una de las modalidades operativas de SL era tomar un pueblo y “ajusticiar" a las autoridades. Estratégicamente, "las acciones subversivas estuvieron especialmente dirigidas en contra de aquellos líderes que se encontraban más estrechamente ligados con sus comunidades, organizaciones y municipios [...] [L]a eliminación de las autoridades locales y comunales fue un objeto central del PCP-SL para poder controlar a las poblaciones, primero, y sustituir a las

${ }^{423}$ Refiriéndose a una reflexión de Liborio, un personaje de la novela Rosa Cuchillo (1997) de Óscar Colchado, Manuel Méndez Guardiola comenta que, "tan mistis son los militares como los senderistas, y nada desplaza al indio de su sempiterna condición de víctima: cuando colabora con uno u otro bando, lo hace por pura supervivencia" (231). 
dirigencias, después. Ante esta situación, las autoridades y los líderes, si no huían, eran asesinados" (ibíd. 379). ${ }^{424}$

Después de realizar tales “ajusticiamientos” en pequeños poblados, SL se llevaba por la fuerza a niños y jóvenes, bajo la amenaza de asesinar a sus familiares si se resistían a enrolarse. Esa es, precisamente, la historia de Juan (Antonio Callirgos), el protagonista del filme Paloma de Papel (2003) dirigido por Fabrizio Aguilar, quien, al poco tiempo de haber sido asesinado el alcalde de su pueblo (el padre de su amigo Pacho), es secuestrado a los diez años de edad por SL y, luego, pasa toda su juventud encarcelado por cargos de terrorismo. Cuando, siendo todavía un niño, Juan intenta escapar de sus captores, es interceptado por la camarada Carmen - la lideresa de la columna senderista-, quien lo amenaza, diciéndole: "Escúchame bien, Cirilo. Si tú te escapas, yo no te voy a matar a ti. ¡No! Voy a matar a tu madre. Domitila se llama, ¿no? ¿Me entendiste?” (46:45).

Indudablemente, es condenable que - aun siendo culpable de colaborar con los insurrectos-Diego de la Cruz haya sido secuestrado, incomunicado, torturado y asesinado por las fuerzas de la represión; sin embargo, más víctima que él fue, por ejemplo, Lucila, quien, sin tener vínculo alguno con la subversión, salvo el hecho de ser la esposa de un colaborador, fue "desaparecida" por la policía. Por otro lado, sin otra "culpa" que la de ser un joven inquieto y que los investigadores hallaran "volantes contra la incursión militar en las universidades" en la mochila de uno de sus amigos, el hijo mayor de la pareja fue torturado e incomunicado por las autoridades, a las que fue

\footnotetext{
424 "Ello los llevó al asesinato de autoridades locales-alcaldes, gobernadores, tenientes gobernadores, jueces de paz- y de autoridades nacionales - ministros, parlamentarios y otros representantes de los poderes del Estado-. Del total de reportes recibidos por la CVR sobre víctimas fatales causadas por el PCP-SL, el $12 \%$ eran autoridades. Además, el PCP-SL incurrió en el asesinato masivo de dirigentes sociales, hombres y mujeres, dirigentes comunales, alcaldes varas, dirigentes campesinos, sindicales, barriales, magisteriales y de organizaciones de mujeres. ( $\left.H W 437, \mathrm{C} . \mathrm{N}^{\circ} 27\right)$.
} 
necesario sobornar para que el joven pudiese recobrar su libertad. Peor aún, uno de los amigos del muchacho, que también era inocente, fue asesinado.

Refiriéndose al montaje del documental La pelota vasca: la piel contra la piedra (2003) de Julio Medem, Paul Julian Smith considera que hay una "falsa equivalencia moral" cuando se equipara a las víctimas directas de las acciones terroristas de ETA con los afectados a consecuencia de la represión de tales acciones:

Most disturbing is the use of parallel montage where footage of a terrorist's wife visiting her husband in jail is crosscut with a widow recounting her husband's murder by ETA. // Such sequences suggest a false moral equivalence between the two sides. Medem has repeatedly said that ETA and the People's Party represent extremes and that the solution to the conflict will be found somewhere in the middle. The problem is that while the former is a terrorist group that has taken armed struggle upon itself, the latter is a democratically elected government with an overwhelming mandate from Spanish voters. ("The Basque Ball” 45)

No es dable, pues, meter a todas las víctimas en un mismo saco, porque no existe equivalencia moral en el nivel de sus respectivas desgracias.

\section{Desazón existencial de los excombatientes de las fuerzas armadas}

En la novela, el comandante Blanco, el oficial no uniformado y los torturadores de Diego son el epítome de la corrupción, del abuso y de la arbitrariedad con que actuaban algunos miembros de las fuerzas represivas del Estado. El siguiente diálogo, que más parece un 
soliloquio, corresponde a una conversación que tiene uno de los referidos torturadores con un colega, y que la víctima escucha desde el calabozo en donde está secuestrado:

Te juro que me siento ahuesado, le dice, mira, a los terrucos [terroristas] les hemos hecho mierda y se puede decir que la guerra se acabó, pero no hay que ser cojudos, no hay que olvidar que el ahogado tira manotazos, que hay intentos de volver a las andadas, por eso no entiendo, carajo, que nos tengan aquí como si hubiéramos quedado mancos, yo no sé si tú, pero yo soy un perro de presa, un hombre de acción, lo mejor de mi vida fue cuando me la jugué despachándome terrucos al otro mundo, qué carajo, eso sí que era hacer patria $[\ldots][\mathrm{E}] \mathrm{s}$ hora $[\ldots]$ de hacer una buena barrida de terrucos en la sierra [...] i[P]uta madre, los tiempos de Ayacucho!, eso era diferente, si tenías los huevos bien puestos, la pasabas bien. ¿Te imaginas una misión en la misma mata del terrorismo? Alto riesgo pero total libertad de acción $[\ldots][\mathrm{N}]$ unca te faltaba una buena tanda de terrucos que liquidar de uno en uno, así, pempén, en la nuca carajo, haciendo patria, y luego venía lo otro, las hembritas, que no faltaban. Teníamos todo a nuestro favor y atrapábamos terrucas universitarias y terrucas del campo, y otras que ni de lejos eran terrucas, de todo, qué mierda, muchas de ellas mamacitas sin estrenar, imagínate, cojudo, y para que no quede ni rastro de nada, a toditas las enterrábamos luego de pasarlas por las armas. Por las dos armas, dirás, cojudo, dice riéndose el otro, a quien no alcanzas a ver. Por supuesto, huevón, hasta la tropa sacaba su tajada, hubieras visto a los cholos, se avivaban y le pedían anuencia al jefe para tirarse a la terruquita 
vendada a la que después tenían que pegarle un tiro en la cabeza. La guerra era la guerra y hacíamos patria, déjate de huevadas, pero aquí, oh, aquí me siento francamente un ahuesado. (402-4)

La desazón existencial que experimentaban muchos militares al retornar de la llamada "zona de emergencia" también se ve reflejada en el filme Días de Santiago (2004) de Josué Méndez. En esta película, Santiago Román (Pietro Sibille), el protagonista, y algunos de sus excolegas combatientes se han convertido en desadaptados sociales porque hallan su realidad previa—la de su hogar en la ciudad—por demás insustancial, debido a que, por un lado, están traumatizados por los fantasmas de la guerra y, por el otro, sus respectivos cuerpos ya no generan los mismos niveles de adrenalina que les producía el hecho de vivir constantemente en inminente peligro y matando gente. Las siguientes son palabras de Santiago:

Allá éramos lo máximo. Éramos unos tigres, armados hasta los dientes. Destruíamos todo, decapitábamos a los “tucos” [terroristas]. Enterrábamos a los monos [forma despectiva de aludir a los ecuatorianos]. La pasábamos así, matando, hombres, mujeres, niños; todos los días. Acá ya no somos nada. Algunos son choferes, guardianes, guardaespaldas; los excombatientes estamos por todas partes, pero nadie nos reconoce, nadie sabe lo que somos. Pero a un comando se le distingue por cómo lleva el arma, por cómo camina, por cómo mira. (17:50-18:31)

Santiago regresa a Lima después de seis años, tras haber combatido en el Conflicto del Alto Cenepa, entre Perú y Ecuador en 1995, y, luego, en la Guerra Interna. Trastornado de la mente, suele tenderse sobre el somier de su cama, vestido de comando 
y con pasamontañas (22:49-23:08, 23:51-23:58, 1:09:16-1:09:24). También suele simular maniobras militares en el arenal del 'pueblo joven' (chabola) en donde vive (23:0923:50, 24:21-24:27). Uno de los excolegas, apodado el Rata, está confinado a una silla de ruedas y su frustración es tanta que lo conduce al suicidio (09:58-12:03, 21:45-22:48). ${ }^{425}$ "[A]mplios sectores de la población afectada por la violencia sufren una u otras formas de secuelas psicosociales, lo que debilita sus capacidades de desarrollarse y superar las heridas del pasado". (HW 463, C. $\left.\mathrm{N}^{\circ} 159\right)$.

Ni Santiago ni sus excolegas consiguen trabajo. Santiago desea estudiar pero no cuenta con los medios económicos para hacerlo. Una de las reparaciones que plantea la CVR es que el Estado brinde "nuevas o mejores oportunidades de acceso a las personas que como producto del conflicto armado interno perdieron la posibilidad de recibir una adecuada educación o de culminar sus estudios" ( $H W 419)$. Los excombatientes tampoco encajan en la sociedad por el hecho de haber perdido años claves de su juventud: "Seis años allá sin fines de semana, sin salir a bailar, sin nada. Aquí, tres de la tarde, día de semana y ¡mira! Todos bailando, fumando, chupando [ingiriendo bebidas alcohólicas], pasándola bien. Toda la gente de los institutos y de las academias; toda la juventud limeña, todo el futuro del Perú. Aquí no hay emboscadas ni misiones que cumplir. Seis años, sin poder pasarla así, como cualquiera" (Santiago, voz en off: 38:16-38:44).

Los excolegas le proponen a Santiago asaltar un banco pero él se niega:

Excolega 1: ¡Un banco, promoción [tratamiento entre colegas militares de la misma promoción]! ¡Puta, que un banco! Hacemos un

\footnotetext{
${ }^{425}$ En Días de fuego (2009) de Fernando Cueto, Rentería-el protagonista, un miembro de la DINCOTE (Dirección Nacional Contra el Terrorismo) - también queda postrado en una silla de ruedas a consecuencia de un ataque senderista.
} 
plan de operación como si fuera una misión más. ¡Y sale! Ver bien la seguridad, los relevos, cuestión de practicar.

Excolega 2: ¿ ¿Un banco? Está bien, pero sin disparos, sin matar a nadie.

Excolega 3: ¡Pero tiene que ser como allá, pues, promoción! Matar antes [de] que te maten. Si te bajas un tombo [policía], ¡tombo salado [con mala suerte], pues, carajo!

Santiago: ¡Pucha, promoción! Pero ¿vamos a salir de todo para meternos otra vez a la cochinada?

$[\ldots]$

Excolega 1: Santiago: Aquí nunca se van a acordar de nosotros ni de lo que hemos hecho. ¡Hay que hacer algo pues, huevón! $(18: 32-19: 56)$

Excolega: $\quad$ Lo del banco podrá ser arriesgado, pero es lo único que está claro. ¡Vamos a hacerla promoción, como en los viejos tiempos! ¡Vamos a hacerlo para estar otra vez en situación! ¡Sólo faltas tú!

Santiago: $\quad$ Yo ya saqué mi línea aquí, promoción. Si yo me fui de la Marina es para estar bien con mi conciencia. Porque así como yo no puedo dormir, yo sé que tú tampoco puedes dormir. ¿Tú puedes dormir? ¿Duermes? ¿Ah? Y si nos seguimos metiendo en cosas, así nunca vamos a estar tranquilos con nuestra conciencia. Yo me acuerdo de todo, 
todos los días y no me deja dormir. Yo ahora quiero estar tranquilo. (24:47-25:57)

Finalmente, los excolegas de Santiago llevan a cabo el asalto al banco y en la televisión dan la noticia de la siguiente manera: "Los autores del robo de los $\$ 40,000$ serían, nada menos, que excomandos de la Marina [...] Dos de ellos con antecedentes en asaltos similares $[\ldots]$ Lo lamentable de esta información es que se trataría de personas que sirvieron a nuestra patria y que habrían pasado de ser casi héroes a avezados delincuentes" (1:08:00-1:09:15).

La CVR propone el establecimiento de un programa de reparaciones en salud que contribuya a que "la población afectada por el conflicto armado interno recupere la salud mental y física, que se reconstruyan las redes de soporte social y se fortalezcan las capacidades para el desarrollo personal y social. Todo ello contribuirá a favorecer en las víctimas el desarrollo de la autonomía necesaria para reconstruir su proyecto de vida, individual y colectivo" ( $H W 419)$.

\section{Banalidad del mal}

En Hienas, los torturadores de Diego-así como muchos miembros de las fuerzas represivas que participaron en la lucha antisubversiva - probablemente no nacieron con una proclividad sanguinaria, sino que se volvieron crueles y despiadados en un momento de quiebre en su vida, debido a que recibían órdenes aberrantes de sus superiores, con las que, quizás, no comulgaban por hallarlas crueles e inhumanas. Lamentablemente, no 
tenían ni el temple ni el coraje — o la posibilidad—de desacatarlas y, menos aún, de rebatirlas. $^{426}$

Sobre el proceso judicial y la ejecución de Adolf Eichmann, uno de los principales responsables del genocidio del pueblo judío durante la Segunda Guerra Mundial, Hannah Arendt reflexiona en su libro Eichmann en Jerusalén (1963) sobre lo que ella llama la "banalidad del mal". Para Arendt, la desmedida crueldad de los inhumanos actos de Eichmann no se explica por haber sido él intrínsecamente un monstruo, sino por haber sido un burócrata estúpido e insensible para quien, tras renunciar a su capacidad crítica-lo cual no lo exime de culpa—, el cumplimiento eficiente de las órdenes con la finalidad de ascender profesionalmente estaba por encima de la naturaleza malvada de lo que se ordenaba hacer.

En el caso peruano, “Guzmán mandó a matar y a morir a miles de personas, sin mayor preocupación. No es que fuera cruel o que gozara de esas muertes. Se trataba simplemente de hacer los sacrificios necesarios para develar la naturaleza pérfida y sangrienta de la reacción y, paralelamente, demostrar al pueblo que la violencia es el único camino de la liberación” (Portocarrero, Profetas 213). Tras comparar la sangre fría de Guzmán con la del Marqués de Sade y con la de Eichmann, Portocarrero se decanta por el segundo. Pero antes elucubra: "[1]o anterior nos lleva a pensar que todo el inmenso mal, el dolor y sufrimiento, que este hombre produjo en la sociedad peruana no obedece a un goce sádico o a la crueldad, cuanto a una indiferencia por la vida de los otros, a un desinterés acompañado por el fanatismo que lo lleva a glorificar la violencia (ibíd. 213).

\footnotetext{
426 Sobre la banalidad del mal, consúltese también: Haslam, Alexander S. y Stephen D. Reiche. "Questioning the banality of evil". The Psychologist 21 (2008): 16-9.
} 
Por otra parte, del bando contrario al de Guzmán, el general Luis Cisneros Vizquerra declaró a la revista Caretas el 17 de septiembre de 1984 que, de ser necesario, las fosas comunes podrían ser un hecho cotidiano (Fernández Salvatteci 70).

En la novela Abril rojo (2006) de Santiago Roncagliolo, "a medida que Chacaltana [un fiscal] se va transformando por fuerza de las circunstancias en un 'hombre de acción', momento marcado significativamente con la recepción de una pistola, reproducirá los tan temidos comportamientos del militar represor, excitado y liberado al sentir su propio poder y el miedo de los otros" (Prendes Guardiola, "Constantes temáticas" 235). ${ }^{427}$ La otra cara de la moneda sería el teniente Águila (Pietro Sibille), en The True Story of Liz (2007), un docudrama de Eduardo Guillot basado en el caso de Liz Marcela Rojas Valdés, uno de los tantos casos analizados por la CVR. El teniente Águila es un militar que, genuina aunque infructuosamente intenta ayudar a Liz Rojas (Evelyn Azabache en el papel de niña, y Nídea Bermejo en el de joven) a recuperar a su madre (Patricia Altuna), una maestra que salió de casa para comprar papas y jamás regresó porque fue secuestrada y "desaparecida" por las fuerzas antisubversivas. ${ }^{428} \mathrm{La}$ madre de Liz fue secuestrada, torturada (16:18), violada (16:01 y 16:26) y, presuntamente, asesinada por las autoridades en el año 1991. "Según el análisis de

\footnotetext{
427 "Según sus portavoces, los militares habrían arriesgado su vida para defender la democracia y ahora se veían traicionados, enjuiciados, y perseguidos; según ellos se podría hablar de 'excesos', de eventos singulares en la lucha contrasubversiva, como las masacres de mujeres y niños, de gente inocente. Situaciones desde luego lamentables pero que se explicarían por el propio frenesí de la guerra" (Portocarrero, Profetas 198).

428 "La CVR denuncia que "la autoridad civil desatendió durante mucho tiempo las miles de denuncias de violaciones de los derechos humanos cometidas por las fuerzas del orden en las zonas más afectadas por el conflicto. Incluso, en varios casos, se facilitó y garantizó la impunidad a los responsables de las mismas" (HW 18-19).
} 
Henríquez (71 y ss.), ${ }^{429}$ el empleo de la violación por parte de los miembros de las Fuerzas Armadas dejó de constituir un método de 'tortura' propiamente dicho (es decir, el medio para obtener algún tipo de información militar), sino más bien como reafirmación de la masculinidad asociada al ancestral estatus del 'guerrero"' (Prendes Guardiola 233). ${ }^{430}$. En el tiempo narrativo del docudrama de Guillot, Liz aparece embarazada, pero no se dice explícitamente quién es el padre de la criatura que lleva en su vientre y que ella rechaza. “¿A quién le preocupa? ¿A quién le importa? ¿Alguien protesta? ¿Alguien se queja?” (14:08), son algunas de las preguntas que se hace el Teniente Águila, asqueado de las cosas que ve y que tiene que hacer en contra de su voluntad.

\section{Abuso de poder}

Cuando las funciones y facultades del Estado (poder constituyente, legislativo, ejecutivo, judicial y electoral, respectivamente) no están separadas, lamentablemente el Estado puede oprimir al ciudadano mediante las facultades coercitivas que posee y, peor aún, puede hacerlo con impunidad. "[D]e repente se te aclara algo que no debes olvidar: que estos son sus dominios, que aquí mandan ellos y que, sin testigos dispuestos a declarar honestamente, pueden hacerte lo que les venga en gana y luego justificarlo" (402), reflexiona Diego en el calabozo. El abuso y la arbitrariedad por parte de las autoridades empeoran mucho más cuando éstas ejercen su ilimitado poder en lugares alejados de la

\footnotetext{
${ }^{429}$ Henríquez Ayín, Narda Zoila. Cuestiones de género y poder en el conflicto armado en el Perú. Lima: CONCYTEC, 2006.

430 "La CVR condena particularmente la práctica extendida de la violencia sexual contra la mujer" (C. $\left.\mathrm{N}^{\circ} 46 . H W 441\right)$.
} 
capital. Refiriéndose a Abril rojo, la novela de Roncagliolo, Manuel Prendes Guardiola comenta que "[la] enorme distancia entre Lima y Ayacucho garantiza la impunidad de quienes 'defienden' la ley mediante la mentira, la amenaza, el crimen o el fraude electoral" (230).

Pero no es necesario ir tan lejos. En pleno corazón de San Isidro, un distrito limeño de clase alta, durante la Operación Chavín de Huántar del 22 de abril de 1997, cuyo objetivo era rescatar a los 72 rehenes que el MRTA mantenía secuestrados en la embajada del Japón, murieron dos soldados, un rehén y los catorce emerretistas. Aunque existía la presunción de que algunos de los emerretistas fueron ejecutados sumariamente, el 29 de junio de 2015 la Corte Interamericana de Derechos Humanos CIDH determinó que sólo en uno de los casos había elementos que podrían sugerir esa posibilidad. En todo caso, una sola víctima es demasiado. La CVR "[c]ondena [...] las ejecuciones extrajudiciales que se habrían producido, injustificadas por tratarse de personas rendidas" $\left(H W 452, \mathrm{C} . \mathrm{N}^{\circ} 102\right) .{ }^{431}$

\section{Reclutamiento de cuadros senderistas en áreas rurales}

Pasando al bando de los subversivos, al inicio de la Guerra Interna debió de ser relativamente fácil para SL reclutar nuevos adeptos, si no por la fuerza, por la vía de la persuasión. En caseríos ubicados en los Andes peruanos a miles de metros de altura sobre

\footnotetext{
${ }^{431}$ Una vez concluida la Operación Chavín de Huántar, los cadáveres de los emerretistas no fueron trasladados al Instituto de Medicina Forense, como sería lo acostumbrado, sino a la morgue del Hospital de Policía. Ni a los representantes de la Oficina del Fiscal General ni a los familiares de los difuntos se les permitió entrar en contacto con los cuerpos. Tampoco se dieron a conocer los resultados de las autopsias hasta el año 2001. Los cadáveres fueron enterrados sin ceremonia y en secreto en varios cementerios. A pesar del hermetismo, el cuerpo de Néstor Cerpa Cartolini-el líder del grupo del MRTA-fue hallado en el cementerio Nueva Esperanza de Villa María del Triunfo (un distrito ubicado en el Cono Sur de la capital peruana), de donde fue exhumado y robado por personas desconocidas.
} 
el nivel del mar, en donde la presencia del Estado se resumía, en el mejor de los casos, a una alcaldía, a una escuálida guarnición policial y, con suerte, una precaria posta médica y una escuelita elemental; en parajes de difícil acceso debido a la topografía, en donde el destino de un niño analfabeto se había de circunscribir a labrar la tierra o a pastar un puñado de animales por el resto de su vida, si lograba sobrevivir a la mortalidad infantil, que era moneda corriente en esos lares; en una mente inactiva, apenas poblada de otras cosas que no fueran impresiones telúricas, el "pensamiento Gonzalo" probablemente estimuló las neuronas de los discípulos y fue asimilado sin cuestionamientos, al ser probablemente la única "verdad" que alguna vez les presentó.

Salomón Lerner Febres, quien fuera el presidente de la CVR, declara en una entrevista que "[e]n una sociedad fracturada, en donde hay marginación, exclusión y discriminación, surgieron dos movimientos subversivos [SL y MRTA], pero los partidos políticos no ofrecieron ninguna ideología alternativa. Simplemente callaron" (The True Story of Liz 22:01-22:21). En consecuencia, el papel de educador que le correspondía al Estado y que éste incumplió fue suplantado por el adoctrinamiento impartido por los insurgentes. Esto explica que, al principio, los jóvenes prestaran oídos al discurso de SL: “[L]a prédica del PCP-SL pudo tener aceptación fugaz, en razón de la incapacidad del Estado y de las élites del país para responder a las demandas educativas de una juventud frustrada en sus esfuerzos de movilidad social y de aspiración de progreso" ( $H W$ 436, C. $\mathrm{N}^{\circ} 23$ ). El documental State of Fear: The Truth about Terrorism (2005), dirigido por Pamela Yates, intenta mostrar que "[1]a extrema pobreza y [el] aislamiento en que algunas zonas del país vivían resultaba tierra fértil para ideologías mesiánicas y extremistas" (Noemí, "Para una genealogía" 44). 


\section{Lavado cerebral}

En una de las secuencias de Paloma de papel se aprecia a los niños Juan (Antonio Callirgos), Modesto (Jesús Carbajal) y Yeni (Melania Urbina) — la hermana menor de la camarada Carmen (Tatiana Astengo) — sentados en la orilla de un lago, dibujando en la arena. Modesto les explica lo que representa su dibujo:

—Esta es mi casa que se está quemando. Hay mucho fuego. Un compañero le ha prendido candela. Y acá hay dos compañeros: uno tiene un arma y el otro tiene una piedra. Y con esa piedra le está rompiendo la cabeza a mi papá. Mientras, acá, mi mamá me está agarrando de la mano, mientras yo estaba llorando. Antes yo lloraba.

— ¿Y tu papá murió?

—Sí, de allí me han traído con mi mamá a los 8 años. Mi mamá murió de enferma. Con mucha pena estaba, porque los camaradas me dijeron que mi papá era un imperialista reaccionario. Y tú sabes que eso es malo. Por eso yo ahora lucho por mi patria por mis compañeros que necesitan de nosotros, para no quedar mal como los Estados Unidos donde todos son malos. $(44: 24-45: 19)$

Y, mediante otro diálogo entre Wilmer (Sergio Galliani) y Juan (ahora rebautizado como camarada Cirilo), la película muestra el proceso de concientización—de lavado cerebral—por el que pasaban los niños "reclutados":

—Ahora ya no tienes casa, Cirilo. Ahora ésta es tu casa. Aquí vivimos todos juntos porque juntos estamos haciendo algo bueno. Estamos haciendo una nueva vida. Tu mamita está bien en su casa y tú estás bien 
aquí. Y aquí no hay mamitas. Aquí estamos nosotros, tus amigos, tus compañeros... ¿Qué quieres ser de grande?

-Herrero, como el viejo.

_ ¿Y a ti te gustaría, cuando seas herrero y cuando tengas mucha plata, que haya gente que se muera de hambre?

- No.

—Y qué harías, Juan?

- Les regalaría plata y un pan.

—No está mal. Pero, lo que debes hacer es no cobrarles por tu trabajo. —Nada?

—Nada. Si nadie cobra nada, todos tendríamos todo. ¿Me entiendes?

_ ¿Y si quiero comprarme algo y comer una galleta y no tengo plata?

-Eso no te debe importar porque tampoco va a costar.

¿Las galletas van a ser gratis?

—Nosotros queremos que así sea y peleamos por eso; por eso luchamos contra el gobierno reaccionario, la burguesía, la autoridad y el sistema semifeudal. ¿Me entiendes? Queremos cambiar para mejorar. Pero hay gente mala que no quiere esos cambios. Por eso nosotros luchamos contra ellos.

—Pero el papá de Pacho era bueno.

— ¿Y quién era el papá de Pacho?

-El alcalde. 
—Los alcaldes no quieren cambios, Cirilo. Y aquí el que no cambia y no quiere cambiar serán muertos por las balas del pueblo. Seguro que el papá de Pacho no quería que las galletas sean gratis. ¿Me entiendes? (37:5440:37)

El filme también incluye una secuencia en la que los líderes de SL les enseñan a los niños a fabricar granadas "huaraca" (con explosivo, aserrín y pernos dentro de una lata) (41:4743:99) y otra en la que se les ve entrenando para operaciones de comando (45:49). Pero una de las escenas más dramáticas—y traumáticas—de la película es cuando Juan es obligado a asesinar a un jefe militar. El camarada Wilmer le ordena a Juan/Cirilo que le clave un puñal en el abdomen:

—Ahora te vas a convertir en un verdadero hijo del pueblo. ¡Mátalo! Juan/Cirilo se resiste.

— ¡Vamos, Cirilo! ¡Mátalo! ¡Mátalo! (Le da el puñal). Ellos mataron a Modesto, Cirilo. Ahora nos toca a nosotros. ¡Mátalo! ¡Mátalo!

La camarada Carmen le conduce la mano a Cirilo para que introduzca el puñal en el vientre del militar. (57:26-58:43).

En un enfrentamiento entre los senderistas de esa columna y los ronderos del pueblo, a quienes Juan alerta de la llegada de los primeros, mueren, entre muchas otras personas, Domitila (Liliana Trujillo), la madre de Juan, y Yeni, la hermana de la camarada Carmen. La película acierta en presentar el profundo dolor que sienten los de uno y otro bando por la pérdida de sus seres amados. 


\section{"Hombres rojos"}

En Paloma de papel, Modesto — el pequeño senderista—es comisionado a dinamitar una torre de alta tensión y pierde una pierna porque el área había sido minada por los militares para proteger la estructura: "Yo no lloro, camarada. Yo no quiero ser parásito, camarada... Ajustícieme. Yo soy parte de la cuota. En nombre de la revolución, camarada...", clama el niño transido de dolor, y, atendiendo a sus súplicas, Wilmer, el líder de la columna terrorista, le dispara, asesinándolo (52:33- 54:13). Gonzalo Portocarrero explica que la doctrina de SL exigía a sus miembros estar dispuestos a ofrecer la vida por la causa revolucionaria: "La ideología de Sendero Luminoso pretendió crear 'hombres rojos', militantes devotos de la causa, personas capaces de matar o morir en función de órdenes del partido, del 'Presidente Gonzalo'. La propuesta era entonces 'dame tu libertad, entrégate a la causa, sé consecuente. A cambio lograrás una elevada autoestima, un sentimiento de seguridad sobre tu propio valor. Te sentirás como un héroe, un hombre, o mujer, bueno y noble"” (Profetas 180). ${ }^{432}$ En Razones de sangre, Portocarrero explica que, "[a] partir de una concepción de lo individual como pecaminoso [...], Guzmán invita a sus interpelados a eliminar su privacidad e integrarse a un colectivo que absorberá todas sus energías. Esta renuncia es postulada como el fundamento de una metódica de vida que conduce a un estado de gracia" (53).

\footnotetext{
432 "Los documentos del PCP-SL reconocen alrededor de 1,700 bajas entre militantes del partido, el ejército guerrillero popular y las denominadas "masas" que los apoyaron, para el período comprendido entre mediados de 1983 y mediados de 1985. Aunque no hay convicción absoluta al respecto, la CVR considera que parte de los militantes muertos del PCP-SL pueden corresponder al total de 2,000 desaparecidos a manos del PCP-SL, sobre los que se puede razonablemente considerar que fueron jóvenes reclutados forzosamente que nunca más volvieron, posiblemente porque cayeron en enfrentamientos" $(H W$ 443, pie de página $\mathrm{N}^{\circ} 6$ ).
} 
La CVR expresa su pesar por los miles de jóvenes que resultaron seducidos por una propuesta que constataba los profundos problemas del país y proclamaba que "la rebelión se justifica". Muchos de ellos, con voluntad de transformar esa realidad injusta, no advirtieron que el tipo de rebelión que planteaba el PCP-SL implicaba el ejercicio del terror y la implantación de un régimen totalitario. Quedaron así encuadrados en una organización absolutamente vertical y totalitaria que les inculcaba el desprecio a la vida, castigaba las discrepancias y exigía plena sumisión. Muchos de ellos murieron inútil y cruelmente. (HW 438, C. N³2)

\section{Reclutamiento de cuadros senderistas en áreas urbanas}

A diferencia del método de reclutamiento forzado utilizado en las áreas rurales, los sindicatos de trabajadores $\mathrm{y}$, sobre todo, las universidades eran las canteras urbanas que proveían a SL de militantes estrategas e intelectuales que, así como el personaje de Elías en Hienas, se encargaban de difundir la soflama subversiva. ${ }^{433}$ "El mito revolucionario circulaba como una verdad científica inapelable" (Portocarrero, Profetas 194). Todo esto contribuyó a que el éxito de SL en el ámbito académico fuera posible. Adicionalmente,

el Estado descuidó durante varias décadas el tema educativo [...] En aquellos espacios que [...] dejando en su repliegue, germinaron nuevas propuestas [que] propugnaban un cambio radical, no asimilable por el sistema social y político, solo alcanzable por la vía de la confrontación y

\footnotetext{
433 “[E]1 PCP-SL se aprovechó de ciertas instituciones del sistema educativo como principal cabecera de playa y [...], a través de ellas, logro expandir su prédica y captar núcleos minoritarios de jóvenes de uno y otro sexo en diferentes partes del país" ( $H W 436$, C. $\left.\mathrm{N}^{\circ} 22\right)$.
} 
sustentado en un marxismo dogmático y simplificado, que se expandió ampliamente en las universidades durante la década de 1970. (HW 458, C. $\left.\mathrm{N}^{\circ} 136\right)$

De esa manera, SL halló “entre muchos maestros y estudiantes universitarios" un caldo de cultivo propicio para sus planteamientos, logrando que se volviera "parte del sentido común considerar el cumplimiento fatal de la historia a través de la vía de la confrontación. Esa visión abrió espacios para el desarrollo de propuestas autoritarias de extrema izquierda. La del PCP-SL fue solo la más extrema (ibíd. 458, C. №137). La Buena Moza es el perfecto ejemplo de que no todos los universitarios que se vinculaban a la subversión tenían una base doctrinaria clara y, no obstante su ignorancia o desconocimiento, ella llegó incluso a colocar una bomba que estalló en la puerta principal de un banco (58-61).

\section{Perfil de un terrorista}

La novela incluye una subhistoria sobre el padre de la Buena Moza, un activista de una rama disidente del APRA y extrabajador en una hacienda azucarera. ${ }^{434}$ Por soliviantar a los obreros para que se declaren en huelga, el padre de la Buena Moza no solo es despedido sino que debe huir y permanecer escondido durante varios años para no ser prendido por las autoridades. Finalmente, pierde la vida en el asalto a un puesto policial perpetrado por él y por algunos de sus correligionarios. ¿Era un guerrillero? José Fernández Salvatteci proporciona la siguiente definición:

\footnotetext{
434 APRA: Siglas Alianza Popular Revolucionaria Americana, un partido de centroizquierda y antiimperialista fundado por Víctor Raúl Haya de la Torre en 1924.
} 
El guerrillero es un civil-político-armado que ha optado, conscientemente, [por] ser un agente revolucionario en tarea insurreccional" (29). Entre los guerrilleros hay desde los "más radicales, a los que experimentan frustración para realizarse dentro del sistema, a los más ambiciosos elementos de los partidos políticos proscritos, a los más idealistas de clase media, a los ultrajados y aguijoneados por la opresión, a los que les hicieron creer que tenían derechos y se encontraron de pronto que se les había privado de todos ellos. (Ibíd. 29).

Sin duda, tanto el padre de la Buena Moza como ella, Elías Guevara y Diego de la Cruz son del tipo anti-establishment; es decir, personas que no se identifican con el sistema de gobierno ni con los gobernantes, debido a la corrupción y a la inequidad socioeconómica imperantes, y que, al estar disconformes con el ordenamiento establecido, realizan acciones orientadas a cambiar el statu quo. Elías, por ejemplo, se refiere al Perú como “este país manejado por corruptos, asesinos y ladrones” (344), en tanto que la Buena Moza rechaza el sistema capitalista al punto de hacer estallar una bomba en las puertas de un banco (ibíd. 58-61). Diego, por otro lado, en vez de saberse amparado por las autoridades, se siente amenazado por ellas (ibíd. 24-5) y su desconfianza empeora aún más cuando secuestran a su hijo, porque queda "marcado para siempre con un odio casi irrefrenable hacia todo militar o policía, llevara o no uniforme" (96). ${ }^{435}$

\footnotetext{
${ }^{435}$ Diego desconfía de la policía en distintas ocasiones: primero, cuando halla la maleta con dinero y no reporta el hallazgo (272) y, luego, cuando es emboscado por los terroristas y es obligado a asaltar un puesto policial, pero decide no denunciar el hecho debido a que, en vez de saberse amparado por las autoridades, se siente amenazado por ellas (24-25). César Ángeles interpreta que Diego no desea involucrar a la Policía porque apoya a los senderistas y tiene algo grave que ocultar ("Dos novelas sobre la guerra").
} 
Probablemente debido a que el tema principal de la novela es la guerra sucia, a los personajes arriba mencionados se les presenta más "humanos" en comparación y contraste con los agentes de las fuerzas represivas del Estado. Por ejemplo, la Buena Moza describe a Elías de la siguiente manera:

Su extremada bondad, su desprendimiento y su entrega a los amigos podía llevar a equívocos $[\ldots]$, pero, conociéndolo de verdad, cualquiera se daba cuenta de que tenía las cosas claras y jamás hacía concesiones cuando se trataba de decidir algo relacionado con la política $[\ldots][\mathrm{P}]$ ero otra cosa era cuando se trataba de sus amigos, abría un marco de comprensión tan grande que daba la impresión de estar actuando casi en los límites de la inocencia y de lo incorrecto. Además de exigente y riguroso, era un militante leal y disciplinado y le gustaba predicar con el ejemplo [...] Dos cosas ponía por encima de todo: la revolución y la amistad. (Ibíd. 49)

La percepción que tiene Diego de Elías es similar a la de la Buena Moza, porque él lo considera un hombre "transparente, confiado y bueno hasta la inocencia" (ibíd. 175), aunque alguna vez le haya dicho que la revolución "[e]s una empresa dura y de alto riesgo $[\ldots]$ en la que te metes no solo porque tienes los huevos si no, sobre todo, porque tienes la convicción de que ella encarna tus sueños de justicia y libertad" (ibíd. 343-4). ${ }^{436}$

Para José Fernández Salvatteci, un guerrillero “[p]uede ser el maestro de escuela, el vendedor, el sacerdote, el policía, el soldado, el peluquero, cualquier 'pacífico ciudadano', el universitario, el funcionario público, el médico, el hermano, el hijo, la

\footnotetext{
436 "En las universidades, sindicatos, escuelas [...] los senderistas — los hombres rojos- se atribuían una superioridad moral que los hacía despreciar al resto de la gente. Ellos se sentían los elegidos, los íntegros, los iluminados, los buenos" (Portocarrero, Razones 69).
} 
secretaria, el padre, la novia, el triste, el olvidado, el que se muere de asco o de hambre" (29); es decir, un guerrillero puede ser cualquier persona común y corriente. Es así que John P. Gabriele percibe a los terroristas—que no son lo mismo que guerrilleros—como figuras "desconcertantes y polivalentes". Amplía esta idea, señalando que

[1]los terroristas tienen más de un perfil. Son, como demuestra Maxwell Taylor, personajes multifacéticos. Pueden ser hombres o mujeres, jóvenes o mayores, de origen urbano o rural, fanáticos religiosos o políticos, defensores de la libertad o representantes de la opresión, miembros de una banda terrorista o individuos sin ninguna afiliación de grupo. Hay quienes los elogian como héroes que están dispuestos a defender su causa hasta la muerte. Pero para otros son personas indignas, despreciables y repugnantes que causan muertes y destrucción innecesarias ("Teatralidad y terrorismo"122-34). ${ }^{437}$

La Buena Moza es un personaje más complejo que Diego y que Elías. El lector tiene la posibilidad de conocerla mejor que a los otros dos debido a que ella se explaya en los diálogos que tiene, principalmente, con Diego. Por ejemplo, en una conversación con él la Buena Moza se autodefine como una hija responsable y, a la vez, preocupada por el bienestar de su hijo, al que no puede criar a su lado porque ella debe trabajar largas horas, en un lugar aislado, en donde el niño no recibiría ni la atención ni la instrucción necesarias.

Simplemente soy una mujer pobre $[\ldots]$ con una madre tullida a mi cargo y un hijo de siete años que está desde hace un año al cuidado de la familia

\footnotetext{
${ }^{437}$ Taylor, Maxwell. The Terrorist. Londres: Brassey’s Defense Publishers, 1988.
} 
de un hermano de mi madre, en la capital. Lo trajeron hace un año, antes de mandarlo a la escuela, y me dio pena no haber podido dedicarme a él, atenderlo. El pobre debe de haberse aburrido de soledad mirando estos arenales. Cuando le tocó irse, al verlo indiferente, poco apegado a mí, me entraron los remordimientos y quise irme con él, acompañarlo en el viaje, pero no sé qué me dio volver a Lima luego de vivir lo que viví allí. (Ibíd. $37)$.

Asimismo, por la propia boca de la Buena Moza nos enteramos de que, en su juventud, cuando colocó la bomba en las puertas de un banco-acción que la convirtió en una terrorista—, carecía de convicciones ideológicas; ella, sencillamente, se dejó arrastrar por una causa que no comprendía a cabalidad:

[E]1 año en que estallaron las guerrillas, yo seguía en las mismas, entusiasmada con las prédicas y acoplada a las revueltas callejeras, creyendo en todo eso pero sin atreverme a asumir un compromiso mayor, no porque tuviera miedo sino porque me faltaba la fuerza de la convicción, no me creía preparada, la masa de pobres y explotados por los que había que luchar no cuajaban en mi cabeza como debían cuajar: como una realidad deplorable y patética. (Ibíd. 49).

Es elocuente que las dos terceras partes de los dirigentes de SL hayan sido mujeres (Portocarrero, Profetas 171-2). Este es el caso de Elena Iparraguirre, quien "no era solo la número dos de Sendero Luminoso, fue también la encargada de idear los planes militares de la organización” ibíd. 235). Según Georges-Abeyie, “[e]l terrorismo le proporciona a la mujer cierta oportunidad de liderazgo y fuerza política que no puede conseguir en la 
sociedad $[\ldots][E] s$ una forma de rechazar el papel estereotípico de la mujer sumisa y subordinada" ("Women as Terrorists" 77). La aseveración del criminólogo se condice con comentarios que la Buena Moza le hace a Diego acerca del limitado papel que muchas mujeres desempeñan en una sociedad eminentemente patriarcal, como la peruana. ${ }^{438}$

De acuerdo con Carlos Iván Degregori, los principales dirigentes del SL emergieron de la élite provinciana universitaria que había sido marcada profundamente por "un sistema tradicional en descomposición" (Qué difícil 144). Estos jóvenes ilustrados “[a]brazan el marxismo-leninismo buscando en él sobre todo el orden, tanto en la explicación del mundo como en su proyecto de nueva sociedad. Todo allí debe tener un 'un lugar' jerárquicamente determinado con el partido en el vértice superior de la pirámide. Y todo aquello que no tenga un lugar, debe ser eliminado radicalmente. Surge así un discurso que ofrece una explicación coherente y simple" (ibíd. 144), en contraste con el hegemónico: "rechazan las explicaciones muchas veces retorcidas de los intelectuales limeños" (ibíd.145). El éxito de SL en el reclutamiento de cuadros radica en que "[e]ste discurso encuentra eco centralmente en sectores juveniles provenientes de las áreas rurales andinas", que se sienten desarraigados y que "exigen seguridad, buscan

438 "Bien vistas, con toda su intrascendencia y su carácter alienante, las tareas domésticas hacían posible la vida [...] Eran una necesidad no bien valorada por quienes proclamaban la liberación de la mujer [...] ¿ $[\mathrm{N}] \mathrm{o}$ era igualmente alienante para una mujer proletaria pasarse ocho horas o más al día frente a un telar, una máquina, una palanca o una faja mecánica, sin posibilidad de matizar la tarea? Ganaban un salario pero anulaban sus sueños y, encima, al volver a casa, les esperaba el íntegro de las tareas domésticas. Ganar dinero no las liberaba [...] [L]o que decían mis amigas del movimiento estudiantil: la mujer no se liberaría si primero no se liberaba la sociedad [...] Tal vez lo alienante estaba en el caso de que esas tareas -incluso otras que se cumplían en oficinas o cualquier lugar fuera del hogar- frustraran la vocación intelectual de una mujer" (Hienas 61).

El Perú es una sociedad patriarcal y esto puede apreciarse desde el momento mismo de la fundación del Imperio incaico, cuando Mama Ocllo y las mujeres bajo su tutelaje quedaron subordinadas a Manco Cápac y a los hombres bajo su tutelaje, y quedaron establecidos los roles considerados propiamente masculinos y propiamente femeninos (Inca Garcilaso, Comentarios reales I.XVI.31-32). 
orden, claridad" (ibíd. 146). Pero lo más álgido es que se trata de "sectores ya sin lugar en la sociedad rural tradicional y que tampoco lo encuentran en el Perú 'moderno' asfixiado por la crisis y el desempleo" (ibíd. 146). Por el contrario, para Gonzalo Portocarrero esto no fue así. Según él la propuesta de SL resultó "muy atractiva para jóvenes desgarrados, náufragos a la deriva, que no sabían cómo orientar su inquietud y su libertad" (Profetas 181). En cualquier caso, aunque SL "ofrecía a los jóvenes una utopía que les brindaba identidad totalizante, en el fondo los encerraba en una organización fundamentalista y opresora a través de cartas de sujeción a Abimael Guzmán Reynoso" (HW 436, C. N²2). Portocarrero piensa que tal sujeción podía ser atractiva para quienes no encuadraban en una vía de desarrollo personal (Razones 53).

La personalidad que proyectaba Abimael Guzmán como líder es muy interesante. “[T]ransmitía la sensación de que nunca podía estar equivocado [...] Y la gente le creía, no tanto por lo persuasivo de su argumentación, cuanto por lo decidido y categórico de su enunciación. Las cosas eran como él las decía, ese era el mensaje que transmitía lo rotundo de su voz, lo cerrado e inapelable de sus posiciones, su culto a la intransigencia, su permanente reclamo de representar la veracidad y la consecuencia" (Portocarrero, Profetas 213). Desde luego, era un líder carismático que, “[a]pelando a su seguridad de tener una relación privilegiada con la verdad, $[\ldots]$ desarrolló un poder total sobre sus seguidores, que lo veneraban como a un ser extraordinario. Sus planteamientos no podían discutirse, él tenía que ser obedecido" (ibíd. 213). En Razones, Portocarrero lo presenta como un mesías:

Su visión del mundo se asemeja a ciertos relatos cosmogónicos en los que las fuerzas del caos amenazan constantemente el cosmos. La salvación 
puede estar entonces en manos de un héroe [...] que en un inicio ignora su misión pero que, luego, gracias a su fuerza y valor extraordinarios, podrá conjurar las amenazas y reordenar el mundo. Hay, pues, [...] un discurso alucinado que le permite a Guzmán justificar su pretendida superioridad, la conjunción en sí de las figuras del sabio, el santo y el guerrero. (48-49) Portocarrero observa que "el discurso senderista está calcado sobre el cristiano apocalíptico, pero está coloreado con matices cientificistas [...] Para cualquier persona razonable, sus afirmaciones serían evidentes. No sería necesaria la fe” (ibíd. 70).

Es muy distinta la percepción que, de Guzmán, tenía Miguel Gutiérrez Correa, quien lo conoció en persona. En 1988, Gutiérrez escribió lo siguiente acerca del referido mesías a quien, en la época en que era profesor universitario en Ayacucho, sus admiradores solían llamar el Tigre y Puca Inca, que significa inca rojo (La generación 261): “[S]i Abimael Guzmán y el camarada Gonzalo son la misma persona, entonces quien viene dirigiendo este gran acontecimiento histórico es un hombre de inteligencia superior, de voluntad y disciplina inquebrantables, y [...] si los militantes aceptan su liderazgo no lo hacen por imposición autoritaria, sino por la corrección de su pensamiento y la coherencia entre el ser y el pensar" (ibíd. 263). ${ }^{439}$

\footnotetext{
${ }^{439}$ Miguel Gutiérrez perdió a su esposa y a su hijastro, ambos vinculados a SL" (Ledgard, "Orientalismo" 52). En su libro La generación del 50: Un mundo dividido (1988) aparece la siguiente desgarradora dedicatoria: "A Carlos Eduardo Ayala Aguilar, mi hijo, desaparecido durante el genocidio de los combatientes sociales presos en la isla El Frontón, Callao, Perú, los días 18 y 19 de junio de 1986, con estas palabras de Balzac: 'De todas la semillas confiadas a la tierra, la que da más rápida cosecha es la sangre vertida por los mártires". Y, en el cuerpo del libro, Gutiérrez explica el contexto en el que ocurrió la matanza: "En julio de 1985 el APRA, a través de Alan García, asume la dirección del Estado en medio de una gran algarabía demagógica, pero apenas un mes después de asumir el gobierno da la primera prueba de su vocación genocida con los sucesos de Aqomarca, Huambalpa, Umaru, Bellavista, Pucayacu, y en octubre del mismo año lleva a efecto la primera prueba de su plan de exterminio de los presos políticos acusados de terrorismo en el penal de Lurigancho, acción en que son asesinados 30 combatientes populares; luego este plan siniestro alcanzará su apoteosis de sangre los días 18 y 19 de Junio de 1986 en
} 


\section{¿Una cuestión de definición?}

En una entrevista con Abelardo Sánchez-León, publicada en septiembre de 2003, Fernando Rospigliosi, quien fuera ministro del Interior durante el gobierno de Alejandro Toledo, declara lo siguiente: “[E]1 concepto de terrorista también tiene un significado político [...] [E]n la década del 80 hubo gran debate sobre si se calificaba a Sendero Luminoso y al MRTA como terroristas. No cabe duda de que ellos cometían actos terroristas, pero también se les calificaba de subversivos, de guerrilleros [...]. La definición de terrorista para estos grupos fue muy importante en el camino de aislarlos [...] Calificarlos como terroristas era ponerles una lápida encima, políticamente" (Rospigliosi y Abelardo Sánchez-León, “¿Terrorismo y corrupción?”).

De otro lado, Marcelo Sanhueza señala que el establishment se ha atribuido y monopolizado el "derecho" de determinar cuáles actos de violencia son legítimos y están justificados y cuáles no:

De acuerdo a la ideología capitalista de las clases dominantes, que se ha impuesto y difundido en la actual opinión pública, la democracia occidental representativa se ha erigido como el modelo universal pacífico y ciudadano de administración de los diferentes Estados-naciones contemporáneos. Un problema que se puede visualizar tras estas posiciones, defendidas por organismos internacionales como la Organización de las Naciones Unidas (ONU) o la Unión Europea (UE), es que existe una definición laxa, o derechamente hipócrita de la violencia en

que son asesinados, en uno de los más espantosos y cobardes genocidios de la historia contemporánea, 300 prisioneros de guerra de los penales de Lurigancho, El Frontón y Santa Bárbara” (213). 
la política. En tal perspectiva, se condena y se desconfía de la violencia política antiestatal o antisistémica, porque, como ha advertido Bolívar Echeverría, sólo se acepta como natural la que ha sido institucionalizada y monopolizada por el Estado moderno. Así, el Estado burgués-capitalista se ha transformado en el único ente capaz de resolver conflictos, justificando la administración de la violencia para proteger los privilegios de la sociedad civil burguesa y "garantizar el buen funcionamiento de la circulación mercantil" (Echeverría, "Violencia" 183). Toda violencia que atente contra los intereses oficiales del poder político y económico es, en su versión más reaccionaria, calificada de terrorista o, en una versión más progresista, de vandálica. ("Violencia/contraviolencia").

Michel Foucault, quien vincula inextricablemente el saber con el poder, ${ }^{440}$ señala con sarcasmo que los movimientos populares son presentados como si fuesen "producidos por el hambre, los impuestos, el paro; nunca como una lucha por el poder, como si las masas pudiesen soñar con comer bien pero no con ejercer el poder. La historia de las luchas por el poder y, en consecuencia, las condiciones reales de su ejercicio y de su sostenimiento, siguen estando casi totalmente ocultas. El saber no entra en ello: eso no debe saberse" ("Entrevista sobre la prisión: el libro y su método", La microfísica del poder 32).

¿Qué diferencia, entonces, a un terrorista de un revolucionario o de un guerrillero? En el ámbito internacional, Nelson Mandela, por ejemplo, quien al principio

\footnotetext{
440 "El saber oficial ha representado siempre al poder político como el centro de una lucha dentro de una clase social (querellas dinásticas en la aristocracia, conflictos parlamentarios en la burguesía); o incluso como el centro de una lucha entre la aristocracia y la burguesía" (La microfísica del poder 32).
} 
consideraba que "a nonviolent strategy for political change that focused on mass civil disobedience was the most effective weapon in the struggle against apartheid" (Brookfield, "Radical Questioning" 101), posteriormente fue uno de los principales dirigentes de La Lanza de la Nación, una organización clandestina en la lucha armada contra el apartheid: "Claiming that the government's actions had forced his hand; Mandela moved reluctantly to urge the ANC [African National Congress] to take up arms, in particular to conduct a campaign of sabotage against power stations, arms depots, and communications networks" (ibíd. 102). Mandela fue condenado en 1964 por sus actividades calificadas como terroristas, pero en 1993 recibió el Premio Nobel de la Paz, conjuntamente con Frederik Willem de Klerk, "for their work for the peaceful termination of the apartheid regime, and for laying the foundations for a new democratic South Africa" (“The Nobel Peace Prize 1993”). De otro lado, en la historia reciente del Perú, el 29 de octubre de 2000 los hermanos Ollanta y Antauro Humala se alzaron en Locumba (Tacna), exigiendo la renuncia del entonces presidente Fujimori. A pesar de haberse sublevado, el Congreso les concedió una amnistía basada en que habían ejercido el "derecho a insurrección contra un gobierno ilegítimo y totalitario". Poco tiempo después, Ollanta Humala llegó a ser presidente del Perú, democráticamente elegido (2011-2016).

Existiría consenso académico en la siguiente definición de terrorismo formulada por Schmidt (entiendo que se refiere a Alex Schmidt), en 1988, y que ha sido acogida por las Naciones Unidas:

Terrorism is an anxiety-inspiring method of repeated violent action, employed by (semi-) clandestine individual, group or state actors, for 
idiosyncratic, criminal or political reasons, whereby —in contrast to assassination - the direct targets of violence are not the main targets. The immediate human victims of violence are generally chosen randomly (targets of opportunity) or selectively (representative or symbolic targets) from a target population, and serve as message generators. Threat-andviolence based communication processes between terrorist (organization), (imperiled) victims, and main targets are used to manipulate the main target (audience(s), turning it into a target of terror, a target of demands, or a target of attention, depending on whether intimidation, coercion, or propaganda is primarily sought.

Por otro lado, José Fernández Salvatteci señala las siguientes características de un guerrillero que, en algunos aspectos, son parecidas a las de un terrorista:

El guerrillero, si bien cumple funciones militares, no olvida que su tarea esencial es la política: la propaganda, la agitación, el diseminar ideas revolucionarias. Se da cuenta de que su propia lucha armada no pasa de ser un instrumento de agitación y que su objetivo superior es elevar el nivel de madurez revolucionaria y, en consecuencia, la participación popular hasta llegar al punto en el cual la revolución se generalice por todo el país y las masas populares cumplan su objetivo final: destruir el orden existente e implantar las bases de uno nuevo. (30)

Durante la Guerra Interna, miembros de las Fuerzas Armadas asesinaban a gente "para enviar mensajes a Sendero [...] [H]acían alarde de su condición de elementos 
gubernamentales para evitar equívocos en la recepción del mensaje" (Hidalgo Morey, Sendero Luminoso 289-90).

Retomando la novela de Morillo, en ella se relata que "[e]l APRA había hecho un pacto electoral con sus enemigos" ${ }^{441}$ y que el padre de la Buena Moza, "conjuntamente con otros apristas de la guardia vieja, creyéndose traicionados por el jefe y los altos mandos del partido, se apartaron de la vida partidaria y juraron no solo recuperar la fe en los principios revolucionarios primigenios sino también emular las acciones heroicas de quienes ofrendaron su vida en la revolución de 1931” (44-5). Es claro que el padre de la Buena Moza era un subversivo, incluso un guerrillero y que, como tal, empleaba la violencia, pero no cometió crímenes de lesa humanidad. De acuerdo con la definición que proporciona la CVR, "[1]os crímenes de lesa humanidad hacen referencia a actos contra la vida y la integridad personal, actos de tortura y actos contra la libertad individual, entre otros, que para ser tales deben ser perpetrados contra la población civil y haberse practicado de una manera sistemática o reiterada en un tiempo de paz o en el curso de un conflicto armado de cualquier índole" ( $H W$ 33). El padre de la Buena Moza no arremetió contra blancos-personas o instalaciones-civiles sino militares.

\section{Desengaño de numerosos seguidores de SL}

Si al inicio SL logró persuadir ideológicamente a muchos de sus seguidores, las víctimas que sobrevivieron a la violencia demencial se desengañaron de lo que la organización

\footnotetext{
${ }^{441}$ En 1956, "el Jefe Máximo del APRA [Víctor Raúl Haya de la Torre] decidió respaldar políticamente a uno de los representantes del bloque oligárquico [Manuel Prado Ugarteche], a cambio de la legalización de su partido y del apoyo que le era necesario para alcanzar la presidencia en las siguientes elecciones de 1962. Para tal efecto, la dirigencia aprista abandonó su ideario nacionalista y revolucionario y se aisló de las protestas sociales [...] [E]sta insólita decisión sustentada en el cálculo político inmediato determinó que importantes sectores juveniles se desgajaran del partido y [...que se sumaran] a los nuevos actores reformistas y nacionalistas" (Cotler, Clases, Estado y nación en el Perú 20-1).
} 
subversiva representaba como una genuina propuesta de cambio, debido a que SL "no tomó en cuenta las necesidades y aspiraciones económicas del campesinado, ni sus organizaciones propias ni sus especificidades culturales, y convirtió, más bien, a los campesinos en 'masa' que debía someterse a la voluntad del partido" ( $H W$ 436, C. N²4). Sin embargo, lo peor fue que “[1]a disidencia individual en la 'masa' llevó a asesinatos y aniquilamientos selectivos, y la disidencia colectiva condujo a masacres y arrasamientos de comunidades enteras" (ibíd.).

\section{Formación de rondas campesinas y comités de autodefensa}

Como el Estado no garantizaba la seguridad y protección que requerían algunos poblados, para defenderse de SL los vecinos de los caseríos y aldeas organizaron las llamadas rondas campesinas, que luego tuvieron que ser reguladas por el ordenamiento jurídico (Ley N²7908). “[P]oco a poco los campesinos fueron alejándose de la insurrección senderista y formando comités de autodefensa en coordinación con las fuerzas del orden” (ibíd. 198). Pero, “[a] pesar de existir iniciativas propias de las comunidades para formar rondas o comités de autodefensa en sus zonas, la mayor parte de las experiencias recogidas dan cuenta de cierta presión por parte de las Fuerzas Armadas y Policiales para que se constituyan grupos armados desde la sociedad civil capaces de apoyar y hasta, en algunos casos, reemplazar a estas instituciones en las diversas zonas de conflicto" ( $H W$ 378). Tácticamente, algunos miembros de estas organizaciones paramilitares también se autodenominaban ronderos, probablemente con el propósito de generar confusión y de inculpar a otros por los crímenes cometidos. "En ningún otro actor de la guerra, la línea divisora entre perpetrador y víctima, entre héroe y 
villano es tan delgada y tan porosa como en los Comités de Autodefensa (CAD) o rondas campesinas contrasubversivas [...] Pacificadores para unos, asesinos para otros" [Informe Final de la CVR, tomo II, 1.5). ${ }^{442}$

De acuerdo con la Doctrina de la guerra justa de la Iglesia católica-parcialmente cónsona con los principios de Jus ad bellum—, el derecho a la legítima defensa está justificado cuando: a) todos los medios para poner fin a la agresión han resultado impracticables o ineficaces y se han agotado todas las instancias para llegar a un acuerdo por la vía pacífica, b) el daño causado por el agresor es duradero, grave y cierto, c) exista la posibilidad real de tener éxito (entiéndase, de resultar vencedor), y d) el empleo de armas no cause peores males y desórdenes que los que se pretende eliminar (Catechism of the Catholic Church numeral 2309). ${ }^{443}$ Sin embargo, en el numeral 127 de su encíclica Pacem in terris [La paz entre los pueblos], de 1963, Juan XXIII concluye que, "en nuestra época, que se jacta de poseer la energía atómica, resulta un absurdo sostener que la guerra es un medio apto para resarcir el derecho violado". En la práctica, si no se ejerce el derecho a la autodefensa, el enemigo se fortalece y, por ende, se torna aún más peligroso. En aparente contradicción, si bien "[1]a CVR reconoce el derecho de los campesinos a la autodefensa en el contexto excepcional planteado por la agresión senderista" (ibíd. 444, C. №66), para Lerner Febres, "[1]a violencia deslegitima cualquier causa que uno quiera defender" (The True Story of Liz 22:48-23:21).

\footnotetext{
$442<$ http://www.derechos.org/nizkor/peru/libros/cv/ii/15.html>

${ }^{443}$ Catecismo de la Iglesia católica, segunda edición, Parte tres: Vida en Cristo, Sección dos: Los diez mandamientos, Capítulo dos: “Amarás a tu prójimo como a ti mismo”, Artículo 5: El quinto mandamiento, III: Salvaguardando la paz, Evitando la guerra, numeral 2309).

<http://www.scborromeo.org/ccc/p3s2c2a5.htm\#2309>
} 


\section{Responsables de las víctimas fatales}

De una cifra estimada de 69280 muertos o "desaparecidos" durante el período comprendido entre los años 1980 y 2000, sólo 23969 han sido identificados (ibíd. 17). SL es responsable del 54\% de las víctimas fatales reportadas a la CVR (ibíd. 435, C. $\mathrm{N}^{\circ} 13$ ), el MRTA lo es del 1.5\% (ibíd. 438-9, C. $\mathrm{N}^{\circ} 43$ ) y “[1] os agentes del Estado Fuerzas Armadas y Policía-, los comités de autodefensa y los grupos paramilitares son responsables del $37 \%$ de los muertos y desaparecidos reportados a la CVR. De este porcentaje, los miembros de las Fuerzas Armadas son responsables de poco más de los tres cuartos de los casos" (ibíd. 19). Lo que es peor: "[L]a tortura y la desaparición forzada de personas [por parte de las fuerzas de represión del Estado] [...] no son hechos aislados sino una práctica sistemática". Asimismo, "determinados comportamientos terroristas constituyen prácticas sistemáticas y no sólo hechos aislados o difíciles de evitar en las situaciones en que se desarrolló el conflicto interno" (ibíd. 32-3). Para Salomón Lerner Febres,

[1]a cifra [69 mil víctimas fatales] es demasiado grande como para que nuestra Nación permita que se siga hablando de errores o excesos de parte de quienes intervinieron directamente en estos crímenes. Y es, también, demasiado estridente y rotunda como para que alguna autoridad o ciudadano cualquiera pueda alegar ignorancia en su descargo. Este informe expone, pues, un doble escándalo: el del asesinato, la desaparición y la tortura masivos, y de la indolencia, la ineptitud y la indiferencia de quienes pudieron impedir esta catástrofe humana y no lo hicieron. ( $H W$, Prefacio de Salomón Lerner Febres a la primera edición 9). 
Gonzalo Portocarrero destaca la no aceptación cabal de responsabilidades por parte de los actores armados: "Según sus portavoces, los militares habrían arriesgado su vida para defender la democracia y ahora se veían traicionados, enjuiciados, y perseguidos; según ellos se podría hablar de 'excesos', de eventos singulares en la lucha contrasubversiva, como las masacres de mujeres y niños, de gente inocente. Situaciones desde luego lamentables pero que se explicarían por el propio frenesí de la guerra" (Profetas 198). En el bando contrario, aunque la estrategia de SL "implicó el uso sistemático y masivo de extrema violencia y terror, y desconoció deliberadamente las normas básicas de la guerra y los principios de los derechos humanos" ( $H W 18)$,

[1]os portavoces de Sendero Luminoso [...] no han reconocido el haber puesto en práctica una estrategia donde el terror era un elemento fundamental. Cuanto más, los líderes del movimiento reconocen excesos puntuales, y hasta dicen que necesarios, para mantener la credibilidad de su propuesta entre la población civil. A Sendero Luminoso no le habría quedado más remedio que compensar su falta de poder de fuego con una crueldad extrema. (Portocarrero, Profetas 199)

No obstante, Portocarrero se contradice cuando relata que Abimael Guzmán asume y justifica la matanza de Lucanamarca:

En 1983, campesinos de Huancasancos, movilizados por militantes senderistas, entraron a sangre y fuego a la comunidad Lucanamarca. Fueron asesinadas alrededor de 80 personas. Hombres, mujeres y niños. La crueldad fue extrema. Guzmán defiende esta acción señalando que fue emprendida como resultado de un cálculo preciso y que sus consecuencias 
son favorables, de manera que se justifica plenamente. (Portocarrero, Razones 35-6)

\section{Inconsecuencia de Abimael Guzmán con la doctrina que proclamaba}

Mediante el sistema de reclutamiento forzado en los caseríos y poblados andinos, SL lograba "adeptos" que engrosaban sus filas con tropa que le servía de carne de cañón:

La CVR hace notar la profunda irresponsabilidad y menosprecio del PCPSL hacia sus propios militantes, a quienes se inducía a matar y a morir de la manera más cruel y sanguinaria, mientras que sus dirigentes máximos, especialmente Abimael Guzmán Reynoso, permanecían en Lima, exentos de riesgos físicos y privaciones, prácticamente durante todo el conflicto.

Dice Elías en Hienas: "Yo he tenido que hacer una rectificación de mi línea y de mi concepción revolucionaria [...] y te puedo asegurar que ahora sí estamos en vísperas de la verdadera revolución, la que avanzará no desde un foco, sino del corazón de las masas organizadas. Se acabó el burocratismo de los falsos revolucionarios enquistados en la ciudad (343) (énfasis mío). Es pertinente mencionar que, siguiendo las tácticas de Mao Zedong para lograr "zonas liberadas" que, añadidas progresivamente unas a otras, liberarían a todo el país, los subversivos optaron por la guerra de guerrillas, puesto que es "la única arma revolucionaria que tiene un pueblo o parte de él, débilmente armado y mal equipado, para enfrentarse y lograr victoria frente a determinadas Fuerzas Armadas, de armas técnicas y modernas, pertenecientes a un Poder gubernamental" (Fernández Salvatteci, Terrorismo y guerra sucia 9). Con esa mentalidad, reflexiona Elías: "[L]a revolución tiene que empezar donde corresponde: en el campo, para luego avanzar a las 
ciudades, cercándolas" (343). Es por eso que, en los años 80, “[d]esde el campo el terror llega a las ciudades; y muchas son las noches que se pasan a la luz de las velas [los terroristas solían volar torres de alta tensión]" (Noemí 44). En este tipo de combate desigual, "un ejército pierde si no gana, una guerrilla gana si no pierde" (Henry Kissinger).

Lo cierto es que Guzmán, en vez de luchar en el monte al frente de sus seguidores, optó por permanecer en la comodidad de la ciudad". La prédica y la práctica no coincidían. "Esta incongruencia se expresó de la manera más patente cuando, tras ser capturado, $[\ldots]$ solicitó al gobierno un "acuerdo de paz" junto con un reconocimiento explícito y sumamente elogioso al gobierno dictatorial de Alberto Fujimori y Vladimiro Montesinos. (Ibíd. 438, C. N³1). Gonzalo Portocarrero también resalta la falta de coherencia de Abimael Guzmán con la doctrina que proclamaba, puesto que la consigna de dar la vida por la causa-como le exigía a sus seguidores-estuvo fuera de consideración cuando le llegó el momento de la verdad a este mesías:

En sus primeras declaraciones como prisionero Guzmán interpretó su captura como un 'recodo; en una marcha que debería proseguir. No obstante, unos meses después, Guzmán cambia de posición. Reclama un 'acuerdo de paz' y conmina a sus partidarios a dejar la lucha armada $[\ldots]$ [L]a inconsecuencia del 'Presidente Gonzalo' lo llevó a un rápido y total descrédito. En poco tiempo su prestigio se desvaneció y la gente que alguna vez simpatizó con su planteamiento pretendió nunca haberlo tomado en serio. La insurrección colapsó. (Profetas 199) 
La insurrección colapsó porque estaba centrada en un falso líder mesiánico, en una persona y no en una institución con una verdadera estructura organizacional sólida que fuera capaz de trascender la acefalía temporal.

\section{Desvalorización de la vida humana e impunidad}

Hubo sevicia entre los actores armados de ambos bandos en la Guerra Interna: "Hemos encontrado que los crímenes cometidos contra la población peruana no fueron $[\ldots]$ atropellos de ciertos sujetos perversos que se apartaban, así, de las normas de sus organizaciones [... sino] la perpetración masiva de crímenes coordinados o previstos por las organizaciones o instituciones que intervinieron directamente en el conflicto" ( $H W$, Prefacio de Salomón Lerner Febres a la primera edición 11). Del lado de los insurgentes, debido a "su carácter inherentemente criminal y totalitario, despectivo de todo principio humanitario, el PCP-SL es una organización que, en cuanto tal, no puede tener cabida en una nación democrática y civilizada" (ibíd.). De lado del Estado, "en ciertos períodos y lugares, las fuerzas armadas incurrieron en una práctica sistemática o generalizada de violaciones de derechos humanos y [...] existen fundamentos para señalar la comisión de delitos de lesa humanidad, así como infracciones del derecho internacional humanitario [...] Ejecuciones extrajudiciales, desapariciones, torturas, masacres, violencia sexual contra las mujeres y otros delitos igualmente condenables conforman, por su carácter recurrente y por su amplia difusión, un patrón de violaciones de los derechos humanos" (ibíd.).

En la novela, Diego reflexiona de la siguiente manera acerca de la impunidad con que se cometieron los crímenes de la guerra sucia: 
Los horrendos crímenes cometidos por efectivos policiales, militares o paramilitares en la represión contra la insurgencia nunca tendrán castigo. Y no importa que gran parte de las víctimas hayan sido inocentes. Hace tiempo, un general considerado demócrata, dijo con cinismo que los militares eran profesionales de la muerte, que su carrera era una preparación para matar, que cuando les tocara actuar no iban a tener miramientos y que si $[\ldots]$ en una acción se llegara, por ejemplo, a matar a sesenta, de los cuales cincuenta y siete fueran inocentes y tres culpables, la acción quedaba plenamente justificada" (328).

Portocarrero refiere las siguientes declaraciones del general del Ejército peruano Luis Cisneros Vizquerra (Buenos Aires, 1926 - Lima, 1995) a la revista Quehacer, en las que "anuncia que las Fuerzas Armadas 'tendrán que comenzar a matar senderistas y no senderistas, porque esa es la única forma de asegurarse el éxito. Matan a 60 personas y a lo mejor allí hay 3 senderistas. Y seguramente la policía dirá que los 60 eran senderistas”. Portocarrero refiere, asimismo, que Cisneros Vizquerra declaró a la revista Caretas: "Yo me sentía ufano de estar sentado en el banquillo de los acusados, como pueden estarlo ahora mis colegas argentinos, porque ellos salvaron a su país de la subversión" (Razones 77-8). ${ }^{444}$ Cabe recordar que Cisneros Vizquerra fue ministro del Interior (1976-1978) durante el gobierno de Francisco Morales Bermúdez, y ministro de Guerra (1981-1983) durante el gobierno de Fernando Belaúnde Terry.

${ }^{444}$ Las siguientes referencias aparecen como pie de página $\mathrm{N}^{\circ} 10$ en el libro de Portocarrero: "González, Raúl (1983). 'Ayacucho: la espera del gaucho'. Quehacer, (24), 44-67. También en: Caretas, (817), 17 septiembre 1984” (78). José Fernández Salvatteci recurre a la misma cita (69). 
La distancia que nos separa (2015) de Renato Cisneros (hijo de Luis Cisneros Vizquerra) incluye el mentís de que su obra es una "novela de autoficción" y que, por lo tanto, ni los hechos narrados ni los personajes descritos deben ser juzgados fuera de la literatura (3). En todo caso, resulta sumamente interesante que el autor "cite" las siguientes declaraciones que hace el personaje el Gaucho Cisneros-el general que representa (que representaría) a su padre, en la vida real—, cuando ya no ejerce cargos públicos y se siente exento de guardar las formas:

"Si los jueces tienen miedo, los terroristas deben ser juzgados por tribunales militares. Punto", dice en Oiga. "Si el terrorismo llegara a los niveles argentinos de los años setenta, las Fuerzas Armadas se verán obligadas a tomar el poder", advierte en el Canal 4. "Hay que interceptar los teléfonos y comunicaciones postales, yo lo hice antes", revela en Expreso. [...] "Si están cayendo más senderistas, debe ser porque las Fuerzas Armadas tienen mejor puntería", ironiza en El Comercio. "No podemos tener una democracia mojigata para tiempos de paz cuando el país vive una situación de guerra prolongada", observa en Caretas. "No puedo entender cómo en una zona de guerra se pretende mantener el estado de derecho. Le encargamos a las Fuerzas Armadas la eliminación de Sendero y cuando va a apretar el gatillo aparece el Fiscal de la Nación para ver si al hombre lo vamos a matar de frente o de costado, y se presentan el abogado, el periodista, el fotógrafo, el cura. ¿Dónde estamos?", se queja en El Nacional. (112) 
En el Prefacio a la primera edición del Informe Final de la CVR, Lerner Febres concluye: "[E]xiste la culpa de la omisión, que involucra a todos los que dejamos hacer sin preguntar en los años de la violencia [...] Pero al mismo tiempo advertimos que existen responsabilidades concretas $[\ldots][$ E]1 Perú $[\ldots]$ no puede permitir la impunidad $[, \ldots]$ incompatible con la dignidad de toda nación democrática" ( $H W 10)$.

De acuerdo con Gonzalo Portocarrero, en la actualidad "[c]ombatir el terror con un terror más grande es considerado como una estrategia válida". Se considera que es mejor "sospechoso muerto que un terrorista vivo". Portocarrero interpreta que, para muchos peruanos, "[e]1 uso sistemático del terror es una verdad que todos saben pero que nadie debería decir en los espacios públicos. Es un tema tabú sobre el que nadie debería pensar. Y es que el uso del terror con la población civil pone en evidencia una realidad inconfesable, la vigencia de una actitud que convierte a la vida del otro, aunque sea un compatriota, ciudadano o parte del pueblo que se pretende redimir, en totalmente prescindible (Portocarrero, Profetas 200).

\section{La matanza de La Cantuta}

En Hienas, el terror que experimenta Diego al presentir su inminente muerte, hace que evoque, mediante "rememoraciones libres, gatilladas por la situación de indefensión y carcelería" (Ángeles, "Dos novelas sobre la guerra"), la matanza de La Cantuta, un hecho macabro ocurrido durante el fujimorato que ilustra la manera en que miembros del Servicio de Inteligencia Nacional (SIN) violaban los derechos humanos y cometían crímenes de lesa humanidad (Hienas 327-8). 
El 18 de julio de 1992, el Grupo Colina-brazo paramilitar del Servicio de Inteligencia del Ejército (SIN)—secuestró y desapareció a nueve estudiantes y a un profesor de la Universidad Nacional de Educación Enrique Guzmán y Valle—ubicada en La Cantuta, un lugar en la periferia rural de Lima Metropolitana-, cuyo consejo estudiantil estaba copado por miembros de SL. ${ }^{445}$ La "intervención" del Grupo Colina en La Cantuta habría sido en respuesta al atentado terrorista que SL había realizado dos días antes, el 16 de julio de 1992, en la calle Tarata de Miraflores (un distrito limeño de clase media), detonando dos coches bomba, en el que perdieron la vida 25 personas y hubo más de 200 heridos. A la vez, el atentado de la calle Tarata fue la venganza de SL por los casi 40 senderistas asesinados en el mes de abril en el penal de Cantogrande, en circunstancias no esclarecidas (Portocarrero, Razones 38).

La matanza de La Cantuta es un hecho macabro que ilustra la manera en que algunos miembros del Grupo Colina—brazo paramilitar del Servicio de Inteligencia del Ejército-violaban los derechos humanos y cometían crímenes de lesa humanidad:

En La Cantuta secuestraron en horas de la madrugada a diez [sic] estudiantes y un profesor. Siguen en paradero desconocido a pesar de las evidencias del secuestro [...] El gobierno y las instancias policiales negaron toda vinculación con esta desaparición masiva. Una congresista del régimen llegó a decir, con incalificable descaro, que la versión del secuestro era una patraña, toda vez que el profesor y los alumnos habían

\footnotetext{
445 Otros crímenes atribuidos al Grupo Colina durante el fujimorato son la masacre de Barrios Altos (3 de noviembre de 1991), la desaparición de diez campesinos del valle del río Santa (2 de mayo de 1992), el asesinato de Pedro Huilca, el secretario general de la Confederación General de Trabajadores del Perú (CGTP) (18 de diciembre de 1992), y el asesinato de Pedro Yauri, un periodista que investigó el secuestro de cuatro miembros de la familia Ventocilla por efectivos militares el 25 de mayo de 1992.
} 
decidido pasar a la clandestinidad [...] Los familiares se cansaron de reclamar en las dependencias comunes y especiales de la policía y ya no sabían ante quién denunciar. No todos les dieron crédito pero algo de la verdad se llegó a publicar [...] [L]as consecuencias no se hicieron esperar: como en casos anteriores, más de una de esas personas, las únicas capaces de aportar pruebas concluyentes, fueron encontrados [sic]...en algún lugar despoblado con un balazo en la cabeza o atropellados en un lamentable accidente de tránsito. (327-8)

El 21 de febrero de 1994, los responsables de la matanza de La Cantuta fueron sentenciados y condenados por el Consejo Supremo de Justicia Militar. Sin embargo, contando con el apoyo de las fuerzas armadas, el 5 de abril de 1992, Alberto Fujimoripresidente de la República, democráticamente elegido en las elecciones generales de 1990 - había disuelto el Congreso de la República y suspendió temporalmente las actividades del Poder Judicial. En el nuevo orden, "en muchos casos, la mayoría oficialista del Congreso después del golpe de Estado [“autogolpe”] [...] no solo abdicó su función constitucional de fiscalización, sino que avaló y promovió el encubrimiento y la impunidad [...] El Parlamento se convirtió en la práctica en una caja de resonancia de los planteamientos del Poder Ejecutivo y del SIN [Servicio de Inteligencia Nacional]" ( $H W$ 455, C. $\left.\mathrm{N}^{\circ} 122\right)$.

Es así que, el 14 de junio de 1995, entre gallos y medianoche, en una sesión nocturna el Congreso, de mayoría fujimorista, aprobó la "Ley de Amnistía" (Ley $\mathrm{N}^{\circ} 26749$ ), cuyo primer artículo estipula lo siguiente: 
Concédase amnistía general al personal Militar, Policial o Civil, cualquiera que fuese su situación Militar o Policial o Funcional correspondiente, que se encuentre denunciado, investigado, encausado, procesado o condenado por delitos comunes y militares en los Fueros Común o Privativo Militar, respectivamente, por todos los hechos derivados u originados con ocasión o como consecuencia de la lucha contra el terrorismo y que pudieran haber sido cometidos en forma individual o en grupo desde Mayo de 1980 hasta la fecha de la promulgación de la presente Ley. [...]

El segundo artículo es un tanto más concluyente: "Los hechos o delitos comprendidos en la presente amnistía, así como los sobreseimientos definitivos y las absoluciones, no son susceptibles de investigación, pesquisa o sumario; quedando, todos los casos judiciales, en trámite o en ejecución, archivados definitivamente. [...]”. Al mes siguiente de la promulgación de esta ley, empezaron a salir en libertad los prisioneros vinculados a la masacre de la Cantuta, así como los acusados o presos por otros crímenes durante la lucha antiterrorista. En relación con la Ley de Amnistía, la CVR considera que "[1]a dictadura de Alberto Fujimori pretendió legalizar de forma espuria la impunidad a las violaciones de los derechos humanos realizadas por agentes del Estado, logrando que el Congreso Constituyente Democrático aprobase por mayoría dos leyes de amnistía que vulneraban disposiciones constitucionales y tratados internacionales soberanamente ratificados por el Perú” (Ibíd. 457, C. N¹29). Afortunadamente, un lustro y un año más tarde la Corte Interamericana de Derechos Humanos_órgano judicial de la OEA—dejó sin efecto la Ley de Amnistía y la ley complementaria 26492. 
Otros ejemplos de leyes de impunidad son la Ley de Punto Final (1986) y la Ley de Obediencia Debida (1987), en la Argentina; así como el Decreto Ley N²191 (1978), en Chile, que concedía amnistía "a todas las personas que, en calidad de autores, cómplices o encubridores hayan incurrido en hechos delictuosos, durante la vigencia de la situación de Estado de Sitio" (durante el período comprendido entre el 11 de septiembre de 1973 y el 10 de marzo de 1978). Por decir lo menos, este tipo de leyes promueve la impunidad y la recurrencia de los crímenes, amén de insultar la capacidad que tienen los pueblos para enfrentar su pasado.

\section{Racismo y exclusión socioeconómica: el meollo del problema}

La mayoría de las víctimas reportadas a la CVR pertenecían a la población civil más desfavorecida desde el punto de vista socioeconómico: el 85\% de las víctimas provenía de los departamentos de Ayacucho, Junín, Huánuco, Huancavelica, Apurímac y San Martín. “[E]sos departamentos son tan pobres que en conjunto concentran tan sólo el 9\% del ingreso de todas las familias peruanas" ( $H W$ 433-4, C. $\left.\mathrm{N}^{\circ} 4\right)$. Adicionalmente, el $68 \%$ de las víctimas no tenía educación secundaria (ibíd. 434, C. №7). ${ }^{446}$ Más aún, “conjuntamente con las brechas socioeconómicas, el proceso de violencia puso de manifiesto la gravedad de las desigualdades de índole étnico-cultural”, dado que el idioma materno del $75 \%$ de las víctimas fatales era el quechua u otra lengua nativa (ibíd. 434, C. $N^{\circ}$ 6). Lerner Febres señala que, en el Perú, "las diferencias no son solamente eso; constituyen también pretextos para la preservación de un orden jerárquico cuestionable

\footnotetext{
${ }^{446} \mathrm{El} 68 \%$ es un porcentaje que puede ser comprendido a cabalidad sólo si se les contrasta con el $40 \%$ del total de la población peruana que compartía la característica de no poseer educación secundaria, de acuerdo con los datos del censo nacional de 1963 ( $H W$ 434, C. ํ7).
} 
$[\ldots] \quad[$ S]e presume como dato natural, y por ende innecesario de justificarse, la superioridad de unos sobre otros en razón de sus orígenes étnicos" ( $H W$, Prefacio i). La academia se refiere a este mecanismo como "ideología" (Marger 28). En la labor realizada por la CVR se hizo evidente que

el develamiento de nuestra propia constitución como sociedad enemistada consigo misma. Los recelos entre sectores sociales y culturales diversos y atendidos de manera muy desigual por el Estado; las presunciones altaneras de los poderosos sobre los excluidos; la vocación elitista de los poderes públicos, todo ello apareció como el sustrato histórico de la violencia misma, como el fermento que ayuda a explicar — aunque de ningún modo lo justifique - el proceder atroz de los actores armados y la complacencia de ciertos sectores sociales con la violencia, según el lado del que ella viniera. ( $H W$, Prefacio i)

Si el tema de la identidad era, per se, sumamente complejo, la situación se agravó aún más a raíz de la Guerra Interna, principalmente por la desconfianza y el resentimiento - si no el odio - que el conflicto armado ha acentuado entre los peruanos. Dos de las conclusiones más trascendentales de la CVR son las siguientes: "[L]a tragedia que sufrieron las poblaciones del Perú rural, andino y selvático, quechua y asháninka, campesino, pobre y poco educado, no fue sentida ni asumida como propia por el resto del país; ello delata, a juicio de la CVR, el velado racismo y las actitudes de desprecio subsistentes en la sociedad peruana a casi dos siglos de nacida la República” (ibíd. 434, C. $\left.N^{\circ} 9\right)$. Adicionalmente, "[1]a CVR encuentra [...] un potencial genocida en proclamas del PC-PSL que llaman a 'pagar la cuota de sangre' (1982), 'inducir genocidio' (1985) y 
que anuncian que 'el triunfo de la revolución costará un millón de muertos' (1988). Esto se conjuga con concepciones racistas y de superioridad sobre pueblos indígenas" (ibíd. 436, C. $\mathrm{N}^{\circ} 21$ ). Reñidos con la religión católica y habiendo sepultado a los dioses del panteón andino, ya sin expectativa de trascendencia ultramundana los senderistas ateos no tendrán reparo en segarle la vida a quien se interponga en su camino.

El racismo y la inequidad socioeconómica — traducidos en la postergación de las etnias nativas (y también de las mestizas con un fuerte componente indígena) durante siglos y su consiguiente exclusión del plan nacional republicano-, el resentimiento de las víctimas sobrevivientes de la Guerra Interna (que, en la mayoría de los casos, pertenecen a las etnias nativas y/o a las clases postergadas); todo esto sumado al odio de clases, a la sed de venganza y a la falta de respeto por la vida humana constituirían, en resumen, la causa central del gran problema que hoy enfrentamos los peruanos en relación con la (re)construcción de nuestra identidad.

\section{Situación actual}

El diagnóstico de Lerner Febres en el 2008, cinco años después de que la CVR presentara su Informe Final, es el siguiente:

En sectores considerables de la población germina cierta convicción sobre el valor superior de la paz y de los métodos de defensa del orden público respetuosos de la vida humana. Hoy, a diferencia de ayer, son ya minoría - aunque existan todavía - las voces que exigen sangre y fuego ante cualquier expresión de descontento social o de reclamo de justicia. También las ideologías de la revolución violenta —el hechizo de la 
redención por el fuego- se han difuminado y han perdido toda gravitación moral. ( $H W$, Prefacio de Lerner Febres i-ii)

Éste sería el aspecto positivo y esperanzador. Sin embargo,

En lo sustancial, el Perú de hoy todavía se parece bastante al Perú de hace treinta años, cuando se preparaba el proyecto criminal de Sendero Luminoso [...] Se está desatendiendo la lección dejada por la violencia. El país — y sobre todo sus sectores privilegiados - parecen haber decidido que se puede vivir indefinidamente tal como habíamos vivido hasta fines del siglo XX: con espasmos de crecimiento económico en un contexto de perdurable exclusión. (Ibíd. ii)

En la actualidad, el terrorismo ha sido prácticamente erradicado en el Perú, aunque es posible que todavía subsistan grupúsculos de senderistas que aspiren a reorganizase. No obstante la aparente calma, Jennifer S. Holmes alerta lo siguiente en relación con el narcoterrorismo:

Although some claimed victory, Sendero was never completely absent in the coca growing regions such as the VRAEM (Valleys of the Apurímac, Ene and Mantaro rivers) and the Upper Huallaga Valley (Kernaghan 2009, 16). Attacks throughout the country over the last decade [2001-2010] have caused concern (Caretas 2009). For example, during the 2008 APEC meeting in Lima, Sendero targeted top-level officials, politicians, and civilians. In November 2010, an army patrol was ambushed in San Martín de Pangoa in the VRAEM and besieged for almost a month before being rescued by government forces (Gorriti 2011). The deaths of dozens of 
Peruvian soldiers and police in ambushed, attacks on military bases, and failed government offenses signal that Sendero needs to be taken seriously; even though, its violence has not reached the level of the late 1980s and early 1990s. ("Sendero Luminoso after Fujimori” 30-1)

De hecho, "[e]l miedo al regreso de la violencia es frecuente [..., en especial entre las comunidades asháninkas asentadas en el valle del río Ene [, quienes] todavía se sienten desamparados por el Estado y temen el regreso de los subversivos" ( $H W$ 355). En general, "[e]l daño psicológico — individual y social—creado por la violencia [se hace palpable en] el denso clima de miedo y desconfianza creado por la conducta abusiva y criminal de los actores armados contra la población indefensa” (ibíd. 345).

Las experiencias traumáticas de muchas víctimas se agravaron debido al prolongado y obligado silencio que debieron guardar y que les impidió procesarlas adecuadamente. Afortunadamente, en los últimos años "[1] as organizaciones de víctimas de violaciones de derechos humanos se han multiplicado [y] el silencio impuesto durante años ha sido sustituido por la demanda ciudadana" (ibíd., Prefacio de Lerner Febres x). Por otro lado, "la apuesta de las mayorías es olvidar. La idea es que la vida sigue y que no tiene sentido estancarse en el pasado. La consecuencia es que no hay una presión significativa por esclarecer los hechos y menos por solucionar las responsabilidades de las violaciones a los derechos humanos. (Portocarrero, Profetas 200). 


\section{EPÍLOGO Y CONCLUSIONES}

Academic evidence is a euphemism for linguistic colonization of oral tradition

and popular memories

Gerald Vizenor (Manifest 183)

Como el lector habrá podido apreciar en los capítulos precedentes, el etnovaivén (blanqueamiento $\leftrightarrow$ cholificación) es la estrategia de resistencia que ha desarrollado el subalterno peruano para hacerle frente a la colonialidad y que, a la vez, el subalterno fragua su singularidad cultural entre el etnovaivén y el etnobúmeran. En algún momento y lugar del desplazamiento entre estas dos posturas antagónicas se cristalizan identidades sincréticas con características distintivas que, en la actualidad, se manifiestan a través de la cultura chicha. El hecho de oscilar permanentemente entre polos contrarios (blanqueamiento $\leftrightarrow$ cholificación y etnovaivén $\leftrightarrow$ etnobúmeran) produce como resultado identidades fragmentadas, esquizofrénicas. Ante esta realidad, Luis Guillermo Lumbreras se pregunta cómo llevar a cabo las reformas estructurales que necesita un país "mortalmente escindido y modularmente fracturado" ("Esbozo de una crítica de la razón colonial" 74).

Las identidades culturales que surgen como resultado de las estrategias de resistencia del subordinado (cultura chicha) no equivalen, en lo absoluto, por más sui géneris que sean, a una identidad nacional peruana. Son dos las razones de este impedimento: en primer lugar, aunque el subalterno represente una mayoría numérica en función de la cantidad de habitantes, su condición de subalterno lo define como una minoría. Por ende, no es su discurso el que prevalece en la sociedad. En 1990 Uriel 
García Cáceres especulaba que una explosión demográfica mestiza produciría una masa crítica capaz de cambiar la situación sociorracial del Perú ("El día que el Perú se jodió” 134). Sin embargo, aunque ahora los mestizos constituyen el grueso de la población y muchas cosas han cambiado para bien desde entonces, todavía no ha sucedido lo que esperaba este pensador cusqueño. En segundo lugar, no será posible el forjamiento de una identidad nacional en tanto no se resuelvan las diferencias raciales subjetivas entre los pobladores del Perú.

En mi opinión, el racismo y la discriminación—no sólo de la clase hegemónica hacia la subalterna, sino principalmente entre los mismos subalternos (etnobúmeran)— son los problemas más graves que frenan o impiden la integración de los peruanos. No es extraño observar a personas que glorifican el pasado inca y que, al mismo tiempo, les produce incomodidad la mera presencia de conciudadanos indígenas coetáneos. La expresión "incas sí, indios no" de Cecilia Méndez sintetiza esa actitud de orientalismo selectivo. Con una mirada eurocéntrica, esas personas se sienten fascinadas por un Otro, digno de honor y alabanza, que la pátina del tiempo ha rodeado de un aura de exotismo; pero a la vez, rechazan la versión contemporánea de ese Otro, que ellos han mistificado y estereotipado como abyecto. Mientras subsista una mentalidad de este tipo difícilmente podrán coexistir en armonía las distintas etnias que cobija la nación.

Si en algún momento de principios del siglo XX se esperaba que el "alma nacional" estuviese conformada por la síntesis racial y cultural (Flores Galindo, "Sueños y pesadillas" Obras completas 369-70), en la actualidad ese discurso homogeneizadoramén de populista y demagógico—es considerado pasadista (al igual que las retóricas hispanistas e indigenistas). Este discurso se ha vuelto anacrónico porque las comunidades 
reimaginadas han reclamado su justo derecho a la diferencia y a la diversidad. Para superar las prácticas discriminatorias, antes que nada "debemos reconocernos positivamente como un país multiétnico, pluricultural y multilingüe" ( $H W$ 465, C. $\mathrm{N}^{\circ} 171$ ). Lamentablemente, todavía nos resulta difícil aceptar nuestra diversidad cultural “como un activo, más allá del folklore y del turismo" (Degregori, "Perú: identidad” 214).

Una de las más graves consecuencias de la Guerra Interna es la relativización del valor de la vida humana. Este trastrocamiento en la escala de valores ha generado un altísimo grado de desconfianza mutua: "[E]l conflicto armado interno intensificó hasta niveles insoportables el miedo y la desconfianza, que a su vez contribuyeron a fragmentar y atomizar la sociedad. En esas condiciones, el sufrimiento extremo ha causado resentimiento y ha teñido de recelo y violencia la convivencia social y las relaciones interpersonales" ( $H W$ 463, C. 158). Para revertir esta situación es imperativo restaurar la confianza - investigando los hechos a fondo, sancionando a los responsables y resarciendo a las víctimas en la medida de lo posible-, amén de concientizar al pueblo de que la vida humana es el valor más preciado.

La creación de la CVR en el año 2001 tuvo un espíritu opuesto al de la Ley de Amnistía (Ley $\mathrm{N}^{\circ 26749)}$ de 1995, que había sido derogada en el año $2000 .{ }^{447}$ Como señala la CVR, “[n]o se puede construir un país éticamente sano y políticamente viable sobre los cimientos de la impunidad" ( $H W 465$, C. $\left.\mathrm{N}^{\circ} 168\right)$. Bajo esta premisa, la CVR entregó al Ministerio Público los casos de alrededor de 24 mil víctimas de la Guerra

\footnotetext{
${ }^{447}$ Algo similar ocurrió en España con la promulgación de la Ley de Memoria Histórica en el año 2007 "por la que se reconocen y amplían derechos y se establecen medidas en favor de quienes padecieron persecución o violencia durante la guerra civil y la dictadura [franquista]", que modificó la Ley de Amnistía de 1977, dada durante la Transición.
} 
Interna que logró identificar, con el afán de que se ampliaran las investigaciones y, de esa manera, pudieran sustentarse los respectivos reclamos de justicia (ibíd. 465, C. N${ }^{\circ} 168$ ).

Es imposible devolverles la vida a las víctimas fatales y resarcir a los deudos por la pérdida de sus seres queridos. Tampoco es posible reconstituir hogares deshechos y recuperar los años malgastados, especialmente los de la niñez o de la juventud que no pudieron ser vividos plenamente y conforme a la edad. La sevicia ha dejado traumas y secuelas psicológicas indelebles en muchos sobrevivientes. La violencia también ha dejado a mucha gente con discapacidades físicas que han mermado para siempre su capacidad productiva. Los daños materiales y la destrucción de estructuras sociales y comerciales son incalculables.

Desde el año 2003, la Defensoría del Pueblo ha venido haciéndole seguimiento a las recomendaciones de la CVR en asuntos de justicia y de reparación, y ha presentado informes de los progresos obtenidos (ibíd., Prefacio xi). Otro logro importante de la CVR ha sido la localización de 4644 sitios de entierro, en donde un trabajo de arqueología forense permitiría identificar a algunas de las víctimas y que sus familiares procesen el respectivo duelo (ibíd. 465, C. $\mathrm{N}^{\circ} 169$ ). Las exequias son particularmente importantes en la cultura peruana, tanto así que una de las prácticas terroristas era, precisamente, la prohibición de entierros después de los “ajusticiamientos” (ibíd. 436, C. N²0).

\section{Clamor de justicia de los muertos a través de sus deudos}

Pasado e Historia no son sinónimos, debido a que todo texto (historiografía) es el resultado de un proceso de mediación a través del lenguaje y del autor, quien, inevitablemente, ha de interpretar la información o la realidad según su propia 
cosmovisión y ha de priorizar los hechos de acuerdo con su criterio y/o interés. Santiago Juan-Navarro expresa esta idea con más claridad:

Difícilmente podemos hablar hoy en día de un discurso histórico exclusivo; en su lugar, sólo parece haber posiciones, perspectivas, modelos, ángulos que fluctúan de acuerdo con diferentes paradigmas [...]

Esta visión de la historia parte de la base de que podemos observar un mismo fenómeno desde múltiples perspectivas sin que ninguna de las narrativas resultantes tenga una necesaria permanencia o sea expresiva de esencia alguna [...] El pasado es obviamente el objeto de estudio de la historia, pero dicho pasado sólo puede ser "leído" a través de aproximaciones textuales limitadas, pero nunca concluyentes. ("El furioso Daimón" 3)

Independientemente de la manera en que nos cuenten la Historia, la Guerra Interna es un hecho que ha repercutido para siempre en la vida social, cultural, política y económica de todos los peruanos, y el trauma compartido forma parte de nuestra "identidad".

En Hienas en la niebla, el hijo mayor de Diego-que ha sobrevivido para dar a conocer la fatal historia de sus padres, ambos desaparecidos y asesinados por las fuerzas de la represión—cumple la función de ventrílocuo de los caídos, mediante una recreación "imposible" de la voz de su progenitor. "Su objetivo central será dar testimonio de la verdadera naturaleza de su padre, remar contra la impunidad y el olvido del crimen cometido" (Ángeles, "Dos novelas sobre la guerra").

En el mundo real, Héctor Abad Faciolince relata en El olvido que seremos (2006) la historia del asesinato de su padre-Héctor Abad Gómez-, perpetrado por 
paramilitares en Medellín, Colombia, en 1987. Aunque cabría suponer que el hecho de contar lo sucedido le sirvió al autor como ejercicio catártico-como les sucede a muchos escritores (MVLL afirma que, a través de la escritura, el escritor tiene la posibilidad de exorcizar sus propios demonios interiores)-, Abad Faciolince manifestó en una entrevista radial que ése no fue su caso. El escritor colombiano revela que su motivación para escribir el libro fue la siguiente:

Me saco de adentro estos recuerdos como se tiene un parto, como se saca un tumor [...] Han pasado casi veinte años desde que lo mataron, y durante esos veinte años, cada mes, cada semana, yo he sentido que tenía el deber ineludible, no digo de vengar su muerte, pero sí, al menos de contarla $[\ldots]$ Sus asesinos siguen libres, cada día son más y más poderosos, y mis manos no pueden combatirlos. Solamente mis dedos, hundiendo una tecla tras otra, pueden decir la verdad y declarar la injusticia. Uso la misma arma: las palabras. ¿Para qué? Para nada; o para lo más simple y esencial: para que se sepa. Para alargar su recuerdo un poco más, antes de que llegue el olvido definitivo. (253-55)

La publicación de El olvido que seremos debió aguardar 19 años desde la fecha en que murió Héctor Abad Gómez, el tiempo necesario para que su hijo pudiese serenarse y así poder escribir sin quebrarse emocional ni psicológicamente, y, a la vez, ser capaz de producir un testimonio que también fuera, literariamente, valioso. En opinión de Fanta Castro, "[1]a escritura de este texto se le impone al escritor como un imperativo que va más allá de 'testimoniar del dolor'. Se esconde detrás de esta afirmación el clamor de la justicia a través de la verdad narrada. El imperativo de contar la verdad [...] tiene una 
doble interpretación: hacer justicia con sus propias manos —a través de la escritura-, estableciendo una relación entre verdad y justicia, y además, impugnar la incapacidad del Estado de proteger a sus ciudadanos" ("Imágenes del tiempo" 32). Quizás el silencio literario inicial que observa Reyes Tarazona en relación con el tema de la Guerra Interna en el Perú (Presentación 13) tenga que ver con el tiempo prudencial y la distancia crítica que impone el luto en el ámbito social para empezar a asimilarlo.

\section{Yuyanapaq (para recordar) y no repetir los errores}

La CVR ha contribuido significativamente a reivindicar y a dignificar a las víctimas sobrevivientes de la Guerra Interna que, de otro modo, habrían guardado silencio por el temor a las represalias, y no habrían tenido la posibilidad de aliviar los traumas sufridos. Asimismo, de no haber sido por la CVR, que recibió las denuncias y escuchó los testimonios de, aproximadamente, 17 mil víctimas, probablemente sus dramáticas historias individuales habrían estado condenadas al desconocimiento y al olvido. "[C]ombatir el olvido es una forma poderosa de hacer justicia" (HW, Prefacio de Salomón Lerner Febres a la primera edición 12). Beatriz Merino Lucero-la Defensora del Pueblo (2005-2011) — sostiene que "un pueblo sin memoria es un pueblo sin destino. Una nación que se resuelva a cerrar los ojos ante las tragedias de la guerra, el crimen inhumano, la violencia contra las mujeres, la matanza a inocentes, será finalmente una sociedad incapaz de mirarse a sí misma y, por lo tanto, proclive a repetir las causas y los efectos de la violencia, la discriminación y la muerte" (ibíd., Prefacio xii). Más adelante, Merino agrega: "La convivencia pacífica solo es viable si se cuenta con una sociedad reconciliada consigo misma, que se preocupa de sus víctimas al preservar su memoria, 
que mira con confianza a sus autoridades, y que cultiva el respeto y la solidaridad entre sus ciudadanos y ciudadanas. La memoria nos ayudará a construir un futuro con esperanza" (ibíd.). La memoria histórica es útil para que la sociedad reflexione acerca de sus errores y que, de ese análisis, extraiga una lección para no volver a cometer las mismas equivocaciones. Sin embargo, [e]n el Perú, la dificultad para elaborar una memoria colectiva es un hecho recurrente [...] Esta dificultad nos revela como una sociedad que es aún prisionera de su pasado. Ella se expresa en el poder del autoritarismo, el escaso vigor de la crítica y, sobre todo, lo precario de la identidad nacional. Con frecuencia, ocurren hechos que, pese a su importancia, no llegan a ser inscritos en una trama que los explique y les dé significado. (Portocarrero, Razones 13).

\section{El arte como revisión del pasado y dignificación de las víctimas}

El arte en sus diversas expresiones cumple un rol fundamental y privilegiado en la preservación de la memoria histórica, porque tiene la capacidad de revisar el pasado tocando fibras sensibles, de manera individual, en las personas que conforman la sociedad, en la cual sólo podrá operarse un cambio positivo si, en principio, los individuos están persuadidos racional y emocionalmente de llevarlo a cabo. Las expresiones artísticas-literatura, cine, teatro, pintura, fotografía, música, etcétera (diversas formas de texto)—que intentan preservar y/o recuperar la memoria histórica constituyen una legítima y poderosísima herramienta para revisar y reescribir (re-escribir) el pasado, para cuestionar el discurso oficial y, sobre todo, para revertir la amnesia selectiva que se pretendió imponer mediante la promulgación de leyes de impunidad. A la 
vez, este tipo de manifestaciones artísticas sirve para reivindicar la dignidad de las víctimas, dándoles voz y rescatándolas del olvido.

\section{Corpus literario y cinematográfico}

La literatura y el cine peruanos han asumido concienzudamente la responsabilidad de preservar la memoria histórica de la Guerra Interna. La mayoría de historias que se narran están basadas o inspiradas en testimonios de víctimas y de testigos. Hienas en la niebla es una representación literaria bastante fiel, aunque incompleta, de casos que ocurrían en los años de la Guerra Interna, dado que el relato está focalizado en el terrorismo de Estado del que son víctimas Diego y sus familiares. Sin embargo, debido a la complejidad que revisten tanto el tema de la Guerra Interna como su representación, por más vocación totalizante que tenga una obra individual, es imposible que por sí sola pueda abarcar todas las variables del conflicto y presentarlas desde todos los ángulos; como, por ejemplo, los traumas que sufrieron muchos militares y paramilitares involucrados en prácticas de guerra sucia, ${ }^{448}$ el sufrimiento de civiles que fueron obligados por Sendero Luminoso a enrolarse en sus filas, ${ }^{449}$ y un largo, larguísimo, etcétera. La imposibilidad de una representación totalizante de la Guerra Interna hace imprescindible la producción de un corpus literario, cinematográfico y demás, cada vez más robusto y comprometido, que, en conjunto, cubra un amplio espectro de las experiencias vividas durante ese oscuro episodio de la historia.

\footnotetext{
${ }^{448}$ El filme Días de Santiago (2004) de Josué Méndez aborda este tema.

${ }^{449}$ El filme Paloma de papel (2003) dirigido por Fabrizio Aguilar aborda este tema.
} 
Roberto Reyes Tarazona hace notar que "el tema de la guerra interna, después de una década de haber captado la atención de escasos narradores, hoy es motivo de interés de muchos" (Presentación 13). Quienes han escrito sobre la Guerra Interna se han centrado en la atribución y en el deslinde de responsabilidades; sin embargo, los temas y el punto de vista de cada texto son distintos. Manuel Prendes Guardiola observa que, por ejemplo, en Rosa Cuchillo (1997) de Óscar Colchado Lucio, en La hora azul (2005) de Alonso Cueto y en Abril rojo (2006) de Santiago Roncagliolo, "el poder entendido como autoridad institucional siempre será recreado $[\ldots]$ como arbitrario y corrupto. Existe, por una parte, la uniforme crueldad del militar, que propaga el miedo y al mismo tiempo lo padece, que odia a los terroristas y desprecia a los campesinos" ("Constantes temáticas" 235). De otro lado, Días de fuego (2009) de Fernando Cueto "tiene la particularidad de agregar [...] un punto de vista que proviene de la propia institución policial" (Ángeles, "Dos novelas sobre la guerra"). Por otra parte, las respectivas historias de Un lugar llamado Oreja de Perro (Anagrama, 2000) de Thays y Abril rojo (Alfaguara, 2006) de Roncagliolo se centran en el trauma que han sufrido víctimas indirectas de la violencia. Andrea Fanta Castro señala que el hecho de privilegiar ciertas historias sobre otras "es lo que nos ayuda a explorar la dimensión política de las narrativas" ("Imágenes del tiempo" 29).

Daniel Noemí reflexiona sobre la función del arte literario en la representación de la Guerra Interna, preguntándose “¿cuál es el papel de la literatura y del escritor ante esa inconmensurable realidad?" Él mismo se responde: "Más de veinte años después la interrogante se reformulará en cómo recordar ese pasado reciente que, como se sabe, es al mismo tiempo presente" ("Para una genealogía" 44). El corpus literario que se ha 
generado en torno a la Guerra Interna es vasto: “[E]n la literatura peruana, durante los últimos años vienen apareciendo diversas obras que, sobre todo desde la narrativa, buscan plasmar una visión de dicha época, a veces como cuadros o viñetas de situaciones concretas, o también como si fuera un fresco con mayores proporciones" (Ángeles, "Dos novelas sobre la guerra"). ${ }^{450}$ Más que servir de mero entretenimiento, el material producido conlleva el propósito de denuncia social. Fanta Castro sostiene que "[s]i aceptamos que 'la memoria es el punto de partida de la ética' (Mèlich 26), la escritura que recupera una cierta memoria ausente es, en sí misma, un acto político" (“Imágenes del tiempo" 29).

Tras un prolongado silencio, a mediados de los años 1980 en el cine ocurrió una explosión similar a la que se dio en la literatura y, al igual que ésta, con enfoques muy variados. Por ejemplo,

La Boca del lobo/The Lion's Den (Francisco Lombardi 1988) investigated the motives and actions of soldiers on the Andean front line, while another, La vida es una sola/You Only Live Once (Marianne Eyde 1993) focused on the experiences of an Andean community caught between

\footnotetext{
${ }^{450}$ En el pie de página $\mathrm{N}^{\circ} 1$, Ángeles amplía: "Me refiero a los casos, por ejemplo, de Julio Ortega, Feliciano Padilla, Zeín Zorrilla, Rosas Parravicino, Dante Castro, Óscar Colchado, Julián Pérez Huaranca, José de Piérola, Daniel Alarcón, Alonso Cueto, Santiago Roncagliolo y Mario Vargas Llosa, entre otros narradores. Cada uno, por cierto, debe ser considerado con sus particulares características y posiciones, en más de un caso, divergentes entre sí, sobre el común tema de la guerra interna. Asimismo, el profesor norteamericano Mark Cox ha aportado un vasto corpus a tener en cuenta, con sus libros recopilatorios: $E l$ cuento peruano en los años de la violencia (2000), Pachaticray: Testimonios y ensayos sobre la violencia política y la cultura peruana desde 1980 (2004), y Sasachacuy Tiempo: Memoria y pervivencia / Ensayos sobre la literatura de la violencia política en el Perú. En el 2008, publicó Bibliografía anotada de la ficción narrativa peruana sobre la guerra interna de los años ochenta y noventa (Con un estudio previo), con 306 cuentos y 68 novelas por 165 escritores en el número 68 de la Revista de Crítica Literaria Latinoamericana. Por su parte, el novelista Miguel Gutiérrez tiene artículos sobre este asunto [...] como "Narrativa de la guerra 1980-2006" (en la revista Libros y Artes N$^{\circ}$ 16-17; noviembre 2006: 16-20) que ofrecen un buen marco para situar la producción textual (literaria y no literaria) inspirada en la pasada conflagración interna" ("Dos novelas sobre la guerra").
} 
Sendero rebels and the Armed Forces [...]. Other feature films, such as $N i$ con Dios ni con el Diablo/Neither with God nor the Devil (Nilo Pereira 1991), Alias La Gringa/AKA 'La Gringa' (Alberto Durant 1991), Reportaje a la muerte/Report on Death (Danny Gavidia 1994) and Coraje/ Courage (Alberto Durant 1998), direct their attention towards the effects of the violence on the country's capital. (Barrow 2$)^{451}$

Siguiendo a Susan Hayward, Sarah Barrow manifiesta que el cine juega un papel importante en la articulación de la nación (ibíd. 15).

\section{Aunsencia de una literatura chicha}

El grupo hegemónico asocia la cultura chicha al "mal gusto, a lo grotesco, a lo que no corresponde con los prototipos sociales, a la transgresión de espacios culturales, a la invasión de y al acceso a espacios antes privados, a la borrachera, el pandillaje, la marginalidad, la delincuencia, el achoramiento, la ignorancia, la viveza o la mala educación" (Espezúa 102). Javier Garvich piensa que ésta es una de las razones por las que muchos intelectuales y artistas se inhiben de cultivar la estética chicha. Sin embargo, si esta apreciación fuera correcta, tampoco habrían surgido ni la música, ni el arte escénico, ni el arte gráfico, ni el arte plástico chicha, que continúan floreciendo hasta hoy.

\footnotetext{
${ }^{451}$ En un pie de página $\left(\mathrm{N}^{\circ} 4\right)$, Barrow añade los siguientes títulos: “Juliana (1989) by the Chaski Group, Caídos del cielo/Fallen from the Sky (1990) and Sin compasion/No Compassion (1994) by Francisco J. Lombardi, Anda, corre, vuela/Walk, Run, Fly (1995) by Augusto Tamayo, Bajo la piel/Under the Skin (1996) by Francisco J. Lombardi. Short films on the topic include: Una pequeña mirada/A Glance (1992) by Danny Gavidia, Enigma de Santos (1992) by Edgardo Guerra, La misma carne, la misma sangre/The Same Flesh, the Same Blood (1992) and Kentishani y Shaavaja (1995) by Aldo Salvini.
} 
De otro lado, Garvich compara el valor que tuvo la literatura indigenista en su momento con la que podría tener una literatura chicha si contase con cultores. Plantea que, de manera similar a la cantera indígena, en la cultura chicha podemos "encontrar nuevas formas, actitudes, éticas y expectativas que enriquezcan nuestro arte” (ibíd. 64). Estoy totalmente de acuerdo con este planteamiento, máxime si tomamos en cuenta que el fenómeno chicha es la expresión del "tránsito de una sociedad de corte aristocráticocriolla hacia una sociedad más popular, confluyente, de corte democrático, en la que coexist[e]n todas las culturas vivas del país" (Quispe, "La cultura chicha en el Perú").

\section{Asumir el pasado}

En 1988, Miguel Gutiérrez Correa escribía que "[n]acer en el Perú constituye una situación límite y significa llevar una herida nunca cicatrizada fruto de una violencia original primigenia" (La generación 186). El trauma de la invasión española continúa latente en la mente y en el corazón de muchos subalternos, y aflora a la superficie cada vez que se produce una situación crítica, tanto en pequeños detalles de la vida cotidiana como en situaciones límite. Con la Guerra Interna se produjo una hemorragia que, tras mucho esfuerzo y padecimientos, se ha logrado detener, pero la costra es muy delgada y la sempiterna llaga—como la que padecía el pequeño Yococo—difícilmente cerrará si se

continúa alimentando ese rencor atávico que predispone a la revancha. ${ }^{452}$ "Una persona que quiere venganza guarda sus heridas abiertas", decía Sir Francis Bacon.

\footnotetext{
${ }^{452}$ Contrariamente, haciéndose eco de Ann Kaplan, Sarah Barrow sugiere que, mantener las heridas abiertas mediante expresiones artísticas que ayuden a interpretar el trauma, paradójicamente podría ser útil para (re)construir la nación (15).
} 
Para enmendar rumbos, debemos aprender de los errores cometidos, asumiendo el pasado (la escisión, la violencia, el trauma) y fortaleciendo la fe en nuestra capacidad de mejorar. "Reconocer el pasado no significa admitirlo. Buscar sus lecciones y tratar de interrogar desde allí al futuro, no quiere decir prolongarlo" (Flores Galindo, "Sueños y pesadillas" Obras completas 374). Asumir el pasado no supone olvidarlo ni perdonar, necesariamente, a los culpables del sufrimiento y de la muerte de miles de inocentes. Pero tampoco significa buscar chivos expiatorios para responsabilizarlos injustamente de los agravios y de las afrentas que nos hicieron. Asumir el pasado implica darle vuelta a la página para que podamos librarnos de las ataduras que nos anclan en un tiempo que ya no nos corresponde; es actuar en el presente para que las acciones de hoy repercutan mañana de manera positiva. Sin duda, es mucho más sencillo decirlo que llevarlo a la práctica, sobre todo en el caso de las víctimas sobrevivientes de la Guerra Interna, cuyas heridas son recientes. Asumir el pasado es voltear la página poniendo un marcador en la anterior.

Aunque es cierto que el Perú sufre de taras originadas por la invasión, el coloniaje y el consiguiente trauma, no es útil ni provechoso achacar a esos episodios históricos la culpa de todos nuestros males contemporáneos, porque con ese engañoso argumento se ha intentado justificar una infinidad de acciones demenciales y destructivas. Tampoco debemos injuriar a los descendientes de los conquistadores por las faltas cometidas por sus ancestros. La equivocada creencia de que las culpas se heredan - como lo sugiere $L a$ violencia — debe ser desterrada, porque lejos de permitirnos avanzar, nos mantiene anclados en un tiempo pretérito. ${ }^{453}$ "El odio acumulado puede sustentar a una

\footnotetext{
${ }^{453}$ En el folclor andino, al danzaq — bailarín que ejecuta la danza de tijeras—se le prepara desde niño y la enseñanza se transmite de manera intergeneracional, en una larga tradición de tusuq laykas, o sacerdotes, brujos, adivinos y curanderos semidiabólicos. En el cuento "La agonía de Rasu Ñiti" (1962) de José María
} 
sublevación; no necesariamente la construcción de una sociedad diferente" (Flores Galindo, "Sueños y pesadillas", Obras completas 375), como lo evidencian las nefastas secuelas de la Guerra Interna.

\section{Una ventana abierta para otros estudios literarios}

Juan Morillo Ganoza (1939...), Miguel Gutiérrez Correa (1940-2016) y Cronwell Jara Jiménez $(1949 \ldots)$ - tres de los escritores que incluyo en este trabajo-nacieron en o alrededor de la década de 1940, cuando se inició el éxodo rural en el Perú. A este grupo pueden sumarse Eduardo González Viaña (1941-...) y Gregorio Martínez Navarro $(1942 \ldots){ }^{454}$ "Los cinco" empezaron a publicar entre 23 y 30 años después de su nacimiento, cuando los primeros descendientes de los andinos migrantes ya se habían afianzado en la costa y formaban parte del panorama urbano. Dado que estos autores continuaron publicando, es posible comparar su visión actual con la que tenían cuando debutaron como escritores noveles. Asimismo, sus respectivas obras dan cabida a la

\footnotetext{
Arguedas, cuando el danzaq Pedro Huancayre o Rasu Ñiti ("el que aplasta la nieve") fallece, su discípulo Atok Sayku ("el que cansa al zorro") "salió junto al cadáver. Se elevó ahí mismo, danzando; tocó las tijeras que brillaban. Sus pies volaban". En el preciso momento de la muerte de su maestro, el sucesor hereda el Wamani, el espíritu de la montaña que, en este caso, adopta la forma del cóndor que guiaba los movimientos de su anterior protegido y mensajero. En referencia a La hora azul (2005) de Alonso Cueto, Fernando Castanedo comenta que esta novela "apunta al resurgimiento de un atavismo que la religión cristiana, y sobre todo el catolicismo, contribuyó a erradicar en el pasado: la creencia de que la culpa se hereda hasta la tercera y la cuarta generación (Babelia). De otro lado, el doctor Kenneth McAll (19102001) ha publicado varios libros que avalan esta creencia. La noción de que "una antigua culpa se transmite de una generación a otra, como una enfermedad hereditaria, viene del "pensamiento arcaico griego' y es una idea que se expresaba normalmente a través del concepto de contaminación (miasma)" (Bettini y Guidorizzi, El mito de Edipo 34).

${ }^{454}$ Cabe mencionar que Cronwell Jara y Gregorio Martínez, junto a Enrique López Albújar (1872-1966) y Antonio Gálvez Ronceros (1932...), son los pioneros y unos de los pocos cultores en el Perú de la literatura negroide (aquélla hecha por autores que no son negros ni mulatos, a diferencia de la literatura negrista, hecha por ellos mismos). De otro lado, Eduardo González Viaña es un defensor de los derechos de los inmigrantes hispanos en los Estados Unidos, que es un tema afín al de la construcción de la identidad cultural.
} 
realización de un análisis tanto diacrónico como sincrónico del pensamiento intelectual durante un poco más de medio siglo (desde los años sesenta del siglo XX hasta el presente), especialmente en relación con el tema de la construcción de la identidad nacional en la literatura peruana. Determinar si Los cinco forman o no parte de una misma generación literaria rebasa ampliamente el alcance de este trabajo, pero les dejo mi inquietud a otros investigadores que, quizás, se animen a indagar si estos escritoresque surgieron en un momento clave en la génesis de la identidad cultural contemporánea de los peruanos—-, además las coincidencias cronológicas, geográficas y culturales, que son evidentes, comparten rasgos de forma y contenido, y se distinguen marcadamente de otros narradores. También sería interesante comparar la manera en que Los cinco han influido en autores peruanos de generaciones posteriores. Me refiero, por ejemplo, a Mario Bellatín (1960-...), Fernando Iwasaki (1961-..), Jaime Bayly (1965-...), Iván Thays (1968-...) y Santiago Roncagliolo (1975-...). De llegar a demostrarse la hipótesis que aquí planteo, se podría ahondar en la representación de la identidad cultural peruana desde una perspectiva generacional.

\section{Palabras finales}

Si en el pasado hubo siembras sin fruto y lances abortados, rutas ciegas y oportunidades que perdimos, fue porque era hora de elegir. Esta, en cambio, es hora de decidir

Carlos Milla Batres (En qué momento se jodió el Perú 13)

El lazo más fuerte que une a la mayoría de subalternos peruanos es su espíritu solidario, que proviene del ancestral ayni. Es relevante que ese espíritu de solidaridad y esa vocación de servicio comunitario estén basados en un sustrato étnicocultural premoderno, 
porque lo antiguo legitima y contribuye a la formación de identidades colectivas sólidas (nótese el uso del plural), que podrían ser muy bien aprovechadas si el país optara, por ejemplo, por fomentar el cooperativismo como fórmula de progreso. Al igual que Haya de la Torre (1927) y Castro Pozo (1936), estoy pensando en el ayllu. Y también concurro con Flores Galindo en que "[n]o se trata de transponer las organizaciones del pasado al presente. Sin negar las carreteras, los antibióticos y los tractores, se trata de pensar en un modelo de desarrollo diseñado desde nuestros requerimientos [sic] y en el que no se sacrifique inútilmente a las generaciones" (“Sueños y pesadillas”, Obras completas 373), como ocurre en el caso de algunas explotaciones mineras que atentan contra la ecología.

Empero, sin justicia y sin equidad socioeconómica es imposible construir y mantener identidades culturales cohesionadas: "[N]uestra verdadera guerra debe orientarse contra la dependencia, contra el subdesarrollo, contra la miseria, contra la explotación, contra la enfermedad, contra la desocupación, contra la injusta repartición de riquezas, contra la inmoralidad en todas sus formas, contra la división nacional" (Fernández Salvatteci 7). Para edificar un futuro más justo y equitativo es imperativo promover el compromiso de todos los peruanos, con verdaderos líderes que sirvan de modelo e inspiración. La esperanza y el optimismo son también condiciones necesarias para que podamos reconciliarnos y (re)construir algún tipo de identidad colectiva. "Necesito ser feliz. Tal vez sólo por esa fuerza estoy aquí" (23:48), declara Liz Rojas ante la CVR (Guillot, The True Story of Liz). 


\section{BIBLIOGRAFÍA}

Abanto Aragón, David. "Grupo Narración: la redención a través del compromiso". Prólogo a El grupo Narración en la literatura peruana. Tenorio Requejo, Néstor. Lima: Arteidea Editores, 2007.

Abrams, Jerold J. "Peirce, Kant, and Apel on Transcendental Semiotics: The Unity of Apperception and the Deduction of the Categories of Signs". Transactions of the Charles S. Peirce Society: A Quarterly Journal in American Philosophy 40.4 (2004): 627-77.

Accorsi, Simone. "Los cuatro cantos del mundo". Historia y espacio 39 (2012): 1148.

Adorno, Rolena. "The Depiction of Self and Other in Colonial Peru”. Art Journal 49.2 (1990): 110-18.

- The Nueva Corónica Y Buen Gobierno: A New Look at the Royal Library's Peruvian Treasure. Copenhague: Kongelige Bibliotek, 1980.

Adler, Alfred, y Colin Brett. Social Interest: Adler's Key to the Meaning of Life. Oxford: Oneworld Publications, 1998.

Ágreda, Javier. “Jaque perpetuo. 40 años del Grupo Narración”. La República [Lima] 23 abril 2007.

Alberdi, Juan Bautista. Bases y puntos de partida para la organización política de la República de Argentina. Valparaíso (Chile: Imprenta del Mercurio, 1852.

Alcón Tancara, Sofía. Formación docente en Warisata: el constructivismo y el papelógrafo. La Paz (Bolivia: PINSEIB, 2005.

Alim, H Samy, John R. Rickford, y Arnetha F. Ball. Raciolinguistics: How Language Shapes Our Ideas About Race, 2016.

Anderson, Benedict. Comunidades imaginadas. 1983. México: Fondo de Cultura Económica, 2013.

Andrews, George Reid. The Afro-Argentines of Buenos Aires. Madison: University of Wisconsin Press, 1980. En Beane.

Ángeles L., César. "Dos novelas sobre la guerra: Días de fuego de Fernando Cueto, y Hienas en la niebla de Morillo Ganoza". www.letras.s5.com: Página chilena al servicio de la cultura. Ed. Luis Martínez S. Proyecto Patrimonio (2012): s. pág. 
Ardito Vega, Wilfredo. Reflexiones Peruanas: por un país sin discriminación. Lima: Coordinadora Nacional de Derechos Humanos, 2009.

Arendt, Hannah. Eichmann in Jerusalem: a Report on the Banality of Evil. Nueva York: Viking Press, 1963.

Ares Quejia, Berta. “El Inca Garcilaso y sus 'parientes' mestizos”. Humanismo, mestizaje y escritura en los Comentarios reales. Ed. Carmen de Mora. Fráncfort del Meno, 2010.

Arguedas, José María. Cuentos mágico-realistas y canciones de fiestas tradicionales: Folklore del Valle del Mantaro, Provincias de Jauja y Concepción. Lima: Editora Médica Peruana, 1953.

Ari Chachaki, Waskar. "Construyendo la Ley de Indios: un proceso de descolonización en Bolivia”. Antología del pensamiento crítico boliviano contemporáneo. Coord. Silvia Rivera Cusicanqui y Virginia Aillón Soria. Buenos Aires: CLACSO, 2015.

Armstrong, John. Nations before Nationalism. Chapel Hill: University of North Carolina Press, 1982.

Arrambide, Víctor. "La conquista”. El Peruano. 29 febrero 2017. 13.

Arriaza, Bernardo T. "Chinchorro Bioarchaeology: Chronology and Mummy Seriation." Latin American Antiquity 6.1 (35-55).

Arrizabalaga, Carlos. "Noticias de la desaparición del voseo en la costa norte del Perú". Lingüística Española Actual 23.2 (2001): 257-74.

Baeza Pérez, Francisco. Selec. José Carlos Mariátegui: Obras: Tomo 2. La Habana: Casa de las Américas, 1982.

Bhabha, Homi K. El lugar de la cultura. Trad. César Aira. Buenos Aires: Manantial, 2002.

_ Problemas de la poética de Dostoievski. México: Fondo de Cultura Económica, 2005 .

Bajtín, Mijaíl. La cultura popular en la Edad Media y en el Renacimiento: El contexto de Francois Rabelais. 1941. Madrid, Alianza, Madrid, 2005.

_ - Problemas de la poética de Dostoievski. 1936. México: Fondo de Cultura Económica, 2005.

- Teoría y estética de la novela: Trabajos de investigación. Trad. Helena S. Kriúkova y Vicente Cazcarra. Madrid: Taurus, 1989. 
Baquerizo, Manuel. “Cronwell Jara y sus cuentos" Palabra en libertad 18.136 (2016): 28-33.

Barjau, Luis. La conquista de la Malinche. México: MR Ediciones, 2009.

Barrow, Sarah. "Out of the Shadows: 'New' Peruvian Cinema, National Identity and Political Violence". Modern Languages Open (2014): 1-17.

Barry, Peter. Beginning Theory: An Introduction to Literary and Cultural Theory. Manchester: Manchester University Press, 2009.

Basadre Grohmann, José María, David Sobrevilla, y Miguel A. Rodríguez. "Ubicación sociológica de González Prada". Perú: problema y posibiblidad y otros ensayos. Caracas: Biblioteca Ayacucho, 1992.

Bastos, Santiago. "Los indios, la nación y el nacionalismo". Espiral. Estudios sobre Estado y Sociedad 2.6 (1996): 161-206.

Baudrillard, Jean. "La violencia política y la violencia transpolítica". 1994. Los límites de la estética de la representación. Ed. Adolfo Chaparro Anaya. Bogotá: Editorial Universidad del Rosario, 2006. 325-35.

Beane, Carol. "'Un día solemne; una fiesta original: África en un discurso musical de la Identidad en Matalaché de Enrique López Albújar". Revista Iberoamericana 65 (1999): 613-32.

Belaúnde, Víctor Andrés. Meditaciones Peruanas. 1932. Lima: Talleres Gráficos P. L. Villanueva, 1963.

_. "Peruanidad: elementos esenciales". Obras Completas 5. Peruanidad. Edición de la Comisión Nacional del Centenario, 1987.

Bergson, Henri. Matter and Memory. Mineola, N.Y: Dover Publications, 2004.

Bertonio, Ludovico. Vocabulario de la Lengua Aymara. Casa de la Compañía de Jesús de Iuli (Puno, Perú, 1612.

Betanzos, Juan de. Suma y narración de los Incas, que los indios llamaron capaccuna, que fueron señores de la ciudad del Cuzco y de todo lo a ella sujeto. 1551. Publicado por Marcos Jiménez de la Espada. Madrid: Imprenta de Manuel G. Hernández, 1880.

Bettini, Maurizio, y Giulio Guidorizzi. El mito de Edipo: Imágenes y relatos de Grecia a nuestros días. Madrid: Ediciones Akal, 2008. 
Boldori, Rosa. "La ciudad y los perros, novela del determinismo ambiental". Revista peruana de cultura 9-10 (1966): 92-105.

Bonifacio VIII. "Unam sanctam". 1302. Papal Encyclicals Online.

"Ausculta fili". 1301. Red.

"Clericis Laicos". 1296. Paul Halsall. Internet Medieval Sourcebook.

Fordham University, 1999.

Bonilla, Heraclio. La Independencia en el Perú. Lima: Instituto de Estudios Peruanos, 1981.

Bonilla-Silva, Eduardo. Racism without Racists: Color-blind Racism and the Persistence of Racial Inequality in the United States. Lanham, Md.: Rowman \& Littlefield, 2006.

Bourricaud, François. "Elogio del 'Cholo'." Cuadernos del Congreso para la libertad de la cultura 63 (1962): 26-33.

Borges, Jorge Luis. Narraciones. Ed. Marcos Ricardo Barnatán. Madrid: Cátedra, 2010.

Braudy, Leo. From Chivalry to Terrorism: War and the Changing Nature of Masculinity. Nueva York: Knopf, 2003.

Britton, Rosa María. “Amor se escribe con G”. La muerte tiene dos caras. San José: Editorial Costa Rica, 1987. 115-29.

Brookfield, Stephen. "Radical Questioning on The Long Walk to Freedom: Nelson Mandela and the Practice of Critical Reflection". Adult Education Quarterly 58.2 (2008): 95-109.

Bush, Mathew. "A History of Violence: Melodrama and Mestizaje in Enrique López Albújar's Matalaché". Chasqui: Revista de literatura latinoamericana 41.1 (2012): 3-17.

Butler, Judith. "Performative Acts and Gender Constitution: An Essay in Phenomenology and Feminist Theory." Writing on the Body: Female Embodiment and Feminist Theory. Ed. e introd. Katie Conboy. Nueva York: Columbia UP, 1997. 401-17.

Cadena, Marisol de la. Indigenous Mestizos: The Politics of Race and Culture in Cuzco, Peru, 1919-1991. Durham (NC: Duke University Press, 2000.

Calderón Moncloa, Luis Felipe. "Mal manejo emocional: clave del subdesarrollo". Universidad Continental. Lima, 29 de abril 2014. Conferencia. 
Callirgos, Juan Carlos. "El racismo peruano”. Biblioteca Virtual de Ciencias Sociales.

Camayd-Freixas, Erik. "Vacilación 'nosotros' / 'ellos' en el Inca Garcilaso: punto de vista e historia; simulación barroca y mímica colonial. Etnografía imaginaria: Historia y parodia en la literatura hispanoamericana. Guatemala: F\&G Editores, 2012. 17-42.

_. Realismo mágico y primitivismo: Relecturas de Carpentier, Asturias, Rulfo y García Márquez. Lanham, Maryland: University Press of America, 1998.

Carazas Salcedo, Milagros. "Una relectura de Matalaché de López Albújar: imagen e identidad del sujeto afroperuano". Escribir la identidad: creación cultural y negritud en el Perú. Comp. M'Bare N'Gom. Lima: Editorial Universitaria, 2008. 243-66.

Cárcamo-Huechante, Luis. "Cuerpos excedentes: violencia, afecto y metáfora en Montacerdos de Cronwell Jara. Revista de Crítica Literaria Latinoamericana 31.61 (2005): 165-80.

Castanedo, Fernando. "De culpas y tristezas". Babelia [Suplemento del diario El país de Madrid], 24 dic. 2009.

Castillo-Durante, Daniel. Los vertederos de la postmodernidad: Literatura, cultura y sociedad en América Latina. Ottawa: Dovehouse Editions Canada, 2000.

Castro Arenas, Mario. "Las tres crisis del Inca Garcilaso". Autodestrucción de los incas. Panamá: Universal Books, 2007. 272-91.

Castro Pozo, Hidelbrando. Del ayllu al cooperativismo socialista. Lima: Peisa, 1973.

_. Nuestra comunidad indígena. Lima: Ed. El Lucero, 1924.

Catechism of the Catholic Church. Picayune (Mississippi: Saint Charles Borromeo Catholic Church.

Cheng, William J. "La función de la memoria en La violencia del tiempo de Miguel Gutiérrez: un tormento transgeneracional y la reivindicación de un linaje agraviado". Hipertexto 14 (2011): 3-19.

Chocano, José Santos. Alma América: Poemas indo-españoles. Prefacio de Miguel de Unamuno. Madrid: Ed. Suárez, 1906.

"Cholear". Diccionario de la Lengua Española - Edición Tricentenario. Real Academia Española (RAE).

"Cholo Power". Quehacer: revista bimestral del Centro de Estudios y Promoción del Desarrollo-DESCO170 (2008): 85. 
Cieza de León, Pedro. El señorío de los Incas [Segunda parte de la Crónica del Perú]. 1553. Lima: Instituto de Estudios Peruanos, 1967.

Cisneros, Renato. La distancia que nos separa. Lima: Planeta, 2015.

Claro Valdés, Samuel, Carmen Peña Fuenzalida, y María Isabel Quevedo Cifuentes. Chilena o cueca tradicional. Santiago de Chile: Ed. Univ. Católica de Chile, 1994.

Cobo, Bernabé. Historia del Nuevo Mundo. 1653. Ed. D. Marcos Jiménez de la Espada. Sevilla: Sociedad de bibliófilos andaluces, 1890-1893.

“Complejo de superioridad e inferioridad”. IPolis/WordPress, 31 Mar. 2010.

Contreras, Fernando. El pueblo maravilloso. 1927. Santiago de Chile: LOM Ediciones, 2007.

Córdova, Carlos Joaquín. El habla del Ecuador: diccionario de ecuatorianismos, Tomos I y II. Cuenca: Universidad del Azuay, 1995.

Cornejo Polar, Antonio. “Aves sin nido como alegoría nacional”. Prólogo a Aves sin nido. Notas de Efraín Kristal. Caracas: Biblioteca Ayacucho, 1994. .

"Aves sin nido". Escribir en el aire: ensayo sobre la heterogeneidad socio-cultural en las literaturas andinas. 1994. Lima: Centro de Estudios Literarios "Antonio Cornejo Polar", 2011. 108-13.

"Aves sin nido: indios, 'notables' y forasteros". Cahiers detudes romanes 9 (1984): 7-27.

"Discurso de la armonía imposible (E1 Inca Garcilaso de la Vega: discurso y recepción social)". Revista de Crítica Latinoamericana 38 (1993): 73-80.

"Cinco preguntas en torno a Garcilaso". Literaturas andinas 1.2 (1989): 19-27.

—. Escribir en el aire: ensayo sobre la heterogeneidad socio-cultural en las literaturas andinas. 1994. Lima: Centro de Estudios Literarios "Antonio Cornejo Polar", 2011.

_. La novela peruana. Siete estudios. Lima: Editorial Horizonte, 1977.

_. "Las voces subalternas". Escribir en el aire: ensayo sobre la heterogeneidad socio-cultural en las literaturas andinas. 1994. Lima: Centro de Estudios Literarios "Antonio Cornejo Polar", 2011. 184-95. "Literatura peruana e identidad nacional: tres décadas confusas".

Perú 1964-1994: Economía, sociedad y política. Ed. Julio Cotler. Lima: Instituto de Estudios Peruanos, 1995. 293-302.

“Corregidor”. Diccionario de la Lengua Española - Edición Tricentenario. Real Academia Española (RAE). 
Cotler, Julio. Clases, Estado y nación en el Perú. Lima: Instituto de Estudios Peruanos, 2006.

Cuché, Denys. Poder blanco y resistencia negra en el Perú: Un estudio de la condición social del negro en el Perú después de la abolición de la esclavitud. Lima: Instituto Nacional de Cultura, 1975.

D’Abadal i de Vinyals, Ramon. "A propos du Legs Visigothique en Espagne”. Settimane di Studio del Centro italiano di studi sullëalto medioevo 2 (1958): 541-85.

Degregori, Carlos Iván. "Del mito de Inkarrí al mito del progreso: poblaciones andinas, cultura e identidad nacional". Cambios culturales en el Perú. Por Carlos Franco, Carlos Iván Degregori, y Antonio Cornejo Polar. Cusco: Ministerio de Cultura Dirección Desconcentrada de Cultura de Cusco, 2016. 54-68.

_. "Ocaso y replanteamiento de la discusión del problema indígena (1930-1977)". Indigenismo, clases sociales y problema nacional. Carlos Iván Degregori, Mariano Valderrama et al. Lima: Centro Latinoamericano de Trabajo Social, 1980.

"Perú: identidad, nación y diversidad cultural". Territorio, cultura e historia: Materiales para la renovación de la enseñanza sobre la sociedad peruana. Ed. Patricia Oliart. Lima: Instituto de Estudios Peruanos (IEP), 2003.

Deleuze, Gilles. Difference and Repetition.1968.Trad. Paul Patton New York: Columbia University Press, 1994.

Denegri, Francesca. El abanico y la cigarrera: La primera generación de Mujeres ilustradas en el Perú. Lima: Instituto de Estudios Peruanos, y Centro de la Mujer Peruana Flora Tristán, 2004.

De Soto, Hernando, en colaboración con Enrique Ghersi y Mario Ghibellini. El otro Sendero: La Revolucion Informal. 1986. México, D.F: Diana, 1987.

Días de Santiago. Guion de Josué Méndez y Tito Bonicelli. Dirección de Josué Méndez. Actuaciones de Pietro Sibille (Santiago Román), Marisela Puicón, Milagros Vidal (Andrea), Alhelí Castillo (Mari), Lili Urbina (Mamá), Ricardo Mejía (Papá), Erick García (Coco), Ivy La Noire (Inés). Perú: Chullachaki Producciones, 2004. Película.

Díaz del Castillo, Bernal. Historia verdadera de la conquista de la Nueva España I.117. Introducción y notas por Joaquín Ramírez Cabañas. México, Pedro Robredo, 1939.

Historia verdadera de la conquista de la Nueva España; Tomo I. Cervantes Virtual.

_. Historia verdadera de la conquista de la Nueva España; Tomo II. Cervantes Virtual. 
Duncan, Quince. Contra el silencio: Afrodescendientes y racismo en el Caribe continental hispánico. San José, Costa Rica: EUNED Editorial Universidad Estatal a Distancia, 2001.

Echeverría, Bolívar. La modernidad de lo barroco. México: Era, 2005.

_. Vuelta de siglo. México: Fundación Editorial el Perro y la Rana, 2005.

EFE. "Momias chilenas más antiguas del mundo buscan ser Patrimonio de la Humanidad”. Empresa El Mercurio S.A.P., 23 Oct. 2016.

Eliot, Thomas Stearns. Lo clásico y el talento individual. Presentación de Juan Carlos Rodríguez. México: UNAM, 2004.

Elmore, Peter. "La sangre y la letra: los modos de filiación en La violencia del tiempo de Miguel Gutiérrez". Revista Iberoamericana 73.220 (2007): 631-48.

"Vallejo, Arguedas y Gutiérrez: las ceremonias de la vergüenza". Del viento, el poder y la memoria: Materiales para una lectura crítica de Miguel Gutiérrez Monteagudo. Ed. Cecilia, y Víctor Vich.Lima: Fondo Editorial de la PUCP. 2002. 19-52.

"Encastar". Diccionario de la Lengua Española - Edición Tricentenario. Real Academia Española (RAE).

Enríquez, Mariana. "El marxista rabioso”. Radar Libros, Página 12. 3 mayo 2009.

Escajadillo, Tomás G. “Aves sin nido ¿Novela 'indigenista’?” Revista de Crítica Literaria Latinoamericana 59 (2004): 131-54.

- La narrativa de López Albújar. Lima: CONUP, 1972.

_. Mariátegui y la literatura peruana. Lima: Amauta Editores, 2004.

Espezúa Salmón, Dorian. “Cultura chicha?”. Crónicas urbanas: análisis y perspectivas urbano regionales.13.14 (2009): 99-110.

Fanon, Frantz. Los condenados de la tierra. 1961. Trad. Julieta Campos. México. D. F.: Fondo de Cultura Económica, 2009.

__. Piel negra, máscaras blancas. 1952. Tres Cantos [Madrid]: Akal, 2009.

Fanta Castro, Andrea. "Imágenes del tiempo en El olvido que seremos de Héctor Abad Faciolince". Letral 3 (2009): 28-40.

_. Residuos de la violencia: Producción cultural colombiana, 1990-2010. Bogotá: Editorial Universidad del Rosario, 2015.

Fernández Salvatteci, José. Terrorismo y guerra sucia en el Perú. Lima: Ediciones Fernández Salvatteci, 1986. 
Fiengo-Varn, Aurora. "Reconciling the divided self: Inca Garcilaso de la Vega's Royal Commentaries and his platonic view of the conquest of Peru". Revista de Filología y Lingüística de la Universidad de Costa Rica 29.1 (2003): 119-27.

Fitzcarraldo. Guion, dirección y producción de Werner Herzog. Fotografía Thomas Mauch. Música Popol Vuh. Actuaciones de Klaus Kinski (Brian Sweeney Fitzgerald), Claudia Cardinale (molly), José Lewgoy (Don Aquilino), Miguel Ángel Fuentes (Cholo). Alemania Occidental: Werner Herzog Filmproduktion, 1982. Película.

Fletcher, Nataly. "Más allá del cholo: Evidencia lingüística del racismo poscolonial en el Ecuador”. Sincronía 8.28 (2003).

Flores Galindo, Alberto. “Arguedas y la utopía andina”. Dos ensayos sobre José María Arguedas. Lima: Casa de Estudios del Socialismo Sur, 1992. 5-34.

_. La agonía de Mariátegui. La polémica con la Komintern.Lima: DESCO, 1980.

- "Los últimos años de Arguedas". Dos ensayos sobre José María Arguedas. Lima: Casa de Estudios del Socialismo Sur, 1992. 35-47.

- Obras completas III (I). Lima: Sur Casa de Estudios del Socialismo, 2015.

Foucault, Michel, Microfísica del poder. Trad. Julia Varela, y Fernando Álvarez-Uría. Madrid: La Piqueta, 1979.

, y Noam Chomsky. La naturaleza humana: justicia versus poder: un debate. Ed. Fons Elders. Trad. Leonel Livchits. Buenos Aires: Katz, 2006.

Fox Lockert, Lucía. "El mito del Inkarri en la historia y la literatura del Perú". Mitos en Hispanoamérica: Interpretación y literatura. East Lansing, Michigan: Nueva Crónica, 1989.

Franco, Carlos. "Exploraciones en 'otra modernidad': de la migración a la plebe urbana”. Cambios culturales en el Perú. Por Carlos Franco, Carlos Iván Degregori, y Antonio Cornejo Polar. Cusco: Ministerio de Cultura: Dirección Desconcentrada de Cultura de Cusco, 2016. 11-53.

Freud, Sigmund. Totem and Taboo: Resemblances between the Psychic Lives of Savages and Neurotics. Trad. A. A. Brill. Mineola, N.Y: Dover Publications, 1998.

Fuenzalida Vollmar, Fernando. "Identidad cultural e integración del pueblo peruano". La biblioteca del diablo o hellfire tomb of knowledge.

"Poder, raza y etnia en el Perú contemporáneo". El indio y el poder en el Perú. Ed. Fernando Fuenzalida. Lima: Instituto de Estudios Peruanos y MoncloaCampodónico Editores, 1970. 15-86.

Gabriele, John P. "Teatralidad y terrorismo en Los amantes del demonio de Alberto Miralles". RILCE: Revista de Filología Hispánica 29.1 (2013): 25-35. 
Gaceta del Gobierno de Lima Independiente 15 (29 de agosto de 1821): 67. Gobierno de Lima Independiente: Tomos I a III, Julio 1821-Diciembre 1822. Buenos Aires: Kraft, 1950. HathiTrust.

Galdo, Juan Carlos. "Un conglomerado de voces disímiles y antagónicas: historia, memoria y duelo en La violencia del tiempo". Colorado Review of Hispanic Studies 1.1 (2003) 41-64.

Gamero, Gonzalo. Deep Inside Lima. Puchi Art Studio, Miami, Florida. 19 Feb. 2010. Exposición fotográfica.

García Cáceres, Uriel. "El día que el Perú se jodió". En qué momento se jodió el Perú. Ed. Carlos Milla Batres. Lima: Milla Batres, 1990. 125-34.

García, José Uriel. El nuevo indio: Ensayos indianistas sobre la sierra sur-peruana. 1930. Cusco: H.G. Rozas sucesores Librería e Imprenta, 1937.

García Bedoya, Carlos. Para una periodización de la literatura peruana. Lima: Fondo Editorial de la Universidad Mayor de San Marcos, 2004.

García Canclini, Néstor. La globalización imaginada. 1999. Buenos Aires: Paidós, 2001.

_. Consumidores y ciudadanos: Conflictos multiculturales de la globalización. México, d.F: Grijalbo, 1995.

Garcilaso de la Vega, Inca. Comentarios reales. 1609. México: Editorial Porrúa. 1990.

_. Historia general del Perú. Córdova: Por la viuda de Andrés Barrera, y à su costa, 1617. Facsímil de la edición príncipe. Lima, SCG, 2009.

_. La Florida del Inca. Barcelona: Linkgua, 2008.

García Márquez, Gabriel. Cien años de soledad. Nueva York: Vintage Español, 2003.

Garvich, Javier. "El carácter chicha en la cultura peruana contemporánea: ¿Literatura de la miseria o miseria de la literatura?” Revista Peruana de Literatura 4.6 (2007): 60-4.

Gellner, Ernest. Nations and Nationalism. Ithaca: Cornell University Press, 1983.

Georges-Abeyie, Daniel E. "Women as Terrorists”. Perspectives on Terrorism. Eds. Alexander, Yona y Lawrence Zelic Freedman. Wilmington, Dl: Scholarly Resources, 1983. 71-84.

Giesecke Sara Laffose, Margarita. "Escribir no es sólo cosa de hombres". Revista Quehacer 125 (2000): 40-47.

_. La insurrección de Trujillo: jueves 7 de julio de 1932. Lima: Fondo Editorial del Congreso del Perú, 2010. 
Giesecke Sara-Lafosse, Mercedes. "Cuestionando la globalización desde la interculturalidad”. Revista de Antropología 1.1. [Cuarta época] (2003): 151-64.

Gnecco, Cristóbal. "De la arqueología del pasado a la arqueología del futuro: anotaciones sobre multiculturalismo y multivocalidad". Jangwa Pana 10.1 (2011): 26-42.

"Discursos sobre el otro. Pasos hacia una arqueología de la alteridad étnica". CS 2 (2008): 101-29.

Gómez de Avellaneda, Gertrudis. Sab. Ed. José. Servera. Madrid: Cátedra, 2003.

González Prada, Manuel. "Discurso en el Politeama". 1888. Páginas escogidas [sic] Callao: Municipalidad Provincial del Callao, 1996.

_. "Nuestros indios". 1904. Memorias de América Latina. Caracas: Universidad Central de Venezuela, Facultad de Humanidades y Educación, 2002. 121-38.

Gramsci, Antonio. The Gramsci Reader: Selected Writings, 1916-1935. Ed. David Forgacs. Nueva York: New York University Press, 2000.

Granados, Manuel Jesús. "El PCP Sendedo Luminoso: aproximaciones a una ideología”. Juicio a Abimael: Sendero, ideologia y realidad. Ed. Raúl Vento García. Lima: Agenda 2000 Editores, 1992. 35-148.

Grau-Llevería, Elena. "El romanticismo social en Dos mujeres de Gertrudis Gómez de Avellaneda." Bulletin of Spanish Studies 87.1 (2010): 31-49.

Grijalva, Juan Carlos. "Vasconcelos o la búsqueda de la Atlántida. Exotismo, arqueología y utopía del mestizaje en La raza cósmica". Revista de Crítica Literaria Latinoamericana 30.60 (2004): 333-49.

Guamán Poma de Ayala, Felipe. Nueva cononica y buen gobierno. Caracas: Biblioteca Ayacucho, 1979.

Guardia, Sara Beatriz. "La escritura femenina en el Perú del siglo XIX.” Escritoras del siglo XIX en América Latina. Ed. Sara Beatriz Guardia. Lima: CEMHAL, 2012. 17-33.

Guerra Martinière, Margarita. Historia general del Perú. Tomo XII. La República Contemporánea (1919-1950). Lima: Milla Batres, 1984.

_. "Los grupos y las tensiones sociales en el Perú de 1879". En tomo a la Guerra del Pacífico. Percy Cayo Córdova et al. Lima: Pontificia Universidad Católica del Perú, 1983. 71-125.

Guibernau, Monserrat. "Anthony D. Smith on nations and national identity: a critical assessment". Nations and Nationalism 10 (2004): 125-41. 
Gutiérrez Correa, Miguel. La generación del 50: Un mundo dividido: Historia y balance. Lima: Ediciones Sétimo Ensayo, 1988.

. La violencia del tiempo. 1991. Lima: Punto de Lectura, 2010.

_. La violencia del tiempo I, II y III. Lima: Milla Batres, 1991.

Gutiérrez de Quintanilla, Emilio. "Juicio crítico". Matto de Turner, Clorinda. Aves sin nido. Valencia: F. Sempere \& Cía., Editores, 1906.5-26.

Guzmán Reynoso, Abimael. Guerra popular en el Perú: el Pensamiento Gonzalo. Ed. Luis Arce Borja. Brucelas: L.A. Borja, 1989.

Jauretche, Arturo. El medio pelo en la sociedad argentina: Apuntes para una sociología nacional. Buenos Aires: Ed. A. Peña Lillo, 1967.

Hatun Willakuy [Gran relato]: Versión abreviada del Informe Final de la Comisión de La Verdad y Reconciliación, Perú. (2004). Lima: Comisión de Entrega de la Comisión la Verdad y Reconciliación, 2008.

Hayes, Carlton J. H. El nacionalismo: una religión. Trad. Ma. Luisa L. de del Real. México: Unión Tipográfica Editorial Hispano Americana, 1966.

Hampe Martínez, Teodoro. "El renacentismo del Inca Garcilaso revisitado: los clásicos greco-latinos en su biblioteca y en su obra". Biblioteca Virtual Universal. Editorial el Cardo, 2010. 1-19.

Hastings, Adrian. The Construction of Nationhood: Ethnicity, Religion, and Nationalism. Cambridge: Cambridge University Press. 1997

Hernández, Max. Memoria del bien perdido: Conflicto, Identidad y nostalgia en el Inca Garcilaso de la Vega. Madrid: Sociedad Estatal Quinto Centenario, 1991.

Hidalgo, David. Entrevista con Juan M. Ossio. "Ezequiel Ataucusi: el profeta que contuvo a Sendero Luminoso". Actualidad. 19 de enero de 2015.

Hidalgo Morey, Teodoro. Sendero Luminoso: Subversión y contrasubversión: Historia y tragedia. Lima: Aguilar, 2004.

Holmes, Jennifer S. "Sendero Luminoso after Fujimori: a Sub-National Analysis". The Latin Americanist 59.2 (2015): 29-55.

Hutcheon, Linda. A Theory of Parody: The Teachings of Twentieth-Century Art Forms. Methuen (Nueva York, 1985.

Instituto Nacional de Estadística e Informática (INEI). Censos Nacionales de Población y Vivienda de 1940, 1961, 1972, 1993 y 2007. 
_. "Tasa de analfabelismo". Perú: Indicadores de Educación por Departamentos, 2001-2012.

Iwasaki Cauti, Fernando. "El pensamiento político de Bartolomé Herrera: el proyecto conservador del siglo XIX”. Boletín del Instituto Riva-Agüero 13 (1984-1985): $127-50$.

Jackson, Jean. "Is there a way to talk about making culture without making enemies". Dialectical Anthropology 14.2 (1989): 127-43.

Jara Jiménez, Cronwell. Patíbulo para un caballo. Lima: Mosca Azul Editores, 1989. Montacerdos. 1981. Lima: Editorial San Marcos, 2006.

—. Entrevista con Frank Otero Luque. "Las palabras brotan como una cascada y me inundan". Palabra en libertad 16.76 (2014): 52-60.

Juan-Navarro, Santiago. "El Furioso Daimón de Lope de Aguirre: hacia un postmodernismo de resistencia en la narrativa histórica de Abel Posse". Delaware Review of Latin American Studies 7.1 (2006): 1-7.

_. "The Dialogic Imagination of Salman Rushdie and Carlos Fuentes: National Allegories and the Scene of Writing in Midnight's Children and Cristóbal Nonato". Neohelicon 20.2 (1993): 257-311.

Kaplan, E. Ann. Trauma Culture: The Politics of Terror and Loss in Media and Literature. Nueva Brunswick (N.J: Rutgers, 2005.

Kaulicke, Peter. Historia del Perú: El Perú antiguo I (9000 A.c.-200 D.c.): Los periodos arcaico y formativo. Lima: Empresa Editora El Comercio, 2011.

Karttunen, Frances. "Rethinking Malinche". Indian Women of Early Mexico. Ed. Susan Schroeder, Stephanie Wood y Robert Haskett. Norman: University of Oklahoma Press. 1997. En Valdeón.

Keith, Robert G. "Encomienda, Hacienda, and Corregimiento in Spanish America: A Structural Analysis". Hispanic American Historical Review 52.3 (1971): 431-46.

Kirkpatrick, Susan. Las Románticas: Escritoras y subjetividad en España (1835-1850). Madrid: Cátedra, 1991.

Klaiber, Jeffrey. La Iglesia en el Perú: su historia social desde la Independencia. Lima: Pontificia Universidad Católica del Perú, Fondo Editorial, 1996.

Kohan, Néstor. "El poder y la hegemonía". [Publicado originalmente en el periódico Madres de Plaza de Mayo, 6, diciembre 2003]. Rebelión: Cátedra Ernesto Che Guevara. 
Konetzke, Richard. "Los mestizos en la legislación colonial". Revista de estudios políticos 112 (1960): 113-48.

Kubler, George. "The Quechua in the Colonial World". 1946. Handbook of South American Indians II. Julian H. Steward. Nueva York: Cooper Square, 1963. 331.410.

Kuon Arce, Elizabeth, Rodrigo Gutiérrez Viñuales, Ramón Gutiérrez, y Graciela María Viñuales. Cuzco - Buenos Aires: Ruta de intelectualidad americana (1900-1950). Lima: USMP Fondo Ed, 2009.

La boca del lobo. Guion de Augusto Cabada, Gerardo Herrero y Giovanna Pollarolo. Dirección de Francisco Lombardi. Actuaciones de Gerardo Herrero, Gustavo Bueno (Teniente Iván Roca), Toño Vega (Vitín Luna), José Tejada (Gallardo). Perú y España: Inca Films, Tornasol Films y Televisión Española, 1988. Película.

Lacan, Jacques. "The line and the light". The Four Fundamental Concepts of PsychoAnalysis. Ed. Jacques-Alain Miller. Trad. Alan Sheridan. London: Hogarth Press, 2004. 99.

La crónica Hellstrom [The Hellstrom Chronicle]. Dirigido por Ed Spiegel y Walon Green. Guion de David Seltzer. Actuación de Lawrence Pressman. Producido por David L. Wolper. Estados Unidos: Cinema 5 Distributing, 1971. Mockumentary dramático.

La naturaleza humana: justicia versus poder. Un debate. Noam Chomsky/Michel Foucault. Trad. Leonel Livchitz. Buenos Aires: Katz Editores, 2006.

La Torre Silva, Ricardo. "La inmigración china en el Perú". Boletín de la Sociedad Peruana de Medicina Interna 5.3, 1992.

Lausent-Herrera, Isabelle. "Tusans (tusheng) and the Changing Chinese Community in Peru". Journal of Chinese Overseas, Brill Academic Publishers 7.1 (2009): 11552.

Larriva de Llona, Lastenia. Fe, patria y hogar: Colección de poesías. Lima: Librería e Imprenta Gil, 1902. Reprint from the collections of the University of California Libraries. Lexington, KY, 2013.

_. Un drama singular: Historia de una familia. Guayaquil: s.n., 1888.

Ledgard, Melvin. "Orientalismo contemporáneo para curtidos novelistas peruanos: Oswaldo Reynoso y Miguel Gutiérrez en la China". Monteagudo, Cecilia, y Víctor Vich. Del viento, el poder y la memoria: Materiales para una lectura crítica de Miguel Gutiérrez. Lima: Fondo Editorial de la PUCP. 36-52. 
Llano, Aymará de. "Problemáticas de la crítica literaria: la novela: narrativa negrista en el Perú”. Estudios Hispánicos 18 (2010): 109-18.

Lima, Paolo de. "400 años de los Comentarios reales del Inca Garcilaso de la Vega: Entrevista a José Antonio Mazzotti." Inti: Revista de literatura hispánica 67-68 (2008): 261-68.

Loli S., Pamela. "Ezequiel Ataucusi: a los 15 años de la muerte del candidato del 'Pescadito"'. El Comercio, 19 junio 2015.

López Albújar, Enrique. Matalaché. 1928. Lima: Juan Mejía Baca \& L.P. Villanueva Ed., 1950.

López Chau, Alfonso. "Destrucción y restauración ¿1910?”. Juicio a Abimael: Sendero, ideologia y realidad. Ed. Raúl Vento García. Lima: Agenda 2000 Editores, 1993. 149-76.

"Los conceptos del ayllu y la marka". Mundo aymara sin fronteras. Red.

Luque Luna, Julio César. La realidad nacional que encuentra el político nuevo. Lima: Imp. El cóndor, 1956.

Macaulay, Thomas B. "Minute by the Hon'ble T. B. Macaulay, dated the 2nd February 1835”. Red.

Macera, Pablo. "El arte mural cusqueños: siglos XVI-XX”. Serie Estudios y notas. Apuntes, Revista de Ciencias Sociales 2.4 (1975): 59-113.

Malgesini, Graciela, y Carlos Giménez. Guía de conceptos sobre migraciones, racismo e Interculturalidad. Madrid: Libros de la Catarata, 2000.

Manrique, Nelson. "Clorinda Matto y el nacimiento del indigenismo literario: Aves sin nido, cien años después". Debate agrario 6 (1989): 81-101.

_. "Historia, literatura y violencia en el Perú de los 80". Del viento, el poder y la memoria. Ed. Cecilia Monteagudo y Víctor Vich. Lima: Fondo Editorial de la PUCP, 2002. 106-25.

- La piel y la pluma: escritos sobre literatura, etnicidad y racismo. Lima: Centro de Informe y Desarrollo Integral de Autogestión (CIDIAG), 1999.

Manzo-Robledo, Francisco. "La Metaotredad en Comentarios reales del Inca Garcilaso de la Vega”. Espéculo. Revista de estudios literarios 25.2003. 
Mapa Etnolinguistco del Perú 2010. Instituto Nacional de Desarrollo de Pueblos Andinos, Amazónicos y Afroperuanos - INDEPA.

$<$ http://siar.minam.gob.pe/lima/fuente-informacion/instituto-nacional-desarrollopueblos-andinos-amazonicos>

Marable, Manning. Race, Reform, and Rebellion: The Second Reconstruction in Black America, 1945-1990. Jackson: University Press of Mississippi, 1991.

Marger, Martin. Race and Ethnic Relations: American and Global Perspectives. Stamford (CT: Cengage Learning, 2015.

Mariátegui, José Carlos. 7 ensayos de interpretación de la realidad peruana. 1928. Lima: Biblioteca Amauta, 1995.

José Carlos Mariátegui: Obras: Tomo 2. Selección de Francisco Baeza Pérez. La Habana: Casa de las Américas, 1982.

- "La unidad de la América indo-española". José Carlos Mariátegui: Obras: Tomo 2. Francisco Baeza Pérez. La Habana: Casa de las Américas, 1982. 247-50.

- "Punto de vista anti-imperialista". José Carlos Mariátegui: Obras: Tomo 2. Francisco Baeza Pérez. La Habana: Casa de las Américas, 1982. 187-93.

Morillo, Ganoza J. Hienas en la Niebla. Lima: Universidad Ricardo Palma, Editorial Universitaria, 2010.

Martínez, Gregorio. Crónica de músicos y diablos. Lima: PEISA, 1991.

Marx, Karl. El capital: I. México: Fondo de Cultura Económica, 1973.

"Prólogo a la Contribución a la Crítica de la Economía Política". 1859.

Marxists Internet Archive. Dig. Germán Zorba. Mar. 2001.

Mason, Eudo C. Rilke, Europe, and the English-Speaking World. Cambridge: Cambridge University Press, 1961.

Matto de Turner, Clorinda. Aves sin nido. 1989. Buenos Aires: Stockcero, 2004.

_. Leyendas y recortes. Lima: La Equitativa, 1893.

Mayer, Enrique. "Mestizo e indio: el contexto social de las relaciones interétnicas". El indio y el poder en el Perú. Ed. Fernando Fuenzalida. Lima: Instituto de Estudios Peruanos y Moncloa-Campodónico Editores, 1970. 87-152.

Mazzotti, José Antonio. "Garcilaso en el Inca Garcilaso: los alcances de un nombre". Lexis 29.2 (2005): 179-219.

Melville, Herman. Moby-dick o la ballena. Ed. Fernando Velasco Garrido. Madrid: Akal, 2012. 
Méndez G., Cecilia. "De indio a serrano: nociones de raza y geografía en el Perú (siglos XVIII- XXI)". Histórica 35.1 (2011): 53-102.

_. "Incas sí, indios no". Apuntes para el estudio del nacionalismo criollo en el Perú. Documento de trabajo del IEPA, 1985. En Vich, Víctor.

Mèlich, Joan-Carles. La ausencia del testimonio: Ética y pedagogía en los relatos del Holocausto. Rubí (Barcelona: Anthropos, 2001.

Milla Batres, Carlos, Luis Guillermo Lumbreras et al. En qué momento se jodió el Perú. Lima: Editorial Milla Batres, 1990.

Miller, Marilyn Grace. Rise and Fall of the Cosmic Race: The Cult of Mestizaje in Latin America. Austin: University of Texas Press, 2004.

Millones-Figueroa, Luis. "Alma blanca, cuerpo negro: La construcción ideológica del mulato en la novela antiesclavista (Los casos de Sab y Matalaché)". Lucero 5 (1994): 77-87.

Millones Santa Gadea, Luis. "Cinco preguntas en torno a Garcilaso". Literaturas Andinas 2 (1989): 23-4.

Montes, Cristián. "El imaginario perruno en La ciudad y los perros de Mario Vargas Llosa”. Revista Chilena de Literatura 80 (2011): 65-86.

Montoya Rojas, Rodrigo. Prólogo. Tempestad en los Andes. 1929. Por Luis E. Valcárcel. Lima: Ministerio de Cultura - Dirección Regional de Cultura del Cusco, 2013.

Morillo Ganoza, Juan. Hienas en la Niebla. Lima: Universidad Ricardo Palma, Editorial Universitaria, 2010.

Morin, Edgar. Seven Complex Lessons in Education for the Future. Trad. Nidra Poller. París: United Nations Educational, Scientific and Cultural Organization, 1999.

Muñoz-Nájar, Teresina. "Buscando al Inca”. Caretas 1679. 19 Jul. 2001.

Neira Samanez, Hugo. Las independencias: Doce ensayos. Lima: Universidad Inca Garcilaso de la Vega, Fondo Editorial, 2010.

Negri, Antonio, y Michael Hardt. Imperio. Bogotá, D.C: Ediciones desde abajo, 2001.

Nelson, Diane M. A Finger in The Wound: Body Politics inQuincentennial Guatemala. Durham: Duke University Press, 1999. 
Nitschack, Horst. "Miguel Gutiérrez - La violencia de la historia: olvidar y recordar". Del viento, el poder y la memoria: Materiales para una lectura crítica de Miguel Gutiérrez Monteagudo. Ed. Cecilia, y Víctor Vich.Lima: Fondo Editorial de la PUCP. 2002. 126-52.

Noemí, Daniel. "Para una genealogía de la narrativa peruana reciente (escribir después del terror)". Letral 3 (2009): 41-53.

Nugent, José Guillermo. Nugent, José G. El laberinto de la choledad: Páginas para entender la desigualdad. Lima: Universidad Peruana de Ciencias Aplicadas (UPC), 2014.

Obando, Enrique. Identidad peruana: La percepción de los intelectuales. Lima: Instituto de Estudios Políticos y Estratégicos (IDEPE), 2002.

Oberst, Úrsula, Virgili Barz y Ramón León. "La psicología individual de Alfred Adler y la psicosíntesis de Olivér Brachfeld”. Revista de Neuro-Psiquiatría 67 (2004): 3144.

Oboler, Suzanne. "El mundo es racista y ajeno: orgullo y prejuicio en la sociedad limeña contemporánea". Documento de trabajo $N^{0} 74123$. Serie Antropología $N^{o} 10$. Lima: Instituto de Estudios Peruanos (1966): 1-47.

Ojeda, Martha. Nicomedes Santa Cruz: Ecos de África en Perú. Rochester (NY: Tamesis, 2003.

Ordóñes, Damary. “Acercamiento existencialista al drama La noche de los asesinos de José Triana. El papel de la 'mirada' en las relaciones intersubjetivas”. Latin America Theater Review 49.2 (2016): 147-60.

Oré Chávez, Iván. "Perú: los nuevos dueños de la tierra". Perspectiva internacional: Revista internacional de investigación, análisis y debate (2010).

Orrego Penagos, Juan Luis. “La república oligárquica 1850 - 1950”. Ed. Teodoro Hampe Martínez. Historia del Perú. Etapa republicana. Barcelona: Lexus, 2000.

Ortega, Francisco A., "Trauma and Narrative in Early Modernity: Garcilaso's 'Comentarios reales' (1609-1616)'. Hispanic Issue (2003): 393-426.

Ortega, Julio. "El Inca Garcilaso y el discurso de la cultura". Cuadernos Hispanoamericanos: Revista mensual de cultura hispánica 357 (1980): 670-77.

Ortiz, Fernando. Contrapunteo cubano del tabaco y el azúcar. 1940. Caracas: Biblioteca Ayacucho, 1979. 
Ortiz Rodríguez, María de las Mercedes. "La fisura irremediable: indígenas, regiones y nación en tres novelas de Mario Vargas Llosa". Antípodas, Revista de Antropología y Arqueología 15 (2012): 111-36.

Ossio, Juan M. Entrevista con David Hidalgo. "Ezequiel Ataucusi: el profeta que contuvo a Sendero Luminoso". Actualidad (19 de enero de 2015). Red.

_. Ideología mesiánica del mundo andino. Ed. Ignacio Prado Pastor. Lima: s.n., 1973.

Otero Luque, Frank. "Borges, uno de los tantos autores de 'Pierre Menard, autor del Quijote.'” Argus-a 6.22 (2016): 1-17.

- Entrevista con Cronwell Jara. "Cronwell Jara: 'Las palabras brotan como una cascada y me inundan"”. Palabra en libertad 16.76 (2014): 52-60.

_ - "Cronwell Jara: reseña biográfica". Palabra en libertad 16.76 (2014): 60-2.

_. "El Inca Garcilaso desde el escepticismo: identidad mestiza conflictiva, subvaluación de la Otredad preincaica y dioses ocupados". Inca Garcilaso de la Vega: 400 Aniversario. Comp. José Beltrán Peña. Lima, Gaviota Azul Editores, 2016.46-88.

- "Intérpretes y transculturados: Gonzalo Guerrero, Jerónimo de Aguilar y Doña Marina como íconos culturales". Palabra en libertad 16.45 (2014): 37-8.

"Hienas en la niebla (2010) de Juan Morillo Ganoza: estrategias narrativas y representación de la Guerra Interna librada en el Perú entre 1980 y 2000”. Argus-a 5.21 (2016): 1-20. "La Lima profunda". Palabra en libertad 18.136 (2016): 26-27.

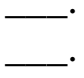
"Literaturas y comunidades imaginadas de Mariátegui”. Argus-a 5.20 (2016): 125. "Mercedes Cabello de Carbonera y Blanca Sol (1888): iconoclasia, muerte social y locura". Decimonónica 12.2 (verano de 2015): 47-56.

Oviedo, José Miguel. Breve historia del ensayo hispanoamericano. Madrid: Alianza, 1991.

_. Historia de la literatura hispanoamericana 3. Madrid: Alianza Editorial, 1995.

_. Mario Vargas Llosa: la invención de una realidad. Barcelona: Seix Barral, 1982.

Pacheco Ibarra, Juan José. "La fiesta de San Juan de Amancaes y el volcán de agua" [Fragmento de "La fiesta de Amancaes (1650-1950) una festividad limeña a través del tiempo"]. Rincón de historia peruana. 24. Jun. 2012.

Palma, Ricardo. Cartas a Piérola: sobre la ocupación chilena de Lima. Lima: Milla Batres, 1979. En Portocarrero.

“Genialidades de la Perricholi". Tradiciones peruanas. Cuarta serie. Tomo II. Barcelona: Montaner y Simón, 1893. 
Paloma de papel. Guion y dirección de Fabrizio Aguilar. Actuaciones de Antonio Callirgos (Juan niño), Eduardo Cesti (Viejo), Aristóteles Picho (Fermín), Liliana Trujillo (Domitila), Sergio Galliani (Wilmer), Melania Urbina (Yeni), Tatiana Astengo (Carmen), Jesús Carbajal (Modesto), Anaís Padilla (Rosita). Perú: Luna LLena Films, 2003. Película.

Papa Juan XXIII (1963). "Pacem in terris. Carta encíclica sobre la paz entre todos los pueblos que ha de fundarse en la verdad, la justicia, el amor y la libertad". Vaticano: Libreria Editrice Vaticana, 1963.

Paz, Octavio. El laberinto de la soledad. Paz, Octavio. Nueva York: Penguin Books, 1997.

Peluffo, Ana. Lágrimas andinas: sentimentalismo, género y virtud republicana en Clorinda Matto de Turner. Pittsburgh, PA: Instituto Internacional de Literatura Iberoamericana, Universidad de Pittsburgh, 2005.

"Why can't an Indian be More Like a Man? Sentimental Bonds in Manuel González Prada and Clorinda Matto de Turner". Revista de estudios hispánicos 38.1 (2004): 2-21.

Pérez Canto, Pilar. "La población de Lima en el siglo XVIII". Boletín americanista 32 (1982): 383-407.

Pinedo Bravo, Enith. “¿Quién es indígena en el Perú?”. Iberoamericana 12.48 (2012): 177-83.

Pitt-Rivers, Julian. "Race, Color, and Class in Central America and the Andes." Daedalus 96.2 (1967): 542-59.

Polo de Ondegardo, Juan. Tratado y averiguación sobre los errores y supersticiones de los indios.1559. Revista histórica.

Polo, José Toribio. Memorias de los virreyes del Perú: Marqués de Mancera y Conde de Salvatierra. Lima: Imprenta del Estado, 1899

Porras Barrenechea, Raúl. "El Inca Garcilaso de la Vega (1539-1616)”. Porras Barrenechea, Raúl, Franklin Pease, Oswaldo Holguín Callo. Los cronistas del Perú (1528-1650) y otros ensayos. Lima: Banco de Crédito del Perú, 1986. 391451.

Portocarrero Maisch, Gonzalo. La urgencia por decir "nosotros": Los intelectuales y la idea de nación en el Perú republicano. Lima: Fondo Editorial de la Pontificia Universidad Católica del Perú, 2015.

_. Profetas del odio: Raíces culturales y líderes de Sendero Luminoso. Lima: Fondo Editorial de la PUCP, 2015. 
_. Razones de sangre: aproximaciones a la violencia política. 1998. Fondo Editorial de la PUCP, 2015.

Portugal, José Alberto. "Miguel Gutiérrez y Mario Vargas Llosa: el amargo sueño de la utopía". Del viento, el poder y la memoria: Materiales para una lectura crítica de Miguel Gutiérrez. Lima: Fondo Editorial de la PUCP. 53-69.

Prado y Ugarteche, Javier: "Estado social del Perú durante la dominación española". 1894. Anales Universitarios del Perú XXII. Lima: Universidad Nacional Mayor de San Marcos, 1897. 125-6.

Prendes Guardiola, Manuel. "Constantes temáticas en tres novelas peruanas sobre la época del terrorismo".Romance Notes 50.2 (2010): 229-39.

Pupo-Walker, Enrique. "Sobre la configuración narrativa de los Comentarios reales". Revista Hispánica Moderna 39.3 (1976-1977): 123-35.

Quijano, Aníbal. "Colonialidad y modernidad-racionalidad". Los conquistados. 1492 y la población indígenade las Américas. 1991. Ed. Heraclio Bonilla. Bogotá: Tercer Mundo-Libri Mundi, 1992. 437-47.

"Colonialidad del poder, cultura y conocimiento". 1998. Dispositio 24.51 (1999): 137-48.

"Coloniality of Power, Eurocentrism, and Latin America". Nepantla 1:3 (2000): 533-80.

_. Dominación y cultura: Lo cholo y el conflicto cultural en el Perú. 1971. Lima: Mosca azul, 1980.

"La emergencia del grupo cholo en el Perú y sus implicaciones en la sociedad peruana”. Memorias del VII Congreso Latinoamericano de Sociologí. Bogotá: Asociación Colombiana de Sociología, 1965.

- e Immanuel Wallerstein. "La americanidad como concepto, o América en el moderno sistema mundial". 1992. Revista Internacional de Ciencias Sociales 134. (1992): 583-92.

Quispe Lázaro, Arturo. "La cultura chicha en el Perú”. Revista Electrónica Construyendo Nuestra Interculturalidad 1.1 (2004): 1-17.

Rama, Ángel. La ciudad letrada. Hanover, N.H.: Ediciones del Norte, 2002. "Literatura y cultura en América Latina". Revista de crítica literaria latinoamericana 9.18 (1983): 7-35.

_. Transculturación narrativa en América Latina. 1982. Buenos Aires: Ediciones El adariego, 2008.

Ramos-García, Luis A. "Rock-and-roll en las barriadas peruanas: identidad cultural, hibridismo y transculturación". ALPHA: Revista de artes, letras y filosofía 13 (1997): 123-34. 
Ramos, Samuel. El perfil del hombre y la cultura en México. 1934. México, D.F: Planeta México, 2001.

Reátegui, Carrillo F. Hatun Willakuy: versión abreviada del informe final de la Comisión de la Verdad y Reconciliación, Perú. Lima: Comisión de entrega de la Comisión de la Verdad y Reconciliación, 2008.

Redfield, Robert. "Race as a Social Phenomenon". Race: Individual and Collective Behavior. Eds. Edgar T Thompson, y Everett C. Hughes. Glencoe: The Free Press, 1958. 66-71.

Renan, Ernest. “¿Qué es una nación?”. 1882. Ed. digital de Franco Savarino, 2004.Université de Fribourg, 2004.

_. “Qu'est-ce qu'une nation?”. París : Librairie Rutebeuf, 1882.

Reyes Tarazona, Roberto. "Aproximación a La violencia del tiempo". Del viento, el poder y la memoria: Materiales para una lectura crítica de Miguel Gutiérrez. Monteagudo. Ed. Cecilia, y Víctor Vich.Lima: Fondo Editorial de la PUCP. 2002. 153-63.

_ Presentación. Morillo Ganoza, Juan. Hienas en la Niebla. Lima: Universidad Ricardo Palma, Editorial Universitaria, 2010. 9-16.

Ribeyro, Julio Ramón. La palabra del mudo. Lima: Milla Batres, 1973.

Riva-Agüero, José de la. Introducción. Comentarios reales. Por Inca Garcilaso de la Vega. México: Editorial Porrúa. 1990. i-xliii.

. “Elogio al Inca Garcilaso". 1916. Del Inca Garcilaso a Eguren. Lima: PUCP, 1962.

Campra, Rosalva. "Lo fantástico: una isotopía de la transgresión” Teorías de lo fantástico. Ed. David Roas. Madrid: Arco/Libros, 2001. 153-92.

Rendón Vásquez, Jorge. “El racismo en el Perú”. Los Andes, 3 feb. 2013.

Rodríguez Demorizi, Los Dominicos y las encomiendas de Indios de la Isla Española. Santo Domingo: Academia Dominicana de la Historia, 1971.

Rodríguez, Gustavo, y Sandro Venturo. Ampay Perú: 357 listas para entender cómo somos los peruanos. Lima: Aguilar, 2007.

Rodríguez-Mansilla, Fernando. "La sombra del padre es alargada: la Relación de la descendencia de Garci Pérez de Vargas del Inca Garcilaso”. Symposium: A Quarterly Journal in Modern Literatures 68:4 (2014): 177-87. 
Rospigliosi, Fernando. Entrevista con Abelardo Sánchez-León. “¿Terrorismo y corrupción? Una entrevista con Fernando Rospigliosi”. Revista Quehacer 143 (2003).

Rostworowski de Diez Canseco, María. "El Señor de los Milagros". Instituto de Estudios Peruanos. Estructuras andinas del poder: Ideología religiosa y Política. Lima: Instituto de Estudios Peruanos, 1983.

- Historia del Tahuantinsuyu. Lima: Instituto de Estudios Peruanos, 1988. Salazar, Eduardo. "Causas de la inmigración china en el Perú". Bitácora sobre la inmigración en el Perú, siglo XIX.

Rowe, John Carlos. The New American Studies. Minneapolis, Minn: University of Minnesota Press, 2002.

Said, Edward W. Orientalismo. Barcelona: Debate, 2016.

Salazar, Eduardo. "Causas de la inmigración china en el Perú". Bitácora sobre la inmigración en el Perú, siglo XIX.

Salles, Estela Cristina, y Héctor Omar Noejovich. "El repartimiento real de Chucuito en el Virreinato del Perú: La tributación temprana y su evolución, 1539-1547". Fronteras de la Histoiria 18.2 (2013): 47-75.

Sánchez, Luis Alberto. La Perricholi. Santiago de Chile: Editorial del Pacífico, 1955.

_. Literatura peruana. Derrotero para una historia cultural del Perú, Lima: EMI editores, 1989.

_. Colofón. Tempestad en los Andes. Por Luis Eduardo Valcárcel Vizcarra. Lima: Ministerio de Cultura - Dirección General del Cusco, 2013.

Sánchez Patzy. Mauricio. "Aproximaciones a la estética chola: La cultura de la warawa en Bolivia a principios del siglo XXI". Estudios sociales del NOA 13 (2004): 532.

Sanhueza, Marcelo. "Violencia/contraviolencia: descolonización y reinterpretación del marxismo revolucionario en Los condenados de la tierra de Frantz Fanon". Surcoaustral (2014).

Sarmiento, Domingo Faustino. Facundo o civilización y barbarie en las pampas argentinas. Santiago de Chile: Imprenta del Progreso, 1845.

Sartre, Jean Paul. ¿Qué es la literatura? 1948. Ed. Aurora Bernández. Buenos Aires: Losada, 2003.

Schmidt, [i,Alex?]. 1988. "Definitions of Terrorism - Academic Consensus Definition". United Nations. Office on Drugs and Crime. 
Sepúlveda, Juan Ginés. Tratado sobre las justas causas de la guerra contra los indios. Con una advertencia de Marcelino Menéndez y Pelayo y un estudio de Manuel García Pelayo. México: Fondo de Cultura Económica, 1987.

Servera, José. “Introducción”. Gómez de Avellaneda, Gertudis. Sab. Madrid: Cátedra, 2003. 9-89.

Seton-Watson, Hugh. Nations and States: An Enquiry into the Origins of Nations and the Politics of Nationalism. Boulder, Colo: Westview Press, 1977.

Shady, Solís Ruth Martha. La ciudad sagrada de Caral-Supe en los albores de la civilización en el Perú. Lima: Universidad Nacional Mayor de San Marcos, Fondo Editorial, 1997.

Slemson, Stephen. "Post-Colonial Allegory and the Transformation of History". Journal of Commonwealth Literature 21 (1988): 157-68.

Smith, Anthony D. Chosen Peoples: Sacred Sources of National Identity. Oxford: Oxford University Press, 2003.

_. The Nation in History: Historiographical Debates about Ethnicity and Nationalism. Hanover, NH: University Press of New England, 2000.

- The Ethnic Origins of Nations. 1986. Oxford: Blackwell, 2005.

- Nationalism and Modernism: A Critical Survey of Recent Theories of Nations and Nationalism. Londres: Routledge, 1998.

Smith, Paul Julian. 2004. "The Basque Ball. Skin Against Stone”. Sight and Sound 5. 4445.

Solano, Francisco de. Cedulario de tierras. Compilación de la legislación agraria Colonial (1497-1820). Instituto de Investigaciones Jurídicas. Universidad Nacional Autónoma de México. Ciudad de México, 1991.

Sommer, Doris. “Sab C'est Moi”. Foundational Fictions. Berkeley: University of California Press, 1991.

Spivak, Gayatri. Can the Subaltern Speak? 1985. Basingstoke: Macmillan, 1988.

Sproul, Barbara C. Primal Myths: Creation Myths Around the World. San Francisco: Harper Collins, 1991.

Tauro, Alberto. Clorinda Matto de Turner y la novela indigenista. Lima: Universidad Mayor de San Marcos, 1976.

Terrazas, Francisco de, “Andanzas a Jerónimo de Aguilar”. Red. 
“The Nobel Peace Prize 1993”. The Official Website of the Nobel Price. Nobelprice.org.

The True Story of Liz (La historia de Liz Rojas). Guion de Augusto Cabada. Dirección de Eduardo Guillot. Actuaciones de Evelyn Azabache, Nídea Bermejo, Pietro Sibille, Alexis Neira, Patricia Altuna, Aristóteles Picho, Pamela Lloclla, Flor Castillo y Lilia Trujillo. Perú: Imagia Films, 2007. Docudrama.

Thomas, Gregory Anthony. "Realism in Nineteenth-Century Spanish America: Clorinda Matto de Turner's 'Birds Without a Nest'”. The Journal of the Midwest Modern Languages Association 41.2 (2008): 55-68.

Todorov, Tzvetán. La conquista de América: El problema del otro. México, D.F: Siglo Veintiuno, 2007.

Torre, María Elena. "Entre la fundación y el derrumbe: La violencia del tiempo de Miguel Gutiérrez. Revista Iberoamericana 80.247 (2014): 373-98.

Torre López, Arturo E. de la. Movimientos milenaristas y cultos de crisis en el Perú: Análisis histórico y etnológico. Lima: Pontificia Universidad Católica del Perú, Fondo Editorial, 2004.

Torres-Pou, Joan. "Clorinda Matto de Turner y el ángel del hogar”. Revista hispánica moderna 43.1 (1990): 3-15.

Ugarte, César A. Bosquejo de la historia económica del Perú. Lima: Imp. Cabieses, 1926.

UNESCO. "Declaración Universal de la UNESCO sobre la diversidad cultural". Portal oficial de la Organización de las Naciones Unidas para la Educación, la Ciencia y la Cultura.

UNICEF. “Atlas sociolingüístico de Pueblos Indígenas de América Latina - Fichas nacionales". Red.

Valcárcel Vizcarra, Luis Eduardo. Tempestad en los Andes. 1927. Lima: Ministerio de Cultura - Dirección General del Cusco, 2013.

Valdeón, Roberto A. "Doña Marina/La Malinche: A Historiographical Approach to the Interpreter/Traitor". Target: International Journal of Translation Studies 25.2 (2013): 157-79.

Varese, Stefano. "Territorio, tierra y recursos". Resistencia y territorialidad. Culturas indígenas y afroamericanas. Coord. Javier Laviña, y Gemma Orobitg. Barcelona: Publicacions y Edicions de la Universitat de Barcelona, 2008. 31-61. 
Vargas Llosa, Álvaro. Lessons from the Poor: Triumph of the Entrepreneurial Spirit. Oakland, CA: Independent Institute, 2008.

Vargas Llosa, Mario. Conversación en la Catedral. 1969. Lima: Peisa, 2001.

_. . Conversación en la Catedral. 1969. Barcelona: Debolsillo, 2015.

"El arte de mecer". El Comercio, 21 feb. 2010.

"El Inca Garcilaso y la lengua de todos". Biblioteca Virtual Miguel de Cervantes (2009).

"El nacimiento del Perú". Hispania 75.4 (1992): 805-811.

El pez en el agua: memorias. Barcelona: Seix Barral, 1993.

"José María Arguedas descubre al indio auténtico". Visión del Perú 1 (1964): 2844.

. La ciudad y los perros. 1962. Madrid: Punto de Lectura, 2012.

"La hora de los charlatanes". El lenguaje de la pasión. Lima: Peisa, 2001.

La utopía arcaica: José María Arguedas y las ficciones del indigenismo. Madrid: Alfaguara, 2008.

Prólogo. El otro Sendero. 1986. Hernando de Soto. México, D.F: Diana, 1987.

- "Questions of Conquest: What Columbus wrought, and what he did not". Harper's Magazine (Dic. 1990): 1-8.

"Raza, botas y nacionalismo". Diario El País, SL 15 enero 2006.

Vargas Yábar, Miguel. Las empresas del pensamiento: Clorinda Matto de Turner (18521909). Lima: Facultad de Letras y Ciencias Humanas, Universidad de San Marcos: Pakarina, 2013.

_. "Clorinda Matto: constructora de la nación en El Perú Ilustrado (1889-1891) y constructora de América en el Búcaro Americano (1896-1908)". Boletín del Instituto Riva-Agüero 35 (2009-2010): 223-42.

Vasconcelos, José. La raza cósmica: Misión de la raza iberoamericana. 1925. México: Espasa-Calpe, 1966.

Vega Loyola, José "Japoneses, chinos e indios en Lima cosmopolita de inicios del siglo XVII". Cátedra Villarreal 3.2 (2015): 155-72.

Velázquez Castro, Marcel. Las máscaras de la representación: El sujeto esclavista y las rutas el racismo en el Perú (1977-1895). Lima: U. Nacional Mayor de San Marcos / Banco Central de Reserva del Perú, 2005.

_. "Los 7 errores de Mariátegui o travesía por el útero del padre". Revista de Literatura Ajos \& Zafiros 3-4 (2002): 117-32.

Vento García, Raúl. Juicio a Abimael: Sendero, ideologia y realidad. Lima: Agenda 2000 Editores, 1992.

Veres, Luis. La narrativa del indio en la revista Amauta. Serie Cuadernos de filología 40. Valencia: Universitat de Valencia, 2001. 
— "El problema de la identidad nacional en la obra de José Carlos Mariátegui". Amnis: Revue de civilisation contemporaine Europes/Amériques 2 (2012): Les identités culturelles et nationales dans les societés européennes et américaines. Les cahiers de Revues.org.

Vizenor, Gerald. Manifest Manners: Postindian Warriors of Survivance. Hanóver y Londres: Wesleyan UP, 1994.

Vilanova, Núria. "La ficción de los márgenes". Revista de Crítica Latinoamericana 6.51 (2000): 201-14.

Vich, Cynthia. "Entre el mito y la historia: la construcción imaginaria de la barriada peruana en Patíbulo para un caballo de Cronwell Jara". Inti 67-68 (2008): 13956.

Vich, Víctor. Del viento, el poder y la memoria: Materiales para una lectura crítica de Miguel Gutiérrez Monteagudo. Ed. Cecilia, y Víctor Vich.Lima: Fondo Editorial de la PUCP. 2002. 187-206.

Watson, Maida. "Arte y literatura en el costumbrismo peruano decimonónico". Revista de la Casa Museo Ricardo Palma 6 (2006): 41-62.

Weismantel, Mary y Stephen F. Eisenman. "Race in the Andes: Global Movements and Popular Ontologies". Bulletin of Latin American Research 17.2 (1998): 121-4.

White, Hayden. Entrevista con Juan Pablo Bertazza. "La historia es un sueño eterno". Página 12, 17 abril 2011.

_. Figural Realism: Studies in the Mimesis Effect. Johns Hopkins UP, 1999.

Yarza Rovira, Enrique Javier. "Génesis y evolución del mestizaje en el Río de la Plata". 2005. Revista del Instituto de Estudios Genealógicos del Uruguay 31 (2009).

Zaferson Aranzaens, Olga. El hilo conductor: Tradición y moda en el Perú. Lima: Hipocampo, 2013.

Zamora, Margarita. Language, Authority, and Indigenous History in the Comentarios Reales de Los Incas. Cambridge (Cambridgeshire: Cambridge University Press, 1988.

Zhou, Min. The Transcription of Identities: A Study of V.s. Naipaul's Postcolonial Writings. Bielefeld: Transcript, 2015.

Zohar, Ayelet. "Strategies of Camouflage: Depersonalization, Schizoanalysis and Comtemporary Photography". Deleuze and the Schizoanalysis of Visual Art. Eds. Ian, Buchanan, y Lorna Collins. Londers: Bloomsbury Publishing, 2014. 
—. "The Elu[va]sive Portrait: Mimicry, Masquerade and Camouflage: Conceptual and Theoretical Notes, an Introduction". TAP, Trans Asia Photogrtaphy Review 2.1 (2011).

Zuelow, Eric G.E. "What is Nationalism?” The Nationalism Project. Red.

Zuidema, Reiner Tom. The Ceque System of Cuzco; the Social Organization of the Capital of the Inca. Leiden: Brill, 1964. 
VITA

\section{FRANK OTERO LUQUE}

Born, Lima, Peru

2012

B.A. in Spanish

Florida International University

Miami, Florida

2013

M.A. in Spanish

Florida International University

Miami, Florida

2013-2014

Digital Assistant

Florida International University

Miami, Florida

2014-2016

Teaching Assistant

Florida International University

Miami, Florida

2015

Doctoral Candidate

Florida International University

Miami, Florida

2017 (Spring \& Summer)

Dissertation Year Fellowship

Modern Languages

Florida International University

Miami, Florida

\section{PUBLICATIONS AND PRESENTATIONS:}

"La ciudad y los pelos: la representación del indígena peruano en La ciudad y los perros (1963) de Mario Vargas Llosa". Argus-a 6.24 (2017): 1-27.

Otero Luque, Frank. "La ciudad y los pelos: la representación del indígena peruano en La ciudad y los perros (1963) de Mario Vargas Llosa". Argus-a 6.24 (2017): 1-27. Red.

"El Inca Garcilaso desde el escepticismo: identidad mestiza conflictiva, subvaluación de la otredad preincaica y dioses ocupados". Inca Garcilaso de la Vega: 400 Aniversario. Comp. José Beltrán Peña. Lima, Gaviota Azul Editores, 2016.46-88. 
"Montacerdos (1981) de Cronwel Jara: seres inmortales en la barriada peruana". Palabra en libertad - Revista peruana de literatura 18.156 (2016) 15-34.

"La prosa del Transiberiano y la pequeña Juana de Francia (1913): ¿Simultaneidad y poesía?" Palabra en libertad - Revista peruana de literatura 18.145 (2016): 9-33

"Borges, uno de los tantos autores de 'Pierre Menard, autor del Quijote.'” Argus-a 6.22 (2016): 1-17.

"Hienas en la niebla (2010) de Juan Morillo Ganoza: estrategias narrativas y Representación de la Guerra Interna librada en el Perú entre 1980 y 2000". Argus-a 5.21 (2016): 1-20.

“Literaturas y comunidades imaginadas de Mariátegui”. Argus-a 5.20 (2016): 1-25.

"Mercedes Cabello de Carbonera y Blanca Sol (1888): iconoclasia, muerte social y locura". Decimonónica 12.2 (2015): 47-56.

"La gran aldea (1884) de Lucio Vicente López: la ciudad de Buenos Aires como tropo literario". Argus-a 4.14 (2014): 1-18.

El Señor de Palpa. Lima: Milla Batres, 2003.

"De pobre huerfanita a despiadada viuda negra: la agencia de la mujer en las Tristanas de Pérez Galdós y Buñuel". SAMLA’s 88th Annual Conference, Jacksonville, Florida, November 4-6, 2016.

"Tres postulados de integración nacional de Clorinda Matto de Turner en Aves sin nido y en El Perú Ilustrado, a la luz de algunas ideas de José Carlos Mariátegui en sus 7 ensayos de interpretación de la realidad peruana". Nineteenth-Century Latin American \& Spanish Literature International Conference, FIU, November 20, 2015.

"Matrimonio y mortaja del cielo bajan: ¿un destino inexorable en Los pazos de Ulloa de Emilia Pardo Bazán?”. SAMLA’s 86th Annual Conference, Atlanta, November. 7-0 , 2014.

"Sab, abuelo de Matalaché: la novela cubana como parámetro para reclasificar la peruana". The 200th Anniversary of the Birth of Gertrudis Gómez de Avellaneda: A Celebration of Nineteenth-Century Cuban Literature, FIU, Miami, April 4, 2014. 